\title{
France: Financial Sector Assessment Program- Detailed Assessments of Observance of Standards and Codes including Banking Supervision, Insurance Regulation, Securities Legislation, Monetary and Financial Policy Transparency, Payments Systems, Securities Settlement, and Anti-Money Laundering and Combating the Financing of Terrorism
}

These Detailed Assessments of Observance of Standards and Codes on France were prepared by a staff team of the International Monetary Fund as background documentation for the Financial Sector Assessment Program with the member country. It is based on the information available at the time it was completed in April 2005. The views expressed in this document are those of the staff team and do not necessarily reflect the views of the government of France or the Executive Board of the IMF.

The policy of publication of staff reports and other documents by the IMF allows for the deletion of market-sensitive information.

To assist the IMF in evaluating the publication policy, reader comments are invited and may be sent by e-mail to publicationpolicy@imf.org.

Copies of this report are available to the public from

International Monetary Fund $\bullet$ Publication Services

700 19th Street, N.W. • Washington, D.C. 20431

Telephone: (202) 6237430 • Telefax: (202) 6237201

E-mail: publications@imf.org • Internet: http://www.imf.org

Price: $\$ 15.00$ a copy

\section{International Monetary Fund} Washington, D.C. 

Financial Sector Assessment Program

\section{FRANCE}

\section{DETAILED ASSESSMENT OF OBSERVANCE OF STANDARDS AND CODES}

APRIL 2005 


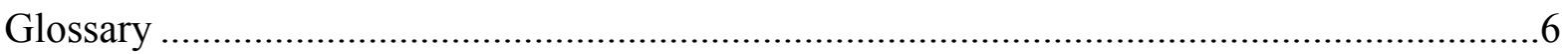

I. Compliance with the Basel Core Principles for Effective Banking Supervision...........10

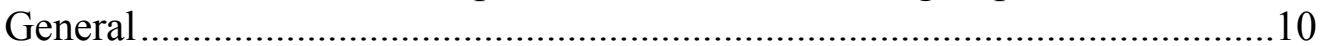

Information and methodology used for assessment...................................10

Market structure overview ........................................................................ 11

Preconditions for effective banking supervision.......................................11

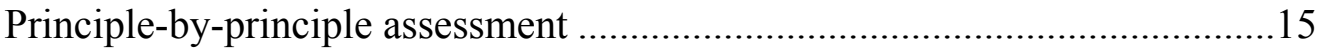

Recommended action plan and authorities' response to the assessment .........55

II. Observance of the IAIS Insurance Core Principles.....................................................56

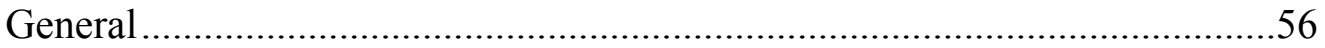

Information and methodology used for assessment..................................56

Institutional and macro prudential setting_overview ...............................57

General preconditions for effective insurance supervision..........................60

Principle-by-principle assessment ....................................................60

Recommended action plan and authorities' response to the assessment .........84

III. Observance of the CPSS Core Principles for Systemically Important Payment Systems .87

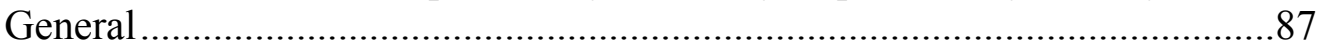

Information and methodology used for assessment ..................................87

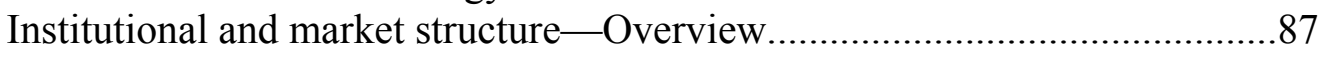

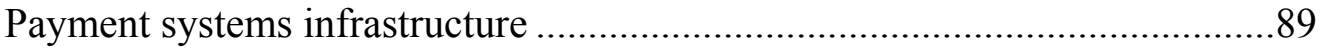

Assessment of observance of the CPs by the TBF ......................................89

Recommended action plan for the TBF ...............................................100

Assessment of observance of the CPs by the PNS ...................................101

Recommended action plan for the PNS ...................................................112

Assessment of observance of the CPs by the SIT ......................................113

Recommended action plan for the SIT ....................................................126

Assessment central bank responsibilities in applying the CPs ...................127

Recommended action plan on central bank responsibilities ........................132

Authorities' response to the assessment ...............................................133

IV. Implementation of the IOSCO Objectives and Principles of Securities Regulation .......133

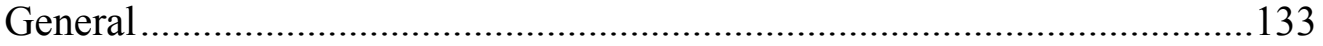

Information and methodology used for assessment................................134

Institutional and macroprudential setting, market structure ......................135

Description of regulatory structure and practices ...................................139

General preconditions for effective securities regulation ..........................141

Principle-by-principle assessment ........................................................143

Recommended actions and authorities' response to the assessment ............192

V. Observance of the CPSS/IOSCO Recommendations for Securities Settlement Systems 195 


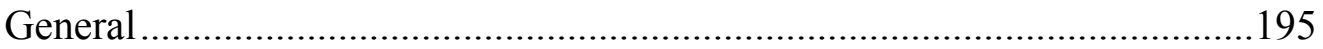

Scope of the assessment ............................................................................195

Institutional and market structure ...............................................................195

Description of regulatory structure and practices .........................................196

Information and methodology used for the assessment..................................197

Assessment against the CPSS/IOSCO recommendations for securities settlement systems …….........................................................................197

Recommended action plan and authorities' response to the assessment .......238

VI. Observance of the IMF Code of Good Practices on Transparency in Monetary and

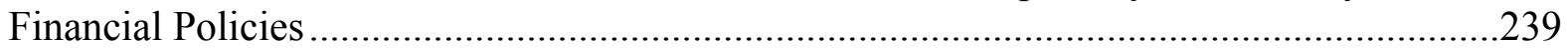

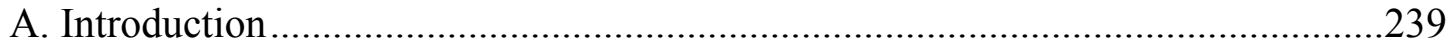

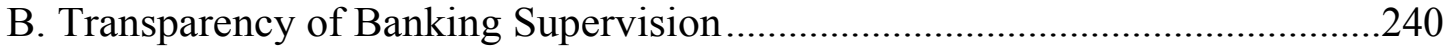

Practice-by-practice assessment ...................................................................2240

Recommended action plan and authorities' response to the assessment .......252

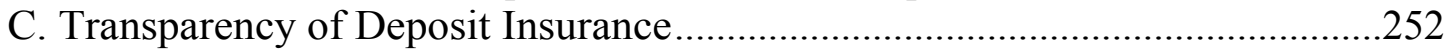

Practice-by-practice assessment.................................................................2252

Recommended action plan and authorities' response to the assessment .......263

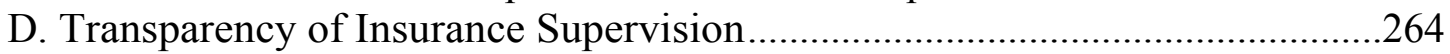

Practice-by-practice assessment................................................................2.

Recommended action plan and authorities' response to the assessment .......275

E. Transparency of Payment and Settlement Systems Oversight ..............................276

Practice-by-practice assessment...............................................................277

Recommended action plan and authorities' response to the assessment .......289

F. Transparency of Securities Regulation and Supervision ......................................28

Practice-by-practice assessment...................................................................290

Recommended action plan and authorities' response to the assessment ........301

VII. Compliance with the FATF Recommendations for Anti-Money Laundering and Combating the Financing of Terrorism...........................................................................302

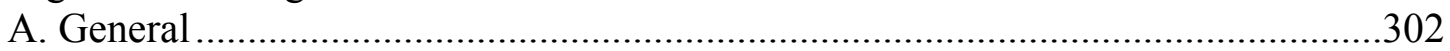

Information and methodology used for the assessment..................................302

General situation of money laundering and financing of terrorism................303

Overview of measures to prevent money laundering and terrorism financing303

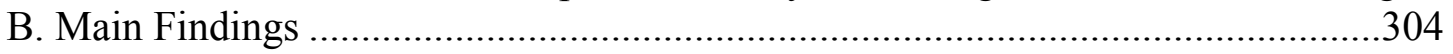

Criminal justice measures and international cooperation ...............................304

Preventive measures for financial institutions ..............................................306

C. Detailed Assessment ………………...........................................................308

Assessing Criminal Justice Measures and International Cooperation ............308

Assessing Preventive Measures for Financial Institutions...............................322

Description of the Controls and Monitoring of Cash and Cross Border

Transactions

D. Ratings of Compliance with FATF Recommendations, Summary of Effectiveness

of AML/CFT Efforts and Recommended Action Plan .............................................343

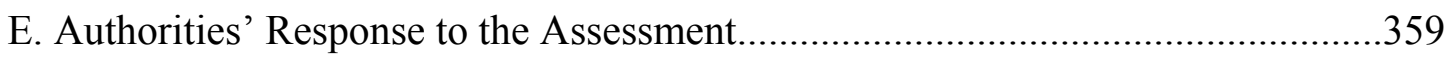


Tables

1. Detailed Assessment of Compliance of the Basel Core Principles.................................15

2. Summary Compliance of the Basel Core Principles.....................................................55

3. Recommended Action Plan to Improve Compliance of the Basel Core Principles.........56

4. Detailed Assessment of Observance of the IAIS Insurance Core Principles..................61

5. Summary Observance of IAIS Insurance Core Principles..........................................84

6. Recommended Action Plan to Improve Observance of IAIS Insurance Core Principles84

7. Detailed Assessment of Observance by the TBF of CPSS Core Principles for SIPS......89

8. Summary Observance of TBF of the CPSS Core Principles .......................................100

9. Recommended Actions to Improve Observance of TBF of the CPSS Core Principles. 100

10. Detailed Assessment of Observance of Paris Net Settlement System (PNS) of the CPSS Core Principles for SIPS.

11. Summary Observance of PNS of the CPSS Core Principles

12. Recommended Actions to Improve Observance of PNS of the CPSS Core Principles. 112

13. Detailed Assessment of Observance of Système Interbancaire de Télécompensation (SIT) of CPSS Core Principles for SIPS

14. Summary Observance by SIT of the CPSS Core Principles.

15. Recommended Actions to Improve Observance by SIT of the CPSS Core Principles .126

16. Detailed Assessment of the Responsibilities of BdF in Applying the Core Principles .127

17. Summary Observance of the Central Bank Responsibilities in Applying the CPs........132

18. Recommended Actions to Improve Observance of the Central Bank Responsibilities in Applying the CPs

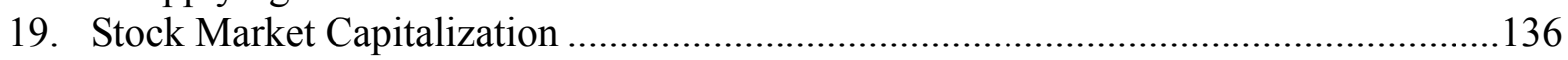

20. Detailed Assessment of Observance of the IOSCO Objectives and Principles of Securities Regulation

21. Summary Implementation of the IOSCO Objectives and Principles of Securities Regulation

22. Recommended Plan of Actions to Improve Implementation of the IOSCO Objectives and Principles of Securities Regulation

23. Trades Settled in Euroclear France's Securities Settlement Systems

24. Detailed Assessment of Euroclear France as a Central Securities Depository and the RGV2-Irrevocable Trade for Trade Settlement System operated by Euroclear France of CPSS/IOSCO Recommendations for Securities Settlement Systems .

25. Summary Observance of Euroclear France as a Central Securities Depository and of the RGV2 irrevocable Trade for Trade channel operated by Euroclear France of the CPSS/IOSCO recommendation for Securities Settlement Systems

26. Recommended Actions to Improve Observance of Euroclear France and the RGV2 of CPSS/IOSCO Recommendations for Securities Settlement Systems

27. Detailed Assessment of Relit+, the Multilateral Netting Scheme for the Clearing and Settlement of Stock Exchange and OTC Securities Transactions of the CPSS/IOSCO Recommendations for Securities Settlement Systems

28. Summary Observance of Relit+ of the CPSS/IOSCO Recommendations for Securities Settlement Systems .... 
29. Recommended Actions to Improve Observance of Relit+ of the CPSS/IOSCO

Recommendations for Securities Settlement Systems

30. Detailed Assessment of Observance of IMF's MFP Transparency Code-Banking Supervision

31. Summary Observance of IMF's MFP Transparency Code_-Banking Supervision......251

32. Recommended Action Plan to Improve Observance of IMF's MFP Transparency Code Practices-Banking Supervision.

33. Detailed Assessment of Observance of IMF's MFP Transparency Code-Deposit Insurance

34. Summary Observance of IMF's MFP Transparency Code-Deposit Insurance Supervision

35. Recommended Action Plan to Improve Observance of IMF's MFP Transparency Code Practices-Deposit Insurance Supervision.....

36. Detailed Assessment of Observance of IMF's MFP Transparency Code-Insurance Supervision

37. Summary Observance of IMF's MFP Transparency Code-Insurance Supervision....275

38. Recommended Action Plan to Improve Observance of IMF's MFP Transparency Code Practices-Insurance Supervision.

39. Detailed assessment of Observance of IMF's MFP Transparency Code Practices-

Payment and Settlement Systems (November 2003 update)

40. Summary Observance of IMF's MFP Transparency Code Practices-Payment and Settlement Systems ....

41. Recommended Actions to Improve Observance of IMF's MFP Transparency Code Practices-Payment and Settlement Systems.

42. Detailed Assessment of Observance of IMF's MFP Transparency Code PracticesTransparency of Securities Regulation

43. Summary Observance of IMF's MFP Transparency Code-Securities Regulation .....301

44. Recommended Action Plan to Improve Observance of IMF's MFP Transparency Code Practices-Securities Regulation

45. Detailed Assessment of Criminal Justice Measures and International Cooperation ........308

46. Detailed Assessment of the Legal and Institutional Framework for Financial Institutions and its Effective Implementation.

47. Description of the Controls and Monitoring of Cash and Cross Border Transactions ....342

48. Ratings of Compliance with FATF Recommendations Requiring Specific Action ........343

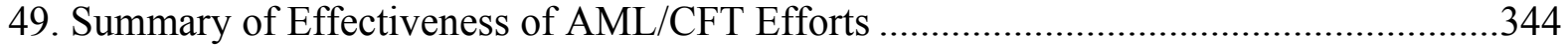

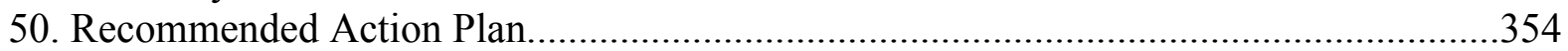




\section{GLOSSARY}

AFECEI Association Française des Établissements de Crédit et des Entreprises d'Investissement

AFG-ASFFI Association Française de la Gestion Financière

AMF Autorité des Marchés Financiers

AG CRI Assemblée Générale de la Centrale des Règlements Interbancaires

AML Anti-Money Laundering

APE Agence des Participations de l'État

Art. Article

ATM Automated Teller Machines

ATS Automated Trading Systems

BAFI Base des Agents Financiers

BALO Bulletin des annonces légales obligatoires

BCP Basel Committee's Core Principles for Effective Banking Supervision

BdF Banque de France

BIC Bank Identification Code

BIS Bank for International Settlements

BTANs Bons à faux fixe et à intérêt annuel

BTFs Bons du Trésor à faux fixe et à intérêts prècomptés

CACESF College des Autorités de Contrôle des Entreprises du Secteur Financier

CAC Commissaire Aux Comptes (French external auditor)

CAR Capital Adequacy Ratio

CB Commission Bancaire

CBFA Commission Bancaire et Financière

CCA

CCAMIP

CCP

Commission de Contrôle des Assurances

CCR

Commission de Contrôle des Assurances, Mutuelles et Institutions de Prévoyance

Central Counter Parties

Compte Courant de Règlement

CCMIP

CCSF

Comité Consultatif pour la Législation et la Réglementation Financieres

CDC

CDD

Commission de Contrôle des Mutuelles et des Institutions de Prévoyance

Comité Consultatif du Secteur Financier

Caisse des Dépôts et Consignations

Customer Due Diligence

CDGF Conseil de Discipline de la Gestion Financière

CDI

CEA

Comité de Déontologie de l'Indépendance des commissaires aux comptes des sociétés faisant appel public a l'épargne

CECEI Comité des Établissements de Crédit et des Entreprises d'Investissement

CEIOPS Committee of European Insurance and Occupational Pension Fund Supervisors

CEL Compte d'Épargne-Logement

CESR Committee of European Securities Regulators

CFONB Comité Français d'Organisation et de Normalisation Bancaires

CFT Combating the Financing of Terrorism

CIRCE Charte Interbancaire Régissant les Conditions d'Échange

CIS Collective Investment Schemes

CLAMEF Comité de Liaison des Autorités Monétaires et Financières

CLS Continuous Linked Settlement

CMF Code Monétaire et Financier

CMT Conseil des Marchés à Terme 


\begin{tabular}{|c|c|}
\hline $\mathrm{CNC}$ & Conseil National de la Comptabilité \\
\hline $\mathrm{CNCC}$ & Compagnie Nationale des Commissaires aux Comtes \\
\hline $\mathrm{CNCT}$ & Conseil National du Crédit et du Titre \\
\hline $\mathrm{COB}$ & Commission des Opérations de Bourse \\
\hline CODIRSEC & Comité Directeur de la Sécurité \\
\hline COMOFI & Code Monétaire et Financier \\
\hline CPSS & Committee on Payment and Settlement Systems \\
\hline CPSIPS & CPSS's Core Principles for Systemically Important Payment Systems \\
\hline $\mathrm{CRB}$ & Comité de la Réglementation Bancaire \\
\hline $\mathrm{CRBF}$ & Comité de la Réglementation Bancaire et Financière \\
\hline $\mathrm{CRC}$ & Comité de la Réglementation Comptable \\
\hline CRI & Centrale des Réglements Interbancaires \\
\hline CSD & Central Securities Depository \\
\hline $\mathrm{DC}$ & Direction du Contrôle \\
\hline DCP & Délégation au Contrôle sur Place \\
\hline DGL/GR & Direction de la Gestion des risques, de l'Audit et de la sécurité \\
\hline DGDDI & Direction générale des douanes et des droits indirects \\
\hline DIF & Décisions et Informations Financières \\
\hline DOM-TOM & Départements et Territoires d'Outre-Mer (Overseas departments and territories) \\
\hline DVP & Delivery versus Payment \\
\hline DNRED & Direction Nationale du Renseignement et des Enquêtes Douanières \\
\hline DSJ & Direction des Services Juridiques \\
\hline EAF 2 & Electronic Access Frankfurt 2 \\
\hline $\mathrm{EBF}$ & European Banking Federation \\
\hline $\mathrm{ECB}$ & European Central Bank \\
\hline EEA & European Economic Area \\
\hline EMU & European Monetary Union \\
\hline ESCB & European System of Central Banks \\
\hline EU & European Union \\
\hline FAMA & Financial Activity Modernization Act \\
\hline FATF & Financial Action Task Force \\
\hline FBF & Fédération Bancaire Française \\
\hline FCC & French Commercial Code \\
\hline $\mathrm{FCP}$ & Fonds communs de placement \\
\hline FFSA & Fédération francaise des sociétés d'assurance \\
\hline FGD & Fond de Garantie des Dépôts \\
\hline FIBEN & Fichier Bancaire des Entreprises \\
\hline FIFO & First in, First out \\
\hline FIU & Financial Intelligence Unit \\
\hline FOP & Free of Payment \\
\hline FSAP & Financial Sector Assessment Program \\
\hline FSR & Financial Stability Review \\
\hline FSSA & Financial System Stability Assessment \\
\hline FT & Financing of Terrorism \\
\hline GECO & Gestion Collective \\
\hline GEMA & Groupement des Entreprises Mutuelles d'Assurances \\
\hline GIE & Groupement d'Intérêt Economique (Economic Interest Group) \\
\hline GSIT & Groupement pour un Système Interbancaire de Télécompensation \\
\hline
\end{tabular}




\begin{tabular}{|c|c|}
\hline $\mathrm{HCCC}$ & Haut Conseil du Commissariat aux Comptes \\
\hline IAIS & International Association of Insurance Supervisors \\
\hline IAS & International Accounting Standards \\
\hline IASB & International Accounting Standards Board \\
\hline ICOTT & Interface Connection TBF-TARGET \\
\hline ICP & Insurance Core Principles \\
\hline IEDOM & Institut d'Émission des Départements d'Outre-Mer \\
\hline IFRS & International Financial Reporting Standards \\
\hline IGF & Inspection Générale des Finances \\
\hline IL & Inflation linked \\
\hline IOSCO & International Organization of Securities Commissions \\
\hline IRB & Internal ratings based \\
\hline ISIN & International Securities Identification Number \\
\hline ISP & Investment Service Provider \\
\hline JORF & Journal offficiel de la République Française \\
\hline LEP & Livret d'Épargne Populaire \\
\hline LIFFE & London International Financial Futures Exchange \\
\hline LVPS & Large Value Payment System \\
\hline LSF & Loi No. 2003-706, de Sécurité financière \\
\hline MAC & Market Advisory Committee \\
\hline MATIF & Marché à Terme International de France (French Financial Future Market) \\
\hline MFP & Monetary and Financial Policies \\
\hline MINEFI & Ministry of Economy, Finance, and Industry \\
\hline ML & Money laundering \\
\hline MoE & Minister in charge of the Economy \\
\hline MONEP & Marché des Options Négociables de Paris (Paris Traded Options Market) \\
\hline $\mathrm{MoU}$ & Memorandum of Understanding \\
\hline NAV & Net Asset Value \\
\hline $\mathrm{NCB}$ & National Central Bank \\
\hline NCCT & Non-cooperating countries or territories \\
\hline NPL & Nonperforming loans \\
\hline OATs & Obligations Assimilables du Trésor \\
\hline OCRGDF & Office Central pour la Répression de la Grande Délinquance Financière \\
\hline OECD & Organization for Economic Cooperation and Development \\
\hline OF & Obligations Foncières \\
\hline OPSR & Objectives and Principles of Securities Regulation \\
\hline ORAP & Organisation et Renforcement de l'Action Préventive \\
\hline OTC & Over-the-Counter \\
\hline PEA & Plan d'Épargne en Actions \\
\hline PEL & Plan d'Épargne Logement \\
\hline PERP & Plan d'Épargne Retraite Populaire (Retirement plan) \\
\hline PNS & Paris Net Settlement system \\
\hline POS & Point of Sale \\
\hline PSSC & Payment and Settlement Systems Committee (of the ECB) \\
\hline PSPWG & Payment Systems Policy Working Group \\
\hline QLB & A Commission Bancaire reporting form on AML/CFT measures \\
\hline RGV & Relit Grande Vitesse \\
\hline RGV2-TFT & Relit Grande Vitesse 2 \\
\hline
\end{tabular}




\begin{tabular}{|c|c|}
\hline ROA & Return on assets \\
\hline $\mathrm{ROE}$ & Return on Equity \\
\hline ROSC & Report on Observance of Standards and Codes \\
\hline RSSS & CPSS/IOSCO Recommendation for Securities Settlement Systems \\
\hline RTGS & Real-Time Gross Settlement systems \\
\hline SA & Sociétés Anonymes \\
\hline SAABA & Système d'Aide à l'Analyse Bancaire \\
\hline $\mathrm{SCP}$ & IOSCO's Core Principles of Securities Regulation \\
\hline SCPA & Société en Commandité Par Actions \\
\hline SCR & Service Central des Risques \\
\hline SCSS & Securities Clearing and Settlement Systems \\
\hline SEPA & Single European Payments Area \\
\hline SEPI & Service de Surveillance des Systèmes de Paiements et de Titres \\
\hline SERI & Service des Réglements Interbancaires \\
\hline SEMOP & Service Études, Maîtrise d'Ouvrage et Organisation des Systèmes de Paiements \\
\hline SFD & Settlement Finality Directive \\
\hline SFSA & Savings and Financial Securities Act \\
\hline SIGAL & Système d'Information de l'Inspection Générale \\
\hline SIPS & Systemically Important Payment Systems \\
\hline SIT & $\begin{array}{l}\text { Système Interbancaire de Télécompensation (French automated clearing house for retail } \\
\text { payments) }\end{array}$ \\
\hline SLA & Service Level Agreement \\
\hline SRDs & Service de Réglement Différé (Deferred settlement positions) \\
\hline SSS & Securities Settlement System \\
\hline STR & Suspicious Transaction Report \\
\hline SWIFT & Society for World-wide Interbank Financial Telecommunication \\
\hline TARGET & Trans-European Automated Real-time Gross settlement Express Transfer system \\
\hline TBF & Transferts BdF \\
\hline TFT & Trade For Trade gross settlement system for securities \\
\hline TIP & Titre Interbancaire de Paiement \\
\hline TMWG & TARGET management working group \\
\hline TRACFIN & $\begin{array}{l}\text { Traitement du Renseignement et Action contre les Circuits Financiers Clandestins (Treatment } \\
\text { of Information and Action Against Clandestine Financial Circuits), the French FIU }\end{array}$ \\
\hline UCITS & Undertakings for the Collective Investment of Transferable Securities \\
\hline UN & United Nations \\
\hline UNSCR & United Nations Security Council Special Resolution \\
\hline
\end{tabular}




\section{Compliance With the Basel Core Principles for Effective Banking SUPERVISION}

\section{General}

1. This update of the $2001 \mathrm{MAE}^{1}$ assessment of compliance by France with the Basel Core Principles for Effective Banking Supervision was performed during the 2004 assessment of France in the context of the FSAP. The assessment was conducted from January 28-February 10, 2004. The assessment covered the activities of the key banking regulatory and supervisory bodies in France, in particular the Banque de France (BdF), the Commission Bancaire (CB), the Comité des Établissements de Crédit et des Entreprises d'Investissement (CECEI), and the Comité de la Réglementation Bancaire et Financière (CRBF). The updated assessment was prepared by Jan Willem van der Vossen, Monetary and Financial Systems Department (MFD).

\section{Information and methodology used for assessment}

2. The $2001 \mathrm{BCP}$ assessment performed by MAE, showed a very high level of compliance with the BCP, with "compliant" gradings for 21 out of 25 BCPs. The four BCPs which had not been graded "compliant" had been graded "largely compliant" or "largely compliant - improvement underway." The 2004 assessment was prepared on the basis of the Basel Core Principles Methodology, the April 2000 self-assessment by the French authorities, the August 2001 MAE assessment, information provided by the French authorities how the recommendations of the 2001 assessment had been addressed, and the response to the pre-FSAP questionnaire. Furthermore, the mission studied laws and regulations relative to banking regulation and supervision. Discussions were held with representatives of the regulatory and supervisory agencies, and with representatives of the major banks, rating agencies and of the accounting and auditing profession.

3. The mission also consulted the Annual Reports and Official Bulletins of the BdF, the CB, the CECEI, and the Conseil National du Crédit et du Titre (CNCT), websites of the major banking groups, a Cour des Comptes report on the government's intervention in the financial sector crisis, L'Intervention de l'Etat dans la Crise du Secteur Financier, a KPMG publication on comparative bank performance data in the EU, rating agency reports, and other sources. In addition, the authorities provided information notes on specific topics, for instance compliance of the French accounting system with IAS, and the institutional structure of the system for financial sector regulation and supervision.

4. The authorities were very open and cooperative, made excellent preparations for the meetings of the mission, and provided helpful post-mission information.

\footnotetext{
${ }^{1}$ The Monetary and Exchange Affairs department (MAE) was changed to the Monetary and Financial Systems department (MFD) on September 2, 2003.
} 


\section{Market structure overview ${ }^{2}$}

5. The French banking system, which has been modernized and restructured over the past two decades, is large, sophisticated, and of international importance. The system is dominated by six vertically integrated universal banks and their subsidiaries. Four of the six are organized on a mutual basis. Further consolidation of the sector could pose a range of challenges, including stability concerns that many banks are "too big to fail." Two large financial institutions, La Poste and the Caisse des Dépôts et Consignations (CDC), remains in government ownership.

\section{Preconditions for effective banking supervision}

\section{Macroeconomic soundness and stability}

6. After a slowdown in economic activity during 2002-03, a cyclical recovery has been gathering pace. Inflation has only moderately picked up and ex-post real interest rates have sunk to unusually low levels. Despite slow growth up to mid-2003, the financial situation of the corporate sector has deteriorated only slightly since 2000 and, except for a few large companies, corporate leverage is generally low. Likewise, households' debt levels relative to incomes and assets are comparatively low (albeit rising), and savings rates are high. However, low interest rates and rising prices may induce households to take out larger mortgage loans, which may impact on their future financial position. Equity prices remain below their 2000 highs, despite the recent recovery, but some investors enjoy offsetting gains on bonds. Commercial real estate prices have remained stable following the early-1990s boom-bust cycle.

\section{Public infrastructure and institutional arrangements for supervision}

7. The legal and regulatory framework for banking supervision in France is clear, easily accessible and updated periodically (Principle 1(1)). All banking and financial laws are codified in the Code Monétaire et Financier (COMOFI). The COMOFI also incorporates new legislation on the Fonds de Garantie des Dépôts (FGD), and on the new Autorité des Marchés Financiers (AMF), which regulates and supervises securities operations, including banks' asset management activities for third parties. The main banking and accounting regulations are collected in the Recueil des Textes Réglementaires published by the CRBF.

8. The legal framework to conduct banking business is also well developed, with clear and concise legislation. The legal profession and the judiciary are well trained and have a strong understanding of financial and banking issues. Supervisory staff are well versed in the application of financial sector legislation. Rules on contracts and contract enforcement, as well as establishment and foreclosure of security interests are well developed, although legal

${ }^{2}$ In FSAP/FSSA reports, this information will be contained in other parts of the FSAP report. Salient details, however, may be briefly restated for convenience. 
procedures are lengthy. The accounting and auditing professions are well regulated, and subject to rigorous training and entry requirements. They are subject to regulation and codes of conduct issued by the Haut Conseil du Commissariat aux Comptes (HCCC) and the Compagnie Nationale des Commissaires aux Comtes (CNCC).

9. France has separate supervisory institutions for the main financial sectors: banking, insurance and securities. Arrangements have been put in place to ensure adequate coordination between these authorities. The CB, the CRBF, the CECEI, the Commission de Contrôle des Assurances, Mutuelles et Institutions de Prévoyance (CCAMIP) and the AMF are the supervisory and regulatory agencies for, respectively, the banking system, insurance, and securities industries, this far latter including banks' asset management for third parties. Later in 2004, the CRBF, which issued banking regulations, subject to approval by the minister in charge of the economy (MoE), will close to exist. Henceforth, the MoE will issue regulations directly under his own name, after consultation of the Comité Consultatif pour la Législation et la Réglementation Financieres (CCLRF).

10. Thus, financial sector oversight is fundamentally set up as a matrix, with a separate column for each of the main financial sectors of banking, securities and insurance, each with separate layers for regulatory, licensing and supervisory functions. The three columns are coordinated through joint bodies for cooperation, coordination and exchange of information and cross-membership in the oversight boards of the supervisory authorities. The legal provisions on financial sector regulation and supervision are incorporated in the COMOFI, except those for the insurance sector, which are laid down in the Code des Assurances.

11. This structure, while it may be seen as complex, is internally consistent and effective on a day-to-day basis. The following are examples of how coordination and cooperation are structured between the agencies:

a. Joint working groups of the $\mathrm{CB}$ and the Commission des Opérations de Bourse (COB) (precursor of the AMF) have issued common recommendations on measures to deal with transactions that have failed to clear (are in suspens); a common recommendation on financial information concerning credit risk, and a common recommendation on asset de-recognition and de-consolidation;

b. The $\mathrm{CB}$ and the $\mathrm{COB}(\mathrm{AMF})$ have jointly prepared restrictions on the use of credit derivatives by unit trusts, rules on large exposures for unit trusts, and have cooperated on many practical issues;

c. Annually, more than 50 bilateral or multilateral meetings take place between the CECEI, the CB, CCAMIP and the AMF, as well as approximately 100 exchanges of letters between the $\mathrm{CB}$ ad the COB (AMF);

12. Cooperation and coordination between the BdF, CB, the AMF and CCAMIP also takes place through their membership in the CACESF, chaired by the MoE. 
13. Cooperation between the CCAMIP and the CB is formalized in a charter signed in October 2001. Cooperation extends to mutual training, exchange of staff, exchange of information, performance of joint studies, coordinated on-site inspections of institutions that combine banking and insurance activities. Cooperation between the CB and the CCAMIP has been strengthened through the Financial Security Act of August 2003. Joint meetings between the CCAMIP and the CB take place as needed, but at least twice a year. The CB chair is member of the CCAMIP and vice versa.

14. Coordination between the $\mathrm{CB}$ and the $\mathrm{AMF}$ is supported by BdF membership in both bodies. Off-site supervisors of both bodies meet on a monthly basis, on-site staff bimonthly. Information is also exchanged ad-hoc. Participation of CB inspectors in AMF inspection teams is based on a 1999 agreement between the $\mathrm{CB}$ and the $\mathrm{CMF}$ (which was merged with the COB in the AMF). The AMF retains responsibility for the follow-up to these inspections.

15. The BdF remains the pivotal institution in the general governance and day-to-day operations of the $\mathrm{CB}$ and the CECEI. It provides their staff and other resources. The two institutions meet on a monthly basis to discuss individual cases. The CB, CECEI and AMF also meet with the same frequency to discuss general as well as institution-specific issues. The staffs of the three bodies are in day-to-day contact on for instance licensing issues, changes in shareholdings, and assessment of business plans. Cooperation between the insurance and banking supervisory agencies takes place through dedicated working groups, joint on-site inspections and regular meetings.

16. The authorities stress that the $\mathrm{CB}$ is the responsible agency in a crisis involving an individual banking institution. Nevertheless, in view of the complex institutional arrangements, it could be useful to lay down an explicit protocol for crisis-management involving more than one supervisory body, as speed of action will be essential, and established procedures may need to be cut short.

17. Independence of banking supervision, with an autonomous board, is generally adequate (Principle 1(2)), although the presence of the Director of the Trésor on the board of the CB could raise the issue of independence from the MINEFI. Furthermore, the presence of industry representatives on the Boards of the CECEI and the AMF raises the issue of a potential conflict of interest for these members when issues are discussed that are relevant to their business interests. The authorities stress however, that (i) the rules of procedure require that industry representatives recuse themselves when a potential conflict of interest arises; (ii) members are under strict secrecy obligations; (iii) industry representatives can provide valuable input; and (iv) this structure promotes acceptance of the supervisors' work by the industry.

18. The CB and the CECEI are clearly not independent from the BdF, which controls its resources and whose governor chairs its board. However, given (i) the independence of the BdF itself; (ii) the absence of obvious conflicts of interest with the prudential objectives of the $\mathrm{CB}$ and the CECEI (particularly in view of the centralization of monetary policy 
decisions at the European Central Bank), the linkages between the BdF and the CB do not appear to be a matter for serious concern. The staff of the $\mathrm{CB}$, particularly on-site, is still somewhat tight in view of the size of the French banking system, but it is steadily growing. The professionalism of the CB and CECEI staff is well-recognized. The legal protection of supervisors (Principle 1(5)), although not explicit in statute, is a well recognized tenet of administrative law in France - and other EU countries - and is considered satisfactory.

\section{Market discipline and governance}

19. The CRBF's and CNC's accounting rules and regulations may be considered to be generally appropriate and in line with European and international standards. Since the assessment in 2001, the authorities have taken a number of actions to enhance convergence between IAS and French accounting standards (See also description of BCP 21). Important reforms have already been enacted through the 1999 SFSA and further improvements aiming at better disclosure in several key areas have been made. A more systematic approach to and more disclosure of nonperforming loans (NPLs) have been introduced, facilitating comparisons of risk exposure and management across banks. Introduction of the Basel II framework in all EU countries will further harmonize treatment of credit risk in France with other EU countries. The credit institutions should sometimes adopt more systematically open and timely communication policies as regards significant difficulties or relevant external events that affect their risk exposure.

\section{Problem resolution}

20. The good record of the French supervisory system for early detection of troubled institutions is based, in part, on effective analytical and micro-monitoring capabilities (Principle 16). Particularly impressive are the CB's early warning system (SAABA) and the CAMELS-type bank-by-bank assessment and rating system (ORAP), which make extensive use of available databases, including the BdF's voluminous database on enterprises.

21. The CB has an adequate enforcement capacity, derived from well designed coordination arrangements between on-site and off-site supervisors and with other financial sector supervisory bodies, a flexible and comprehensive set of notification and corrective action procedures, effective follow-up, and sound legal and other enforcement powers (Principles 1(4), (16), and 22). As regards bank exit policies, substantial progress has been achieved with the reform of the deposit insurance system in defining more effective bank resolution procedures and allowing for intervention in banks by the FGD at the request of the CB.

22. Appeals against the decisions of the CB and the CECEI do not in principle suspend implementation of the decisions, unless the institution can show to the court that the decision will most probably be overturned, or if implemented, would cause irreparable harm to the institution involved, and should therefore not be implemented pending a final court decision. In theory, this can hamper efficient implementation of supervisory decisions. A system in which the implementation can go forward, but the supervisor might afterwards be held liable 
for damages could address this problem. In actual practice, the possibility to obtain such a suspension of implementation has not been successfully applied.

23. Bank governance needs to be kept under close review, especially with regard to the large mutualist organizations, which are seen to be lesser or greater degree expanding their activities and changing their corporate structures in order to make better use of their accumulated cooperative capital bases. They are embarking on a path of change and will need to carefully manage that process.

\section{Safety net}

24. The FGD was established by the SFSA of June 25, 1999, which is codified in the COMOFI, under Articles L.312-4 through L.312-18. The FGD replaces the previously existing separate guarantee funds. The COMOFI sets out that the FGD guarantees deposits and other nominally repayable funds deposited in any registered credit institution in France. The FGD's legal personality, activation, scope, governance, funding, intervention powers, its right to sue managers of the institution, as well as an enabling clause for the Minister in charge of the economy to issue more detailed regulations, are also clearly set out in the COMOFI. Depositors in banks are protected to a maximum of EUR 70,000 per customer, per bank, through the FGD. Depositors wishing to achieve full coverage of their deposits, should these be larger than EUR 70,000, may spread their deposits over several banks, limiting their deposit in each bank to EUR 70,000. Regulations 99-05, 99-06 and 99-07 of the CRBF provide more detail on the functioning of the FGD.

25. Furthermore, banks have access on their own initiative to the Eurosystem marginal lending facility to obtain overnight liquidity against collateral of eligible assets.

\section{Principle-by-principle assessment}

\section{Table 1. Detailed Assessment of Compliance of the Basel Core Principles}

\begin{tabular}{|c|c|}
\hline Principle 1. & $\begin{array}{l}\text { Objectives, autonomy, powers, and resources } \\
\text { An effective system of banking supervision will have clear responsibilities and objectives for } \\
\text { each agency involved in the supervision of banks. Each such agency should possess } \\
\text { operational independence and adequate resources. A suitable legal framework for banking } \\
\text { supervision is also necessary, including provisions relating to authorization of banking } \\
\text { establishments and their ongoing supervision; powers to address compliance with laws as } \\
\text { well as safety and soundness concerns; and legal protection for supervisors. Arrangements } \\
\text { for sharing information between supervisors and protecting the confidentiality of such } \\
\text { information should be in place. }\end{array}$ \\
\hline Description & See descriptions of principles $1(1)-(6)$ \\
\hline Assessment & See assessments of principles $1(1)-(6)$ \\
\hline Principle 1(1). & $\begin{array}{l}\text { An effective system of banking supervision will have clear responsibilities and objectives for } \\
\text { each agency involved in the supervision of banks. }\end{array}$ \\
\hline Description & $\begin{array}{l}\text { The main legislative basis of financial sector supervision in France is the COMOFI, which } \\
\text { compiles the Banking Act 1984, as amended in } 1996 \text { by the Financial Activity Modernization }\end{array}$ \\
\hline
\end{tabular}


Act (FAMA 1996), the 1999 Savings and Financial Security Act (SFSA 1999), and the 2003 Financial Security Act (Loi de Sécurité Financière, LSF). The COMOFI identifies and clearly regulates the three authorities separately responsible for the three main banking supervisory functions: (a) regulation: Minister in charge of the economy, (b) licensing: CECEI, and (c) supervision: $\mathrm{CB}$. The $\mathrm{BdF}$, the $\mathrm{CB}$, and the $\mathrm{CECEI}$ are closely connected through joint staff and chairmanship (see also CP 1(2)). The legislative framework for financial supervision, as currently compiled in the COMOFI, has been recently revised to take account of new developments and to accommodate institutional streamlining.

The CB is an "independent administrative authority" responsible for the supervision of individual credit institutions (banks and other credit institutions) and individual investment firms with regard to their financial condition, operating practices and compliance with rules and regulations. The $\mathrm{CB}$ has powers to issue injunctions and impose sanctions. The FSA 2003 has expanded the range of sanctions that it could impose on the retail Bureaux de Change, or door-to-door selling of financial services (COMOFI, Articles L.520-3 and L.341-17 respectively).

Under the FSA 2003, the MoE is now directly responsible for setting regulations for credit institutions and investment firms, notably also covering internal controls, minimum capital, and management standards. Previously the authority to issue prudential standards was vested in the CRBF, with formal approval by the MoE; the CRBF has issued a broad network of regulations on all aspects of prudential supervision. In particular, all relevant regulations, for instance on licensing, capital adequacy, liquidity, internal controls, risk diversification, reporting, and other intervention mechanisms have been issued. COMOFI, Art. L.611-1 now vests this authority in the MoE. The MoE also chairs the Comité de la Réglementation Comptable (CRC), which sets accounting rules for, inter alia, banks, investment firms and financial holding companies. Before regulations are issued, the Comité Consultatif de la Législation et de la Réglementation Financières (CCRLF) and the Autorité des Marchés Financiers (AMF) with regard to investment firms should be consulted. Regulations issued by the MoE may not infringe upon the jurisdiction of the AMF (COMOFI, Art. L.614-2). The CCLRF, together with the Comité Consultatif du Secteur Financier (CCSF) are consultative bodies with cross sector membership and with industry membership. The CCSF may issue recommendations and provide advice on general matters relating to the financial sector, upon the initiative of its members, or of the MoE. The CCLRF advises the MoE on all draft regulations with regard to financial matters and draft EU directives, except in areas under the competence of the AMF (COMOFI L 614-3). The composition of the CCRLF is to be established by a decree of the Council of Ministers.

Under the COMOFI (Articles L.612-1-L.612-5), the CECEI is responsible for granting licenses, authorizations, and exemptions for banks and investment firms (except asset management firms). When a license is withdrawn as a sanction, the $\mathrm{CB}$ is the competent authority. The CECEI may obtain advice from the CB on any prudential issues that come up in the licensing process. In practice, both bodies cooperate closely on a day-to-day basis. CECEI authorization must also be obtained in case of significant changes in the situation of the institution. The latter includes restructuring of the shareholder base, changes in corporate legal form, and the appointment of senior managers. The CECEI is consulted by the Conseil de la Concurrence with regard to any change in ownership structure in a bank or investment firm which could affect competitive conditions in the banking or investment industry. The CECEI is also responsible for the inward and outward implementation in France of the EU rules on a single EU banking passport (right of cross border establishment of branches and cross-border provision of services).

Under the new legislative framework, overall surveillance of the financial markets in which banks and investment firms operate is shared between the AMF and the BdF. The AMF, an "independent public authority" with legal personality, issues authorizations to engage in the 
business of an investment firm. Supervision exercised by the AMF focuses on asset management companies, and supervision of compliance with rules of conduct by investment firms and credit institutions. It specifically, (a) verifies information published by companies; (b) issues authorizations for unit trusts and mutual funds; (c) approves the program of operations of banks and investment firms when these intend to provide asset management services; and d) monitors compliance with laws against insider trading and market manipulation. It also participates in the regulation and oversight of European and international markets of financial instruments (COMOFI L.621-1). The BdF has a residual supervisory role in the negotiable debt instrument markets and monitors the unregulated money market.

Separate legislative and institutional arrangements have been made for supervision of the insurance sector. France does not have a unified system of financial sector supervision, although arrangements are in place to assure sufficient cooperation and coordination.

The creation and functioning of a FGD is regulated by the COMOFI Articles L.312-4 through L.312-18. The FGD has legal personality and comprises a system for the reimbursement of deposits which have become unavailable due the illiquidity of the institution. The FGD also covers bank guarantees (cautions, Art. L.313-50), as well as certain forms of investments in securities (COMOFI Articles L.322-1 and L.322-2). The FGD is funded by the participating institutions through contributions and if needed borrowings or guarantees from the members. The FGD is overseen by a Conseil de Surveillance made up of bank members of the FGD, and managed on a day-to-day basis by a directoire appointed by the Conseil de Surveillance. The overall contribution levels are fixed by the MoE, but calculations for individual bank contributions are performed by the $\mathrm{CB}$, as are the pay-out levels. The FGD has an excellent website (www.garantiedesdepots.fr) which provides very clear information how the FGD functions and can be accessed. The mutual banks are also mandatory members of the FGD, and contribute to its funds (COMOFI Art. L.312-7 III). Upon request of the CB, the FGD can intervene in a bank (COMOFI Art. L.312-5 II), when a bank is considered unable to meet its obligations when due. It may also lend to, or take an equity interest in a bank in distress, and is authorized to accept participations in a mutualist structure, in exchange for assistance.

A number of elements have been put in place in the interest of adequate coordination and cooperation between the agencies responsible for aspects of banking supervision, for instance:

- The College des Autorités de Contrôle des entreprises du Secteur Financier (CACESF), replacing the former Comité de Liaison des Autorités Monétaires et Financières (CLAMEF), in which the chairs of the CB, AMF and the CCAMIP exchange information on cross-sector issues, prepare regulatory proposals to improve cross-sector supervision, and facilitate exchange of staff to enhance a cross-sector approach to financial sector supervision (COMOFI Art. L.631-2).

- Chairmanship of the governor of the BdF of the Boards of the CECEI and the CB (COMOFI Articles L 612-3, and L 613-3);

- Representation of the governor of the BdF on the Board of the AMF (COMOFI Art. 621-2);

- Membership of the Boards of the three main supervisory bodies overlaps to a considerable extent (see COMOFI, L.612-3, L.613-3, and L.621-2): all three boards comprise members of the judiciary (Cour de Cassation), representatives of the MINEFI and/or the Trésor; the president of the AMF is member of the CECEI, the $\mathrm{MoE}$ appoints representatives of the state in all three Boards, and civil society is represented on all three Boards;

- Staff regularly rotates between the department of the BdF which services the $\mathrm{CB}$ and CECEI and other departments of the BdF;

- Exchange of information between the CB, CECEI, AMF, CCAMIP, the Comité des 


\begin{tabular}{|c|c|}
\hline & 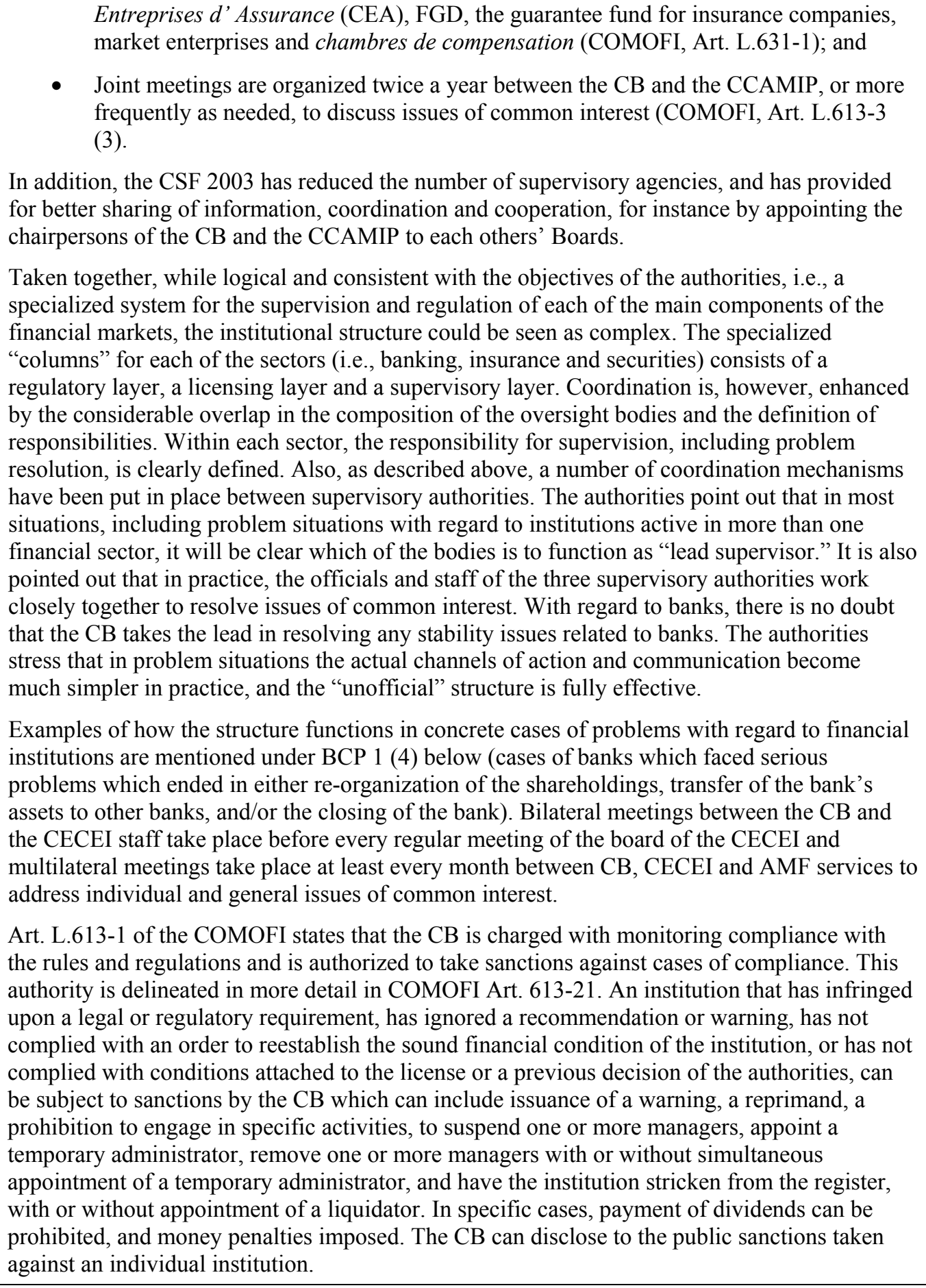 \\
\hline Assessment & Compliant \\
\hline \multicolumn{2}{|l|}{ Comments } \\
\hline Principle 1(2). & Eacn sucn agency snould possess operational independence and adequate resources. \\
\hline Description & $\begin{array}{l}\text { Operating as an "independent administrative authority," i.e., placed outside the regular } \\
\text { administrative structures, the CB is a College of seven members, i.e., the governor of the BdF }\end{array}$ \\
\hline
\end{tabular}


(or his/her representative), "chairman ex officio," the president of the CCAMIP (or his/her representative), the Director of the Trésor of the MINEFI (or his/her representative), and four members appointed by the MoE, including a member of the Conseil d'Etat, a judge of the Cour de Cassation, and two members chosen for their individual expertise in banking and finance. The oversight of the CB is therefore subject to considerable checks and balances. The CB can independently issue instructions to implement regulations set by the MoE, and take a broad range of remedial actions against banks. Licensing authority is vested in the CECEI, which is also the competent authority for a number of administrative decisions with regard to banks, for instance approval of new establishments of banks, changes in management and share ownership. The CECEI is also chaired by the governor of the BdF (or his/her representative). Other members of the board of the CECEI include the Director of the Trésor of the MINEFI (or his/her representative), the Chairperson of the AMF (or his/her representative), the Chairperson of the Managing Board of the Deposit Guarantee Fund (FGD) (or his/her representative, member of the Managing Board), and eight members, including a member of the Conseil d'État, a member of the Cour de Cassation, a senior manager or ex-manager of a credit institution, a senior manager or ex-manager of an investment firm, two trade union officials representing the staff of credit institutions, and two individual experts. Also here, elaborate checks and balances have been put in place with regard to the governance of the agency. Although the chairmanship of the CECEI and the CB is by law performed by the governor of the BdF, who is appointed by the Council of Ministers for a term of six years, once renewable, the secretaries general of these two bodies are appointed for an open term by the $\mathrm{MoE}$, on a proposal of the Governor of the BdF. It is thus assumed, although the COMOFI does not make this explicit, that the Secretaries General of the CB and the CECEI can be removed from their position at any time, for just cause and following the same process. The grounds for removal would not be disclosed.

The BdF plays a pivotal role in the overall governance and the day to day operations of the $\mathrm{CB}$ and the CECEI. The governor also has a seat on the AMF and the CCAMIP. The CB and the CECEI are staffed and provided with logistical support by the BdF, according to an agreement between the $\mathrm{BdF}$ and the $\mathrm{CB}$ (COMOFI Art. 613-7), thus removing direct budgetary interference in the resources of the $\mathrm{CB}$. The governor and two deputy governors of the BdF are appointed by the Council of Ministers for an irrevocable six year, once renewable, term. The remaining six members of the Governing Council of the BdF are also appointed by the Council of Ministers for an irrevocable renewable nine-year term. The fixed term appointments help assure the independence of the $\mathrm{BdF}$, which provides the chair, primary resources and coordinates the oversight of the $\mathrm{CB}$ and the CECEI. Decision making within the CB is by simple majority.

The Director of the Trésor of the MINEFI, also appointed by the Council of Ministers may, as a member of the oversight bodies of the CECEI, request that any matter for decision by the CECEI be postponed for further consideration, thus giving the MINEFI a degree of power over the agenda of the CECEI. In practice, however, there is no significant evidence of interference by the authorities in the operational independence of each agency. Both have the resources needed to carry out their mandate. The budgets of the $\mathrm{CB}$ and the CECEI are part of the budget of the $\mathrm{BdF}$, and are thus independent from direct political interference.

Currently, there are almost 1,200 institutions under supervision of the $\mathrm{CB}$, and the $\mathrm{CB}$ and CECEI together have some 585 staff to perform this task. The staff of the $\mathrm{CB}$ and of the CECEI are highly respected by the industry. They are well trained and the CB has attracted staff with university degrees in the disciplines necessary for the work of the $\mathrm{CB}$ (economists, lawyers, accountants). Effective IT systems are in place to facilitate the work of the CB with regard to individual institutions and in aggregate. Salaries offered, career prospects and benefit levels seem to be sufficiently competitive to withstand competition from the private sector. Furthermore, the $\mathrm{CB}$ has allocated funds for training and inspection travel abroad, and has been able to attract for temporary as well as permanent assignments senior level staff from 


\begin{tabular}{|c|c|}
\hline & rs and academic institutions to help develop its expertise on certain issues. \\
\hline Assessment & Compliant \\
\hline Comments & $\begin{array}{l}\text { The CB and the CECEI are independent administrative authorities, and their governance is } \\
\text { subject to checks and balances that help maintain its operational autonomy. However, they are } \\
\text { clearly not independent from the BdF. Based on the requirements of the Maastricht Treaty, and } \\
\text { reflected in the Charter of the BdF, "the BdF, represented by its governor, deputy governors or } \\
\text { any other member of the Monetary Policy Council shall neither seek nor accept instructions } \\
\text { from the government or any other body in the performance of the tasks arising from its } \\
\text { participation in the European System of Central Banks." The dependence of the CB and the } \\
\text { CECEI on the BdF is not a matter of concern. } \\
\text { Also, given the statutory membership of the governing bodies of the CB and the CECEI, in } \\
\text { particular the role of the Director of the Trésor, and the role of the MINEFI in setting } \\
\text { regulations, it is difficult to assert that policies, plans and processes are set entirely } \\
\text { independently from the government, and that the latter is not involved in operational } \\
\text { supervisory and regulatory activities. Privatization of the government-owned banks has } \\
\text { reduced the scope for conflict of interest, and there is no clear evidence that the participation of } \\
\text { the Trésor in supervision and regulation has been a substantial issue in the past. Nevertheless, } \\
\text { this involvement contrasts with the recent trend in many European countries toward greater } \\
\text { institutional independence of the supervisory and regulatory agencies. } \\
\text { In view of the size of the French banking system, the staff of the CB and the CECEI appears } \\
\text { somewhat limited. Nevertheless, senior management of the CB and the CECEI are firmly of } \\
\text { the view that budgets and staff are adequate, and that excessively rapid expansion could lead to } \\
\text { problems of absorption. }\end{array}$ \\
\hline Principle 1(3). & $\begin{array}{l}\text { A suitable legal framework for banking supervision is also necessary, including provisions } \\
\text { relating to the authorization of banking establishments and their ongoing supervision. }\end{array}$ \\
\hline Description & $\begin{array}{l}\text { The COMOFI (Articles L 612-1, L 511-10 and L 511-15) clearly grants the CECEI the } \\
\text { exclusive authority to issue and withdraw banking licenses. The CECEI may attach conditions } \\
\text { to the license, that go beyond minimum standard prudential requirements. Based on compliance } \\
\text { with the terms and conditions of the original license, or when the institution requests, the } \\
\text { CECEI can withdraw the license. Only the CB is authorized to withdraw the license as a } \\
\text { sanction. } \\
\text { The COMOFI also sets out the conditions that must be met for the issuance of a license, } \\
\text { including the program of operations (business plan) of the bank, its proposed technical and } \\
\text { financial resources, the suitability (fit and properness) of the managers and contributors of the } \\
\text { bank's capital and where applicable their guarantors. Any substantive change in the way a bank } \\
\text { meets the condition must receive prior approval of the CECEI. This can include the acquisition } \\
\text { of capital shares that cross or fall below a threshold of 10, 20, 33, and } 50 \text { percent (the latter as a } \\
\text { measure of full control over the bank), changes in the legal form of the institution, and } \\
\text { redefinition of the scope of operations. } \\
\text { The CECEI is to be notified in advance of intentions of banks outside France to open } \\
\text { representative, liaison or information offices in France, must be informed immediately when } \\
\text { persons are appointed to positions with powers to determine the policies of a bank, and after } \\
\text { any changes to the capital structure of the bank. } \\
\text { The CECEI is also the implementing agency for France of the single European banking } \\
\text { passport, vets French banking institutions' plans to set up branches in other EU countries, and } \\
\text { must be notified in case of cross border provision of services in other EU countries. } \\
\text { Based on the COMOFI (Arts. L.613 vv), the CB has full supervisory powers over licensed } \\
\text { institutions, including the powers to gather information from banks in the form of periodic }\end{array}$ \\
\hline
\end{tabular}




\begin{tabular}{|c|c|}
\hline & $\begin{array}{l}\text { reports, ad-hoc information requests, off-site analysis, on-site inspections, and imposition of } \\
\text { sanctions including withdrawal of the license. } \\
\text { Under COMOFI Art. L.611-1 vv., the key regulatory powers are granted to the MoE. The MoE } \\
\text { may issue regulations on capital of banks, acquisition of shareholdings, setting up of networks, } \\
\text { acquisition of equity participations, solvency, liquidity, financial condition, disclosure of } \\
\text { information to be sent to the supervisory authorities, rules on types and conditions of credit, } \\
\text { deposit protection, rules on accounting, internal controls, IT, and safety of information. } \\
\text { Regulations are adopted after consultation of the CCLRF. In case the CCLRF issues a negative } \\
\text { opinion on the proposed regulation, the MoE is obliged to seek a second opinion of the CCLRF } \\
\text { before the regulation can be adopted. }\end{array}$ \\
\hline Assessment & Compliant \\
\hline Comments & $\begin{array}{l}\text { New regulations are generally prepared in close cooperation with the banking industry and thus } \\
\text { implemented smoothly. }\end{array}$ \\
\hline Principle 1(4). & $\begin{array}{l}\text { A suitable legal framework for banking supervision is also necessary, including ... powers to } \\
\text { address compliance with laws as well as safety and soundness concerns. }\end{array}$ \\
\hline Description & 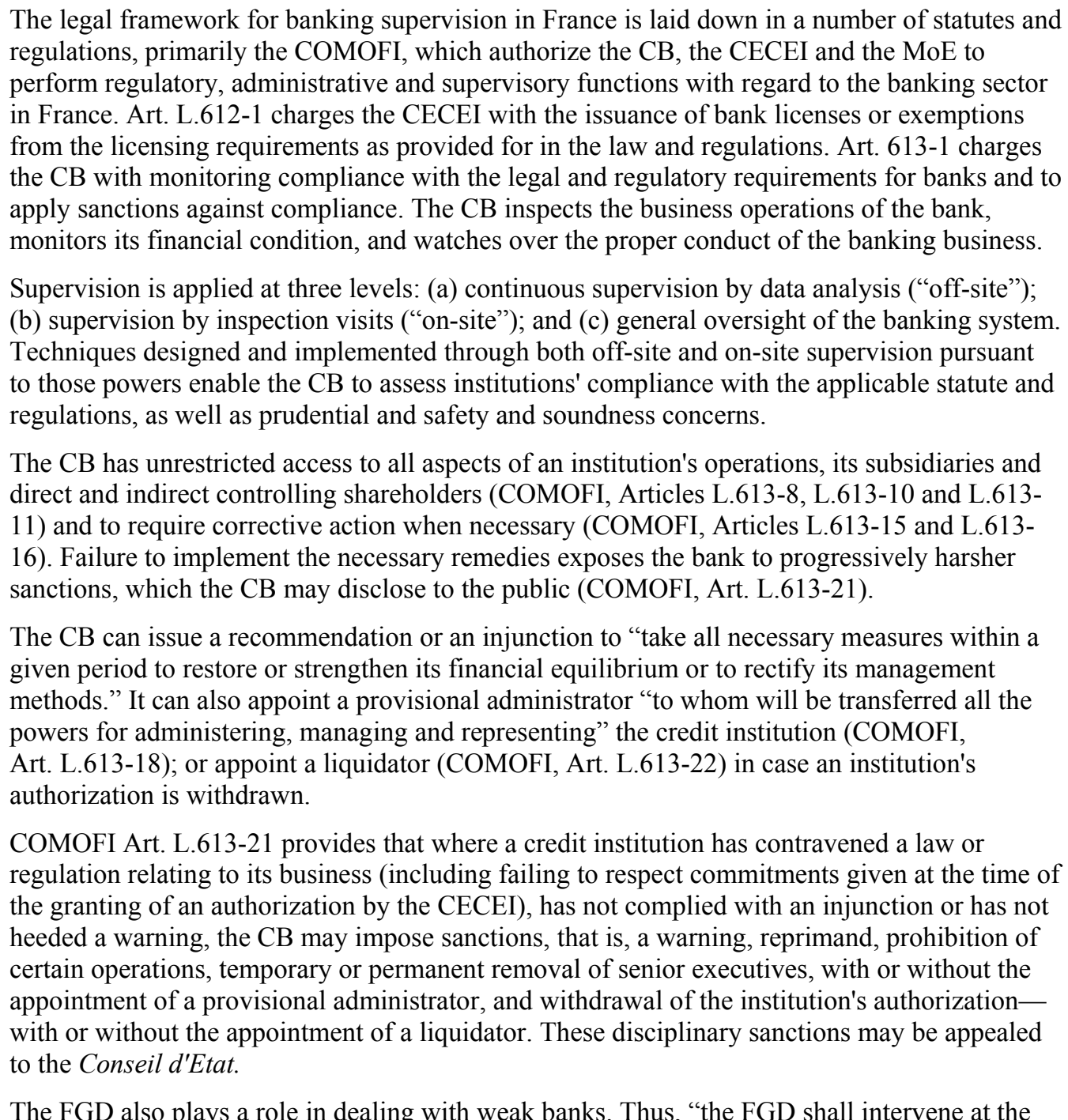 \\
\hline
\end{tabular}




\begin{tabular}{|c|c|}
\hline & 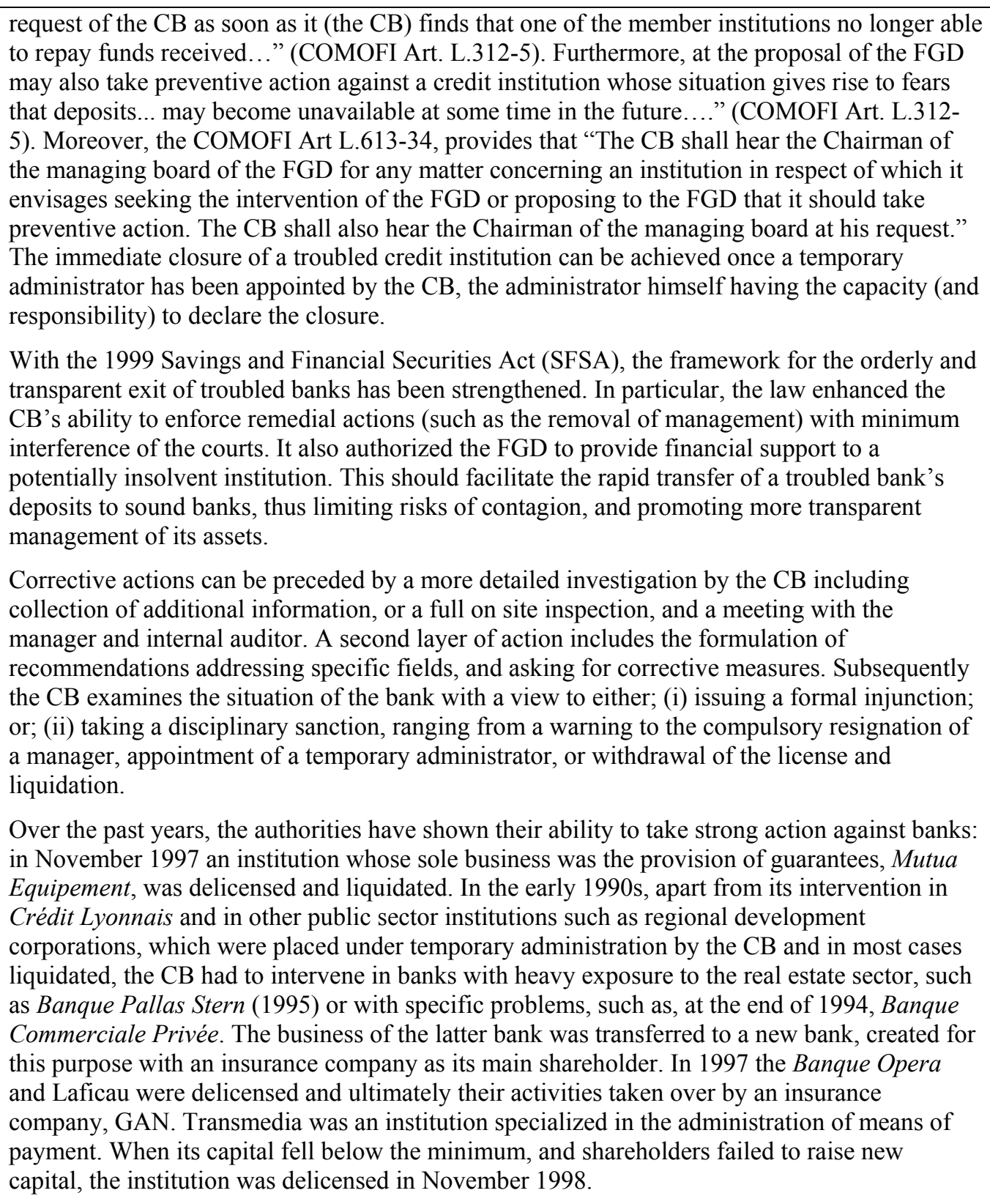 \\
\hline Assessment & Compliant \\
\hline \multicolumn{2}{|l|}{ Comments } \\
\hline Principle 1(5). & $\begin{array}{l}\text { A suitable legal framework for banking supervision is also necessary, including... legal } \\
\text { protection for supervisors. }\end{array}$ \\
\hline Description & $\begin{array}{l}\text { The CB and the CECEI operate under general French administrative law. As neither are legal } \\
\text { persons, they cannot incur liability in their own right. Actions against the acts or omissions of } \\
\text { the CB or the CECEI need to be brought against the French state. In cases where a suit is } \\
\text { brought against an official of the CB or the CECEI, the case is redirected against the state. } \\
\text { Furthermore, the state may incur liability by the CB's or CECEI's acts or omissions which can } \\
\text { be qualified as serious negligence (confirmed on two occasions in the last two years). }\end{array}$ \\
\hline
\end{tabular}




\begin{tabular}{|c|c|}
\hline & $\begin{array}{l}\text { Senior officials and employees of the CB, CECEI, and of the BdF's Credit Institutions and } \\
\text { Investment Firms Division are protected by general principles of administrative law applicable } \\
\text { to the persons in charge of a public function. A Public Servant may not incur personal liability } \\
\text { for an administrative error committed in the exercise of his/her public office. In those instances } \\
\text { where such senior officials and employees are pursued for actions taken in the course of their } \\
\text { duties, they are entitled to claim their costs from their employer. Only in case of an alleged } \\
\text { personal fault (e.g., abuse of a client) or criminality, the Public Servant may be held liable. } \\
\text { Nonetheless, should he/she be able to argue convincingly that no personal fault is involved, } \\
\text { he/she may request the employer to cover the legal expenses. }\end{array}$ \\
\hline Assessment & Compliant \\
\hline Comments & $\begin{array}{l}\text { The collegial nature of the CB's decision-making provides a further layer of protection against } \\
\text { suits aimed at any one of its members. Moreover, both the CB and the staff of its General } \\
\text { Secretariat are adequately protected against the legal costs of defending legitimate actions. } \\
\text { Thus, legal protection for supervisors is satisfactory at present. }\end{array}$ \\
\hline Principle 1(6). & $\begin{array}{l}\text { Arrangements for sharing information between supervisors and protecting the confidentiality } \\
\text { of such information should be in place. }\end{array}$ \\
\hline Description & 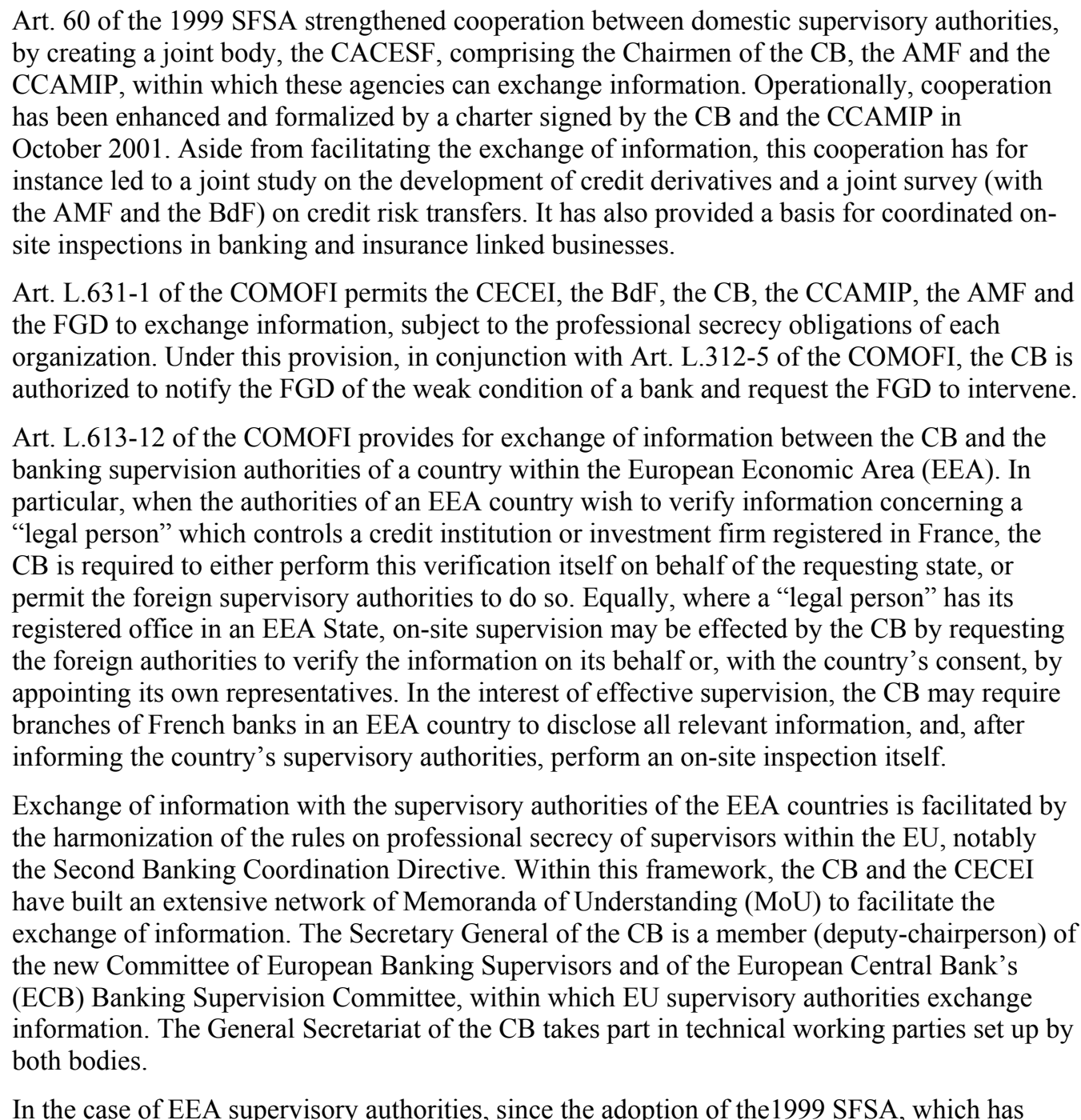 \\
\hline
\end{tabular}




\begin{tabular}{|c|c|}
\hline & 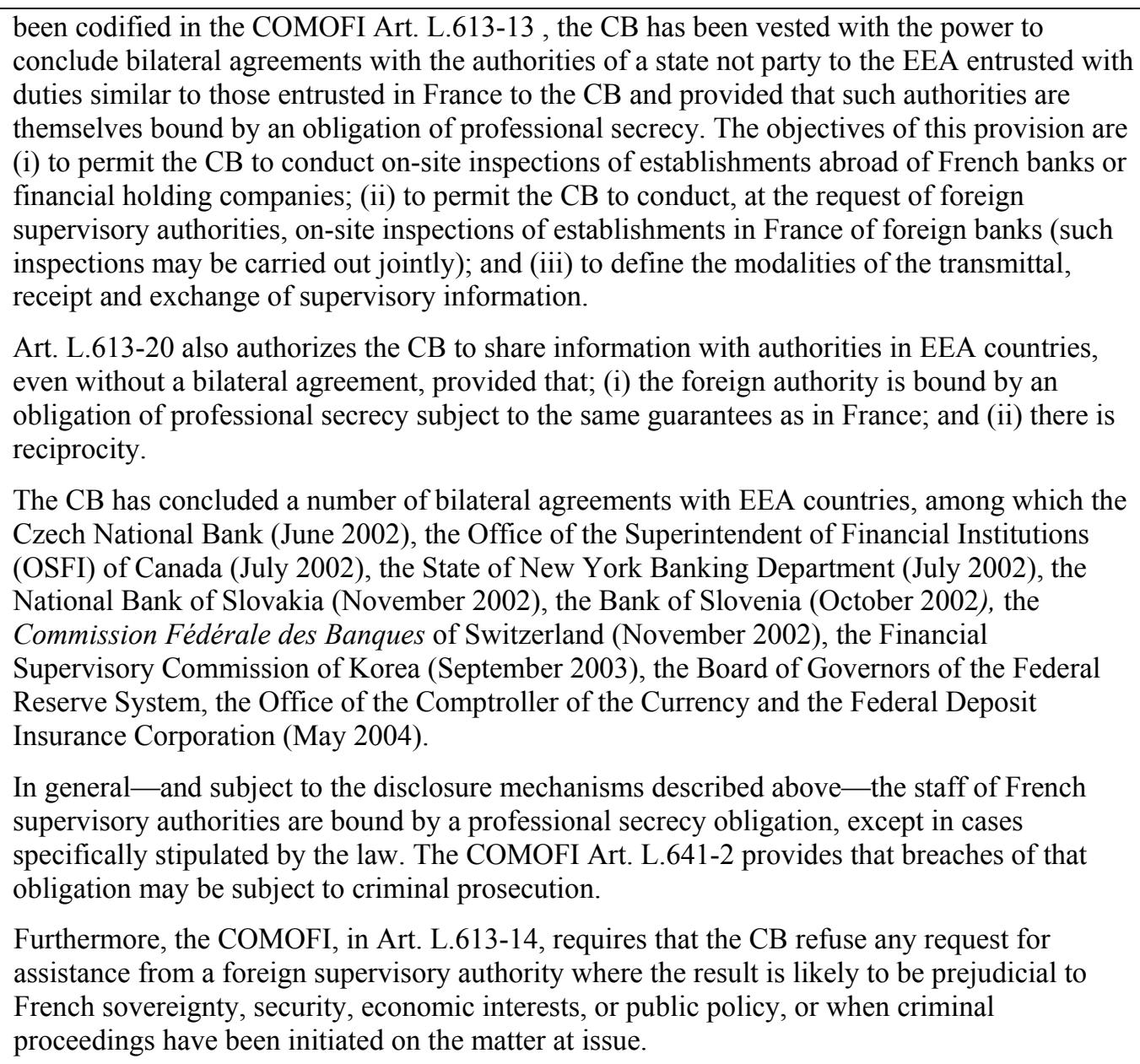 \\
\hline Assessment & Compliant \\
\hline Comments & \\
\hline Principle 2. & $\begin{array}{l}\text { Permissible activities } \\
\text { The permissible activities of institutions that are licensed and subject to supervision as banks } \\
\text { must be clearly defined, and the use of the word "bank" in names should be controlled as far as } \\
\text { possible. }\end{array}$ \\
\hline Description & $\begin{array}{l}\text { France has a broader definition of "credit institution" than other EU countries (the definition of } \\
\text { a bank under the Second Banking Coordination Directive includes the elements deposit taking } \\
\text { and granting of credits for the bank's own account). } \\
\text { In Art. L.611-1 of the COMOFI, "credit institutions" are defined as "legal persons carrying out } \\
\text { banking operations as their usual business." "Banking operations" are then defined as any of } \\
\text { the following three main categories of activities: the "receipt of funds from the public, credit } \\
\text { operations, and making available to customers or managing means of payment." Art. L.511-9 } \\
\text { then further refines the definition of "credit institutions," by setting out the various types of } \\
\text { banking operations in which each category (i.e., "banks," "mutual or co-operative banks," } \\
\text { "savings and provident institutions," "municipal credit banks," "financial companies" or } \\
\text { "specialized financial institutions") is permitted to engage. The definition of credit institutions } \\
\text { thus includes institutions that provide credits, but do not collect deposits. This helps to explain } \\
\text { the rather high number of institutions licensed by the CECEI and supervised by the CB. }\end{array}$ \\
\hline
\end{tabular}




\begin{tabular}{|c|c|}
\hline & $\begin{array}{l}\text { Art. L.511-5 of the COMOFI states that "it shall be prohibited for any person other than a } \\
\text { credit institution to carry out banking operations on a regular basis." Art. L.531-10 of the } \\
\text { COMOFI provides that "no one other than an investment service provider may provide } \\
\text { investment services to third parties as its usual business." The COMOFI, in Arts. L.511-8 and } \\
\text { L 531-11, prohibit - under threat of criminal liability (see COMOFI Articles L.571-3 and } \\
\text { L. } 573-2 \text { ) - the use of business names, advertising or any expression wrongfully implying that, } \\
\text { or causing confusion whether an institution is an authorized credit institution. } \\
\text { The CECEI's authority under Art. 511-10 of the COMOFI to impose terms and conditions on a } \\
\text { banking license, and that of the CB to impose sanctions on an institution where such terms and } \\
\text { conditions are not respected (COMOFI Art. L.613-21), allow considerable control by the } \\
\text { authorities over the nature of a bank's business. }\end{array}$ \\
\hline Assessment & Compliant \\
\hline Comments & \\
\hline Principle 3. & $\begin{array}{l}\text { Licensing criteria } \\
\text { The licensing authority must have the right to set criteria and reject applications for } \\
\text { establishments that do not meet the standards set. The licensing process, at a minimum, should } \\
\text { consist of an assessment of the banking organization's ownership structure, directors and } \\
\text { senior management, its operating plan and internal controls, and its projected financial } \\
\text { condition, including its capital base; where the proposed owner or parent organization is a } \\
\text { foreign bank, the prior consent of its home country supervisor should be obtained. }\end{array}$ \\
\hline Description & 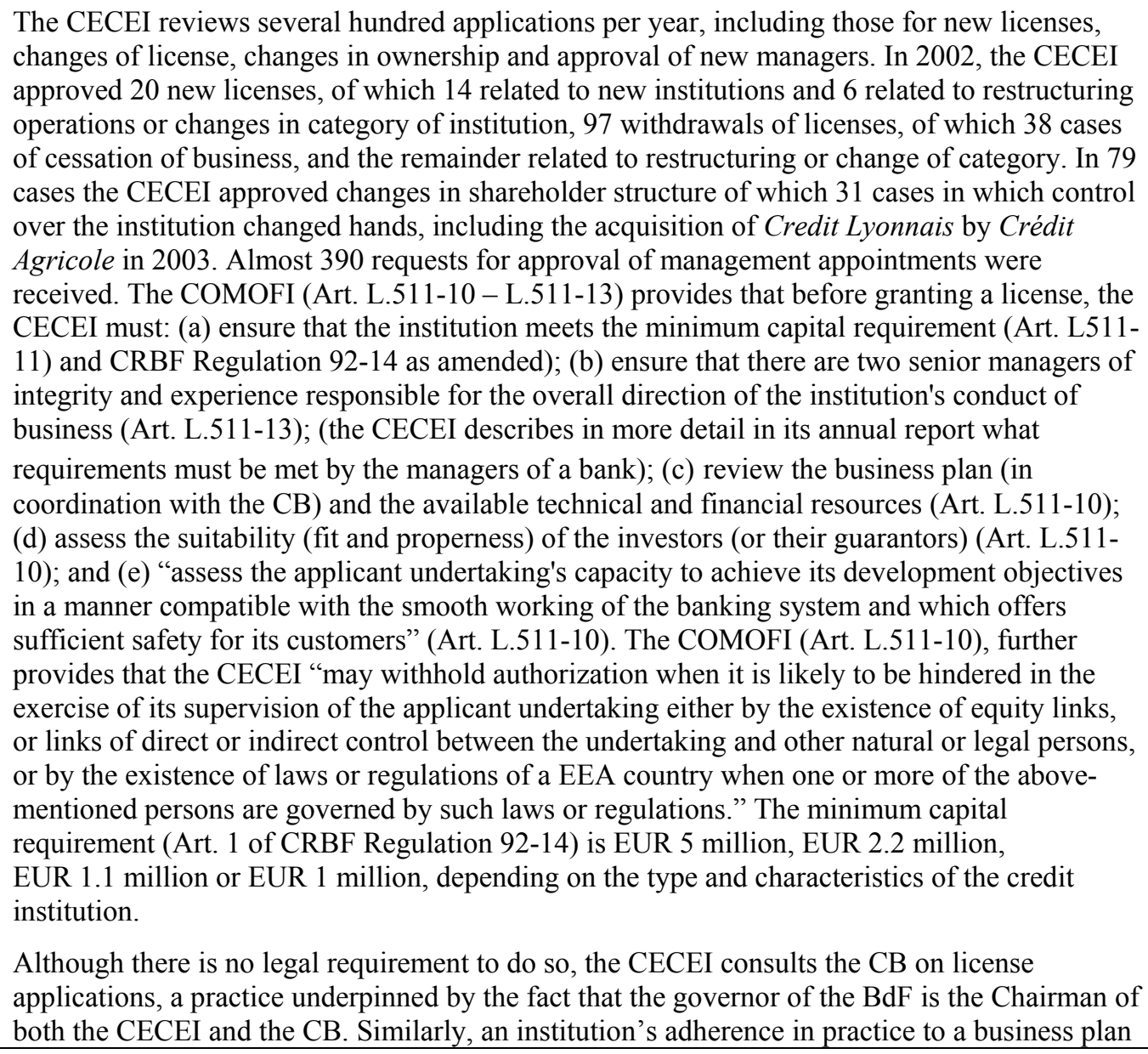 \\
\hline
\end{tabular}




\begin{tabular}{|c|c|}
\hline & $\begin{array}{l}\text { submitted to the CECEI is determined by the CB during its ongoing supervisory activities. } \\
\text { The information needed to take a decision on the granting of the license is largely collected } \\
\text { through CECEI's application form ("Authorization Dossier") which requests specific } \\
\text { information on: (a) management; (b) proposed management and control procedures; } \\
\text { (c) strategy; and (d) the origin of the initial capital. The CECEI may insist on increased initial } \\
\text { capital in light of the business plan. Part IV of the Authorization Dossier, entitled "Declarations } \\
\text { to be forwarded by the Contributors of Capital" requires shareholders to confirm that they are } \\
\text { aware of Art. L.511-42 of the COMOFI, which allows the governor of the BdF, in his capacity } \\
\text { as chairman of the CB, to call upon shareholders to contribute further capital if needed, in light } \\
\text { of the financial condition of a credit institution. } \\
\text { A centralized database on "fit and proper" characteristics of banking and financial institutions } \\
\text { managers (FIDEC) has been created and is operational. }\end{array}$ \\
\hline Assessment & Compliant \\
\hline Comments & $\begin{array}{l}\text { Although a formal requirement to do so is not in place, the CECEI routinely requests evidence } \\
\text { of a EEA home supervisor's prior consent to establish a subsidiary in France. The introduction } \\
\text { of a formal regulation on this matter would be desirable. }\end{array}$ \\
\hline Principle 4. & $\begin{array}{l}\text { Ownership } \\
\text { Banking supervisors must have the authority to review and reject any proposals to transfer } \\
\text { significant ownership or controlling interests in existing banks to other parties. }\end{array}$ \\
\hline Description & 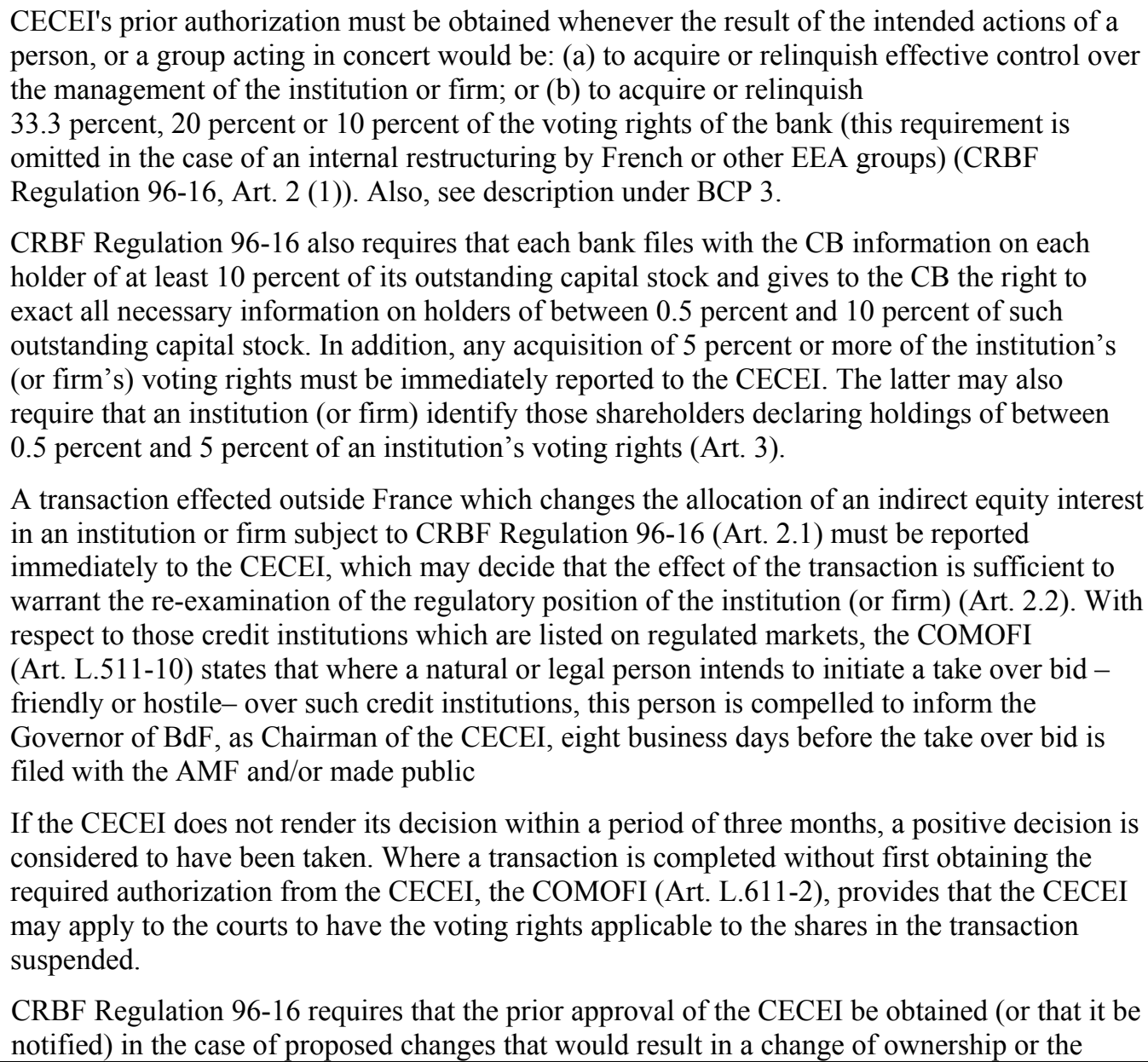 \\
\hline
\end{tabular}




\begin{tabular}{|c|c|}
\hline & $\begin{array}{l}\text { exercise of voting rights over threshold levels or a change in controlling interest. Given the } \\
\text { "collegiality" of the French system of banking supervision, there is close collaboration between } \\
\text { the CECEI and the CB on any such proposed changes. The CECEI may reject any request for } \\
\text { approval of a change in ownership changes, but must state its reasons. }\end{array}$ \\
\hline Assessment & Compliant \\
\hline Comments & \\
\hline Principle 5. & $\begin{array}{l}\text { Investment criteria } \\
\text { Banking supervisors must have the authority to establish criteria for reviewing major } \\
\text { acquisitions or investments by a bank and ensuring that corporate affiliations or structures do } \\
\text { not expose the bank to undue risks or hinder effective supervision. }\end{array}$ \\
\hline Description & 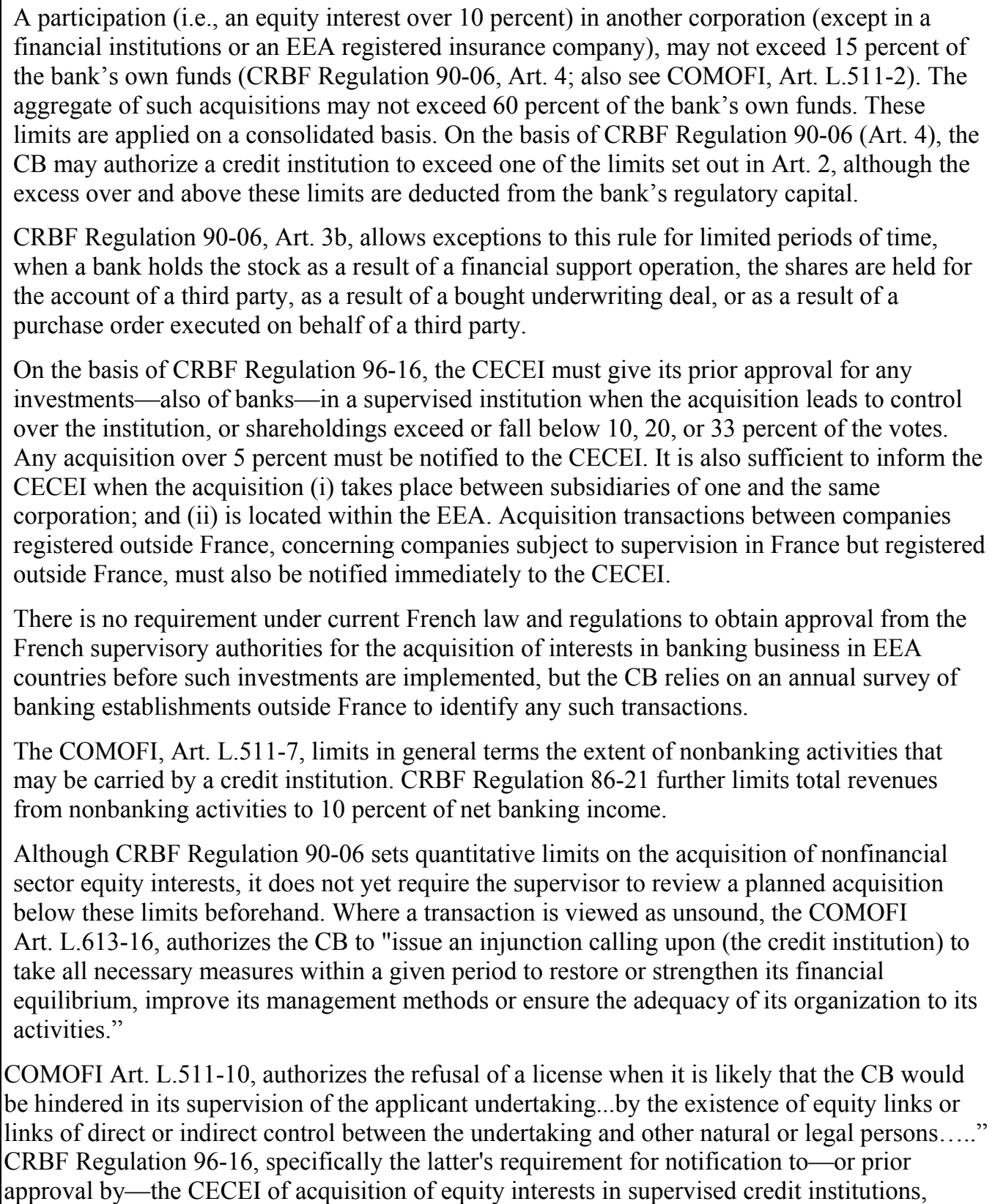 \\
\hline
\end{tabular}




\begin{tabular}{|c|c|}
\hline & $\begin{array}{l}\text { allows the CECEI to reject corporate structures that present undue risk to the credit institution or } \\
\text { create an impediment against effective supervision by the CB. The CB is also aided by CRBF } \\
\text { Regulation 90-06, in particular the quantitative limits set out with regard to nonfinancial sector } \\
\text { equity interests. }\end{array}$ \\
\hline Assessment & Largely compliant \\
\hline \multirow[t]{2}{*}{ Comments } & $\begin{array}{l}\text { With the implementation of Directive 2002/87/EC ("Financial Conglomerates Directive"), this } \\
\text { prior consultation procedure will be extended to cover equity interests taken in insurance } \\
\text { companies, either in France or in any other EEA country. }\end{array}$ \\
\hline & $\begin{array}{l}\text { In order to reinforce the French regulation in this respect, revision of the CRBF Regulation } \\
\text { 96-16 is under preparation and will be adopted by the MoE once the new CCLRF is appointed, } \\
\text { This amendment will require prior approval of the CECEI for the acquisition of nonfinancial } \\
\text { equity holdings as well as for the opening by French banks of branches or subsidiaries outside } \\
\text { the EEA. Improvement in compliance with this principle is therefore underway. }\end{array}$ \\
\hline \multirow[t]{2}{*}{ Principle 6.} & Capital adequacy \\
\hline & $\begin{array}{l}\text { Banking supervisors must set minimum capital requirements for banks that reflect the risks the } \\
\text { bank undertakes, and must define the components of capital, bearing in mind its ability to } \\
\text { absorb losses. For internationally active banks, these requirements must not be less than those } \\
\text { established in the Basel Capital Accord. }\end{array}$ \\
\hline \multirow[t]{3}{*}{ Description } & $\begin{array}{l}\text { Laws and regulations require credit institutions to maintain both an absolute level of minimum } \\
\text { capital (CRBF Regulation 92-14, Art. 1) and a minimum ratio of own funds to risk weighted } \\
\text { assets (CRBF Regulation 91-05 and 95-02). Art. L.511-40 of the COMOFI states that all credit } \\
\text { institutions must be able at any time to prove that their assets exceed their liabilities by an } \\
\text { amount at least equal to the minimum capital. Moreover, according to CRBF Regulation } 91-05 \\
\text { and 95-02, credit institutions shall observe at any time a minimum } 8 \text { percent ratio of own funds } \\
\text { to risk weighted assets, on a consolidated basis, also covering market risk exposure and off } \\
\text { balance sheet exposure. The capital adequacy requirements apply to all types of credit } \\
\text { institutions, whatever their legal form or their structure. Financial holding companies are also } \\
\text { subject to the same capital requirements. In addition, the CB can require (an) institution(s) to } \\
\text { meet requirements on a solo or sub-consolidated basis, when allocation of capital within the } \\
\text { group is perceived to be unbalanced or inadequate (see Principles } 18 \text { and 20) and it may refuse } \\
\text { to include certain resources in the calculation of own funds when certain conditions are not } \\
\text { met. }\end{array}$ \\
\hline & $\begin{array}{l}\text { Components of capital and own funds and the method for their calculation are defined in CRBF } \\
\text { Regulation } 90-02 \text { and further detailed in the CB Instructions } 90-01 \text { and } 96-01 \text {. Tier } 1 \text { capital is } \\
\text { restricted to core capital and general reserves. Provided they meet strict requirements with } \\
\text { regard of stability and capacity of absorbing losses, certain subordinated debt instruments } \\
\text { (Tier 2) are taken into account but are limited in importance. Tier } 3 \text { instruments are strictly } \\
\text { limited to the coverage of market risks (transposition of the Basel market risk amendment } \\
\text { of 1993). }\end{array}$ \\
\hline & $\begin{array}{l}\text { French requirements on capital adequacy are fully in line with the Basel Capital Accord and } \\
\text { European legislation. The latter includes both balance sheet and off balance sheet } \\
\text { commitments, weighted according to the Basel Capital Accord rules. The COMOFI (Art. } \\
\text { L.613-16), moreover, enables the CB to take disciplinary action against institutions that fail to } \\
\text { meet minimum requirements ; the CECEI and the CB may also require higher solvency ratios } \\
\text { than this legal minimum whenever they deem this justified by specific risk characteristics of a } \\
\text { credit institution. This power can be exercised in full discretion, no binding policy or line of } \\
\text { conduct having been published by the CECEI or the CB in this respect. Moreover, whenever } \\
\text { overall weaknesses or negative trends should appear in the financial system or with regard to } \\
\text { significant types of activity, the governor of the BdF can issue a formal warning to the }\end{array}$ \\
\hline
\end{tabular}




\begin{tabular}{|c|c|}
\hline & $\begin{array}{l}\text { profession (as happened for real estate financing). } \\
\text { Capital adequacy requirements for banks' market risk exposures are set according to the } \\
\text { standardized approach (CRBF Regulation 95-02). While most French banks use the } \\
\text { standardized method to determine the capital charges incumbent upon their market risk } \\
\text { exposures, major banks use their own internal models. The adequacy and effectiveness of these } \\
\text { models must be assessed and approved by the CB, which has a specialist team for assessing } \\
\text { their adequacy and effectiveness (see Principle 16). } \\
\text { At least semi-annual comprehensive reporting on solvency to the CB is mandatory. In case a } \\
\text { credit institution fails to meet the requirements, or whenever the evolution of ratios puts it at } \\
\text { risk of shortfalls, the CB may require the bank to take corrective action. }\end{array}$ \\
\hline Assessment & Compliant \\
\hline Comments & $\begin{array}{l}\text { France intends to implement the new Basel Capital Accord (Basel II) in due course, and to } \\
\text { permit banks to apply the internal ratings based (IRB) capital adequacy calculation methods } \\
\text { and advanced operational risk capital adequacy charge calculations envisaged in the new } \\
\text { Accord. Several working groups involving on-site and off-site supervisors have been put in } \\
\text { place in order to prepare future implementation of the Accord. In } 2003 \text {, the CB has also } \\
\text { engaged in a series of Information Missions with major French groups in order to evaluate the } \\
\text { state of preparation of their IRB systems. French banks have participated in the quantitative } \\
\text { impact studies of the Basel Committee to test the effect of the new proposals on banks' capital } \\
\text { adequacy levels. }\end{array}$ \\
\hline Principle 7. & $\begin{array}{l}\text { Credit policies } \\
\text { An essential part of any supervisory system is the independent evaluation of a bank's policies, } \\
\text { practices and procedures related to the granting of loans and making of investments and the } \\
\text { ongoing management of the loan and investment portfolios. }\end{array}$ \\
\hline Description & $\begin{array}{l}\text { CRBF Regulation } 97-02 \text { (as amended by Regulation 2001-01 and Regulation 2004-02) sets } \\
\text { standards for the internal control structure of credit institutions and investment firms supervised } \\
\text { by the CB. It indicates that it is a key responsibility for the bank's management and board to } \\
\text { provide for proper credit administration, risk measurement and monitoring, and to supervise the } \\
\text { effectiveness of the policies and procedures established for this purpose (Art.s 18-24). Internal } \\
\text { controls should include a control system for operations and internal procedures, the } \\
\text { organization of accounting and information processing systems, risk and result measurement } \\
\text { systems, risk monitoring and supervision systems, and a documentation and information } \\
\text { system. Each credit institution must set up a consolidated system adapted to the nature and } \\
\text { volume of its activities, its size, its establishments and the various types of risk to which it is } \\
\text { exposed. } \\
\text { Specifically, the regulation requires clear criteria to be set for the granting of loans according to } \\
\text { their nature and importance, and to conduct a comprehensive forecast analysis of credit risk } \\
\text { and verification after the fact of the profitability of credit operations. All operations must be } \\
\text { analyzed by a unit that is independent of the operational entity, and lending or commitment } \\
\text { decisions must be taken by two persons. For transactions of a certain nature or size, the two } \\
\text { persons must occupy senior positions. Commitments must subsequently be subject to strict and } \\
\text { frequent monitoring and analysis. } \\
\text { The responsibilities of the decision-making body, executive body, and of internal and external } \\
\text { auditors are clearly defined. Lending criteria should be set by top management and compliance } \\
\text { controlled by the internal auditors. The regulation lays particular emphasis on the need to } \\
\text { involve the decision-making body, with the optional assistance of an audit committee, in } \\
\text { setting lending and loss limits, and to inform it of the extent of exposure, the main } \\
\text { characteristics and concentration of risks, doubtful debts, and the results of the internal } \\
\text { auditor's work. Each year, credit institutions must provide to the supervisory authorities a }\end{array}$ \\
\hline
\end{tabular}




\begin{tabular}{|c|c|}
\hline & $\begin{array}{l}\text { report on the conditions in which internal control is conducted and on the measurement and } \\
\text { monitoring of their exposure. } \\
\text { The assessment of the credit process and risk management is conducted in large part through } \\
\text { off-site supervision (including through a study of the abovementioned annual report), through } \\
\text { the analysis of credit portfolios using the ratings produced by rating agencies and the BdF, and } \\
\text { through regular meetings with bank managers. It is also a main area of attention in regular on- } \\
\text { site supervision. As described below under Principle 16, several external sources (national } \\
\text { credit register, ratings by the BdF and by rating agencies, access to a national register of } \\
\text { published annual accounting statements) allow CB inspectors to use information from multiple } \\
\text { sources to help assess banks' systems and procedures, including bank' own credit risk } \\
\text { assessment. On-site inspections also give adequate attention to the total exposure of debtors } \\
\text { and to large exposures. }\end{array}$ \\
\hline Assessment & Compliant \\
\hline Comments & $\begin{array}{l}\text { For large segments of the credit market, especially for credit to small and medium enterprises, } \\
\text { the toughness of competition between banks appears to have often impaired banks' capacity to } \\
\text { secure margins that adequately reflect the credit risk involved, particularly in the event of an } \\
\text { economic downturn. While the BdF and the CB have repeatedly stressed such risks (including } \\
\text { through the publication of a White Paper (Livre Blanc) on this matter), and have instituted a } \\
\text { procedure for notifying all credits with abnormal margins to the CB, only limited results have } \\
\text { been obtained so far. This issue is revisited under Principle } 8 \text {. }\end{array}$ \\
\hline Principle 8. & $\begin{array}{l}\text { Loan evaluation and loan loss provisioning } \\
\text { Banking supervisors must be satisfied that banks establish and adhere to adequate policies, } \\
\text { practices and procedures for evaluating the quality of assets and the adequacy of loan loss } \\
\text { provisions and reserves. }\end{array}$ \\
\hline Description & 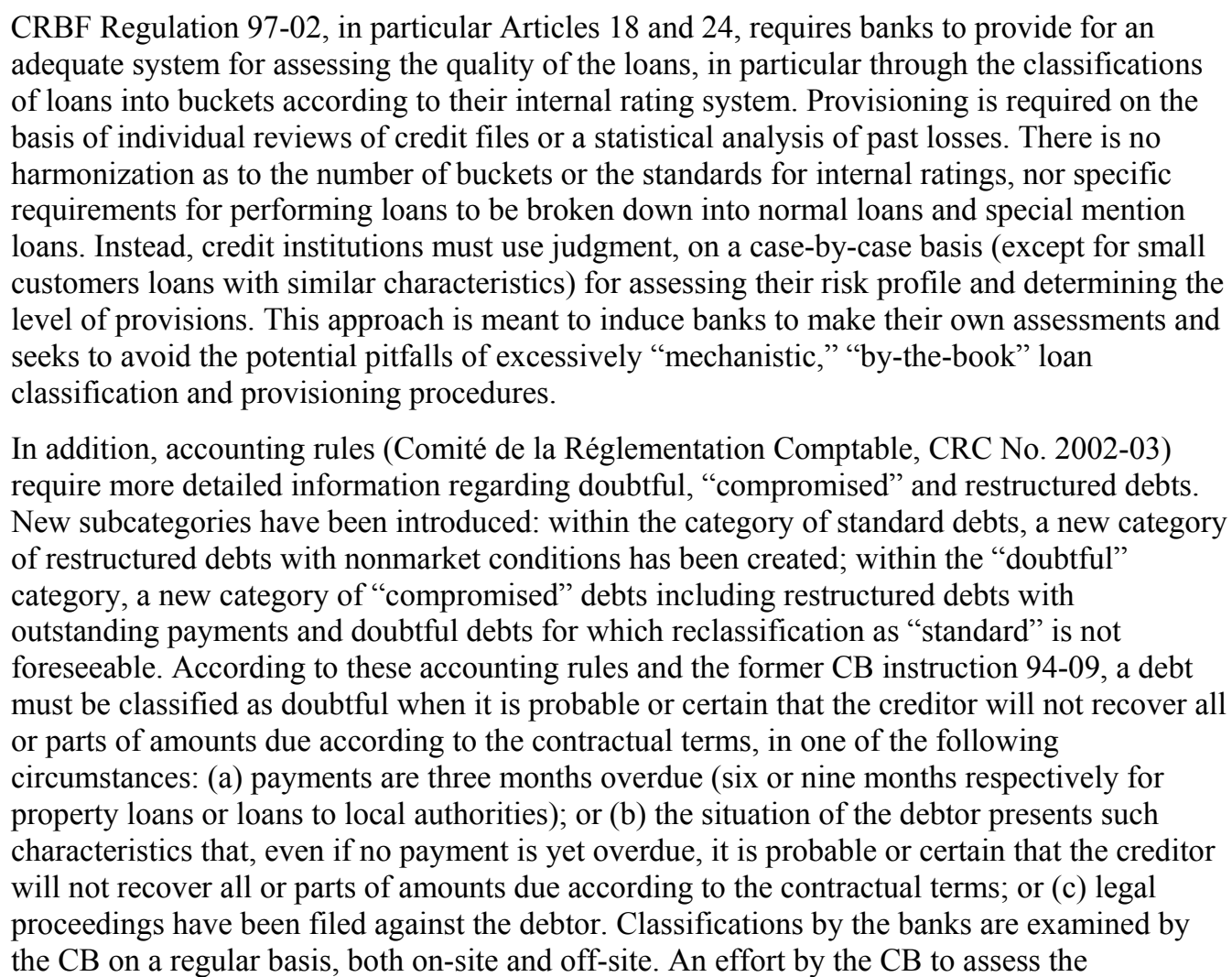 \\
\hline
\end{tabular}




\begin{tabular}{|c|c|}
\hline & 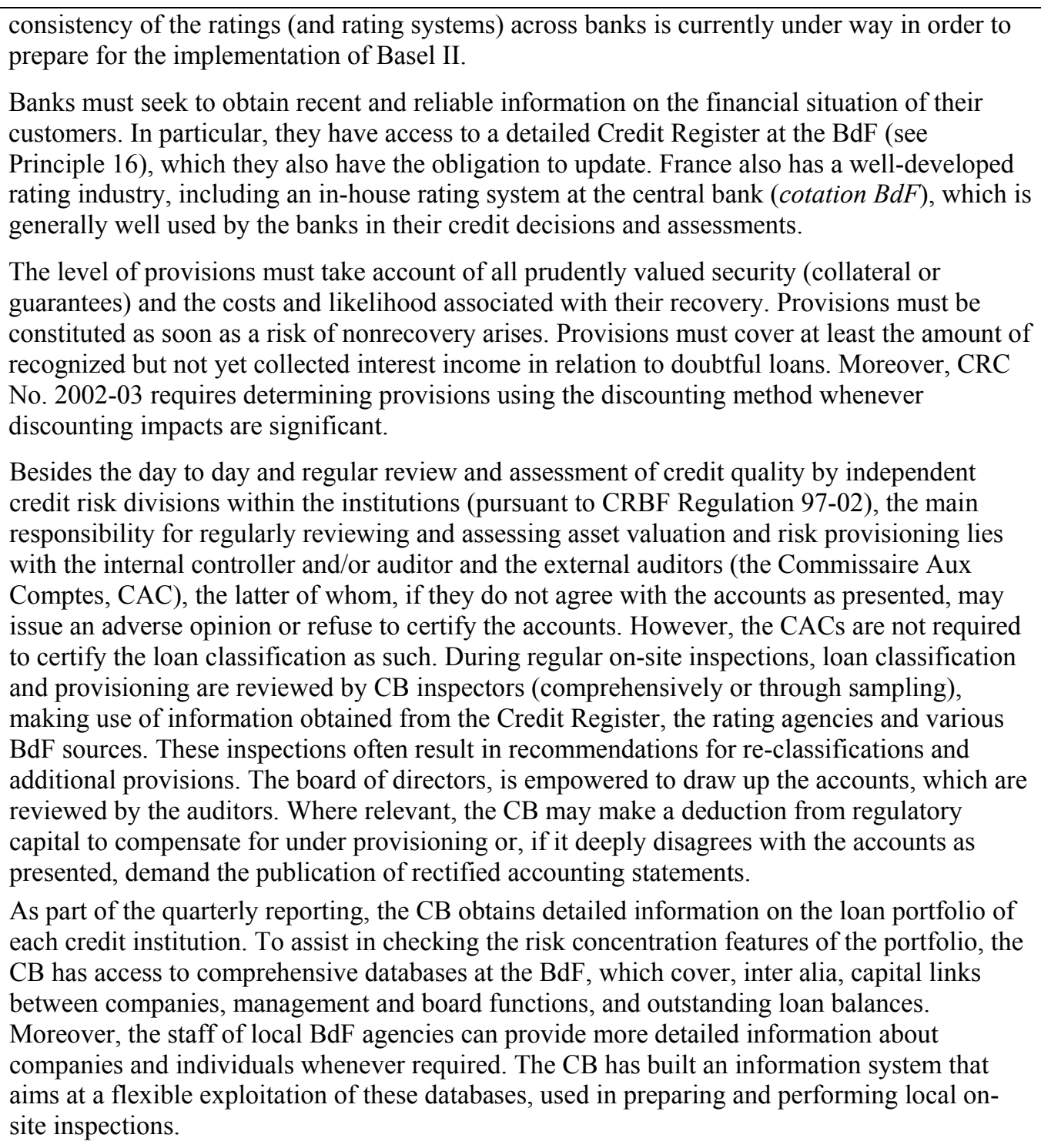 \\
\hline Assessment & Compliant \\
\hline Comments & $\begin{array}{l}\text { As the CB strives to encourage prudent provisioning, some banks build up, in addition to } \\
\text { specific loan loss provisions relating to doubtful loans-the amount of which can be determined } \\
\text { on an individual or statistical basis, according to Regulation } 2002-03 \text {, different types of general } \\
\text { loan loss provisions that are not expressly provided for in the accounting rules and which are } \\
\text { intended to cover credit risk related to nondoubtful loans. These additions to reserves are } \\
\text { mostly not tax-deductible. } \\
\text { Some loan loss provisions are recognized on the liability side of the balance sheets and are } \\
\text { classified as contingencies and loss provisions, based on comprehensive estimations rather than } \\
\text { statistical calculations; these provisions comprise provisions related to overall risks linked to } \\
\text { particular countries or economic sectors. Others are recognized as a reduction of the carrying } \\
\text { amount of the assets and are statistical provisions relating to homogeneous groups of loans, } \\
\text { particularly in the field of consumer credits; they constitute a form of dynamic provisioning. } \\
\text { However, the build-up of general loan loss provisions is not systematic, nor uniform, especially } \\
\text { on the liability side. }\end{array}$ \\
\hline
\end{tabular}




\begin{tabular}{|c|c|}
\hline & $\begin{array}{l}\text { A system of general forward-looking (dynamic) provisioning-favored by the French authorities } \\
\text { for the large numbers of standardized credits, based on historical and statistical analysis of } \\
\text { large credit portfolios, was discussed at the international level notably with the IASB, which } \\
\text { introduced such a proposal in its exposure draft on amending IAS } 39 \text { issued in June } 2002 \text {. } \\
\text { France, which has been somewhat of a precursor in this area with discussions on this issue } \\
\text { starting as early as mid-1998, published an exposure draft proposing to introduce this } \\
\text { provisioning approach in March 2002. However, the IASB finally decided to maintain an } \\
\text { "incurred loss model" in its final amended IAS } 39 \text { issued in December 2003. But it introduced } \\
\text { the possibility to use bankers' expert judgment to estimate or adjust amounts of impairment } \\
\text { loss. This is a first step toward recognition of a more forward looking provisioning for banks. }\end{array}$ \\
\hline \multirow[t]{2}{*}{ Principle 9.} & Large exposure limits \\
\hline & $\begin{array}{l}\text { Banking supervisors must be satisfied that banks have management information systems that } \\
\text { enable management to identify concentrations within the portfolio and supervisors must set } \\
\text { prudential limits to restrict bank exposures to single borrowers or groups of related borrowers. }\end{array}$ \\
\hline \multirow[t]{4}{*}{ Description } & $\begin{array}{l}\text { CRBF Regulation } 93-05 \text { and CB Instruction } 2000-07 \text { limit large exposures to a single borrower } \\
\text { or group of connected borrowers to } 25 \text { percent of the bank's own funds. This limit is to be } \\
\text { applied on a consolidated basis for on- and off-balance sheet exposures. The aggregate of such } \\
\text { large exposures, defined as individual exposures of } 10 \text { percent or more of the bank's own } \\
\text { funds, may not exceed } 800 \text { percent of own funds. A large exposure is to be measured net of } \\
\text { collateral, guarantees or other deductions. A "single borrower," as the basis for defining large } \\
\text { exposures, is formulated by CRBF Regulation } 93-05 \text { Art. } 3 \text { as: "persons connected in such a } \\
\text { way that, were one of them to encounter financial problems, the others would probably } \\
\text { experience payment problems." }\end{array}$ \\
\hline & $\begin{array}{l}\text { Regulation } 97-02 \text { requires banks to put in place adequate monitoring procedures for large } \\
\text { exposures, actively involving top-management in the assessment process. Notwithstanding } \\
\text { these precise prescriptions, the CB has large discretion in assessing and adapting the notion of } \\
\text { closely related exposures to deal with the complexity of relations between companies, groups } \\
\text { and individuals acting as managers or directors. Moreover, while institutions are required to } \\
\text { comply with the rules on a consolidated basis, the CB may require compliance on an individual } \\
\text { or sub-consolidated basis, especially when it considers that the distribution of own funds within } \\
\text { a group is unsatisfactory with regard to the exposure of the institutions concerned. }\end{array}$ \\
\hline & $\begin{array}{l}\text { The regulation also requires that monitoring of group exposures be backed by a sector-wide } \\
\text { and geographical analysis of the portfolio. All exposures over } 10 \text { percent (see above) must be } \\
\text { reported to the CB on a quarterly basis ( } 5 \text { percent in the case of exposure to a shareholder or } \\
\text { manager). Moreover, quarterly reporting is mandatory bearing on all exposures in excess of } \\
10 \text { percent of the banks' own funds and credit institutions must declare their principal risks on a } \\
\text { gross basis if those risks exceed } 10 \text { percent of own funds or EUR } 300 \text { million (CB } \\
\text { Instruction 2000-07 on large exposures and exposures on a gross basis). }\end{array}$ \\
\hline & $\begin{array}{l}\text { The CB obtains detailed information on the loan portfolio of each credit institution on a } \\
\text { quarterly basis. To assist in checking the risk concentration features of the portfolio, the CB } \\
\text { has access to comprehensive databases at the BdF, which cover, inter alia, capital links } \\
\text { between companies, management and board functions, and outstanding loan balances. } \\
\text { Moreover, the staff of local BdF agencies can provide more detailed information about } \\
\text { companies and individuals whenever required. The CB has built an information system that } \\
\text { aims at a flexible exploitation of these databases, used in preparing and performing local on- } \\
\text { site inspections. }\end{array}$ \\
\hline Assessment & Compliant \\
\hline Comments & \\
\hline •. & nnected lending \\
\hline
\end{tabular}




\begin{tabular}{|c|c|}
\hline & $\begin{array}{l}\text { In order to prevent abuses arising from connected lending, banking supervisors must have in } \\
\text { place requirements that banks lend to related companies and individuals on an arm's-length } \\
\text { basis, that such extensions of credit are effectively monitored, and that other appropriate steps } \\
\text { are taken to control or mitigate the risks. }\end{array}$ \\
\hline Description & $\begin{array}{l}\text { The } 1966 \text { Commercial Companies Act regulates all transactions with related parties for all } \\
\text { corporations and fully applies to all credit institutions. These transactions require arm's length } \\
\text { lending, full board authorization and reporting to the annual General Assembly of shareholders } \\
\text { of transactions between the company and a director or senior manager (including their close } \\
\text { relatives) which is not in the line of a company's day-to-day business or not entered into under } \\
\text { normal market conditions. Related parties, as defined by banking regulations (CRBF } \\
\text { Regulation 93-05, Art. 3) are persons that have capital links such as one of them exercises, } \\
\text { directly or indirectly, exclusive or joint control or that are subject to common management, or } \\
\text { persons connected in such a way that, were one of them to encounter financial problems, the } \\
\text { others would probably experience payment problems (see description of BCP 9). } \\
\text { CRBF Regulation } 97-02 \text { (modified by Regulation } 2001-01 \text { ), Art. } 21 \text {, and Art. } 42 \text { (f) provide } \\
\text { that credit institutions and investment firms should set up adequate internal control in view of } \\
\text { monitoring and controlling risks, including for connected lending. Lending to related parties } \\
\text { and to their parent companies, subsidiaries, significant shareholders (or their partners) must be } \\
\text { reported under the same regulations and procedures as that for reporting large exposures } \\
\text { whenever they exceed } 5 \text { percent of the banks' own funds. Under the discretionary powers } \\
\text { available to them, supervisors may also require that exposure to borrowers between whom } \\
\text { there is no apparent link be aggregated. } \\
\text { To tighten up these regulations, the authorities introduced measures (CRBF Regulations 90-02, } \\
\text { Art. } 6 \text { ter, and } 2000-09 \text { ), which impose a deduction from the bank's regulatory own funds of all } \\
\text { commitments to shareholders or linked staff exceeding } 3 \text { percent of own funds. Some } \\
\text { exceptions, essentially for investment grade commitments to related parties, are allowed. }\end{array}$ \\
\hline Assessment & Compliant \\
\hline \multicolumn{2}{|l|}{ Comments } \\
\hline Principle 11. & $\begin{array}{l}\text { Country risk } \\
\text { Banking supervisors must be satisfied that banks have adequate policies and procedures for } \\
\text { identifying, monitoring and controlling country risk and transfer risk in their international } \\
\text { lending and investment activities, and for maintaining appropriate reserves against such risks. }\end{array}$ \\
\hline Description & $\begin{array}{l}\text { Banks' country risk exposure, including credit, market risk, is regulated in CB } \\
\text { Instruction 2001-01 on international claims, which applies to all balance sheet and off-balance } \\
\text { sheet exposures to private or public borrowers residing in non-G10 and non-EEA countries or } \\
\text { having a non G10 or non-EEA nationality. Also included are local claims denominated in local } \\
\text { currencies on the private sector and short term local commercial loans. Moreover, through the } \\
\text { CRBF Regulation 97-02, banks are required to have information and management systems that } \\
\text { allow for proper identification, monitoring and controlling of country-risk. These policies and } \\
\text { procedures are reviewed during the regular on-site inspections. } \\
\text { Annual (semi-annual for the share held by large or internationally active banks) reports on } \\
\text { country risk exposure except to G10 and EEA countries, are sent by credit institutions to the } \\
\text { CB, which closely monitors exposures. Exposures are broken down by type of borrower and } \\
\text { type of credit. The CB carries out cross studies on the basis of prudential reports. } \\
\text { Country-risk provisions are not mandatory, and each credit institution is entirely responsible } \\
\text { for the level of its reserves. Nevertheless, the CB has strongly recommended, on a case-by-case } \\
\text { basis and if the economic situation of a given country deteriorates, to constitute what it } \\
\text { considers to be a minimum provision. Special attention is given to country risk provisioning by }\end{array}$ \\
\hline
\end{tabular}




\begin{tabular}{|c|c|}
\hline & $\begin{array}{l}\text { both the external auditors and the CB in the audit of financial reports. The CB also pays } \\
\text { particular attention to large international groups' internal control systems for country risk, } \\
\text { especially as regards procedures for setting limits and channels for issuing authorizations and } \\
\text { centralizing loans. } \\
\text { The CB also carries out regular cross studies on emerging economies or countries at risk. It } \\
\text { also performs stress tests in order to assess the resilience of French banks to a deterioration of } \\
\text { economic or financial conditions in emerging countries and to evaluate the potential impact of } \\
\text { an emerging crisis. }\end{array}$ \\
\hline Assessment & Compliant \\
\hline Comments & \\
\hline Principle 12. & $\begin{array}{l}\text { Market risks } \\
\text { Banking supervisors must be satisfied that banks have in place systems that accurately } \\
\text { measure, monitor, and adequately control market risks; supervisors should have powers to } \\
\text { impose specific limits and /or a specific capital charge on market risk exposures, if warranted. }\end{array}$ \\
\hline Description & 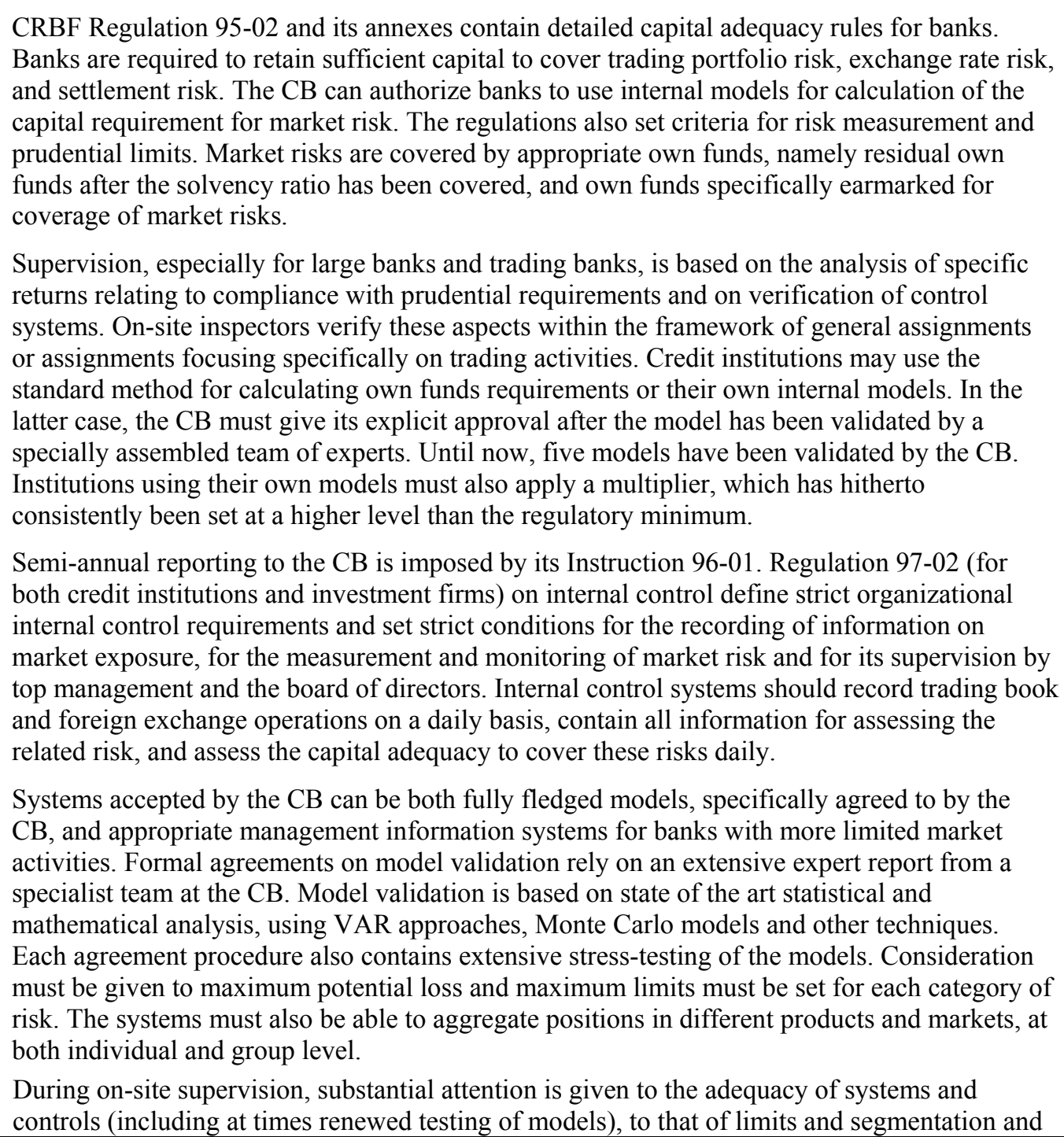 \\
\hline
\end{tabular}




\begin{tabular}{|c|c|}
\hline & $\begin{array}{l}\text { to the validity of assumptions for both day-to-day measurement and stress-testing. The model } \\
\text { validation specialists are actively involved during such on-site inspections. As a result of such } \\
\text { reviews, the CB often makes comments or asks for changes to be made. Similarly, bi-annual } \\
\text { returns relating to the calculation of prudential ratios are carefully scrutinized, and disciplinary } \\
\text { action may be taken in the event of an infringement. }\end{array}$ \\
\hline Assessment & Compliant \\
\hline Comments & \\
\hline Principle 13. & $\begin{array}{l}\text { Other risks } \\
\text { Banking supervisors must be satisfied that banks have in place a comprehensive risk } \\
\text { management process (including appropriate board and senior management oversight) to } \\
\text { identify, measure, monitor, and control all other material risks and, where appropriate, to hold } \\
\text { capital against these risks. }\end{array}$ \\
\hline Description & 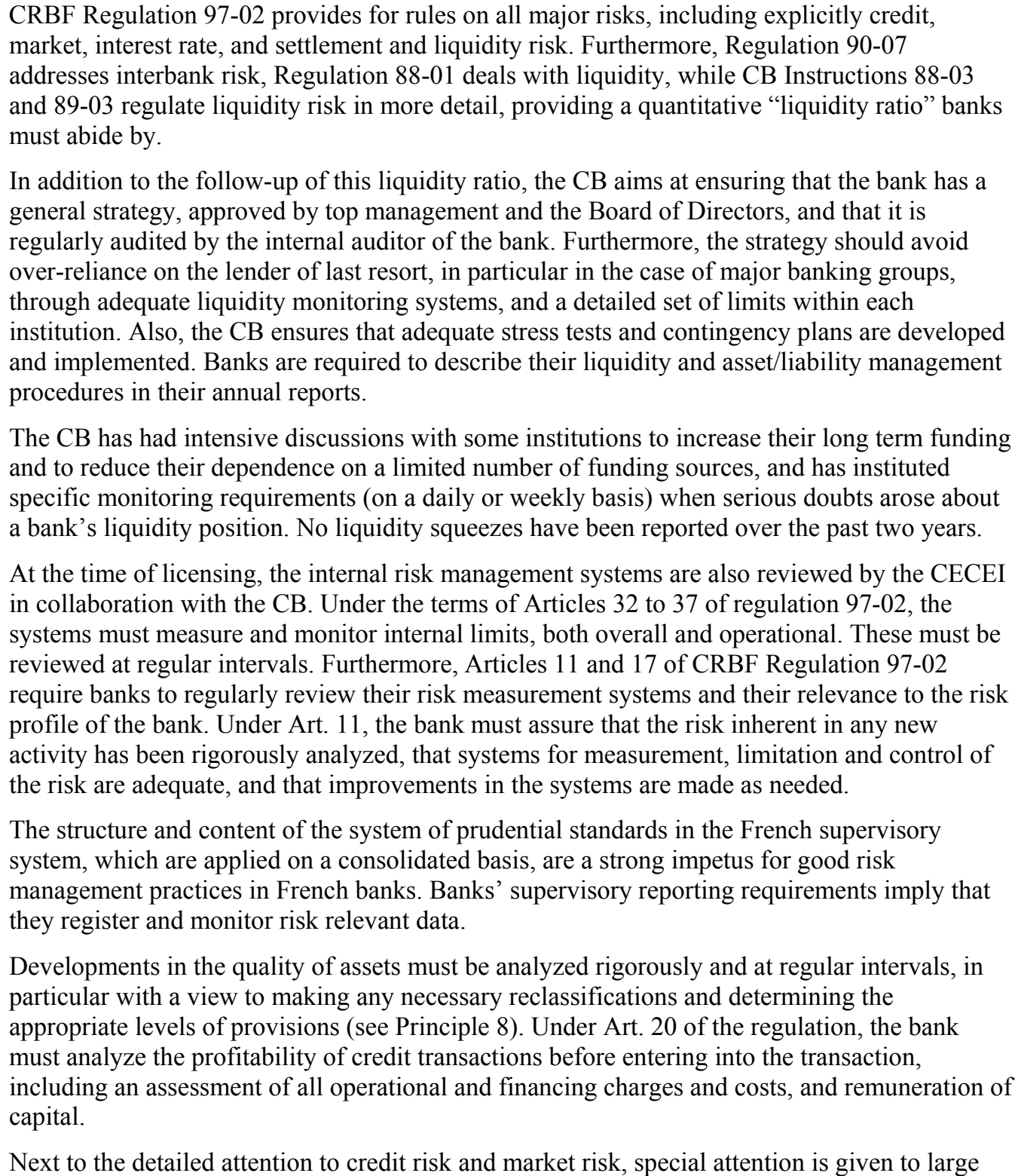 \\
\hline
\end{tabular}




\begin{tabular}{|c|c|}
\hline & 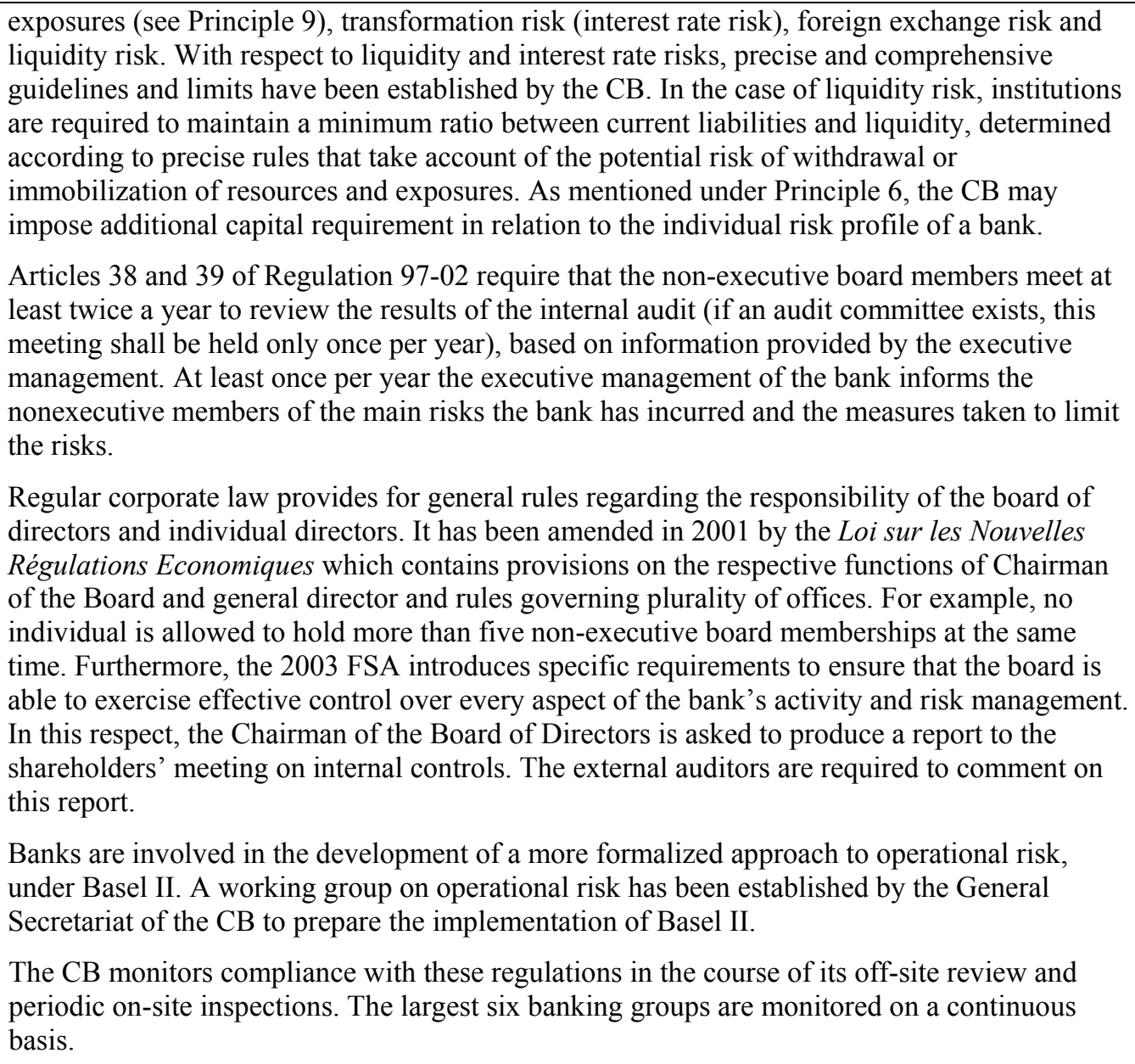 \\
\hline Assessment & Compliant \\
\hline Comments & $\begin{array}{l}\text { In view of the adoption of the Loi sur les Nouvelles Régulations Economiques, and the } 2003 \\
\text { FSA, improvements have been introduced in corporate governance since the previous } \\
\text { assessment. Furthermore implementation of Basel II-which is already being prepared-will } \\
\text { in general be a strong impetus for continued improvement of risk management practices in } \\
\text { French banks. EU regulators are cooperating to develop a common approach to Basel II } \\
\text { implementation. }\end{array}$ \\
\hline e 14. & $\begin{array}{l}\text { Internal control and audit } \\
\text { Banking supervisors must determine that banks have in place internal controls that are } \\
\text { adequate for the nature and scale of their business. These should include clear arrangements } \\
\text { for delegating authority and responsibility; separation of the functions that involve committing } \\
\text { the bank, paying away its funds, and accounting for its assets and liabilities; reconciliation of } \\
\text { these processes; safeguarding its assets; and appropriate independent internal or external audit } \\
\text { and compliance functions to test adherence to these controls as well as applicable laws and } \\
\text { regulations. }\end{array}$ \\
\hline Description & $\begin{array}{l}\text { Efforts have been undertaken to strengthen bank governance, particularly to ensure that the } \\
\text { composition of the board of directors allows for a full understanding and assessment of all } \\
\text { activities undertaken by a bank and the risks it assumes. Indeed, in two reports published } \\
\text { respectively in } 1995 \text { and } 1999 \text {, the Rapports Viennot, special attention has been drawn on the } \\
\text { importance for financial institutions to conform to the principles and rules of corporate }\end{array}$ \\
\hline
\end{tabular}




\begin{tabular}{|c|c|}
\hline & 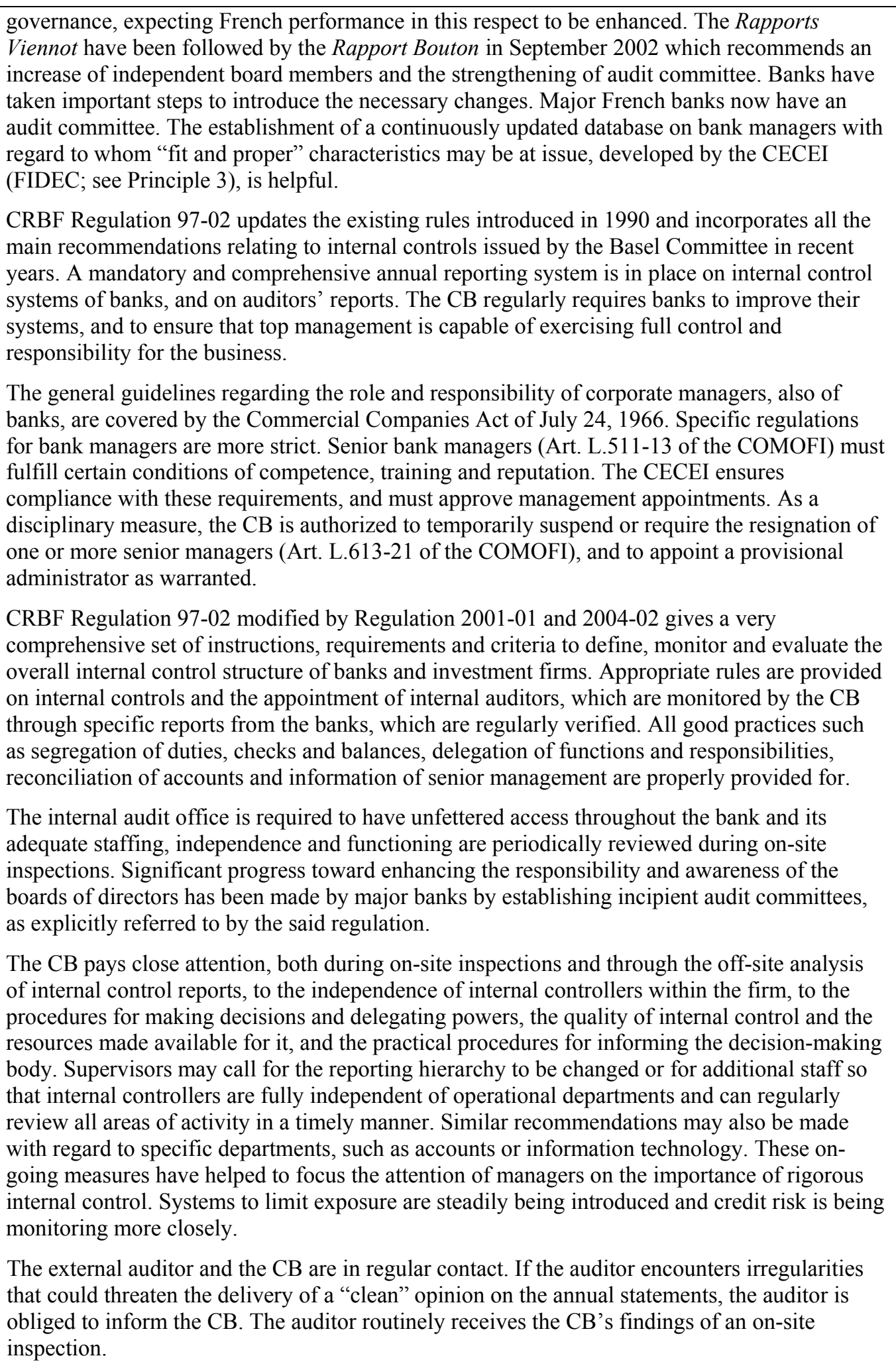 \\
\hline sess & Compliant \\
\hline
\end{tabular}




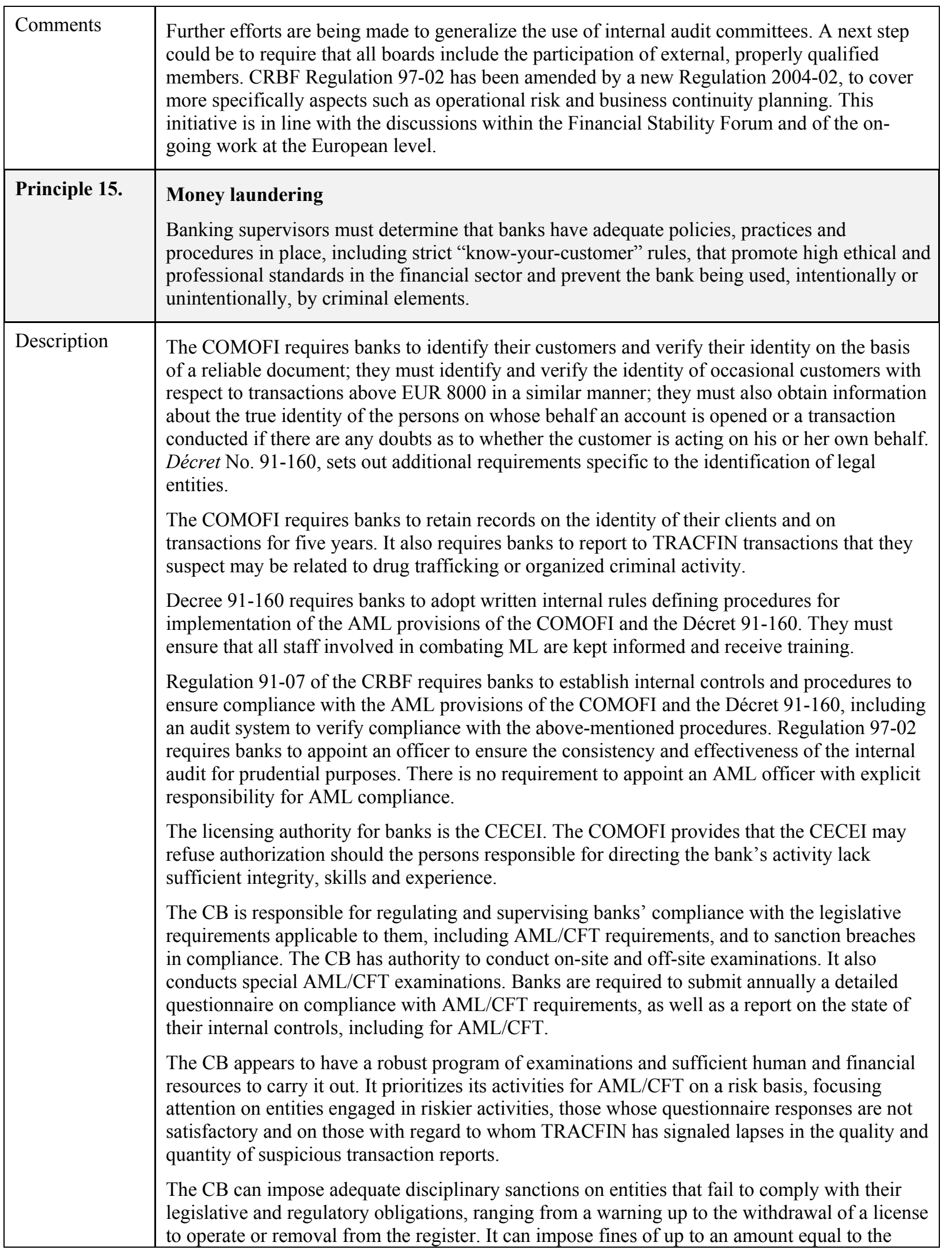




\begin{tabular}{|c|c|}
\hline & $\begin{array}{l}\text { minimum capital of the legal entity. CB indicates that AML/CFT compliance levels are } \\
\text { generally good and steadily improving. The CB has imposed sanctions for breaches relating to } \\
\text { AML/CFT requirements. The sanctions ranged from a warning to removal from the register, } \\
\text { but the most frequent sanction was a warning plus a fine. Decisions involving the imposition of } \\
\text { sanctions mainly for failure to implement AML/CFT requirements were systematically } \\
\text { publicized. }\end{array}$ \\
\hline Assessment & Compliant. \\
\hline Comments & $\begin{array}{l}\text { A more comprehensive assessment of compliance against international AML/CFT standards } \\
\text { can be found in the AML/CFT detailed assessment report. }\end{array}$ \\
\hline Principle 16. & $\begin{array}{l}\text { On-site and off-site supervision } \\
\text { An effective banking supervisory system should consist of some form of both on-site and off- } \\
\text { site supervision. }\end{array}$ \\
\hline Description & 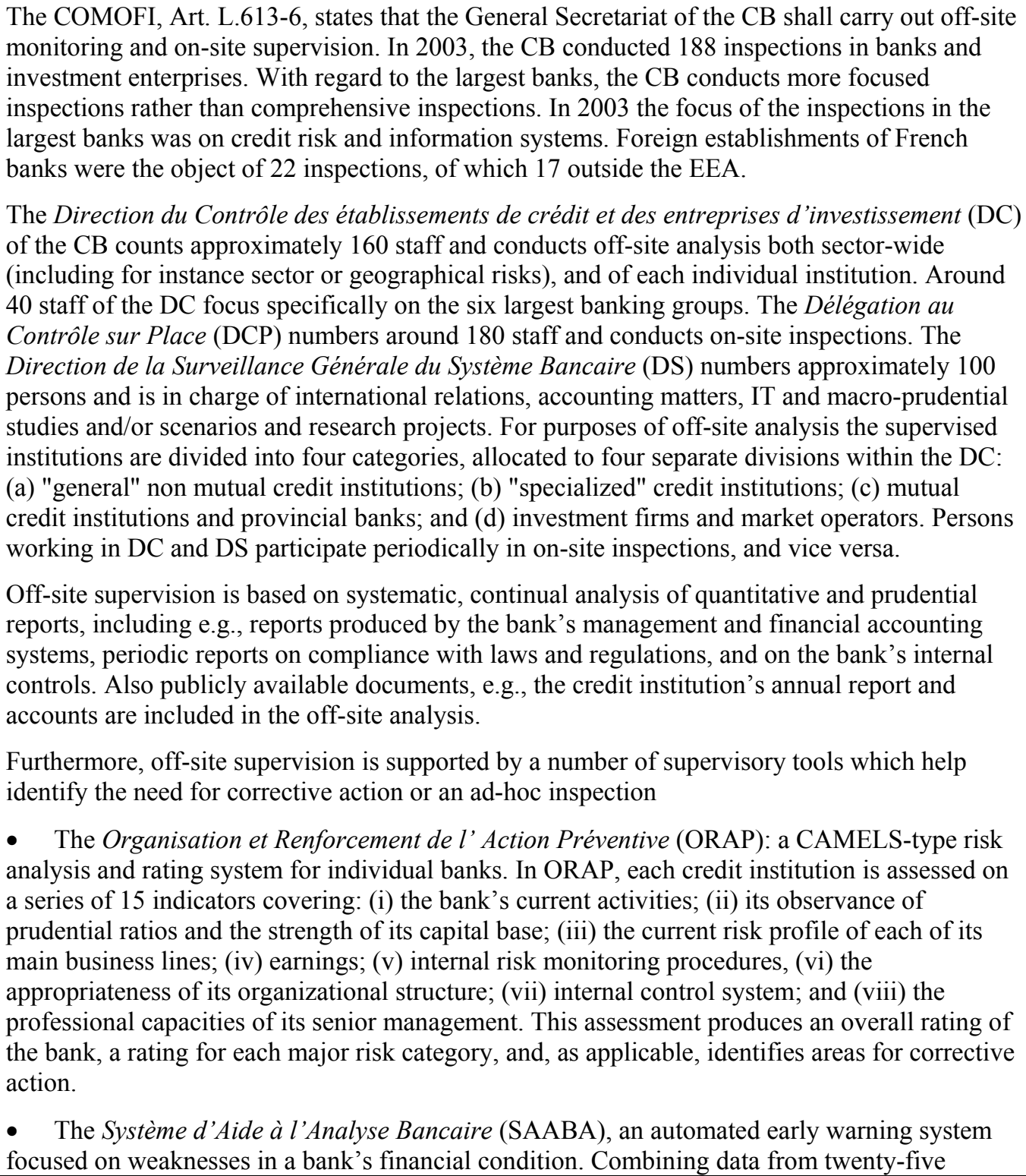 \\
\hline
\end{tabular}


databases, SAABA produces: (i) a detailed loan quality analysis on each credit institution;; (ii) a partial analysis of the principal aspects of banking risk; and, as required; (iii) an aggregate overview of these aspects across the banking system. It can also be adapted to simulate the effects of various events, e.g., sector-specific economic shocks. Besides the BdF's databases, SAABA also uses the product of special surveys (e.g., real estate risk, country risk) and external sources, such as rating agencies.

- $\quad$ The Base des agents financiers (BAFI), which is drawn from accounting and prudential returns filed by supervised institutions with the $\mathrm{CB}$;

- $\quad$ The Service Central des Risques (SCR), which contains information on performance of all loans of more than EUR 75,000 to nonbank entities reported to the BdF by credit institutions;

- $\quad$ The Fichier Bancaire des Entreprises (FIBEN), which collects information on businesses and managing directors and contains accounting and financial data reported to the BdF by all nonbank businesses in France with annual gross revenues exceeding EUR 750,000. FIBEN covers 200,000 firms, and thus accounts for 90 percent of total bank credit to businesses in France. Thus, FIBEN provides a regularly updated rating system for most French businesses, that goes substantially beyond the capacity of the private rating agencies, and thereby plays a fundamental role in bank lending to small and medium businesses.

- $\quad$ Furthermore, the $\mathrm{CB}$ has access to databases maintained by the BdF.

Further, the CB has developed a cross-industry methodology for "homogenous line(s) of business groups" (peer groups) enabling it to analyze profitability and capital structures of credit institutions with closely comparable line(s) of business profiles.

The off-site supervision process also encompasses regular direct contact with the credit institution's management by telephone or in meetings, to discuss with bank management the results of the off-site analysis.

On-site supervision is especially important to determine the exact state of the credit institution's loan portfolio or its system of internal controls. Various types of inspections are held: (i) a general, periodic inspection; (ii) inspections limited to a specific sector of the activity (especially used with regard to the largest banks); (iii) triggered by the bank's perceived financial condition; (iv) "thematic" inspections, focused for instance on AML/CFT compliance; (v) preparedness for Basel II; and (vi) "follow-up" of compliance with earlier recommended corrective actions.

In addition to the supervisory tools supporting off-site supervision an on-line Système d'Information de l'Inspection Générale (SIGAL) to retrieve financial information, accessible to inspectors on their laptops during inspections. SIGAL analyzes accounting statements and prudential reports, extracts statistical information concerning the structure and quality of a credit institution's loan book and scans for connected borrowers.

A wide spectrum of risks (credit risk, liquidity risk, operational risk, etc.) may be addressed in the course of on-site inspections, with particular focus on internal control systems, adequacy of regulatory and management reporting, internal and external audit and management capabilities. More specific areas of attention include capital adequacy, asset quality, management, earnings, liquidity and sensitivity to market risk, as well as compliance with the law and regulations.

On-site inspection "teams" are led by a Chief Inspector, assisted by two or more examiners, with the same "team members" remaining as a unit for several inspections. The "teams" are helped, as needed, by two groups of specialists, specifically on Information Technology and Model Risk Analysis.

For the "Big Six" largest banking groups, on-site inspection is almost continuous, focusing on key risk areas, and on a consolidated basis, including foreign branches and subsidiaries where deemed necessary. Comprehensive on-site inspections of nonsystemic institutions and where 
off-site supervision has not revealed significant weaknesses, are conducted on a three-to-five year cycle. On-site inspections outside the "Big Six" may also have a specific focus (e.g., rapid growth in assets, marked deterioration in observance of prudential standards or, on a general basis, a specific activity, such as lending to particular segments of the economy).

In addition to general licensing, prudential and supervisory rules which fully apply to this kind of credit institutions, the COMOFI, Articles L.511-31 and L.511-32, states that central bodies of mutualist credit institutions shall ensure that the laws and regulations applying to these institutions are implemented and exercise administrative, technical and financial supervision over their organization and management. On-site supervision may be extended to their direct and indirect subsidiaries and to those of affiliated institutions. Central bodies may take disciplinary action as authorized by the laws and regulations. Without prejudice to the powers conferred on the $\mathrm{CB}$ to exercise supervision, the central bodies shall assist in implementing the laws and regulations. The central bodies shall bring any noncompliance to the attention of the CB.

On-site inspections are conducted on the basis of specific standardized, written procedures. The program of inspections is proposed by the DC, after input from on-site inspectors, and approved by the CB, and can be modified as needed. Approximately 240 on-site inspections per year are performed. On-site inspections are characterized by ongoing communication with the DC, the DS (accounting and prudential issues) or the DSJ (legal matters). During the inspections (especially when a credit institutions or an investment firm appears in distress) the team leader files progress reports to the $\mathrm{CB}$, so the $\mathrm{CB}$ could be informed as quickly as possible.

The DC sends letters with recommendations or requirements for action to banks with a "substandard" or "poor" rating. It can also ask for remedial action when a banks has been perceived as financially vulnerable, or sensitive to the deterioration of individual clients, sectors, geographical areas or macro-economic developments.

To minimize misunderstandings, a draft inspection report is first discussed with the top management of the credit institution who may submit written comments. Where the inspection report contains matters of concern (e.g., regarding provisions, the organization and the management, the interpretation of the license or of the regulations) the Senior Inspector usually discusses its content in detail with the DC, so as to cross-check the technical or regulatory features. The final report is signed by the Senior Inspector and forwarded to the DCP. The result of the on-site inspection -i.e., the follow-up letter (lettre de suite) of recommendations and prescriptions- has to be communicated to the institution's Board of Directors or the managing or supervisory board (or other similar decision-making body) and to the external auditors (COMOFI Art. L.613-10). The lettre de suite is drafted by the DC and signed by the CB's Secretary General or, in certain instances, by the Governor of the BdF, as chairman of the CB. Follow-up of the required remedial actions is the responsibility of the DC. The Senior Inspector in charge of the inspection is kept informed of the bank's follow up actions.

Staff of the four divisions of the CB can exchange views in periodic working groups, e.g. on draft regulations or reviews of emerging risks. Monthly meetings between the senior management of the $\mathrm{CB}$ and the Senior Inspectors permit discussion of current issues. To foster collaboration, the four divisions of the $\mathrm{CB}$ regularly exchange personnel. Recruits to the other divisions are regularly seconded to DCP inspection teams to gain field experience. Heads of divisions periodically head on-site inspections. Conversely, inspectors are seconded to positions in the DC at various hierarchical levels.

Staffing numbers have increased considerably since 1995 in order to cope with the growing demands of banking supervision. Currently the CB and the CECEI together have some 585 staff at their disposal. In addition, in response to the growing complexity of banking, the $\mathrm{CB}$ has recruited specialists, for instance on derivatives.

The CB continues to complement its micro economic analysis by strengthening its capacity to 


\begin{tabular}{|c|c|}
\hline & $\begin{array}{l}\text { assess macro-prudential risks and to take early action to limit systemic risks. In particular, DC } \\
\text { and DS use databases, and collect detailed information from the banks when needed, to analyze } \\
\text { what impact a macro-economic or sectoral deterioration could have on the financial soundness } \\
\text { of the credit institutions. The CB is developing a module in the SAABA system to simulate the } \\
\text { impact of for instance a deterioration in the housing and construction sectors, or fluctuations in } \\
\text { macroeconomic variables such as the interest rates, exchange rates, or growth rates. } \\
\text { Over the past years reinforcement of the supervision of large systemically important groups has } \\
\text { been one of the main objectives of the CB, and has led to the design of a "reinforced } \\
\text { surveillance program," including a significant increase in staff supervising these groups. A } \\
\text { yearly or semi-annual meeting takes place with top executives of the groups (including heads of } \\
\text { business lines, financial officers, risk managers), more specific meetings on issues identified by } \\
\text { the off-site analysis performed by the CB, with the objective of assessing the risk profile of the } \\
\text { institution more precisely, and the ability of the institution to monitor the risks. The results of } \\
\text { these contacts serve as input to the on-site inspection program. A number of inspections take } \\
\text { place with regard to each group per year, for instance different types of risk, risk management } \\
\text { regulatory compliance and audit functions. CBRF Regulation } 97-02 \text { on internal controls is to be } \\
\text { amended soon to include a requirement for business continuity planning by banks. }\end{array}$ \\
\hline Assessment & Compliant \\
\hline Comments & $\begin{array}{l}\text { Analytical tools are improved continuously to stay abreast of the changing environment and } \\
\text { emerging issues, and to introduce macro-prudential approaches to supervision. Ongoing work } \\
\text { on macro-prudential issues within the ECB's Banking Supervisory Committee comprising the } \\
15 \text { banking supervisory authorities and national central banks, remains of great importance. }\end{array}$ \\
\hline Principle 17. & $\begin{array}{l}\text { Bank management contact } \\
\text { Banking supervisors must have regular contact with bank management and a thorough } \\
\text { understanding of the institution's operations. }\end{array}$ \\
\hline Description & $\begin{array}{l}\text { Also see the description under BCP 16. In general, the CB enhances its understanding of the } \\
\text { bank's operations and management through meetings with senior management. These meetings } \\
\text { are an integral part of the supervisory process. } \\
\text { Overall, with a degree of variation depending on the significance of the institution, contacts } \\
\text { between the bank and the CB are frequent, including for instance the quarterly discussion of the } \\
\text { results, some ten meetings annually of the CB's and the bank's specialists on technical matters, } \\
\text { and a yearly meeting between top management of the banks and the CB. The inspection process } \\
\text { with regard to the big six groups in practice is virtually an ongoing process, with some four to } \\
\text { five inspections per year, covering different topics. The CB meets regularly with the CACs of } \\
\text { the banks to discuss broader issues relative to the banks. } \\
\text { During an on-site supervision working meetings take place with senior management and } \\
\text { external auditors, permitting the supervisory authority to convey its impression of the standard } \\
\text { of performance achieved by both. Off-site supervisors also hold regular contacts with banks' } \\
\text { senior management and are kept well-informed by on-site supervisors, as well as through the } \\
\text { outputs of the analytical tools at their disposal. } \\
\text { On-site inspections also give the opportunity to meet with management and the external } \\
\text { auditors, to convey the ongoing findings of the inspection, listen to explanations and, where } \\
\text { required, resolve matters of interpretation. On completion of the examination, inspectors discuss } \\
\text { the draft report with the bank before the final report is officially forwarded to the CB and the } \\
\text { chairman of the bank. } \\
\text { The inspection process helps to inform the CB's assessments of top managers, especially their } \\
\text { ability to define and implement a consistent and sound strategy for the institution, and of the } \\
\text { quality of the management team. Inspection assessments are taken into account in the ORAP }\end{array}$ \\
\hline
\end{tabular}




\begin{tabular}{|c|c|}
\hline & $\begin{array}{l}\text { criteria. If serious operational deficiencies or statutory infractions are encountered, the CB may } \\
\text { take disciplinary action against the Chairman and/or the executive officers. } \\
\text { Also outside the inspection process, periodic contacts take place between the bank's key } \\
\text { officers and top management and the DC and the DS, but also with the Secretary-General of the } \\
\text { CB and his/her deputy. The agenda of these meetings depends on the size and risk profile of the } \\
\text { institution and may include discussions with such key executives as the chief financial officer, } \\
\text { the chief risk manager, the head of internal audit, the external auditors and the senior officers } \\
\text { responsible for the critical risk areas, as established by the CB's risk-based approach to } \\
\text { supervision. Discussions include remedial actions, amendments to corporate strategy, } \\
\text { operational performance, changes in asset quality and any other significant issues that have } \\
\text { arisen in the period under review. } \\
\text { CRBF Regulation 96-16, requires that banks notify the CECEI of any significant changes in } \\
\text { their circumstances, including the appointment of senior managers (Articles 9-11). The CECEI } \\
\text { can inform the bank that a modification of the license is needed, or that a proposed management } \\
\text { appointment is not acceptable. }\end{array}$ \\
\hline Assessment & Compliant \\
\hline Comments & \\
\hline Principle 18. & $\begin{array}{l}\text { Off-site supervision } \\
\text { Banking supervisors must have a means of collecting, reviewing and analyzing prudential } \\
\text { reports and statistical returns from banks on a solo and consolidated basis. }\end{array}$ \\
\hline Description & 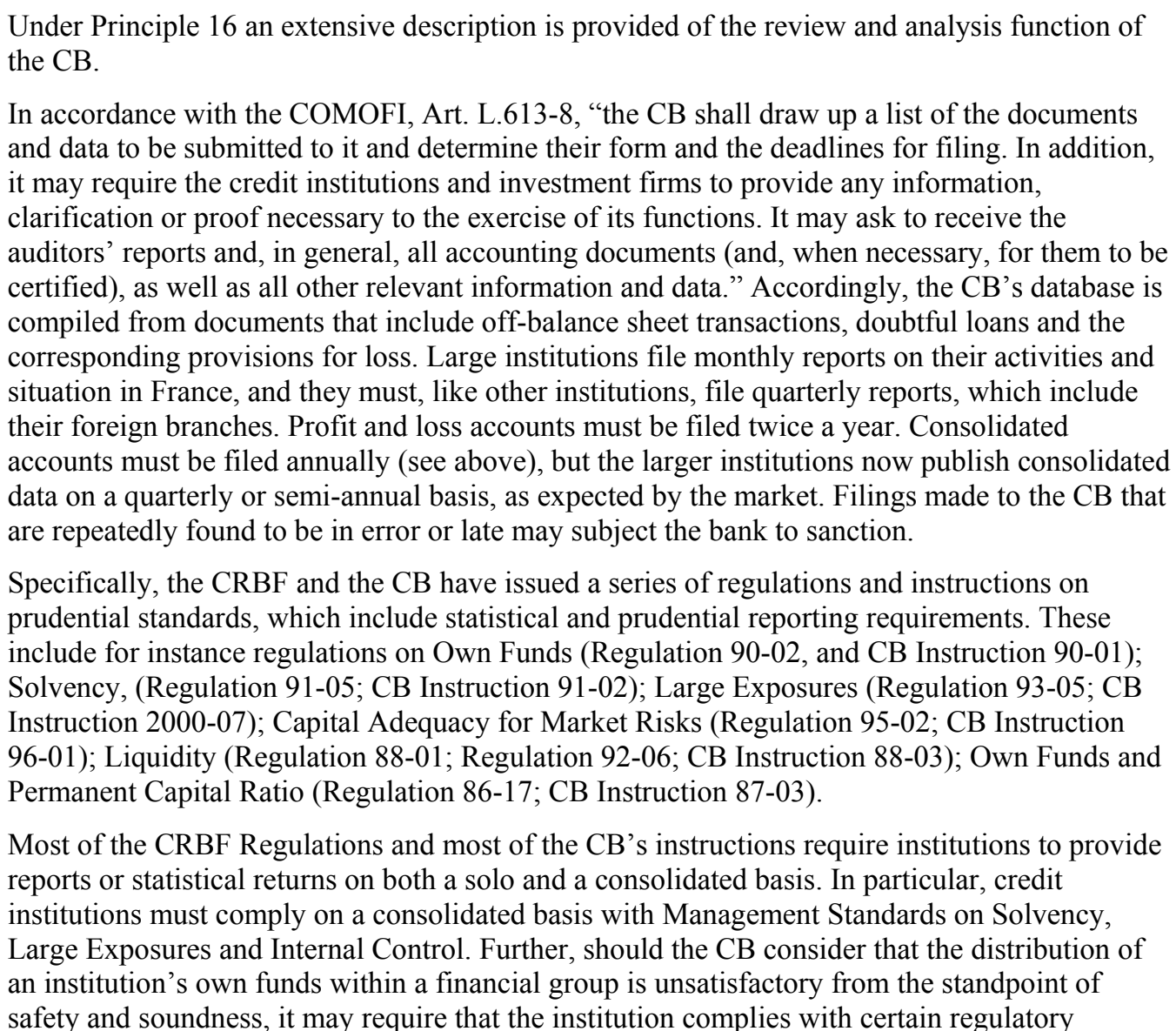 \\
\hline
\end{tabular}




\begin{tabular}{|c|c|}
\hline & $\begin{array}{l}\text { standards on an individual or sub-consolidated basis. } \\
\text { The CRC's Regulation 99-07 applies consolidation rules according to the nature of the activity } \\
\text { carried out by the consolidated entity and the level of control. Thus, institutions constituting an } \\
\text { economic group must prepare and publish audited consolidated annual accounts, a copy of } \\
\text { which must be sent to the CB. In accordance with the COMOFI, Art. L.511-37, the CB ensures } \\
\text { that periodic publication takes place. } \\
\text { CRBF Regulation } 2000-03 \text { on consolidated supervision, as modified by Regulations 2001-03 } \\
\text { and } 2001-05 \text { to explicitly include the mutualist groups, reflects the new accounting rules } \\
\text { introduced by CRC Regulation 99-07. Regarding the particular case of mutualist groups-in } \\
\text { which, typically, local banks hold the capital stock (and elect the Board of Directors) of } \\
\text { regional banks and the latter, in turn, hold the capital stock of the central institution-the CRBF } \\
\text { Regulation } 2001-03 \text { clearly obliges such groups to provide fully consolidated accounts. It must } \\
\text { also be pointed out that new reporting obligations have been set, for each mutual or non mutual } \\
\text { group, concerning subsidiaries and branches abroad. } \\
\text { The data received though the reporting system provide the input for a number of supervisory } \\
\text { tools, i.e., the SAABA system, which analyses each bank's risk profile, ORAP, which grades } \\
\text { the individual banks and serves as an early warning system. Furthermore, the CB may require } \\
\text { banks to provide any information the CB considers necessary for its supervision. }\end{array}$ \\
\hline Assessment & Compliant \\
\hline Comments & $\begin{array}{l}\text { Since the } 2001 \text { assessment, measures have been taken to ensure that the mutualist groups report } \\
\text { on a consolidated basis, }\end{array}$ \\
\hline Principle & $\begin{array}{l}\text { Validation of supervisory information } \\
\text { Banking supervisors must have a means of independent validation of supervisory information } \\
\text { either through on-site examinations or use of external auditors. }\end{array}$ \\
\hline Description & $\begin{array}{l}\text { Under CRBF Regulation 91-01, banks are under an obligation to publish annual financial } \\
\text { statements. The statements must be certified by a registered public accountant (CAC). This } \\
\text { system provides an important means of verification of the supervisory information provided by } \\
\text { the bank. } \\
\text { Furthermore, the supervisor has access to all information concerning the supervised institution's } \\
\text { affairs and, where necessary, to its Board of Directors, senior management and staff. The } \\
\text { COMOFI, Art. L.613-8, authorizes the CB to require supervised institutions to deliver to it all } \\
\text { information the CB considers necessary, and in the format and with the frequency that it deems } \\
\text { appropriate. Included in this broad power is the CB's capacity to "require delivery to it of the } \\
\text { official auditors' reports and, in general, all accounting documents (and, when necessary, for } \\
\text { them to be certified)." Art. L.613-9 also authorizes the CB to ask for any clarification from the } \\
\text { bank's external auditors with regard to their work for the bank. If the CB strongly objects to the } \\
\text { bank's financial statements, it can demand that a rectification be published (Description of BCP } \\
8 \text { ). } \\
\text { As noted in the discussions of Principles } 16 \text { and } 17 \text {, the CB operates a highly developed system } \\
\text { of off-site and on-site supervision, the latter providing-as part of its mandate-a means of } \\
\text { verification. Integral to the supervision process is the practice that the CB inspectors hold two } \\
\text { meetings with the CAC in the course of an on-site inspection. } \\
\text { The external audit is entrusted to a CAC, who is required to be a member of the CNCC. In order } \\
\text { to reinforce the supervision of this profession, the } 2003 \text { CSF created the Haut Conseil du } \\
\text { Commissariat aux Comptes (HCCC), which is in charge of monitoring the CACs activities and, } \\
\text { together with the CNCC, has established a code of conduct for CACs. Decree } 84-709 \text {, as } \\
\text { modified by decree } 2002-30 \text {, provides (Art. } 29 \text { ) that a credit institution must advise the CB of } \\
\text { the external auditors that it proposes to nominate and that the CB has two months to give its }\end{array}$ \\
\hline
\end{tabular}




\begin{tabular}{|c|c|}
\hline & 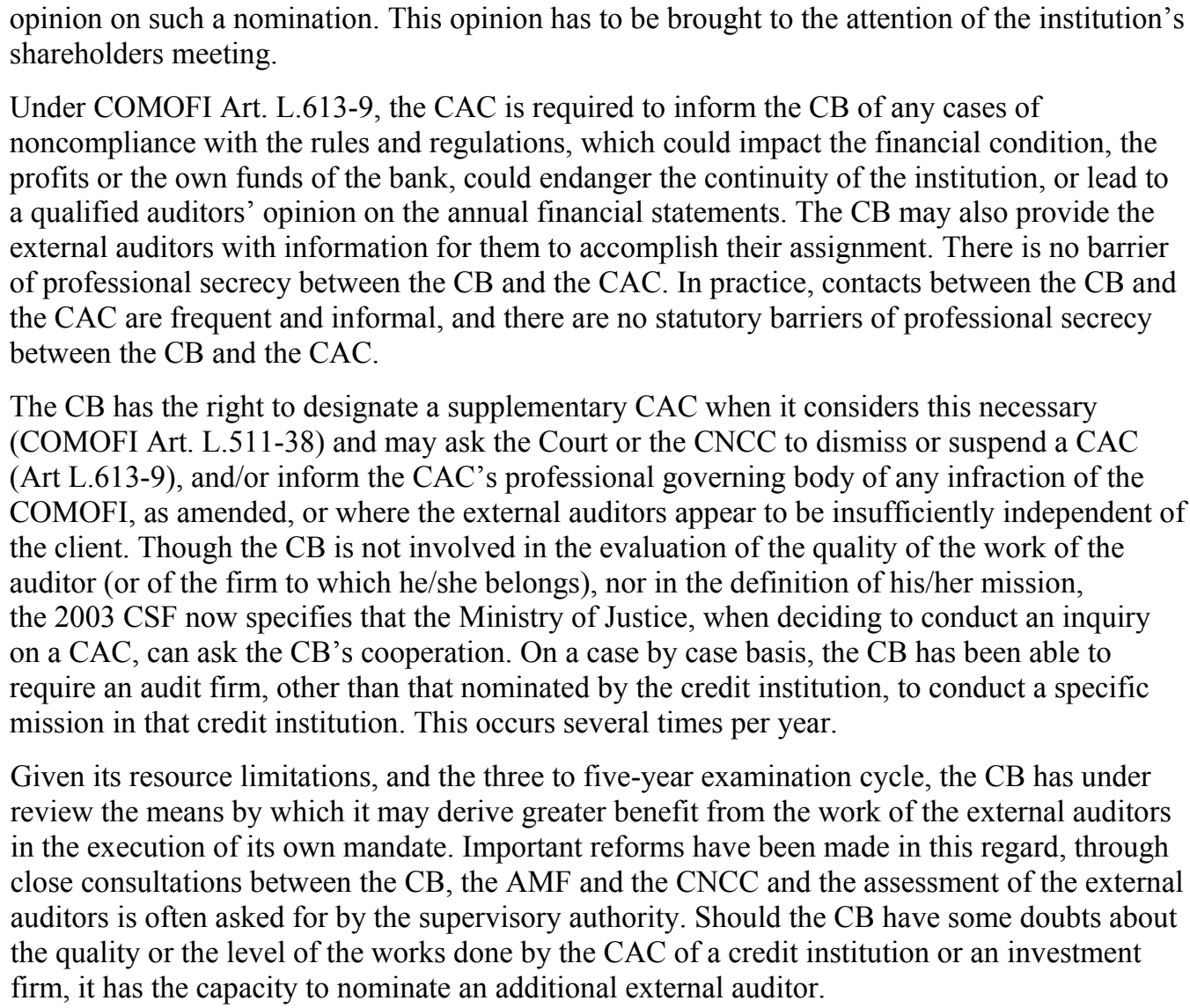 \\
\hline Assessment & Compliant \\
\hline Comments & $\begin{array}{l}\text { Following the adoption of the } 1999 \text { SFSA, France has acquired a corpus of legislation that } \\
\text { should enable external auditors and supervisors to develop more effective relations within the } \\
\text { framework of their respective legal responsibilities. The implementing decrees concerning the } \\
\text { CAC nomination proceedings toward the CB are now in force. Decrees of application of } \\
\text { the } 2003 \text { FSA remain to be adopted, and the new Code of Ethics of the accountancy profession } \\
\text { confirmed. }\end{array}$ \\
\hline Principle 20. & $\begin{array}{l}\text { Consolidated supervision } \\
\text { An essential element of banking supervision is the ability of the supervisors to supervise the } \\
\text { banking group on a consolidated basis. }\end{array}$ \\
\hline Description & $\begin{array}{l}\text { According to the rules set out in CRBF Regulation 2000-03 (which codified previous } \\
\text { regulations), as amended by Regulations 2001-03, and 2001-05, banking regulations taken as a } \\
\text { whole (see below) require regulatory filings to be prepared on a consolidated basis. The CRBF } \\
\text { Regulation 98-03 (Art.) provides that the CB may insist that an entity be excluded from the } \\
\text { scope of consolidation where there exist obstacles to the transfer of information necessary to } \\
\text { determine accurately the level of exposure, or in those cases where consolidation would be } \\
\text { misleading or inappropriate from the standpoint of prudential supervision. As noted in Principle } \\
\text { 18, the applicable CRBF Regulations and CB instructions require that institutions provide to the } \\
\text { supervisory authority their reports or statistical returns on both a solo and consolidated basis. } \\
\text { The CB is well aware of the overall structure of banking organizations or groups (i.e., the credit } \\
\text { institution and its subsidiaries) and has an understanding of the operations conducted therein. } \\
\text { The COMOFI, as amended, empowers the CB to supervise the entire activities of a credit }\end{array}$ \\
\hline
\end{tabular}


institution, whether those activities are carried on directly (including branch operations located outside France), or by means of subsidiaries and/or affiliates. At the same time, the CB's on-site and off-site supervisory processes enable it to evaluate the risks that nonbanking activities conducted by a credit institution or the other elements of the banking group may pose for the institution or group as a whole.

The CB's risk-based approach to supervision encompasses the evaluation of all significant activities of the institution, whether or not these constitute "banking operations" within the meaning of the term given by the COMOFI, as amended (Art. L.511-1) (see Principle 2). As discussed above, the $\mathrm{CB}$ has access to all the records of a credit institution or investment firm. In addition, the COMOFI (Articles L.613-10 and L.613-11) requires that the CB has on-site access to the business and records of the corporate entities controlled by the institution, including subsidiaries or affiliated companies, as well as to the business and records of "the legal persons directly or indirectly controlling it (i.e., the institution) and to their subsidiaries." For corporate entities located outside France, the $\mathrm{CB}$ has all powers necessary to collect data and information from the group's corporate headquarters in France and to extend its supervisory activities (including on-site inspections) to those entities when necessary. In that regard, the CB has signed a large number of MoUs with supervisory bodies within and outside the EU. When no $\mathrm{MoU}$ has been concluded, on-site inspections will require the permission of the host country. In addition, the $\mathrm{CB}$ monitors the relationships of credit institutions with regulatory bodies in other jurisdictions to ensure that the credit institution complies with all regulatory requirements, on a globally consolidated basis.

The CRC Regulation 99-07 contains new rules for the drawing up of consolidated accounts for credit institutions. It includes a definition of exclusive control and introduces consolidation criteria for special-purpose entities, including the possibility for networks affiliated with a "central body" (as defined in the COMOFI, as amended, Articles L.511-31 and L.511-32) to draw up consolidated accounts comparable to those of other bank groups. Thus, as indicated under Principle 18, the CRBF Regulation 2001-03 obliges the mutualist groups to report fully consolidated accounts, and all mutualist groups now prepare a form of consolidated accounts.

Under COMOFI Articles L.613-10 and L.613-11, the CB may inspect the activities of a bank's direct or indirect parent and sister companies. Protection of the credit institution against adverse developments at the parent or nonbank affiliate companies would be achieved through application of the general provisions of the COMOFI on sanctions (Articles L.613-15, L.613-16 and L.613-21).

In respect of owners of parent companies, the CRBF Regulation 96-16 requires the prior authorization — by the CECEI — of the acquisition of defined levels of direct — or indirect equity interests in credit institutions. Indirect acquisitions of French credit institutions through acquisition of parent companies by acquirers domiciled outside France require immediate notification to the CECEI, which may find reason that the credit institution's authorization be reexamined. Given the close operational links between the CECEI and the CB, the supervisor thereby has a means of establishing and enforcing "fit and proper" standards for owners.

For senior managers, the COMOFI, as amended (Art. L.517-1), makes "financial holding companies" subject - inter alia - to the "four eyes" principle, laid down in Art. L.511-13 of the COMOFI, under conditions set out in Regulation. CRBF Regulation 96-16 (Art. 9) requires notification of changes in senior management to the CECEI, affording the latter the opportunity to state whether an appointment is seen as compatible with the credit institution's authorization. This provides an oblique means of establishing and enforcing "fit and proper" standards for senior managers of parent companies of credit institutions.

Information exchange mechanisms with other domestic and foreign regulators allow the $\mathrm{CB}$ to adequately access information on the financial condition and the risk management practices and controls of business vehicles within a banking group. In non-EEA countries, bilateral 


\begin{tabular}{|c|c|}
\hline & $\begin{array}{l}\text { agreements are strengthening this aspect of supervision, though the scope of competence is a } \\
\text { frequent stumbling block in certain countries with a tradition of opacity (see Principle 24). }\end{array}$ \\
\hline Assessment & Compliant \\
\hline Comments & $\begin{array}{l}\text { The authorities are encouraged to continue attempts to obtain access to information from all } \\
\text { countries where French banks have business units. }\end{array}$ \\
\hline Principle 21. & $\begin{array}{l}\text { Accounting standards } \\
\text { Banking supervisors must be satisfied that each bank maintains adequate records drawn up in } \\
\text { accordance with consistent accounting policies and practices that enable the supervisor to } \\
\text { obtain a true and fair view of the financial condition of the bank and the profitability of its } \\
\text { business, and that the bank publishes on a regular basis financial statements that fairly reflect } \\
\text { its condition. }\end{array}$ \\
\hline Description & 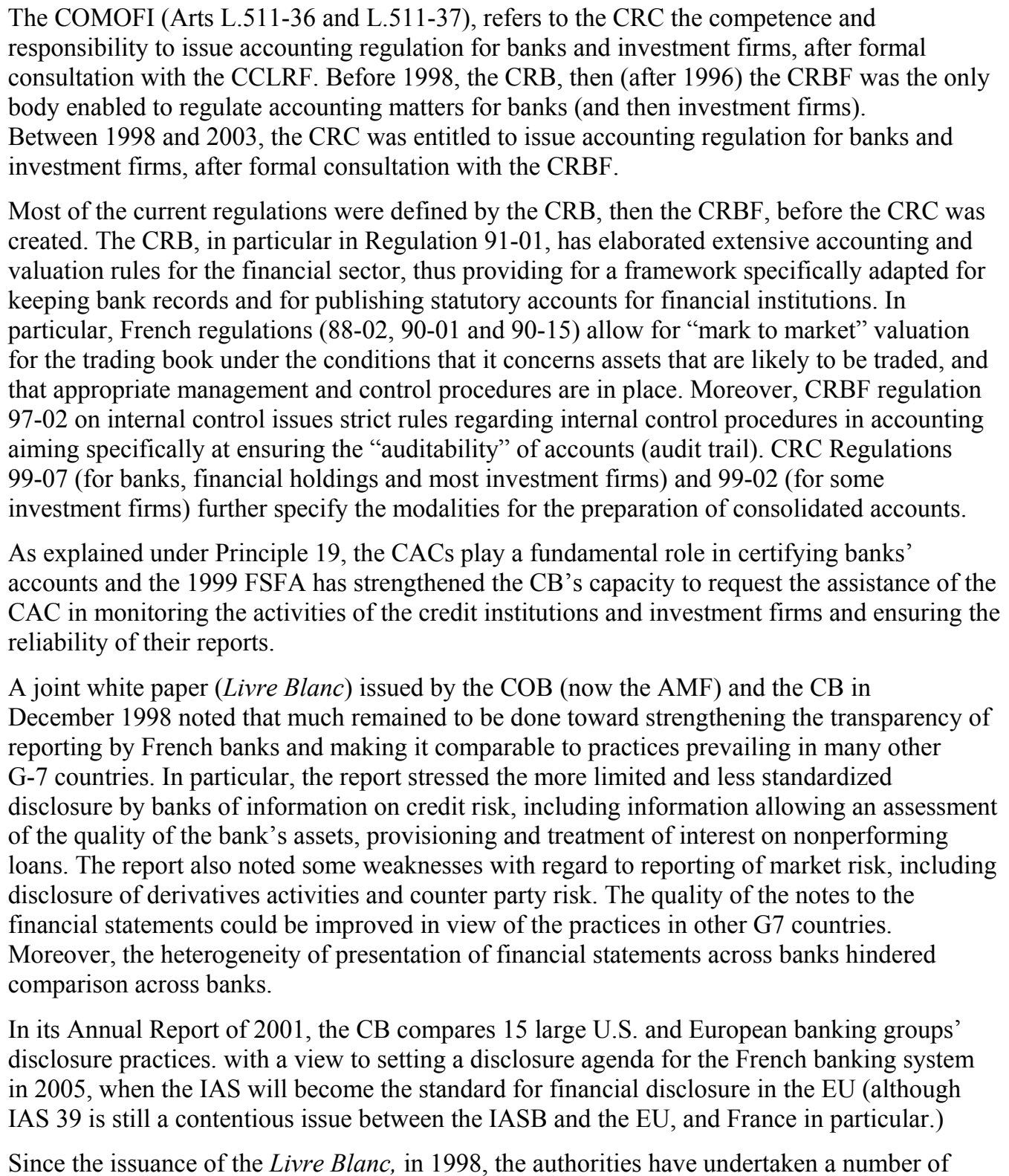 \\
\hline
\end{tabular}


measures to improve the quality of financial disclosure by banks.

- Decision 98.05 and recommendation 98.R.01 of the Conseil National de la Comptabilité (CNC), on market risk disclosure;

- Joint recommendation of the COB, precursor of the AMF, and the CB of January 2000, on credit risk disclosure, which recommends that banks' financial disclosure break down credit risk by economic sector, counterpart (government, banks, businesses, individuals, etc.) and geographical area, as well as provide information on bad loans and provisions, and the ratio between general provisions and overall credit risk;

- Joint Recommendation of the COB and the CB of November 2002 on deconsolidation and separation of assets;

- $\quad$ Regulations of the Comité de la Réglementation Comptable (CRC) No. 2000-03 on solo accounts, and No. 2000-04 on consolidated accounts;

- $\quad$ Regulation of the CRC No. 2002-03 on disclosure of credit risk.

Furthermore, the annual analysis by the Transparency Group of the Basel Committee, for the accounts of major French banks (BNP Paribas, SG, CASA, CL) over bookyear 2002 shows that major improvements have taken place since 1999, although the improvements relate to different aspects across banks.

In its 2001 Annual Report, the CB published a study on financial disclosure by banks, summarizing the main international developments on bank accounting, and foreshadowing the need for change in the French financial accounting system.

Again in its Annual report over 2002, the CB performs a preliminary analysis of the coming changes to the international accounting system. Clearly, the CB wishes to keep the debate alive, and to sensitize the French financial institutions to the need to adapt to more internationally recognized standards. Specifically with regard to credit risk, the Report states on page 173 that "current French standards appear to be too restrictive and insufficiently conservative with regard to credit risk provisioning, to the extent that provisioning often takes place rather late.." Under current rules, provisioning seems to depend on classifying a loan as "doubtful," which requires occurrence of a concrete event. The CB expects that implementation of IAS 39, a main component of which relates to credit risk, would lead to earlier and smoother provisioning.

However, these comments were issued in a context where the exposure draft of IAS 39 published at this time was based on an "expected loss" model, incorporating a concept of "dynamic provisioning" largely suggested by the CB. The final version of IAS 39 is based finally on an "incurred loss" model which appears to be a bit more restrictive than the actual French Regulation (see comment on Principle 8).

French banks are making progress toward meeting the requirements of Pillar 3 of the new Basel Capital Accord. A survey conducted by the CB in May 2003 shows that French banks have fulfilled the majority of the Pillar 3 requirements for market risk disclosure, but still need to continue work on credit risk disclosure.

Nevertheless, CRC Regulation 2002-03, of December 2002, addresses a number of important areas of credit risk disclosure. It requires banks to make a distinction in their accounts between standard and doubtful loans, dividing the latter into two categories, "non compromised" doubtful loans and "compromised" doubtful loans, the latter of which where payment is not expected, assuming that loans for which a loss occurs are derecognized from outstanding amounts in the balance sheet to the extent of the loss amount (Articles 3 and 9). Banks are required to disclose in their financial statements the gross amounts of standard, restructured, doubtful and compromised loans, as well as the criteria used to define these categories (see Articles 22 and 24). The rules applied by the banks to determine the level of provisions need to 


\begin{tabular}{|c|c|}
\hline & $\begin{array}{l}\text { be disclosed (Art. 26) as well any changes made in these rules since the last set of statements. } \\
\text { All loans need to be broken down into categories relative to the most significant sectors (within } \\
\text { geographical, economic sector, counterparty (also interbank)), and by residual maturity. The } \\
\text { doubtful and compromised loans, as well as the provisions taken must be broken down into the } \\
\text { same categories (see Articles } 28 \text { through } 30 \text {, and Chapters } 3 \text { and 4). } \\
\text { The CNC envisages to resolve one area of divergence concerning the choice offered to French } \\
\text { banks in the calculation of the present value of restructured loans by proposing to the CRC to } \\
\text { allow only the calculation of the present value on the basis of the original loan conditions. } \\
\text { However, no formal decision has been announced yet by the CNC, which prepares the future } \\
\text { regulations to be adopted by the CRC. } \\
\text { The issuance of regulations since } 2000 \text { by the CRC, in particular Regulation } 2002-03 \text { that } \\
\text { ensure broader disclosure "on a uniform and internationally comparable basis," have thus } \\
\text { contributed to the improvement of disclosure by the French banks. Financial statements have } \\
\text { also been improved by harmonization of key ratios that facilitate the comparison of banks' } \\
\text { performances. } \\
\text { The most delicate matter concerns communication by banks of problem situations. } \\
\text { Notwithstanding clear evidence, as noted in the report on financial transparency, of the } \\
\text { beneficial effects of timely crisis communication, most bankers remain reluctant to accept } \\
\text { regulations or to make firm commitments in this respect. While the CB has encouraged banks } \\
\text { to adopt a policy of open and timely communication on any significant difficulties and on } \\
\text { relevant external events that affect their risk-exposure, results so far have been mixed. }\end{array}$ \\
\hline Assessment & Compliant \\
\hline Comments & $\begin{array}{l}\text { Progress is being pursued toward greater convergence with IAS, and the authorities clearly } \\
\text { stimulate greater convergence, in the interest of greater comparability of financial statements. }\end{array}$ \\
\hline Principle 22. & $\begin{array}{l}\text { Remedial measures } \\
\text { Banking supervisors must have at their disposal adequate supervisory measures to bring about } \\
\text { timely corrective action when banks fail to meet prudential requirements (such as minimum } \\
\text { capital adequacy ratios), when there are regulatory violations, or where depositors are } \\
\text { threatened in any other way. In extreme circumstances, this should include the ability to } \\
\text { revoke the banking license or recommend its revocation. }\end{array}$ \\
\hline Description & $\begin{array}{l}\text { As noted with regard to Principle 1(4), the COMOFI, Articles L.613-1, L.613-15-19, and } \\
\text { L.613-21-23 confer a broad range of enforcement and sanctioning powers upon the CB. } \\
\text { Measures range from a recommendation (Art. 613-16) to an injunction both aiming at making } \\
\text { the credit institution take appropriate corrective action within a given period of time in order to } \\
\text { improve its financial situation, enhance its management methods or insure the adequacy of its } \\
\text { organization to its activities or development targets up to the withdrawal of the license (Art. } \\
\text { L.613-21). The most common and effective means to obtain remedial measures are the lettres } \\
\text { de suite following an on-site inspection. They call on the responsibility of both management } \\
\text { and Board of Directors to ensure correction of the situation. } \\
\text { Under COMOFI Art. 613-21, if a bank ignores a recommendation or is in breach of a law or } \\
\text { regulation, the CB can: (i) issue a warning; (ii) issue a supervisory reprimand; (iii) prohibit to } \\
\text { perform certain activities; (iv) suspend one or more managers, with or without appointment of a } \\
\text { temporary administrator; (v) remove one or more managers, with or without appointment of a } \\
\text { temporary administrator; (vi) withdraw the license, with or without appointment of a liquidator. } \\
\text { Pecuniary sanctions may also be imposed upon the bank in addition to these measures. } \\
\text { Moreover, the CB may impose the withdrawal of the voting rights of certain or all shares, the } \\
\text { prohibition to pay dividends or other form of remunerations to shareholders and the obligation }\end{array}$ \\
\hline
\end{tabular}




\begin{tabular}{|c|c|}
\hline & $\begin{array}{l}\text { for the credit institution to disclose, at its own expenses, the disciplinary sanctions. The CB may } \\
\text { mention infringements or criminal offenses to the Public Prosecutor's Office. } \\
\text { Whenever a bank is deemed to be at risk of not being able to meet its commitments toward its } \\
\text { customers, the CB can request intervention of the FGD (COMOFI Art. L.312-5). Given that the } \\
\text { primary concern in such case is the optimal protection of the interest of private customers } \\
\text { covered by the FGD, the CB and the FGD cooperate closely both in the decision-making and } \\
\text { the implementation of the measures. } \\
\text { When imposing sanctions, the CB is an administrative judiciary authority (Art. L.613-23 of the } \\
\text { COMOFI), and its decisions and sanctions can therefore only be challenged before the Conseil } \\
\text { d'Etat, the highest administrative judicial authority. In particular, bank customers and/or } \\
\text { management and directors can contest the appointment of temporary administrators by the CB. } \\
\text { They can also contest the decisions and actions of these administrators. In urgent cases, appeals } \\
\text { against the decisions of CB to appoint an administrator or a liquidator do not suspend their } \\
\text { implementation (Art. L.613-23 II). } \\
\text { Moreover, under Art. L.613-21, the CB may prohibit payment of dividends or other form of } \\
\text { remunerations to shareholders and the obligation for the bank to disclose, at its own expenses, } \\
\text { the disciplinary measures. } \\
\text { In } 2002 \text {, the CB issued one injunction against a bank, } 8 \text { warnings, } 15 \text { supervisory complaints } \\
\text { (some of which with a pecuniary penalty), ordered one bank to limit its activities, and } \\
\text { delicensed three investment companies for disciplinary reasons. Five disciplinary actions were } \\
\text { initiated against money changers. }\end{array}$ \\
\hline Assessment & Compliant \\
\hline Comments & \\
\hline Princ & $\begin{array}{l}\text { Globally consolidated supervision } \\
\text { Banking supervisors must practice global consolidated supervision over their internationally } \\
\text { active banking organizations, adequately monitoring and applying appropriate prudential } \\
\text { norms to all aspects of the business conducted by these banking organizations worldwide, } \\
\text { primarily at their foreign branches, joint ventures and subsidiaries. }\end{array}$ \\
\hline Description & $\begin{array}{l}\text { CRBF Regulation } 2000-03 \text { specifically obliges banks and their holding companies to comply } \\
\text { with the prudential standards on a consolidated basis, without distinction whether consolidated } \\
\text { entities are located abroad or not. Furthermore, with regard to internal controls and banks' } \\
\text { management of specific types of risk, CRBF Regulation } 97-02 \text { requires that banks view their } \\
\text { risks on a consolidated basis, including all its foreign subsidiaries and branches, and its } \\
\text { controlling entity and to the subsidiaries of the latter. One of the key-features of Regulation } \\
97-02 \text { on internal control is that each institution must ensure that its organization and } \\
\text { procedures are adequate for its activities and that of the group it belongs to. This covers the } \\
\text { inclusion of foreign branches and subsidiaries in management information, the internal control } \\
\text { structure of the organization and the daily oversight responsibility of management. During on- } \\
\text { site inspections on internationally active banks, the CB ascertains that the organization and } \\
\text { internal control of the French parent fully meet this requirement. Part of the on-site inspection is } \\
\text { in many cases carried out at the premises of foreign branches (and in some cases even jointly } \\
\text { with the local supervisor) of French banks. Even when rules, regulations and requirements are } \\
\text { not fully equivalent to those for the parent bank, the CB requires fully consolidated prudential } \\
\text { information on all entities of a group, both purely national groups and those also operating } \\
\text { abroad, on the basis of the groups' internal accounting and external prudential norms. } \\
\text { The French regulations make a distinction between EEA branches and other entities. In the case } \\
\text { of EEA branches, which have to be notified to the CECEI prior to their establishment, the } \\
\text { "home" supervisory authority retains all its sanctioning powers and can withdraw the }\end{array}$ \\
\hline
\end{tabular}


authorization to run a branch that is deemed to be unsound or in violation of the home regulations. The home authority should advise (and consult with) the "host" authority. In the other cases, if the branch does not comply with the host country's regulations, only the host supervisor can directly sanction it. However, as home supervisor, the CB could sanction the parent bank or require it to stop or limit its activities, making use of the powers specified by COMOFI Art. L.613-21.

As noted in Principle 1(6), the CB and CECEI have established an extensive network of MoUs with supervisory authorities Within the EEA, specific directives require the supervisory authorities to cooperate by mutually allowing each other to properly exert consolidated supervision. Thus, France has a wide range of MoUs in place to implement these directives. Wherever a significant presence of French banks abroad (or vice versa for foreign banks) exists, these MoUs give rise to regular consultations, both formal (MoU meetings on a regular basis) and informal. For a limited number of international financial conglomerates, involving French banks, these consultations are frequent and intense and are covered by special, sometimes multi-party MoU agreements. It should be noted that the EU Directive 2002/87/EC on the supplementary supervision of financial conglomerates further expands the scope of consolidated supervision.

For some non-EEA countries, similar bilateral agreements have been established following the 1999 SFSA vesting the CB with the power to conclude bilateral agreements with the authorities of a state not party to the EEA entrusted with duties similar to those entrusted in France to the CB. Apart from this formal aspect, the $\mathrm{CB}$ already engages in close cooperation with all the main G10 or industrialized countries' supervisory agencies. In this framework, regular individual sharing of information is carried out between the $\mathrm{CB}$ and non-EEA supervisors, periodic meetings take place and stand alone or joint on-site inspections of French branches and subsidiaries are usual, especially in North America and Asia where most French foreign operations are located.

These bilateral agreements, regarding mutual cooperation and exchange of information in the performance of prudential supervision, provide for arrangements for the collection and sharing of information, in particular through on-site inspections. In this case, information should be shared in support of the objective to facilitate and meet the requirements for effective consolidated supervision. However, for countries for which the scope for cooperation is limited by the opacity of local rules on establishment, supervision and professional secrecy, the CB asks the institutions themselves, on a case by case basis, to provide the information it requires in order to carry out its supervisory duties on a consolidated basis.

Any inspection carried out by foreign supervisory authorities representatives may only concern compliance with the prudent management standards of the State concerned so as to permit assessment of the financial situation of a banking or financial group. A report on the inspection must be provided to the $\mathrm{CB}$, which alone may impose sanctions with regard to the branch or subsidiary inspected in France.

In addition, the 2003 FSA has broadened the scope of cooperation with non-European banking groups. In particular, it enables undertakings established in France that are part of the financial group or mixed group to which belong credit institutions or investment firms having their registered office in a State with which France has concluded a bilateral agreement of sharing of information, to transmit the necessary information to undertakings of the same group having their registered office in the State party to the bilateral agreement. These exchanges of information can cover, in accordance particularly with COMOFI Art. L.511-34, all matters related to the consolidated supervision of the financial situation of a cross-border establishment as well as the organization of the fight against money laundering and the financing of terrorism.

In order to address the cross border implications of the implementation of Basel II, the CB has created working arrangements with all foreign supervisory jurisdictions in which French banks 


\begin{tabular}{|c|c|}
\hline & have establishments or which have establishments in France. \\
\hline Assessment & Compliant \\
\hline Comments & \\
\hline Principle 24. & $\begin{array}{l}\text { Host country supervision } \\
\text { A key component of consolidated supervision is establishing contact and information exchange } \\
\text { with the various other supervisors involved, primarily host country supervisory authorities. }\end{array}$ \\
\hline Description & 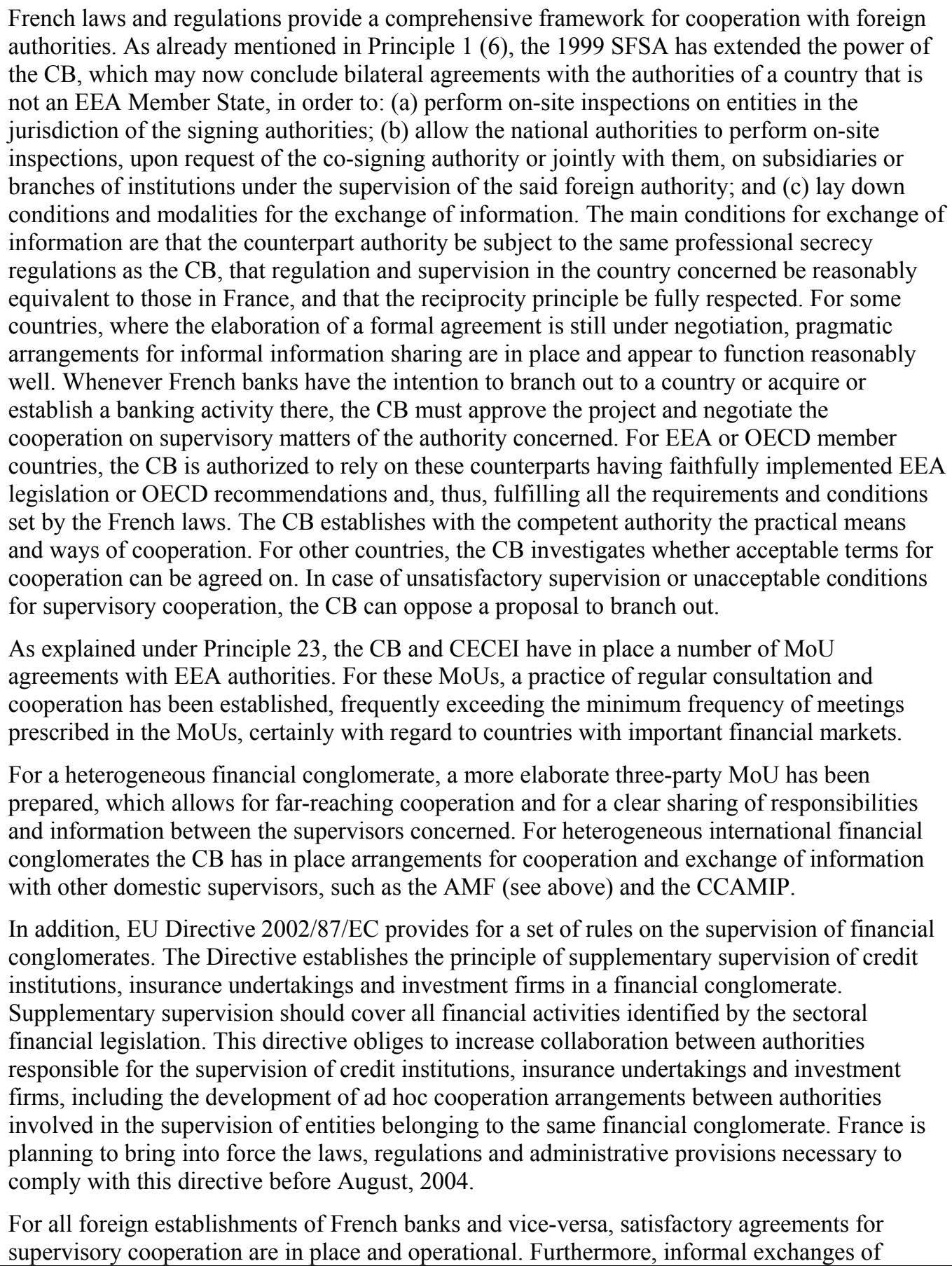 \\
\hline
\end{tabular}




\begin{tabular}{|c|c|}
\hline & $\begin{array}{l}\text { information have been taking place for several years now with other supervisors of the world's } \\
\text { leading financial markets. Other formal bilateral agreements are under preparation. However, } \\
\text { the CB wishes to limit the formal bilateral agreements to countries which share the same } \\
\text { concern for transparency in the communication of information, professional secrecy and, more } \\
\text { generally, compliance with and effective application of the criteria developed by the Basel } \\
\text { Committee. } \\
\text { In the context of international arrangements for the exercise of supervision over cross border } \\
\text { financial institutions or conglomerates, the arrangements include names and coordinates of } \\
\text { contact persons, to facilitate and expedite the establishment of contact between home and host } \\
\text { supervisors, of which there could be several, between countries as well as within countries. } \\
\text { At present, the activities of French banks in other EEA countries are generally small when } \\
\text { compared to their domestic activities (by contrast, operations in the United States and in several } \\
\text { Asian countries account for a significant part of the consolidated balance sheet of the largest } \\
\text { banking groups). Thus, the coordination of France's supervisory activity with that of its } \\
\text { counterparts appears to be sufficient, based on bilateral MoUs, and discretionary exchanges of } \\
\text { information. The active participation of the French authorities in both European and } \\
\text { international consultation forums on matters of cooperation places them in the forefront of } \\
\text { international cooperation. }\end{array}$ \\
\hline Assessment & Compliant \\
\hline Comments & \\
\hline Principle 25. & $\begin{array}{l}\text { Supervision over foreign banks' establishments } \\
\text { Banking supervisors must require the local operations of foreign banks to be conducted to the } \\
\text { same high standards as are required of domestic institutions and must have powers to share } \\
\text { information needed by the home country supervisors of those banks for the purpose of carrying } \\
\text { out consolidated supervision. }\end{array}$ \\
\hline Description & $\begin{array}{l}\text { As stated under Principle 24, the CB has full power to enter into any agreement or arrangement } \\
\text { to mutually share information with its peers abroad concerning internationally active banks. For } \\
\text { branches of EEA banks, European regulation entrusts full supervisory responsibility to the } \\
\text { home-country supervisor, with the exception of liquidity supervision and the compliance with } \\
\text { rules of conduct and money laundering provisions. Branches of non-EEA banks are subject to } \\
\text { the same rules and regulations as are French banks. The CB may, however, accept that these } \\
\text { branches meet different requirements (e.g., with regard to solvency and large exposures) } \\
\text { provided that: (a) the home-country regulations require full consolidation of the risks taken } \\
\text { abroad by the mother-bank; (b) the latter commits itself to supervise the operations and the } \\
\text { situation of its branch on the same basis and principles as for a home-based institution and this } \\
\text { under the supervision of its national supervisory authority; and (c) an equivalent treatment is } \\
\text { granted to the branches of French banks in the country concerned. } \\
\text { For subsidiaries, France, as the host-country, must provide for the full respect of its rules and } \\
\text { regulations, as such institutions are incorporated under French law, and hence are subject to full } \\
\text { CB-supervision, with both on-site and off-site examinations, on the same basis as French banks. } \\
\text { The CB also has the same sanctioning powers over such subsidiaries as over French banks, } \\
\text { inclusive of the right to close their operations. Unlike branches of foreign banks, French } \\
\text { subsidiaries of foreign banks are also covered by the FGD. Since branches of EEA banks are } \\
\text { covered by the deposit guarantee scheme of their home country, in accordance with EEA } \\
\text { directives on deposit guarantees, the coverage of their customers is equivalent to that under the } \\
\text { French regime. } \\
\text { Cooperation with the home-country supervisor ensures that the latter is enabled to perform fully } \\
\text { consolidated supervision and that it can be called upon to take supervisory action whenever } \\
\text { serious problems might occur. In addition, for licensing, the CECEI, before making any }\end{array}$ \\
\hline
\end{tabular}




\begin{tabular}{|l|l|}
\hline & $\begin{array}{l}\text { decision, may seek the advice from the home-country supervisory authority and its assessment } \\
\text { of the project. } \\
\text { Overall, the prudential norms applied to foreign banks are as stringent as those applied to } \\
\text { French banks. Within the EEA, prudential rules are harmonized. Nevertheless, the CB may } \\
\text { allow exceptions for branches from countries whose regulations are at least as stringent as in } \\
\text { France. Furthermore, the CB does not rule out the possibility of asking such branches to } \\
\text { increase their own funds if they appear insufficient in relation to their exposure. Off-site } \\
\text { supervisors regularly verify the rules that apply to foreign institutions. Likewise, the CB } \\
\text { frequently organizes on-site supervision of the branches of foreign banks, as for branches of } \\
\text { French banks. In the event of a serious deficiency, the matter may be referred to the home } \\
\text { country authorities, a practice which has become more widespread with the possibilities offered } \\
\text { by the 1999 FSFA. } \\
\text { The annual report of the CECEI describes in more detail its practices with regard to cooperation } \\
\text { with foreign supervisory authorities, including obtaining in all cases of establishment of a } \\
\text { foreign bank in France the approval of the supervisory authority charged with the supervision } \\
\text { on a consolidated basis of the group. }\end{array}$ \\
\hline Assessment & \begin{tabular}{l} 
Compliant \\
\hline Comments
\end{tabular} \\
\hline
\end{tabular}


Table 2. Summary Compliance of the Basel Core Principles

\begin{tabular}{|c|c|c|c|c|c|}
\hline Core Principle & $\mathrm{C}^{1 /}$ & $\mathrm{LC}^{2 /}$ & $\mathrm{MNC}^{3 /}$ & $\mathrm{NC}^{4 /}$ & $\mathrm{NA}^{\underline{5 /}}$ \\
\hline 1. Objectives, Autonomy, Powers, and Resources & $\mathbf{X}$ & & & & \\
\hline 1.1 Objectives & $\mathbf{X}$ & & & & \\
\hline 1.2 Independence & $\mathbf{X}$ & & & & \\
\hline 1.3 Legal framework & $\mathbf{X}$ & & & & \\
\hline 1.4 Enforcement powers & $\mathbf{X}$ & & & & \\
\hline 1.5 Legal protection & $\mathbf{X}$ & & & & \\
\hline 1.6 Information sharing & $\mathbf{X}$ & & & & \\
\hline 2. Permissible Activities & $\mathbf{X}$ & & & & \\
\hline 3. Licensing Criteria & $\mathbf{X}$ & & & & \\
\hline 4. Ownership & $\mathbf{X}$ & & & & \\
\hline 5. Investment Criteria & & $\mathbf{X}$ & & & \\
\hline 6. Capital Adequacy & $\mathbf{X}$ & & & & \\
\hline 7. Credit Policies & $\mathbf{X}$ & & & & \\
\hline 8. Loan Evaluation and Loan-Loss Provisioning & $\mathbf{X}$ & & & & \\
\hline 9. Large Exposure Limits & $\mathbf{X}$ & & & & \\
\hline 10. Connected Lending & $\mathbf{X}$ & & & & \\
\hline 11. Country Risk & $\mathbf{X}$ & & & & \\
\hline 12. Market Risks & $\mathbf{X}$ & & & & \\
\hline 13. Other Risks & $\mathbf{X}$ & & & & \\
\hline 14. Internal Control and Audit & $\mathbf{X}$ & & & & \\
\hline 15. Money Laundering & $\mathbf{X}$ & & & & \\
\hline 16. On-Site and Off-Site Supervision & $\mathbf{X}$ & & & & \\
\hline 17. Bank Management Contact & $\mathbf{X}$ & & & & \\
\hline 18. Off-Site Supervision & $\mathbf{X}$ & & & & \\
\hline 19. Validation of Supervisory Information & $\mathbf{X}$ & & & & \\
\hline 20. Consolidated Supervision & $\mathbf{X}$ & & & & \\
\hline 21. Accounting Standards & $\mathbf{X}$ & & & & \\
\hline 22. Remedial Measures & $\mathbf{X}$ & & & & \\
\hline 23. Globally Consolidated Supervision & $\mathbf{X}$ & & & & \\
\hline 24. Host Country Supervision & $\mathbf{X}$ & & & & \\
\hline 25. Supervision Over Foreign Banks' Establishments & $\mathbf{X}$ & & & & \\
\hline
\end{tabular}

${ }^{1 /} \mathrm{C}$ : Compliant.

${ }^{2 /}$ LC: Largely compliant.

${ }^{3 /} \mathrm{MNC}$ : Materially non-compliant.

4/ NC: Non-compliant.

${ }^{5 /}$ NA: Not applicable.

\section{Recommended action plan and authorities' response to the assessment}

\section{Recommended action plan}

26. The system in France for banking regulation and supervision is of high quality, and only one BCP has been assessed largely compliant and not fully compliant. However, notwithstanding this conclusion, the authorities might usefully consider taking additional steps to address two issues which the mission wishes to bring to the attention of the authorities. 
Table 3. Recommended Action Plan to Improve Compliance of the Basel Core Principles

\begin{tabular}{|l|l|}
\hline \multicolumn{1}{|c|}{ Reference Principle } & \multicolumn{1}{c|}{ Recommended Action } \\
\hline Investment criteria (BCP 5) & $\begin{array}{l}\text { Introduce the obligation to obtain prior approval of the CECEI for } \\
\text { acquisitions of equity in nonfinancial enterprises by banks } \\
\text { (measures have been developed but not yet enacted) }\end{array}$ \\
\hline Accounting Standards (BCP 21) & $\begin{array}{l}\text { Continue to strive toward convergence between French accounting } \\
\text { standards and IAS }\end{array}$ \\
\hline
\end{tabular}

\section{Authorities' response to the assessment}

27. The authorities are broadly in agreement with the assessment.

\section{ObServance OF The IAIS Insurance CoRe Principles}

\section{General}

28. This assessment examines France's observance of the International Association of Insurance Supervisors (IAIS) Insurance Core Principles (ICP) on the effective supervision of the insurance sector. The assessment was performed according to the new October 2003 ICP methodology by a two person team as part of the IMF FSAP. ${ }^{3}$

\section{Information and methodology used for assessment}

29. The assessment of observance of the IAIS Core Principles involved the review of: (i) an extensive self-assessment prepared in 2000 prepared by the former Commission de Contrôle des Assurances (CCA) based on the old methodology; (ii) comparison with the Core Principles and the Core Principles Methodology; and (iii) a review of the relevant laws governing the insurance sector in France. The legal basis regulating insurance is the Code des Assurances (as amended), which is supported by numerous decrees and implementation regulations, and the recent Loi de sécurité financière (Financial Security Law, LSF).

30. In addition, through the period of January 29-February 11, 2004, a series of meetings and discussions were held in France with officials from the insurance supervisory authority, ${ }^{4}$ the $\mathrm{MINEFI}$, the $\mathrm{BdF}$, the $\mathrm{CB}$, the insurance industry associations (Fédération

\footnotetext{
${ }^{3}$ The mission took place in February 2004. The team consisted of Andrea M. Maechler (IMF) and Helmut Müller (formerly German Bundesaufsichtsamt für das Versicherungswesen).

${ }^{4}$ Legally, the insurance supervisory authority refers to the newly created CCAMIP, in accordance with the new Financial Security Law of August 1, 2003. In practice, however, the CCAMIP was not operational yet at the time of the assessment and the meetings were held with the CCA. While the new legislation was fully in effect, some areas, such as the
} 
francaise des sociétés d'assurance-FFSA and the Groupement des Entreprises Mutuelles d'Assurances-GEMA), the actuaries association (Institut des Actuaires), private insurance companies, associations of intermediaries, auditors (the Compagnie Nationale des Commissaires aux Comptes-CNCC), and other financial institutions. On this basis, the assessors attempted as far as possible to evaluate whether the legal framework is implemented faithfully and effectively.

31. The supervisory staff at the insurance supervisory authority and other concerned agencies cooperated fully with the assessment, providing answers to an extensive questionnaire, preparing the self assessments against the IAIS Core Principles, meeting additional requests for information, and being available for a wide variety of meetings. In addition, the insurance supervisory authority and MINEFI staff assisted with logistical arrangements for the meetings with industry bodies and companies, for which the mission expresses its gratitude.

32. The assessment was undertaken during a period of transition. On the one hand, the ICP are relatively new. The old version dating from 2000 was revised in 2003.

33. On the other hand, the French supervisory environment has been significantly modified by the Financial Security Law of August 1, 2003. This legislation created the joint insurance supervision body, called Commission de Contrôle des Assurances, des Mutuelles et des Institutions de Prévoyance (CCAMIP), as the result of the merger of the CCA, responsible for the supervision of companies regulated by the old insurance code, and the Commission de Contrôle des Mutuelles et des Institutions de Prévoyance (CCMIP), responsible for the supervision of certain mutual insurers. The provisions of the law also gave financial independence to the CCAMIP, strengthened coordination with the banking sector supervisors, and extended the powers of the supervisory authorities to request and receive information from supervised entities and auditors. The implementation orders (décrets d'application) for the new law were under review by the Conseil d'Etat at the time of the assessment; the transition period ended as of July 2004 with the publication of outstanding orders.

\section{Institutional and macro prudential setting-overview}

34. The French insurance sector is large and of systemic importance. With a 5 percent market share of gross premiums in the OECD in 2001, France's insurance sector was ranked the fifth largest in the world and the third largest in Europe. ${ }^{5}$ In terms of density (premiums

operational set-up of the CCAMIP, needed the publication of additional implementation orders (décrets d'application) for the new law on financial security to come into force. The current assessment, however, is based on the new legislation and refers to the new supervisory agency CCAMIP.

${ }^{5}$ OECD, 2003, Insurance Statistics Yearbook 1994-2001. 
per capita), France ranks slightly lower at the tenth position in the OECD. With an insurance penetration ratio (premiums as a percentage of GDP) slightly over 10 percent, France ranks eighth in the OECD.

35. The French insurance industry includes a variety of insurance companies, including life, and health and accident (henceforth referred to as "mixed") (126), nonlife (295) and reinsurance (33). ${ }^{6}$ In 2002, the French insurance sector was largely dominated by the life and mixed sectors, accounting for over 80 percent of total assets ( 30 percent for life and 53 percent for mixed). Non-life insurance represented only 14 percent of total assets. Reinsurance plays only a minor role, accounting for 4 percent of total insurance assets. ${ }^{7}$ By legal form, stock companies accounted for 80 percent of premium income, mutual insurance companies 11 percent, public-owned institutions 9 percent, and the branches of foreign companies (outside the EEA) less than 0.1 percent. $^{8}$

36. The insurance industry seems to be supported by a healthy level of competition. Market concentration is higher in the life insurance sector, where at end 2002 the three (10) largest insurance companies represented 29 percent (60 percent) of total assets. In nonlife, the three (10) largest companies represented 22 percent (45 percent) of total assets. A notable feature of the industry is the prevalence of bancassurance: a large minority (by assets) of insurance companies are subsidiaries of banks, which also offer policies from nonsubsidiaries. The French insurance market is notable for its broad range of distribution channels, which include tied agents, insurance brokers, salaried sales forces (as in the case of bancassurance), direct writing mutuals, and financial institutions.

37. In life sector, the most common product is a type of savings product (assurance $\grave{a}$ capital différé avec contre-assurance en cas de décès or "mixed capital insurance" product), accounting for almost 65 percent of total life premium income. This product is subsequently paid out in the form of a lump-sum benefit or multiple payment if the insured dies or outlives the term of the policy. This product can be taken out directly by the individuals or through an employer or association (group policies account for 7 percent of pure endowment premium income). Such policies have a guaranteed rate of return which is used to calculate technical provisions. The second largest type of life insurance policies (representing 15 percent of total life premium income) is a unit-linked contract. This type of policy is expressed in the units of an investment vehicle, such as shares of a mutual fund or a real-estate partnership. Since the

\footnotetext{
${ }^{6}$ Unless indicated otherwise, the health and accidents sectors are lumped together with life sector.

${ }^{7}$ In terms of total premium income, however, reinsurance accounts for a much higher market share, with 14.5 percent of total premium income.

${ }^{8}$ There are approximately 80 small mutual companies not under the supervision of the CCAMIP and regulated by the code of social security. These companies provide social security related insurance (health, unemployment, maternity leave, etc.) and are under the control of the state.
} 
contract benefits fluctuate with the market values of the underlying investment instruments, the investment risk is entirely borne by the policyholders, unless there are linked to some minimum guarantees.

38. The regulatory framework for life insurance companies relies on three pillars: (i) solvency requirements (approximately 4 percent of total mathematical provisions for endowment products and 1 percent for unit-linked contracts) $;{ }^{9}$ (ii) regulations on the measurement of liabilities (i.e., technical provisions); and (iii) regulations governing investment policies (including conservative accounting principles applied to asset valuation). At end-2002, the solvency margin (including unrealized capital gains) was estimated at 9.3 percent of provisions, or 2.4 times the required minimum. Non-life insurance companies are required to have a minimum regulatory ratio equal to 18 percent of annual premiums (16 percent for large companies), or 26 percent of average claims paid out in the preceding three years (23 percent for large companies), whichever amount is higher. ${ }^{10}$ At end-2002, the solvency margin (including unrealized capital gains) was estimated at 39.3 percent of provisions, or 4.8 times the required minimum. ${ }^{11}$ In addition, the CCAMIP is promoting a sound level of asset-liability management expertise on the industry-wide basis. Since 2001, insurers are required to conduct periodically a series of stress tests, aimed at monitoring the ability of insurance companies to model and anticipate the consequences of various financial market shocks (such as movements in interest rates, or equity or real estate prices) on their asset-liability match.

39. Overall, the condition of the French insurance industry suggests that systemic vulnerabilities are well contained. The sector seems to have demonstrated its resilience in the face of a number of significant shocks in recent years (including, among others, a significant fall in international equity prices in 2001-2003, historically low interest rates, and international and national natural catastrophes, including September 2001 and major storms or flooding in France in 1999 and 2000).

40. Sources of stability include: (i) the ability of the life sector to reduce progressively the level of guaranteed interest rates (to zero percent for most new contracts) and shorten the contract duration, in an effort to reduce interest rate risks borne by the insurers; (ii) greater product mix diversification with unit-linked products, where the investment risk is fully borne by the policyholders (even after the recent poor equity market performance, unit-linked products continue to represent 18 percent of life and mixed insurance premiums); (iii) a conservative investment portfolio, with over three quarter of total assets invested in fixed-

${ }^{9}$ In life insurance, this minimum requirement can be lowered up to 15 percent, depending on existing reinsurance agreements.

${ }^{10}$ In non-life insurance, this minimum requirement can be lowered up to 50 percent, depending on existing reinsurance agreements.

${ }^{11}$ Alternatively, at end-2002, the solvency margin (including unrealized gains) represented 72.4 percent of premiums. 
income instruments (in life, equity represents only 12 percent of total assets and real estate less than 5 percent, leaving the remaining 84 percent invested in fixed-term instruments; this asset composition has helped shield the French insurance sector from the consequences of the recent fall in international equity prices); (iv) despite the presence of large bancassurance groups, limited risk transfer between the banking and insurance sectors; and (v) a relatively small reinsurance activity, accounting for only 3 percent of total assets in the French insurance sector.

41. The insurance industry is facing a number of challenges. These include: (i) the demographic trend (longer life expectancy and decline in working population), which creates concerns about financial sustainability of the currently fully state-funded pension and medical plans; (ii) the up-coming implementation of the new International Accounting Standards (IAS) norms in 2005, which expose the insurance industry to vulnerable accounting risks; and (iii) a possible sharp and sustained increase in interest rates, which could generate a wave of contract repurchases, which in turn would force insurance companies to sell some of their assets (fixed-income instruments) at loss-making values in order to pay out the surrender values. However, the authorities seem aware of these challenges and are considering how to take preemptive measures, including the promotion of a new generation of private retirement products or ensuring a sound and sophisticated system of asset-liability management at the industry-wide level.

\section{General preconditions for effective insurance supervision}

42. The supervision of insurance companies in France is based on the EU Directives and French insurance law, ordinances, codes and circulars. The legal requirements governing insurance companies originate in both company law and insurance law. In France, the regulation of insurance falls under the jurisdiction of the MoE, while the supervision is under the responsibility of the CCAMIP and the CEA.

43. The legal system in France operates effectively. The auditing and accounting professions in France are well developed and follow best international practices. In the case of large companies, the accuracy of the financial statements must be confirmed simultaneously by two sets of external auditors. The auditing and accounting rules applicable to insurance companies generally comply with international standards. Further harmonization will be achieved in 2005 when the whole EU area will implement IAS. The actuarial profession is large and well-developed in France.

44. The French economy is well large, well diversified, and generally relatively stable in both real and nominal terms. These conditions not only contribute to the growth of the insurance sector, but also facilitate effective supervision.

\section{Principle-by-principle assessment}

45. The legal, regulatory and supervisory framework observes a large majority of the essential criteria of the IAIS Principles Methodology. The assessment reveals that most of the 
28 ICP of the IAIS are observed. ICP 9, 10, 17 and 18 are largely observed, and ICP 3, 24 and 28 are partly observed.

46. The level of observance for each principle reflects the assessments of the essential criteria established by the IAIS. A principle is considered "observed" whenever all the essential criteria are considered to be observed or when all the essential criteria are observed except for a number that are considered not applicable. For a criterion to be considered "observed," it is usually necessary that the authority has the legal authority to perform its tasks and that it exercises this authority to a satisfactory standard and ensures that requirements are implemented. The existence of a power in the law is insufficient for full observance to be recorded against a criterion except where the criterion is specifically limited in this respect. In the event that the supervisor has a history of using a practice for which it has no explicit legal authority, the assessment may be considered as "observed" if the practice is substantiated as common and undisputed.

47. A principle is considered to be "not applicable" when the essential criteria are considered to be "not applicable." A criterion would be considered 'not applicable' whenever the criterion does not apply given the structural, legal and institutional features of a jurisdiction.

48. For a principle to be considered "largely observed," it is necessary that only minor shortcomings exist which do not raise any concerns about the authority's ability to achieve full observance with the principle. A principle will be considered "partly observed" whenever, despite progress, the shortcomings are sufficient to raise doubts about the authority's ability to achieve observance. A principle will be considered "not observed" whenever no substantive progress toward observance has been achieved.

\section{Table 4. Detailed Assessment of Observance of the IAIS Insurance Core Principles}

\begin{tabular}{|l|l|}
\hline Principle 1. & $\begin{array}{l}\text { Conditions for effective insurance supervision } \\
\text { Insurance supervision relies upon } \\
-\quad \text { a policy, institutional and legal framework for financial sector supervision, } \\
\text { - a well developed and effective financial market infrastructure, } \\
\text { - and efficient financial markets. }\end{array}$ \\
\hline Description & $\begin{array}{l}\text { The environment in which the French insurance supervisory authority operates is conducive to } \\
\text { effective supervision and the achievement of its objectives. }\end{array}$ \\
& $\begin{array}{l}\text { 1. Financial sector policy framework } \\
\text { financial stability, including through the effective supervision in insurance and other financial } \\
\text { sectors. An example of this policy is the Financial Security Law of August } 1^{\text {st }}, 2003 \text { (Loi de } \\
\text { securité financière, LSF), which is designed to strengthen the efficiency of financial sector } \\
\text { supervision. } \\
\text { The legal and institutional framework is mostly enshrined in the form of codes (the Code des } \\
\text { Assurances, for instance), which are comprehensive, carefully drafted, and publicly disclosed. }\end{array}$ \\
\hline
\end{tabular}




\begin{tabular}{|c|c|}
\hline & $\begin{array}{l}\text { The laws and regulations are updated, as necessary, to maintain consistency with developments } \\
\text { in national and international standards and best practices. } \\
\text { 2. Financial market infrastructure } \\
\text { The infrastructure necessary for effective supervision is in place. The general legal system } \\
\text { (civil law, administrative law, penal law, tax law, etc.) is accountable and reliable; the court } \\
\text { system is generally reliable and transparent; accounting, actuarial and auditing standards are } \\
\text { consistent; qualified and experienced actuaries, accountants, auditors and lawyers are available; } \\
\text { general and special statistics are accessible; professional associations are available to assist and } \\
\text { protect persons and companies in their various different functions for the insurance sector. } \\
\text { Macroeconomic policy promotes overall stability and the conditions under which the } \\
\text { population and industry have incentives to make use of insurance (for example, by maintaining } \\
\text { low and stable inflation rates). Tax policy is also used to encourage demand for insurance. } \\
\text { 3. Efficient capital market } \\
\text { Paris is one of the most important and sophisticated financial centers of the world, with well } \\
\text { functioning money and security markets. }\end{array}$ \\
\hline Assessment & Observed. \\
\hline Comments & None. \\
\hline Principle 2. & $\begin{array}{l}\text { Supervisory objectives } \\
\text { The principal objectives of insurance supervision are clearly defined. }\end{array}$ \\
\hline Description & $\begin{array}{l}\text { The supervisory objective is clearly defined in Art. L.310-12 Code des Assurances. The main } \\
\text { objective is the protection of the interests of the insured. These interests are defined in a broad } \\
\text { sense that includes the interests of the policyholder, the insured person, the beneficiaries and- } \\
\text { in the case of third party liability insurance-the interests of the victims. } \\
\text { There are no other legal objectives which could conflict with the attainment of the main target. }\end{array}$ \\
\hline Assessment & Observed. \\
\hline Comments & None. \\
\hline Principle 3. & $\begin{array}{l}\text { Supervisory authority } \\
\text { The supervisory authority: } \\
\text { - has adequate powers, legal protection and financial resources to exercise its functions and } \\
\text { - powers } \\
\text { - is operationally independent and accountable in the exercise of its functions and powers } \\
\text { - treats confidential information appropriately. }\end{array}$ \\
\hline Description & $\begin{array}{l}\text { Supervisory bodies } \\
\text { Most supervisory responsibilities are allocated between the Comité des Entreprises } \\
\text { d'Assurance (CEA) and the Commission de Contrôle des Assurances, des Mutuelles et des } \\
\text { Institutions de Prévoyance (CCAMIP). } \\
\text { The new LSF assigned to the CEA some of the responsibilities that had been the responsibility } \\
\text { of the MoE. Hence, the CEA is responsible for the issuing of authorizations (see ICP 6), for the } \\
\text { test of whether owners, board members and senior managers are fit and proper to fulfill their } \\
\text { roles (see ICP 7), and for authorizing portfolio transfers and mergers of undertakings (see } \\
\text { ICP 8). }\end{array}$ \\
\hline
\end{tabular}


The Financial Security Law mandated the merger of the $C C A$ with the $C C M I P$, which was the authority supervising mutual health insurance societies and professional protection schemes. The new CCAMIP will supervise all insurance undertakings as defined in Art. 8 of the First EU Non-Life and the First EU Life Insurance Directives.

The MoE has retained some functions in insurance supervision (e.g., power to issue rules by administrative means, and the possibility of asking the CEA to postpone any of its decisions; see Art. L.413-5 Code des Assurances).

The CEA is composed of a chairman (appointed by the MoE), the director of the treasury, the chairman and the secretary general of the CCAMIP and eight members whom the Minister of the Economy, Finance, and Industry appoints for terms of three years. These comprise: two representatives of insurance companies; one representative of the staff of insurance companies; one representative of the health mutual societies and professional protection schemes (the last without voting right); two members representing the Conseil d'Etat and the Cour de Cassation; and two are individuals selected for their knowledge in the insurance sector.

The CCAMIP is composed of nine members: the chairman; the governor of the BdF; one member of the Conseil d'Etat; one member of the Cour de Cassation; one representative of the Cour des Comptes; and four individuals selected for their competence in insurance.

The CCAMIP has a secretariat headed by the Secretary General, to whom responsibility for ongoing operations is assigned. The Secretary General attends meetings of the CCAMIP but has no voting power.

\section{Legal framework}

The Code des Assurances clearly fixes the allocation of authority in insurance supervision.

Neither the CCAMIP nor the CEA have the power to issue rules by administrative means. The legal framework provides sufficient and appropriate powers to the supervisors for effective discharge of supervisory responsibilities.

\section{Independence and accountability}

Internal governance requirements are in place, but they are dispersed in several laws and regulations (Code Pénal, Code des Assurances, etc.). The CCAMIP has prepared a Code of Conduct for its staff, which is expected to come into force after approval by the new Commission. This Code contains the legal requirements (e.g., requirements regarding professional secrecy), principles of the jurisprudence, prohibitions (e.g., regarding the holding of shares of insurance companies), and guidelines on staff conduct, internal information sharing, etc.

Procedures regarding the appointment and dismissal of the head and members of the CCAMIP are in place. The chairman and the other members of the Commission cannot be removed during the period they are appointed, except in a case they commit a crime.

Institutional relationships between the supervisory authority and other organizations of the executive, legislature and judiciary are clearly defined.

The supervisory authority and their staff are free from undue political, governmental and industrial interference. For example, the Minister of the Economy, Finance and Industry does not have the power to give directions or guidelines to the supervisor. The supervisory authority is financed in a manner that does not undermine its independence (see below).

Supervisory processes are transparent. The decisions are consistent across similar cases, and need to be justified. Proposals for new legislation or regulation are normally subject of prior hearings with market participants. New legislation or regulation as well as changes in supervisory policy must be publicly explained by the supervisory authority. The disclosure of information limited only by the confidentiality principle and the need to protect the interests of 


\begin{tabular}{|c|c|}
\hline & 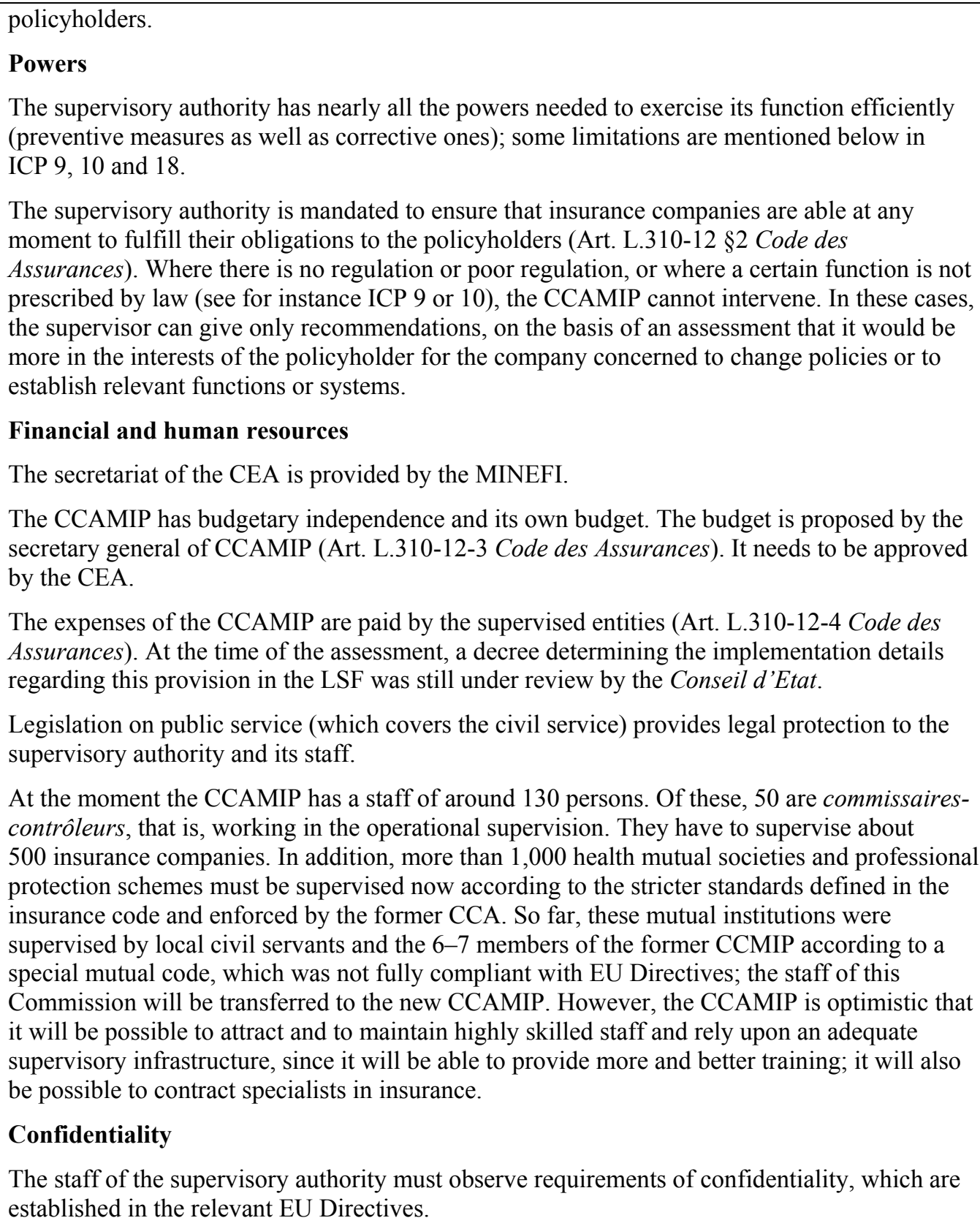 \\
\hline Assessment & Partly observed. \\
\hline Comments & $\begin{array}{l}\text { The supervisory authority lacks powers to issue rules by administrative means. This power } \\
\text { belongs exclusively to the MoE. This situation is not compliant with ICP3: while the laws lay } \\
\text { down the principles of supervision, the details within the legal framework must be determined } \\
\text { by regulations of the supervisory authority. The latter has better knowledge and more } \\
\text { experience, and above all, the supervisor is responsible for the achievement of the legally fixed } \\
\text { supervisory objectives. It is indispensable that only this authority and nobody else should have } \\
\text { the power to issue the necessary indications of how the legal supervisory principles have to be }\end{array}$ \\
\hline
\end{tabular}




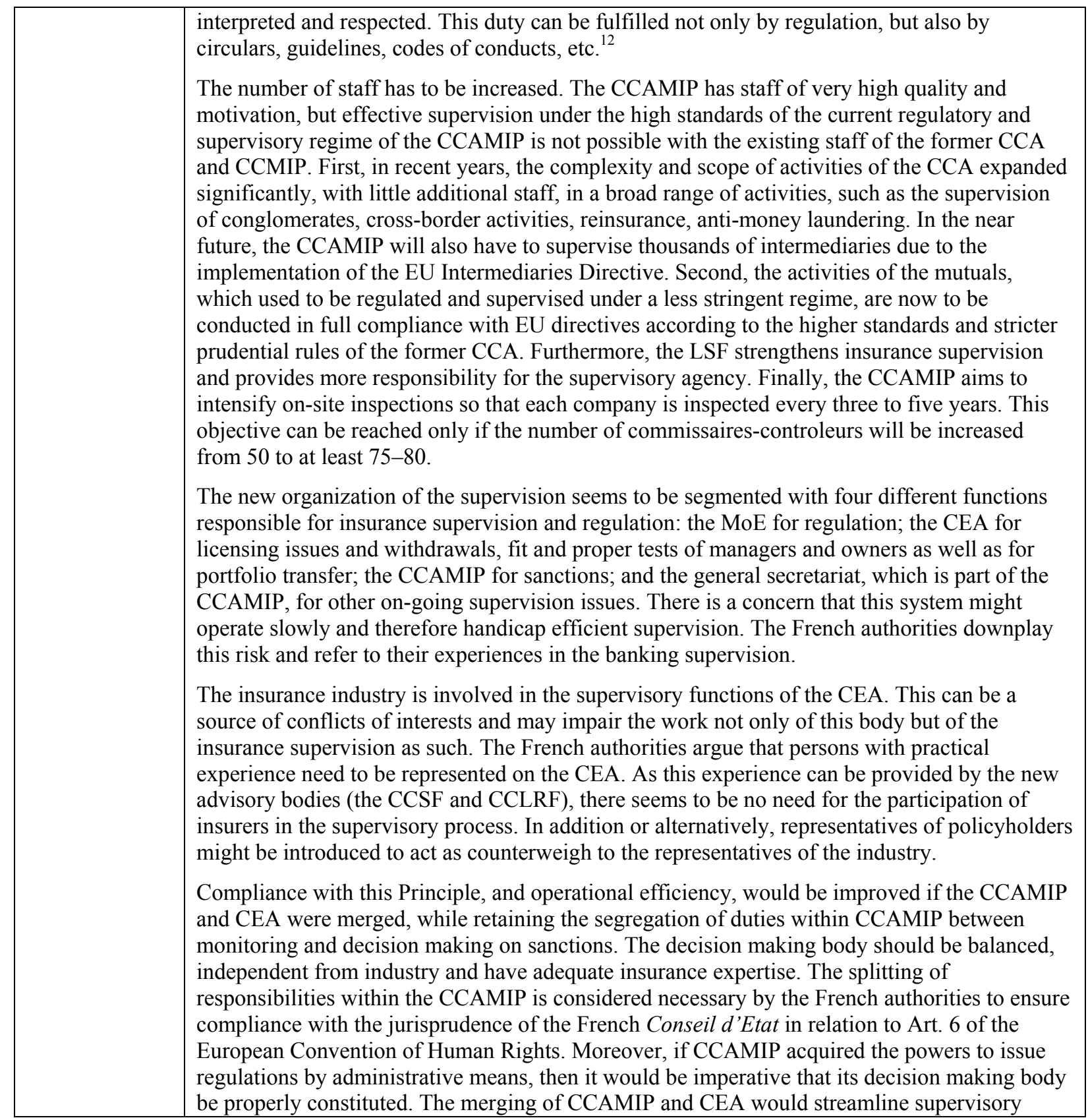

${ }^{12}$ The fact that in its introduction (para. 8), the ICP methodology acknowledges that the body that sets out the legal framework may be different from the body that implements it, is not inconsistent with the requirement in ICP3, essential criterion b, that the supervisory authority must have the administrative means to issue and enforce the regulatory framework. The legal framework in this case refers to the totality of the relevant laws, whereas the regulatory framework refers to the totality of the regulations, which must be under the responsibility of the insurance supervisory authority. Otherwise, ICP3, criterion b would not make any sense. 


\begin{tabular}{|c|c|}
\hline & $\begin{array}{l}\text { processes and allow the planned increase in staff to be deployed in the most efficient manner } \\
\text { possible. The current arrangement (four functional units) is, however, very new and its } \\
\text { performance should be closely monitored, and a date set for reviewing the structure. } \\
\text { In view of the fact that three of the main essential criteria (no administrative regulation power, } \\
\text { possible conflicts of interests in the CEA and not enough staff) are not fulfilled, the ICP must } \\
\text { be considered as only partly observed. }\end{array}$ \\
\hline Principle 4. & $\begin{array}{l}\text { Supervisory process } \\
\text { The supervisory authority conducts its functions in a transparent and accountable manner. }\end{array}$ \\
\hline Description & $\begin{array}{l}\text { The supervisory process is established in the Code des Assurances and in the associated } \\
\text { regulations. These are updated regularly following discussions with the insurance industry. } \\
\text { Measures taken by the supervisory authorities are consistent and equitable. Insurance } \\
\text { companies have the right to appeal to the relevant court against decisions of the supervisory } \\
\text { authority. An action against a supervisory measure does not lead to its suspension. } \\
\text { A full description of the role, objective and activities of the supervisory authorities is published } \\
\text { on the internet, in annual reports and other media (see also Annex III of the Annual report of } \\
\text { the former CCA). Information about the situation of the insurance market, national and } \\
\text { international developments, the most important decisions, cooperation with other national and } \\
\text { international institutions, and other current issues is contained in the CCAMIP's annual report } \\
\text { and its tableaux de synthèse des entreprises d'assurance et de réassurance. }\end{array}$ \\
\hline Assessment & Observed. \\
\hline Comments & None. \\
\hline Principle 5. & $\begin{array}{l}\text { Supervisory cooperation and information sharing } \\
\text { The supervisory authority cooperates and shares information with other relevant supervisors } \\
\text { subject to confidentiality requirements. }\end{array}$ \\
\hline Description & $\begin{array}{l}\text { The CCAMIP is allowed to exchange information with other French financial supervisors } \\
\text { without any restrictions. In October 2001, the CCA and the } C B \text { concluded a Charte relative à } \\
\text { la coopération en matière de contrôle et d'échange d'information. } \\
\text { As regards the relations between the French supervisor and foreign supervisors, a distinction } \\
\text { must be made between supervisors in the EEA and non-EEA supervisors, since for the latter } \\
\text { the possibilities of cooperation are more limited. } \\
\text { Cooperation between EEA insurance supervisors, including information sharing, is regulated } \\
\text { through several directives and multilateral protocols of application. These arrangements allow } \\
\text { for the unrestricted exchange of information, including on a cross-sector basis in the case of } \\
\text { supervision of insurance groups or financial conglomerates. The French legislative has } \\
\text { transferred these arrangements into French law. } \\
\text { As regards non-EEA insurance supervisors, the CCAMIP has the authority to enter into } \\
\text { agreements with foreign competent authorities on the exchange relevant information (provided } \\
\text { the foreign supervisor is subject to professional secrecy constraints); allowing the French } \\
\text { supervisor to carry on on-site inspections in foreign branches of French undertakings; and } \\
\text { allowing, under certain conditions, foreign supervisors to participate in the on-site inspections } \\
\text { carried on by the CCAMIP in French branches of foreign companies (Art. L.310-21 Code des } \\
\text { Assurances.) }\end{array}$ \\
\hline Assessment & \\
\hline
\end{tabular}




\begin{tabular}{|c|c|}
\hline Comments & None. \\
\hline Principle 6. & $\begin{array}{l}\text { Licensing } \\
\text { An insurer must be licensed before it can operate within a jurisdiction. The requirements for } \\
\text { licensing are clear, objective and public. }\end{array}$ \\
\hline Description & 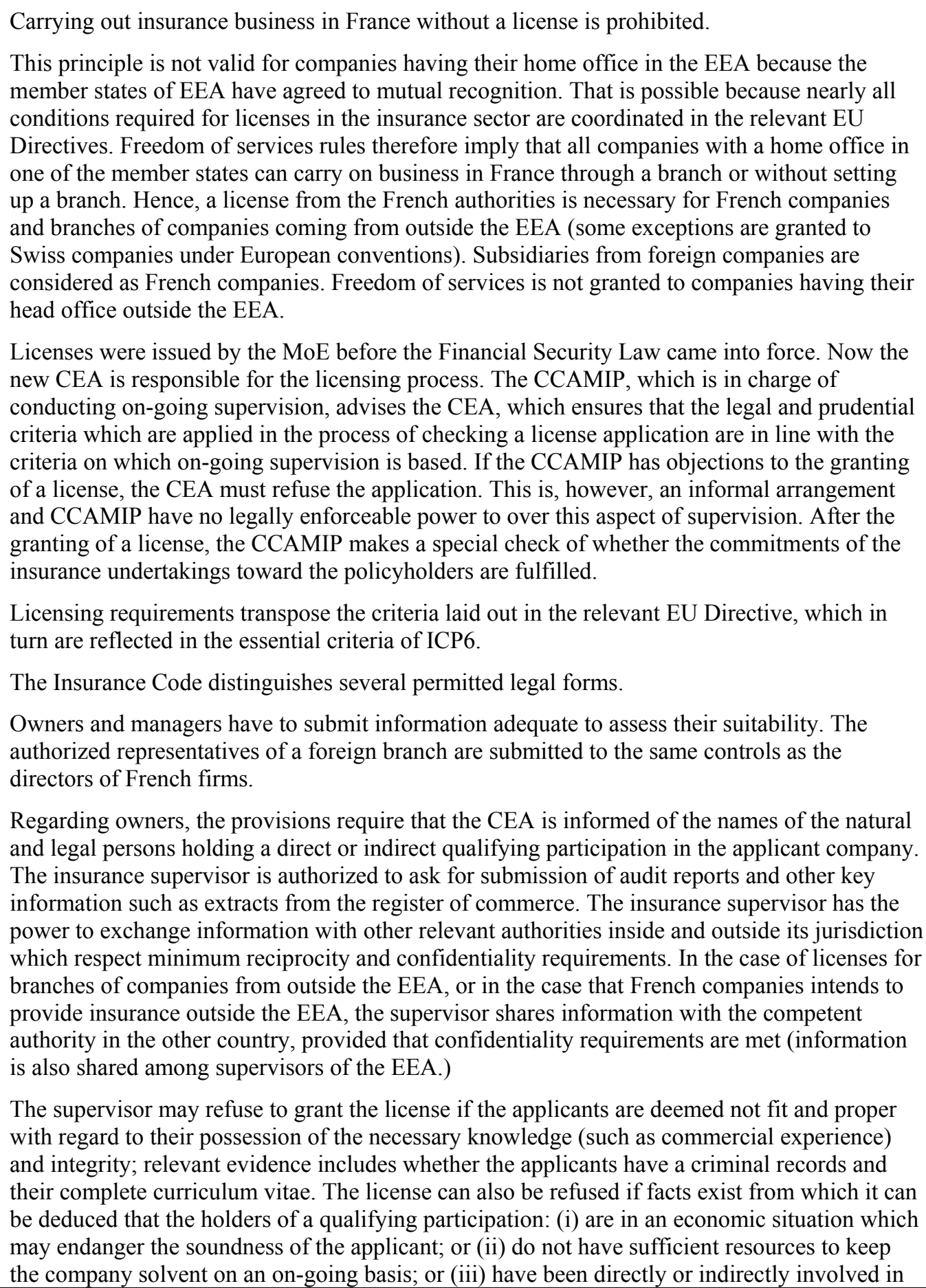 \\
\hline
\end{tabular}




\begin{tabular}{|c|c|}
\hline & 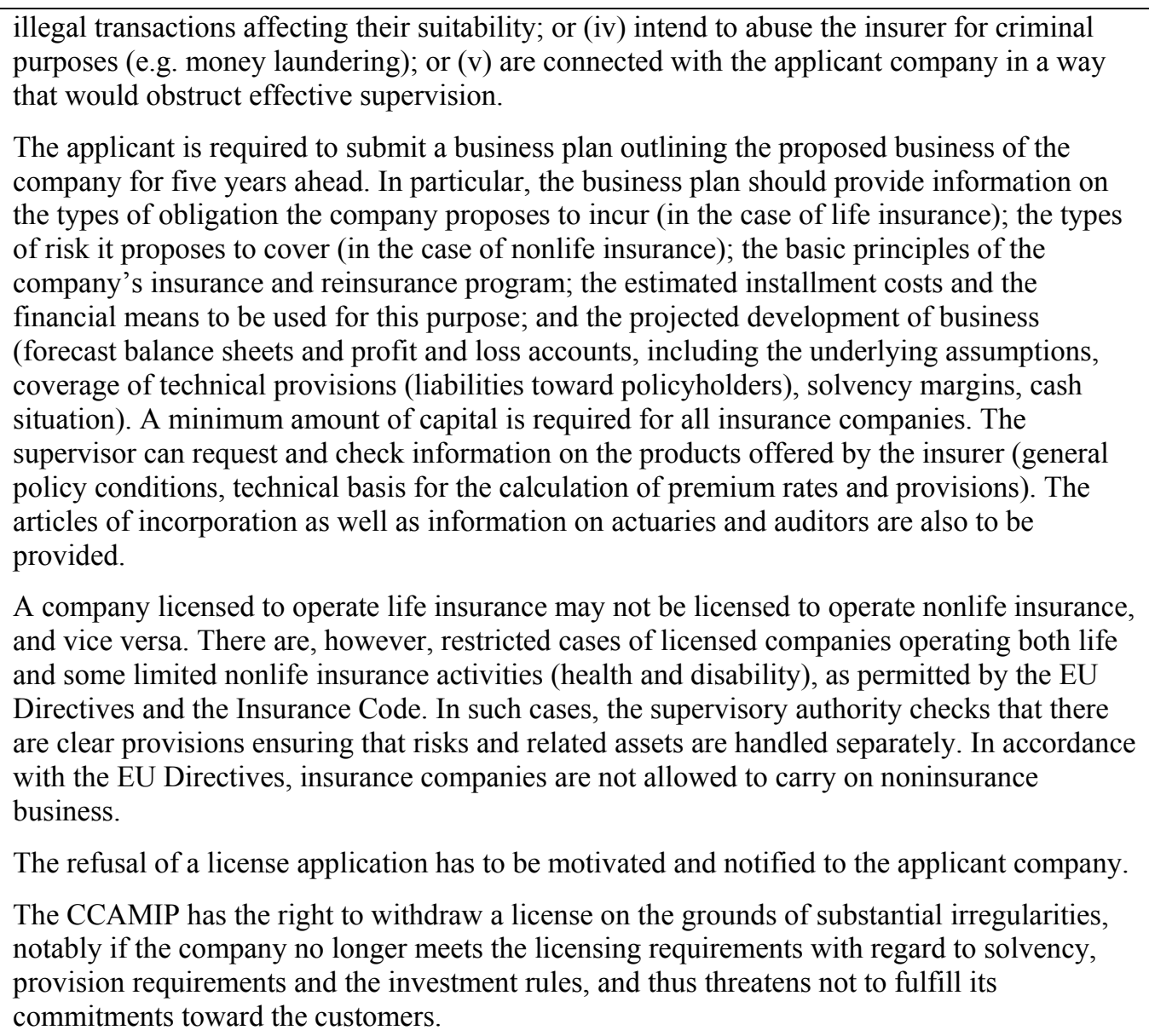 \\
\hline Assessment & Observed. \\
\hline Comments & None. \\
\hline Principle 7. & $\begin{array}{l}\text { Suitability of persons } \\
\text { The significant owners, board members, senior management, auditors and actuaries of an } \\
\text { insurer are fit and proper to fulfill their roles. This requires that they possess the appropriate } \\
\text { integrity, competency, experience and qualifications. }\end{array}$ \\
\hline Description & $\begin{array}{l}\text { The Code des Assurances (Art. L.322-2) requires that the board members have to be fit and } \\
\text { proper in the sense of competency, experience and integrity. The details are laid down in } \\
\text { decrees. They are compliant with the standards in the EU and with the criteria of ICP7. The } \\
\text { insurer has to justify that the candidate fulfils the requirements. The company has to inform the } \\
\text { supervisor at least one day before an appointment comes into force; the CEA must decide in at } \\
\text { least three months whether the license has to be removed due to a change of board members } \\
\text { (Art. R. 321-17-1, A. 310-2 Code des Assurances). In practice the CCAMIP takes other, more } \\
\text { appropriate measures if a manager is deemed not fit and proper, such as the appointment of a } \\
\text { temporary administrator who substitutes for concerned person. } \\
\text { An insurance company is not required to inform the supervisory authority if it becomes aware } \\
\text { of circumstances that may lead to doubts about the fitness and propriety of the person in } \\
\text { question. } \\
\text { The supervisory authority exchanges information on board members with other authorities at }\end{array}$ \\
\hline
\end{tabular}




\begin{tabular}{|c|c|}
\hline & $\begin{array}{l}\text { home and abroad, if necessary. } \\
\text { Actuaries are not legally required to be employed in an insurance company. France has not } \\
\text { foreseen the institution of an appointed actuary (as in the UK) or a responsible actuary (as in } \\
\text { Germany) with special functions and duties. } \\
\text { External auditors (commissaires aux comptes) must be notified to the supervisory authority } \\
\text { (Art. L.319-19-1 Code des Assurances). If the CCAMIP has doubts or concerns about the } \\
\text { quality of the auditor, it may not ask the company to nominate another person or itself appoint } \\
\text { another person. Rather, it can nominate a second auditor in whom the CCAMIP is confident. In } \\
\text { the case that the auditor has violated its duties, the CCAMIP can ask the relevant court to } \\
\text { dismiss the auditor. }\end{array}$ \\
\hline Assessment & Observed. \\
\hline Comments & $\begin{array}{l}\text { Regulations should be introduced requiring an insurance company to inform the supervisory } \\
\text { authority if it becomes aware of circumstances that may lead to doubts about the fitness and } \\
\text { propriety of owners, senior management, and others in positions of responsibility. } \\
\text { Senior managers of French companies are members of the board (whether the Administrative } \\
\text { Board or the Managerial Board). }\end{array}$ \\
\hline Principle 8. & $\begin{array}{l}\text { Changes in control and portfolio transfers } \\
\text { The supervisory authority approves or rejects proposals to acquire significant ownership or any } \\
\text { other interest in an insurer that results in that person, directly or indirectly, alone or with an } \\
\text { associate, exercising control over the insurer. } \\
\text { The supervisory authority approves the portfolio transfer or merger of insurance business. }\end{array}$ \\
\hline Description & $\begin{array}{l}\text { 1. Changes in control } \\
\text { The process regarding the changes in control of an insurance company is laid down in the } \\
\text { relevant EU Directives, which are transposed into French law. The European requirements are } \\
\text { compliant with ICP7. } \\
\text { The Code des Assurances lays down the obligation to notify to the CEA of changes in control } \\
\text { and whenever changes in shareholding are planned that affect } 10,20,33 \text { or more than } \\
50 \text { percent of shares or voting rights. The CEA is entitled to refuse the operation within a } \\
\text { maximum delay of } 3 \text { months. Any violation of the obligation to declare changes in } \\
\text { participation exceeding the thresholds indicated by the Code des Assurances is a cause for the } \\
\text { suspension of the voting rights attached to the shares concerned. In all cases, the suitability of } \\
\text { the new owners and the consequences of these changes for the business plan are checked, and } \\
\text { on this basis the CEA can oppose the operation or ask for commitments ensuring the soundness } \\
\text { and stability of the insurance undertaking. } \\
\text { 2. Portfolio transfer } \\
\text { The transfer of portfolio (totally or partly) needs prior approval of the supervisory authority } \\
\text { (the CEA) (Code des Assurances, Art. L.324-1). The policyholders and the creditors must be } \\
\text { informed by publication in the Journal Officiel. They can present their objections during the } \\
\text { two month following publication. The CEA checks together with the CCAMIP whether the } \\
\text { interests of the policyholders of both the transferee and the transferor are protected. The } \\
\text { policyholders can immediately cancel their contract even if the CEA approves the transfer. } \\
\text { A transfer is possible without approval of the supervisory authority if all policyholders declare } \\
\text { explicitly that they agree to the transfer and consent to conclude a new contract with the } \\
\text { cessionary. }\end{array}$ \\
\hline
\end{tabular}




\begin{tabular}{|c|c|}
\hline Assessment & Observed. \\
\hline Comments & None. \\
\hline \multirow[t]{2}{*}{ Principle 9.} & Corporate governance \\
\hline & $\begin{array}{l}\text { The corporate governance framework recognizes and protects rights of all interested parties. } \\
\text { The supervisory authority requires compliance with all applicable corporate governance } \\
\text { standards. }\end{array}$ \\
\hline \multirow[t]{3}{*}{ Description } & $\begin{array}{l}\text { Regulations on corporate governance are largely covered in the Code de Commerce } \\
\text { (Art. L. } 225-17 \text { etc.) for joint stock companies, and in the Code des Assurance (L.322-26-2, } \\
\text { etc.) for mutual companies. These regulations are not very detailed and have a general } \\
\text { character. Many of the requirements in the essential criteria of ICP9 are not mentioned in the } \\
\text { regulations (for example, on the establishment of independent risk management functions and } \\
\text { audit and actuarial functions, distinction between responsibilities, decision-making, interaction } \\
\text { and cooperation between the different boards and functions, establishment of a remuneration } \\
\text { policy, fair treatment of customers, responsibilities of the senior management, prohibition of } \\
\text { incentives that would encourage imprudent behavior, and appointment of a compliance } \\
\text { officer). }\end{array}$ \\
\hline & $\begin{array}{l}\text { The supervisory authority (CCAMIP) requires and verifies (mainly through on-site inspections) } \\
\text { that the insurer complies with the existent corporate governance principles. In the case of } \\
\text { irregularities, the supervisor can give recommendations (Art. L.310-17 Code des Assurances) } \\
\text { and, if necessary, take sanctions on the basis of the general legal clause in Art. L.310-18 Code } \\
\text { des Assurances. Where principles are not clearly established in the regulations, the supervisory } \\
\text { agency can still make recommendations (Art. L.310-17 Code des Assurances), but it is much } \\
\text { more difficult for the CCAMIP to require and enforce the observance of these principles, } \\
\text { except in cases of serious infringements, where it can easily prove that that noncompliance may } \\
\text { threaten the solvability margin and fulfillment of policy commitments of the supervised entity } \\
\text { (see Art. L.310-12 } \$ 2 \text { of the Code des Assurances for CCAMIP's scope of responsibilities and } \\
\text { Art. L.310-18 for possible sanctions). }\end{array}$ \\
\hline & $\begin{array}{l}\text { Neither the legislative, the supervisory authority, nor the associations of the insurance industry } \\
\text { have issued code of conducts regarding corporate governance. Some of the largest companies } \\
\text { (especially these which are listed on the New York Stock Exchange) have established their } \\
\text { own code. }\end{array}$ \\
\hline Assessment & Largely observed. \\
\hline Comments & $\begin{array}{l}\text { Many of the principles laid down in the essential and advanced criteria of ICP } 9 \text { are established } \\
\text { in the regulations dealing with corporate governance. It is recommended to give to the } \\
\text { CCAMIP the power to issue a Code of Conduct of Corporate Governance for all insurance } \\
\text { companies supervised by this authority. This suggested Code of Conduct should also contain } \\
\text { the requirements for efficient internal control that must be resected by all supervised insurance } \\
\text { companies. }\end{array}$ \\
\hline \multirow[t]{2}{*}{ Principle 10.} & Internal control \\
\hline & $\begin{array}{l}\text { The supervisory authority requires insurers to have in place internal controls that are adequate } \\
\text { for the nature and scale of the business. The oversight and reporting systems allow the board } \\
\text { and management to monitor and control the operations. }\end{array}$ \\
\hline
\end{tabular}

${ }^{13}$ A similar argument applies also to ICP 10 and 18. 


\begin{tabular}{|c|c|}
\hline Description & $\begin{array}{l}\text { The situation is similar to that existing in the field of corporate governance. } \\
\text { The legal framework is rather poor: while internal control is mentioned expressly in } \\
\text { Art. R. 336-1 Code des Assurances, the requirements of this article refer only on the } \\
\text { investment policy and investment business of an insurance company. In this field, nearly all } \\
\text { requirements of the criteria of ICP } 10 \text { are fulfilled. Another legal base for internal control } \\
\text { matters is Art. L.322-2-4 Code des Assurances, according to which the board of directors has } \\
\text { to prepare an annual report on solvency. This report contains information on the financial } \\
\text { condition of the company, on which basis it is to fulfill its commitments (technical provisions } \\
\text { and assets). This report has to be submitted to the external auditors as well as to the supervisory } \\
\text { authority. However, regulations do not address how the internal auditing function is exercised } \\
\text { (regarding having access to all business lines, all files, all other information; independence and } \\
\text { sufficient resources, etc.). There is no regulation about the internal control of actuarial and } \\
\text { compliance functions, of market conduct activities, or of the regular (not only annual) } \\
\text { provision of information. } \\
\text { As in the matter of corporate governance, the supervisory authority can directly require and } \\
\text { enforce actions only in the areas expressly mentioned in the regulation. In all other areas, it can } \\
\text { give recommendations (Art. } 310-17 \text { Code des Assurances), which can be enforced on the basis } \\
\text { of the already mentioned general clause in Art. } 310-18 \text { Code des Assurances. Nevertheless, } \\
\text { these sanctions represent only indirect enforcement powers, which may not be sufficient to } \\
\text { ensure that insurance companies implement proper corporate governance principles in a timely } \\
\text { manner. }\end{array}$ \\
\hline Assessment & Largely observed. \\
\hline Comments & $\begin{array}{l}\text { Current regulations focus mainly on investment policy and the preparation of a limited report. } \\
\text { The supervisory authority cannot require and enforce directly some of the measures and } \\
\text { systems that are mentioned in the ICP and necessary for an efficient internal control. } \\
\text { It is recommended to empower the supervisory authority to issue a Code of Conduct containing } \\
\text { the requirements for efficient internal control that must be respected by all supervised } \\
\text { insurance companies. This code could be combined with a code addressing the requirements } \\
\text { for adequate corporate governance. }\end{array}$ \\
\hline Principle 11. & $\begin{array}{l}\text { Market analysis } \\
\text { Making use of all available sources, the supervisory authority monitors and analyses all factors } \\
\text { that may have an impact on insurers and insurance markets. It draws the conclusions and takes } \\
\text { action as appropriate. }\end{array}$ \\
\hline Description & $\begin{array}{l}\text { The CCAMIP analyzes market conditions that can influence the insurance sector, with the aim } \\
\text { of foreseeing trends and future scenarios that could cause systemic and other risks. This } \\
\text { analysis is based on perceptions from in and outside the supervisory authority, published as } \\
\text { well as confidential information, national as well as international developments. } \\
\text { The supervisory authority may require the provision of information only in certain areas } \\
\text { defined in legislation; other information is provided on a voluntary basis. } \\
\text { The CCAMIP as well as the associations of insurance companies (Fédération Française des } \\
\text { Compagnies d'Assurance-FSSA-and GEMA) publish aggregated market data (see for } \\
\text { instance the Tableaux de Synthèse des entreprises d'assurance et de réassurance published by }\end{array}$ \\
\hline
\end{tabular}

${ }^{14}$ See also ICP 9 and 18, where a similar argument applies. 


\begin{tabular}{|c|c|}
\hline & the CCAMIP). \\
\hline Assessment & Observed. \\
\hline Comments & None. \\
\hline Principle 12. & $\begin{array}{l}\text { Reporting to supervisors and off-site monitoring } \\
\text { The supervisory authority receives necessary information to conduct effective off-site } \\
\text { monitoring and to evaluate the condition of each insurer as well as the insurance market. }\end{array}$ \\
\hline Description & $\begin{array}{l}\text { Insurance companies have to send the following documents to the CCAMIP every year } \\
\text { (Art. A. } 344-8 \text { Code des Assurances): } \\
\text { within } 5 \text { months after the end of the financial year, a detailed file including: general } \\
\text { information on the company (name, bylaws, managers, auditors, classes and countries of } \\
\text { activity, staff including intermediaries, list of reference contracts); balance sheet (including } \\
\text { off-balance sheets accounts), profit and loss accounts and appendix; forms analyzing the } \\
\text { accounts (coverage of technical provisions, solvency margin, claims, technical provisions } \\
\text { and their development, claims ratio per year of occurrence of the claims etc.) } \\
\text { within a month after their approval by the shareholders' meeting: the balance sheet; the } \\
\text { profit and loss account and the appendix; the management report by the company's board } \\
\text { and the report by the auditors; in motor insurance, provisional forms analyzing the } \\
\text { accounts are to be provided before March } 15 \text {. } \\
\text { In addition, each insurance company has to send a quarterly report (Art. A.344-13 Code des } \\
\text { Assurances) concerning their investments and other data (number of contracts, premiums, } \\
\text { claims, expenses, financial returns) to the CCAMIP. Furthermore, each company has to } \\
\text { provide the CCAMIP with the annual solvency report (Art. L.322-2-4 Code des Assurances) } \\
\text { demonstrating the adequacy of technical provisions, the required solvency, and the capacity of } \\
\text { the company to fulfill its commitments, and a report on its investment policy. The standards for } \\
\text { preparing all these documents are set by the Code des Assurances. } \\
\text { All these documents are analyzed by insurance supervisors. In addition, insurance supervisors } \\
\text { have all powers of investigation and may obtain additional information through special } \\
\text { requests, on site inspections and communication with auditors. } \\
\text { According to Articles R. } 332-23 \text { to R. } 332-29 \text { Code des Assurances, the CCAMIP can prescribe } \\
\text { the valuation of any kind of asset by an expert at the expense of the company. } \\
\text { In some circumstances when companies want to waive a rule of tariff (e.g., relating to death } \\
\text { insurance) or of valuation of provisions (e.g., relating to building guarantee and liabilities), } \\
\text { they need to provide evidence based on actuarial estimates. }\end{array}$ \\
\hline Assessment & Observed. \\
\hline Comments & None. \\
\hline Principle 13. & $\begin{array}{l}\text { On-site inspection } \\
\text { The supervisory authority carries out on-site inspections to examine the business of an insurer } \\
\text { and its compliance with legislation and supervisory requirements. }\end{array}$ \\
\hline Description & $\begin{array}{l}\text { The CCAMIP has wide-ranging powers to conduct on-site inspections and to gather in this way } \\
\text { all information deemed necessary to fulfill its duties (Code des Assurances Art. L.310-12 to } \\
\text { 310-17, Art. L.310-19 to 21, Art. R 310-17 and 18). } \\
\text { On-site inspections are undertaken exclusively by the staff of the CCAMIP (commissaires- }\end{array}$ \\
\hline
\end{tabular}




\begin{tabular}{|c|c|}
\hline & $\begin{array}{l}\text { contrôleurs.) } \\
\text { The power of investigation of supervisors concerns all the operations of licensed insurance } \\
\text { undertakings. Supervisors can at any moment verify on site the operations of any company. } \\
\text { The Code des Assurances (Art. L.310-15) also lays down that, whenever the CCAMIP feels the } \\
\text { need, it can extend the checking to "any company in which the supervised insurance company } \\
\text { holds, directly or indirectly, more than half the capital or voting rights, as well as to bodies of } \\
\text { any nature having signed directly or indirectly with the said company a management, } \\
\text { reinsurance or any other type of agreement likely to affect its independence of operation or } \\
\text { decision-making." } \\
\text { When a company has been subject to remedial and protective measures, on-site inspection can } \\
\text { also be extended to the legal persons who control it directly or indirectly, in order to check } \\
\text { whether these persons have the capacity to provide sufficient financial support to the company } \\
\text { in question. The CCAMIP can also decide to submit to supervision any natural or legal person } \\
\text { having received an underwriting or management mandate from an insurance company which it } \\
\text { supervises, or pursuing insurance brokerage in whatever respect. } \\
\text { Supervisors can examine all the company documents, particularly its books, registers, } \\
\text { contracts, statements, reports and accounting vouchers. } \\
\text { The focus of an on-site inspection is at the discretion of the supervisors. Supervisors may too } \\
\text { extend their investigations without any formal procedure to address issues that become of } \\
\text { concern in the course of an investigation; the range of an inspection is never limited a priori. } \\
\text { The on-site inspection procedure entails a full hearing of both sides. In each case, the } \\
\text { supervision report is sent to the managers of the company concerned, who are invited to make } \\
\text { any remarks before the supervisor drafts his final conclusions. }\end{array}$ \\
\hline Assessment & Observed. \\
\hline Comments & None. \\
\hline Principle 14. & $\begin{array}{l}\text { Preventive and Corrective Measures } \\
\text { The supervisory authority takes preventive and corrective measures that are timely, suitable } \\
\text { and necessary to achieve the objectives of insurance supervision. }\end{array}$ \\
\hline Description & $\begin{array}{l}\text { The Code des Assurances (Art. L.323-1, L.323-1-1, R. 323-1 to 323-10) provides the } \\
\text { supervisory authority with a wide range of powers. These powers enable the CCAMIP to act } \\
\text { preventatively to protect the interests of the policyholders, even before law or regulation has } \\
\text { been breached. The regulation foresees progressive escalation of appropriate actions and } \\
\text { measures. The CCAMIP may also ask for information on all important decisions the company } \\
\text { intends to take in the near future. The CCAMIP has powers to verify that the company } \\
\text { concerned is fulfilling legal and supervisory requirements and demands. } \\
\text { Specifically, the CCAMIP can take the following protective measures and powers of } \\
\text { injunction: } \\
\text { Protective Measures } \\
\text { When the financial situation of an insurance company is such that policyholders' interests are } \\
\text { jeopardized or are likely to be so, the CCAMIP takes measures to protect those interests. It can } \\
\text { place the company under special supervision, and in particular require that a recovery program } \\
\text { be submitted for approval, within one month. It can also restrict or prohibit the free use of } \\
\text { company assets. } \\
\text { In addition, the CCAMIP can appoint a provisional receiver to whom the necessary powers of } \\
\text { company management are transferred (Art. L.323-1-1 Code des Assurances). }\end{array}$ \\
\hline
\end{tabular}




\begin{tabular}{|c|c|}
\hline & $\begin{array}{l}\text { Should the circumstances so require, the CCAMIP can order a life insurance company to } \\
\text { suspend the payment of surrender values or of advances on contracts (Art. L.323-1). } \\
\text { Finally, when the solvency margin does not reach the required level, the CCAMIP requires a } \\
\text { restoration plan, and if the solvency margin falls below the guarantee fund (one third of the } \\
\text { required solvency margin), the supervisor requires the undertaking to submit a short-term } \\
\text { finance scheme to its approval. } \\
\text { These decisions can be taken without first holding a full hearing of both sides; the law } \\
\text { authorizes the CCAMIP to hear the managers at a later date. However, when it restricts or } \\
\text { prohibits the free use of assets or appoints a provisional administrator, the CCAMIP must } \\
\text { either withdraw or confirm these measures within a period of three months, after having } \\
\text { allowed the managers to present their remarks. } \\
\text { Power of injunction } \\
\text { The CCA uses, whenever necessary, the powers conferred on it by Art. L.310-17 of the Code } \\
\text { des Assurances: it can send a warning to a company which is deemed to have infringed a } \\
\text { legislative provision or adopted a behavior that endangers the fulfillment of its underwriting } \\
\text { liability toward its policyholders and beneficiaries of contracts. } \\
\text { Similarly, it can send a company whose operation or situation justifies such action an } \\
\text { injunction compelling it, in a given frame of time, to take all necessary measures to re-establish } \\
\text { or strengthen its financial balance, or correct any practices deemed to be prejudicial to the } \\
\text { interests of the policyholders. } \\
\text { The warning and injunction powers also apply, under Art. L.310-18-1, to reinsurance } \\
\text { companies subject to French supervision (only French reinsurers) and to insurance holdings } \\
\text { companies which infringe a legislative or regulatory provision applicable pursuant to Book III } \\
\text { of the Code des Assurances. }\end{array}$ \\
\hline Assessment & Observed. \\
\hline Comments & None. \\
\hline Principle 15. & $\begin{array}{l}\text { Enforcement or sanctions } \\
\text { The supervisory authority enforces corrective action and, where needed, imposes sanctions } \\
\text { based on clear and objective criteria that are publicly disclosed. }\end{array}$ \\
\hline Description & $\begin{array}{l}\text { The supervisors (commissaires-controleurs) have no sanctions power; only the Commissioners } \\
\text { of the CCAMIP have the powers to sanction the companies. Definite legal rules have to be } \\
\text { respected in the sanction process. } \\
\text { After issuing an injunction, the CCAMIP assesses the measures implemented in response by } \\
\text { the insurance company concerned. Should the CCAMIP consider that the company has not } \\
\text { adopted sufficient measures or if the company infringes the law, it has the power to start } \\
\text { disciplinary proceedings against that company or its managers. } \\
\text { Disciplinary proceedings entail a full hearing of both sides: the company managers are heard } \\
\text { by the Commissioners once they have heard from the supervisors who were responsible for } \\
\text { preparing the report that identified the infraction. The Commissioners, meeting in the presence } \\
\text { of the secretary general, can then impose one or several of the sanctions under Art. L.310-18 } \\
\text { Code des Assurances, namely: } \\
\text { - a warning; } \\
\text { - a reprimand; } \\
\text { - prohibition to carry on certain operations and other limitations on the pursuit of business; } \\
\text { - temporary suspension of one or several company managers; }\end{array}$ \\
\hline
\end{tabular}




\begin{tabular}{|c|c|}
\hline & $\begin{array}{l}\text { - total or partial withdrawal of license; } \\
\text { - compulsory transfer of all or part of the portfolio of contracts; or } \\
\text { - pecuniary sanctions, which cannot exceed } 3 \text { percent of the company's turnover before } \\
\text { deducting VAT during the last closed tax year ( } 5 \text { percent for a repeat offence). } \\
\text { When a reinsurance company subject to supervision or an insurance holding company infringes } \\
\text { an applicable legislative or regulatory provision, or does not comply with an injunction, the } \\
\text { CCAMIP can, in the same conditions as for insurance companies, pronounce a warning or a } \\
\text { reprimand, decide on its publication, and impose pecuniary sanctions. }\end{array}$ \\
\hline Assessment & Observed. \\
\hline Comments & None. \\
\hline Principle 16. & $\begin{array}{l}\text { Winding-up and exit from the market } \\
\text { The legal and regulatory framework defines a range of options for the orderly exit of insurers } \\
\text { from the marketplace. It defines insolvency and establishes the criteria and procedure for } \\
\text { dealing with insolvency. In the event of winding-up proceedings, the legal framework gives } \\
\text { priority to the protection of policyholders. }\end{array}$ \\
\hline Description & $\begin{array}{l}\text { Winding-up follows the withdrawal of the license (Art. L.326-2 Code des Assurances). The } \\
\text { license can be removed as a sanction if the company has not fulfilled the requirements of the } \\
\text { legislation (Art. L.310-18 Code des Assurances). The company can also lose its license if it has } \\
\text { not begun to carry on business in the first year after the license was granted or had no business } \\
\text { during the last two years (Art. R. 321-20/21 Code des Assurances). } \\
\text { The procedure is defined by law (Art. L.326-1 etc. Code des Assurances). The court has to } \\
\text { open the procedure on application by the CCAMIP. Two liquidators are appointed: one by the } \\
\text { court, another by the CCAMIP. The latter has to establish in detail and verify the insurance } \\
\text { obligations and the assets linked to the obligations. } \\
\text { A certain priority is given to the policyholders in receiving payouts for all lines of business and } \\
\text { all assets (privilège général). } \\
\text { A policyholder protection fund has been established for life insurance policies and compulsory } \\
\text { insurance (details see Art. L. } 423-2 \text { and } 421-1 \text { Code des Assurances). }\end{array}$ \\
\hline Assessment & Observed. \\
\hline Comments & None. \\
\hline Principle 17. & $\begin{array}{l}\text { Group-wide supervision } \\
\text { The supervisory authority supervises its insurers on a solo and a group-wide basis. }\end{array}$ \\
\hline Description & $\begin{array}{l}\text { The supervision of insurance groups, mainly in order to avoid risk concentration or double or } \\
\text { multiple gearing of capital, is regulated on the EEA level by the EU Insurance Group Directive, } \\
\text { which has been transposed into French regulations (Art. L.334-2 and 334-2, Art. R. 334-40 to } \\
\text { R. 334-45, A. 334-4 and 334-5, A335-14 Code des Assurances). Some practical issues relating } \\
\text { to the implementation are fixed in the so called "Protocol of Helsinki," elaborated by the } \\
\text { former Conference of the EU Supervisory Authorities (now called the Committee of European } \\
\text { Insurance and Occupational Pension Fund Supervisors, CEIOPS). } \\
\text { Insurance groups as well as the scope of supervision are clearly defined. Effective group-wide } \\
\text { supervision can be ensured by the CCAMIP. The legal framework allows cooperation with } \\
\text { other supervisors at home and abroad. The responsibilities are well defined. Group structure, } \\
\text { capital adequacy, reinsurance relationship, risk concentration, intra-group transactions and }\end{array}$ \\
\hline
\end{tabular}




\begin{tabular}{|c|c|}
\hline & $\begin{array}{l}\text { exposures, internal control mechanisms, risk processes and fit and proper tests of the } \\
\text { management are object of the group-wide supervision as a supplement of the solo supervision } \\
\text { of the individual companies belonging to a group. The CCAMIP requires groups to have } \\
\text { reporting systems in place that allow them to fulfill information requirements. The license can } \\
\text { be removed if the structure of the group hinders effective supervision. } \\
\text { The EU Directive dealing with financial conglomerates is not yet transposed into French law. } \\
\text { The CCAMIP monitors in close cooperation with the relevant banking and security supervisors } \\
\text { the existing conglomerates on an informal basis. }\end{array}$ \\
\hline Assessment & Largely observed. \\
\hline Comments & $\begin{array}{l}\text { At present, regulation on financial conglomerates is incomplete. The supervisory authority } \\
\text { lacks the power to intervene if necessary. In the near future the relevant EU Directive will be } \\
\text { transposed. The assessment will then possibly be "Observed." }\end{array}$ \\
\hline Principle 18. & $\begin{array}{l}\text { Risk assessment and management } \\
\text { The supervisory authority requires insurers to recognize the range of risks that they face and to } \\
\text { assess and manage them effectively. }\end{array}$ \\
\hline Description & $\begin{array}{l}\text { The supervisory authority has the power to require a risk management system for the } \\
\text { investment policy of the company (R. 336-1 Code des Assurances). For other risks, such as } \\
\text { technical risks and operational risks, there is no special legal basis for regulation. However, big } \\
\text { insurers have in place risk management policies and systems capable to assess all or the main } \\
\text { material risks. } \\
\text { The CCAMIP has the possibility of assessing the financial situation of the companies through } \\
\text { off-site and on-site inspection. The solvency report (Art.322-2-4 Code des Assurances) and the } \\
\text { accounting information delivered to the supervisory authority are useful information tools } \\
\text { which help the supervisor to see whether the calculation of premiums and technical provisions } \\
\text { are sufficiently prudent, or whether the reinsurance policy are appropriate. } \\
\text { When the supervisory agency finds significant inadequacies regarding a supervised entity's risk } \\
\text { management systems, it is entitled to issue recommendations (Art. 310-17 Code des } \\
\text { Assurances) and impose sanctions if the company does not respect these recommendations (see } \\
\text { general clause of Art. } 310-18 \text { Code des Assurances). In the case of less serious risk } \\
\text { management shortfalls, however, it is more difficult for the CCAMIP to impose direct } \\
\text { sanctions and it relies mostly on making recommendations and following-up on these } \\
\text { recommendations. }\end{array}$ \\
\hline Assessment & Largely observed. \\
\hline Comments & $\begin{array}{l}\text { Under current arrangements, an insurer may fail to manage its business in a prudent manner, } \\
\text { and the supervisor may not be able to apply directly preventive supervisory measures in a } \\
\text { timely fashion. The legislation should require explicitly that all insurance companies establish } \\
\text { risk management systems which touch all material risks. The supervisor should have powers to } \\
\text { require that all supervised entities establish an effective risk management system, appropriate } \\
\text { to the complexity, size and nature of the insurer's business. }\end{array}$ \\
\hline Principle 19. & $\begin{array}{l}\text { Insurance activity } \\
\text { Since insurance is a risk taking activity, the supervisory authority requires insurers to evaluate } \\
\text { and manage the risks that they underwrite, in particular through reinsurance, and to have the }\end{array}$ \\
\hline
\end{tabular}

${ }^{15}$ See also ICP 9 and 10, where a similar argument applies. 
tools to establish an adequate level of premiums.

\begin{tabular}{l|l} 
Description & The CCAMIP requires that the companies have in place underwriting and tarification policies
\end{tabular} The approval of the board is not expressly required in the regulation, but it is clear that such important items can only be applied with agreement of the board.

The insurance companies have to establish controls for the expenses related to premiums and claims (acquisition costs, expenses for administration and claims settlement (Art. A.344-10 Code des Assurances). In life insurance, the companies have to fulfill the requirements regarding the mortality tables and interest rate (Art. A.335-1 Code des Assurances). In nonlife, form C10 and C11 (Art. A.344-10 Code des Assurances) permits the CCAMIP to check whether the tariffs and expenses for claims settlements were calculated in a prudent manner.

The CCAMIP has the power to ask any information necessary to fulfill its duties, especially those regarding tarification (Art. L.310-14 Code des Assurances.)

A company's reinsurance strategy (including the nature and amount of ceded risks, as well as the choice of the reinsurance company) must be approved by the board of administration or supervision (Art. R. 335-5 Code des Assurances.)

The CCAMIP reviews the appropriateness of the reinsurance cover and the security of the reinsurer. Two new forms (C8 and C9 (Art. A. 344-10 Code des Assurances) will be introduced in the near future asking companies for information on their reinsurance strategies, the names of the reinsurers and some simulations of negative events.

\begin{tabular}{|l|l}
\hline Assessment & Observed. \\
\hline Comments & None. \\
\hline Principle 20. & Liabilities
\end{tabular}

The supervisory authority requires insurers to comply with standards for establishing adequate technical provisions and other liabilities, and making allowance for reinsurance recoverables. The supervisory authority has both the authority and the ability to assess the adequacy of the technical provisions and to require that these provisions be increased, if necessary.

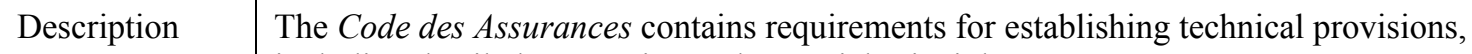
including detailed accounting and actuarial principles.

The CCAMIP is responsible for assessing the sufficiency of the technical provisions on a regular basis through on-site and off-site inspections.

The CCAMIP has the authority to require these provisions to be increased if necessary.

Liabilities toward policyholders are assessed before reinsurance.

The CCAMIP allows amounts recoverable under reinsurance agreements with a given reinsurer to cover gross liabilities, provided that the collectability of these amounts (claims to be paid and other technical provisions due from reinsurers) is reliably secured (by collateral or letters of credit).

Reinsurance arrangements are not approved a priori by the supervisors. However, if the supervisor believes that the cover is not sufficient, he can ask the company to change its cover.

The requirement of a reinsurance cover report will be included in the regulation in the near future.

Financial reinsurance must include an element of risk transfer; otherwise the CCAMIP will not accept it as a valid method to affect the valuation of liabilities. The CCAMIP can prescribe changes in the accounting treatment of a financial reinsurance arrangement if it is not accurate; 


\begin{tabular}{|c|c|}
\hline & $\begin{array}{l}\text { these powers have been reinforced by the implementation of the new solvency rules and in } \\
\text { particular its provisions on the calculation of technical provisions (see ICP 23). }\end{array}$ \\
\hline Assessment & Observed. \\
\hline Comments & None. \\
\hline Principle 21. & $\begin{array}{l}\text { Investments } \\
\text { The supervisory authority requires insurers to comply with standards on investment activities. } \\
\text { These standards include requirements on investment policy, asset mix, valuation, } \\
\text { diversification, asset-liability matching, and risk management. }\end{array}$ \\
\hline Description & 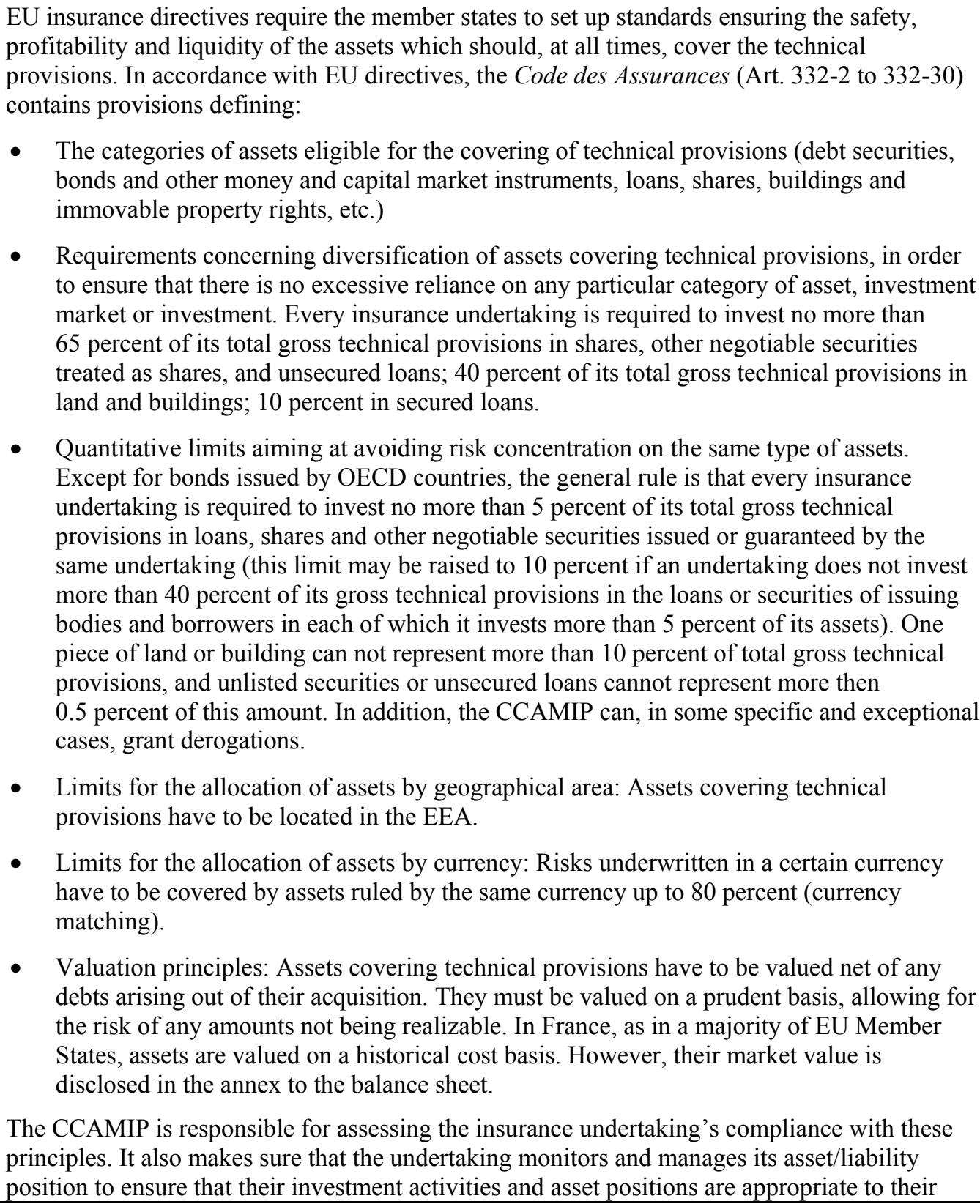 \\
\hline
\end{tabular}




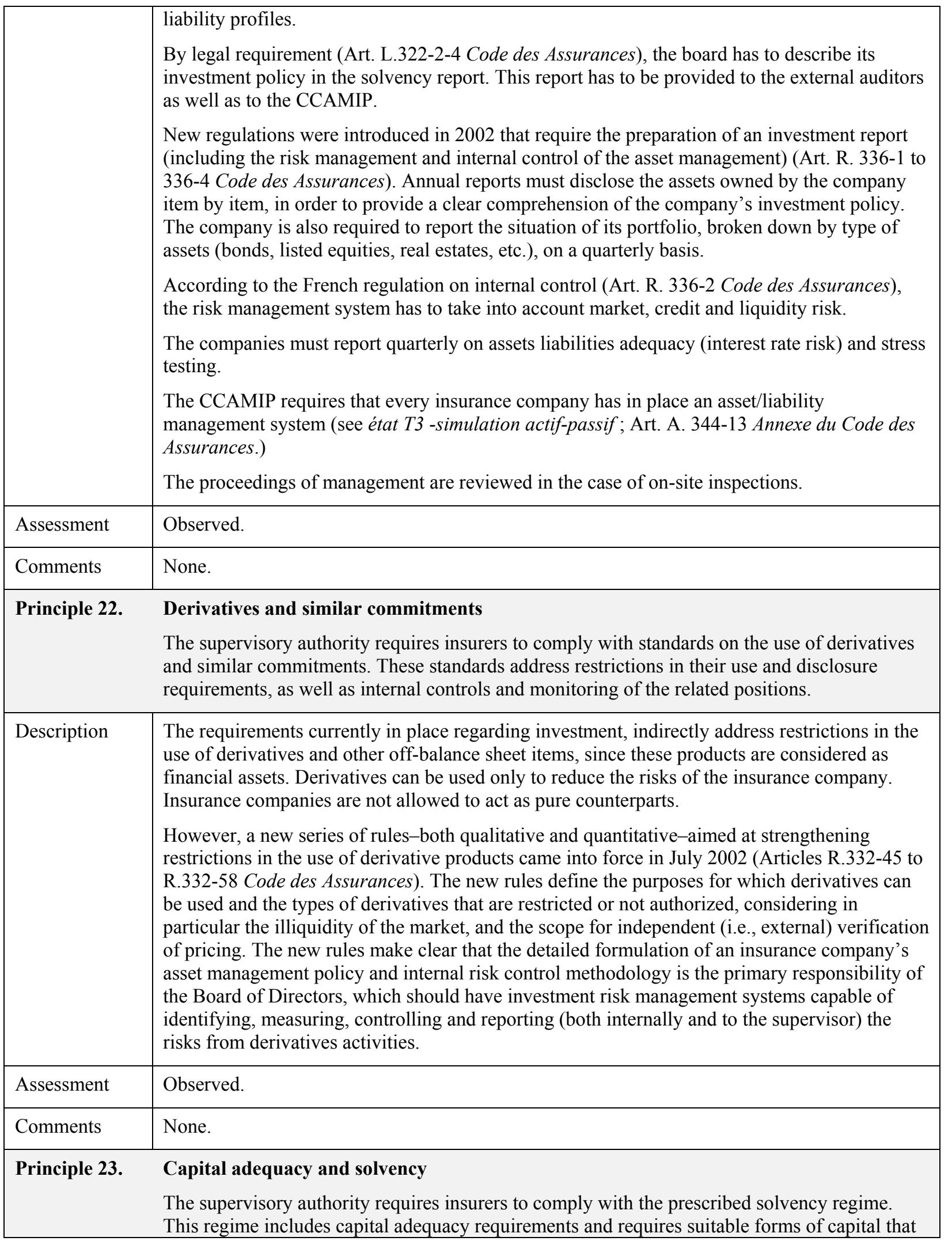


enable the insurer to absorb significant unforeseen losses.

\begin{tabular}{|l|l}
\hline Description & $\begin{array}{l}\text { The insurance company's solvency, that is, its ability to fulfill its commitments at any time, } \\
\text { relies, according to EU insurance directives, on the level of technical provisions (see ICP 20), } \\
\text { the adequate coverage of these provisions by relevant assets (see ICP 21), and the existence of } \\
\text { an additional capital buffer. }\end{array}$
\end{tabular}

Requirements regarding this additional buffer (the solvency margin) are defined in the EU directives, and transposed in the Code des Assurances.

In life insurance, the minimum solvency margin roughly corresponds to 4 percent of mathematical provisions. In nonlife insurance, it is defined roughly by the highest of the two following indexes: 18 percent of the premiums (16 percent for large companies) or 26 percent of the claims (23 percent for large companies).

The solvency margin corresponds to the assets of the undertaking free of any foreseeable liabilities, less any intangible items. The following are included: paid-up share capital, any profits brought forward, half of the unpaid share capital, subordinated debts, and hidden reserves (the last two items are admitted only according to specific conditions).

The EU Directives forbid member states to prescribe any rules as to the choice of the assets covering the solvency margin.

For the purposes of restoring the financial situation of an undertaking whose solvency margin has fallen below the minimum required, the CCAMIP is entitled to require that a plan for the restoration of a sound financial situation be submitted for its approval.

If the CCAMIP finds that the financial situation of an undertaking jeopardizes or is likely to jeopardize policyholders' interests, it takes safeguarding measures, such as restricting or prohibiting the free disposal of the undertaking's assets.

The EU directive on consolidated supervision of insurance groups-which is currently being transposed into French law-empowers the CCAMIP to prevent the inflation of supervisory capital through double or multiple gearing.

It should be noted in this context that the EU solvency requirements are currently being reviewed by the European Commission in consultation with the member states. In a first round, the existing solvency requirements were adjusted for inflation recorded since they were put in place (Art. 323-1-1 Code des Assurance). In a next step, the European commission will provide a new proposal for a solvency directive, which — after a long in-depth analysis of the current solvency system - will have more sophisticated risk-based features.

The current law does allow the CCAMIP to require a company to hold more capital than the legal requirement only in the case that some other requirements are not fulfilled (e.g., inadequate coverage of technical provisions).

Since the financial year 2001, the adequacy of the capital at the group level is assessed (Art. R. 334-40 to R. 334-45 Code des Assurances).

It should be mentioned in this context that every company has to provide the CCAMIP with the annual solvency report (Art. L.322-2-4 Code des Assurances), justifying the sufficiency of the technical provisions, the required solvency and the capacity of the company to fulfill its commitments, and the report on the investment policy.

\begin{tabular}{|l|l}
\hline Assessment & Observed.
\end{tabular}

\begin{tabular}{l|l} 
Comments & None.
\end{tabular}

Principle 24. Intermediaries 


\begin{tabular}{|c|c|}
\hline & $\begin{array}{l}\text { The supervisory authority sets requirements, directly or through the supervision of insurers, for } \\
\text { the conduct of intermediaries. }\end{array}$ \\
\hline \multirow[t]{3}{*}{ Description } & $\begin{array}{l}\text { Intermediaries (brokers and agents) must be honorable and must have the necessary } \\
\text { professional knowledge; brokers have to provide financial guaranties and a professional third } \\
\text { party liability insurance cover. }\end{array}$ \\
\hline & $\begin{array}{l}\text { Brokers (not agents) must be registered (register of commerce and societies). The CCAMIP has } \\
\text { no enforcement powers regarding the intermediaries (for example, it cannot force a broker to } \\
\text { apply for registration). Intermediaries who violate existing legal requirements can be } \\
\text { sanctioned (Art. R.511 -8- Code des Assurances). }\end{array}$ \\
\hline & $\begin{array}{l}\text { The CCAMIP has no power to require that intermediaries give customers the information about } \\
\text { their status (broker or agent). The intermediaries have no such obligation. }\end{array}$ \\
\hline Assessment & Partly observed \\
\hline \multirow[t]{2}{*}{ Comments } & $\begin{array}{l}\text { The supervisory authority lacks the powers to supervise insurance intermediaries (i.e., brokers } \\
\text { and independent agents). Agents are not registered. Brokers cannot be forced to apply to be } \\
\text { registered. Compliance with existing requirements does not seem to be monitored or enforced. } \\
\text { There is scant on-going supervision. }\end{array}$ \\
\hline & $\begin{array}{l}\text { The transposition of the EU Intermediary Directive into French Law (scheduled for beginning } \\
\text { of 2005) will most likely conduct to full compliance of ICP } 24 \text {. }\end{array}$ \\
\hline \multirow[t]{2}{*}{ Principle 25.} & Consumer Protection \\
\hline & $\begin{array}{l}\text { The supervisory authority sets minimum requirements for insurers and intermediaries in } \\
\text { dealing with consumers in its jurisdiction, including foreign insurers selling products on a } \\
\text { cross-border basis. The requirements include provision of timely, complete and relevant } \\
\text { information to consumers both before a contract is entered into through to the point at which all } \\
\text { obligations under a contract have been satisfied. }\end{array}$ \\
\hline \multirow[t]{4}{*}{ Description } & $\begin{array}{l}\text { The objective of French insurance supervision is the protection of the policyholder in a broad } \\
\text { sense (including insured, beneficiaries and victims in the third party liability insurance). The } \\
\text { requirements of professional competence are high for the management as well as for the } \\
\text { intermediaries (Art. L.322-2, R. } 513 \text {-1 to } 4 \text { Code des Assurances). The CCAMIP monitors } \\
\text { compliance with these requirements. }\end{array}$ \\
\hline & $\begin{array}{l}\text { The requirements of professional competence are high for the management as well as for } \\
\text { intermediaries (Art. L.322-2, R. } 513-1 \text { to } 4 \text { Code des Assurances). The CCAMIP monitors } \\
\text { compliance with these requirements. }\end{array}$ \\
\hline & $\begin{array}{l}\text { The CCAMIP monitors, through on-site supervision, the commercial practices of a company } \\
\text { affecting its clients. The Bureau des Relations avec le Public of the CCAMIP, which has the } \\
\text { function of helping the insured and to respond to their complaints and questions, collects } \\
\text { information consumer concerns about the insurance business. The CCAMIP has the power to } \\
\text { intervene if a company or an intermediary fails to respect regulations on fair and correct } \\
\text { treatment of the policyholder. In accordance with the requirements of the Third EU Directives, } \\
\text { the CCAMIP requires insurers and intermediaries to assess a client's needs before they } \\
\text { conclude a contract. Companies and intermediaries have to inform their clients about the } \\
\text { product, the obligations of the policyholder, the expenses, etc. (Art. L.112-2, L.132-5-1, } \\
\text { A.132-4, L.140-4 Code des Assurances). }\end{array}$ \\
\hline & $\begin{array}{l}\text { The CCAMIP and the insurers' associations have establish institutions dealing with complaints } \\
\text { and claims of policyholders (Bureau des Relations avec le Public of the CCAMIP, Médiateur } \\
d u \text { FFSA, Médiateur du GEMA.) }\end{array}$ \\
\hline
\end{tabular}




\begin{tabular}{|c|c|}
\hline Assessment & Observed. \\
\hline Comments & None. \\
\hline \multirow[t]{2}{*}{ Principle 26.} & Information, disclosure and transparency toward the market \\
\hline & $\begin{array}{l}\text { The supervisory authority requires insurers to disclose relevant information on a timely basis in } \\
\text { order to give stakeholders a clear view of their business activities and financial position and to } \\
\text { facilitate the understanding of the risks to which they are exposed. }\end{array}$ \\
\hline Description & $\begin{array}{l}\text { Insurance companies have to report to the public their financial positions and the risks to which } \\
\text { they are exposed, as do other commercial entities (Art. L.342-1, R.341-1 to R.341-8 Code des } \\
\text { Assurances.) Insurance companies have to produce audited financial statements. These are } \\
\text { made available to the stakeholders (Art. R.341-2, R.341-8, A.344-4 Code des Assurances.) } \\
\text { Based on Art. L.310-12 § } 2 \text { Code des Assurances, the CCAMIP monitors that the prescribed } \\
\text { information is disclosed. }\end{array}$ \\
\hline Assessment & Observed. \\
\hline Comments & None. \\
\hline \multirow[t]{2}{*}{ Principle 27.} & Fraud \\
\hline & $\begin{array}{l}\text { The supervisory authority requires that insurers and intermediaries take the necessary measures } \\
\text { to prevent, detect and remedy insurance fraud. }\end{array}$ \\
\hline \multirow[t]{3}{*}{ Description } & $\begin{array}{l}\text { Insurance fraud is regulated under the Code Pénal, as are all other kinds of fraud. The MoE } \\
\text { issues regulations in this area. }\end{array}$ \\
\hline & $\begin{array}{l}\text { The supervisory authority does not have powers to establish any regulations in this area. It } \\
\text { lacks powers to require that companies take measures to combat fraud. It monitors, through on- } \\
\text { site inspections, whether companies take effective action to prevent fraud, and provides } \\
\text { recommendations. }\end{array}$ \\
\hline & $\begin{array}{l}\text { The industry itself has taken necessary measures in nonlife as well as in life insurance (death). } \\
\text { The supervisory authorities are given explicit authority to cooperate with supervisors abroad to } \\
\text { combat fraud (see ICP 5). }\end{array}$ \\
\hline Assessment & Observed. \\
\hline Comments & None. \\
\hline \multirow[t]{2}{*}{ Principle 28.} & AML/CFT \\
\hline & $\begin{array}{l}\text { The supervisory authority requires insurers and intermediaries to take effective measures to } \\
\text { deter, detect and report money laundering and the financing of terrorism. }\end{array}$ \\
\hline Description & $\begin{array}{l}\text { The COMOFI sets out the main AML/CFT requirements and the scope of application of such } \\
\text { requirements. The requirements apply to insurance companies, agents and brokers, as well as } \\
\text { other financial institutions. The COMOFI sets out suspicious transaction reporting } \\
\text { requirements and other measures of diligence for financial institutions. The Code des } \\
\text { Assurances sets out additional requirements for insurance companies. In general, there are no } \\
\text { specific CDD requirements for financial institutions to take account of particular risks } \\
\text { associated with non-face-to-face transactions, politically exposed persons and reliance on third } \\
\text { parties for the conduct of customer due diligence, nor a requirement to systematically identify } \\
\text { and verify the identity of beneficial owners in a manner required by the revised FATF } 40 \\
\text { Recommendations. Although the CCAMIP has issued recommendations to assist insurance } \\
\text { companies in complying with AML/CFT requirements, they are neither enforceable nor do }\end{array}$ \\
\hline
\end{tabular}




\begin{tabular}{|c|c|}
\hline & 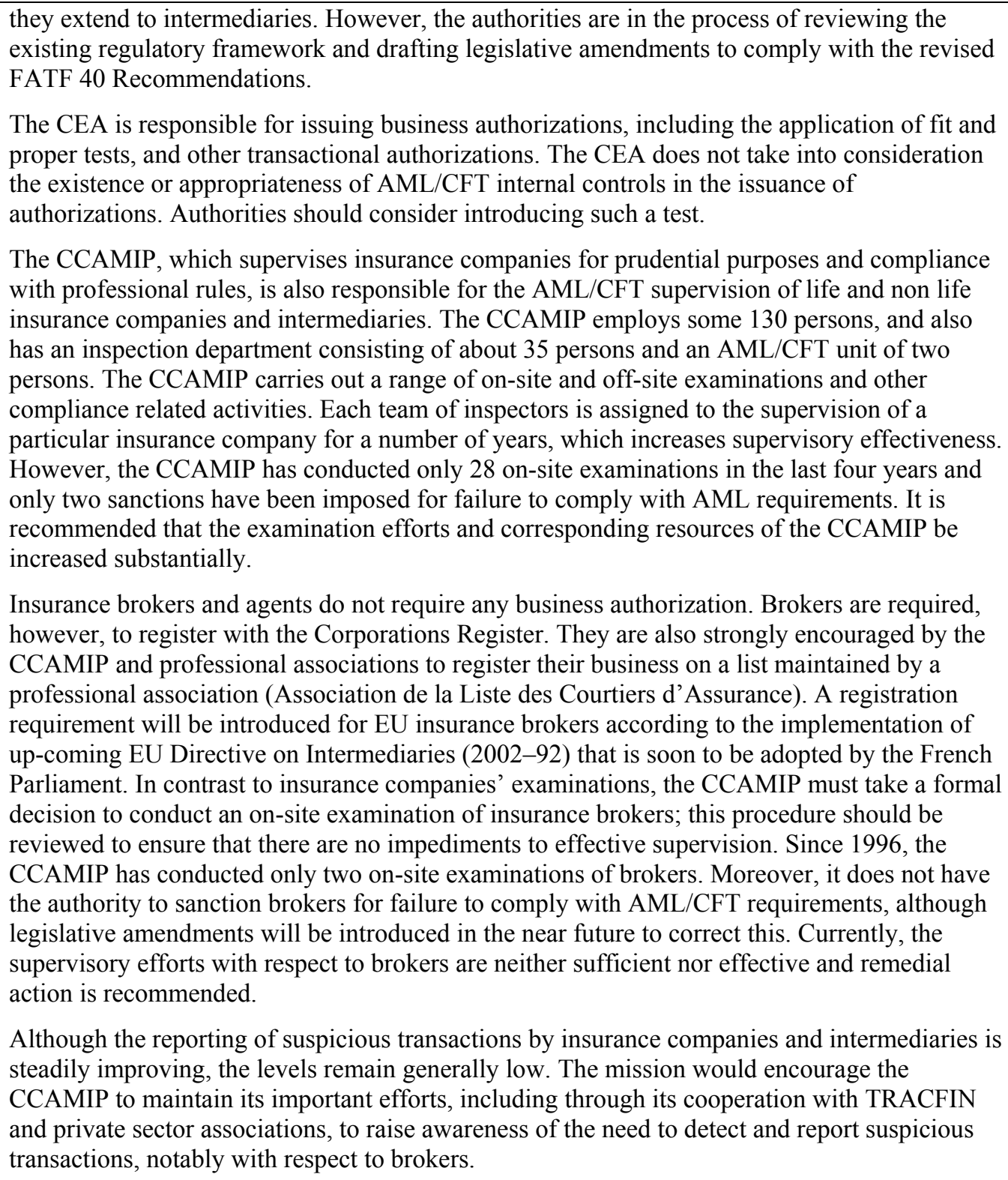 \\
\hline Assessment & Partly observed. \\
\hline Comments & $\begin{array}{l}\text { While significant steps have been taken by the authorities, there remain some gaps in the } \\
\text { regulation and supervision of insurance companies and intermediaries. The main issues } \\
\text { include: (i) the authorities do not consider the quality of insurers' AML/CFT internal controls } \\
\text { when issuing business authorizations to insurance companies; (ii) the rate of on-site } \\
\text { examinations of insurance companies is generally low and overall, there is an urgent need for a } \\
\text { substantial increase in supervisory resources, both in the case of insurance companies and } \\
\text { intermediaries; (iii) there is no effective supervision of intermediaries, including appropriate } \\
\text { sanctioning powers; and (iv) guidelines (i.e., recommendations) that have been issued are } \\
\text { neither enforceable nor do they extend to intermediaries, and there are no specific measures to } \\
\text { implement the CDD requirements under the revised FATF } 40 \text { Recommendations, notably for } \\
\text { the handling of higher risk customers. }\end{array}$ \\
\hline
\end{tabular}


Table 5. Summary Observance of IAIS Insurance Core Principles

\begin{tabular}{|l|c|l|}
\hline \multirow{2}{*}{ Assessment Grade } & \multicolumn{2}{|c|}{ Principles Grouped by Assessment Grade } \\
\cline { 2 - 3 } & Count & \multicolumn{1}{c|}{ List } \\
\hline Observed & 21 & $\begin{array}{l}\text { ICP } 1,2,4,5,6,7,8,11,12,13,14,15, \\
16,19,20,21,22,23,25,26,27\end{array}$ \\
\hline Largely observed & 4 & ICP 9,10, 17,18 \\
\hline Partly observed & 3 & ICP $3,24,28$ \\
\hline Non-observed & 0 & -- \\
\hline Not applicable & 0 & -- \\
\hline
\end{tabular}

\section{Recommended action plan and authorities' response to the assessment}

\section{Recommended action plan}

49. The recommendations are summarized in the following table.

Table 6. Recommended Action Plan to Improve Observance of IAIS Insurance Core Principles

\begin{tabular}{|c|l|}
\hline Reference Principle & \multicolumn{1}{|c|}{ Recommended Action } \\
\hline Supervisory authority & $\bullet \begin{array}{l}\text { Give power to the supervisory authority to issue regulation. } \\
\text { Increase of the staff of the supervisory authority. } \\
\text { Monitor the effectiveness and efficiency of the new organization, } \\
\text { setting a date for reviewing the structure. } \\
\text { Eliminate the participation of the industry in the supervisory decision } \\
\text { making process. }\end{array}$ \\
\hline Suitability of persons & $\begin{array}{l}\text { Introduce requirement that an insurance company must inform the } \\
\text { supervisory authority if it becomes aware of circumstances that may lead } \\
\text { to doubts about the fitness and propriety of owners, senior management, } \\
\text { and others in positions of responsibility. }\end{array}$ \\
\hline Corporate governance & $\begin{array}{l}\text { Empower the CCAMIP to issue and enforce a Code of Conduct of } \\
\text { Corporate Governance for all supervised insurance companies. }\end{array}$ \\
\hline Internal control & $\begin{array}{l}\text { Empower the CCAMIP to issue and enforce a Code of Conduct } \\
\text { containing the requirements for effective internal control for all } \\
\text { supervised insurance companies. This code could be combined with the } \\
\text { code dealing with the requirements of corporate governance. }\end{array}$ \\
\hline Group-wide supervision & $\begin{array}{l}\text { Issue regulation regarding the group-wide supervision of financial } \\
\text { conglomerates headed by insurance companies (transposition of the EU } \\
\text { Directive on financial conglomerates). }\end{array}$ \\
\hline
\end{tabular}




\begin{tabular}{|c|l|}
\hline Reference Principle & \multicolumn{1}{c|}{ Recommended Action } \\
\hline Risk assessment and management & $\begin{array}{l}\text { Require by law that all insurance companies establish risk management } \\
\text { systems which cover all material risks of an insurance company. }\end{array}$ \\
\hline Intermediaries & $\begin{array}{l}\text { Empower the CCAMIP to supervise intermediaries. Require that all } \\
\text { agents and brokers be registered. }\end{array}$ \\
\hline Anti-money laundering & $\begin{array}{l}\text { Increase supervisory staff and raise AML/CFT on-site inspections of } \\
\text { insurance companies and intermediaries. Regulate and supervise, with } \\
\text { appropriate enforcement powers, intermediaries for AML/CFT activities. } \\
\text { Consider adequacy of internal AML/CFT controls when issuing business } \\
\text { authorizations. Issue enforceable guidelines for insurance companies and } \\
\text { extend these to intermediaries. Promptly enact draft legislative } \\
\text { amendments to comply with FATF 40 Recommendations. }\end{array}$ \\
\hline
\end{tabular}

\section{Authorities' response to the assessment}

\section{Regarding ICP 3 comments}

Essential Criterion b: "The legislation gives the supervisory authorities the power to issue and enforce rules by administrative means."

First, the French supervisory and regulatory framework distinguishes, on one hand, the Treasury, which sets out the legal framework for insurance supervision, and on the other hand, the Insurance Control Commission, which implements it. This framework is explicitly allowed by Insurance Core Principle $n^{\circ} 3 .^{16}$

Second, the Financial Security Law, that was passed on August 1, 2003, harmonizes the bank and insurance regulatory framework. Both the insurance supervisory authority and the Commission Bancaire will participate to the newly created financial regulation advisory council, which issues an opinion before any law or decree is passed. The law also creates the CCAMIP, as the only insurance companies and mutuals supervisory authority. The CCAMIP is enabled to recruit staff and to invest in any equipment judged necessary to reinforce its expertise and its control.

Lastly, the Financial security law transferred the responsibility for licensing insurance companies from the Minister of Finance to an independent and collegial body (the CEA), which limits even more the concentration of powers by the Ministry of Finance.

16 "Insurance supervision within an individual jurisdiction may be the responsibility of more than one authority. For example, the body that sets out the legal framework for insurance supervision may be different from the body that implements it. In this document, the expectation is that the core principles are applied within the jurisdiction rather than necessarily by one supervisory." 


\section{Essential Criterion g: "The supervisory authority and its staff are free from undue political, governmental and industry interference in the performance of supervisory responsibilities."}

The question that is raised by the mission deals only with CEA (participation of the industry in this body). Or, CEA members are retired professionals, who are tied by strict deontology and secrecy rules.

As far as the CCAMIP is concerned, it is entirely free of undue interference.

Therefore, we would request that the observance of this criterion be considered as "largely observed."

Essential Criterion o: "The supervisory authority has its own budget sufficient to enable it to conduct effective supervision. The supervisory authority is able to attract and retain highly skilled staff, hire outside experts as necessary, provide training, and rely upon an adequate supervisory infrastructure and tools.."

Although the merging of CCA and CCMIP may lead to temporary shortage of staff, the financial independence of the CCAMIP will enable it to manage its own budget (this budget will be funded by a levy from the industry) and, therefore, to hire sufficient staff in a near future.

Therefore, we consider that this criterion is "largely observed."

\section{Other comments:}

50. In the third paragraph of the comments, it is stated that "Four different administrations are responsible...the CCAMIP for sanctions; and the secretariat of the CCAMIP for other on-going supervision." In fact CCA (MIP) is one entity and the distinction between the board and the secretariat is a distinction of functions inside an entity which remains an unique one. According to the Art. 6 of European Convention of Human rights, when a body is entitled to take sanctions it is absolutely necessary that preliminary investigations would be separated from the decision. It is the reason why clear distinction is made between the board and the staff of the Secretariat Général.

\section{Regarding ICP 28}

The financial autonomy of the CCAMIP should facilitate staff recruitment, which is necessary to reinforce AML/CFT controls, and higher the rate of on-site controls. Until now, the CCA has focused on life companies (as the principles stresses it).

As far as the supervision of brokers is concerned, it should be noted that the Financial security law authorized the supervisory authority to impose sanctions on brokers. Moreover, the directive on insurance intermediates, which should be implemented in France very soon, creates a national registry of all intermediates, comply them to have a financial guarantee and 
a professional civil responsibility insurance police, centralize the control on fit and proper conditions, and enables the CCA to withdraw a broker's registration on grounds of regulation infringement.

Finally, the CEA is considering regulatory measures, so that the quality of insurers' AML/CFT internal controls be considered when licensing insurance companies.

To the extent that criterion a, b, c, e are observed, considering ICP 28 as "partly observed" would not give an exact picture of the reality.

\section{ObSeRvance OF THE CPSS CORE Principles For SySTEMiCAlly IMPORTANT PAYMENT SYSTEMS}

\section{General}

51. This part of the report contains the assessments of the compliance of the three systemically important payment systems in France with the Core Principles developed by the Basel-based CPSS. The systems covered are: Transferts Banque de France (TBF) (a public sector Real-Time Gross Settlement system-RTGS), Paris Net Settlement (PNS) (a private sector large-value payment system) and Système Interbancaire de Télécompensation (SIT) (a private sector retail payment system). The assessments were conducted during the two missions in February and May 2004 in the framework of the IMF/World Bank Financial Sector Assessment Program (FSAP) and prepared by Daniel Heller of the Swiss National Bank and Jan Woltjer of the IMF (MFD).

\section{Information and methodology used for assessment}

52. The methodology for the assessments was derived from the Guidance Note for Assessing Observance of Core Principles for Systemically Important Payment Systems of the IMF and the World Bank of August 2001. Prior to the mission the BdF made self assessments for all the relevant systems and filled in the Questionnaire on Payments and Securities Settlement Systems. In addition, the assessors studied laws, articles, brochures, guidelines, data and presentations provided by the BdF, and used information published in the CPSS publication on "Payment and Settlement Systems of Selected Countries."

53. The assessments involved discussions with directors and senior officials from several departments of the BdF. In addition, several meetings with the private sector operators (Centrale des Réglements Interbancaire, CRI, and Groupement pour un Système Interbancaire de Télécompensation, GSIT), the Bankers' Association and commercial banks took place.

\section{Institutional and market structure-Overview}

54. The French banking law gives a broad definition of means of payments, referring to "all instruments which, irrespective of the medium or technical procedure used, enables any person to transfer funds." The issuance and the management of means of payments are 
defined as banking operations that may, according to the COMOFI, be conducted only by credit institutions, the Treasury, the Post Office, the CDC, the BdF and the monetary institutions for the French Overseas Departments and Territories.

55. Following the merger and consolidation process within the financial sector, roughly 1,000 credit institutions conduct business in France (compared to 1,608 in 1994). The Post Office's financial arm plays a significant role in the French financial system as it holds a significant number of demand accounts and time accounts.

56. Payment system oversight forms an integral part of the BdF's statutory tasks. It performs its duties of ensuring the smooth functioning and the security of payment systems within the framework of the tasks of the European systems of Central Banks (ESCB), as mentioned in the Art. 105 (2) of the Treaty of Maastricht and in Articles 3 and 22 of the Statute of the ESCB. The responsibilities and powers of the BdF with respect to payment system oversight are laid down in the COMOFI. The oversight task also explicitly cover the oversight of Securities Settlements systems (SSSs) and Central Counter Parties (CCPs). The $\mathrm{BdF}$ is also entitled to monitor the security level of the different payment media and to make recommendations about it.

57. In addition to cash, the check is still widely used in France. However, the relative share of checks in cashless payments has been declining since 1993. Direct debits have been very successful ever since their introduction in 1967. They are generally used for recurrent payments such as electricity, gas, phone and water bill payments. The use of the interbank order Titre Interbancaire de Paiement (TIP) has been growing steadily. A TIP works in the same way as a direct debit, except the payer is required to consent to each payment by signing the TIP form, which is sent with the corresponding invoice.

58. Credit transfers are also widely used in the retail area, for instance, for payments made by companies, government agencies and local authorities. The interbank exchange of all credit transfers takes place in paperless form. Ordinary transfers are settled on the day of presentation while credit transfers for payment on a future due date are presented two or three days in advance of the settlement.

59. Bank cards are mostly debit cards which can be used for both payments and cash withdrawals through a nationwide network of Point of Sale (POS) terminals and Automated Teller Machines (ATM). Since several years, cards have been equipped with a computer chip which resulted in a decline of fraudulent transactions to a very low level. A specific network is used for the transmission and authorization for withdrawals and payments. This network enables an ATM or a POS terminal to obtain authorization from the issuing bank. This authorization also means that the payment is guaranteed for the beneficiary. At the end of 2001, 32,500 ATMs and 750,000 POS terminals were installed nationwide. As in other EU countries, the circulation of electronic money is still fairly limited. Three consortiums are currently providing their e-money schemes. 
60. The interbank payments area is dominated by three systems, each of which is considered systemically important by the French authorities. Large-value operations are processed in two systems: the RTGS system TBF which is the French component of the TARGET. TBF is managed and operated by the BdF. The hybrid system PNS is managed and operated by the CRI, an interbank body owned by 10 banks and the central bank.

61. Retail transactions are processed in the French Automated Clearing House SIT. SIT is a deferred net settlement system and is managed and operated by GSIT, a group of 12 founding members (banks).

62. The banking industry and the BdF are continuing their efforts to improve the safety and efficiency of the payment infrastructure. At the BdF, a separate oversight unit has been established within the payment department in order to deepen the quality and independence of this activity. Both TBF and PNS, while technologically still modern systems, are approaching the end of their life cycles since they will be obsolete with the introduction of TARGET 2 in 2007. The clearing of an increasing number of retail payment instruments in SIT has led to the appraisal of the BdF that SIT is of systemic importance. Hence, SIT is one of the very few retail payment systems that has to comply with the Core Principles. One of the challenges for SIT will be the still unclear effects of the Single European Payments Area (SEPA) on the landscape for the clearing and settlement of retail payments.

\section{Payment systems infrastructure}

63. France fulfills all prerequisites for effective payment clearing and settlement systems. Historically, the private sector has been playing an important role both in the provision of payment instruments and in payment clearing services. The BdF, in turn, is also an established player in the area of payment services. In the field of payments, the relationship between the $\mathrm{BdF}$ and the banking sector is well established and co-operative. The needs of the users are accounted for in the development of the payment infrastructure.

64. The oversight of payment systems is three-tiered: defining the principles or standards underpinning their conception and operation, monitoring their implementation and lastly overseeing actual conditions of operation and use. The oversight activities are embedded into the framework which was developed by the Eurosystem.

65. The legal framework is sound. Fraud and delays are minimal. Mechanisms for dispute resolution are in place and respected.

\section{Assessment of observance of the CPs by the TBF}

Table 7. Detailed Assessment of Observance by the TBF of CPSS Core Principles for SIPS

\begin{tabular}{|l|l|}
\hline Principle 1. & \multicolumn{1}{l}{ The system should have a well-founded legal basis under all relevant jurisdictions. } \\
\hline Description & $\begin{array}{l}\text { French law and the contractual arrangements within the framework of TBF payment system } \\
\text { provide a well-established and reasonably comprehensive legal foundation for fund transfers }\end{array}$ \\
\hline
\end{tabular}


in a RTGS

Completeness and reliability of framework legislation

- There is a consistent and reliable set of laws, regulations, and contractual arrangements that form the legal basis for TBF and payment transfers executed in this system.

\section{Enforceability of laws and contracts}

- All relevant laws as well as contractual arrangements within the framework of TBF between the different parties involved are fully enforceable.

Definition of timing and legal protection of irrevocability and finality

- Although a zero hour rule and a regulation on a suspect period exist under the French Bankruptcy law, these regulations do not apply while transactions are processed within a payment system or SSS (Art. L.330 I-II of the Monetary and Financial Code). TBF falls within the scope of this finality regulation and is notified to the European Commission as a payment system pursuant to the Finality Directive (directive 98/26 EC).

- Irrevocability and finality are clearly defined in the law and in the rules of the system and are ensured even in case an insolvency procedure is opened against a direct or indirect participant in the system.

- All payment orders are irrevocable from the moment they are accepted by the system. After acceptance the sender cannot revoke, cancel or modify the orders.

- Finality occurs at the moment the account of the bank involved is debited. According to the functioning of the system, the account of the receiving bank will simultaneously be credited. Final payments made by a direct participant on its own behalf or on behalf of an indirect participant cannot be challenged and no retroactive action is possible.

\section{Enforceability of collateral arrangements for intraday and overnight credit}

- Collateral arrangements in payments and securities settlement systems are fully enforceable. The legal basis for collateral arrangements in payment and securities settlement systems is formed by Art. L.330-2 of the COMOFI. Transfer of collateral is performed through a transfer of ownership without any formal requirement to inform third parties. The transfer of collateral in the form of highly liquid and first-rate securities to cover intraday and overnight credit takes place in $\mathrm{RGV} 2$ via repo transactions. In RGV2, repurchase agreements (repos) are settled trade for trade, in real time and on a delivery versus payment basis. The international master agreement for these repurchase agreements is fully recognized under French Law. The transfer of ownership of bank loans to the private sector, that are used to collateralize intraday credit granted by the BdF at the opening of the system, is also well regulated under the Loi Dailly.

Legal support of electronic processing

- Art. 1316-3 of the Civil Code specifies that a payment order may be given electronically and that electronic data has the same value to settle a dispute as a writing on paper. Also recognition of the electronic signature is well established in French Regulations (Art. 1316-4 of the Civil Code and decree no. 2001-272 of March 30, 2001).

Relevance of laws outside the domestic jurisdiction

- $\quad$ BdF as system provider requires foreign participants (both branches and remote 


\begin{tabular}{|c|c|}
\hline & $\begin{array}{l}\text { members) to become participants in the system, and to provide a legal opinion } \\
\text { compliant with the terms of reference given by the Governing Council of the } \\
\text { European Central Bank (art } 1.2 \text { of the Conditions spécifiques d'accès aux systemes } \\
P N S \text { et TBF). However, providing of legal opinion was not requested from foreign } \\
\text { participants already participating in the system before } 1999 \text {. Within the context of } \\
\text { the European Central Bank a grandfather clause was agreed upon for this category } \\
\text { in all large-value systems in the European Union. At the moment, there are } \\
10 \text { direct foreign participants in TBF, only four of them having provided a legal } \\
\text { opinion. } \\
\text { However, the relevance of foreign law is limited while there are no participants } \\
\text { from outside France that participate on a remote access basis. The foreign banks } \\
\text { that participate in the system do so via their branches in France to which French } \\
\text { law will apply. }\end{array}$ \\
\hline Assessment & Observed \\
\hline Comments & \\
\hline Principle 2. & $\begin{array}{l}\text { The system's rules and procedures should enable participants to have a clear under- } \\
\text { standing of the system's impact on each of the financial risks they incur through } \\
\text { participation in it. }\end{array}$ \\
\hline Description & $\begin{array}{l}\text { Description of the system } \\
\text { Annex } 7 \text { of the TBF settlement account convention Specifications utilisateurs TBF, gives a } \\
\text { comprehensive description of the system design, functionalities, timetables and risk } \\
\text { management procedures. } \\
\text { Understanding of risk and comprehensiveness of the relevant regulations } \\
\text { - The relevant rules and regulations of the systems extend over a number of } \\
\text { documents issued by the BdF and the CRI. For many issues documents of both } \\
\text { sources are relevant. The overall organization of the documentation should be } \\
\text { clarified. Similarly, a handbook could be made available in which the relevant } \\
\text { topics would be accessible to users in a practical way (topic by topic, including the } \\
\text { references to the different rules and regulations) and which would be updated } \\
\text { regularly. } \\
\text { Some essential issues are not dealt with in the agreements signed by the } \\
\text { participants, such as: } \\
\text { - the procedures and behavior of participants in case of a failure of their own } \\
\text { platform; } \\
\text { - the behavior of participants in case of a technical failure of a major } \\
\text { participant; and } \\
\text { - the procedures to be followed in case of bankruptcy of a direct participant or } \\
\text { an indirect participant and the manner in which a participant might or should } \\
\text { react. } \\
\text { Availability and public access } \\
\text { All participants in the TBF system are provided with the relevant documents when } \\
\text { they sign the appropriate contracts with the BdF (the system provider) and with the } \\
\text { CRI- the operator of the common platform used for communication between the } \\
\text { system and the participants and the link with the SWIFT network. All rules and }\end{array}$ \\
\hline
\end{tabular}




\begin{tabular}{|c|c|}
\hline & $\begin{array}{l}\text { regulations relating to payment systems, enclosed in the COMOFI are published on } \\
\text { the internet }\end{array}$ \\
\hline Assessment & Broadly observed \\
\hline Comments & $\begin{array}{l}\text { - Transparency in stress situations could be improved and the smooth functioning of } \\
\text { the system could be promoted if procedures were set out with respect to the } \\
\text { behavior of participants in case of technical failures of their own technical platform } \\
\text { or in case of a technical failure of the platform of a major user or in case of a } \\
\text { bankruptcy of a direct or indirect participant. } \\
\text { - The accessibility of the rules and regulations and their ready understanding could } \\
\text { be increased by improving the overall organization of the documentation and } \\
\text { making them available in a more practical way. }\end{array}$ \\
\hline Principle 3. & $\begin{array}{l}\text { The system should have clearly defined procedures for the management of credit risks } \\
\text { and liquidity risks, which specify the respective responsibilities of the system operator } \\
\text { and the participants and which provide appropriate incentives to manage and contain } \\
\text { those risks. }\end{array}$ \\
\hline Description & $\begin{array}{l}\text { General } \\
\text { As an RTGS-system with queuing facilities, which settles in central bank money, TBF } \\
\text { offers protections against credit risk. Liquidity risk is addressed through unlimited intraday } \\
\text { credit provided against collateral. No interest rate or other fees are charged. } \\
\text { Liquidity in the infrastructure for payments and securities settlement is abundant due to: } \\
\text { 1) the policy of the Eurosystem to allow banks to use their cash reserve requirements } \\
\text { during the day for payment purposes; } \\
\text { 2) the liquidity optimization facilities, especially in the Paris Net Settlement System } \\
\text { (PNS), a hybrid system that reduces liquidity needs for the settlement of large-value } \\
\text { payments (see the assessment of PNS); } \\
\text { 3) the liquidity bridges between TBF, PNS and the RGV2 system. These liquidity } \\
\text { bridges facilitate liquidity management for the users and make it possible to transfer on } \\
\text { line real time liquidity to the system where it is needed most urgently and makes an } \\
\text { optimal liquidity management possible; and } \\
\text { 4) the easy access to intraday liquidity facilities of the BdF and the broad range of } \\
\text { eligible collateral (securities as well as private bank loans). } \\
\text { Due to the abundance of liquidity and the fact that a substantial fraction of large-value } \\
\text { payments in France is channeled through the PNS, TBF is an extremely fluid system. More } \\
\text { than 99 percent of the payments are settled without being queued. } \\
\text { Some of the banks do not uses their cash reserve requirements at all during the day. } \\
\text { Intraday finality and queuing mechanism } \\
\text { payments settled in TBF are final (irrevocable and unconditional) and no retroactive action } \\
\text { is possible in the event of a bankruptcy of a direct or indirect participant due to the finality } \\
\text { obgulation in the COMOFI. Funds received can be used without risk to fulfill the payment } \\
\text { payments. High priority is given to monetary policy operations, settlement of debit positions }\end{array}$ \\
\hline
\end{tabular}


of ancillary systems, payments related to CLS pay-ins via TARGET and requested returned payment orders in case of errors.

Payments in a queue are settled on a strict FIFO (first in, first out) basis. There is a possibility to place time-critical payments in a queue and to check them against the settlement criteria at a point in time designated by the sender.

If a payment in the queue is not settled at the end of the day, it is automatically rejected by the system. However, the number and value of payments rejected by the system is very low. In 2002, four payments of a total value of EUR 109 million were rejected at the end of the day.

\section{Optimization mechanisms}

TBF uses two optimization routines to speed up the settlement of queued payments. The first (global optimization) computes virtual balances for each group of accounts. The second is invoked for the settlement of the ancillary systems.

\section{Liquidity arrangements}

BdF has two arrangements in place for the granting of intraday credit:

- Intraday loans guaranteed by bank loans (Prêts garantis intra journaliers). The bank loans are claims of participants on firms assessed by the BdF and holding the highest credit rating. Participants using this scheme have to transmit every week to the $\mathrm{BdF}$ a file containing the amount of these loans and to indicate each day which amount of these loans they wish to allocate to the collateralization of intraday credit on the following day. After checking the eligibility and applying the relevant haircuts, the BdF credits the account of the participant at the opening of the system. There is an explicit legal framework in place for transferring the ownership of these claims (Loi Dailly). The scheme is not fully watertight because there might be a risk that the underlying assets do no exist, or have been transferred to another financial institution. Within this context $\mathrm{CB}$ is empowered to perform on-site of checks of the books of the credit institutions.

- Intraday repos made on domestic assets issued in the European Economic Area (EEA). The assets are to be held in Euroclear France or in another country of the euro area. To conduct an intraday repo the participant has to send a request to the BdF. The underlying assets should be declared eligible by the Eurosystem and a haircut as set by the ECB should be applicable.

Intraday loans have to be reimbursed at the end of the day. BdF can extend an overnight loan by conducting a repo under the Lombard facility to roll over the intraday loan.

Pursuant to TARGET rules, investment firms are also allowed to get intraday credit from $\mathrm{BdF}$ in RGV2 to settle their transactions. However, investment firms are not eligible counterparties to monetary policy operations. Therefore, in order to prevent spillover to overnight credit, investment firms that want to obtain intraday credit with BdF, have either to obtain the financial backing of a credit institution, or be subject to credit limits defined by $\mathrm{BdF}$. If an investment firm is unable to square its intraday credit at the end of the day, BdF will extend an overnight repo either with the backing credit institution of the investment firm (if any) or with the investment firm itself (if a limit has been fixed by BdF). In the latter case, BdF would apply dissuasive penalties to the defaulting investment firm or even modify the conditions under which this investment firm can obtain intraday credit.

Account group structure

Within the context of an account group structure an exception is made to the rule requiring a participant not to incur a debit position in its TBF account. The system checks whether the 


\begin{tabular}{|c|c|}
\hline & 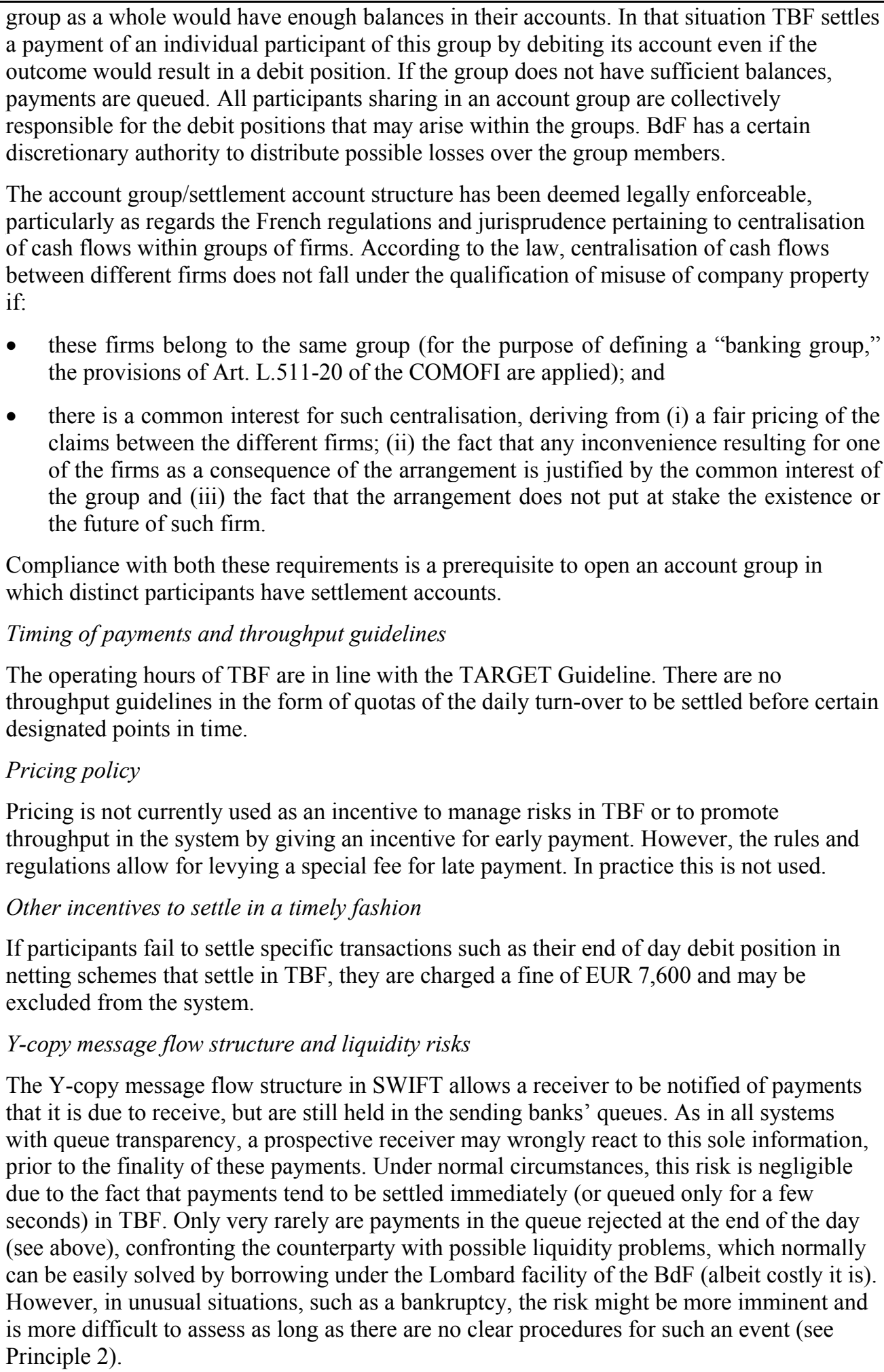 \\
\hline Assessment & Observed \\
\hline
\end{tabular}




\begin{tabular}{|c|c|}
\hline \multicolumn{2}{|l|}{ Comments } \\
\hline Principle 4. & $\begin{array}{l}\text { The system should provide prompt final settlement on the day of value, preferably } \\
\text { during the day and at a minimum at the end of the day. }\end{array}$ \\
\hline Description & $\begin{array}{l}\text { TBF is a real time gross settlement system that provides final settlement during the day at } \\
\text { the moment the account of the payer is debited and the account of the receiver is credited. } \\
\text { Finality is fully endorsed under French law and no retroactive actions are possible in case of } \\
\text { a bankruptcy of a direct or indirect participant, other than those due to willful negligence } \\
\text { and fraud. }\end{array}$ \\
\hline Assessment & Observed \\
\hline \multicolumn{2}{|l|}{ Comments } \\
\hline Principle 5. & $\begin{array}{l}\text { A system in which multilateral netting takes place should, at a minimum, be capable of } \\
\text { ensuring the timely completion of daily settlements in the event of an inability to settle } \\
\text { by the participant with the largest single settlement obligation. }\end{array}$ \\
\hline Description & $\begin{array}{l}\text { TBF is a real-time gross settlement system and not a multilateral netting system that settles } \\
\text { the clearing results at the end of the day. }\end{array}$ \\
\hline Assessment & Not applicable \\
\hline \multicolumn{2}{|l|}{ Comments } \\
\hline Principle 6. & $\begin{array}{l}\text { Assets used for settlement should preferably be a claim on the central bank; where } \\
\text { other assets are used, they should carry little or no credit risk and little or no liquidity } \\
\text { risk. }\end{array}$ \\
\hline Description & TBF is operated by BdF and settles in central bank money. \\
\hline Assessment & Observed \\
\hline \multicolumn{2}{|l|}{ Comments } \\
\hline Principle 7. & $\begin{array}{l}\text { The system should ensure a high degree of security and operational reliability and } \\
\text { should have contingency arrangements for timely completion of daily processing. }\end{array}$ \\
\hline Description & $\begin{array}{l}\text { Complexity of the structure of the system } \\
\text { TBF consists of three different platforms: 1) the TBF platform, on which TBF operations } \\
\text { are executed; 2) the CRI platform, which provides IP technology-based communication } \\
\text { services for both TBF and PNS); and 3) ICOTT, the platform that ensures the } \\
\text { communications between the domestic and European networks within the TARGET } \\
\text { framework. Different communication protocols are implemented to organize the exchange } \\
\text { of information between the three platforms. In addition, there exists a separate interface } \\
\text { between TBF and PNS to handle liquidity transfers between the two. } \\
\text { TBF also has interfaces with different ancillary systems for the settlement of multilateral } \\
\text { clearing results (SIT, the clearing system for retail payments and with Relit+, a securities } \\
\text { settlement system). Other interfaces include a liquidity bridge with RGV2, the system in }\end{array}$ \\
\hline
\end{tabular}


which the on-line, real-time trades for trade settlement of securities transactions in the OTC market take place, as well as all credit operations of the BdF, collateralized via repo transactions. Finally, TBF is connected to ADCRI, the platform through which information and payment orders are channeled to and from systems for the reserve requirements and cash transactions, the management of the accounts of clients of the BdF, and various back office facilities.

As indicated in different internal audits, the complexity of the structure of the system makes TBF vulnerable to technical failures. Severe technical incidents occurred in 2001 and 2002; one of them resulted in a long recovery time.

\section{Contingency}

Contingent measures are in place to ensure business continuity. Within this framework both BdF and CRI have back up systems and secondary production sites at their disposal for production purposes, as well as monitoring and supervision. The secondary sites are at an adequate distance of the primary sites. All production and data communication back up facilities and disaster recovery procedures are regularly tested. In the extreme situation where all production sites are unavailable and no communication exchange via SWIFT or telephone is possible, a specific disaster procedure, the Plan de Secours de Place can be activated by the physical exchange of floppy disks, ensuring the settlement of time-critical domestic and cross border payments, monetary policy operations and the settlement of multilateral netting results in ancillary systems. A crisis team is installed in which the BdF, the CRI, the main ancillary systems managers and several users are participating.

In the context of the September 11 events, new threats were identified. In the opinion of $\mathrm{BdF}$, payment and securities settlement systems need to address these threats adequately. With this in mind, the central bank has undertaken an analysis of the resilience of the French infrastructure to deal with these threats, taking into account the central role of payment and securities settlement systems for the functioning of the financial sector and for the execution of monetary policy. Several concrete actions have been initiated including inter alia the set up of a Paris Market Place Crisis Committee, gathering all operators of payment systems and Securities Settlement Systems, as well as BdF and participants. This committee is charged with formulating proposals to improve business continuity of the whole chain of the settlement infrastructures. Within this context it was also decided to conduct emergency tests of several systems simultaneously.

\section{Risk analysis and auditing}

The system is audited by the internal Audit Department of the BdF. Within the TARGET framework a new and sophisticated methodology for security risk analysis and quality control has recently been implemented within the BdF. The Payment Policy Division is in charge of this TARGET Security Analysis. In addition, there is a separate division of the Payment System Department in charge of the oversight of TBF.

\section{Protection of data communication}

Measures are taken to ensure integrity, confidentiality, protection against the failure of rejection and authentication of data communication between the different systems and between the system and the participants/users. Firewalls are in place to protect the systems from intrusion attempts by outsiders.

\section{Development and procurement}

Adequate measures are in place to ensure the quality of the development of new software and testing of new updates and releases.

Availability and scalability 


\begin{tabular}{|c|c|}
\hline & $\begin{array}{l}\text { The availability of the system between May } 2001 \text { and May } 2004 \text { was } 99.94 \text { percent and is } \\
\text { considerably above the TARGET requirement of } 99.4 \text { percent. } \\
\text { At the moment the sufficiency of the peak capacity of the systems is difficult to test due to } \\
\text { the complex structure of the system. In particular, the capacity of ICOTT, the TARGET } \\
\text { Interface, seems to be the weakest spot in this respect. It is difficult to test peak capacity due } \\
\text { to the lack of technical facilities to simulate peaks during the day. }\end{array}$ \\
\hline Assessment & Broadly observed \\
\hline Comments & $\begin{array}{l}\text { It is recommended: } \\
\text { - to analyze whether there are ways to simplify the complex structure of the system; } \\
\text { - to suppress systems features which are not or no longer needed; } \\
\text { mode could be automated. Meanwhile, a policy decision should be taken which } \\
\text { categorizes how the domestic critical payments should be handled in priority in the } \\
\text { situation where all delivered payments in an emergency situation exceed the } \\
\text { volume capacity of contingency procedures; } \\
\text { - to require participants to make their securities and emergency procedures available } \\
\text { to the system operator for analysis; } \\
\text { - to require participants to test their emergency procedures frequently and make the } \\
\text { switch to the second site regularly, sending summary reports of these tests to the } \\
\text { system operator; } \\
\text { - to implement a "payment injector" capable of transferring a high volume of } \\
\text { payments of different kinds (like the standard operations of ancillary systems) to } \\
\text { the TBF testing environment for throughput test purposes; and } \\
\text { to investigate the potential merits of regular annual audits conducted by competent } \\
\text { internal or external bodies. }\end{array}$ \\
\hline Principle 8. & $\begin{array}{l}\text { The system should provide a means of making payments, which is practical for its } \\
\text { users and efficient for the economy. }\end{array}$ \\
\hline Description & $\begin{array}{l}\text { Crucial functions of the system } \\
\text { TBF is the channel through which monetary policy operations are implemented, thus } \\
\text { enabling the Eurosystem, along with other TARGET components, to fulfill its main task. It } \\
\text { also provides the settlement channel for ancillary systems that clear on a multilateral or } \\
\text { bilateral basis, thus enabling the payments in these systems to acquire finality. TBF is also } \\
\text { widely used for commercial and interbank payments, on a cross-border as well as on a } \\
\text { domestic level. It fully contributes to the creation of uniform money market conditions- } \\
\text { one of the conditions assigned to TARGET at the time it was implemented. } \\
\text { Available functionalities in the system } \\
\text { All the usual facilities in an RTGS-system for sending, queuing and inquiry are in place. } \\
\text { In addition, optimization procedures facilitate the clearing results of the different ancillary } \\
\text { systems and also serve to promote the throughput in the system. An algorithm is available to } \\
\text { solve imminent gridlocks. Moreover, there is a special facility for time-critical payments } \\
\text { and the settlement of payments within a group account structure. } \\
\text { Liquidity management and availability of intraday credit }\end{array}$ \\
\hline
\end{tabular}




\begin{tabular}{|c|c|}
\hline & $\begin{array}{l}\text { Within the framework of the payment policy of the Eurosystem, banks can use their cash } \\
\text { reserve requirements during the day for the settlement of payments. Intraday credit is } \\
\text { granted against eligible paper on the tier } 1 \text { and tier } 2 \text { lists of the Eurosystem and is } \\
\text { abundantly available. The opportunity costs for banks with collateral placed on the French } \\
\text { tier } 2 \text { list (for the largest segment bank loans to the private sector) are particularly low. } \\
\text { These loans cannot be used as collateral elsewhere in the financial markets. No fee is levied } \\
\text { by the BdF for the rating, registration, transfer and holding of collateral in custody. } \\
\text { A participant can channel liquidity via liquidity bridges from its TBF account to its PNS } \\
\text { account and RGV2 account, while managing its liquidity needs in the different systems on } \\
\text { line and in real time. In addition, it can easily raise intraday credit via a repo transaction in } \\
\text { RGV2 and channel the liquidity to TBF. } \\
\text { All things considered, TBF is an extremely fluid system. More than } 99 \text { percent of payments } \\
\text { are processed without being queued and the average settlement time is about seven seconds. } \\
\text { Cost recovery and pricing } \\
\text { A deficiency of the system is its lack of cost recovery. TBF is heavily subsidized by the } \\
\text { BdF. From a strict accounting point of view, only } 15 \text { percent of all costs (operating costs } \\
\text { and investment costs) are covered by revenues. The lack of cost recovery is all the more } \\
\text { severe when the substantial costs related to the provision of intraday credit against private } \\
\text { bank loans are taken into account. The latter are not addressed in the accounting } \\
\text { methodology used. }\end{array}$ \\
\hline Assessment & Broadly Observed \\
\hline Comments & $\begin{array}{l}\text { It is recommended: } \\
\text { to revise the methodology used to determine costs of a TBF payment by isolating } \\
\text { the CRI costs relative to PNS from those relative to TBF to avoid any cross- } \\
\text { subsidies between the two systems; } \\
\text { to analyze whether there might be ways to simplify the current structure of the } \\
\text { system in order to save costs; } \\
\text { to examine whether the acceptance of private loans as collateral creates an } \\
\text { undesired subsidy to the financial industry, since assessing and (potentially) } \\
\text { realizing these loans is relatively costly for the BdF. }\end{array}$ \\
\hline
\end{tabular}

${ }^{17}$ One of the reasons not to take the cost of accepting collateral into account in the standardized TARGET Cost Analyzing methodology was that collateral is also used for monetary policy operations. 


\begin{tabular}{|c|c|}
\hline Principle 9. & $\begin{array}{l}\text { The system should have objective and publicly disclosed criteria for participation, } \\
\text { which permit fair and open access. }\end{array}$ \\
\hline Description & $\begin{array}{l}\text { Participation is open to credit institutions and investment firms established in France as well } \\
\text { as from other parts of the European Economic Area (EEA) when they are authorized to } \\
\text { carry on activities in France under the European passport. Credit and investment firms } \\
\text { incorporated outside the EEA but established in France or in other parts of the EEA are also } \\
\text { allowed to participate, provided they have a European passport in the latter case. } \\
\text { Smaller banks, which mainly use the system for monetary policy operations, can benefit } \\
\text { from specific price conditions. If a smaller bank opts for this procedure, it may conduct all } \\
\text { its monetary operations in TBF, without any restriction, but is not allowed to send more than } \\
500 \text { payment orders a year. } \\
\text { Smaller banks, not willing to open an own account, can become an indirect participant. This } \\
\text { possibility is not used very often. At the moment, there are only } 21 \text { indirect participants in } \\
\text { TBF. Alternatively, a small bank can become a customer of a direct participant in order to } \\
\text { be able to make and receive payments through TBF. It is not known how many banks make } \\
\text { use of this possibility. Investment firms do not have the possibility to apply as indirect } \\
\text { participants }\end{array}$ \\
\hline Assessment & Observed \\
\hline \multicolumn{2}{|l|}{ Comments } \\
\hline Principle 10. & $\begin{array}{l}\text { The system's governance arrangements should be effective, accountable and } \\
\text { transparent. }\end{array}$ \\
\hline Description & $\begin{array}{l}\text { TBF is operated by BdF. Within the BdF an appropriate framework is in place for the } \\
\text { operating, auditing and oversight of the system. } \\
\text { Decisions concerning system changes are made by the Assemblée Générale (General } \\
\text { Assembly) of CRI. Within this framework or in the working groups under the General } \\
\text { Assembly, users of TBF have the possibility to voice their needs and can influence the } \\
\text { development of the TBF system. Smaller banks have no representative in the Assemblée } \\
\text { Générale but are allowed to participate in the working groups. }\end{array}$ \\
\hline Assessment & Observed \\
\hline Comments & \\
\hline
\end{tabular}


Table 8. Summary Observance of TBF of the CPSS Core Principles

\begin{tabular}{|l|c|l|}
\hline \multirow{2}{*}{ Assessment Grade } & \multicolumn{2}{|c|}{ Principles Grouped by Assessment Grade } \\
\cline { 2 - 3 } & Count & \multicolumn{1}{c|}{ List } \\
\hline Observed & 6 & Core Principles 1, 3, 4, 6, 9 and 10. \\
\hline Broadly observed & 3 & Core Principles 2, 7 and 8. \\
\hline Partly observed & 0 & -- \\
\hline Non-observed & 0 & -- \\
\hline Not applicable & 1 & Core Principle 5. \\
\hline
\end{tabular}

\section{Recommended action plan for the TBF}

Table 9. Recommended Actions to Improve Observance of TBF of the CPSS Core Principles

\begin{tabular}{|c|c|}
\hline Reference Principle & Recommended Action \\
\hline Legal foundation & None. \\
\hline $\begin{array}{l}\text { Understanding and management of } \\
\text { risks }\end{array}$ & $\begin{array}{l}\text { - Set out procedures with respect to the behavior of participants in case } \\
\text { of specific emergency situations; } \\
\text { - Improve the accessibility of the rules and regulations. }\end{array}$ \\
\hline Settlement & None. \\
\hline $\begin{array}{l}\text { Security and operational reliability, } \\
\text { and contingency arrangements }\end{array}$ & $\begin{array}{l}\text { - Analyze whether there are ways to simplify the complex structure of } \\
\text { the system; } \\
\text { - Suppress systems features that are no longer needed; } \\
\text { - Analyze whether the procedures for processing critical payments in } \\
\text { contingency mode could be automated. Categorize the critical } \\
\text { payments and define priority rules to process the different payments } \\
\text { categories in situations where all delivered payments in an emergency } \\
\text { situation exceed the volume capacity of contingency procedures; } \\
\text { - Require participants to make their securities and emergency } \\
\text { procedures available to the system operator for analyzing; } \\
\text { - Require participants to test their emergency procedures frequently } \\
\text { and to send summary reports of these tests to the system operator; } \\
\text { - Improve the technical facilities to conduct throughput tests; } \\
\text { - Investigate the potential merits of regular annual audits conducted by } \\
\text { competent internal and external bodies. }\end{array}$ \\
\hline
\end{tabular}




\begin{tabular}{|l|l|}
\hline \multicolumn{1}{|c|}{ Reference Principle } & \multicolumn{1}{c|}{ Recommended Action } \\
\hline $\begin{array}{l}\text { Efficiency and practicality of the } \\
\text { system }\end{array}$ & $\begin{array}{l}\text { - Revise the methodology used to determine the costs of a TBF } \\
\text { payment by isolating the CRI cost relative to PNS from those relative } \\
\text { to TBF to avoid any cross- subsidies between the two systems; } \\
\text { - Analyze whether there are ways to simplify the current structure of } \\
\text { the system in order to save costs; } \\
\text { - Examine whether the acceptance of private loans as collateral creates } \\
\text { an undesired subsidy to the financial industry since assessing and } \\
\text { (potentially) realizing these loans is relatively costly for the BdF. }\end{array}$ \\
\hline Criteria for participation & None. \\
\hline Governance of the payment system & None. \\
\hline
\end{tabular}

\section{Assessment of observance of the CPs by the PNS}

\section{Table 10. Detailed Assessment of Observance of Paris Net Settlement System (PNS) of the CPSS Core Principles for SIPS}

Principle 1. The system should have a well-founded legal basis under all relevant jurisdictions.

Description

French law and the contractual relations within the framework of PNS provide a wellestablished and reasonably comprehensive legal foundation for funds transfers in this system.

Completeness and reliability of framework legislation

- In France, a consistent and reliable set of laws, regulations, and contractual arrangements is in place that forms the legal basis for PNS and payment transfers executed in this system.

\section{Enforceability of laws and contracts}

- All relevant laws, as well as contractual arrangements between the different parties involved within the framework of PNS, are fully enforceable.

Definition of timing and legal protection of irrevocability and finality

- Although a zero hour rule exists in French Bankruptcy law, this regulation is overruled for payment or financial instruments deliveries in a payment or securities settlement systems under the finality regulation in the COMOFI (Art L.330 I-II). PNS falls within the scope of this regulation and is notified to the European Commission as a payment system pursuant to the Finality Directive (directive 98/26 EC).

- Irrevocability and finality are clearly defined in the law and in the rules of the system and are ensured even in case an insolvency procedure is opened against a direct or indirect participant in the system.

- All payment orders sent in are irrevocable from the moment they are accepted by the system. After acceptance, the sender cannot revoke, cancel, or modify the 
orders.

- Finality occurs at the moment the account of the bank involved is debited. According to the functioning of the system, the account of the receiving bank will be credited simultaneously. Final payments by a participant made on its own behalf or on behalf of an indirect participant cannot be challenged and no retroactive action is possible.

- However, due to the restricted-access criteria and the actual design of the relationship between settlement banks (direct participants) and financial institutions that make use of their services (customer banks), in practice, the scope of the protection under the finality regulations is not as large as it could be while the relationship between a customer bank and its settlement agent does not fall under the finality protection, exposing the settlement bank to retroactive action in case of an insolvency of its client. There are at least four hundred customer banks, and possibly far more.

\section{Legal recognition of netting arrangements}

- Off-setting, bilateral, and multilateral netting in the framework of PNS are fully recognized (Art. 1289 of the civil code).

\section{Enforceability of collateral arrangements for intraday and overnight credit}

- This issue is not relevant because no collateral arrangement exists within the framework of PNS. Intraday credit is granted in TBF or in RGV2 and the funds are transferred to PNS via the existing liquidity bridges between the relevant systems. Although bilateral and multilateral offsetting takes place in PNS, no loss sharing or liquidity arrangements are necessary to ensure the timely settlement at the end of the day as in the case of classical large-value netting schemes. Offsetting of payments in PNS will only take place if there is enough liquidity in the accounts of the involved participants. In that situation, all payments involved in the offsetting will immediately be settled simultaneously in real time and will be final (intraday finality). Payments in the queue that cannot be executed due to insufficient balances will automatically be rejected at the closing of the system.

\section{Legal support of electronic processing}

- Art. 1316-3 of the Civil Code specifies that a payment order can be given electronically, and that electronic data have the same value to settle a dispute as a paper document. Recognition of an electronic signature is well established in French Regulations (Art. 1316-4 of the Civil Code and decree no 2001-272 of 30 March 2001).

\section{Relevance of laws outside the domestic jurisdiction}

- The relevance of foreign law is limited. For the time being there are no remote participants. According to the French principles of international law, in the event of bankruptcy of a foreign bank participating in a payment and securities settlement system via its branch in France, French bankruptcy law will apply to the French branch including the finality protection offered under the finality regulations. However this will change when the new winding-up regulation for a financial institution comes into force.

- Foreign participants not established under French law (both branches and remote members) applying to become participants in the system have to provide a legal opinion compliant with the terms of reference given by the Governing Council of 


\begin{tabular}{|c|c|}
\hline & $\begin{array}{l}\text { the European Central Bank (Art } 1.2 \text { of the Conditions spécifiques d'accès aux } \\
\text { systèmes PNS et TBF). However, providing a legal opinion was not requested from } \\
\text { foreign participants already participating in the system before } 1999 \text {. Within the } \\
\text { context of the European Central Bank a grandfathering clause was agreed upon for } \\
\text { this category in all large-value systems in the European Union. At the moment, } \\
\text { there are five direct foreign participants, none of whom have provided a legal } \\
\text { opinion. }\end{array}$ \\
\hline Assessment & Broadly observed \\
\hline Comments & $\begin{array}{l}\text { It is recommended: } \\
\text { to bring the wording of the definition of "irrevocability" in the different bylaws of the } \\
\text { system into line throughout the rules and regulations, in order to avoid confusion; } \\
\text { to see whether the BdF can act as a catalyst to encourage settlement banks to change the } \\
\text { status of their customers from that of customer banks to that of indirect participants, or } \\
\text { can find alternative means to reduce the legal risks for the settlement bank by changing } \\
\text { the status of customer banks into that of indirect participants, for instance by bringing } \\
\text { this issue to the attention of the banking supervisory authority. }\end{array}$ \\
\hline Principle 2. & $\begin{array}{l}\text { The system's rules and procedures should enable participants to have a clear under- } \\
\text { standing of the system's impact on each of the financial risks they incur through } \\
\text { participation in it. }\end{array}$ \\
\hline Description & $\begin{array}{l}\text { Accessibility and transparency of the rules and regulations } \\
\text { The rules and procedures of PNS enable participants to understand the risks resulting from } \\
\text { their participation in the system under normal circumstances. } \\
\text { Direct and indirect participants have to sign a lettre d'adhésion. The annexes to this } \\
\text { document detail the functioning of the system and the financial risks participants incur by } \\
\text { participating in it. The Règlement Général sets out the roles and liabilities of parties and the } \\
\text { legal basis of the system. Further on in this document a chronology of a typical day in PNS } \\
\text { and a clear timetable of the system are given. } \\
\text { Emergency events } \\
\text { The understanding of risk and the smooth functioning of the system could be promoted if } \\
\text { there were procedures in place on how participants should behave in stress situations such } \\
\text { as a technical failure of their own platform or in case of a bankruptcy event and if the } \\
\text { transparency on the possible policy measures of the authorities and system provider would } \\
\text { be enlarged. } \\
\text { Understanding of legal risk in case of a customer bank } \\
\text { PNS has, due to its design and its access criteria, a so-called tiered structure. Only banks and } \\
\text { investment firms with a capital above EUR } 250 \text { million can become direct participants. At } \\
\text { present, there are } 19 \text { direct participants. Banks that do not fulfill these criteria have to make } \\
\text { use of the services of a settlement bank. Most of the smaller banks and investment firms } \\
\text { make use of the settlement services of around } 10 \text { settlement banks to execute their payment } \\
\text { flows in PNS, usually as a so called "customer bank." Over } 440 \text { banks and investment firms } \\
\text { are referenced in the CRI directory as "customer banks," but the total number is probably } \\
\text { higher, since for customer banks there is no obligation to be notified and to appear in the } \\
\text { directory. Only financial institutions using a settlement bank that have the status of "indirect } \\
\text { participant" have to be registered officially. Each indirect participant has to sign a lettre } \\
\text { d'adhésion with PNS. There are currently } 26 \text { indirect participants in PNS. }\end{array}$ \\
\hline
\end{tabular}




\begin{tabular}{|c|c|}
\hline & $\begin{array}{l}\text { The settlement bank of the customer bank that gets into financial trouble will be exposed to } \\
\text { credit risk, for instance, due to the fact that the rules of PNS make it impossible for the } \\
\text { settlement bank to cancel or modify payment orders accepted by the system, but not yet } \\
\text { executed, and still stored in the queue. } \\
\text { This issue was analyzed and discussed in the Rules and Regulation committee (group } \\
\text { Règles) at the CRI (1999/2000). Legal and payment experts of TBF }{ }^{18} \text {, PNS participants, and } \\
\text { the BdF participated in this working group. The group provided tools to allow the } \\
\text { stakeholders to mitigate this risk in the form of creating the fully fledged status of indirect } \\
\text { participant and drafting a standard master agreement between the direct participant and the } \\
\text { indirect participant. } \\
\text { Due to the work of the group the risk is well known at least among settlement banks. }\end{array}$ \\
\hline Assessment & Observed \\
\hline Comments & $\begin{array}{l}\text { Risk management and understanding of risk and the smooth functioning in stress situations } \\
\text { could be improved if procedures were in place concerning the behavior of participants in the } \\
\text { event of a technical breakdown of their own platform or that of a major user, and in a } \\
\text { bankruptcy event. It might also be considered to improve transparency about the risk } \\
\text { management policy of the authorities in a bankruptcy event and the possible actions. }\end{array}$ \\
\hline Principle 3. & $\begin{array}{l}\text { The system should have clearly defined procedures for the management of credit risks } \\
\text { and liquidity risks, which specify the respective responsibilities of the system operator } \\
\text { and the participants and which provide appropriate incentives to manage and contain } \\
\text { those risks. }\end{array}$ \\
\hline Description & $\begin{array}{l}\text { Real-time settlement and bilateral limits } \\
\text { PNS enables participants to manage their credit and liquidity risks vis-à-vis their } \\
\text { counterparties, not only via real-time gross settlement of payments in central bank money, } \\
\text { but also by setting bilateral limits on the amounts to be exchanged during the processing } \\
\text { cycle. Outgoing payments that exceed this limit are queued. } \\
\text { Intraday finality } \\
\text { The payments settled are final (irrevocable and unconditional), and funds received can be } \\
\text { used immediately to settle payments obligations to other participants. } \\
\text { Obligation to settle all validated payments. } \\
\text { To release payments in the queue for a specific counterparty, a participant can increase the } \\
\text { limit established for this counterparty. Although payment orders still remaining in the queue } \\
\text { at the closing of the system are automatically rejected, participants are obliged to prevent } \\
\text { rejection by settling all payment orders sent in before the closing of the system. The system } \\
\text { operator contacts, as a routine, all the participants who have payments in their queues that } \\
\text { might be rejected at the close of the system. } \\
\text { FIFO rule } \\
\text { The system applies a FIFO (first in, first out) rule for queued payments. An exception to the }\end{array}$ \\
\hline
\end{tabular}

${ }^{18}$ In TBF as well, smaller bank financial institutions clear and settle their payments via a settlement bank. The number of customer banks in this system and the amount/volume of payments executed on their behalf are not known, but are probably smaller than in PNS. 
FIFO rule is made for payments of less than EUR 1 million.

\section{Bilateral optimization}

If there are also payments for the participant involved queued by its counterparty, the system will settle incoming and outgoing queued payments simultaneously. This will be done as long as the net amount to be exchanged between the two parties involved in this operation remains within the bilateral limits established for each other, and if there is enough liquidity in the account of the participant with a debit position in this bilateral netting to make the implied net fund transfer possible.

Within the framework of the bilateral optimization facility, the system scans each time when payments from $\mathrm{A}$ to $\mathrm{B}$ or from $\mathrm{B}$ to $\mathrm{A}$ are queued and attempts to settle as many payments as possible between the two participants involved, taking into account the constraints formed by the bilateral limits set and the amounts of liquidity in the accounts. The bilateral limits and the bilateral optimization facility protect the credit institutions from the risk of making all the payments to their counterparties without being paid or being paid very late in the day.

Participants can monitor and change their limits vis-à-vis any other participant in real time by sending requests to PNS. They can both monitor the limits they have established for other participants, as well as those limits other participants have set for them.

\section{Multilateral optimization}

The system also has a multilateral optimization facility that can be launched by the system operator when a gridlock might be imminent. This mechanism tries to settle simultaneously as many payments as possible considering the bilateral limits and the funds in the accounts. To broaden the effectiveness of the multilateral optimization, the FIFO rule is bypassed. The facility is also launched automatically three times during the day (10:30 a.m., 2:30 p.m., and at the close of the system at 4:00 p.m.). The multilateral optimization usually unlocks an important part of the queued payments (30-80 percent) at 10.30 AM. However, the value of the payments involved is relatively low (1-10 percent of the queued payments).

\section{Monitoring liquidity needs and liquidity management}

At the opening of the system participants have to transfer a minimum amount (EUR 15 million) from their cash account in TBF to their cash account in PNS via the liquidity bridge between the two systems in order to ensure a smooth functioning of the system (Art. 8 of the Convention PNS). However, no clear procedure has been established in case a participant does not meet this requirement.

Participants are obliged to calculate on an ongoing basis their "virtual position," the sum of the liquidity in their PNS account plus all queued incoming payments from all other participants minus their outgoing payments. Because of the SWIFT Y-copy format, participants are aware of the payments sent in by other participants to be paid to them. Also the system can provide them with information on their virtual position. The virtual position gives an indication of the additional liquidity needed to settle all the payments in the queue, provided that all incoming payments will be settled.

The notification under the Y-copy message flow scheme might bring forward credit and liquidity risks, due to the fact that the prospective receiver of a queued payment releases its

${ }^{19}$ According to Article 5.1 of the Convention PNS all payments accepted by the system must be settled before the end of the day. 


\begin{tabular}{|c|c|}
\hline & 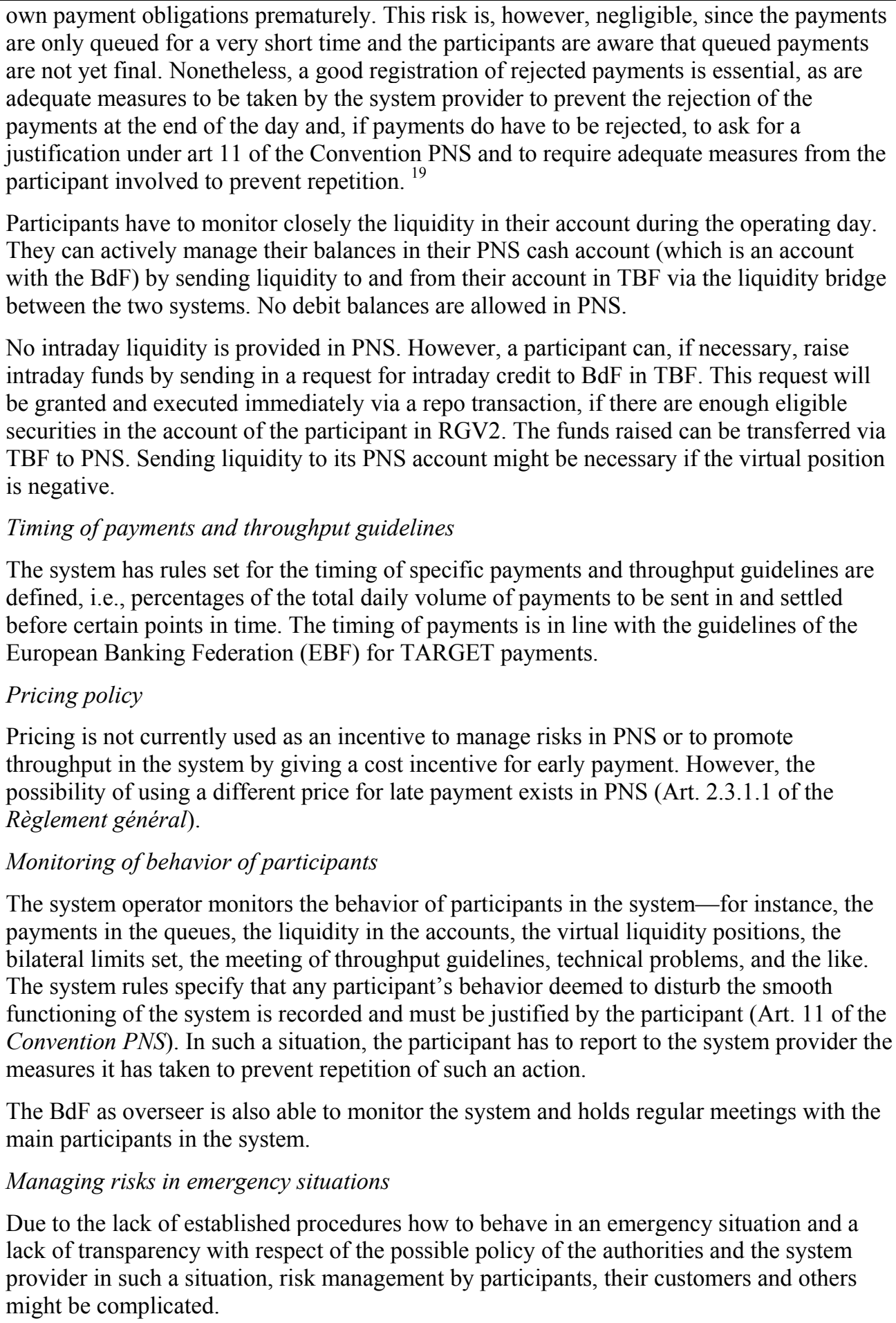 \\
\hline Assessment & Observed \\
\hline Comments & $\begin{array}{l}\text { It is recommended: } \\
\text { - to take adequate actions under Art. } 11 \text { of the Convention PNS in the event a } \\
\text { participant does not transfer the required minimum amount of liquidity to its PNS }\end{array}$ \\
\hline
\end{tabular}




\begin{tabular}{|c|c|}
\hline & $\begin{array}{l}\text { account at the opening of the system, in addition to ensuring that measures are } \\
\text { taken by the participant involved to prevent a repetition of the event; } \\
\text { - to ensure an overview of all relevant data regarding the behavior of participants, } \\
\text { along with a clear recording of all rejected payments; } \\
\text { - to take adequate actions in case of rejected payments by asking justification of the } \\
\text { participant involved and requiring measures to prevent repetition if there is a } \\
\text { breach of Art. } 5.1 \text { of the convention PNS, which specifies that payments sent in } \\
\text { should be settled before the end of the day; } \\
\text { - to establish clear and comprehensive procedures to deal with emergency situations. }\end{array}$ \\
\hline Principle 4. & $\begin{array}{l}\text { The system should provide prompt final settlement on the day of value, preferably } \\
\text { during the day and at a minimum at the end of the day. }\end{array}$ \\
\hline Description & $\begin{array}{l}\text { PNS is a real-time gross settlement system that provides final settlement during the day at } \\
\text { the moment the account of the payer is debited and the account of the receiver is credited. } \\
\text { Finality is fully endorsed under French law and no retroactive actions are possible on } \\
\text { payments done on behalf of the participant itself or on behalf of an indirect participant, } \\
\text { other than those due to willful negligence and fraud. }\end{array}$ \\
\hline Assessment & Observed \\
\hline Comments & $\begin{array}{l}\text { BdF and CRI should continue their efforts that broaden the scope of the finality protection } \\
\text { (see recommendation for CP I). }\end{array}$ \\
\hline Principle 5. & $\begin{array}{l}\text { A system in which multilateral netting takes place should, at a minimum, be capable of } \\
\text { ensuring the timely completion of daily settlements in the event of an inability to settle } \\
\text { by the participant with the largest single settlement obligation. }\end{array}$ \\
\hline Description & $\begin{array}{l}\text { PNS is a real-time settlement system and not a multilateral netting scheme that settles the } \\
\text { clearing results at the end of the day in some other payment system. No debit balances are } \\
\text { allowed in PNS. } \\
\text { Although PNS has optimization facilities that try to settle different payment obligations by } \\
\text { offsetting a restricted number of payments on a bilateral or a multilateral basis, the } \\
\text { payments involved in such an offsetting arrangement are not settled at the end of the } \\
\text { operating day, but in real time with immediate finality. } \\
\text { The multilateral optimization facility is operated automatically by the system three times a } \\
\text { day. The facility can also be activated by the system provider in case a gridlock is imminent. } \\
\text { However, settlement takes place only if there are sufficient balances in the account of the } \\
\text { involved participants. Otherwise, the payments remain in the queue and have to be settled } \\
\text { during the normal operation or they will be rejected at the end of the day. } \\
\text { Due to the above-mentioned design of the system, no loss sharing or liquidity arrangements } \\
\text { to ensure timely settlement at the end of the day are necessary. }\end{array}$ \\
\hline Assessment & Non applicable \\
\hline \multicolumn{2}{|l|}{ Comments } \\
\hline Principle 6. & $\begin{array}{l}\text { Assets used for settlement should preferably be a claim on the central bank; where } \\
\text { other assets are used, they should carry little or no credit risk and little or no liquidity } \\
\text { risk. }\end{array}$ \\
\hline
\end{tabular}




\begin{tabular}{|c|c|}
\hline Description & $\begin{array}{l}\text { Use of central bank money } \\
\text { PNS settles in central bank money. The cash accounts opened in PNS by the participants are } \\
\text { accounts with the BdF and, according to an agreement between CRI, the systems provider } \\
\text { of PNS, and the BdF, CRI is authorized to manage the settlement accounts according to the } \\
\text { rules of PNS. } \\
\text { At any moment of the operating day, participants can transfer money in their account in } \\
\text { PNS to their TBF account and vice versa via the liquidity bridge between the two systems. } \\
\text { This opportunity makes the liquidity management in the total infrastructure for the } \\
\text { settlement of payments and securities highly efficient. }\end{array}$ \\
\hline Assessment & Observed \\
\hline Comments & $\begin{array}{l}\text { Due to the restricted access to PNS, smaller banks and investment firms have to make use of } \\
\text { private settlement banks (direct participants) and are thus exposed to deposit or settlement } \\
\text { bank risk. The amounts at risk are not known and neither is the concentration of banks using } \\
\text { the same settlement agent. It is not known whether they can transfer their balances on the } \\
\text { same day to their account in TBF, if they have such an account. No specific measures are } \\
\text { taken by the system provider to reduce this risk. } \\
\text { It is recommended: } \\
\text { - to thoroughly map the concentration of payment flows initiated by customer banks } \\
\text { via the most important settlement banks; } \\
\text { - the supervisory authorities and the overseer analyze the risks involved in this } \\
\text { concentration and, if deemed necessary, prescribe that adequate risk management } \\
\text { measures be taken by the system provider to reduce these risks. }\end{array}$ \\
\hline Principle 7. & $\begin{array}{l}\text { The system should ensure a high degree of security and operational reliability and } \\
\text { should have contingency arrangements for timely completion of daily processing. }\end{array}$ \\
\hline Description & $\begin{array}{l}\text { Contingency } \\
\text { Contingency measures are in place to ensure business continuity. CRI has back up systems } \\
\text { in place (all computers are duplicated, or clustered, and in a ready standby mode), together } \\
\text { with a secondary production site for production purposes and a separate secondary site for } \\
\text { monitoring and supervision. The secondary sites are an adequate distance from the primary } \\
\text { site. All production, data communication back up facilities, and disaster recovery } \\
\text { procedures are regularly tested. In the extreme situation where all production sites are } \\
\text { unavailable and no communication exchange via SWIFT or telephone is possible, a specific } \\
\text { disaster procedure, the Plan de Secours de Place, can be activated through the physical } \\
\text { exchange of floppy disks. } \\
\text { A crisis team is installed in which the BdF, the CRI, the main ancillary systems managers } \\
\text { and several users are participating. } \\
\text { Participants are required to have a secondary site (Art. } 5.1 \text { of the Règlement général). } \\
\text { Risk analysis and auditing } \\
\text { The PNS system is not regularly audited by an external auditor. As user of the CRI platform } \\
\text { and as settlement bank of PNS, BdF is entitled to carry out on-site inspections and audits on } \\
\text { a contractual or voluntary basis. The Audit department of the BdF carried out audits of the } \\
\text { CRI platform in } 1998 \text { and } 2000 \text {. } \\
\text { Protection of data communication } \\
\text { Measures are taken to ensure integrity, confidentiality, nonrepudiability and authentication }\end{array}$ \\
\hline
\end{tabular}




\begin{tabular}{|c|c|}
\hline & $\begin{array}{l}\text { of data communication between the different systems and between the system and the } \\
\text { participants/users, via the SWIFT-network. } \\
\text { Development and procurement } \\
\text { Adequate measures are in place to ensure the quality of the development of new software } \\
\text { and testing of new updates and releases. } \\
\text { Availability and scalability } \\
\text { The availability of the system between April } 2001 \text { and March } 2004 \text { was } 99.98 \text { percent and } \\
\text { was clearly above the TARGET requirement of } 99.4 \text { percent. There is enough capacity to } \\
\text { handle unpredicted peaks. Due to the migration toward the SWIFT NET FIN, the capacity } \\
\text { of the communication network has improved significantly. }\end{array}$ \\
\hline Assessment & Observed \\
\hline Comments & $\begin{array}{l}\text { It is recommended: } \\
\text { - albeit not explicitly phrased in the Core Principles, to consider whether external } \\
\text { audits should be carried out on a regular basis (see also the Guidance Note page } 21 \\
\text { under q, which was endorsed by the CPSS); } \\
\text { - to require participants to test their back up sites regularly and send in summary } \\
\text { reports to CRI; } \\
\text { - to require participants to transmit their securities procedures to the system provider. }\end{array}$ \\
\hline Principle 8. & $\begin{array}{l}\text { The system should provide a means of making payments, which is practical for its } \\
\text { users and efficient for the economy. }\end{array}$ \\
\hline Description & $\begin{array}{l}\text { General } \\
\text { Due to the payment system's liquidity saving facilities and its efficient risk and liquidity } \\
\text { management tools, along with its relatively short processing times and intraday finality, the } \\
\text { system is practical for its users. } \\
\text { Cost recovering } \\
\text { Although the settlement fee is relatively low for a large-value payment system in Europe } \\
\text { (EUR } 0.25 \text { per payment), the system is able to fully recover its costs. However, it is not } \\
\text { known whether the cost accounting methods are based on a fair distribution of costs } \\
\text { between CRI as provider of PNS and the BdF as provider of TBF for the use of common } \\
\text { facilities operated by CRI and whether there might be cross-system subsidies. } \\
\text { Practicality and efficiency for indirect participants and customer banks } \\
\text { There is no information available whether the system is efficient and practical for indirect } \\
\text { participants and customer banks. It is not known whether customer banks are satisfied with } \\
\text { the services offered by the settlement banks and whether there is enough competition } \\
\text { between settlement banks to ensure efficiency and low costs for their clients. }\end{array}$ \\
\hline Assessment & Observed \\
\hline Comments & $\begin{array}{l}\text { It is recommended: } \\
\text { to revise the methodology used to determine the costs of a PNS payment so as to } \\
\text { isolate the exact costs relative to PNS and those relative to the CRI platform, which } \\
\text { is also used by BdF for the connection with the participants of TBF. }\end{array}$ \\
\hline
\end{tabular}


Principle 9. The system should have objective and publicly disclosed criteria for participation, which permit fair and open access.

\begin{tabular}{|c|c|}
\hline Description & 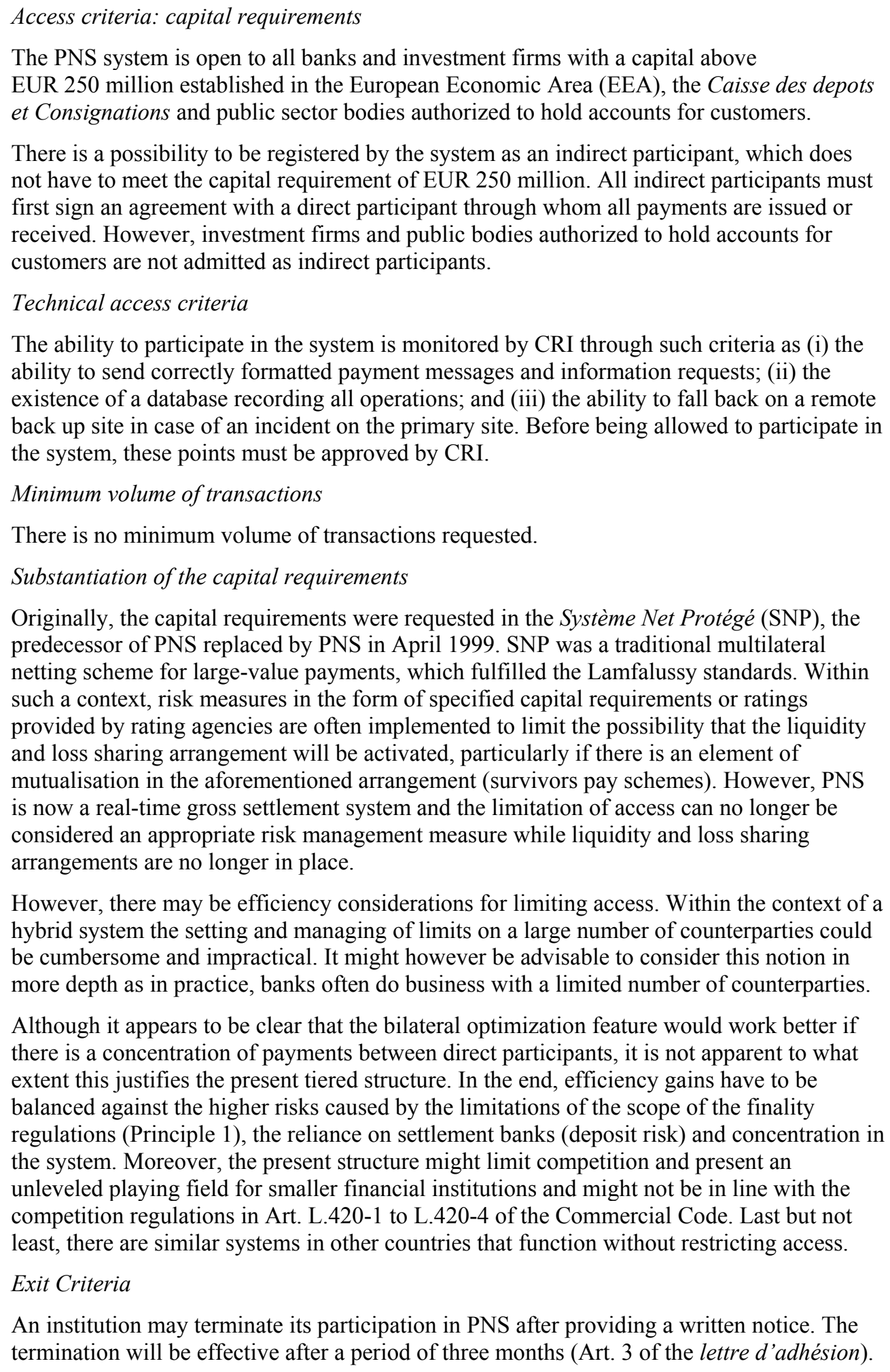 \\
\hline
\end{tabular}




\begin{tabular}{|c|c|}
\hline & $\begin{array}{l}\text { A participant can be eliminated if it no longer fulfils the access criteria, or if its behavior is } \\
\text { deemed to jeopardize the system's security and efficiency. No time lag will apply in this } \\
\text { situation. }\end{array}$ \\
\hline Assessment & Broadly-observed \\
\hline Comments & $\begin{array}{l}\text { The access criteria can be considered as fairly restrictive due to the capital requirement of } \\
\text { EUR } 250 \text { million. As stated in the Core Principles, access restrictions can be justified by } \\
\text { risk (safety) or efficiency considerations (p.54). The original substantiation was based on } \\
\text { risk management considerations in the multilateral netting scheme that was replaced by the } \\
\text { present system. But these considerations are no longer valid in the present design. In this } \\
\text { context it should be noted that for this reason, EAF } 2 \text { moved to open access when it } \\
\text { introduced the real-time feature in RTGS+. Balancing the efficiency gains for the settlement } \\
\text { banks (the major settlement banks are the owners of the system) against the increased risks } \\
\text { brought about by a tiered structure-for instance an increase in concentration risk- the } \\
\text { mission is of the opinion that restricting access is difficult to justify on efficiency grounds } \\
\text { alone. This is all the more so since it is not known whether there might be sufficient } \\
\text { competition between settlement banks to ensure practicality and efficiency of the system for } \\
\text { indirect participants and customer banks. Of course, it would be costly for an indirect } \\
\text { participant to become a direct participant. The decision on how to access the system should, } \\
\text { however, preferably be left to the participant and not to the operator. } \\
\text { For these reasons, it is recommended that the capital requirement be dropped from the } \\
\text { access criteria. }\end{array}$ \\
\hline Principle 10. & $\begin{array}{l}\text { The system's governance arrangements should be effective, accountable and } \\
\text { transparent. }\end{array}$ \\
\hline Description & $\begin{array}{l}\text { The PNS system has an effective, accountable and transparent governance structure. } \\
\text { Decisions are taken by the Assemblée Générale of CRI shareholders acting as the majority } \\
\text { of voters. At present, CRI is owned by nine major banks (eight French and one foreign) and } \\
\text { the BdF. All shareholders currently own the same number of shares. Limits are set on the } \\
\text { maximum amounts of shares that can be held by any one institution. The BdF has two } \\
\text { representatives in the Assemblée Générale. Pursuant to the statutes of CRI, the BdF, as the } \\
\text { system's overseer, is entitled to veto any decision that might jeopardize the security or the } \\
\text { smooth functioning of the system. The Assemblée Générale meets every month. } \\
\text { CRI has a budget consisting of a system of three-year budgets and plans. By statute, CRI's } \\
\text { president cannot spend more than what has been budgeted and approved by the assembly of } \\
\text { shareholders. CRI is able to fully cover its costs. Certain risks, such as operational risks or } \\
\text { fraud are covered by insurance or by a loss-sharing mechanism between the owners of CRI. } \\
\text { CRI has set up different working groups in which the participants in the system can express } \\
\text { their needs and concerns and make remarks. These groups monitor the participants' } \\
\text { satisfaction of the system and participate in the definition of the evolutions they would like } \\
\text { to see. They meet periodically and their conclusions are reported to the Assemblée Générale } \\
\text { Customer banks are not officially represented in the decision structure or in the consultation } \\
\text { framework, although they are sometimes asked to participate in the context of certain issues. }\end{array}$ \\
\hline Assessment & Observed \\
\hline Comm & \\
\hline
\end{tabular}




\section{Table 11. Summary Observance of PNS of the CPSS Core Principles}

\begin{tabular}{|l|c|l|}
\hline \multirow{2}{*}{ Assessment Grade } & \multicolumn{2}{|c|}{ Principles Grouped by Assessment Grade } \\
\cline { 2 - 3 } & Count & \multicolumn{1}{c|}{ List } \\
\hline Observed & 7 & Core Principles $2,3,4,6,7,8$ and 10. \\
\hline Broadly observed & 2 & Core Principles 1 and 9. \\
\hline Partly observed & 0 & -- \\
\hline Non-observed & 0 & -- \\
\hline Not applicable & 1 & Core Principle 5. \\
\hline
\end{tabular}

\section{Recommended action plan for the PNS}

\section{Table 12. Recommended Actions to Improve Observance of PNS of the CPSS Core Principles}

\begin{tabular}{|l|l|}
\hline \multicolumn{1}{|c|}{ Reference Principle } & \multicolumn{1}{|c|}{ Recommended Action } \\
\hline Legal foundation & $\begin{array}{l}\text { - Make the wording of the definition of "irrevocability" in line in the } \\
\text { different bylaws of the system in order to avoid confusion; } \\
\text { - Encourage settlement banks to change the status of their clients to that of } \\
\text { indirect participants in the system, in order to enlarge the scope of the } \\
\text { finality regulations and reduce the existing legal risk for settlement banks. }\end{array}$ \\
\hline $\begin{array}{l}\text { Understanding and management } \\
\text { of risks }\end{array}$ & $\begin{array}{l}\text { - Improve the understanding and transparency of risk management in stress } \\
\text { situations by establishing clear and comprehensive procedures concerning } \\
\text { the behavior of participants in specific stress situations; } \\
\text { - Take adequate actions under Art. 11 of the PNS Convention in the event } \\
\text { participants do not transfer the required minimum amount of liquidity at the } \\
\text { opening of the system; } \\
\text { - Provide a clear overview of all relevant data regarding the behavior of } \\
\text { participants along with a clear recording of all rejected payments; } \\
\text { - Ask justification in case of rejected payments at the end of the settlement } \\
\text { day and take adequate action to prevent repetition of the breach of the } \\
\text { obligation of participants to settle all payments sent in to the system before } \\
\text { the closing of the system. }\end{array}$ \\
\hline Settlement & $\begin{array}{l}\text { - Thoroughly map the concentration of payment flows initiated by customer } \\
\text { banks via the most important settlement banks; } \\
- \text { Analyze the concentration risk due to the tiered structure and, if deemed } \\
\text { necessary, take adequate measures to reduce this risk. }\end{array}$ \\
\hline
\end{tabular}




\begin{tabular}{|l|l|}
\hline \multicolumn{1}{|c|}{ Reference Principle } & \multicolumn{1}{c|}{ Recommended Action } \\
\hline $\begin{array}{l}\text { Security and operational } \\
\text { reliability, and contingency } \\
\text { arrangements }\end{array}$ & $\begin{array}{l}\text { - Consider whether external audits should be carried out on a regular basis; } \\
\text { - Require participants to test their back up sites regularly and to send } \\
\text { summary report of the results to CRI; } \\
\text { - Require Participants to transmit their securities procedures to the system } \\
\text { provider. }\end{array}$ \\
\hline $\begin{array}{l}\text { Efficiency and practicality of the } \\
\text { system }\end{array}$ & $\begin{array}{l}\text { - Revise the methodology used to determine the costs of a PNS payment so } \\
\text { as to isolate the exact costs relative to PNS and those relative to the CRI } \\
\text { platform which is also used by BdF for TBF. }\end{array}$ \\
\hline Criteria for participation & $\begin{array}{l}\text { - Broaden the access to the system by abolishing the capital requirement in } \\
\text { the access criteria. }\end{array}$ \\
\hline $\begin{array}{l}\text { Governance of the payment } \\
\text { system }\end{array}$ & None. \\
\hline
\end{tabular}

\section{Assessment of observance of the CPs by the SIT}

Table 13. Detailed Assessment of Observance of Système Interbancaire de Télécompensation (SIT) of CPSS Core Principles for SIPS

Principle 1. The system should have a well-founded legal basis under all relevant jurisdictions.

Description Legal Framework

SIT is operated on a contractual law basis, ruled by the French civil code (agency rules for transfers, set off rules for netting), the French commercial code (rules governing Economic Interest Groups (EGII)) and the COMOFI (rules governing payment systems-L.330-1, L.330-2, rules governing the oversight of payments systems-L.141-4).

The Settlement Finality Directive (SFD, 98/26/EC of 19 May 1998) was transposed in French law under Art. L.330-1 and L.330-2 of the COMOFI, supplemented by a decree (executive order) published on March 7, 2003.

Provisions as regards instruments of electronic payments apply within the French Law (e.g. Art. 511-7 of the COMOFI and the Regulation of the CRBF of November 21, 2002 transposing the e-money Directive) and within the Community Law (e.g. the EU Regulation number 2560/2001 of December 19, 2001 relating to cross-border payments, including those made with electronic payment instruments). There is no specific legislation in place relating to the electronic processing of payments settled through interbank settlement systems like the SIT. However, the general provisions of the French Civil Code recognize electronic evidence. A payment order may be given electronically: Art. 1316-3 of the Civil Code (introduced by Law No. 2000-230 of March 13, 2000) specifies that "a writing on an electronic support has the same value according to the law as a writing on paper" and Art. 1316-4 of the Civil Code (and decree n'2001-272 of March 30, 2001) recognizes the electronic signature. Concerning the execution of a payment order by a payment system, the question of proof is dealt with in the rules of the system.

The Charte Interbancaire Régissant les Conditions d'Echange (hereafter CIRCE) applies to 


\begin{tabular}{|c|c|}
\hline & 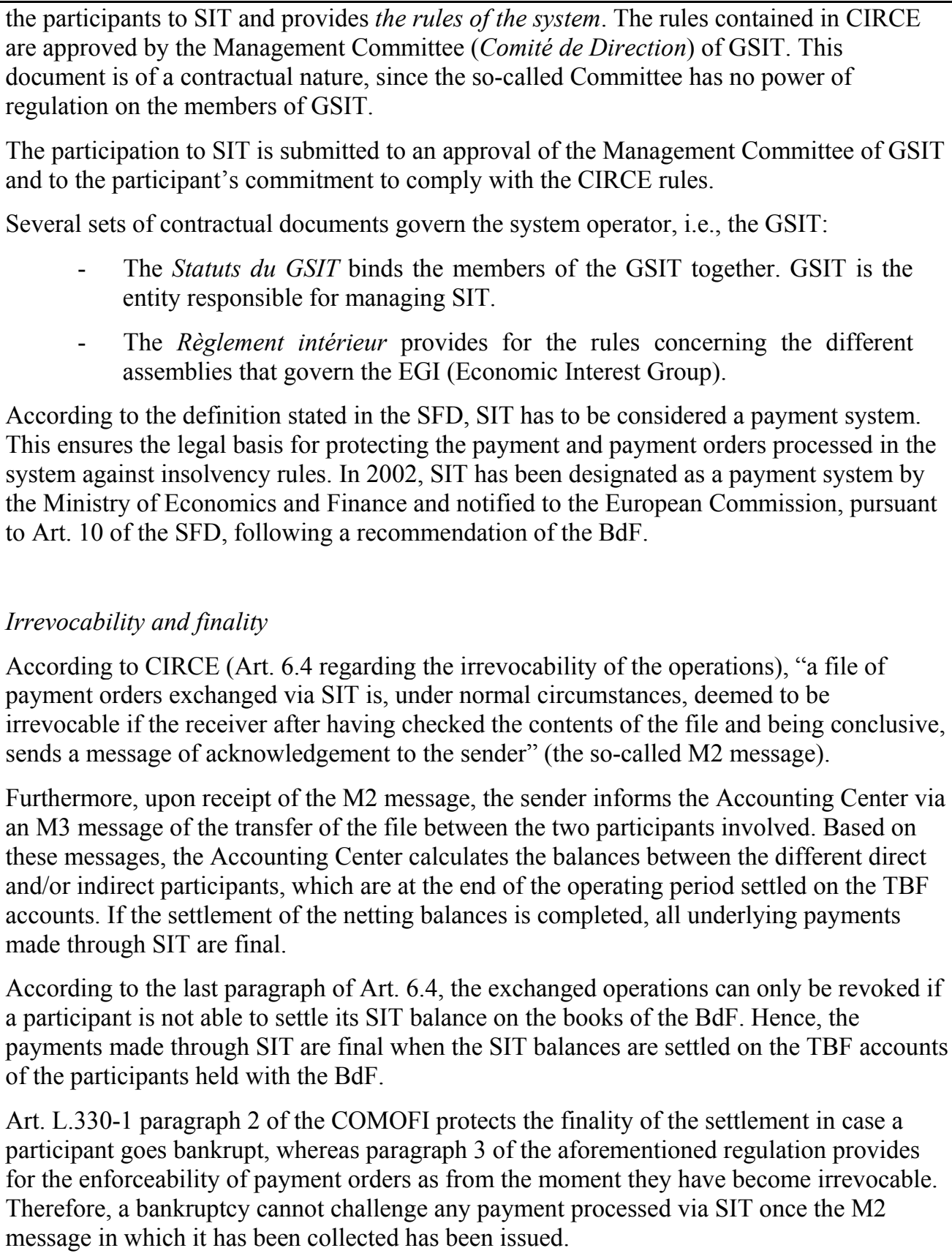 \\
\hline Assessment & Observed \\
\hline Comments & $\begin{array}{l}\text { The operations of SIT are embedded into a solid legal framework. The documentation and } \\
\text { the rules with regard to the revocability and conditionality of payments are described in a } \\
\text { clear and comprehensive way in CIRCE. }\end{array}$ \\
\hline Principle 2. & $\begin{array}{l}\text { The system's rules and procedures should enable participants to have a clear under- } \\
\text { standing of the system's impact on each of the financial risks they incur through } \\
\text { participation in it. }\end{array}$ \\
\hline
\end{tabular}




\begin{tabular}{|c|c|}
\hline Description & 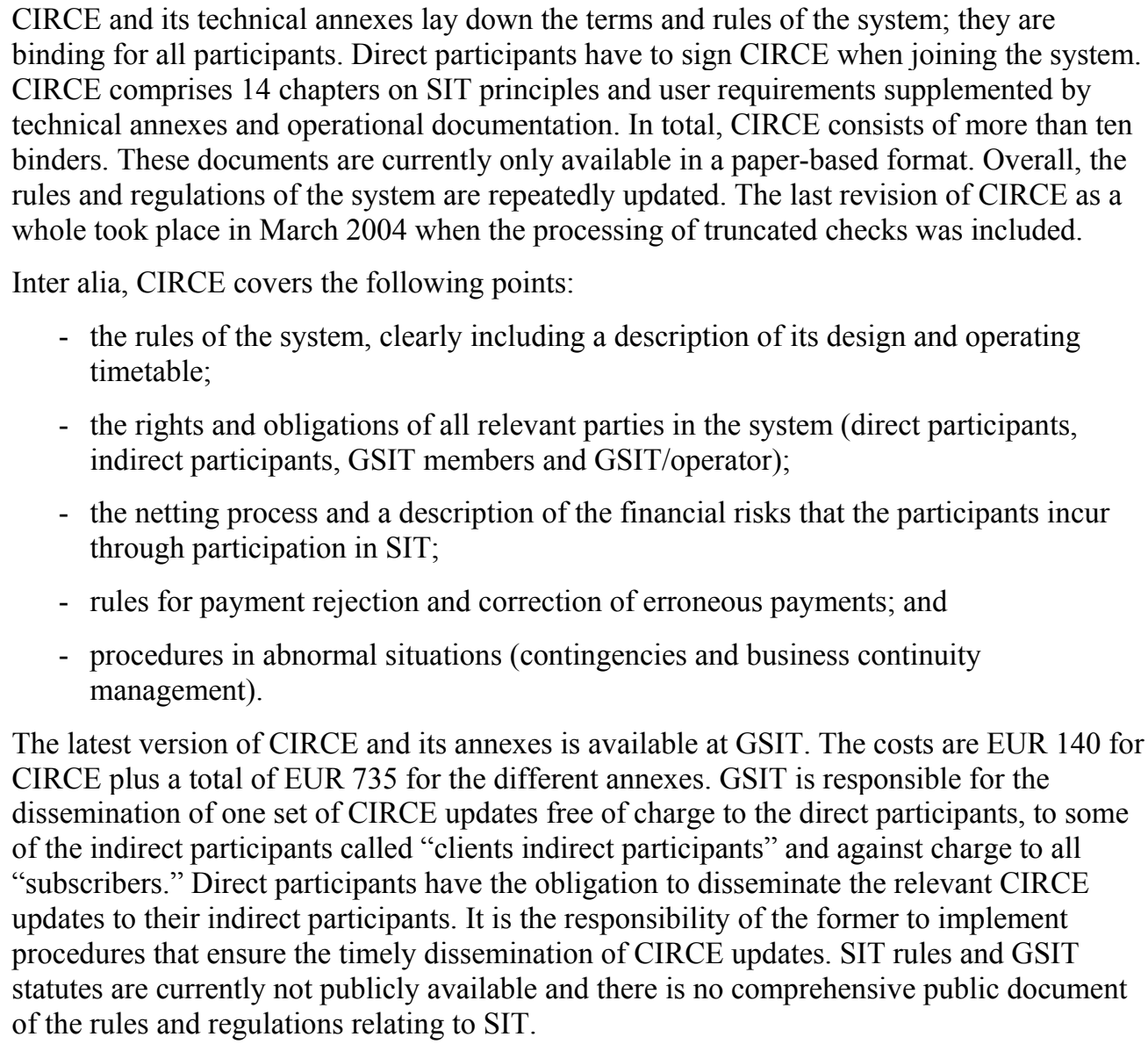 \\
\hline Assessment & Observed \\
\hline Comments & $\begin{array}{l}\text { CIRCE and its annexes enable the participants to understand the risks they bear from their } \\
\text { participation in SIT. The documentation is updated regularly at appropriate intervals. } \\
\text { Recommendation: } \\
\text { The current process for the dissemination of the rules of the system ensures that their latest } \\
\text { version is readily available to direct participants. It is, however, unclear whether the indirect } \\
\text { participants have wide access to the latest version of CIRCE. GSIT might find it appropriate } \\
\text { to investigate whether the documentation could be made available in digital versions and } \\
\text { distributed more directly through electronic channels. }\end{array}$ \\
\hline Principle 3. & $\begin{array}{l}\text { The system should have clearly defined procedures for the management of credit risks } \\
\text { and liquidity risks, which specify the respective responsibilities of the system operator } \\
\text { and the participants and which provide appropriate incentives to manage and contain } \\
\text { those risks. }\end{array}$ \\
\hline Description & $\begin{array}{l}\text { Credit Risk } \\
\text { Out of a total of some } 1000 \text { participants, } 14 \text { are direct participants in SIT. In order to avoid } \\
\text { concentration of risk on these few direct participants, a rule states that the value and volume } \\
\text { exchanged by a direct participant for its indirect participants have to remain below }\end{array}$ \\
\hline
\end{tabular}


30 percent of the total of the direct participant's own payments. The fulfillment of this criterion is, however, not systematically monitored by the operator of the system. The upper limit of a payment to be accepted at SIT is EUR 800,000. Direct participants are required to have an account in TBF. There are volume-based, but no financial access criteria (for instance, minimum capital) for direct participants (for more details see CP IX).

In the event of settlement failure, the balances are sent back to the system's operator, which recalculates participants' net balances after the defaulter's transactions have been removed. The new positions are then again submitted to TBF for settlement. This unwinding procedure eliminates credit risk with regard to the settlement vis-à-vis the defaulting direct participant. Non-defaulters bear the credit risk of having irrevocably paid their clients without having received the corresponding funds in TBF.

As in any multilateral netting system liquidity risk materializes in the event of the inability of a participant with a debit position to fund it when due, causing an unwinding which can adversely impact other participants, even if they have exchanged no payments with the defaulter. Currently, there is no safety mechanism in place to deal with the settlement failure of a direct participant.

GSIT provides a statistical report on the gross values processed and on the net balances before settlement in TBF. The netting ratio in SIT is close to 65 percent (sum of debit positions divided by sum of settled amounts). GSIT also releases quality indicators about the processing.

The system operator has no direct responsibility in credit risk management, but it provides the participants with near real-time information about their position in SIT. An alarm is triggered automatically should the payment orders sent by a bank differ significantly from a forecast provided to GSIT.

When the settlement of SIT positions is delayed, the TBF sends a message to GSIT indicating the reason for the delay. Standard routines are in place to address the various reasons for delay.

The direct participants have several monitoring tools at their disposition, for instance information on their positions and account statements (twice a day). To limit the risk of the inability of a participant to settle its debit position in TBF, the settlement in TBF is structured in two periods: a control period and a settlement period.

- Control period: Before submission for settlement in TBF, the calculated debit and credit positions in SIT are communicated to the participants. This "control period" allows them to check whether the calculation is accurate and, if necessary, to fund their debit position.

- Settlement period: At the end of the control period, the debit and credit positions are posted in TBF for settlement during a "settlement period." Several settlement mechanisms exist in TBF to facilitate the settlement of ancillary systems.

According to TBF rules, a participant can be suspended or excluded if its behavior jeopardizes TBF's security and efficiency. This statement includes multiple failures to settle a debit position in an ancillary system such as SIT. In addition, each participant at the origin of a default (even temporary) has to provide explanations to the BdF in its capacity of overseer of TBF. Furthermore, the latter can transmit the file to the Commission Bancaire (the French banking supervisor) for information. A fine of EUR 8,000 applies if a participant fails to settle the net obligation from an ancillary system such as SIT. According to the rules of SIT (CIRCE, chapter 14), a participant can be suspended or excluded from the system by the Management Committee in the event it does not honor its obligation with 


\begin{tabular}{|c|c|}
\hline & regard to the rules of the system and jeopardizes its smooth functioning. \\
\hline Assessment & Observed \\
\hline Comments & $\begin{array}{l}\text { SIT provides only limited tools to manage risk in the system. Since SIT is an ancillary } \\
\text { system in the retail area that settles in TBF, the extent of the liquidity risk also depends on } \\
\text { the functionality of TBF. }\end{array}$ \\
\hline Principle 4. & $\begin{array}{l}\text { The system should provide prompt final settlement on the day of value, preferably } \\
\text { during the day and at a minimum at the end of the day. }\end{array}$ \\
\hline Description & $\begin{array}{l}\text { The system rules and procedures regarding the clearing and settlement process are described } \\
\text { in CIRCE (chapter 5). The SIT network is open } 24 \text { hours a day, } 6 \text { days a week, with } 5 \\
\text { settlement days. The working day is structured in different exchange periods (périodes } \\
\text { d'échange) for the various types of operations and one technical period (période de } \\
\text { servitude) during which the system is not open to exchanges. The exchange period can be } \\
\text { defined as a period when certain types of payments have to be exchanged in order to be } \\
\text { settled on a given settlement day. The technical period can be defined as the period lasting } \\
\text { from the suspension of the sending of payment orders to the re-opening to exchanges. It is } \\
\text { used for the completion of technical tasks such as end-of-day procedures and data } \\
\text { warehousing. } \\
\text { In the SIT network, there are several cut-offs. These cut-offs indicate the end of the } \\
\text { exchange period for a given type of operations. Payment orders submitted after the cut-off } \\
\text { are settled on the following settlement day. } \\
\text { Currently, there are the following cut-offs: } \\
\text { - Cut-off } 1 \text { ( } 1: 30 \text { pm): credit transfers and card-based transactions for same-day } \\
\text { settlement; } \\
\quad \text { Cut-off } 2 \text { (6:00 pm): truncated checks, Interbank Payment Orders (TIP) and } \\
\text { truncated bills of exchange (Lettre de Change Relevé-LCR-) for next-day } \\
\text { settlement; } \\
\text { - Cut-off } 3 \text { ( } 7: 30 \text { pm): direct debits for next-day settlement; and } \\
\text { - Cut-off } 4 \text { ( } 9: 10 \text { pm or } 11: 10 \text { am on Saturday): nonaccounting transactions and } \\
\text { referenced credit transfers for next day settlement. } \\
\text { The closing of accounts (multilateral netting) occurs at 2:30 pm. Final settlement is } \\
\text { scheduled to take place in TBF between } 2: 45 \text { pm and 3:40pm on value day. } \\
\text { As already mentioned in Core Principle I, payment orders become irrevocable upon the } \\
\text { release of the confirmation message (M2) by the recipient. Usually, M2 messages are sent } \\
\text { just a few seconds after the payment instruction M1 is received. } \\
\text { Participants are required to reconcile their accounts with SIT twice a day. For this purpose, } \\
\text { they are supplied with statements of account issued by the network and with the results of } \\
\text { the account tracking carried out in the bank's processing center. }\end{array}$ \\
\hline Assessment & Observed \\
\hline Comments & $\begin{array}{l}\text { According to CP4, the promptness of final settlement on the day of value entails "ensuring } \\
\text { that the interval between the system's acceptance of a payment and the payment's final } \\
\text { settlement at least never lasts overnight and preferably is much shorter" (p.33). In a deferred } \\
\text { net settlement system like SIT acceptance by the system is defined by the moment when } \\
\text { netting takes place (p.32) and not by the point in time when a payment instruction becomes } \\
\text { irrevocable. Since netting in SIT occurs at } 2: 30 \text { pm and settlement takes place about }\end{array}$ \\
\hline
\end{tabular}




\begin{tabular}{|c|c|}
\hline & 15 minutes later, CP4 is observed. \\
\hline Principle 5. & $\begin{array}{l}\text { A system in which multilateral netting takes place should, at a minimum, be capable of } \\
\text { ensuring the timely completion of daily settlements in the event of an inability to settle } \\
\text { by the participant with the largest single settlement obligation. }\end{array}$ \\
\hline Description & $\begin{array}{l}\text { SIT processes transactions between participants in three stages: continuous exchange of } \\
\text { payment orders directly between banks' IT centers, multilateral netting of orders in an } \\
\text { accounting center, and forwarding of net positions for settlement in TBF. } \\
\text { All transactions related to a sender or receiver in SIT, i.e., all transactions of the direct } \\
\text { participants and its indirect participants, give rise to a balance discharged on the BdF } \\
\text { account of the direct participant. Each direct participant must also request from BdF the } \\
\text { opening of a CCR (compte courant de reglement) within the group of accounts in which it } \\
\text { also participates in TBF. } \\
\text { The C.R.I. and BdF have allocated to GSIT: } \\
\qquad \text { - } \\
\quad \text { the settlement of the daily balances; } \\
\quad \text { daily SIT balances or for the settlement of the balances in case of a } \\
\text { contingency situation. } \\
\text { There are no measures in place to ensure settlement in the case of a default of the participant } \\
\text { with the largest debit position. The only safeguard is an alarm that is triggered should a } \\
\text { participant's position differ from the expected level (see CP3). The multilateral netting in } \\
\text { SIT creates interdependencies among all of the participants in the system, since the failure } \\
\text { of a single participant with a net debit position prevents the settlement of the balances of all } \\
\text { participants, according to the TBF principle of "all or nothing," and consequently of all the } \\
\text { underlying transactions processed by the system. } \\
\text { At the request of the BdF, GSIT has developed ways to protect the system against the } \\
\text { pefault of its largest net debtor. Several task-forces were created by GSIT, bringing together } \\
\text { the different parties involved, i.e., the operator of the system, and representatives of the } \\
\text { fund-supplements, under the aegis of the French Banking Federation. The safety mechanism } \\
\text { transactions exchanged. Collateral would take the form of central bank money holdings. In } \\
\text { line with a grandfathering clause of the Eurosystem, this protection has to be implemented } \\
\text { no later than } 2008 \text {. }\end{array}$ \\
\hline Assessment & Not observed \\
\hline Comments & $\begin{array}{l}\text { The fact that SIT operates almost entirely without safeguards against the default of the } \\
\text { largest net debtor poses a substantial threat to the financial system. } \\
\text { Recommendation } \\
\text { The planned protection should be implemented as soon as possible, preferably before } 2008 \text {. } \\
\text { The present fall back on an unwinding in case of a failure to settle is, from a practical and } \\
\text { technical point of view, difficult to execute, since banks already have processed the received } \\
\text { files in their own systems. Thus, an unwinding is not just a recalculation of the balances by } \\
\text { the accounting centre, but involves also a very cumbersome and time-consuming operation } \\
\text { in the systems of the direct and indirect participants to identify and reverse the already }\end{array}$ \\
\hline
\end{tabular}




\begin{tabular}{|c|c|}
\hline & processed payments involved, if such a reversal is possible at all. \\
\hline Principle 6. & $\begin{array}{l}\text { Assets used for settlement should preferably be a claim on the central bank; where } \\
\text { other assets are used, they should carry little or no credit risk and little or no liquidity } \\
\text { risk. }\end{array}$ \\
\hline Description & $\begin{array}{l}\text { As described in Core Principles } 4 \text { and } 5 \text {, settlement takes place in the books of the BdF in } \\
\text { TBF. Since TBF settles in central bank money, the settlement asset does not carry any credit } \\
\text { risk. Also, balances held in TBF can be speedily moved to another system (PNS) or another } \\
\text { financial institution. }\end{array}$ \\
\hline Assessment & Observed \\
\hline Comments & \\
\hline Principle 7. & $\begin{array}{l}\text { The system should ensure a high degree of security and operational reliability and } \\
\text { should have contingency arrangements for timely completion of daily processing. }\end{array}$ \\
\hline Description & 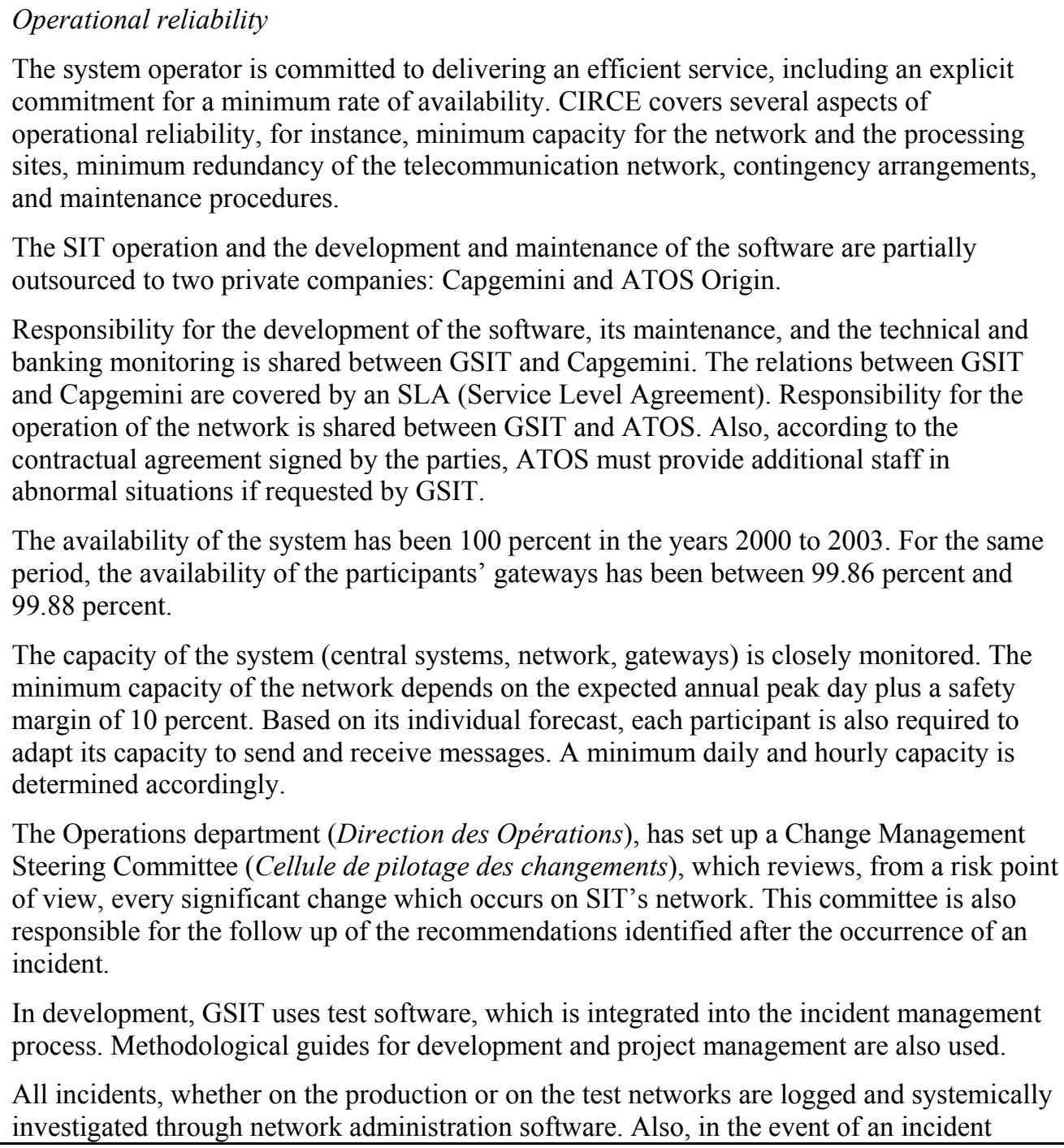 \\
\hline
\end{tabular}


impacting a workstation, three levels of intervention have been defined according to the gravity of the incident.

Security

The system operator has defined clear security policies. They are documented in the "Security Policy of SIT and GSIT" (Politique de sécurité du SIT et du GSIT). The policy is based on ISO 17799. The general objectives of the security policies are to protect the system physically and systemically against fraud, theft or sabotage of the hardware or the software. No assessment of the security controls of GSIT against the security policy has been performed so far. CIRCE (chapter 9) also contains, at a general level, the security policies and the operational service levels that should be met by both the system operator and the participants. Moreover the security policies are fully developed in the "SIT security correspondent handbook" (manuel du correspondant de sécurité).

The SIT network has several levels of security to protect its network. The primary network links together the participants' gateways, the Management Center and the Accounting Center. It also ensures the security of the messages between these different entities.

Connections are made over a TCP/IP Virtual Private Network, the security of which is twotiered:

- $\quad$ the telecom operator provides GSIT with a TCP/IP MPLS Virtual Private Network completely dedicated to SIT; and

- the authentication, confidentiality and integrity of the messages are provided by GSIT-operated IP encrypting equipment (their security and key management processes are under GSIT's sole responsibility.)

Nonrepudiation is not currently available for two main reasons:

- participants have not expressed a clear desire for nonrepudiation (although there have been talks about this issue); and

- $\quad$ the technical solution which was envisaged was not compatible with the high volumes exchanged in SIT.

The secondary network links the participants' gateways and their internal system. The primary responsibility for the security of this network remains with the participants, but GSIT issues strong recommendations with regard to the level of security which should be achieved (Art. 9.3.2 of CIRCE).

Audits

GSIT has set up an Audit, Security and Risk Management Department (Direction de la Gestion des risques, de l'Audit et de la sécurité - DGL/GR), in charge, for instance, of the internal audit and of the review of the risk management processes. The DGL/GR is also to identify potential risks that may arise and establish appropriate measures to mitigate them.

GSIT top management is also involved in the risk management process, through a monthly meeting of the "Security Committee" (CODIRSEC, Comité Directeur de la sécurité), chaired by the General Manager of GSIT. This committee deals with all relevant questions with regard to the security and the risks of GSIT: it approves the security policy and ensures that it is adequately implemented. The participants' security correspondents regularly meet to discuss issues related to the security of SIT's network. The follow-up of the implementation of the recommendations of DGL/GR is ensured by CODIRSEC.

In 2000, top management decided that an external "interbank" audit should be performed. This audit was carried out by the internal audit departments of SIT's main users. This audit focused on two issues: 
- the implementation of the recommendations of a former "interbank" audit carried out in 1995, following several operational incidents; and

- $\quad$ the review of SIT's objectives and strategy.

Overall, no major issues have been raised by the auditors. They acknowledged the improvements made since the previous "interbank" audit. The next audit of this kind is planned to take place in 2005.

\section{Business Continuity}

SIT's overall objective is to be able to resume operations within 48 hours according to a variety of plausible scenarios, including a wide area disaster. The business continuity objectives are based on a risk analysis, which was first carried out in 1993 and validated by top management in 1994. All business continuity arrangements have been formally endorsed by senior level management.

There are several levels of business continuity and contingency arrangements. Three critical components have been identified, each located in a different site: the Accounting Center, the Management Center and the Remote Control Center.

\section{Accounting Center}

The first level of continuity is the use of a high availability fault tolerant hardware. The last failure of this component occurred in 1999. The second level of continuity, in the event of a total failure of this component, is a cold backup. Depending on when the failure occurs it can take up to three days for the cold back up to become operational. The backup site is located more than 25 kilometers away from the primary site. The primary and the secondary site are alternatively used in production. The migration to the secondary site does not necessitate relocation of personnel, since the site is operated remotely from the Remote Control Center.

\section{Management Center}

In the event of a total failure of the Management Centre, a fall back on its backup site is possible within 10 minutes. The backup site is located more than 25 kilometers from the primary site. The primary and the secondary site are used alternatively in production. As above, no migration of human resources to the secondary site is necessary, since operations take place out of the Remote Control Center.

\section{Remote Control Center}

In the event of a total failure of the Remote Control Center, a fall back on its backup site is possible within 4 hours. Two backup sites are located more than 25 kilometers from the primary site. The backup site is regularly tested and used in production several times a year. Staff have to relocate from the primary to the secondary site.

Each SIT Center has redundant access to the primary network through multiple lines that are physically separate (no single point of failure). The lines are connected to at least two different France Telecom gateways nodes. The primary network linking the three critical GSIT components is also built in such a way that a total failure of a link between any two of the three sites does not isolate any of the sites. The SLA between GSIT and the telecom operator mentions that in the event of a failure of any of the lines, the connection should be restored within 4 hours. GSIT uses a single telecom provider.

A variety of business continuity procedures are tested regularly with the participants. Clear lines of responsibilities and decision making process exist to set up a crisis team in the event of a disaster. Procedures cover both internal and external communication. According to the gravity of the incident, an alert team, crisis team (with GSIT top management) or an enlarged crisis team (with the main participants in the system) is set up. Each participant in 


\begin{tabular}{|c|c|}
\hline & $\begin{array}{l}\text { the different teams has access to the crisis procedures, which are clearly documented. The } \\
\text { availability of the participants in the crisis teams is tested periodically. }\end{array}$ \\
\hline Assessment & Broadly observed \\
\hline Comments & $\begin{array}{l}\text { GSIT is paying careful attention to issues of operational reliability. Even though CP7 does } \\
\text { not explicitly require a hot secondary site, the current business continuity arrangements } \\
\text { appear to be insufficient with regard to the back up site. } \\
\text { Recommendation: } \\
\text { Measures should be put in place as soon as possible to be able to settle on the day of value in } \\
\text { case of a large operational disruption. } \\
\text { Recommendation: } \\
\text { The costs and benefits of more regular external audits, for instance every three years, should } \\
\text { be analyzed. }\end{array}$ \\
\hline Principle 8. & $\begin{array}{l}\text { The system should provide a means of making payments, which is practical for its } \\
\text { users and efficient for the economy. }\end{array}$ \\
\hline Description & $\begin{array}{l}\text { SIT is the sole retail payment system in France. In the past few years, it has achieved a high } \\
\text { degree of operational reliability. Its capacity was large enough to smoothly process an } \\
\text { increasing volume of transactions. } \\
\text { GSIT, pursuant to its statutes, is a nonprofit organization. Full-cost recovery is achieved. } \\
\text { The average processing fee is EUR } 0.0599 \text { per transaction. Additional fees that a participant } \\
\text { has to pay are most notably the annual membership fees which are EUR } 147,000 \text { for a direct } \\
\text { participant and EUR } 13,100 \text { for an indirect participant. The pricing policy and the fees are } \\
\text { formally endorsed by the Management Committee, which is composed of the majority of the } \\
\text { direct participants, a representative of the other direct participants, as well as two observers } \\
\text { (see CP10). } \\
\text { The "GSIT profile" provides an indication of the quality of the service delivered to the } \\
\text { participants. Indeed, GSIT periodically issues the "GSIT profile," which summarizes, } \\
\text { through a large series of indicators, the quality of the services it delivers. The indicators fall } \\
\text { under three different categories: } \\
\quad \text { - operational reliability ( } 31 \text { indicators showing, among others, the number of } \\
\quad \text { technical failures, the quality of management and the quality of the tests of } \\
\text { the disaster procedure); } \\
\text { - new projects ( } 8 \text { indicators showing, among others, how well GSIT controls } \\
\text { the costs of the projects and keeps the initial schedule); and } \\
\quad \text { - general and administration ( } 5 \text { indicators including, among others), how well } \\
\quad \text { GSIT controls the budget). } \\
\text { The latest profile available did not reveal any serious issue with regard to the quality of } \\
\text { services delivered. } \\
\text { GSIT communicates with its users through a wide range of decision making and } \\
\text { consultation bodies. There is also no evidence in the different user groups that SIT currently } \\
\text { does not fulfill the needs of the participants. }\end{array}$ \\
\hline Assessment & Observed \\
\hline
\end{tabular}




\begin{tabular}{|c|c|}
\hline Comments & $\begin{array}{l}\text { SIT provides a reliable service to its direct participants that appears to fit the needs of its } \\
\text { users. Cost recovery is achieved and the transaction fees are at an internationally } \\
\text { competitive level. }\end{array}$ \\
\hline Principle 9. & $\begin{array}{l}\text { The system should have objective and publicly disclosed criteria for participation, } \\
\text { which permit fair and open access. }\end{array}$ \\
\hline Description & 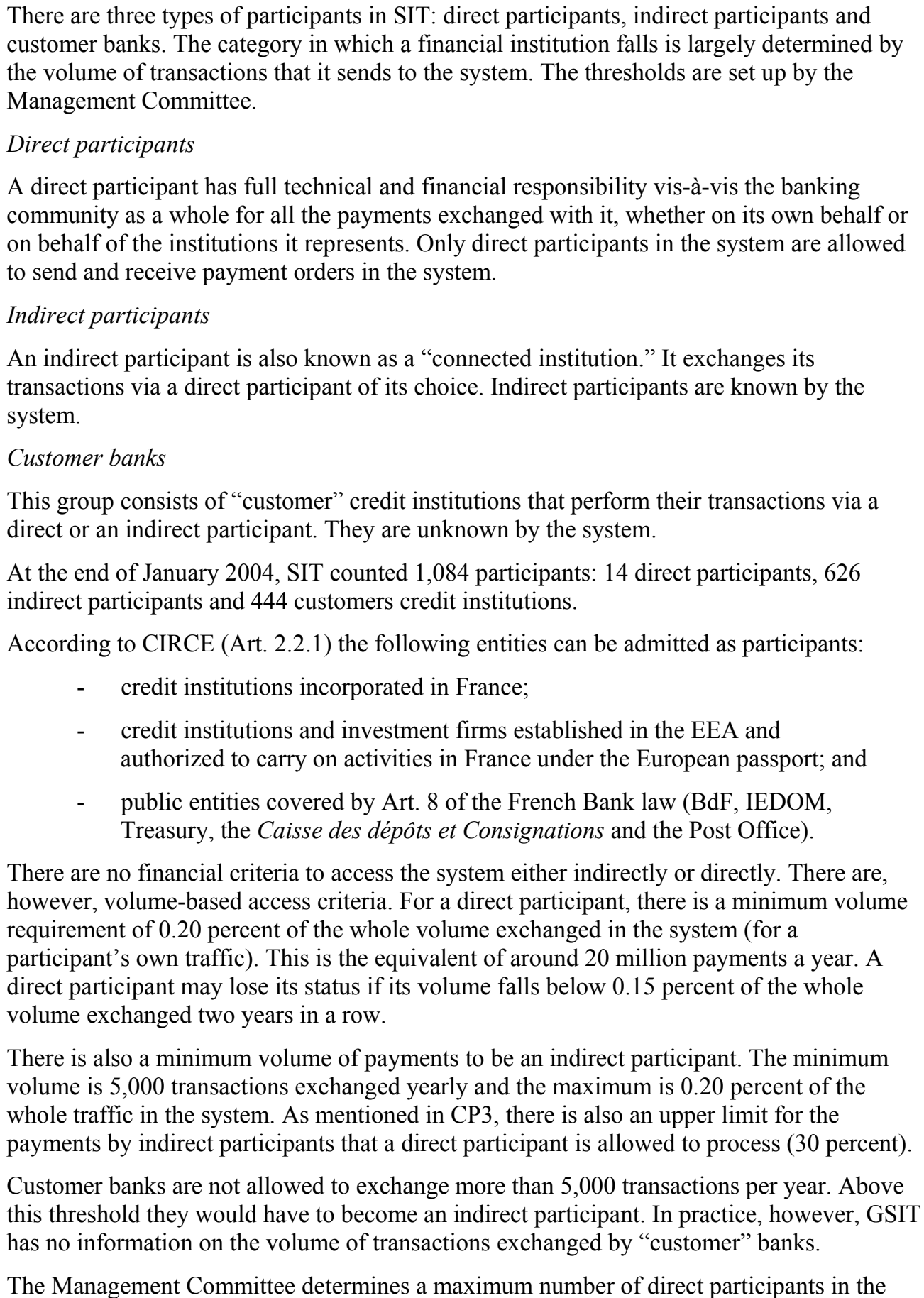 \\
\hline
\end{tabular}




\begin{tabular}{|c|c|}
\hline & $\begin{array}{l}\text { system. This maximum number is currently } 25 \text {, somewhat below the present technological } \\
\text { constraint of the number of the decentralized structure of the system. } \\
\text { The exit criteria and procedures are illustrated in CIRCE (Art. } 2.3 \text { ). They cover the } \\
\text { procedures for the resignation, exclusion, suspension, change of status of participants. A } \\
\text { banking failure of a participant is not covered by these procedures. }\end{array}$ \\
\hline Assessment & Broadly observed \\
\hline Comments & $\begin{array}{l}\text { The access criteria of SIT can be considered as quite restrictive (only } 14 \text { direct participants). } \\
\text { According to CP9 access restrictions are to be justified on the grounds of safety or } \\
\text { efficiency. Safety does not seem to be a sufficient reason here since the settlement values in } \\
\text { SIT are relatively low for a SIPS and intraday credit in TBF is abundant and inexpensive. If } \\
\text { safety concerns existed nonetheless, they could- in light of CP3-be addressed more } \\
\text { appropriately with financial soundness criteria rather than with the current volume based } \\
\text { criteria. Alternatively, the volume threshold could be lowered. This would increase the } \\
\text { competitive pressure from new entrants. In terms of efficiency, there appears to be a few } \\
\text { degrees of freedom since the system could cope with a few additional members without } \\
\text { jeopardizing the quality and reliability of the service. The "power of netting" also cannot } \\
\text { count as an efficiency argument, since the netting ratio is already fairly low. It should be } \\
\text { mentioned that the current access criteria are stated in way that would provide automatic } \\
\text { access to the direct membership should a bank account for more than } 0.2 \text { percent of the total } \\
\text { volume. It seems remarkable in this context that the group of direct participants overlaps to a } \\
\text { great extent with the group of owners of the system. } \\
\text { Recommendation: } \\
\text { The access criteria should be adjusted in a way to provide the option for a small number of } \\
\text { currently indirect participants to join the club of the direct participants. This goal could be } \\
\text { reached in several ways. For instance, the volume based access criteria could be lowered. In } \\
\text { light of CP3, access could also be broadened, through the introduction of explicit financial } \\
\text { soundness criteria. Of course, a combination of the two options would be possible as well. }\end{array}$ \\
\hline Principle 10. & $\begin{array}{l}\text { The system's governance arrangements should be effective, accountable and } \\
\text { transparent. }\end{array}$ \\
\hline Description & $\begin{array}{l}\text { Governance } \\
\text { All the rules regarding governance arrangements are embodied in a document called Statuts } \\
d u \text { GSIT (April 2003). In addition, another document called règlement intérieur specified the } \\
\text { conditions of application of the dispositions of Statuts } d u \text { GSIT, and in particular the rights } \\
\text { and obligations of GSIT members. } \\
\text { The system is owned and managed by GSIT, an economic interest group owned by } \\
12 \text { banks. } \\
\text { GSIT was created in } 1983 \text { with the objective if contributing to the economic activity of its } \\
\text { members through the design, development, management, operation and evolution of a SIT. } \\
\text { The statutes of GSIT provide for GSIT being constituted as a groupement d'intérêt } \\
\text { économique ((GIE) Economic Interest Group), which is a form of legal entity governed by } \\
\text { the French Commercial Code (FCC), dedicated to non profitable activities (it therefore is a } \\
\text { nonprofit organization), GIEs are nevertheless subject to insolvency law, since Art. L.620-2 } \\
\text { of the FCC submits all private law legal entities to insolvency law. GSIT has no capital but, } \\
\text { as an GIE, its members are liable for all debts incurred by GSIT. The Members of GSIT } \\
\text { being only credit institutions and investment firms, one can consider that the liabilities of }\end{array}$ \\
\hline
\end{tabular}


GSIT are warranted by a sufficient amount of assets. The balance sheet of an GIE is audited.

Currently, GSIT is composed of 229 member banks. These 229 members are represented by 12 founding members (the owners of GSIT), who participate in the decision and management structure of GSIT, the Management committee. No new members are accepted since new members would not have contributed to the initial funding of the system.

Articles 13 to 41 of GSIT's Statutes detail the structure, roles and responsibilities of the different entities involved in the decision making process and the control of the decisions taken.

The Management Committee (comité de direction) is composed of representatives of the signatories of the Articles of Association of GSIT, a representative of the other direct participants (nonsignatories of the Articles), a representative appointed as an observer by the French Association of Credit Institutions and Investment Firms (AFECEI-Association Française des Établissements de Crédit et des Entreprises d'Investissement) and a representative designated as an observer by the French Banking Association (Fédération Bancaire Française (FBF). Among others, the Management Committee defines GSIT strategy, elects the Chairman, elects the members of the Executive Committee and approves the budget.

The Executive Committee (le bureau) is composed of the Chairman of GSIT, a BdF representative $(\mathrm{BdF}$ is an ex officio member of the Executive Committee by virtue of its oversight responsibility), five representatives of the GSIT Management Committee elected within this body, and the General Manager of GSIT. It is mainly a consultative body providing assistance to the chairman and the General Manager. The Executive Committee and the Management Committee of GSIT meet every other month.

The General Meeting is composed of all the members of the GSIT. They have competence to approve the accounts of the past exercise, validate the budget, elect and revoke the General Manager, the account controller and the management controllers, admit new members and exclude current members, and modify the Statutes.

GSIT has also set up several specialized committees such as an Operating Committee, a Development Committee and an Administrative and Organization Commission.

\section{Transparency}

Information on the system and its operation is available to participants and to the public through several documents:

- GSIT's annual report is disclosed freely to all participants and is available on GSIT's website. This document encompasses the value and volume processed in the system, safety, reliability and quality of the system indicators, the evolutions of the system operation and management;

- GSIT's annual information document is publicly disclosed on its website. This handbook details the system operations as well as the changes and prospective;

- $\quad$ GSIT monthly reports are publicly disclosed on the GSIT website. It includes statistics on operations exchanged through the system (value, volume and peaks); and

- $\quad$ Monthly reports for direct participants: the GSIT disseminates to direct participants and governing bodies monthly reports on SIT's operations, covering essential statistics, the quality of service, safety and reliability, incidents, profiles of participants in the system, and the GSIT's administrative role.

The participants which are represented at the Executive Committee or at the Management 


\begin{tabular}{|l|l|}
\hline & Committee have access to all information available within these governing structures. \\
\hline Assessment & Observed \\
\hline Comments & $\begin{array}{l}\text { The governance structure is in line with the requirements of the Core Principles. At an } \\
\text { international level, the governance arrangements are by and large comparable with those of } \\
\text { other private sector systems. }\end{array}$ \\
\hline
\end{tabular}

Table 14. Summary Observance by SIT of the CPSS Core Principles

\begin{tabular}{|l|c|l|}
\hline \multirow{2}{*}{ Assessment Grade } & \multicolumn{2}{|c|}{ Principles Grouped by Assessment Grade } \\
\cline { 2 - 3 } & Count & \multicolumn{1}{|c|}{ List } \\
\hline Observed & 7 & Core Principles $1,2,3,4,6,8$ and 10. \\
\hline Broadly observed & 2 & Core Principle 7 and 9. \\
\hline Partly observed & 0 & -- \\
\hline Non-observed & 1 & Core principle 5. \\
\hline Not applicable & 0 & -- \\
\hline
\end{tabular}

\section{Recommended action plan for the SIT}

\section{Table 15. Recommended Actions to Improve Observance by SIT of the CPSS Core Principles}

\begin{tabular}{|l|l|}
\hline \multicolumn{1}{|c|}{ Reference Principle } & \multicolumn{1}{c|}{ Recommended Action } \\
\hline Legal foundation & None \\
\hline $\begin{array}{l}\text { Understanding and management of } \\
\text { risks }\end{array}$ & $\begin{array}{l}\text { - Investigate whether the documentation on SIT rules and procedures } \\
\text { could be made available in digital versions and distributed more } \\
\text { directly through electronic channels. }\end{array}$ \\
\hline Settlement & $\begin{array}{l}\text { - Implement adequate safeguards against the default of the largest net } \\
\text { debtor as soon as possible. }\end{array}$ \\
\hline $\begin{array}{l}\text { Security and operational reliability, } \\
\text { and contingency arrangements }\end{array}$ & $\begin{array}{l}\text { - Put in place as soon as possible adequate measures to ensure } \\
\text { settlement on the day of value in case of a large operational disruption; } \\
\text { and } \\
\text { - Consider whether to establish more regular external audits. }\end{array}$ \\
\hline $\begin{array}{l}\text { Efficiency and practicality of the } \\
\text { system }\end{array}$ & \begin{tabular}{l} 
None. \\
\hline Criteria for participation
\end{tabular} \\
\hline
\end{tabular}




\begin{tabular}{|c|l|}
\hline Reference Principle & Recommended Action \\
\hline Governance of the payment system & None. \\
\hline
\end{tabular}

\title{
Assessment central bank responsibilities in applying the CPs
}

\author{
Table 16. Detailed Assessment of the Responsibilities of BdF in Applying the Core \\ Principles
}

\section{Central Bank Responsibilities in applying the CPSIPS}

Responsibility A. The central bank should define clearly its payment system objectives and should disclose publicly its role and major policies with respect to systemically important payment systems.

\begin{tabular}{l|l} 
Description & Legal and institutional framework
\end{tabular}

The objectives, roles and major policies of the BdF with regards to payment systems are clearly defined and publicly disclosed, in particular through a sound legal and institutional framework.

The BdF operates within the context of the European System of Central Banks (ESCB). The ESCB framework with regards to payment systems is specified in Art. 105(2) of the Treaty establishing the European Community and in Art. 3 of the Statute of the ESCB and of the European Central Bank, which state that "the basic tasks to be carried out through the ESCB shall be $[. .$.$] to promote the smooth operation of payment systems." The ESCB has three$ different kinds of involvement in payment systems issues:

a. Operational involvement through the provision of payment services (TARGET);

b. The oversight function, recognized in the Treaty and in the Statute; and

c. A catalyst role in inducing changes in the field of payment systems through supportive actions aimed at facilitating private sector initiatives.

Art. 22 of the Statute of the European System of Central Banks and of the European Central Bank states that "the ECB and national central banks may provide facilities, and the ECB may make regulations, to ensure efficient and sound clearing and payment systems within the Community and with other countries."

At the domestic level, Art. L141-4 of the COMOFI states that "the BdF shall ensure the smooth operation and the security of payment systems, within the framework of the task of the ESCB relating to the promotion of the smooth operation of payment systems." The Governing Council of the ECB formulates the common policy stance, and in line with the principle of subsidiarity, in areas not specifically covered by the common policy, policies are defined directly by the BdF. The Governing Council determines in particular the objectives and core principles of a common Eurosystem policy in those cases where the functioning of payment systems may affect the implementation of monetary policy, financial stability, the establishment of a level-playing field between market participants and cross-border payments within the EU and with other countries.

Art. L.141-4 of the COMOFI is also the basis for the BdF's threefold role with regards to payment systems.

- $\quad$ The BdF is operationally involved in payment systems since it operates TBF, the 


\begin{tabular}{|c|c|}
\hline & 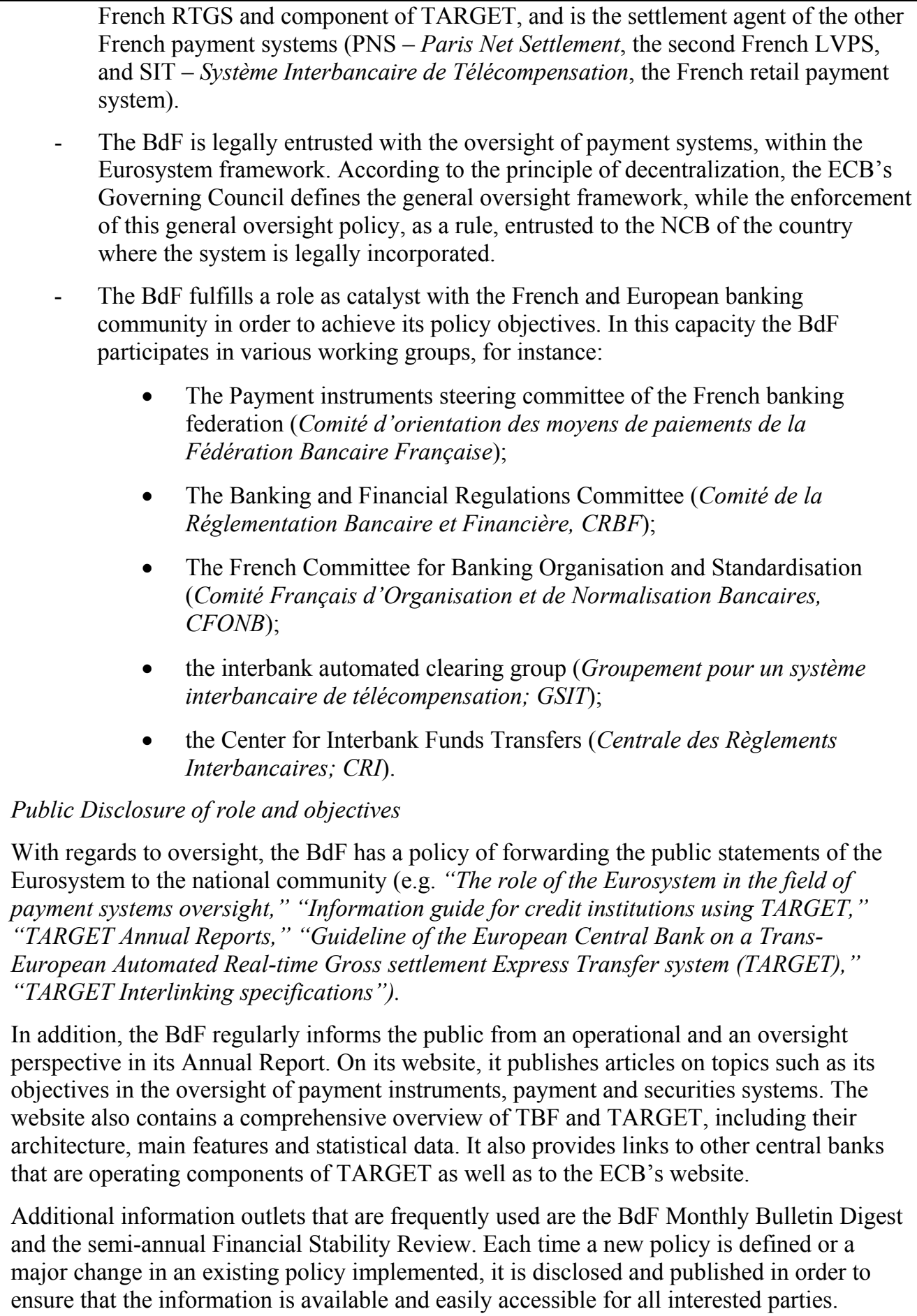 \\
\hline Assessment & Observed. \\
\hline Comments & $\begin{array}{l}\text { The BdF has a sound legal framework on which its oversight activities in the area of } \\
\text { systemically important payment systems are based. The BdF has close relationships with the } \\
\text { banking industry. It informs the public thoroughly about new developments and envisaged }\end{array}$ \\
\hline
\end{tabular}




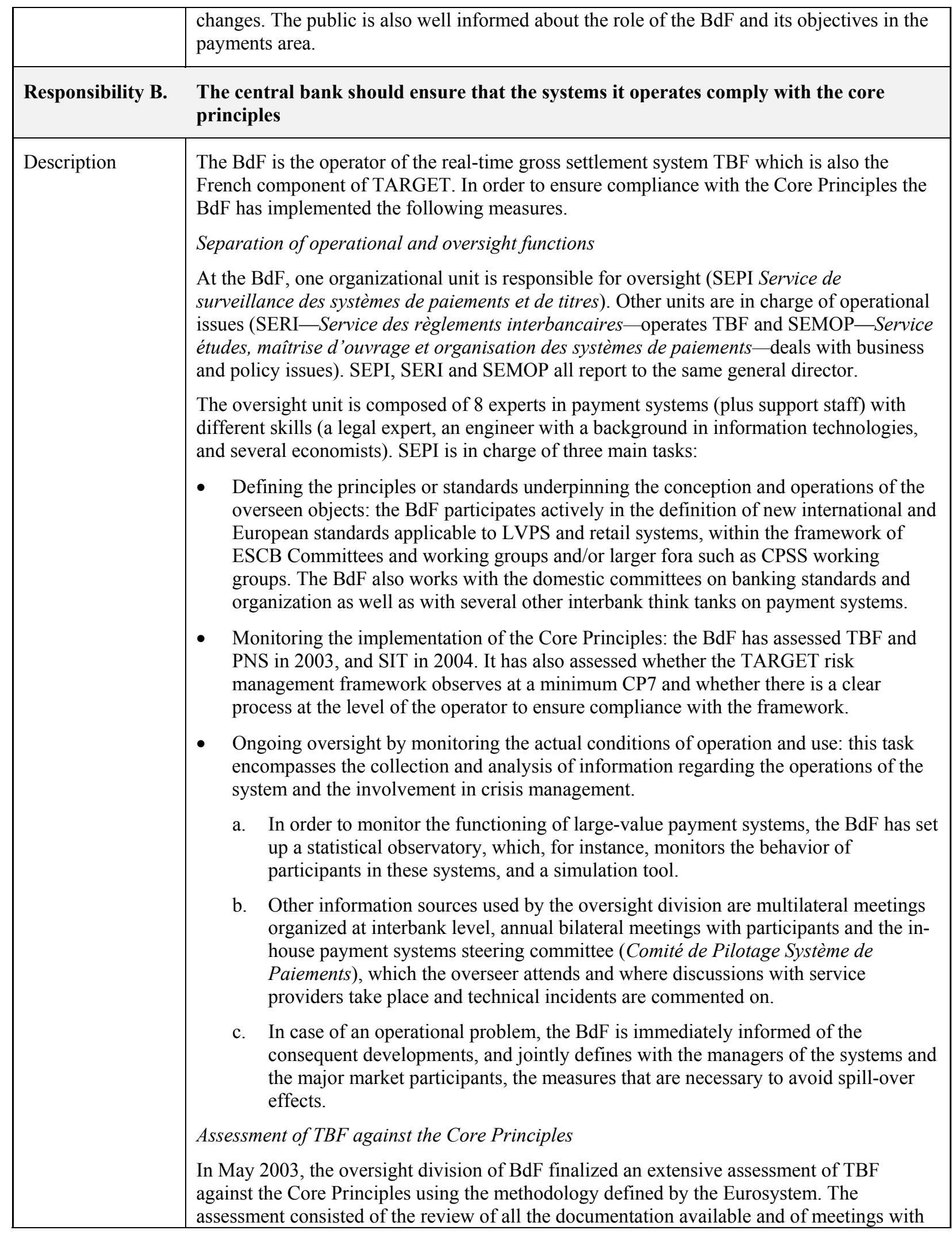




\begin{tabular}{|c|c|}
\hline & $\begin{array}{l}\text { the system operator. The self assessment is } 93 \text { pages long. } \\
\text { The assessment concluded in a full observance of CP1, CP6, CP9, and CP10, in a broad } \\
\text { observance of CP2, CP7 and CP8. The overseer expressed specific and detailed } \\
\text { recommendations in order to improve the level of compliance. The oversight division also } \\
\text { suggested improvements where the observance with the CP had already been achieved. } \\
\text { According to Eurosystem rules and procedures, the assessment of TBF will become final } \\
\text { once it is officially approved by the Governing Council of the ECB, who will also authorize } \\
\text { some form of publication of its results. In the meantime, the overseer has already informed } \\
\text { the system operator of its main findings, which have also been published in the BdF Annual } \\
\text { Report for } 2003 \text {. }\end{array}$ \\
\hline Assessment & Observed. \\
\hline Comments & $\begin{array}{l}\text { The organizational setup with the division between operations and oversight allows the BdF } \\
\text { to oversee TBF effectively. The assessment of TBF is thorough and complete. The skills of } \\
\text { the oversight team are appropriate. However, for some issues, such as operational reliability, } \\
\text { the cooperation with other internal and external entities (in particular auditors) could be } \\
\text { strengthened. }\end{array}$ \\
\hline Responsibility $\mathrm{C}$. & $\begin{array}{l}\text { The central bank should oversee observance with the core principles by the systems it } \\
\text { does not operate and it should have the ability to carry out this oversight }\end{array}$ \\
\hline Description & 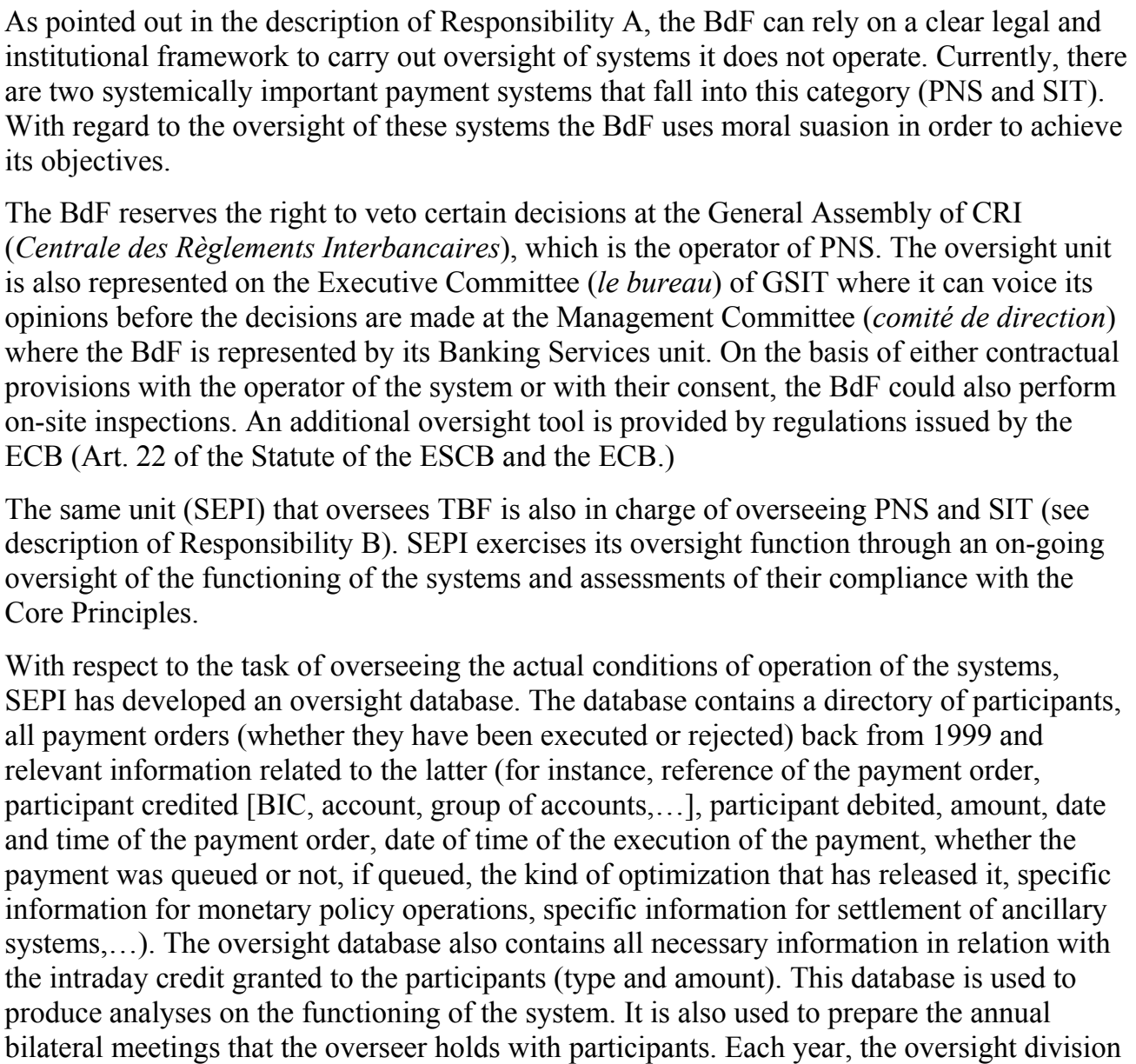 \\
\hline
\end{tabular}




\begin{tabular}{|c|c|}
\hline & $\begin{array}{l}\text { organizes bilateral meetings with the bigger participants of French payment systems and a } \\
\text { sample of smaller participants. Additional sources of information are the minutes of the } \\
\text { governing bodies of the systems (Assemblée Générale de la Centrale des Règlements } \\
\text { Interbancaires (AG CRI) for PNS and Executive Committee of the GSIT for the SIT), } \\
\text { where the BdF is represented, and other documentation collected by the oversight team such } \\
\text { as audit reports, financial reports, rules and procedures of the system. } \\
\text { In } 2003 \text {, SEPI finalized a } 58 \text { page assessment of PNS against the Core Principles. The } \\
\text { assessment was based on a review of all the documentation available and on meetings with } \\
\text { the system operator. The assessment concluded that there was full observance of CP1, } 3,4 \text {, } \\
5,6,7,8,9 \text {,and } 10 \text { and broad observance of CP } 2 \text {. The overseer expressed specific and detailed } \\
\text { recommendations in order to improve the compliance with the CP. The oversight division } \\
\text { also proposed improvement that had no implication for the observance of the CP in fields } \\
\text { covered by the CP1, } 3,7,8 \text { and } 9 \text {. } \\
\text { In spring } 2004, \mathrm{SEPI} \text { produced a first draft assessment of SIT against the Core Principles ( } 67 \\
\text { pages). The assessment found a full observance of CP1, } 2,5,6,8,9 \text {, and } 10 \text {, and broad } \\
\text { observance of CP3, and nonobservance of CP7. Currently, the BdF is waiting to receive } \\
\text { feedback on the draft assessment from GSIT, the operator of SIT. }\end{array}$ \\
\hline Assessment & Observed. \\
\hline Comments & $\begin{array}{l}\text { BdF is charged by law with the oversight of payment systems operated by the private sector } \\
\text { and fulfils this task in line with international standards. }\end{array}$ \\
\hline Responsibility D. & $\begin{array}{l}\text { The central bank, in promoting payment system safety and efficiency through the core } \\
\text { principles, should cooperate with other central banks and with any other relevant } \\
\text { domestic or foreign authorities. }\end{array}$ \\
\hline Description & $\begin{array}{l}\text { The BdF is in close cooperation particularly with the central banks of the Eurosystem. It has } \\
\text { signed several MoU with other authorities. } \\
\text { The cooperation between the BdF and central banks of the Eurosystem for payment systems } \\
\text { in Euro is governed (1) by the oversight framework adopted by the Governing Council in } \\
\text { June } 2000 \text { and (2) the specific decisions of the Governing Council with regards to TARGET. } \\
\text { At the level of the Eurosystem, the BdF has two representatives in the PSSC. The PSSC has } \\
\text { an advisory role to the Governing Council of the ECB on payment systems issues. In } \\
\text { particular, the mandate of the PSSC is to advise in important issues regarding TARGET and } \\
\text { cross-border use of collateral. In addition, the PSSC addresses policy and oversight issues } \\
\text { for payment and securities settlement systems. } \\
\text { The BdF is also represented in two working-groups of the PSSC: The PSPWG and the } \\
\text { TARGET management working group (TMWG). } \\
\text { At the level of the G10, the BdF is a member of the CPSS. The cooperation among G10 } \\
\text { central banks is laid out in the so called Lamfalussy Principles on cooperative oversight. The } \\
\text { BdF takes part in CPSS Subgroup on Foreign Exchange Settlement Risk, which is in charge } \\
\text { of the cooperative oversight of CLS. Currently, the BdF is also represented in the other } \\
\text { working groups of the CPSS. } \\
\text { The BdF has signed several MoUs with other supervisory authorities. In April 2001, the BdF } \\
\text { and the French Commission Bancaire signed an MoU of the Eurosystem between payment } \\
\text { systems overseers and banking supervisors, on specific arrangements for co-operation and }\end{array}$ \\
\hline
\end{tabular}




\begin{tabular}{|l|l|}
\hline \multirow{1}{*}{} & $\begin{array}{l}\text { information sharing in the area of large-value payment systems. } \\
\text { In addition, some provisions of the MoU of March } 2003 \text { on high-level principles of co- } \\
\text { operation between the banking supervisors and central banks of the European Union in crisis } \\
\text { management situations apply to payment infrastructures. This MoU aims to enhance the } \\
\text { practical arrangements for handling crises at the EU level, since smooth interaction between } \\
\text { supervisory and central banking functions will facilitate an early assessment of the systemic } \\
\text { scope of a crisis and contribute to effective crisis management. The MoU consists of a set of } \\
\text { principles and procedures for cross-border co-operation between banking supervisors and } \\
\text { central banks in crisis situations. These principles and procedures deal specifically with the } \\
\text { identification of the authorities responsible for crisis management, the required flows of } \\
\text { information between all the involved authorities and the practical conditions for sharing } \\
\text { information at the cross-border level. }\end{array}$ \\
\hline Assessment & $\begin{array}{l}\text { Observed. } \\
\text { Comments }\end{array}$ \\
\hline careful attention to matters of cooperative oversight.
\end{tabular}

Table 17. Summary Observance of the Central Bank Responsibilities in Applying the CPs

\begin{tabular}{|l|c|l|}
\hline \multirow{2}{*}{ Assessment Grade } & \multicolumn{2}{|c|}{ Principles Grouped by Assessment Grade } \\
\cline { 2 - 3 } Observed & Count & \multicolumn{1}{c|}{ List } \\
\hline Broadly observed & 4 & Responsibilities A, B, C and D. \\
\hline Partly observed & 0 & -- \\
\hline Non-observed & 0 & -- \\
\hline Not applicable & 0 & -- \\
\hline
\end{tabular}

\section{Recommended action plan on central bank responsibilities}

Table 18. Recommended Actions to Improve Observance of the Central Bank Responsibilities in Applying the CPs

\begin{tabular}{|l|l|}
\hline Reference Principle & \\
\hline Responsibility A & None. \\
\hline Responsibility B & $\begin{array}{l}\text { Strengthen the cooperation with other internal and external entities } \\
\text { (especially auditors). }\end{array}$ \\
\hline Responsibility C & None. \\
\hline Responsibility D & None. \\
\hline
\end{tabular}




\section{Authorities' response to the assessment}

66. The BdF takes note that the IMF largely endorses its own findings regarding both the overall situation of the French payment infrastructure and the assessments of TBF, PNS and SIT, performed against the Core Principles as well as BdF responsibilities.

67. The BdF would also like to mention that it has already taken several steps to urge payment systems to achieve full observance with the Core Principles, in the few remaining areas where some improvement is still needed. In particular, compliance of SIT with CP5 is planned to be achieved no later than 2008, in line with the policy stance endorsed by the Eurosystem.

\section{ImPlementation OF THE IOSCO ObJeCtives AND PRINCIPLES OF SECURITIES REGULATION}

\section{General}

68. This assessment addresses the securities regulatory framework in France. France modernized the legal structure for financial services by the Financial Security Act of August 1, 2003 (Loi $N^{\circ}$. 2003-706, de Sécurité financière or LSF). The new law simplifies and consolidates the law affecting financial market institutions, products and professionals. The compilation of the statutory provisions is known as the Code Monétaire et Financier (COMOFI). The revised regulatory framework can be described as a sophisticated, so-called, "twin peaks" model, which separates the performance of prudential and conduct of business regulation, although insurance providers are treated separately and not comprehensively integrated.

69. A twin peaks model was chosen to:

- Take account of the different cultures (and expertise) related to the supervision of banking and trading firms;

- Acknowledge the differences in techniques between prudential and conduct of business oversight and enforcement techniques;

- Provide separate lines of decision making that may reduce the potential for conflicts of interest in addressing particular regulated institutions; and

- Provide coverage of all relevant financial intermediaries, including for example managers of portfolios for third parties and financial analysts.

70. This model, as articulated in the LSF, is fairly complex, albeit simpler than the previous structure. The Autorité des Marchés Financiers (AMF) merges the COB, the Conseil des Marchés Financiers (CMF) and the Conseil de discipline de la gestion financière (CDGF). The AMF has broader powers with respect to collective investment vehicles, asset management, international information sharing and enforcement than is typical of twin peaks models. It also shares certain licensing powers with the prudential authorities. This new framework reflects the evolution of financial market regulation in France and in the 
European community. In particular, it reflects the devolution of market oversight from a shared supervisory activity between a professional body, the CMF, a successor to the Conseil des Marchés à Terme (CMT), and an independent administrative authority, the COB, effected in 1996 by the Financial Modernization Act (Loi MAF) (which also integrated cash and derivatives oversight) to today's new model, where these oversight powers are concentrated in the independent regulatory authority that is the AMF. The new French framework also maximizes the protections that implicate the process of imposing regulatory sanctions and setting regulatory standards, by creating an independent structure for imposing sanctions.

71. As a consequence of this complex structure, this assessment focuses on the remit of the AMF, while also taking account of the activities of several other institutions in so far as the competences of those institutions have responsibilities with respect to investment services providers, markets, clearing and settlement and thus can affect implementation of the IOSCO Objectives and Principles of Securities Regulation (Principles). It also must particularly assess the efficacy of the arrangements whereby such institutions interact and cooperate in the performance of their regulatory, supervisory and enforcement functions. In this regard, the discussion below and in Principle One describes in some detail the various institutional components of the regulatory structure.

72. This assessment is being performed by a securities expert designated to the IMF in accordance with an IOSCO Protocol for the designation of securities experts. Ms. Andrea Corcoran, Director of the Office of International Affairs of the US Commodity Futures Trading Commission and Chairman of the IOSCO Task Force on Implementation of the Principles, is conducting the assessment. It is understood that the conclusions in this assessment are provided in her personal capacity as an expert under contract to the IMF and not in her capacity as an employee of the US government or in her capacity as a representative of IOSCO. It is also understood that such assessments are intended generally to test the legal and regulatory framework - and the application in fact of that framework - to securities regulation against the standards set by IOSCO but that such assessments "....cannot be expected to provide assurance against a political or economic failure or the possibility that a sound regulatory framework can be circumvented." Understanding of the details behind this assessment will be enhanced by review of the working papers, in particular any answers provided to the IOSCO Assessment Methodology.

\section{Information and methodology used for assessment}

73. In making this Assessment, the following guidance with respect to application of the IOSCO Principles was used: the Principles themselves, the Methodology for Assessing Implementation of the IOSCO Objectives and Principles of Securities Regulation (Assessment Methodology), to the extent applicable, the Assessment methodology for "Recommendations for Securities Settlement Systems" (RSSS Assessment), the consultation draft of the CPSS/ IOSCO Recommendations for Central Counterparties released in March, 2004, IMF Guidance Notes and Templates, and, as relevant, the IOSCO reports referenced in the Assessment Methodology and the Principles. 
74. The assessment also is based on meetings with the MINEFI; interviews with senior staff of the AMF responsible for each of the functional areas addressed by the Principles and the Chairman and Secretary General; sessions with knowledgeable staff of the Commission Bancaire (CB), the Comité des Etablissements de Crédit et des Entreprises d'Investissement (CECEI), the BdF (with respect to their respective roles in the securities framework), and the Agence des participations de l'Etat (APE) (in connection with market structure); discussions with Euronext, NV (Paris operations) (regarding cash and derivatives markets), Euroclear (regarding payments and settlement), LCH-Clearnet, SA (regarding clearing); meetings with selected asset management and investment firms (and the related professional associations) representing different scales and complexity of financial services activity; selective review of the websites of the foregoing; annual reports; the COMOFI, existing regulations and published guidance, instructions, and recommendations; statistics on operations; systems for publishing information on issuers; the combined database composing the registry of licensing information; the regulatory and other official mechanisms for publication of regulatory actions; exchange operational oversight and regulatory surveillance systems; AMF responses to the IOSCO "high level" questionnaire and IMF questionnaires on Mutual Funds and Market Structure; the draft AMF responses to the Methodology; reference to the predecessor to the AMF, the COB, responses to detailed questionnaires used by IOSCO to explicate functional aspects of Member programs; information, charts and demonstrations of programmatic elements requested and delivered during the course of the on-site portion of the assessment; and multiple conference calls to address matters of detail. The assessment also reflects the sharing of views of the mission team at mission meetings in which participants briefed each other on findings in their particular areas of emphasis.

75. The AMF and the other institutions and entities and their representatives with securities competences were well-prepared, expert in their areas of focus, consistently helpful and the management of the assessment was well-organized while still sufficiently flexible to accommodate further exploration of particular nuances. The AMF provided a draft answer to the Assessment Methodology for Assessing the Implementation of the IOSCO Objectives and Principles of Securities Regulation. The IMF, however, did not require the AMF to submit its response using the Methodology. Responses to the Assessment Methodology, suggested by IOSCO, have benefited the development of this detailed report.

\section{Institutional and macroprudential setting, market structure}

\section{Structure of the securities industry in France}

76. Capital markets in France are large and sophisticated, with a range of equity, debt, derivative, and mutual fund products available to investors. As a percentage of household savings in France, investments in securities and mutual funds ${ }^{20}$ comprise roughly 7.9 percent

\footnotetext{
${ }^{20}$ Negotiable debt securities, bonds, shares and equity, mutual funds shares, claims on insurance companies.
} 
of disposable income (savings/disposable income of 16.7 percent in 2002), with life insurance products and savings accounts ${ }^{21}$ comprising 6.4 and 2.7 percent respectively.

77. Mutual funds of various types, including the so-called UCITS, are an important investment vehicle in France. Among industrialized countries, only the U.S. had a larger mutual fund asset to GDP ratio (68 percent) than France (64 percent) in 2003. A large proportion of the mutual fund products held by investors are created and sold for the account of life insurance firms. The reason for this is that there are substantial tax benefits to households holding life insurance saving products, including those in the form of mutual funds.

78. The financial sector as a whole is dominated by universal banks - in large part by the six major domestic banks. There are 90 licensed investment/broker firms, 346 commercial banks (1011 credit institutions) and roughly 500 asset management firms. The largest domestic broker/dealers (i.e., investment firms) are part of the same six largest financial institutions. Also, an important portion of assets under management in France (41.5 percent) is managed by the big six banks' asset management companies ${ }^{22}$.

\section{Equity and risk shifting markets}

79. France's only stock exchange, Euronext Paris, which is a subsidiary of Euronext, $\mathrm{NV}$, operates a fully electronic equity exchange. In terms of stock market capitalization, France ranked fourth in the world after the U.S., U.K., and Japan in 2003 (Table 19).

Table 19. Stock Market Capitalization

\begin{tabular}{lrrrrr}
\hline & U.K. & U.S. & Japan & France & Germany \\
\hline In percent of GDP & 146 & 110 & 74 & 73 & 40 \\
In US\$ billions & 2,041 & 10,904 & 1,782 & 968 & 620 \\
\hline
\end{tabular}

80. Euronext Paris was formed as a result of the partial consolidation of European stock markets that took place in 2000. The stock exchanges in Paris, Amsterdam, Brussels and, later on, Lisbon (and Porto) joined forces under the umbrella holding company Euronext NV, a demutualized, public company based in the Netherlands, whose shares are listed on the Premier Marché of Euronext Paris. The shareholders of these European bourses received

\footnotetext{
${ }^{21}$ Currency and deposits (banknotes and coins, transferable deposits, contractual savings, ...)

${ }^{22}$ The top ten asset management companies are: CDC-Ixis AM, Crédit Agricole AM, AXA IM, SGAM, BNP Paribas AM, Crédit Lyonnais AM, AGF AM assurance, Natexis AM Banque Populaire Group, Groupama AM (assurance), AVIVA (assurance). The asset management functions of Crédit Agricole and Crédit Lyonnais will be merged on
} July 1, 2004. 
shares in the new company in exchange for their original holdings. For regulatory oversight and other legal reasons, Euronext NV consists of a set of subsidiaries in each participating country, with each subsidiary holding the local stock market license. The subsidiaries then offer issuers, intermediaries and investors in each country local portals to what is now a unified trading structure. This means that there exists a single quote and a common crossborder order book for the listed securities emanating from each jurisdiction, creating a broader liquidity pool and greater transparency than would have been available before the consolidation. Moreover, there also is a single clearing system, LCH-Clearnet, SA, and a single settlement system, Euroclear France, for all equity securities traded on Euronext markets. ${ }^{23}$ However, as noted above, the local markets are not merged, and hence they continue to be regulated by their respective local authorities. For Euronext Paris, this means that it is overseen by the AMF. The cross-jurisdictional nature of Euronext Paris, LCHClearnet SA, and Euroclear France has lead to the implementation by the French authorities of innovative cooperative cross-border arrangements with the authorities in the other jurisdictions in which these firms are active.

81. The internal market structure of Euronext Paris remains as it was for the Bourse de Paris, with three segments: the Premier Marché, the Second Marché, and the Nouveau Marché. Euronext also offers companies the option to trade its overlapping NextPrime and NextEconomy market segments, which encompass stock listed in four Euronext stock markets. The Marché Libre is an unregulated market in which 258 issues are traded.

82. The total transaction value in equities (per the Electronic order book, counted on one side) was EUR 877.7 billion in 2003, with an average daily turnover of EUR 3,442 million. In 2003, the number of trades was 101 million with an average daily turnover of $396,288,{ }^{24}$ and the five most actively traded shares accounted for 30 percent of turnover. In 2002, the nine most actively traded shares accounted for 30 percent of the total number of trades. According to BdF statistics, equities are primarily traded by institutions and foreign investors.

83. The exchange traded futures and options markets in Paris (MATIF and MONEP respectively) are now also part of Euronext. The Paris derivatives markets have been integrated into the Euronext-liffe trading structure, thus taking advantage of the added liquidity and transparency offered by the common cross-jurisdictional platform. As is the case with the stock exchange, activity in the various derivative instruments that are traded in the Paris segment of Euronext-liffe are regulated by the French authorities. The CAC 40 is the most active contract; most financial futures are traded through the London portal.

${ }^{23}$ Overall, European equity markets remain relatively fragmented compared to the U.S. and Japanese markets. There remain a large number of separate markets in Europe, with differing systems to settle cross-border trades. This increases overall settlement costs.

${ }^{24}$ These figures include all domestic and foreign shares traded on Euronext Paris. 


\section{Bond markets}

84. The current structure of the government bond market includes long-term debt instruments ( 7 to 30 year initial maturities; OATs, OATis, OAT€is, and TEC10 OATs), medium term debt instruments ( 2 and 5 year initial maturities; BTANs) and short-term debt instruments (1 year or less; BTFs). OATs comprise of 65 percent of the marketable government debt outstanding, BTANs 20 percent, and BTFs the remainder. Inflation-linked OAT issuances have grown, particularly with the recent introduction of European inflationlinked bonds (OAT€is) in 2001. Inflation-linked bonds now comprise about 10 percent (Euro 44.5 billion) of the outstanding stock of OATs (or 8 percent of total outstanding government debt instruments). The introduction of large, liquid 10 and 30-year bonds linked to European inflation is said by investment banks to have helped trigger the issuance of other (nonsovereign) inflation-linked (IL) debt instruments (mainly, IL medium term notes) by European institutions as well as the creation of an inflation-linked swaps market. ${ }^{25}$ The main investors are insurance companies, international pension funds, asset managers and alternative traders. These IL debt instruments provide a natural hedge against their inflationlinked obligations.

85. The nonfinancial corporate bond market in France has grown substantially with the introduction of the Euro. At the end of 1998, the corporate bond market comprised 12 percent of outstanding French bonds, while it now stands at 22 percent. Most of this (20 percent) is issued by credit institutions. By comparison, however, this market share is still below that in the U.S., where corporate bonds represent roughly 40 percent of outstanding bonds.

86. Inter-dealer trading for the French government bond market, and to a lesser extent the nongovernment bond market, has almost completely migrated to the MTS electronic trading platform. By significantly improving the market liquidity conditions faced by dealers, the MTS systems generated a significant reduction in trading cost. Although the dealers (banks and investment firms) who trade on the system gain directly from the improved liquidity, the whole of the sovereign bond market also realizes reduced trading costs as competitive forces cause the intermediaries to pass on some of the savings in more transparent and liquid bond trading to their clients, mainly institutional investors.

87. There is also Powernext, a commercial energy exchange owned by Euronext in which nonintermediated trading occurs.

\footnotetext{
${ }^{25}$ In an inflation-linked swap one party (periodically) pays a fixed rate on a notional amount and the other receives the inflation rate, typically the European inflation rate (known as HICP ex. tobacco).
} 


\section{Description of regulatory structure and practices}

88. The AMF is an independent public authority with legal personality and 'taxing' authority, comprised of a 16-member Board ${ }^{26}$ (College), chaired by a full time Chairman and a separate 12-member Commission des Sanctions, and 5 consultative commissions, each with its own Chairman and Vice Chairman as follows: (1) Organisation et fonctionnement du marché, in regard to transposition and implementation of the new investment services directive and market abuse directive; (2) Activités de compensation, de conservation et de règlement-livraison, in regard to international work on clearing and settlement; (3) Activités de gestion individuelle et collective, in regard to application of European guidance, creation of new management techniques and rules of good conduct for managers of individual and collective investments; (4) Opérations et information financière des émetteurs, application of the new transparency and prospectus directives; and (5) Epargnants et actionnaires minoritaires, with regard to minority shareholders and savings.

89. As such, in describing the advent of the AMF, the French press characterized the new institution as enjoying a sui generis legal status.

90. The AMF licenses and prudentially supervises operators of publicly offered collective investment schemes, and portfolio (asset) managers for third parties; regulates the public offer and reporting of financial information with respect to issues, and marketing generally, and also the flow of information relative to takeover bids. The AMF also has responsibility for custodians for securities and assets of collective investment schemes, and for clearing and settlement systems and related custodians, without prejudice to the functions of the BdF and its specific role with respect to payments. The AMF has broad sanctioning powers which must be exercised through its separately constituted Commission des Sanctions.

91. Proceedings before this panel can be commenced against any person, whether or not that person is a regulated person. The Secretary General of the AMF opens investigations, which remain under his authority until referred to the rapporteur designated by the Commission des Sanctions. Cases may be referred to the Commission des Sanctions by the AMF board, based on a report of an investigation undertaken by the Secretary General.

92. They can also be referred by the AMF board, upon review of a file submitted by the Governor of the BdF, or the Chairman of either of the CB or the CCAMIP (L.621-15).

93. Licensing (except for insurance companies engaging in insurance activities) is committed to the CECEI (in consultation with the AMF in the case of credit institutions and investment services providers engaged in investment services, pure custodians and clearing members, and with approval of the program of operation if authorization for asset

26 The Board Members, like members of a typical business board, may engage in other professional activities in addition to their service on the College. 
management activities is sought by such firms). Prudential oversight, including oversight over members of markets, clearing organizations and custodians, but not including insurance companies acting in the capacity of insurance companies, is committed to the $\mathrm{CB}$. The $\mathrm{BdF}$ commits staff to the licensing and prudential supervisors, and provides leadership through its Governor's participation as Chair of both the CB and the CECEI (L.613-3; 612-3). The BdF also has competence over payment system functions, and as a consequence certain aspects of securities settlement.

94. Coordination with the prudential authorities and the AMF is organized, in the case of day-to-day operations, through inter-staff contacts, information sharing, certain combined databases, and regular monthly meetings. In the case of general policy and matters of particular cross-market or common interest, such coordination is accomplished through an inter-institutional, statutorily-prescribed board composed of the heads of the financial services agencies (the Collège des autorités de contrôle des entreprises du secteur financier, henceforth the College (L.631-2), which must meet at least three times a year, and is presided over by the Minister of Finance or his representative. Cross membership of the regulatory/supervisory authorities also fosters cooperation, for example, through the statutory participation of the AMF Chair as a participant on the Board of the CECEI (L.612-3), and participation of the governor of the BdF on the AMF Board.

95. In the case of regulated markets and related clearing arrangements, the AMF may delegate (license specified individuals to perform) certain investigative activities and compliance activities as to their members, including with respect to the transmission of orders by financial services providers (L.621-9-2), in accordance with procedures specified by regulation and subject to conditions of exercise defined by decree of the Conseil d'Etat (the highest administrative court) (Art. 11, 12 and 13 of the Decree).

96. In general, the exchanges and clearing and settlement organizations control/monitor their operations through rules adopted subject to review of the competent authority and those rules (and any powers or actions with respect to their infringement) are regarded as founded in contract and not in public law.

97. Protocols exist among the national regulators and markets within the Euronext, NV group, and the related clearing and settlement institutions in the various jurisdictions which comprise Euronext, Euroclear and Clearnet, that determine how those institutions are operated and supervised. In this respect, Euronext France; LCH-Clearnet, Ltd., the Britishbased holding company for the clearing organization; and LCH-Clearnet, SA are credit institutions with consequent implications for how supervision and regulation of these entities is organized - that is, the $\mathrm{CB}$ and the $\mathrm{BdF}$ as well as the AMF have specific responsibilities.

98. The law applicable to securities is largely contained in the COMOFI and in the precursor instructions, recommendations, and regulations that are in the process of being revised in a to-be-proposed Règlement Général of the AMF. The Règlement Général, when complete, will consolidate, streamline and update previous guidance and fully enforceable regulations of the $\mathrm{COB}$ and $\mathrm{CMF}$, respectively, as well as bring the French regulatory 
framework, which currently implements existing directives, fully into line with new European directives.

99. Pending the conclusion of this project, the rules of the CMF and the COB remain in full force and effect. Applicable law is also found in certain related legislation, such as company law, bankruptcy law, commercial law, property law, penal law, and administrative codes or human rights doctrines that apply to the substance or application of securities laws within France. Indeed, many fundamental protections are referred to as dating from 1789. As part of the EU, France also recognizes credit institutions and investment firms, including market undertakings, that passport into France from other European Economic Area jurisdictions in which they are authorized either by exercising a right of establishment or a right to provide cross border services. France does not automatically recognize remote clearing members, although this conservative approach is not uniformly followed throughout Europe.

100. French financial law also mandates two specific and different forms of consultation, which inform governmental decision-making: (1) the Comité Consultatif du Secteur Financier (CCSF) (composed of representatives of financial professionals representing each of the sectors including insurance agents and their clients) concerning relations between the financial sector and its clients and (2) the Comité Consultatif de la Législation et de la Règlementation Financières (CCLRF) (L.614-1-2), yet to be formed at the time of writing, (concerning all legislation and rules except for those within sole competence of the AMF (L.621-7V), prior to approval by the Ministry). Membership for these bodies is required for each financial services provider. Each investment services provider and market also must adhere to an association of its choice charged with representing the collective rights and interests of members (L.531-8). This organization will be affiliated with the Association Française des Etablissements de Crédit et des Enterprises d'Investissement (L.511-29), which is the related association for credit institutions.

\section{General preconditions for effective securities regulation}

101. In general, the preconditions for an effective regulatory framework for capital markets and the provision of financial services assume the existence of a legal framework that supports the integrity of contract and property rights, a legal structure that recognizes the instruments traded in the market and the rules that facilitate their trading, a commercial and insolvency regime that facilitates the taking of collateral, the use of clearing services, and the enforcement of guarantees, sound company law that protects direct investors, laws which support the ability to identify and protect client assets, reliable and consistent accounting standards, and the confidence of the marketplace that the rules will be consistently and equitably enforced and that the rules of the marketplace can be applied notwithstanding the bankruptcy of particular market participants. These assumptions are further premised on the assumption that the judicial, administrative, and regulatory authorities will reliably honor and equitably apply the rule of law. Certainty as to the application of the law, and confidence in its equity, is fundamental to the reliable functioning of markets and market confidence. There is no evidence that these preconditions are not met in France. Also of particular importance is 
the ability of the regulatory system to respond to new issues, such as those raised by the problems of sell-side analysts.

102. As for the openness of its markets, the market regulators in France historically have been open to cross-border arrangements within the EU—and beyond - and they have been creative in addressing these arrangements, putting in place the regulatory and legal supports necessary for their functioning. The French authorities also are interested in increasing the ability of national jurisdictions in Europe to address events and to implement the new European directives that are pending in a timely way. In particular they indicated support for maximizing the use of the Lamfalussy process, which would more perfectly harmonize the national approaches among various jurisdictions within the single European market, specifically by broader use of the mechanisms for regulatory development and consultation of the Committee of European Securities Regulators (CESR). ${ }^{27}$

103. Based on anecdotal interview evidence, there is some indication that the fiscal treatment of various instruments may (1) induce the market to favor insurance products that may not be the most value-based investment for the retail public or may (2) predispose high wealth individuals to offshore investment. In connection with the foregoing, it should be noted that IOSCO has not comprehensively treated the preconditions for effective regulation and effective securities markets other than by exposition of the Principles themselves. Many issues related to the functioning of markets, such as the stability of the governmental and legal system, and the macroeconomic situation, are beyond the remit of the IOSCO Principles and while applicable in all cases, are most relevant in less mature or sophisticated systems.

104. The twin peaks structure as applied in France is intended to permit that system to focus contemporaneously on high priority customer protection and prudential issues, such as finality of netting. ${ }^{28}$ At the same time, the ability of the system to respond to general and specific problems in the market depends on effective and consistent cooperation as necessary and appropriate among authorities with different functional competences on a day-to-day basis and in the event of a crisis. Although the new framework for securities regulation in France builds upon the preceding high quality structure and preceding interdependent relationships between sectoral authorities and is explicitly designed to meet international standards, the functionality of the framework should be tested after there has been some experience with the changes effectuated by the LSF.

105. Also, while the design of the regulatory framework is intended to take account of the different cultures of securities conduct of business and prudential regulation, to maximize

${ }^{27}$ There are now CESR-like arrangements for insurance and banking as well.

${ }^{28}$ This does not mean that such matters may not be well addressed by alternative regulatory structures. 
functional expertise and to avoid conflicts of interest related to protecting customers from misconduct and protecting institutions and markets from systemic risk, the design could valuably be kept under review to determine if further efficiencies and streamlining are possible and whether essential cooperation continues to occur.

106. Finally, the AMF, although continuing the tradition of its predecessors, just commenced operations November 24, 2003 and announced its new organizational structure, February 12, 2004. Further review of the tentative ratings in this document after some period of operations would more correctly reflect the implementation of changes currently in progress.

\section{Principle-by-principle assessment}

Table 20. Detailed Assessment of Observance of the IOSCO Objectives and Principles of Securities Regulation

\begin{tabular}{|c|c|}
\hline \multicolumn{2}{|r|}{ Principles Relating to the Regulator ${ }^{29}$} \\
\hline Principle 1. & The responsibilities of the regulator should be clear and objectively stated. \\
\hline \multirow[t]{2}{*}{ Description } & $\begin{array}{l}\text { The AMF is the successor agency to the COB, the Conseil des Marchés Financiers (CMF), } \\
\text { and the Conseil de Discipline de la Gestion Financière (CDGF), created by merger under the } \\
\text { LSF, dated August 1, 2003, as made effective November 24, 2003, and reflected in the } \\
\text { COMOFI and appurtenant Decrees (especially Decree } N^{\circ} 2003-1109 \text {, dated } \\
\text { November } 21,2003 \text { ). The responsibilities, powers and authority of the AMF are clearly and } \\
\text { objectively stated, primarily in Section 4, Book VI, Unique Chapter on the AMF, which in } \\
\text { modernizing securities regulatory institutions, builds on two traditions: one drawn from the } \\
\text { governmental overseer and the other drawn from the market. }\end{array}$ \\
\hline & $\begin{array}{l}\text { The AMF's remit reflects the three objectives of IOSCO: investor protection, fair, efficient } \\
\text { and transparent markets and reduction of systemic risk. The AMF oversees the protection of } \\
\text { funds invested in financial instruments and other investments offered to the public, the } \\
\text { disclosure of information to investors and the proper functioning of the markets. It also } \\
\text { participates in European and international forums and works with other sectoral regulators, } \\
\text { which are the primary supervisors of bank and insurance companies for their banking and } \\
\text { insurance activities and conduct prudential oversight of investment firms, markets and } \\
\text { clearing and settlement arrangements also subject to regulation by the AMF. (See description } \\
\text { of the regulatory scheme above, L.621; L.614-1-3; Chapter II, Book VI of the COMOFI). }\end{array}$ \\
\hline
\end{tabular}

${ }^{29}$ The assessor's comments for the first five principles, while the result of reviewing the regulatory system for securities overall, have focused on the AMF, with the $\mathrm{CB}$ and CECEI and $\mathrm{BdF}$ being more comprehensively treated in the Introduction from the perspective of the organizational structure of regulation and in each of the functional segments from the perspective of their specific functions. Nonetheless, the assessor sees no basis to change the ratings for the Regulator under the IOSCO Principles based on an analysis of those securities functions performed by the $\mathrm{CB}$ and the CECEI and by the BdF. 
More particularly, the AMF's responsibilities related to the offering of securities or issues (including the oversight of disclosures related to takeover bids); to the oversight of the conduct of business by investment services providers and their management and compliance employees responsable du contrôle des services d'investissement (RCSI) in the case of investment firms), including asset managers and publicly offered collective investment schemes; the sale or solicitation of securities; the organization and functioning of markets and the rules for execution thereon; the rules relating to the organization and functioning of clearing and settlement systems; any derogations from the concentration rule (i.e., L.421-12); the surveillance of investment services providers (including, among others, brokers, markets, asset managers, depositories and custodians, in connection with AMF competences), as to their professional obligations for example with respect to market abuses and insider trading, as specified in the law (L.621-9); enforcement and information sharing; and representation in international forums (L.621-1).

The AMF can exercise general regulatory authority to carry out its program subject to validation by the MoE. To be effective such regulation must be made public in the Journal offficiel de la République Française (JORF), and other regulatory information appears in the BALO (Bulletin des annonces légales obligatoires), such as approvals of the rules of regulated markets.

Therefore the AMF either has sole power and responsibility, or power combined with other authorities, to effectuate a framework of regulation covering each of the functional areas specified in the IOSCO Principles and related Assessment Methodology. Although certain requirements are applied differently to marketing by credit institutions and to other matters for insurance firms, there are no significant gaps or inequities, in the overall framework for securities regulation.

In this respect it should be noted as described with some particularity in the introduction, the CECEI, addresses licensing of intermediaries (L.612-1 to L.612-7); the CB, addresses prudential issues for investment services providers except asset managers (L.613-1 to L.61334 ; L.613-2), which delineates the scope of oversight; L.613-21 to 24, which relate to disciplinary powers; and L.613-31 regarding liquidations affecting securities of a supervised entity traded on a regulated market, and the role of each is also more particularly described in the discussion of intermediaries below (Principles 21-24). The BdF contributes staff to both the CECEI and the $\mathrm{CB}$ and has responsibilities with respect to the operation of payments systems (See (L.141-1 to L.141-9, and in particular L.141-4). The responsibilities of each of the regulatory authorities in respect of securities are clearly spelled out in the COMOFI.

See also the description in Principle 1(1) of the "Detailed Assessment of Compliance with the Basel Core Principles for Effective Banking Supervision" and the related segment on Transparency (henceforth, "Contemporaneous Basel Report").

The AMF can also issue instructions and recommendations that while not directly binding as a matter of law, can give more content and precision to existing regulation, and to the extent that they clarify or explain, in fact interpret legally binding guidance.

The AMF is in the process of consolidating the rulebook and rulings of the merged entities and expects to have this process completed in 18 months. This consolidation is expected to materially improve the accessibility of applicable law, decisions, and regulation. In the interim, the rules and guidance of the CMF and COB remain in effect and some rules and decisions with respect to investment services providers may be more accessible than others. For example, not all are published on the AMF's own website, the CIS rules are difficult to locate as these are complex and some have been archived, and only some are also available in English (see Principle 4).

The power of the AMF, or by delegation, its President, to apply the AMF regulations through 


\begin{tabular}{|c|c|}
\hline & 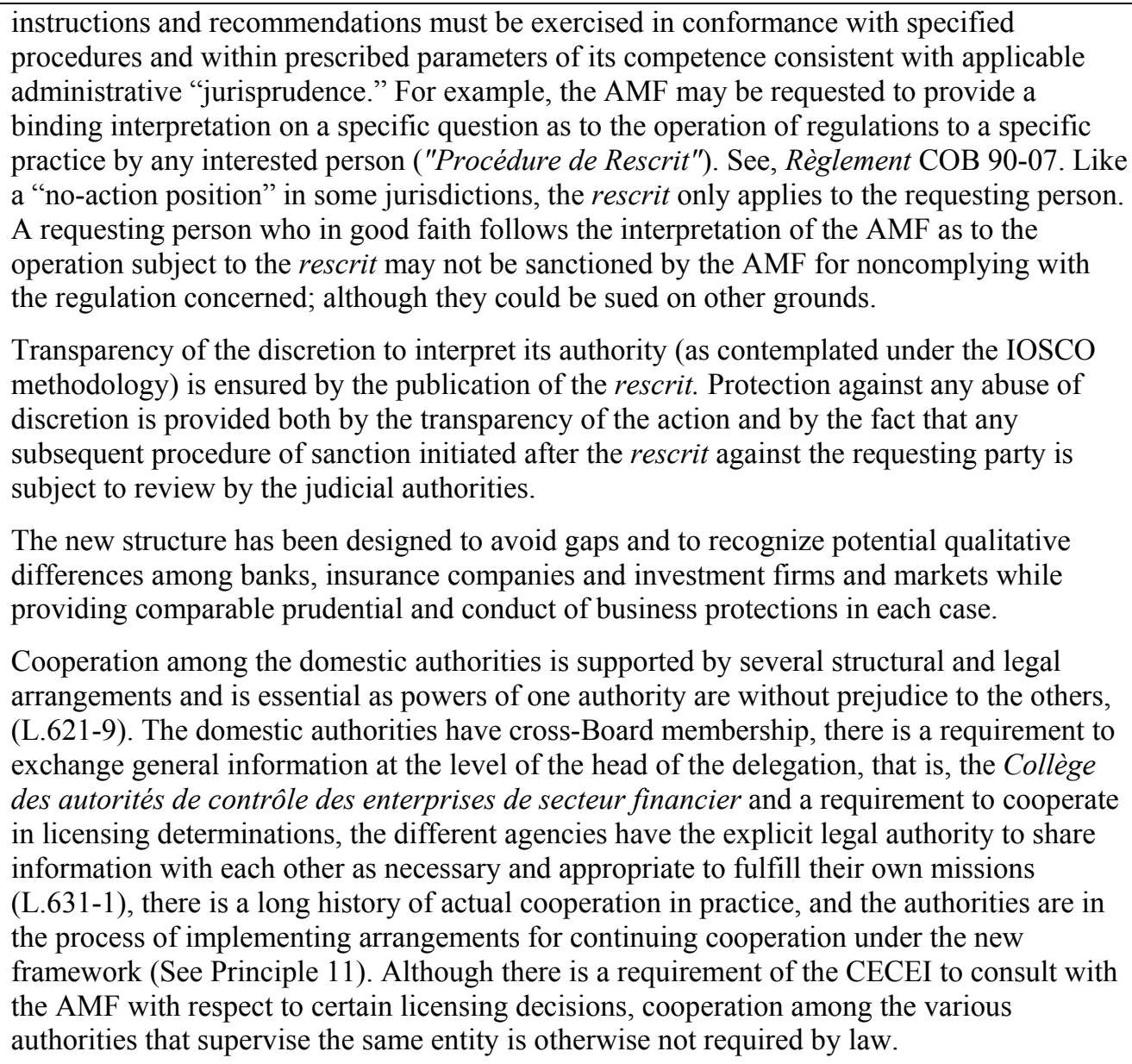 \\
\hline Assessment & Broadly Implemented. \\
\hline Comments & $\begin{array}{l}\text { The new framework is intended to make clear and transparent where one responsibility or } \\
\text { competence begins and the other ends. Mechanisms, both formal and informal, for } \\
\text { discussion and coordination of inspection activities among the various entities involved in } \\
\text { regulation (that is the CB, the CECEI, the AMF and the BdF) currently exist and there is a } \\
\text { long history of cooperation among domestic authorities and no evidence of past cooperative } \\
\text { failures (See also Principles } 8 \text { and 11). Moreover, the authorities are working to develop new } \\
\text { arrangements for working together, which reflect structural changes and new powers } \\
\text { resulting from the adoption of the LSF. } \\
\text { Nonetheless, although it is clear that information may be shared to support the mission of the } \\
\text { AMF or the CB, and among any of the other relevant agencies, including the guaranty funds } \\
\text { for insurance and deposit insurance and regulated markets and clearing organizations, in } \\
\text { operating their respective programs, it is not clear that the CB must promptly support the } \\
\text { AMF if it so requests (L.631-1) to prevent possible gaps of coverage. Cooperation may } \\
\text { always occur in fact (and convincing evidence of such cooperation was provided by both } \\
\text { AMF and the CB), but the practical arrangements and legal support for assistance could be } \\
\text { even clearer. Indeed, although the Assessment Methodology indicates that "protocols" or } \\
\text { exchanges of letters confirming arrangements for cooperation may suffice, it also states that }\end{array}$ \\
\hline
\end{tabular}




\begin{tabular}{|c|c|}
\hline & $\begin{array}{l}\text { where two authorities supervise the same entity, cooperation should be required as a matter } \\
\text { of law". } \\
\text { The AMF believes that the "authorization" to share information between domestic } \\
\text { authorities which supervise the same entity under Art. L.631-1 of the LSF is in fact the } \\
\text { equivalent of a "requirement" based on a long-established practice of cooperation through } \\
\text { the efficient functioning of the College des autorités de contrôle et des entreprises du secteur } \\
\text { financier [Art. L.631-2] and the legal requirement of cross membership of the CB, CECEI } \\
\text { and the AMF. Nevertheless, a more formal arrangement-such as an exchange of letters } \\
\text { among the authorities-addressing the exchange of information procedures, is in the process } \\
\text { of being considered. It is the opinion of this assessor that while there is always value in } \\
\text { developing specific operational cooperative arrangements among authorities with different, } \\
\text { but related, competences affecting the same entity, the French authorities have provided } \\
\text { evidence that their current practices demonstrate that the lack of explicit legislative language } \\
\text { requiring cooperation does not substantially affect the overall adequacy of the regulation that } \\
\text { the Principle is intended to address. }\end{array}$ \\
\hline Principle 2. & $\begin{array}{l}\text { The regulator should be operationally independent and accountable in the exercise of its } \\
\text { functions and powers. }\end{array}$ \\
\hline Description & $\begin{array}{l}\text { By law, the AMF is designated as an independent public authority with legal personality and } \\
\text { financial autonomy with the power to impose specialized taxes (known in some jurisdictions } \\
\text { as "user fees") on regulated entities(L.21-1; L.621-5-2) (see also Principle 3). It is comprised } \\
\text { of a Board and a separate Commission des Sanctions. Salaries of Members of both the Board } \\
\text { and the Commission of Sanctions are fixed by Decree that is submitted for an opinion of the } \\
\text { Conseil d'Etat and their terms of office are set by law. The Members are compensated for } \\
\text { their time. } \\
\text { The Chairman of the AMF is vested with both "own" powers and powers delegated by the } \\
\text { board; the latter are delegated to him within the limits of Decree n'1109 of November } 2003 \text {, } \\
\text { and allow him to take individual decisions to operate the AMF on a day-to-day basis (L.621- } \\
\text { 5) and to act in its name. } \\
\text { The Secretary General of the AMF also has specific statutory powers, in particular related to } \\
\text { investigations. The Secretary General is appointed by the Chairman in consultation with the } \\
\text { Board subject to nonobjection of the Ministry. } \\
\text { The Board and the Commission des Sanctions are separately constituted with no overlapping } \\
\text { membership except for the ex officio representative of the Ministry, the commissaire du } \\
\text { gouvernement, which is not a full Member but only sits at the Board and said Commission. } \\
\text { More particularly, the AMF has a Board of } 16 \text { members including the Chairman, which } \\
\text { comprises: a counselor appointed by each of three highest courts; a representative of the } \\
\text { BdF; three qualified persons appointed by three Constitutional assemblies, six qualified } \\
\text { persons appointed by the Minister of Finance after consultation with representative } \\
\text { organizations of market professionals and investors, the Chairman of the Conseil national de } \\
\text { la comptabilite (accounting board), and a representative of employee shareholders in } \\
\text { consultation with unions. The Commission des Sanctions has } 12 \text { members: two counselors } \\
\text { each from the Conseil d'Etat and the Cour de Cassation from whom the members elect a } \\
\text { Chairman; six experienced members from the industry appointed by the Minister of Finance }\end{array}$ \\
\hline
\end{tabular}

${ }^{30}$ In the past the $\mathrm{CMF}$ and the $\mathrm{CB}$ had a protocol organizing cooperation between them. The $\mathrm{COB}$ was entitled to communicate with other authorities, in particular the CB. 
and two representatives of financial sector employees (L.621-2).

The Board meets approximately fortnightly on a regular basis and otherwise as needed; the Commission des Sanctions meets as needed and can empanel two separate panels of six to hear cases. The members have fixed terms of five years (the membership is rotated by half every 30 months) and members are not removable except by reason of failure to attend meetings or by convening a special investigative committee. The commissaire de gouvernement attends both panels without a voice in deliberations (L.621-3). In the case of the Board, the commissaire can ask for a second deliberation; in the case of the Commission des Sanctions, the decisions are taken without his presence and he cannot ask for such a deliberation. By law, decisions of the Board and the Commission des Sanctions are by majority with the Chair as a tie-breaker. In practice, however, the decisions are by consensus.

As a matter of law, the Minister also must approve the Règlement Général (L.621-6). The Minister does not take positions on individual matters or validate licensing determinations, although a representative of the Treasury sits on the licensing agency or CECEI.

There are various mechanisms for consultation with the industry, through consultative commissions provided for under the LSF, through special committees formed by the AMF as stated in the introduction, through occasional open consultation, and through the facilities of the Committee of European Securities Regulators. With respect to accountability: the AMF's accounts are prepared by an Agent Comptable who serves at the discretion of the Minister, and these upon acceptance by the Board are deposited with and can be audited by the Cour des comptes (Comptroller). The AMF must submit an annual report (with financial statements) to the President and the Parliament, and can be asked to be heard or requested to appear before the Commission of Finance of both parliamentary assemblies (L.621.19 a 1-3 \& 4). Regulations must be published in the JORF and other regulatory actions appear in the BALO. Most actions that affect the general industry or public and individual sanctions are subject to appeal to either the Conseil d'Etat (decisions of general scope against professionals) or to the Appellate Court of Paris, with further appeal on purely legal grounds to the Cour de Cassation (in the case of nonprofessionals).

Persons affected by cases referred to the Commission des Sanctions must be duly "invited" to exercise their defense, or right to be heard, both vis-à-vis the rapporteur and the commission (Cf L.621-15 IV and Art. 19 and 20 of Decree n¹109 of November 23, 2003.). As a matter of law decisions must be motivées, that is, reasons must be given in writing for decisions. In the case of an exceptional abuse by a Member of the Board, the French Parliament could convene an Art. 6 Investigative Committee per the Ordinance (Executive Order) of November 17,1958 . In every case, the law of professional secrecy, which attracts criminal penalties, applies to the handling of information, which does not prevent that such information may be passed to another authority in appropriate circumstances through appropriate channels if necessary for the AMF to perform its mission or to assist foreign authorities (See Principle 13).

Staff and Members of the Board have qualified immunity from lawsuits in the performance of their functions, in bona fide discharge of duties. The AMF has legal personality and therefore can itself be sued in respect to performance of its governmental responsibilities, which is an aspect of its accountability. Such suits would ordinarily only result in liability in the case of faute lourde, that is, a major failure to take action, exercise of powers in bad faith, or failure to follow its own procedures (See, for example jurisprudence of the Conseil d'Etat in regard to the operations of the COB, "Société Pierre et Cristal, Société GIMIF et M.

Jannes c/Etat, , 1984 et.seq.)

The Contemporaneous Basel Report indicates as follows: "The CB and CECEI are independent administrative authorities and their governance is subject to checks and balances that help maintain the operational autonomy of each. However, neither institution is 


\begin{tabular}{|c|c|}
\hline & $\begin{array}{l}\text { independent of the BdF." That assessor concluded that dependence of the CB and the CECEI } \\
\text { on the BdF is not a matter of concern but that fixed terms would be desirable for the } \\
\text { Secretary Generals of each institution. The assessment also stated that it is difficult to assert } \\
\text { that policies, plans and processes are set entirely independently from the government in view } \\
\text { of the role of the Ministry of Finance with respect to adopting regulations, a substantially } \\
\text { broader role than in the case of the AMF, which is able to initiate policies and procedures } \\
\text { itself subject to homologation. The foregoing report nonetheless assesses the CB and CECEI } \\
\text { as compliant with the Basel standards, and as noted in the Introduction to this securities } \\
\text { assessment, the AMF has a well-defined role that respects its independence, with respect to } \\
\text { each of these authorities. } \\
\text { A decree of the Conseil d'Etat specifies the conditions for decision-making and deliberation } \\
\text { of the CECEI. The Règlement intérieur as adopted by the committee is published in the } \\
\text { Journal officiel. All decisions of the CECEI most be motivées, that is reasoned and in } \\
\text { writing, but le directeur du Trésor peut demander l'ajournement de toute décision du comité } \\
\text { (i.e., the director of the Treasury can ask for a dismissal of any decision of the CECEI). This } \\
\text { factor raises some of the same issues with respect to the appearance of a potential for } \\
\text { government interference in individual licensing cases. While this assessor is unaware of the } \\
\text { predominant view with respect to banking institutions, securities standards have sought to } \\
\text { insulate the licensing process as much as possible from interposition of a governmental } \\
\text { authority and has at a minimum required a transparent process. } \\
\text { The CB has particular powers to take prompt corrective action subject to general law, to the } \\
\text { LSF provisions cited in Principle } 1 \text { and various decrees (See especially L.613-16) in matters } \\
\text { committed to its competence. The CB (L.613-21] can also issue sanctions, which are } \\
\text { appealable to the Conseil d'Etat. } \\
\text { Each of the authorities' staff are protected by indemnification from lawsuits that do not } \\
\text { involve bad faith and the BdF is subject to the general law of sovereign immunity. } \\
\text { template. }\end{array}$ \\
\hline Assessment & Broadly Implemented. \\
\hline Comments & $\begin{array}{l}\text { The IOSCO Principles take no position on whether securities commissions should be } \\
\text { governed by full-time or business-type boards and indeed there are advantages to each } \\
\text { system. IOSCO also takes no position on governmental structure per se; its focus is instead } \\
\text { on the independence to act free of commercial and governmental/political interference. The } \\
\text { question is will this specific structure-an independent instrumentality, led by } \\
\text { members representing a balanced spectrum of functions, including judicial, industry } \\
\text { and public functions, with fixed terms and independent funding-which is unique } \\
\text { within the French system, and explicitly designed to achieve independence as a matter } \\
\text { of law, actually confer independence on the AMF in practice. In this regard it should be } \\
\text { noted that of the instrumentalities of financial regulation, the structure of the AMF provides } \\
\text { the most safeguards to independent action. } \\
\text { It should also be noted that various protections are in place to prevent undue interference, } \\
\text { including appointment of members by a number of prescribed institutions, including the } \\
\text { judiciary, which have no political ties, and that there is no record that the COB, or its } \\
\text { leadership, have ever been inappropriately influenced by a change in administration or other } \\
\text { political interference of any kind. } \\
\text { From an external perspective, however, the most troubling issue about the new structure is } \\
\text { the fact that a Ministry representative, albeit one that cannot deliberate and cannot be present } \\
\text { for a decision in the case of sanctions, nonetheless has a "seat" on the Commission of }\end{array}$ \\
\hline
\end{tabular}


Sanctions. The question is "to what end" does the representative need this seat. From the perspective of an international commenter, it appears that such a presence has the potential to have a chilling effect or otherwise to affect the course of the deliberations in practice, even on individual cases, and that the Ministry could remain appropriately and adequately informed of the actions of the Commission des Sanctions by other mechanisms. In effect, the commissaire is able to be a witness throughout most of the proceeding. (In fact, under the previous structure, $\mathrm{COB}$ administrative proceedings did not involve a commissaire $d u$ gouvernement.)

Separately, with respect to Board decisions, the Ministry representative can request a second determination. This could either be seen as a means of information sharing or as a means to remind members of the position of the Ministry. While the day-to-day technical work of the AMF is insulated from interference from any sector, all significant decisions must come to the Board and the Board meets at least fortnightly, and even more frequently as necessary so the fact of this insulation is critical. In the case of the Board as opposed to the Commission des Sanctions, it is pointed out that this structure is not a new one and that past practice indicates that lack of independence is not demonstrated in fact. The AMF also states that the power of the Minister is only a consultative power and not a power to act.

The AMF also documents that the input of the Minister with respect to the Règlement général is only to provide the "stamp" (homologation) necessary for the AMF to adopt rules of general application as a matter of law within the Civil Law system and that the Ministry has never refused to "homologate" a rule proposed by the COB, one predecessor of the AMF. Further, individual decisions are in all cases subject to appeal (L.621-30; Art. 27 Decree 2003-1109). An added protection is that increasingly rulemaking can be done on a Europe-wide basis under the Lamfalussy process and that this process, which permits direct implementation of Europe-wide rules, also reinforces independence. Almost 80 percent of legislation is with respect to implementation of Directives.

It is for this reason that this assessor believes that the integrity of this structure and whether it correctly balances the interests between independence and accountability consistent with the cultural and legal framework within which it operates should be kept under review and tested in practice.

Additionally, in that the composition of the Board includes private sector interest, strict enforcement of conflict of interest provisions should be assured. Among the first postings of the AMF of the new Règlement where those provisions relating to Conflicts. (See also Principle 5)

The two-Board (operating and sanctioning) regulator replaces the previous structure, which had placed all public administrative sanctioning authority directly within the board of the COB. The previous structure was challenged under the fundamental rights concept of impartiality. In addition to keeping under review how independently each Board will execute its function, it may be useful for the Règlement Général to articulate more generally the scope of AMF discretion to act within the regulations on a day-to-day basis. Also, the deliberative process could be more transparent as transparency can be an important protection of independence and integrity. (See below in the section on Enforcement Principles a related concern vis-à-vis application of the doctrine of impartiality to AMF's administrative sanctioning process.)

The AMF believes that the presence of a commissaire du gouvernement on the Commission des Sanctions has been much discussed and that the arrangement was designed with the potential risks in mind to avoid those risks. The AMF underlines that this official has never interfered with the decision-making process of that Commission.

This assessor sees no reason to change its assessment of independence of the securities sector based on its review of the conclusions of other assessors with respect to the $\mathrm{CB}$ and the 


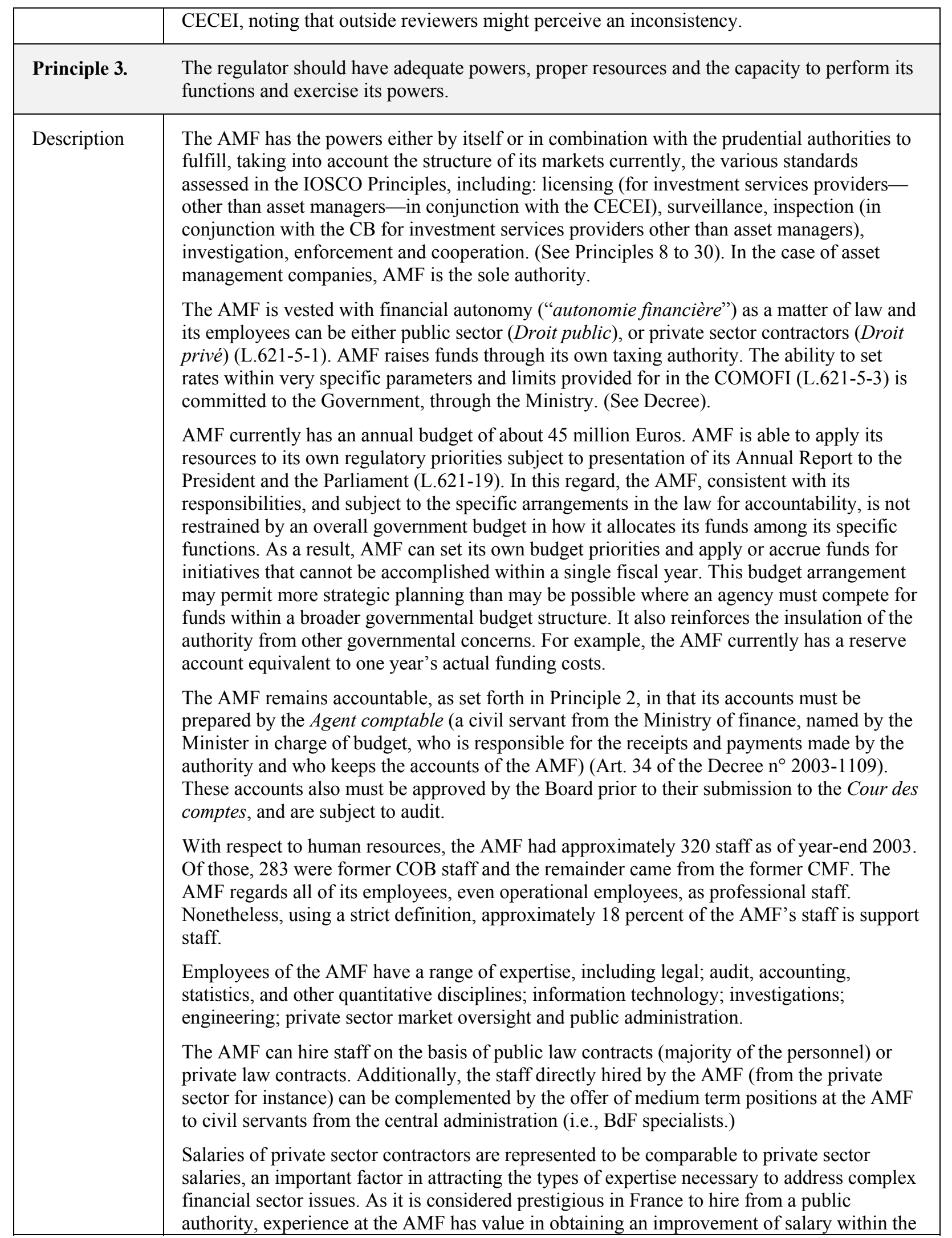




\begin{tabular}{|c|c|}
\hline & 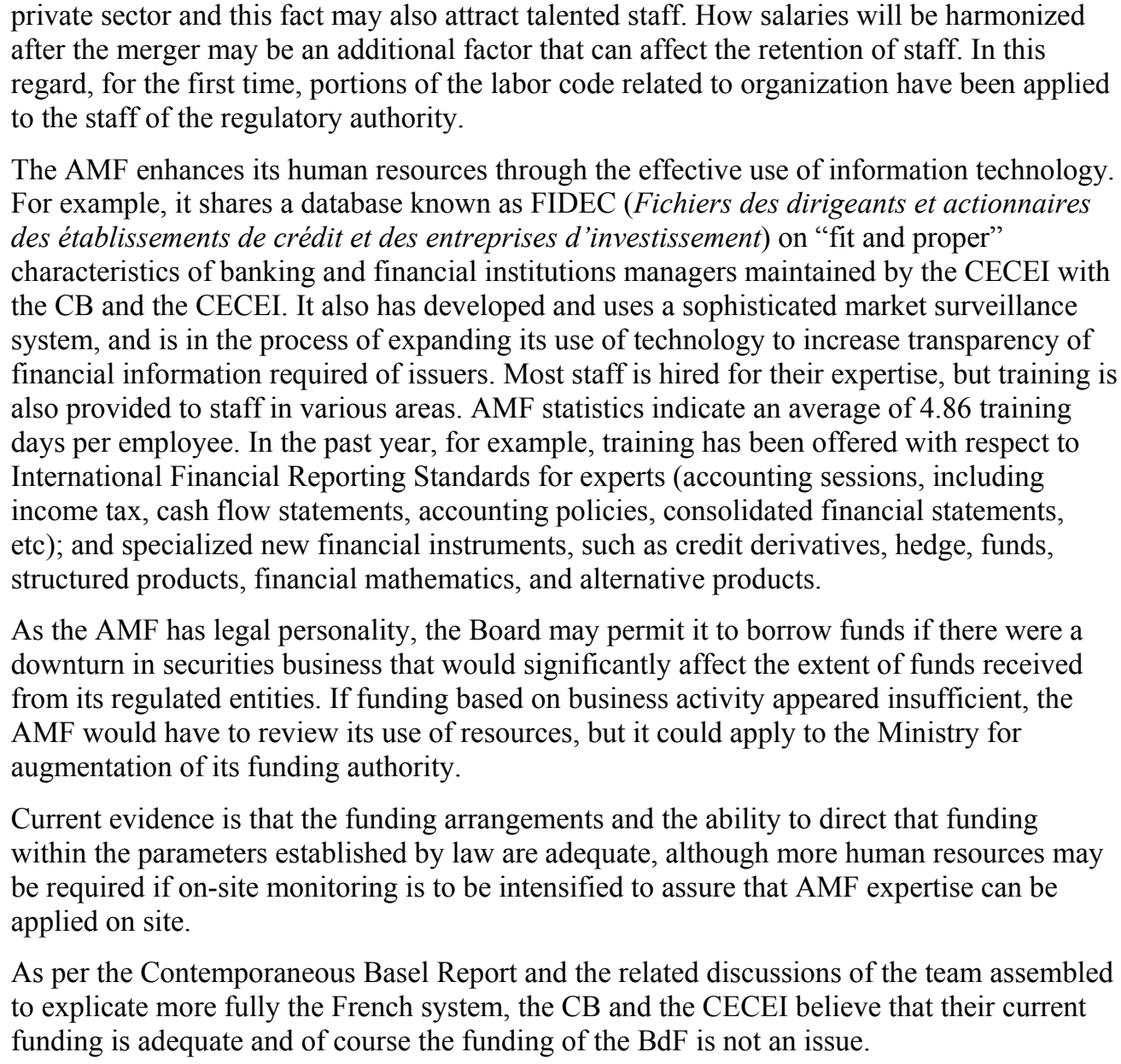 \\
\hline Assessment & Fully Implemented. \\
\hline Comments & $\begin{array}{l}\text { While staff size and expertise appear sufficient, in organizing its staff to implement the new } \\
\text { law, the AMF may seek to devote more human resources to on-site inspections (See } \\
\text { discussion at Principles } 17 \text { and 19), as currently such inspections by the AMF, and the staff } \\
\text { allocated to them, are relatively limited. It is worth noting that the AMF can and does ask the } \\
\text { CB, the Market undertakings and external auditors to make inspections on its behalf. The } \\
\text { Note of the CB, p.4, indicates that from 1999, CB inspectors can be appointed by the AMF } \\
\text { to investigate compliance of investment services providers with AMF rules; and cites that the } \\
\text { AMF since } 1996 \text { also permits the use of external auditors. The LSF also provides new } \\
\text { authority to conduct inspections. In that the AMF is the expert authority with respect to } \\
\text { conduct of business matters (including miss-selling) and market conduct, and of monitoring } \\
\text { of depository functions with respect to CIS, and in that such matters may require on-site } \\
\text { reviews, the AMF should continue to be certain that it takes such steps as may be necessary } \\
\text { to assure that it has sufficient resources to be able to secure effective coverage of these } \\
\text { matters. At this juncture, it is the opinion of the assessor that the matter is largely a question } \\
\text { of allocation of resources and not one of the overall amount. } \\
\text { Further, there is a question whether in light of the way investment products are sold in } \\
\text { France there should be additional capacity within the system to address: conduct of business } \\
\text { with respect to products sold within the bank distribution network (currently provided in part } \\
\text { by consumer law, in part by AMF response to complaints, and some monitoring) and, in the }\end{array}$ \\
\hline
\end{tabular}




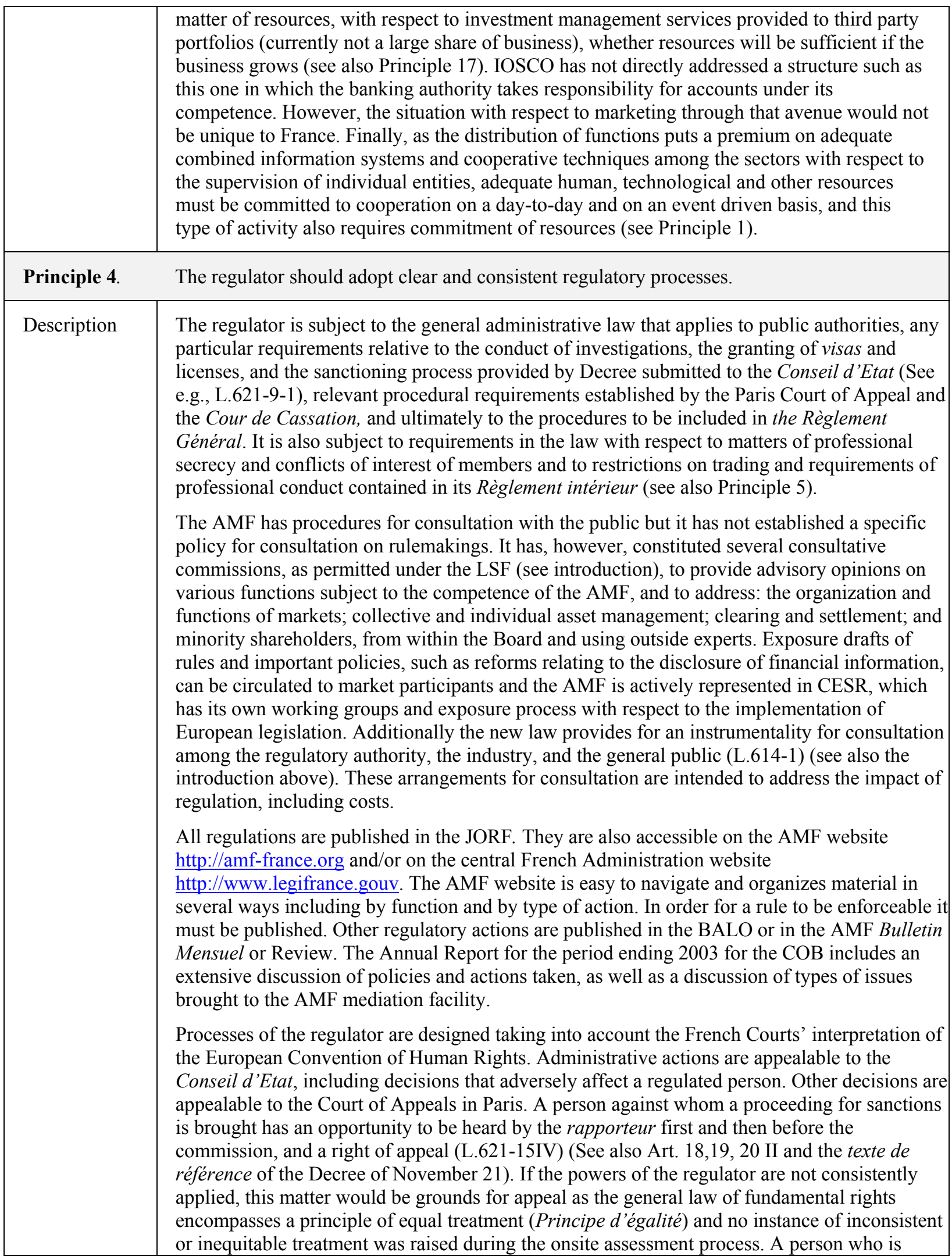




\begin{tabular}{|c|c|}
\hline & $\begin{array}{l}\text { sanctioned must be provided with the reasons in writing. (L.621-15 IV requires decisions to be } \\
\text { "motivées," that is, justified or reasoned. (See also Decree, Art. } 20 \text { V). } \\
\text { The criteria for licenses (and authorization of market undertakings and clearing and } \\
\text { settlement systems) are contained in regulations published in the JORF (see principles on } \\
\text { secondary markets and intermediaries) and/or guidance related to the European Directives, } \\
\text { and application is via a common form known as the Authorization Dossier (dossier type), } \\
\text { which also sets out relevant criteria. } \\
\text { Investigative reports are not made public, only certain sanctions. Sanctions are treated such } \\
\text { that publication is in effect a separate sanction. Publication is not required by law, but the } \\
\text { support for publication has been widened and the practice has been to publish more broadly } \\
\text { than just in the JORF, as was the prior practice. Further, sanctions relevant to status, such as } \\
\text { a withdrawal of a license are public, as are any sanctions, which are appealed. Most } \\
\text { sanctions are described and the disposition of investigations disclosed in the relevant Annual } \\
\text { Report. The AMF expects to continue to make sanctions public in their cases, the objective } \\
\text { being mainly to educate the public by informing the market of what is considered as } \\
\text { misbehavior. } \\
\text { The AMF produces brochures in plain language explaining various aspects of its program } \\
\text { and requirements and holds seminars that are intended to inform investors about the markets } \\
\text { and financial services professionals. It also has a documents room that is open to the public. }\end{array}$ \\
\hline Assessment & Fully Implemented \\
\hline Comments & $\begin{array}{l}\text { Under the previous structure, the procedures related to proceedings before the CMF were } \\
\text { published in its general regulations. Other relevant procedural requirements are also public, } \\
\text { although they are not necessarily collected in one place. The AMF has indicated that it will } \\
\text { develop and consolidate prior rules and instructions of the CMF and the COB, which continue } \\
\text { in effect pending any revision, in a new Règlement Général, and that that compendium would } \\
\text { include internal procedures. Making administrative procedures applicable to the operations and } \\
\text { actions of the AMF as accessible as possible is recommended. While the general process for } \\
\text { rulemaking is through Board adoption followed by submission to the Minister for its stamp, the } \\
\text { AMF may wish to specify in its internal rules the procedures that it uses for rulemaking and its } \\
\text { policies as to when it will conduct an open consultation process. The accessibility and } \\
\text { understandability of AMF rules and procedures will be materially enhanced by adoption of a } \\
\text { final comprehensive Règlement Général. } \\
\text { With respect to the CB and the CECEI, see also the discussion under Principles } 1 \text { and } \\
2 \text { above and the Banking segment of the Transparency Report, which addresses } \\
\text { accountability. }\end{array}$ \\
\hline Principle 5. & $\begin{array}{l}\text { The staff of the regulator should observe the highest professional standards including } \\
\text { appropriate standards of confidentiality. }\end{array}$ \\
\hline Description & $\begin{array}{l}\text { Under the COMOFI (L.621-4), the members and the staff of the AMF as well as the experts } \\
\text { appointed to any consultative commission under III of Art. L.621-2 are subject to } \\
\text { professional secrecy requirements and subject to penal sanctions (L.642-1and L.621-4 II) for } \\
\text { their violation. } \\
\text { The provisions to avoid conflicts of interest involve disclosure of interests to the Chairman of } \\
\text { the AMF, including interests and positions in the financial sector or the fact of a mandate with } \\
\text { a legal entity held within two years of appointment, and any representation of the foregoing, in } \\
\text { the case of Members. Members must recuse themselves with respect to deliberations involving } \\
\text { any matter in which they participated or provided representation with respect to such }\end{array}$ \\
\hline
\end{tabular}




\begin{tabular}{|c|c|}
\hline & relationship. \\
\hline & $\begin{array}{l}\text { There are also restrictions on the holding or trading of securities by staff. For example, the } \\
\text { direct purchase of securities and management of a portfolio are prohibited, although staff } \\
\text { may hold mutual funds (UCITS) or give discretion to a fund manager. As of March 30, 2003, } \\
\text { Art. 1-1-6 of the Règlement Général, among the first new regulations of the AMF, makes } \\
\text { similar restrictions applicable to board Members. The President of the AMF has all necessary } \\
\text { powers to oversee the holdings of Members (see Art. 1-1-7). }\end{array}$ \\
\hline & $\begin{array}{l}\text { An internal audit group (although not currently staffed) is expected to be staffed with a } \\
\text { Director and a Deputy during the summer. The internal audit group will do a review of all the } \\
\text { operations of the AMF and report directly to the Board with respect to its recommendations for } \\
\text { improving efficiency. Individual unit heads are separately accountable for the integrity of the } \\
\text { operations of their sections and report to the Secretary General. }\end{array}$ \\
\hline & $\begin{array}{l}\text { The professional standards relating to staff not otherwise a matter of law are currently } \\
\text { contained in a Statut des personnels (Code of Conduct), subject to review of the Ethics officer } \\
\text { (Déontologue) (who reports directly to the President). The Ethics officer has the power to } \\
\text { investigate violations including violations involving the Internet. All internal professional } \\
\text { conduct regulations are expected to be consolidated within the Règlement Général. Procedural } \\
\text { fairness also is assured under the LSF itself, general national law, and the European } \\
\text { Convention on Human Rights. It is not the practice in most European jurisdictions to set forth } \\
\text { administrative procedures in a single code. }\end{array}$ \\
\hline & $\begin{array}{l}\text { The Contemporaneous Basel Report finds the CB and the CECEI fully compliant with these } \\
\text { requirements as well and further reference may also be made to the Banking segment of the } \\
\text { Transparency Report. It should be noted that the professional staff of the CB and the CECEI } \\
\text { are subject to professional conduct and confidentiality provisions similar to the AMF, which } \\
\text { do not impair their ability to share information with each other or with the AMF. }\end{array}$ \\
\hline Assessment & Fully Implemented. \\
\hline Comments & $\begin{array}{l}\text { Codification of internal professional rules of conduct can reinforce appropriate practice and } \\
\text { should be strongly supported. Monitoring of compliance with applicable standards of ethics } \\
\text { also is desirable as there have been experiences of lapses of compliance at the staff level in } \\
\text { the past. }\end{array}$ \\
\hline & Principles of SElF-REgulation \\
\hline Principle 6. & $\begin{array}{l}\text { The regulatory regime should make appropriate use of Self-Regulatory Organizations (SROs) } \\
\text { that exercise some direct oversight responsibility for their respective areas of competence, } \\
\text { and to the extent appropriate to the size and complexity of the markets. }\end{array}$ \\
\hline Description & $\begin{array}{l}\text { There are no self-regulatory organizations as such in France; all regulatory powers are } \\
\text { concentrated in governmental bodies }{ }^{31} \text {. }\end{array}$ \\
\hline Assessment & Not applicable. \\
\hline Comments & $\begin{array}{l}\text { Notwithstanding the foregoing, the regulated markets are required to enforce their own rules } \\
\text { by means of contract. Oversight of regulated markets and other markets is addressed in }\end{array}$ \\
\hline
\end{tabular}

${ }^{31}$ But see the discussion with respect to the licensing of demarcheurs at Principle 21. 


\begin{tabular}{|c|c|}
\hline & Principle 25. \\
\hline Principle 7. & $\begin{array}{l}\text { SROs should be subject to the oversight of the regulator and should observe standards of } \\
\text { fairness and confidentiality when exercising powers and delegated responsibilities. }\end{array}$ \\
\hline \multicolumn{2}{|l|}{ Description } \\
\hline Assessment & Not Applicable. \\
\hline \multicolumn{2}{|l|}{ Comments } \\
\hline \multicolumn{2}{|r|}{ Principles for the Enforcement of Securities Regulation } \\
\hline Principle 8. & The regulator should have comprehensive inspection, investigation and surveillance powers. \\
\hline Description & 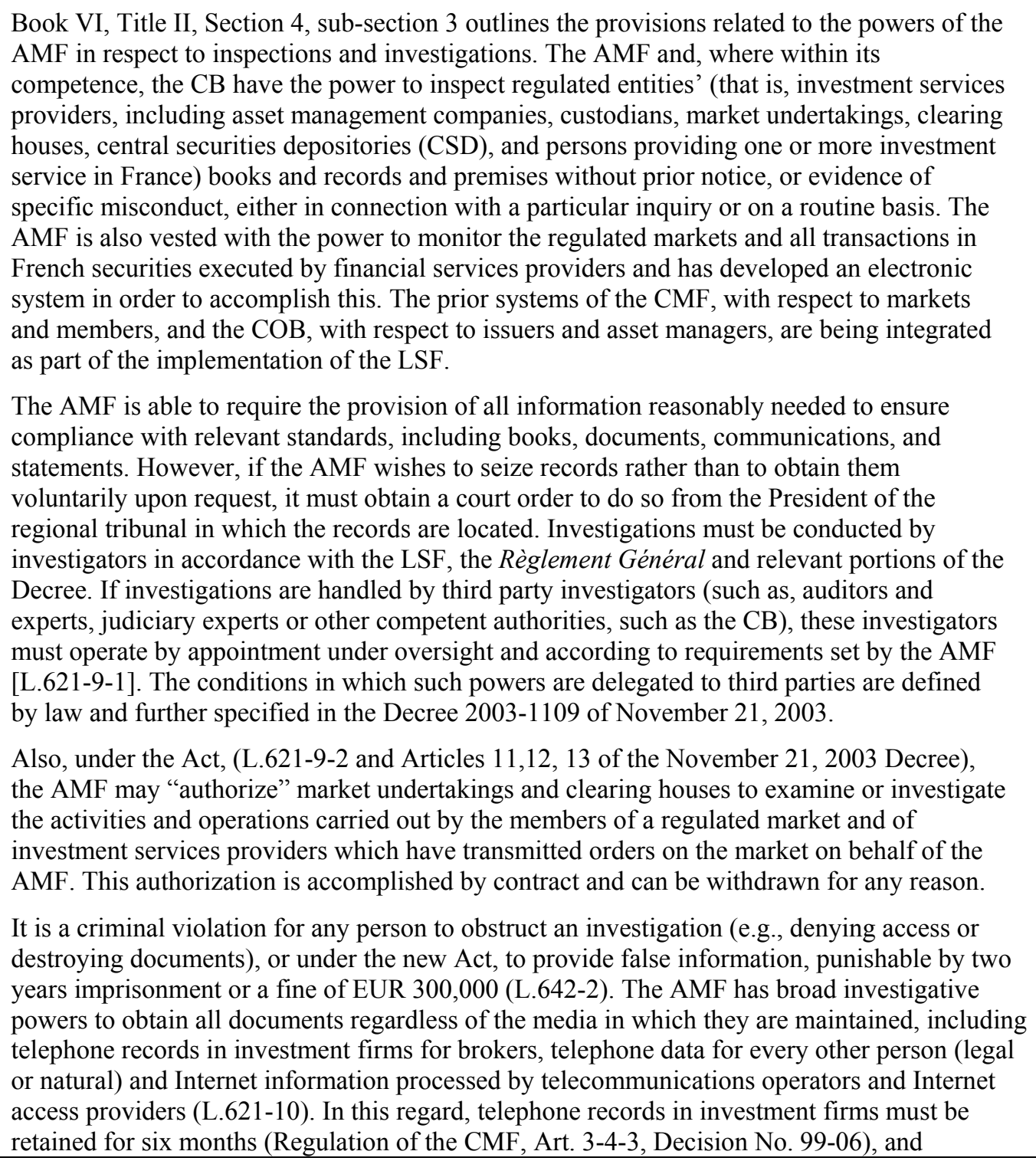 \\
\hline
\end{tabular}




\begin{tabular}{|c|c|}
\hline & 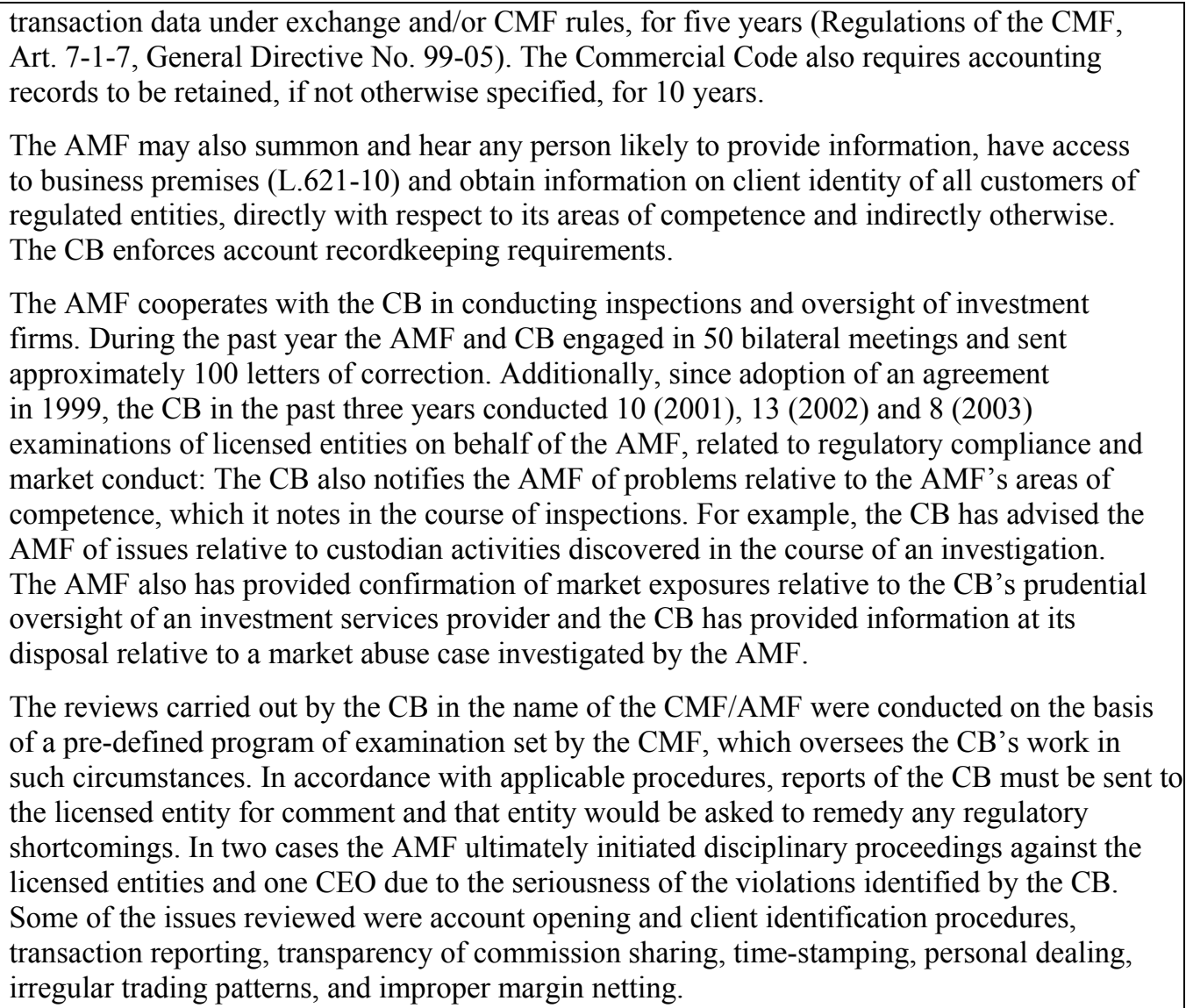 \\
\hline Assessment & Fully Implemented. \\
\hline Comments & $\begin{array}{l}\text { It appears that except for matters committed to the sole authority of the AMF, the AMF's } \\
\text { authority is subject to the power of the CB to conduct inspections with respect to matters within } \\
\text { the competence of the latter (L.621-9II). The AMF can request that the CB conduct an } \\
\text { investigation on its behalf. In that it is possible that conduct of business violations may be } \\
\text { accompanied by prudential violations or may cause them and that prudential violations may } \\
\text { cause conduct of business violations, coordination is important. The law (L.631-1) provides for } \\
\text { sharing inspection information, and/or on-site teams, which involve both competences within a } \\
\text { single inspection with respect to investment services providers. Use is made of the law on a } \\
\text { regular basis; the AMF and the CB plan their yearly examination schedules jointly and } \\
\text { exchange information on respective risk assessments. } \\
\text { ATS are licensed as investment service providers and are subject to the rules and regulations } \\
\text { generally applicable to such entities plus any specific conditions imposed by the regulator at } \\
\text { the time of licensing. } \\
\text { This assessment, which finds that the AMF can obtain beneficial ownership information as } \\
\text { needed, should be compared with any work dedicated specifically to anti-money-laundering } \\
\text { standards. In France, there are no shares printed on paper that can physically be transmitted } \\
\text { from one person to the other as all shares have been 'dematerialized' and are now registered } \\
\text { on share accounts. Even so-called "bearer shares, which remain permitted, are registered on } \\
\text { accounts, which necessarily identify the persons to which they belong, natural or legal. The } \\
\text { CB monitors account records. }\end{array}$ \\
\hline
\end{tabular}




\begin{tabular}{|c|c|}
\hline & $\begin{array}{l}\text { Arrangements for continued cooperation under the new framework should be kept under } \\
\text { review. } \\
\text { See also CIS Principles relative to oversight of depositories and Principle } 10 \text { relative to use of } \\
\text { investigatory information in enforcement proceedings. }\end{array}$ \\
\hline Principle 9. & The regulator should have comprehensive enforcement powers. \\
\hline Description & 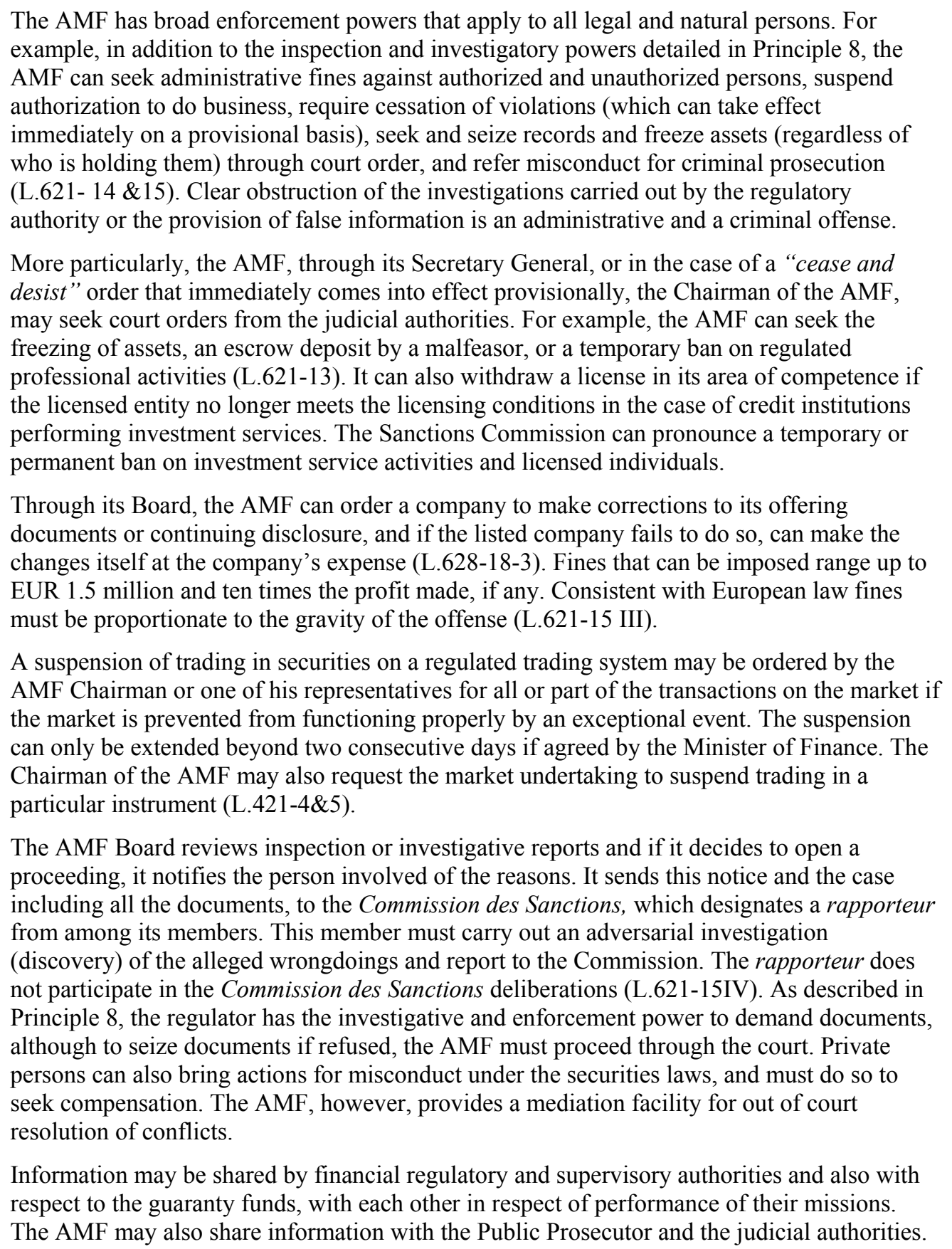 \\
\hline Asses: & pple \\
\hline
\end{tabular}




\begin{tabular}{|c|c|}
\hline Comments & $\begin{array}{l}\text { As discussed more fully below in Principle 10, certain types of offenses must be reported to } \\
\text { the Public Prosecutor and this may affect to whether, and to which extent, the AMF seeks to } \\
\text { take action. For example, the AMF now has wider powers with respect to insider dealing } \\
\text { under the LSF to proceed against "any person," but if a criminal proceeding is concluded no } \\
\text { civil sanctioning proceeding can be commenced for the same offense. In this regard, the AMF } \\
\text { does not have the power to seek disgorgement (and corresponding compensation to defrauded } \\
\text { customers) through its administrative sanctioning process. The powers to address } \\
\text { manipulation or provision of false information to the market are unlikely to be at all } \\
\text { constrained by the related criminal authority with respect to these types of offenses as the } \\
\text { types of cases brought by the AMF are frequently different in type from those in which the } \\
\text { criminal authorities would be interested. } \\
\text { Information may be shared by authorities in the performance of their respective missions. The } \\
\text { CB has provided specific examples of how cooperation has occurred in individual cases and } \\
\text { the AMF indicates that the COB, the CMF and the CB and CECEI have a long record of } \\
\text { successful cooperation. Nonetheless, where issues require the comparison of market } \\
\text { information and prudential information there is a premium on the ability for the CB and AMF } \\
\text { to cooperate immediately. For example, it is clear that for the following responsibilities, } \\
\text { constant communication is necessary: margin and market positions and exposures (AMF), } \\
\text { appropriate segregation or disclosure of customer assets (AMF), client identity records (CB } \\
\text { and AMF) and capital structure (CB), and proper operation of depositories for managed funds } \\
\text { (AMF). The arrangements whereby the CB shares with the AMF in individual cases, where } \\
\text { the information under CB competence is relevant to the AMF competence, could be even } \\
\text { further clarified and kept under review (see L.621-9II, para.2 re inspection authority). In this } \\
\text { regard, note that the CB advises that it has formalized its arrangements with the Insurance } \\
\text { Supervisory Authority (CCAMIP) and with respect to oversight of clearing houses (see } \\
\text { Principle 1). }\end{array}$ \\
\hline Principle 10. & $\begin{array}{l}\text { The regulatory system should ensure an effective and credible use of inspection, } \\
\text { investigation, surveillance and enforcement powers and implementation of an effective } \\
\text { compliance program. }\end{array}$ \\
\hline Description & $\begin{array}{l}\text { The COB and CMF had active enforcement programs in the past, which are now being } \\
\text { combined within the AMF. The AMF has an enforcement department composed of } \\
50 \text { persons with various types of competences (lawyers, accounting specialists, judges, police } \\
\text { officers, and mathematicians, for example). Of these, } 30 \text { are investigators and } 15 \text { engage in } \\
\text { market surveillance. Of the latter, eight monitor the equity markets. Within the Direction des } \\
\text { Prestataires de la Gestion et de l'Epargne, there are also16 inspectors, most of which have } \\
\text { prior industry experience, who are responsible for examining compliance of all regulated } \\
\text { firms and entities with professional rules, regulations and other obligations under the } \\
\text { regulatory scheme. } \\
\text { The electronic system for reviewing transactions on regulated markets accounts for } 50- \\
60 \text { percent of the investigations carried out by the enforcement staff of the AMF and uses } \\
\text { statistical modeling and other information to identify unusual situations for further } \\
\text { investigation. } \\
\text { The structure of the LSF and the COMOFI increase the range of investment service providers } \\
\text { within the authority of the AMF, adding certain financial analysts. The LSF and the COMOFI } \\
\text { also combine the functions of the CMF and the AMF. The AMF makes off-site inspections } \\
\text { routinely and on-site inspections based primarily on risks, review of external audit work, or } \\
\text { based on complaint, although it is in the process of redesigning its inspection program and may } \\
\text { include more onsite inspections, especially of depositories for CIS assets, if resources permit. } \\
\text { The annual examination schedule is based on a ranking of the annual reports filed by }\end{array}$ \\
\hline
\end{tabular}


investment service controllers, an evaluation of their responses to the topical questionnaires issued by the AMF and information gleaned through market monitoring, from other departments of the AMF or reported by other regulators, thus inspections are prioritized and not every firm is visited routinely. There is a yearly action plan but firms are scheduled for visits based on a risk weighting system, "on the basis of the information collected in accordance with CMF general regulation Art. 2.4-16, Art. 3.1.4 \& Art. 7-1-4, 7-1-5, 7-1-6.”

The AMF also has a well-designed electronic system for monitoring market activity for insider trading, manipulation and other market abuses and carries out about 1200 verifications of unusual activity and 80 full investigations a year.

This system analyzes information on transactions, media announcements, news and financial reporting services, among other things. The AMF also has systems for receiving certain information from asset management companies and for reviewing issuer information intended to facilitate oversight of compliance with the law and regulations relative to such financial services providers.

The AMF has its own program to assess compliance with prudential requirements for asset managers and proper segregation and deposit of client assets committed to collective investments. Prudential requirements affecting investment services providers are the province of the $\mathrm{CB}$, although the $\mathrm{AMF}$ can request the $\mathrm{CB}$ to undertake an investigation as to matters within AMF competence as to an investment services provider (see discussion in Principle 9). This program is being enhanced following the restructuring of the regulatory framework contained in the Act. The AMF has a system for handling customer complaints and also a mediation service (L.621-19 para.1, and see information on the mediateur on the AMF website).

The AMF can assess sanctions against persons acting for, or under the authority of authorized investment services providers and markets, etc. subject to the provisions specified in the LSF and the COMOFI (L.621-15II (b)). Failure to supervise such persons, or to communicate relevant requirements can also be sanctioned by the Commission des sanctions. Individuals working for a regulated entity may be sanctioned for breach of regulations. Sanctions may include temporary or permanent withdrawal of his professional license.

French regulation requires brokers to keep relevant order information for five years and phone conversations of trading desks must be recorded and kept for six months (see discussion above). Records of trading activity are provided to the AMF both in real time and daily in batch form to permit further analysis, and trades must be particularly identified at the broker to the trader by regulated market rules. From time to time trade allocations are reviewed (See Principle 17). Regarding insider trading, information from the CSD and client account records permits accounting for, or tracing back trades to specific traders and clients.

The inspection department of the AMF indicates that 84 cases were presented to the Board of the predecessor agencies in 2003, as follows: 25 insider trading cases; 5 market manipulation cases; 17 dissemination of false information cases; 11 asset management related cases ( 3 on CIS, 5 on companies, 2 on depositories, 1 for unauthorized business); and 26 foreign assistance cases. AMF reports that, on average, an investigation takes 8 months to be completed. The minimum duration is usually 3 months and the maximum observed 18 months.

In this regard, there are templates for the examination of the observance of regulatory requirements on financial analysis for instance, for licensees generally, to address emergent issues, such as late trading and on line brokers, and for asset management companies aimed at facilitating the review for compliance with AMF requirements.

The AMF must transmit a case to the Public Prosecutor in Paris, where there is a special competency within the Court for financial crimes, which includes the record of the investigation whenever an AMF investigation discloses facts that constitute a criminal offense (e.g., insider 


\begin{tabular}{|c|c|}
\hline & $\begin{array}{l}\text { trading) (L.621-20-1). If the criminal violation is within the scope of competence of the AMF, } \\
\text { the court may request that the AMF file written submissions (procès verbaux) (L.621-20-1). } \\
\text { The AMF may exercise its rights as a party to the complaint. } \\
\text { Art. L.621-16-1 states that the AMF cannot at the same time be partie civile at the Criminal } \\
\text { court against a specific person and for specific facts and, for these same person and facts, } \\
\text { carry out a sanction procedure. However, the AMF may also bring an administrative case } \\
\text { with respect to such violations if the Prosecutor declines to proceed, or can commence a } \\
\text { proceeding for different sanctions (e.g., withdrawal or restriction of licenses). See also } \\
\text { discussion under Principle 9. }\end{array}$ \\
\hline Assessment & Broadly Implemented. \\
\hline Comments & 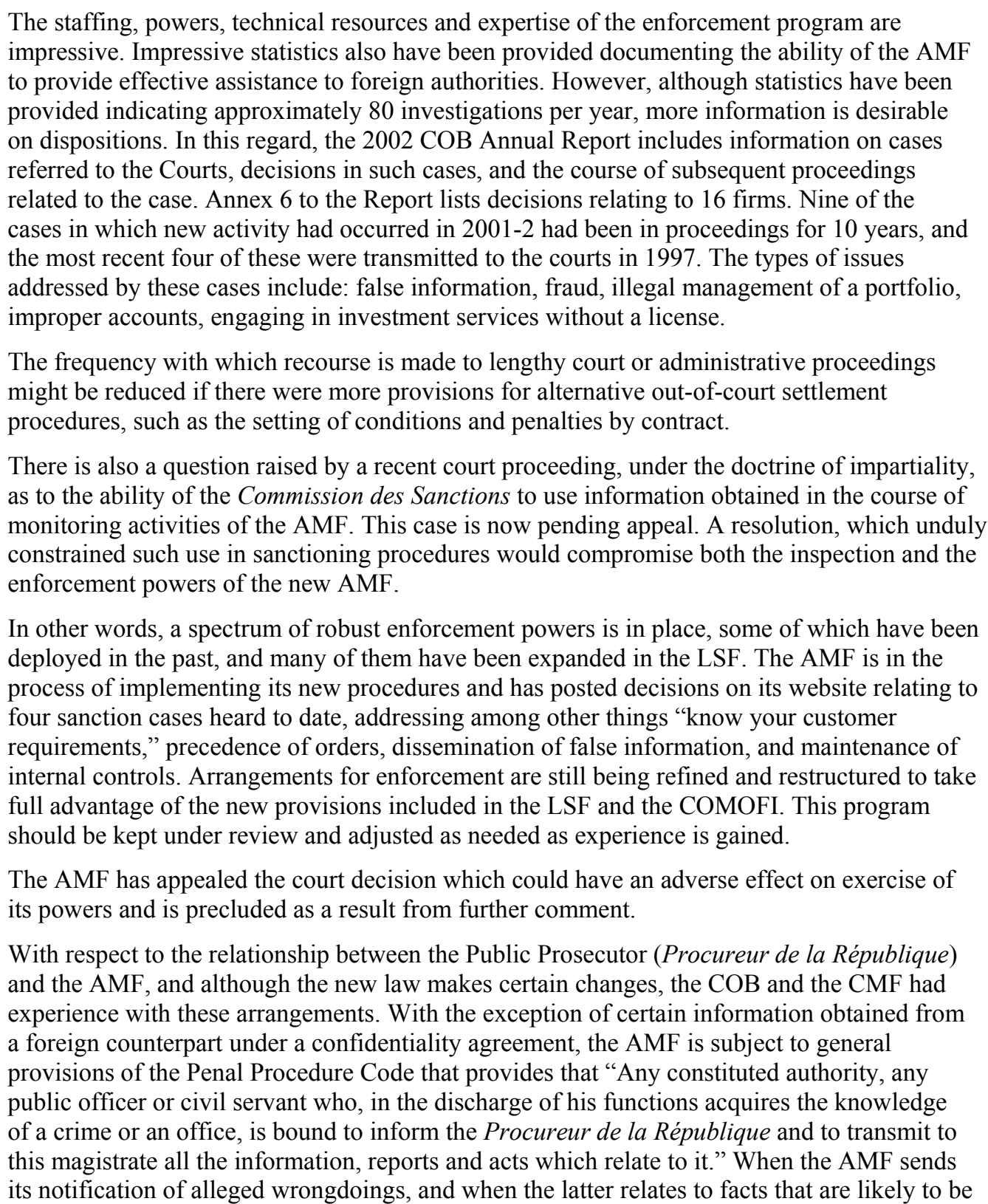 \\
\hline
\end{tabular}




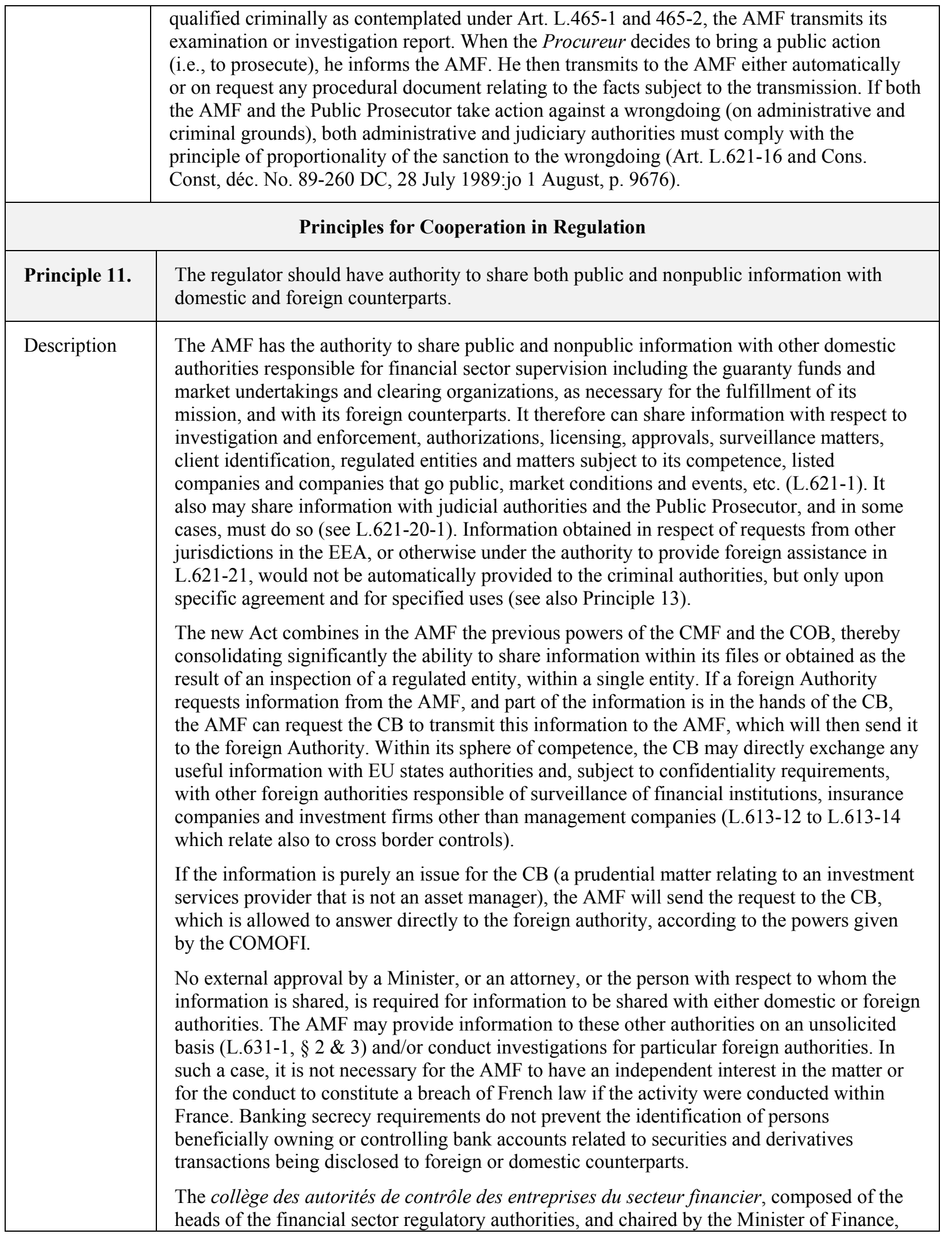




\begin{tabular}{|c|c|}
\hline & $\begin{array}{l}\text { facilitates the exchange of information on matters of common interest (L.631-2). This } \\
\text { college of regulators meets at least three times a year with respect to matters of general } \\
\text { import that are of common interest, not specific cases. Nonetheless, the existence of such a } \\
\text { vehicle for cooperation and information exchange generally assists in promoting a climate of } \\
\text { cooperation among the functional authorities and can prevent inappropriate competition in } \\
\text { the performance of their duties. }\end{array}$ \\
\hline Assessment & Fully Implemented. \\
\hline Comments & $\begin{array}{l}\text { The exceptions to when sharing is required, e.g., in case of national security interest, are } \\
\text { common to securities regulatory authorities. The restriction with respect to sharing where a } \\
\text { criminal investigation on the same facts has been commenced has been a permitted exception } \\
\text { under the Explanatory Notes to the IOSCO Assessment Methodology and accepted in } \\
\text { connection with the IOSCO Multilateral MoU (MMoU), as is also required by EU law. } \\
\text { The protection of information obtained in respect of foreign assistance from automatic } \\
\text { provision to the criminal authorities is also not inconsistent with the IOSCO Principles and } \\
\text { facilitates such sharing. }\end{array}$ \\
\hline Principle 12. & $\begin{array}{l}\text { Regulators should establish information sharing mechanisms that set out when and how they } \\
\text { will share both public and nonpublic information with their domestic and foreign } \\
\text { counterparts. }\end{array}$ \\
\hline Description & 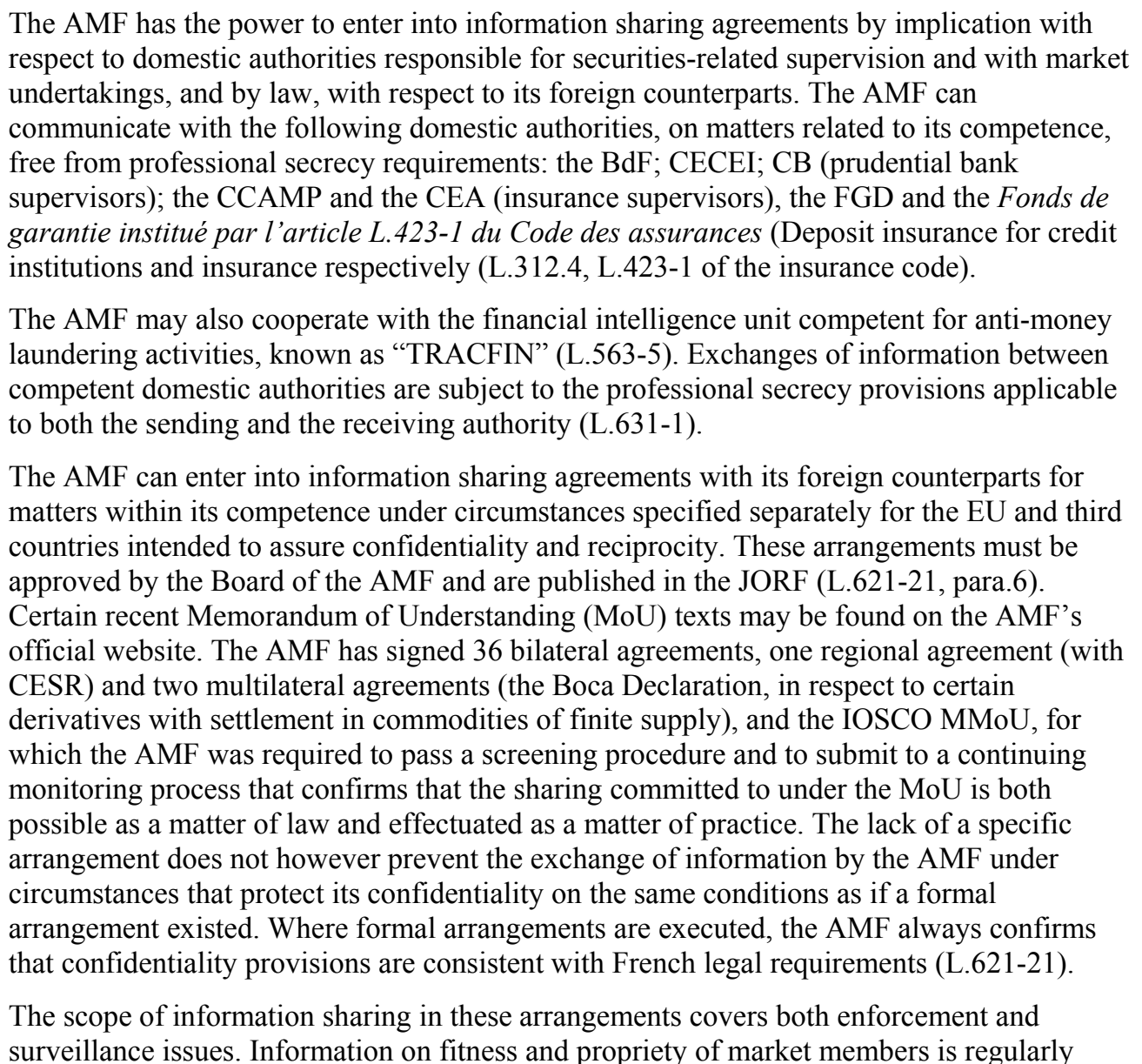 \\
\hline
\end{tabular}




\begin{tabular}{|c|c|}
\hline & $\begin{array}{l}\text { exchanged for example with many authorities, and the various domestic authorities maintain } \\
\text { a common data-base (FIDEC, or Fichier des dirigeants et actionnaires des établissements de } \\
\text { credit et des enterprises d'investissement), which contains licensing status and sanctions. } \\
\text { This facilitates such information sharing. In the last three years the French authorities opened } \\
68 \text { investigations on behalf of foreign authorities relating to a spectrum of abuses, primarily } \\
\text { insider trading (see also Principle 13). } \\
\text { The AMF has also entered into "second generation," or operational, memoranda of } \\
\text { understanding specifying conditions for cooperation with respect to the Euronext, NV group } \\
\text { which is the holding company for the French, Belgian, Dutch, Portuguese and English } \\
\text { markets that comprise Euronext. Similarly, there is a Clearing Coordination Committee that } \\
\text { has adopted an MoU or cooperation arrangement with respect to the Clearnet Group. This } \\
\text { committee includes all competent domestic and international authorities responsible for } \\
\text { oversight of Clearnet. The AMF and CB also have, pursuant to legal authority granted } \\
\text { originally under the MAF, a specific agreement relative to performance by the CB of certain } \\
\text { inspections for the AMF (See Principle 1). }\end{array}$ \\
\hline Assessment & Fully Implemented \\
\hline Comments & $\begin{array}{l}\text { Where necessary information is in the hands or can be obtained by another domestic } \\
\text { Authority within its competence, this other Authority will collect the information and then } \\
\text { pass it to the AMF. The AMF may not obtain it by itself. } \\
\text { In general this structuring of the channels for obtaining needed surveillance and enforcement } \\
\text { information has worked. This may mean that foreign securities authorities with prudential } \\
\text { competences must go directly to the CB. The CB has similar powers as the AMF with } \\
\text { respect to information sharing arrangements but in principle, information on prudential } \\
\text { matters provided to foreign securities regulators with respect to securities products, } \\
\text { professionals, markets, clearing and settlement organizations, and transactions should be } \\
\text { passed through the AMF regardless of the CB's (and/or BdF's) competences with respect to } \\
\text { prudential supervision of certain of these entities (see Principle 13). } \\
\text { As noted above, the AMF has agreed arrangements with other domestic and foreign } \\
\text { regulators in respect to the oversight of the Euronext market complex. The AMF cooperates } \\
\text { in practice with other domestic functional regulators with information relevant to investment } \\
\text { services providers and has practical arrangements for the informal exchange of information } \\
\text { through scheduled monthly staff meetings or on an ad hoc basis. } \\
\text { The AMF may entertain exploring whether it would be useful to commit more of its } \\
\text { domestic arrangements to formal protocols and whether the law regarding information } \\
\text { exchange domestically is sufficiently permissive in respect to prudential matters. }\end{array}$ \\
\hline Principle 13. & $\begin{array}{l}\text { The regulatory system should allow for assistance to be provided to foreign regulators who } \\
\text { need to make inquiries in the discharge of their functions and exercise of their powers. }\end{array}$ \\
\hline Description & $\begin{array}{l}\text { The AMF may, under the same conditions, according to the same procedures and subject to } \\
\text { the same penalties (i.e., civil) for the carrying out of its mission conduct investigations at the } \\
\text { request of foreign authorities that are its counterpart (L.621-1 para.1). The AMF may require } \\
\text { or request the production of documents or the taking of statements and may organize formal } \\
\text { interviews of witnesses. The AMF may provide assistance when the following conditions are } \\
\text { met: the foreign regulator carries out similar duties, there is reciprocity (this is not required } \\
\text { within the European Economic Area), and the foreign regulator applies similar professional } \\
\text { secrecy rules as those of the AMF. } \\
\text { When the AMF commences an investigation for a foreign regulatory authority, it may obtain } \\
\text { the same kind of information and exercise the same powers as it exercises domestically. }\end{array}$ \\
\hline
\end{tabular}




\begin{tabular}{|c|c|}
\hline & 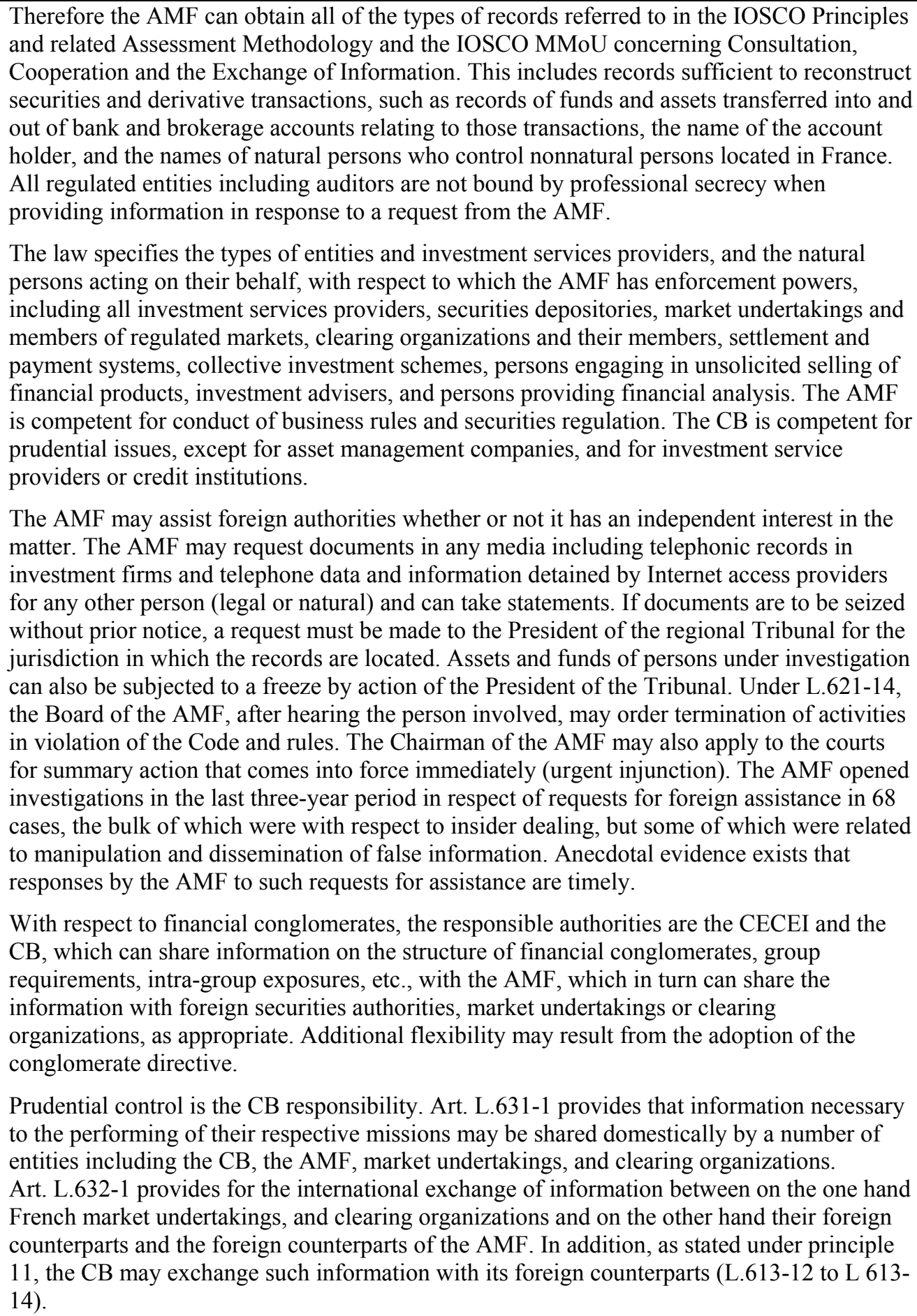 \\
\hline Assessment & Fully Implemented. \\
\hline Comments & $\begin{array}{l}\text { The ability to commence an investigation is within the scope of authority of the Secretary } \\
\text { General of the AMF and no prior approval of any other authority is required. Therefore, } \\
\text { although an investigation must be commenced in order for the AMF to provide foreign }\end{array}$ \\
\hline
\end{tabular}




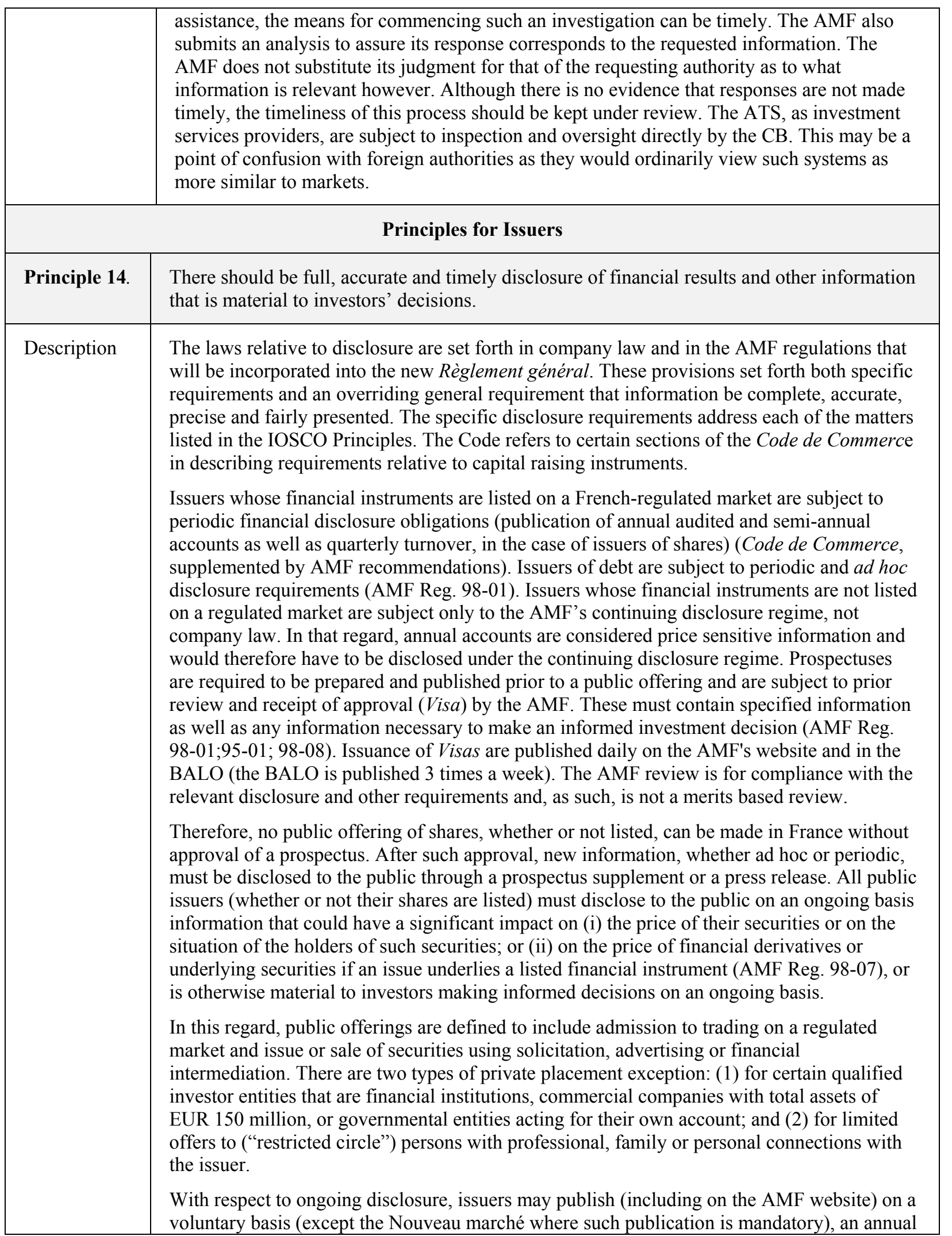


registration (document de référence or shelf registration) with the option to update periodically to meet periodic disclosure requirements (AMF Reg 95-01; 98-01). For issuers on the Nouveau Marché publication of such a document is mandatory (Reg 95-01). In 2003, approximately 400 issuers have published a document de référence. Of these, 138 are listed on the Nouveau Marché and 262 publish voluntarily. Issuers on the Marché libre (which is not a regulated market) have the same continuing disclosure requirements as listed issuers.

All listed issuers have been required to publish a full set of accounts, semi-annually since June 2000 (AMF Recommendation 99-01). The mid-year report must be accompanied by a "limited review" auditor's report and a statement of the management that the accounts produced are true and correct.

In the case of takeover bids, similar disclosure requirements apply (prospectus requirements, on going obligation). In addition, specific information relative to offers, including crossing of thresholds and purchases and sales of insiders is posted on the AMF website, which is updated daily.

Foreign issuers within France are subject to the same prospectus requirements. For continuing disclosure, foreign issuers also are subject to the same disclosure regime (including the requirement to make equivalent disclosures in France to any made to the foreign markets in which they are issuing securities).

Full disclosure is required in connection with shareholder voting decisions, in particular in connection with the general meeting approving the annual accounts or any extraordinary meeting approving a major transaction or a share issue. Notice is required at least 15 days before the annual meeting approving accounts or before any extraordinary meeting approving a major transaction (see Principle 15).

In addition to membership requirements, intermediaries authorized in France acting on a futures market must provide specific disclosure as to the terms of the contracts, the trading mechanisms and the risks associated with such trading. And if derivatives are offered on securities, appropriate information must be available on the underlying.

The AMF also may provide additional guidance. For example, in 2002, it reminded issuers to disclose risk factors precisely, requiring them to be specific to the issue offered, and to address off-balance sheet commitments, goodwill amortization, and corporate governance. In 2003, recommendations were made with respect to credit derivatives, among other things.

Advertising is reviewed and must be consistent with required published disclosures (L.621-8; 412-1).

If false information is provided in connection with disclosures, the AMF can bring an administrative action, a criminal action under the COMOFI (L.621-9;465-1) or an action en responsabilité civile under the Code Civil if causation of damages can be proved. If shareholders believe that they have been improperly informed, they can complain to the AMF. The AMF identifies on its website those public companies that have not filed periodic reports, can request amendments of reports at the issuer's expense and regularly brings actions, even against issuers whose securities are traded on the Marché libre, initiating investigations in 7 cases in the last two years. For issuers listed on a regulated market, the AMF monitors compliance with periodic obligations, and if issuers fail to publish reports even after their name is posted, the AMF can bring a legal action in Commercial court. In practice, most issuers comply upon demand.

The Chief Operating Officer, the preparers of the prospectus as identified therein, and the auditors each have responsibility for its accuracy. Intermediaries offering securities must also undertake appropriate due diligence. Breach of these obligations may give rise to administrative, civil, or criminal liability. 


\begin{tabular}{|c|c|}
\hline & $\begin{array}{l}\text { Required ongoing disclosure can only be deferred (for "legitimate" business purposes, such } \\
\text { as negotiations, as determined by the issuer itself), subject to the injunction that the issuer is } \\
\text { accountable for maintaining the confidentiality of the information and cannot trade on } \\
\text { nonpublic information. The AMF can require an issuer to disclose such information if the } \\
\text { issuer is not able to maintain its confidentiality or can elect to disclose the information itself. } \\
\text { The ongoing disclosure regime applies not only to issuers but also to anyone whose } \\
\text { transactions may be considered price sensitive (AMF Reg. 98-07). }\end{array}$ \\
\hline Assessment & Fully Implemented \\
\hline Comments & $\begin{array}{l}\text { The IOSCO Principles do not define what should be construed to be a public offering and the } \\
\text { definition of the French system is consistent with international practice. Further, the system } \\
\text { applies continuing disclosure obligations across the board and not just to companies listed on } \\
\text { the so-called regulated market. With respect to periodic information, the law requires updated } \\
\text { disclosure and the provision for semi-annual reports that include a full set of accounts } \\
\text { (recommendation 99-01). IOSCO requires at least semi-annual financial reporting for it to be } \\
\text { considered timely. In this case the disclosure should be enough to permit the investor to } \\
\text { evaluate the mid-period performance of the issuer, but summary reports are permitted. } \\
\text { It is suggested that the new Règlement Général use the authority provided in the COMOFI } \\
\text { (L.212-12; relating to the mission of overseeing the savings invested in financial instruments } \\
\text { and the ongoing disclosure requirements to assure adequate public access to periodic financial } \\
\text { information). The AMF has been proactive in providing guidance on issues, such as use of } \\
\text { financial indicators. It also facilitated access to public information on listed and unlisted } \\
\text { public issues readily to the investing public. The same requirements apply to government } \\
\text { owned entities. }\end{array}$ \\
\hline Principle 15. & Holders of securities in a company should be treated in a fair and equitable manner. \\
\hline Description & $\begin{array}{l}\text { Company law (the Code de commerce and the Code Civil) and applicable COB guidance (to } \\
\text { be incorporated in AMF rules) require issuers to treat shareholders in a fair and equitable } \\
\text { manner, as evidenced in takeover and allotment procedures, and prohibitions on selective } \\
\text { disclosures. Although the AMF does not have direct jurisdiction over corporate organization } \\
\text { for example, if a company law provision is not met and is likely to be detrimental to } \\
\text { investors' rights, the AMF may ask for a court order to force the issuer to comply with its } \\
\text { legal obligations. } \\
\text { French companies are either SAs (Sociétés anonymes) or SCPAs (Sociéte en commandité par } \\
\text { actions), which are like limited partnerships. Shares in a listed company can be held in } \\
\text { registered or bearer form, and must be negotiable. All securities are dematerialized and hence } \\
\text { even so-called "bearer shares" must be transferred through an electronic registry. Most listed } \\
\text { companies are SAs. Art. } 1844 \text { of the French Civil Code provides that shareholders must } \\
\text { participate in collective decisions, that profits and losses must be distributed in proportion to } \\
\text { capital contributions, and that, in the event of a winding up, shareholders must participate in } \\
\text { proportion to their stake (see Art. 1844-9 of the Civil Code). Different classes may be treated } \\
\text { differently, but preferential shares would not carry voting rights. } \\
\text { The rights and interests of shareholders cannot be changed without a vote, and in the case of } \\
\text { classes, without a vote of the class affected. For general meetings shareholders are entitled to } \\
\text { (i) financial and accounting documents; (ii) the Board of Directors management report, which } \\
\text { since } 2003 \text { must address governance and internal controls; (iii) the annual report of statutory } \\
\text { auditors; (iv) the proposed resolutions; (v) the aggregated amount of salaries paid to the senior } \\
\text { management; and the (vi) list of related-party transactions (which require approval of the board } \\
\text { prior to execution, a special auditor's report, and shareholder approval). Notice of meetings } \\
\text { must be given } 30 \text { days in advance of convening the meeting, and documents must be provided }\end{array}$ \\
\hline
\end{tabular}




\begin{tabular}{|c|c|}
\hline & 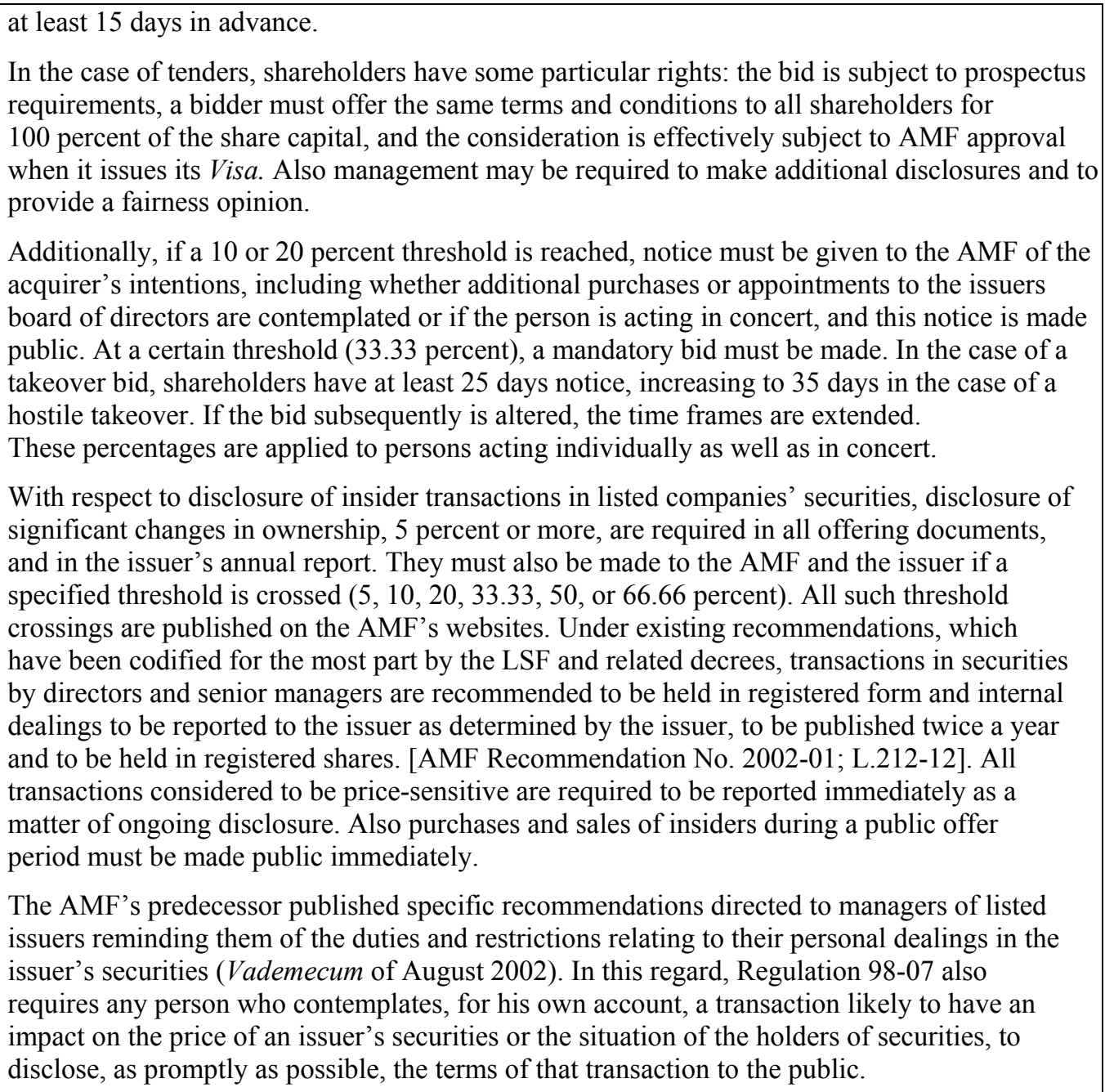 \\
\hline Assessment & Broadly Implemented \\
\hline Comments & $\begin{array}{l}\text { The public float in French companies can be relatively small and there remain companies in } \\
\text { which there is significant governmental ownership or so-called "golden shares." The } \\
\text { activities and interest of the government in these entities is transparent, however, and the } \\
\text { extent of such participation is declining. IOSCO does not take a position on these matters. } \\
\text { While disclosure is made in the listing documents and Annual Report of shareholdings of } \\
\text { officers and directors, it is not clear that material changes in beneficial ownership are } \\
\text { sufficiently timely made to the public, if the change is not sufficient to constitute price } \\
\text { sensitive information. IOSCO requires very timely disclosure of price sensitive change of } \\
\text { control transactions, large shareholder transactions at levels well below a controlling interest, } \\
\text { and "material" changes in beneficial ownership of insiders holding voting shares, when no } \\
\text { tender is pending. The Assessment Methodology does not define materiality, but disclosure at } \\
\text { the } 5 \text { percent threshold or at the price sensitive threshold would not necessarily be sufficient. } \\
\text { Disclosure to the issuer is not a substitute for disclosure to the public. For example, a sale of } \\
\text { all securities by an insider might be of interest, and the requirement of transparency is also a } \\
\text { discipline on insider dealings. Although the LSF (which codified the current AMF } \\
\text { recommendation on the topic) now requires directors and senior managers to report their } \\
\text { dealings (regardless of the size of the transaction) to the issuer, in order for the issuer to }\end{array}$ \\
\hline
\end{tabular}




\begin{tabular}{|c|c|}
\hline & $\begin{array}{l}\text { disclose that information to the public (as described above), the issuer is not required to } \\
\text { publish that information unless it meets another requirement more than semi-annually. As } \\
\text { such disclosure is now a legal obligation (as opposed to a recommendation) as to which the } \\
\text { AMF is vested with the power to set forth, in the Règlement Général, the framework for } \\
\text { disclosure, including the deadlines, this rating can be upgraded at such time as further } \\
\text { guidance as to timeliness of information provided to the general public is made evident. } \\
\text { The Règlement Général may include changes based on a consultation commenced by the } \\
\text { AMF relative to the improvement of information dissemination to the market and the AMF } \\
\text { has the capacity to develop additional regulations with respect to management's voting shares } \\
\text { and major shareholders. The AMF has recently constituted a specialized commission on } \\
\text { minority shareholders' rights, which may make additional enhancements. } \\
\text { In this respect, the AMF advises that a draft proposal for the transposition of the provisions of } \\
\text { the market abuse directive in regard to the disclosure obligation of transactions of managers } \\
\text { and insiders is being reviewed. }\end{array}$ \\
\hline Principle 16. & Accounting and auditing standards should be of a high and internationally acceptable quality. \\
\hline Description & 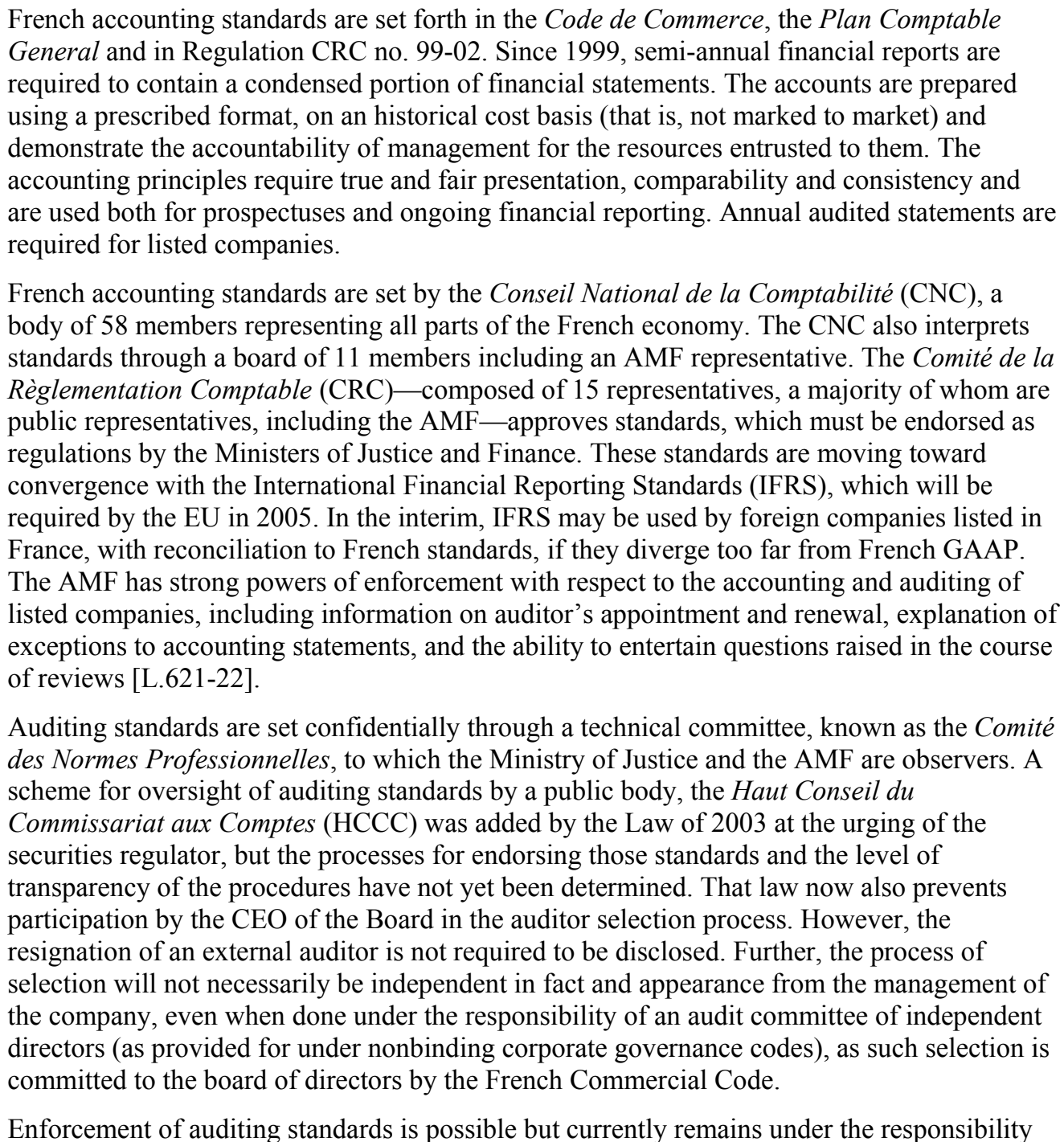 \\
\hline
\end{tabular}




\begin{tabular}{|c|c|}
\hline & $\begin{array}{l}\text { of a professional peer group known as the Compagnie Nationale des Commissaires aux } \\
\text { Comptes (CNCC), which has a quality control mechanism that meets current EU standards. A } \\
\text { debriefing after a quality control review is held with an AMF representative but cannot lead } \\
\text { to a revision of the audit. Standards for independence of auditors are general avoidance of an } \\
\text { appearance of impropriety coupled with certain prohibitions on services relating to, for } \\
\text { example, bookkeeping and valuations. } \\
\text { The relevant French authorities have established additional rules and guidance with respect to } \\
\text { services provided by an accounting firm to an audit client through the Comité de Déontologie } \\
\text { de l'Indépendance des commissaires aux comptes des sociétés faisant appel public a } \\
\text { l'épargne (CDI), in cooperation with the AMF. The CDI became operational in } 1999 \text { and has } \\
\text { been replaced by the newly established HCCC, which became operational in December } 2003 . \\
\text { The AMF has been pro-active in alerting auditors to issues with respect to consolidated } \\
\text { financial statements, including confirmation of balances and transactions; considering } \\
\text { additional procedures where affiliated entities are located in offshore jurisdictions; and } \\
\text { auditing directly significant subsidiaries where significant amounts or risks are involved. }\end{array}$ \\
\hline Assessment & Partly implemented \\
\hline Comments & $\begin{array}{l}\text { The AMF has been at the forefront of the international dialogue on improving accounting and } \\
\text { auditing standards and the new Act contains provision for there to be a domestic audit } \\
\text { oversight board. IOSCO does not specify a particular accounting standard. The European } \\
\text { accounting standard dates from } 1976 \text { and the new standard requires implementation of IFRS } \\
\text { for domestic listed companies filing consolidated returns on a going concern basis as of } \\
\text { January 2005. France currently uses a converging set of accounting standards (see above } \\
\text { discussion). There remain some significant differences between French GAAP and the IFRS } \\
\text { related to depreciation, valuation of investment assets, statements of changes in equity, and } \\
\text { transactions with related parties. } \\
\text { The powers of public authorities to oversee audits should be augmented and this is in process. } \\
\text { The execution of oversight by the new authority should be kept under robust review with } \\
\text { adequate communication with the appropriate regulatory authorities. The AMF appears to be } \\
\text { associated for listed companies only. The ultimate outcome of the work of the Haut Conseil } \\
\text { should provide for a sufficient relationship with the AMF with respect to the audit of any } \\
\text { public company. In this regard the French securities regulator should be commended for its } \\
\text { support of improvements in this area. }\end{array}$ \\
\hline \multicolumn{2}{|r|}{ Principles for Collective Investment Schemes } \\
\hline Principle 17. & $\begin{array}{l}\text { The regulatory system should set standards for the eligibility and the regulation of those who } \\
\text { wish to market or operate a collective investment scheme. }\end{array}$ \\
\hline Description & $\begin{array}{l}\text { In France, the scheme for regulation of CIS covers the product, the manager or operator, the } \\
\text { depository or custodian, and the "eligibility" to operate and to market such schemes. Public } \\
\text { offerings require authorization from the AMF of the offering (Agrément or pre-approval, see } \\
\text { L.214-1 et seq. ; see also Principle 19) and also authorization (Agrément ) of the asset } \\
\text { manager (see also Principle 21). The AMF is the competent authority (L.621-6). } \\
\text { Generally, under the LSF, there are three types of funds of CIS : (1) CIS under the UCITS } \\
\text { Directive, which encompass two main types (open-ended investment companies and } \\
\text { unincorporated investment funds), (2) a second level of registered funds, for qualified } \\
\text { investors (venture capital funds and private equity, future funds and employee investment } \\
\text { funds); and (3) a third level of contractual funds (debt securitization funds and unlisted real } \\
\text { estate investment funds) (See Principle 18). Asset management companies also are of three } \\
\text { types: (1) Sociétés de gestion de portefeuille (SGP), whose activities encompass both }\end{array}$ \\
\hline
\end{tabular}


individual portfolio management and management of Collective Investment Schemes; (2) Sociétés de gestion d'OPCVM (SGO), whose activities are limited to the management of collective investment schemes (although as of adoption of the new UCITS Directive and the LSF this distinction between (1) and (2) will be removed); and (3) investment services providers who offer asset management services (Licensing of these intermediaries is addressed in Principle 21). In this regard, more than 2/3 of all CIS offered in France are UCITS of various types.

All CIS marketed in France, whether domestic or foreign, must be offered through persons authorized by the AMF (or otherwise qualified — such as through banks); although certain qualified investors may purchase offshore funds. Marketing may be done by asset managers, investment services providers with customer accounts, and through the bank network. Direct solicitation is subject to the particular rules for démarchage (direct marketing or unsolicited selling), but neither these, nor the conduct of business rules, except for certain requirements with respect to information disclosure generally apply to sales within the retail banking network through which most CIS are distributed. Depositories (L.214-3) must also be licensed, meet specific capital requirements, and must be constituted as a separate entity from that of the asset management company itself (L.214-17; 214-29).

In the case of asset management companies, authorization requirements pertain to financial capacity, management competence and integrity, an appropriate operational program, and the existence of specified personnel responsible for segregation of duties and adequacy of internal procedures, a déontologue to address conflicts of interests, and someone accountable for risk management (which could be the same person). (See, also Principle 21 re: compliance personnel in investment services providers that perform asset management functions). The authorization process requires the program of operations to be tested taking into account management strategies and the types of clients targeted. The process of authorization requires completion of a specified Authorization dossier, based on the types of CIS being offered and the types of investments to be held by the CIS. More stringent operational requirements could be applied to asset managers offering more complex products than those offering plain vanilla UCITS. Changes relevant to the conditions of authorization must be notified to the AMF.

As of November, 2003 there were 525 approved SGPs; 45 approved for real estate funds, and 6 for securitized offerings listed on the AMF website, plus 170 investment services providers and credit institutions permitted to offer asset management services, 87 depositories, and more than 8000 funds not including private equity, real estate and employee savings. As in the case of other investment services providers, the AMF has authority to undertake investigations, inspections and to bring appropriate enforcement actions (L.621-9 pt. $2,3,7 \& 9)$. The regulatory authority is responsible for continuing compliance, but this authority is shared with (1) external auditors (whose appointment is subject to approval of the AMF), who prepare annual reports and semi-annual reviews (in the case of funds with more than EUR 150,000,000 in assets or which have so-opted, quarterly reviews) of diversification, investment type and eligibility, and which report exceptions in compliance to the AMF, and (2) depositories, which monitor the management activities and compliance with rules and investor's interests and which undertake the role of custodian of the assets of the funds. The AMF engages in on-site inspections of managers and visited 80 management companies and investment services providers in 2002, and 71 in 2003. Target coverage is all managers within a five- year period, although currently the staff designated to conduct on-site inspections is very small (7) and more attention could be paid to oversight of depositories. (See also Principles 18 and 20)

The AMF has a program for prioritizing the firms that it designates for on-site inspection, and conducts theme inspections of emergent issues. However, it does not have an inspection manual. It does have a manual for its offsite oversight activities. The AMF also issues general guidance based on the results of its inspection program. For example, it recently underlined 
the need to ensure strict adhesion to the principles of equal treatment of investors, and commenced a program of reviewing pre-designated allocation provisions for aggregated orders. Theme inspections also have been conducted related to valuation.

The focus in 2002 and 2003 was largely directed toward the use and risks of complex derivatives and illiquid assets. The AMF demands clarifications on the use of asset swaps and the valuation in fixed income funds, the use of credit derivatives, valuation procedures and risk management, through the review of a specific program of the asset management companies concerned (around 20). It also reviews procedures for the selection of "third party validators" and valuation in asset management companies using structured swaps in connection with guaranteed and structured funds (around 30). The number of these is fairly limited. The AMF has also been pro-active in addressing potential vulnerabilities. Hence, for example, it has issued guidance on market timing, and the asset management companies visited in this assessment indicated that either proactively, or in consequence of AMF activities, they had performed internal reviews for problematic activities.

COB Reg. 96-03, most recently amended in 2003, addresses conduct of business generally and Instruction 15 Dec. 1998, addresses delegation specifically, among other things. If aspects of CIS management are delegated, French law requires that the delegee also be authorized in France or in a jurisdiction under circumstances that will not adversely affect the ability of the AMF appropriately to oversee the CIS. In either case, the delegator remains accountable for compliance and must specify how it will oversee the delegee. In the case of a non-European area country the AMF must either have an MoU or arrangements by comfort letter to permit it to audit the delegee. If more than 30 percent of the activity is delegated, preapproval also is required. In any event, the participants in the CIS must receive information on any delegation.

Basic customer protection rules require fair and equitable treatment of customers, fees that are not inconsistent with best execution, and disclosure and in some instances limits, on fees and charges. Joint guidance was recently provided by the $\mathrm{CB}$ and the AMF with respect to soft dollars and payment for order flow. With respect to French products traded on regulated markets, there is currently a concentration rule, therefore no specific guidance is provided on best execution. This may change if derogations from existing law are provided in the future.

Net Asset Value (NAV) is reported daily for funds with marketable securities in excess of 150 million Euros, that is 33 percent of all funds and 75 percent of global assets, at least every two weeks for UCITS with fewer assets, and periodically, but not less frequently than semi-annually for funds, like real estate funds, private equity funds and employee funds. Such data is maintained in an electronic database of the AMF. Annual audited reports are available, and the AMF can call for special reports. More particularly, upon request, the AMF may ask at any time in addition to periodic auditors' reports (quarterly and at least semi annual report) of the CIS, for special reports, for instance to describe the valuation procedure of the fund or of the precise portfolio. Accordingly, although the AMF does not routinely review periodic and annual reports, the NAV of each CIS (except real-estate funds, private equity funds, employee funds) is reported permanently on a ongoing basis to the AMF. Such reports permit the AMF through statistical filters to detect abnormal variation in the NAV, which may lead to demand further information (reports for instance) to the fund. The NAV is established on a daily basis for 2300 funds (in a total of 7900 funds). Other funds calculate an NAV at least every 2 weeks. These data (NAV) have been available for any fund offered to the general public (6500/7900 funds) on the web site of the AMF (with the prospectus) since midMarch 2004.

The AMF examines whether (i) the management company is independent ("Chinese wall" organization); (ii) the UCITS ( and its operator/manager) are organized so as to avoid risks of conflicts of interests and (iii) that the conditions for information disclosure to investors are 


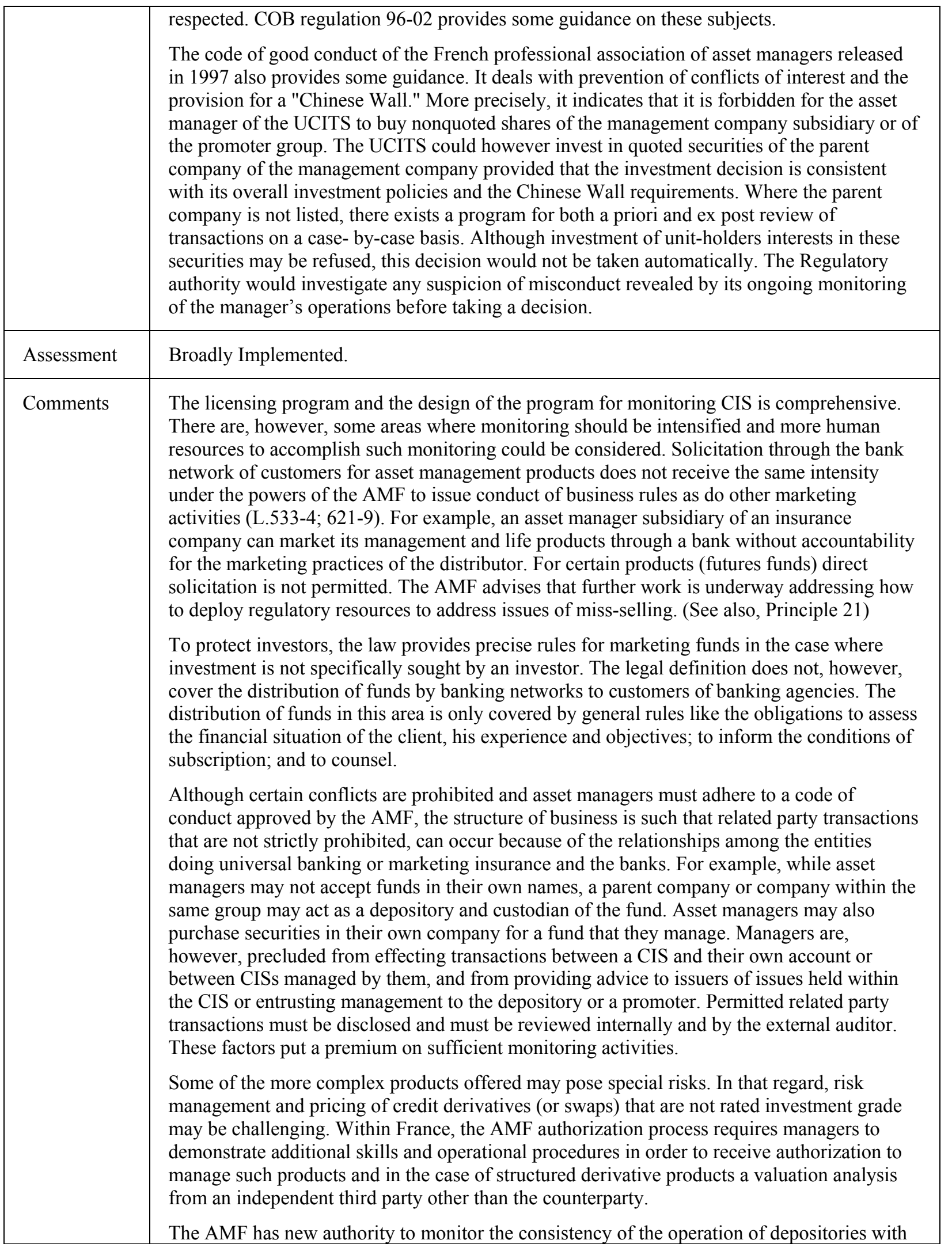




\begin{tabular}{|c|c|}
\hline & $\begin{array}{l}\text { relevant regulations. It advises that it conducted theme inspections of depositories in } 2003 \text { but } \\
\text { has itself determined that a more active program of inspections is desirable. } \\
\text { In this regard, the AMF has conducted a review of the organization and procedures of funds } \\
\text { depositories ( } 87 \text { ) in order to identify risk issues, to assess the situation of the market and to } \\
\text { propose a strengthening of the depositories regulation. The assessor suggests promptly } \\
\text { carrying forward strengthening of this program. } \\
\text { The AMF also advises that changes are being made in these CIS rules, both within France, to } \\
\text { take account of the new law, and at the European level and that therefore adherence to } \\
\text { standards may be enhanced by new requirements or procedures. The AMF published a } \\
\text { modernized text for certain requirements in the JORF on November } 22,2003 \text { and also } \\
\text { indicates that work is ongoing with respect to use of the right to vote in CIS, anti-money- } \\
\text { laundering, prime brokerage, contractual funds and funds submitted to "light" regulation. } \\
\text { Although the AMF believes that appropriate powers and monitoring of related party } \\
\text { transactions are in place, it advises that close attention will be paid to detailing the procedures } \\
\text { and monitoring arrangements. }\end{array}$ \\
\hline Principle 18. & $\begin{array}{l}\text { The regulatory system should provide for rules governing the legal form and structure of } \\
\text { collective investment schemes and the segregation and protection of client assets. }\end{array}$ \\
\hline Description & 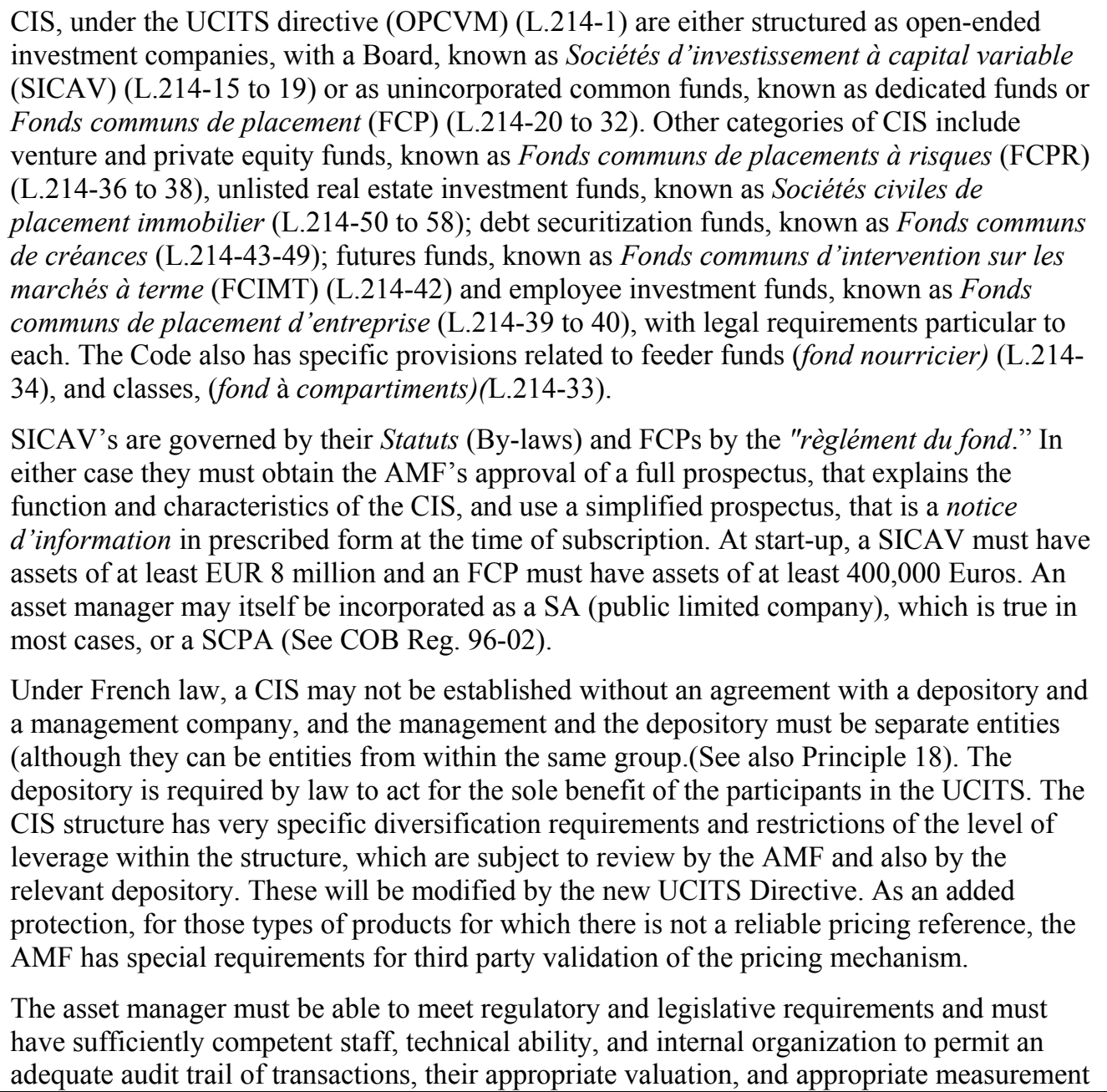 \\
\hline
\end{tabular}




\begin{tabular}{|c|c|}
\hline & $\begin{array}{l}\text { of the risks attributable to the type of fund that is being managed. The manager must also } \\
\text { keep separate portfolio or discretionary activity and other asset management activity for its } \\
\text { clients. Internal audits of the assets of a CIS are required to be made by back office personnel, } \\
\text { whose appointment must be notified to and who can be disapproved by the AMF. Investment } \\
\text { companies that provide asset management services must have specifically designated } \\
\text { compliance officers, and in either case, records must be maintained consistent with a schedule } \\
\text { provided by the AMF in accordance with its guidance or otherwise under relevant national } \\
\text { law and must to permit the reconciliation of transactions. Absent a specific requirement for } \\
\text { retention, under relevant company law, records would be required to be retained for } 10 \text { years } \\
\text { (L.123-22 of the Code de commerce). } \\
\text { Liquidation or transfers of more than } 30 \text { percent of assets must be reported to the AMF, } \\
\text { which may monitor any winding up procedure to assure equitable treatment of customers. } \\
\text { Funds must be returned to participants in such a case within a specified time frame. Mergers } \\
\text { and suspensions must also be reported to the AMF. } \\
\text { The AMF has advised all CIS operators that all investors be individually informed when a } \\
\text { major change (such as a merger) happens. This information must be sent by individual letter } \\
\text { when the change has an impact on the rights on unit-holders/shareholders. When the impact is } \\
\text { neutral for the investor, the information is provided by a press release or a periodic report } \\
\text { (Instruction du } 15 \text { décembre 1998). }\end{array}$ \\
\hline Assessment & Fully Implemented \\
\hline Comments & $\begin{array}{l}\text { Careful attention should be paid in audit programs, whether on- or off-site, to related party } \\
\text { transactions and valuations of products for which there is no market (See Principle 17). The } \\
\text { treatment of these issues, in particular with respect to products that would be characterized as } \\
\text { senior securities, the existence of which (if not covered) has the potential to dilute the fund, } \\
\text { thus adversely affecting participants' interests, should be covered by monitoring programs. In } \\
\text { this regard, the AMF has a program for approving the designation of funds auditors and for } \\
\text { monitoring on-site audits by the professional body (for example, up to } 15 \text { per year.) Further, } \\
\text { use of derivative products, especially structured products within retail CIS, has been limited } \\
\text { to very few companies and receives additional oversight and heightened disclosure of risks. } \\
\text { The AMF can ask for an update on internal controls and did so in } 2003 \text { with respect to the } \\
\text { controls over valuation for complex derivative products. } \\
\text { As mentioned above in Principle } 17 \text { additional capacity to perform on-site work may } \\
\text { facilitate ongoing oversight. }\end{array}$ \\
\hline Principle 19 & $\begin{array}{l}\text { Regulation should require disclosure, as set forth under the principles for issuers, which is } \\
\text { necessary to evaluate the suitability of a collective investment scheme for a particular } \\
\text { investor and the value of the investor's interest in the scheme. }\end{array}$ \\
\hline Description & $\begin{array}{l}\text { COB Regulation } 89-02 \text {, as modified by } 2000-08 \text { and detailed in Instruction } 15 \\
\text { December 1998, relates to the information that must be provided to subscribers to CIS or } \\
\text { individuals with managed portfolios. The funds must be registered except for some offered to } \\
\text { qualified investors, which are very high net worth individuals; these may instead submit to a } \\
\text { "regulation light," or (procédure allégée) which only requires a notice of certain specifics to } \\
\text { the AMF and no pre-approval of a CIS prospectus. Basic information required in this case is } \\
\text { the name of the CIS, its legal nature and type, date of first subscription, asset manager, any } \\
\text { delegations, depository, the auditor, the investment policies and risks, whether it invests in } \\
\text { other OPCVMs, and the frequency of valuation. Specified documents are also provided to the } \\
\text { AMF in this case. } \\
\text { The AMF has a two-level requirement for public offers, a full prospectus (note d'information }\end{array}$ \\
\hline
\end{tabular}




\begin{tabular}{|c|c|}
\hline & $\begin{array}{l}\text { complète) and a summary, or simplified, prospectus or notice d'information, which under EU } \\
\text { law is the basic marketing document. Of course, clients must be provided the full prospectus } \\
\text { free of charge on request. The notice may be offered before subscription, delivered on } \\
\text { subscription and made available to the public. The simplified prospectus or marketing } \\
\text { document must contain information on: the legal form, management company, the depository } \\
\text { and custodian(s) if different, institutions that may accept subscriptions and redemptions, } \\
\text { classification (in relation to types of investments), investment focus and strategy, } \\
\text { recommended minimum period of investment, guarantee or protection, if any, and related } \\
\text { costs, date and frequency and methodology of calculation of net asset value and place of } \\
\text { publication, subscription and redemption terms, fees and charges (if performance fees, } \\
\text { performance indicator), and tax treatment (recommended). Information on the identity of } \\
\text { management and administration of the CIS is in the full prospectus. When the fund is } \\
\text { authorized, the application submitted to the AMF must disclose all the mandates and } \\
\text { activities undertaken by the persons in charge of management and administration. Guaranteed } \\
\text { funds require additional disclosure. } \\
\text { The AMF has to approve the offering (except as specified above) if it is initiated in France. If } \\
\text { initiated from outside France, then it either must be sold through a French management } \\
\text { company or has to be obtained by qualified investors offshore. Material changes must be } \\
\text { reflected in updates to the offering documents. } \\
\text { There are specific book-keeping rules for accounting for CIS. These rules are established by } \\
\text { the CNC and are homologated by the CRC. Mark-to-market valuation is required. The } \\
\text { principle is mark-to-market valuation for derivatives when market prices exist (especially in } \\
\text { regulated markets). Where market prices are not available, especially for certain over-the- } \\
\text { counter products, mark-to-model valuation can be used. In this regard, the AMF requires } \\
\text { substantiation of the valuations by third parties. For SICAVs, each shareholder receives an } \\
\text { annual audited financial report at the time the annual meeting is called. A semi-annual report } \\
\text { is freely available upon request both for SICAVs and FCP. }\end{array}$ \\
\hline Assessment & Fully Implemented \\
\hline Comments & $\begin{array}{l}\text { Additional work is ongoing to make the disclosure requirements more specific, especially } \\
\text { with respect to the articulation of risk factors, investment policies and the type of fund. As the } \\
\text { simplified prospectus is the basic marketing document, consideration should be given to } \\
\text { placing information on principals in that document as well as in the full prospectus. UCITS } \\
\text { with assets of more than EUR } 53.35 \text { million must report their situation to the BdF. These } \\
\text { reports account for almost } 97 \text { percent of all assets held within CIS in France. }\end{array}$ \\
\hline Principle 20. & $\begin{array}{l}\text { Regulation should ensure that there is a proper and disclosed basis for asset valuation and the } \\
\text { pricing and the redemption of units in a collective investment scheme. }\end{array}$ \\
\hline Description & $\begin{array}{l}\text { In principle interests traded on a regulated market must be marked-to-market daily. The } \\
\text { specific requirements for calculation are contained in COB Reg. 89-02, which requires the } \\
\text { regular calculation and reporting of net asset value per share and provides procedures for its } \\
\text { calculation. } \\
\text { As set forth in Principle } 17 \text { above, frequency of reporting of NAV ranges from daily for } \\
\text { UCITS above a certain size, to semi-annually for unlisted real estate investment funds or } \\
\text { funds with other illiquid assets. Futures funds and funds which are traded on an organized } \\
\text { market must quote their net asset prices every trading day. The offering documents must } \\
\text { specify the means and frequency of calculation of per unit value. } \\
\text { With respect to less liquid interests, methods of valuation must be identified by the CIS in its } \\
\text { rules of operation, and methods of valuation for particular products (interest rate products) }\end{array}$ \\
\hline
\end{tabular}




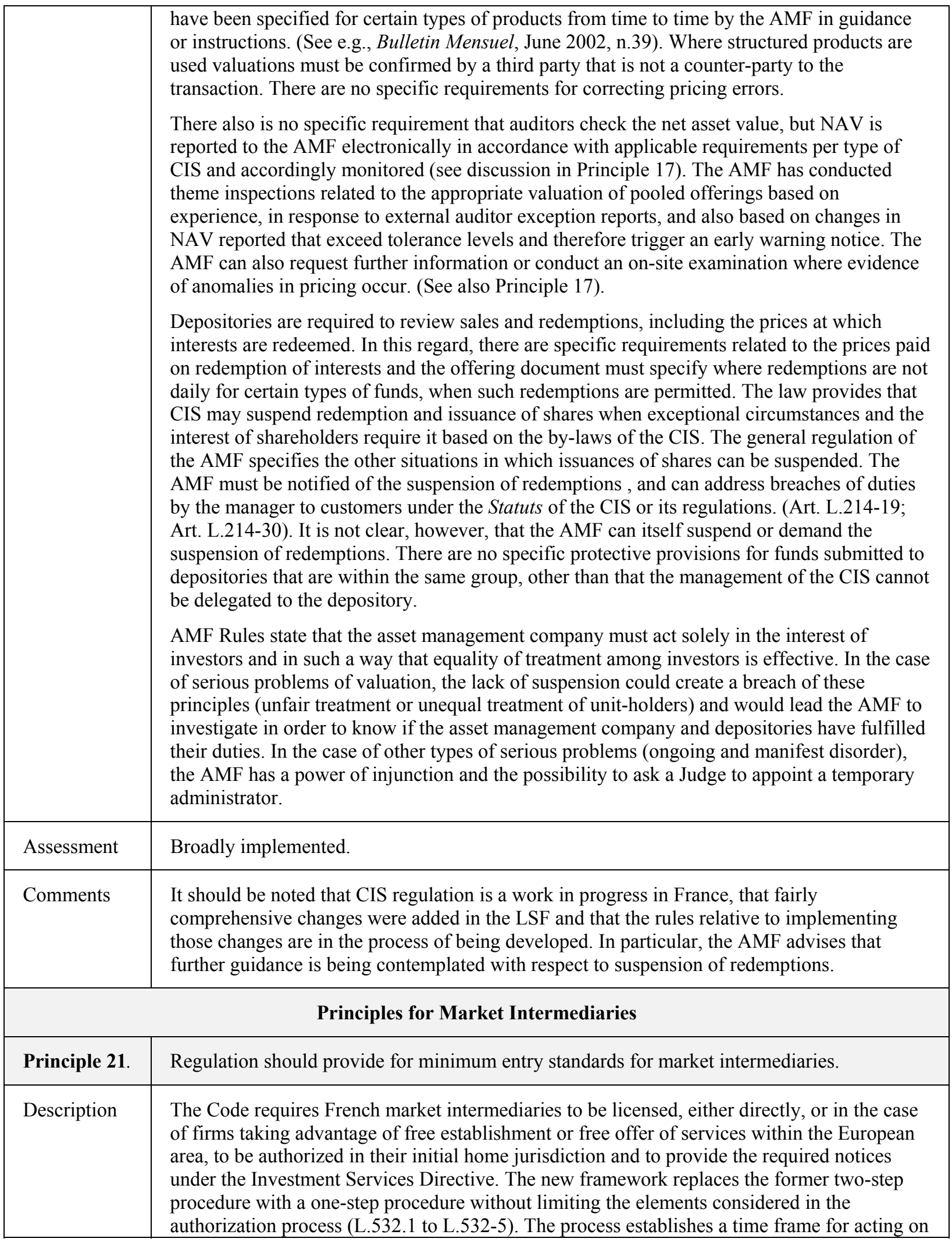




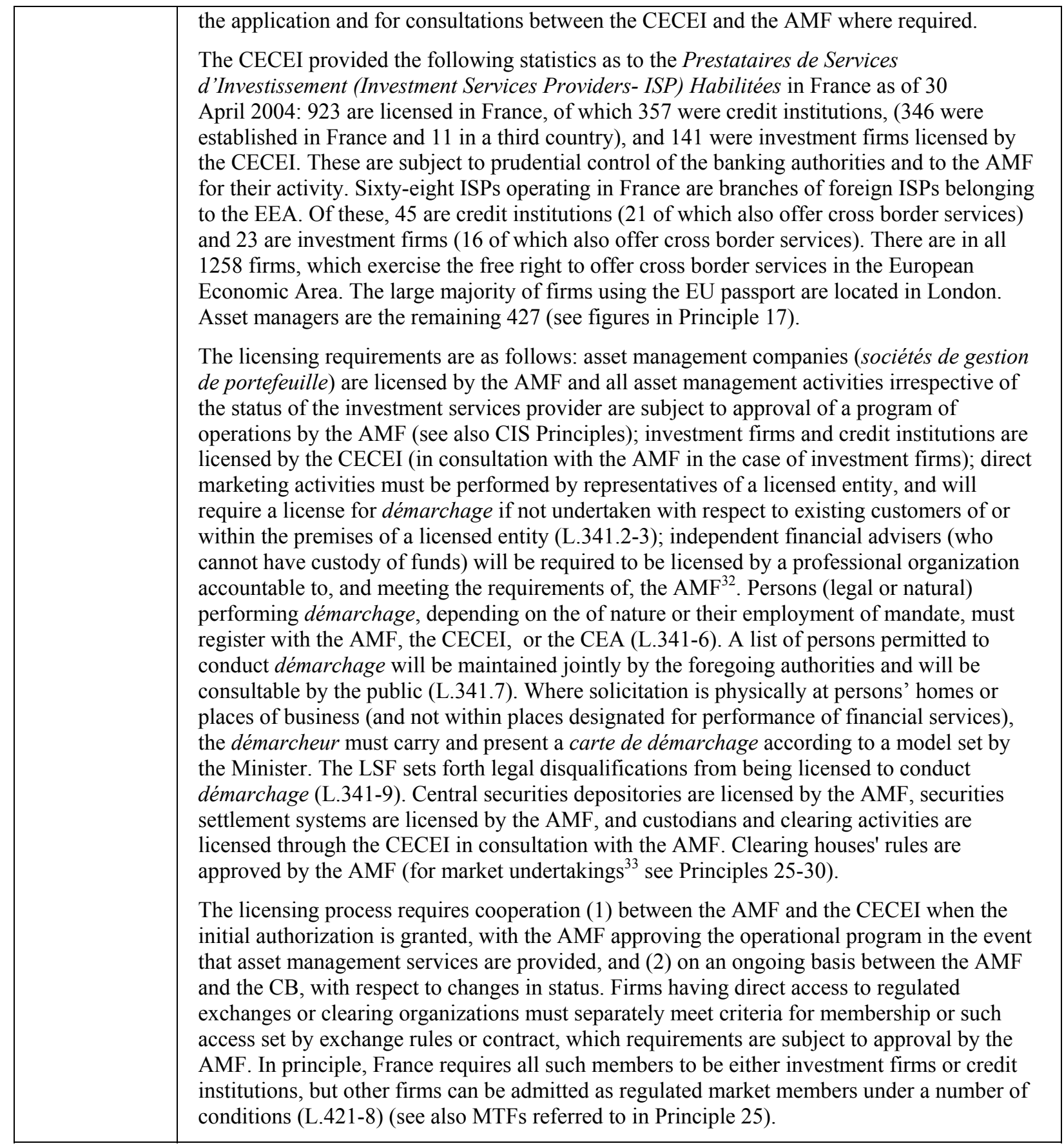

${ }^{32}$ This professional association has rules of conduct, but the license is with the relevant authority.

${ }^{33}$ Market undertakings are commercial enterprises which have as their principal activity operating a regulated market in financial instruments (L.441.1). 


\begin{tabular}{|c|c|}
\hline & 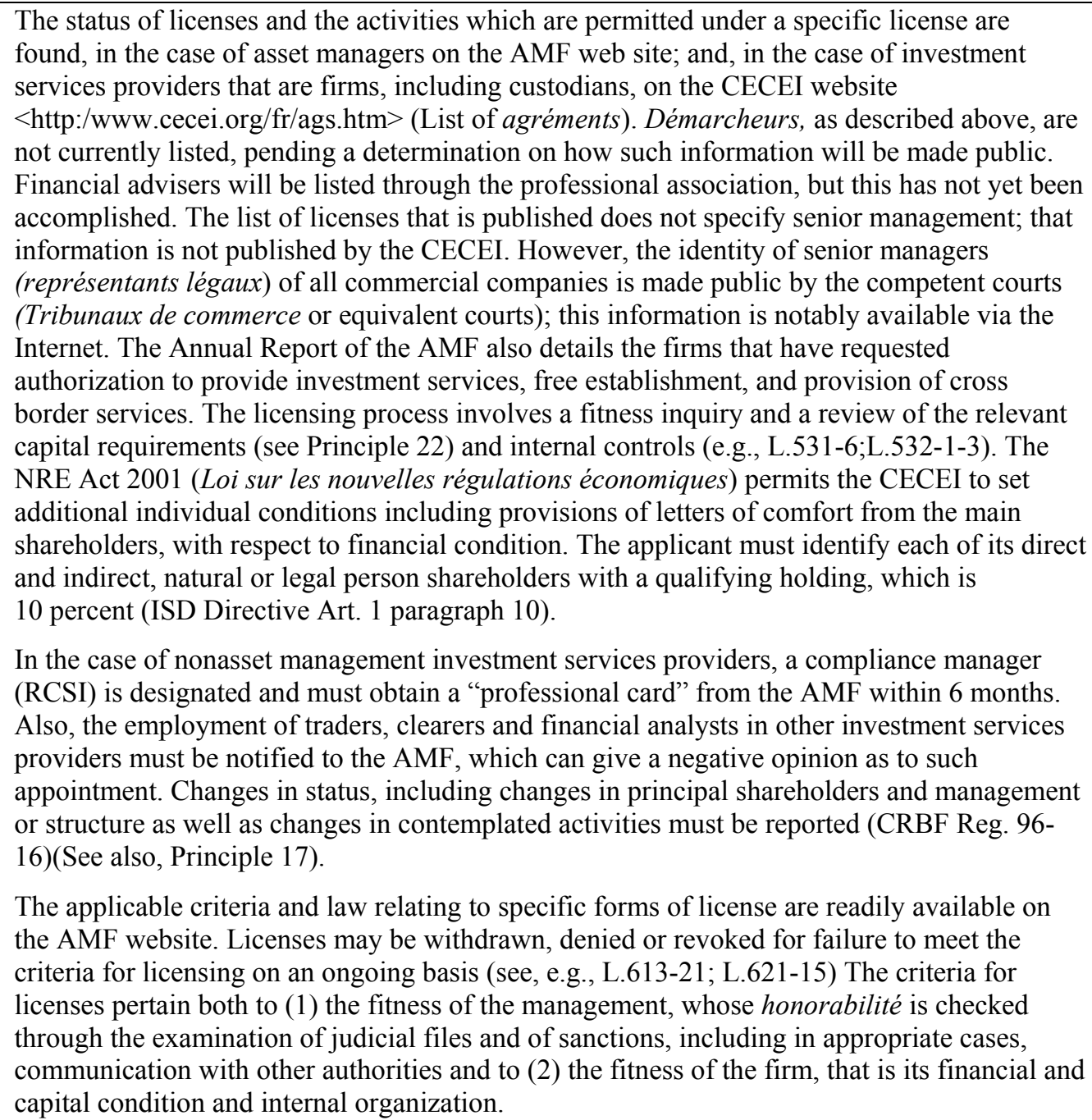 \\
\hline Assessment & Broadly implemented. \\
\hline Comments & $\begin{array}{l}\text { IOSCO finds that the publication of license status is a critical public protection, although } \\
\text { IOSCO does not necessarily require licensing of all employees in the marketing chain, but } \\
\text { only those that manage or control the institution. } \\
\text { Currently, the list of démarcheurs who are permitted to engage in unsolicited selling is not } \\
\text { posted as the decision as to how to make it public has not yet been determined (see AMF } \\
\text { website). The LSF clearly recognizes that publication of properly licensed persons assists the } \\
\text { public to be accountable on its own behalf to deal only with licensed persons. Changes are } \\
\text { currently in process to provide publication of all licensed persons. Licensing information is } \\
\text { currently updated monthly on its website, in the case of AMF, and, in the case of } \\
\text { CECEI/BdF, the information is also updated on the website. More immediate information as } \\
\text { to firms in the course of withdrawing also might be considered. The AMF advises that it is } \\
\text { working on elaboration of the list of démarcheurs and will take steps toward ensuring the } \\
\text { accessibility of such information. } \\
\text { A decree of the Prime Minister, to be adopted after consultation with the Conseil d'Etat, } \\
\text { issues standards/procedures relative to the granting and denial of licenses. It should be }\end{array}$ \\
\hline
\end{tabular}




\begin{tabular}{|c|c|}
\hline & $\begin{array}{l}\text { encouraged that either these requirements for investment services providers or cross- } \\
\text { references be identifiable from the AMF website (see Principle 4). } \\
\text { The CB and the AMF both have programs for monitoring their respective areas of } \\
\text { responsibility. Although various forms of cooperation (for example, a common database, } \\
\text { monthly meetings of senior staff) are used in practice, it is suggested that the CB and AMF } \\
\text { continue to explore assuring that the potential for conduct of business violations to be } \\
\text { evidence of prudential violations or vice versa be adequately addressed by these } \\
\text { arrangements. } \\
\text { The CB also uses preventive analysis based on reporting called Organisation et Renforcement } \\
\text { de l'Action Préventive, which assess various components of risks associated with the activity } \\
\text { of each investment services provider to identify off-site firms that require more attention. } \\
\text { Ideally, this information should be available to the AMF on an as needed basis. }\end{array}$ \\
\hline Principle 22. & $\begin{array}{l}\text { There should be initial and ongoing capital and other prudential requirements for market } \\
\text { intermediaries that reflect the risks that the intermediaries undertake. }\end{array}$ \\
\hline Description & 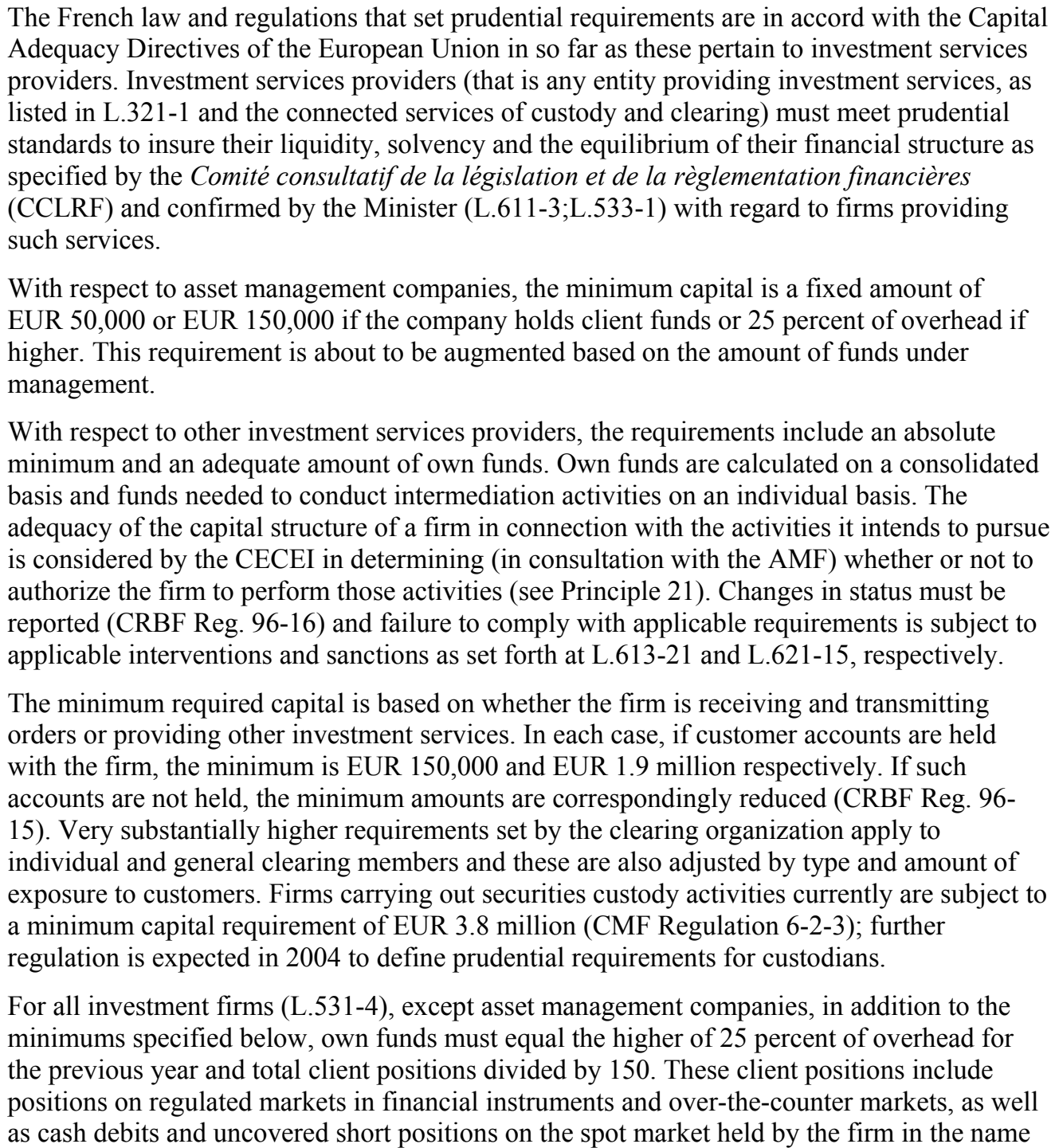 \\
\hline
\end{tabular}




\begin{tabular}{|c|c|}
\hline & 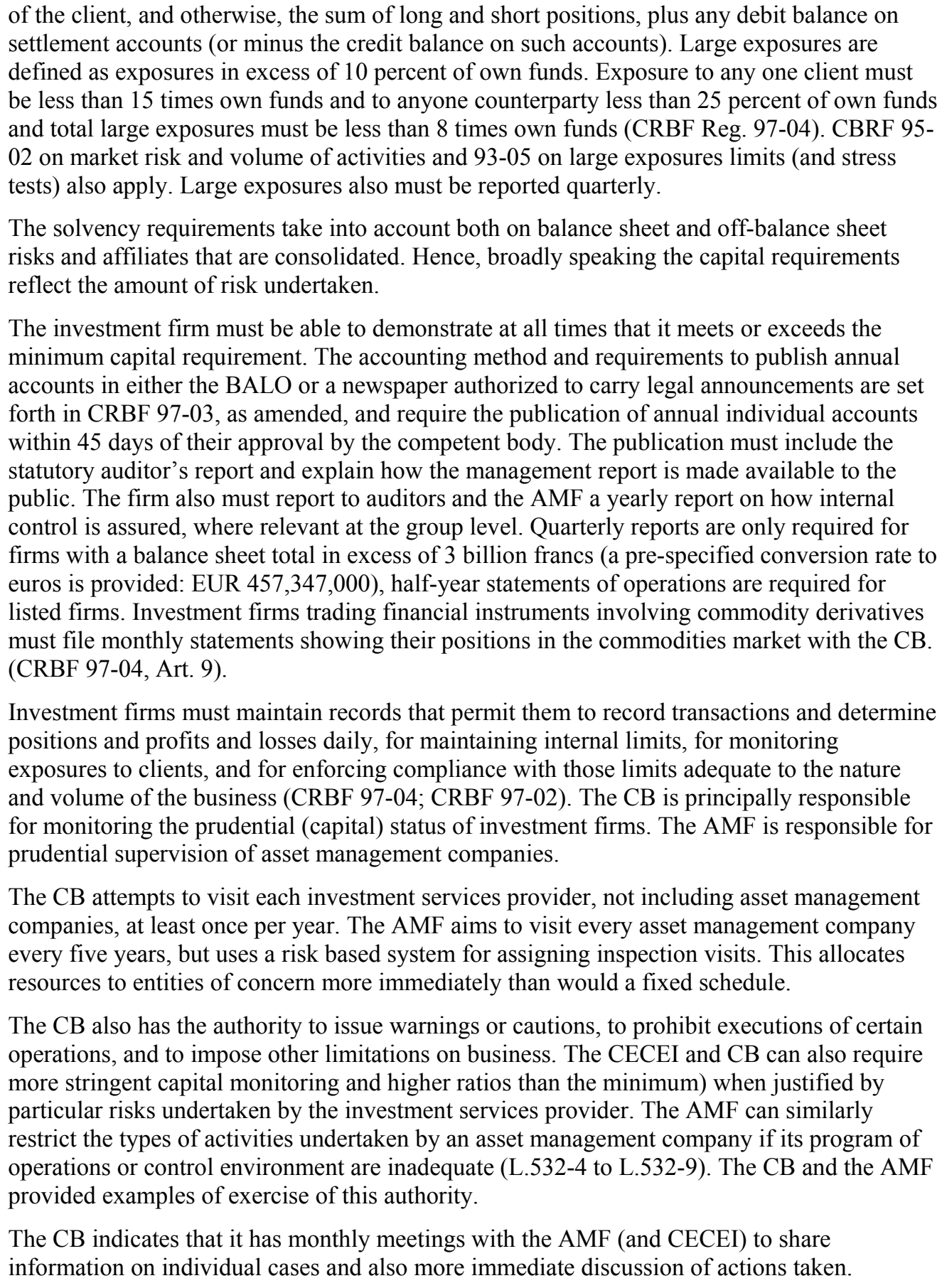 \\
\hline Assessment & Partly Implemented. \\
\hline Comments & $\begin{array}{l}\text { Annual reports or even semi-annual reports may not be sufficient oversight of capital } \\
\text { compliance unless augmented by risk-based or other measures for assuring appropriate } \\
\text { identification of deteriorations of capital (see also Principles } 3,10 \text { and 29). } \\
\text { Typically investment services firms have a trading culture, which may warrant more direct } \\
\text { and frequent supervision than banking institutions, even if they are part of a banking group }\end{array}$ \\
\hline
\end{tabular}


[for example, Barings]. Currently, there is a practice among brokers permitted by Euronext Paris whereby they offer their customers deferred delivery of securities upon deposit of margin as prescribed by AMF rules, although the broker settles on the security on $\mathrm{T}+3$. The customer will make a net settlement with the broker at month end, and is required to post margin daily to account for changes in the market value of the securities purchased. The AMF and the $\mathrm{CB}$ do not regard this as a credit facility, although as in the case of contracts for differences generally there is credit exposure that can be generated as a result of market risk. For this type of activity, for example, monthly reports on deferred settlements - that is settlements between brokers and customers that do not occur within $\mathrm{T}+3$, (taking into consideration the size, as much as EUR 100,000,000 in net exposures at month end-the volatility of securities markets, and the potential for clients to use more than one broker) may not identify problems which are occurring in a timely way. Also, occasional review of margin collections from customers (usually individuals) engaging in such activities may not be sufficient to timely identify significant deteriorations of capital position. Unsystematic perusal of reports required by the $\mathrm{CB}$ and available to the mission on SRDs indicated that one customer had large exposures to several investment firms. Further mid-month testing of such exposures might be desirable for determining the highest level of net exposures, as opposed to only taking a monthly average. Broker SRD exposures are only transparent to the broker and not to the clearing system in which it participates - or for that matter, the market. Indeed, there was anecdotal evidence that some accidents have occurred with respect to SRD activity and the AMF just sanctioned a broker engaged in this activity.

The accumulation of exposures might also indicate other misconduct. In the case of investment firms, which participate as members on French and other regulated markets, in addition to oversight by the regulatory authorities, there is some oversight through the exchange/clearing surveillance process. The Euronext markets for example (and the related clearing house) have rules, as well as trading limits and price limits intended to control the accumulation of risk, that may permit actions resulting in the reduction of positions, and higher clearing capital requirements for investment services firms with direct access to clearing. Typically, clearing houses request more frequent reports of capital condition.

SRDs may only be carried by firms that have sufficient capital to engage in proprietary trading and are limited to the most liquid 260 equities traded on Euronext. The AMF has recently run a test to see how often the 20 percent cash margin deposit had been exceeded in a single day over the past 13 months and the CB includes information on exposures to SRDs in calculating capital ratios.

In the case of SRDs, Euronext Paris also requests a monthly report from its members. This report shows the customers' exposures above EUR 1.5 million. These reports are aggregated by Euronext Paris (and, since January 2004, by LCH-Clearnet SA); a summary is transmitted to the AMF. On the basis of this document, which makes it possible to identify risks linked to a particular security or customer, the AMF may decide to carry out further investigations.

As stated elsewhere, information from the AMF with respect to conduct of business and information of the $\mathrm{CB}$ with respect to prudential compliance should be routinely shared, and shared timely, as problems with respect to conduct of business could affect financial soundness of firms and financial problems can affect conduct of business practices (see Principles 1,8,21,23,29). CB inspectors can be (and are) appointed by the AMF to investigate compliance with AMF rules. In the last three years the $\mathrm{CB}$ has conducted 31 such inspections, in one year amounting to one-third of those conducted. Reports of inspections are provided to the $\mathrm{AMF}$, if completed by the $\mathrm{CB}$ and also to external auditors.

The compensation funds (Euros 70,000/account, which exceeds the EU requirement) also provide some buffer to customers in the event of a firm insolvency. A capital requirement and other prudential requirement for custodians is pending with the Minister of Finance and expected to be effective in 2004. Basel II enhancements with respect to operational risk and 


\begin{tabular}{|c|c|}
\hline & $\begin{array}{l}\text { changes to promote customer funds protection and liquidity also are pending. With respect to } \\
\text { records, each component of investment services provided supervised on a consolidated basis } \\
\text { must maintain necessary records to permit prompt consolidation. }\end{array}$ \\
\hline Principle 23. & $\begin{array}{l}\text { Market intermediaries should be required to comply with standards for internal organization } \\
\text { and operational conduct that aim to protect the interests of clients, ensure proper management } \\
\text { of risk, and under which management of the intermediary accepts primary responsibility for } \\
\text { these matters. }\end{array}$ \\
\hline \multirow[t]{4}{*}{ Description } & $\begin{array}{l}\text { The COMOFI requires investment services providers to have appropriate management and } \\
\text { internal control systems (Principle } 21 \text { and L.611-3; see also L.613-16 and L.613-15), taking } \\
\text { into account the size and nature of their activities. Management organization and the } \\
\text { existence of an internal control structure is part of the licensing process. } \\
\text { Investment services providers other than asset managers are required to have an internal } \\
\text { control structure that meets several specific requirements (CRBF Reg. 97-02; 97-04). For } \\
\text { example, it must address all risks, including credit, market, interest rate, settlement, liquidity, } \\
\text { intermediation (risks to each customer), operational and legal risk, and must have an internal } \\
\text { mechanism for supervising risk limits and for assessing exposure to unsettled } \\
\text { transactions. } 2004 \text { amendments are contemplated to make requirements with respect to } \\
\text { contingency planning and to compliance with all applicable law more precise (see Principle } \\
\text { 24). Although not directly specified, if these risks are managed and customer protection rules } \\
\text { are robust, this should also curtail potential reputational risks. }\end{array}$ \\
\hline & $\begin{array}{l}\text { More generally, investment firm internal controls systems are the responsibility of top } \\
\text { management and the Board, as a matter of law, and must include a particular organization of } \\
\text { accounting and information processing systems, risk and result measurement systems, risk } \\
\text { monitoring and control systems, and cash/securities flow monitoring systems and } \\
\text { arrangements to address settlement risks. The firm must also have mechanisms acceptable to } \\
\text { the CB for valuing financial instruments that do not have an active market. With respect to } \\
\text { separation of functions, CRBF Reg. } 97-02 \text { in particular requires that units responsible for } \\
\text { initiating transactions operate independently of those responsible for validating them at the } \\
\text { accounting level and for settling transactions and implementing risk monitoring procedures. } \\
\text { Corresponding improvements to liquidity and settlement arrangements for securities are being } \\
\text { planned in connection with the relevant settlement system for settling securities on Euronext } \\
\text { markets (See related reports). }\end{array}$ \\
\hline & $\begin{array}{l}\text { The AMF requires a yearly report on the conditions in which investment services and } \\
\text { connected services are provided regardless of where the services are provided. Additionally } \\
\text { those investment services providers supervised by the CB must provide an internal control } \\
\text { report which includes a list of investigations performed, the shortcomings observed, if any, } \\
\text { the follow-up corrective action taken, changes to the control environment, especially related } \\
\text { to new activities or risks, measurement and monitoring of risks, and compliance with } \\
\text { applicable limits that is presented to the decision-making body of the firm and also to the CB. } \\
\text { Independent auditors are not subject to the professional secrecy requirements vis- } a-v i s \text { their } \\
\text { investment services provider customers with respect to communications to the AMF, CB and } \\
\text { CECEI or other public authorities. }\end{array}$ \\
\hline & $\begin{array}{l}\text { Both asset management firms and other investment services providers are required to have a } \\
\text { compliance or related supervisory function, which ensures that the firm's operations, } \\
\text { procedures and organization comply with legal requirements. General conduct of business } \\
\text { requirements for investment services providers are found at L.533-4 et seq.; with L.533-6 } \\
\text { providing special requirements for an internal code of conduct relative to conflicts of interest } \\
\text { and a suitability/ know your customer rule. As specified by IOSCO, investment services } \\
\text { providers must conduct themselves with loyalty and equity in the best interests of their }\end{array}$ \\
\hline
\end{tabular}




\begin{tabular}{|c|c|}
\hline & $\begin{array}{l}\text { customers and of the integrity of the markets; must act with competence, care and diligence; } \\
\text { must devote adequate resources and procedures to conduct these activities related to } \\
\text { customers and market integrity effectively; must determine the financial situation of their } \\
\text { clients and their investment experience; must communicate appropriate information to clients; } \\
\text { must avoid conflicts of interests and treat clients equitably if such conflicts cannot be } \\
\text { avoided; and must comply with all regulation applicable to the exercise of their activities in a } \\
\text { matter that promotes the best interests of their clients and the integrity of the market. More } \\
\text { particularly, a piste d'audit (audit trail) must be maintained to be able to reconstruct } \\
\text { transactions and customers must receive statements of account. General decision } 99-06 \text { of the } \\
\text { CMF and L.123.22 of the Code of Commerce govern the retention of records. In particular, } \\
\text { order tickets must be maintained for five years and trading records at the market must be } \\
\text { maintained longer. In general, accounting records must be retained for } 10 \text { years. } \\
\text { Requirements relative to reconstructing trading activity are in the process of being made more } \\
\text { explicit. Requirements for segregation of customer funds are in compliance with European } \\
\text { requirements (L.533-7) and considerations for enhancement are in process. Disclosure of } \\
\text { risks is provided for derivatives and for other issues, including UCITS, there is prospectus } \\
\text { disclosure. } \\
\text { The intermediary must be able to declare suspicious activities and also report transactions for } \\
\text { which the beneficiaries are unknown. France permits bearer shares, which may affect } \\
\text { customer identification and tracing of funds and should be more fully explored in any AML } \\
\text { review. }\end{array}$ \\
\hline Assessment & Fully Implemented \\
\hline Comments & $\begin{array}{l}\text { With respect to asset management companies, the AMF has procedures to review appropriate } \\
\text { internal controls, but the regulations do not currently provide significant guidance as to } \\
\text { general expectations, other than avoidance of conflicts of interest (and maintenance of certain } \\
\text { ratios) and there is no requirement that the assessment of controls be independent. The AMF } \\
\text { also should consider whether more specific requirements are needed for asset managers- } \\
\text { with respect to "know your customer" from the perspective of suitability of transactions. } \\
\text { Documentation of the planned enhancements to the internal control requirements that are } \\
\text { contemplated is also suggested. }\end{array}$ \\
\hline Principle 24. & $\begin{array}{l}\text { There should be a procedure for dealing with the failure of a market intermediary in order to } \\
\text { minimize damage and loss to investors and to contain systemic risk. }\end{array}$ \\
\hline Description & $\begin{array}{l}\text { In the event that the capital, internal control, and provisions for prudential supervision prove } \\
\text { insufficient to prevent the deterioration of a firm, the CB can appoint a provisional } \\
\text { administrator or a liquidator, or refer the matter to a court as may be appropriate to the } \\
\text { situation (L.613-18 and L.613-22 respectively). It can take intermediate steps to direct the } \\
\text { amelioration of a financial or internal control position as well-by requiring corrective action } \\
\text { in response to an investigation, a response to lettres de suite following an on-site inspection, a } \\
\text { formal recommendation or otherwise (L.613-16). In a case of urgency the CB can act without } \\
\text { a proceeding (L.613-23). } \\
\text { If positions are liquidated the funds and collateral held by the broker and by the clearing } \\
\text { institution can be used to pay debit balances and such payments cannot be reversed by an } \\
\text { administrator or in liquidation (L.442-6; L.431-6). The compensation fund also may be } \\
\text { applied. Customer securities and funds are to be identified on the books of the investment } \\
\text { firm and on the books of the clearing organization, and liquid balances are to be held in the } \\
\text { amount owed to customers. A project is underway to enhance the protection of customer } \\
\text { funds. } \\
\text { The compensation fund also may be asked to intervene by the CB in cooperation with the }\end{array}$ \\
\hline
\end{tabular}




\begin{tabular}{|c|c|}
\hline & $\begin{array}{l}\text { AMF (CRBF reg. 99-05 to 99-08; 99-14 to 99-17) (L.322-1 to4). The individual markets of } \\
\text { Euronext have contingency arrangements as well. In this regard, CRBF regulation 97-02, } \\
\text { modified by CRBF regulation 2001-01 and 2004-02, addresses required contingency } \\
\text { planning. } \\
\text { The French authorities do not permit remote clearing members without an appropriate } \\
\text { comfort letter from the jurisdiction of establishment, even within the European Economic } \\
\text { Area. This comfort letter may establish more specific contacts with the home regulator of } \\
\text { such institutions including identifying them to the French regulatory authority for further } \\
\text { oversight if necessary. If cooperation arrangements or other regulatory arrangements of third } \\
\text { countries (especially non-OECD countries) are not adequate, the AMF has the power to } \\
\text { restrict remote membership (L.442-2). The combination of these arrangements may in } \\
\text { practice prove sufficient to address failures in light of the structure of most firms in France } \\
\text { and the predominance of universal banking. But see comments below. }\end{array}$ \\
\hline Assessment & Fully Implemented. \\
\hline Comments & $\begin{array}{l}\text { In addition to the interventions specified above and under Principle } 22 \text {, there is a } \\
\text { compensation fund that can be used to compensate customers, which is EUR } 70,000 \text { for all } \\
\text { accounts of the same customer held with the same institution anywhere. While actions taken } \\
\text { with respect to that fund can be appealed, one question in reviewing this area is the degree to } \\
\text { which the compensation arrangement can be drawn on to prevent the consequences of failure. } \\
\text { It should also be possible to transfer customer open positions in the event of an insolvency of } \\
\text { a firm carrying futures positions. The clearing house is entitled to do so in case of failure of a } \\
\text { clearing member (see General Regulations of the CMF, Art. } 4-2-23 \text {. This is the classic way to } \\
\text { isolate the risk of a default (see IOSCO reports and the Windsor Declaration to which the } \\
\text { AMF's predecessor is a party.) Nonetheless, with separation of the clearing house from the } \\
\text { market it may be necessary to assure that arrangements to handle market events that can have } \\
\text { an impact on credit risk are coordinated. Also, to the extent possible, default procedures } \\
\text { should be transparent. Cross-border coordination arrangements should be designed to } \\
\text { promote ex ante assurance as to application in a crisis. } \\
\text { As set forth at Principle } 22 \text {, there is the possibility that the deferred settlement activities in } \\
\text { equities could cause a failure of a broker and then the clearing system would not be available } \\
\text { to address the losses, which would be absorbed by the broker itself. If these were significant } \\
\text { they might affect the ability of the broker to perform to the clearing institution on other } \\
\text { matters. There is a combination of arrangements to deal with firm failures, but it may be } \\
\text { useful to keep these under review as to their sufficiency, especially with respect to leveraged } \\
\text { positions at brokers that are not subject to clearing arrangements or frequent on-site } \\
\text { inspections. } \\
\text { Further work is in process pertaining to required contingency planning. }\end{array}$ \\
\hline \multicolumn{2}{|r|}{ Principles for the Secondary Market } \\
\hline Principle 25. & $\begin{array}{l}\text { The establishment of trading systems including securities exchanges should be subject to } \\
\text { regulatory authorization and oversight. }\end{array}$ \\
\hline Description & $\begin{array}{l}\text { Regulated markets are recognized by the Minister of Finance upon recommendation of the } \\
\text { AMF (L.421-1). In most cases, regulated markets' members are investment firms or credit } \\
\text { institutions providing investment services ("investment service providers"), being specified } \\
\text { that market rules may limit access to such providers in good standing but may not provide for } \\
\text { a numerus clauses (L.421-10). However, other legal or natural persons (notably locals) may } \\
\text { be admitted as market members, subject to prior authorization by the AMF (L.421-8 and }\end{array}$ \\
\hline
\end{tabular}


General Regulations of the COMOFI, art. 4-1-17). (But see discussion of Powernext below.)

Admission to the market is conditioned upon respecting the rules of the market (L.421-9). The rules of the market must be submitted to the AMF for approval in connection with its recognition; amendments must be notified to the AMF and the BdF and authorized by the AMF. Financial instruments may be listed subject to objection by the AMF. A prospectus must have been approved by the AMF prior to listing. The COMOFI in the past conducted reviews of the French regulated markets, and these will be continued by the AMF.

Under COMOFI General Regulation Art. 2.4.4, operators of multilateral trading facilities (such as Powernext and MTS), must be recognized as investment services providers (see also Principles 21 and 26). In order to be recognized as a regulated market; a market must guarantee regular functioning of trading; must provide the conditions of access to clearing, as well as regulations with respect to the listing and publication of trades. These must include specific rules related to price manipulation, wash trading, volume aberrations, trading ahead, misallocation, disclosure of price sensitive information, congestion and corners, and so forth. The market undertaking also must commit to enforce these rules. The AMF must refer violations of insider trading provisions to the Public Prosecutor (COMOFI General Regulation 4-1-16). The AMF has a system to prevent insider trading and market abuse and rules of the COMOFI (Art. 3-3-1; 3-3-3;3-4-8) require customer priority and best execution; impose disclosure of the modalities of orders and order of execution; and outlaw frontrunning.

Any 10 percent holder of capital or voting rights in a market undertaking must be disclosed. The regulations of the COMOFI regarding recognition also require the applicant to provide information on its legal status; bylaws; market rules; planned human, technical and financial resources; the experience of its senior management; and, when applicable, the rules of its clearing organization (COMOFI General Regulations, Art. 4-1-1). The AMF also licenses the head of compliance, a trading supervisor and a market member supervisor and each reports directly to the AMF.

The Euronext rulebook addresses: transparency and access to trading information; imposition of trading halts; and treatment of error trades. The order of execution rules are in the pricing algorithm. In 2002 an audit by Deloitte was undertaken with respect to trading rules and the NSC system. COMOFI also undertook inspections and reported its findings. Market undertakings must archive transaction information, including price, quantity, executing broker, time, electronically for ten years.

AMF rules address publication of prices, and the current law addresses the requirement that all trades in listed securities be reported to the market. The law also confers on the AMF Chairman the ability to halt trading in all or a portion of the market and also to halt trading in individual securities to permit the release of information, etcetera (L.421-5). The rules of the COMOFI also require the market operator and market to exercise their activities with diligence, loyalty, neutrality and impartiality in respect to the integrity of the market

The rules of the market itself require that the admission agreement signed between the market undertaking and each market member either specifies an arbitration forum where disputes can be resolved or refers to the competent courts (COMOFI Regulation 4-1-8).

At the moment, the only market operator in France is Euronext Paris, which manages four regulated markets : the Bourse de Paris (comprised of Premier Marché and Second Marché) and the Nouveau Marché for cash and the Matif and the Monep for derivatives. Further consolidation of French regulated markets is expected. Euronext Paris is part of the Euronext, NV group, whose holding company is in the Netherlands. Euronext Paris is also a French credit institution. Some futures trades, notably those in the CAC40 and some commodities take place in France; the market in financial derivatives operated by Euronext, is Euronext-Liffe, largely located in London, using the Liffe-Connect trading system. Euronext's cash market is cleared 


\begin{tabular}{|c|c|}
\hline & $\begin{array}{l}\text { through LCH Clearnet SA and settled through a system operated by Euroclear France. The } \\
\text { derivatives markets are cleared through LCH Clearnet, Ltd., established in London, for the } \\
\text { LIFFE, and LCH Clearnet SA, established in Paris, for the other derivative markets. } \\
\text { Market undertakings will be required to have their own funds to cover at least operational } \\
\text { risks, but Euronext is grand-fathered from this provision and has certain systemic protections } \\
\text { related to being a special purpose credit institution subject to oversight of the CB. Clearing } \\
\text { rules for conduct of business are approved by the AMF, prudential rules and licenses are } \\
\text { addressed by the CECEI and oversight by the CB. }\end{array}$ \\
\hline Assessment & Fully Implemented. \\
\hline Comments & $\begin{array}{l}\text { This principle is only applicable to the ongoing activities of Euronext. There is no ATS for } \\
\text { retail trades, but such systems would be treated as broker dealers except with respect to } \\
\text { oversight for market abuse. Such entities must provide information on the proposed rules of } \\
\text { such systems to the AMF. The AMF may ask for modifications (see also Principle 28). }\end{array}$ \\
\hline Principle 26. & $\begin{array}{l}\text { There should be ongoing regulatory supervision of exchanges and trading systems, which } \\
\text { should aim to ensure that the integrity of trading is maintained through fair and equitable } \\
\text { rules that strike an appropriate balance between the demands of different market participants. }\end{array}$ \\
\hline Description & 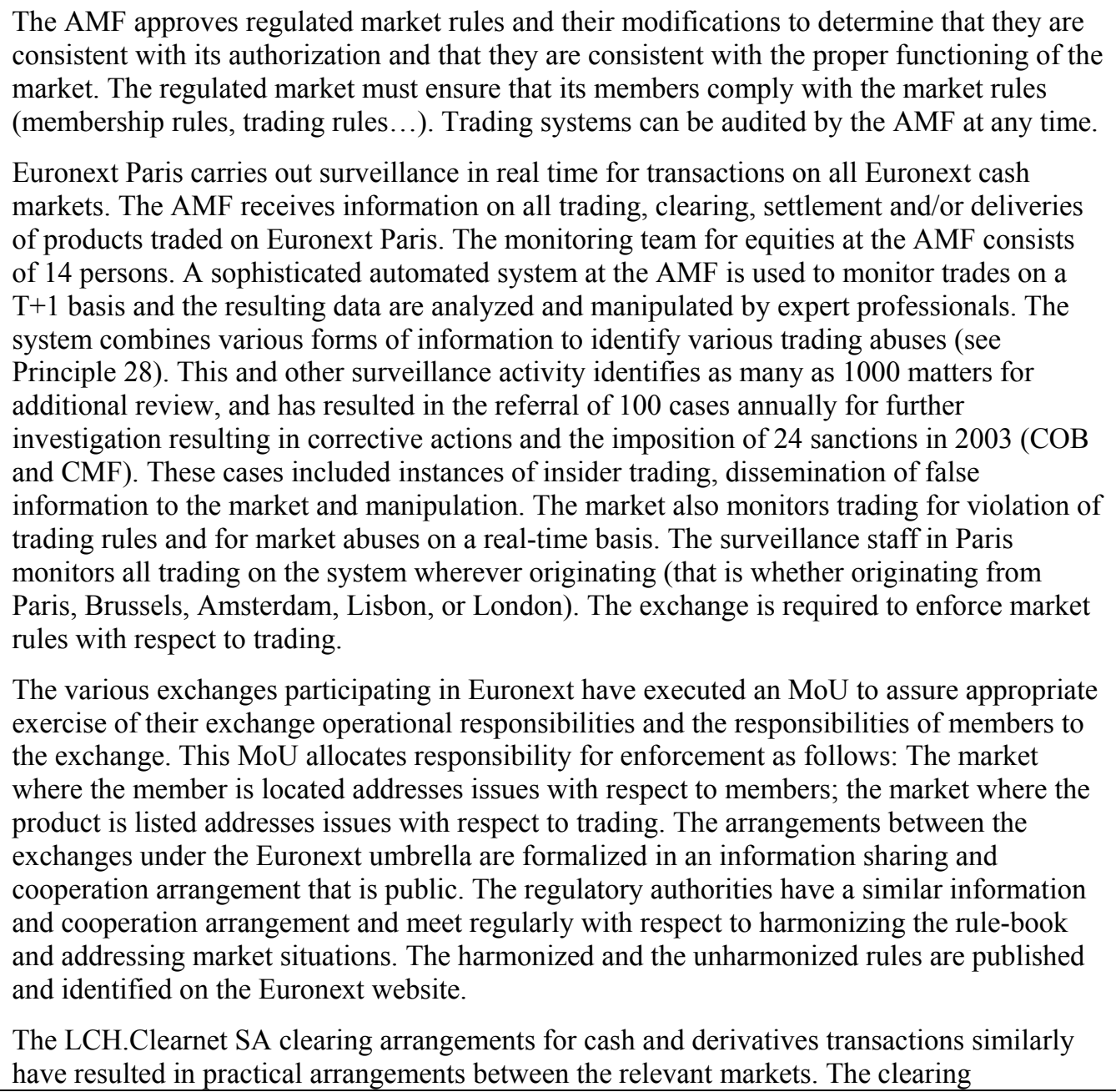 \\
\hline
\end{tabular}




\begin{tabular}{|c|c|}
\hline & $\begin{array}{l}\text { organizations and the regulators have a committee, which meets frequently and is specifically } \\
\text { devoted to consulting on issues of common concern to the regulatory authorities involved in } \\
\text { the clearing and settlement process. The Committee is known as the Coordination Committee } \\
\text { on Clearing Euronext, organized by an MoU among the authorities concluded in } \\
\text { March, 2001, and it has issued Joint Guidance in June } 2002 \text { that represent the common } \\
\text { understanding among the parties, which include the CB, as well as the AMF. } \\
\text { Because Euronext is also a special purpose credit institution, it is under the oversight of the } \\
\text { CB as well as the AMF. Euroclear France, which is a securities settlement system operator } \\
\text { and central securities depository is subject to oversight of the CB, the AMF and the BdF. } \\
\text { The AMF has access to pre-trade and post-trade prices. Upstairs prices are reported as well as } \\
\text { trades on the central order book. The AMF also receives trading information in automated } \\
\text { form. The general sanctions available to the AMF may be applied to a market undertaking } \\
\text { pursuant to the procedures for imposing administrative sanctions. }\end{array}$ \\
\hline Assessment & Fully Implemented. \\
\hline Comments & $\begin{array}{l}\mathrm{COB} / \mathrm{CMF} \text { or their contractors (Deloitte) have performed oversight of the markets, including } \\
\text { onsite reviews, and have issued reports and made recommendations to Euronext Paris (and its } \\
\text { predecessor markets). With the changes in structure, Euronext which had a captive clearing } \\
\text { arrangement for derivatives, now uses Clearnet which is a separately owned entity in which it } \\
\text { has a less than controlling interest. In reviewing the structure of the markets, one question } \\
\text { was the extent to which the clearing organization and the exchange coordinate in addressing } \\
\text { market events or disruptions (nevertheless, see principles } 24,25 \text { and } 29 \text { ). }\end{array}$ \\
\hline Principle 27. & Regulation should promote transparency of trading. \\
\hline Description & $\begin{array}{l}\text { The French system has strict rules for pre-trade and post-trade transparency. Currently, the } \\
\text { "concentration rule" requires all trades in listed equities to be concluded in a regulated market } \\
\text { of the EEA if executed by an intermediary for a customer established or customarily residing } \\
\text { in France and less than EUR } 7.5 \text { million in value or of } 10 \text { percent of the capitalization } \\
\text { Proprietary trades may be concluded over-the-counter. Listed bonds are required to be } \\
\text { transacted in on a regulated market if the transaction size is less than EUR 30,000. As this is a } \\
\text { professional market, most trades are in fact transacted over the counter. Euronext permits } \\
\text { certain trades above a specified size outside the central order book provided that there is a } \\
\text { price relationship or link to prices in the order book or to the spread. These trades are } \\
\text { designated upstairs trades. } \\
\text { For the moment, therefore, an intermediary trading for a French retail customer must trade on } \\
\text { a regulated market. There are two markets that are not regulated markets, Powernext, which } \\
\text { permits commercial users trading for their own account to have direct access and MTS } \\
\text { France where plain vanilla bonds are traded. } \\
\text { Regulated markets must publish the best bid and the best ask and related quantities for each } \\
\text { financial instrument traded-in fact, Euronext publishes the five best bids and offers, although } \\
\text { it permits orders which do not disclose the full quantity on bid or offer. See general regulations } \\
\text { of CMF now continued in effect under the new Act until adoption of the Règlement général } \\
\text { (Title IV, Chapter I, especially Art. } 4.1 .28 \text { ). Prices and quantities for every trade executed on } \\
\text { the market must be published as follows: Immediately for those products conducted by } \\
\text { continuous trading; by the opening of the following trading session for trades settled by auction, } \\
\text { and T+1 for over-the-counter trades, although the trades are reported immediately to Euronext } \\
\text { (and AMF). Upstairs trades that are executed as an agent must be reported and published } \\
\text { immediately and proprietary trades if less than five times the Normal Block Size must be }\end{array}$ \\
\hline
\end{tabular}




\begin{tabular}{|c|c|}
\hline & $\begin{array}{l}\text { published in } 60 \text { minutes and if greater than that within } 120 \text { minutes. } \\
\text { Hidden orders are permitted, but receive a new time priority if their price is hit and they are } \\
\text { activated for any portion of the quantity that was not disclosed. These rules provide equitable } \\
\text { treatment of users of the market. The requirement that block trades be required to sweep the } \\
\text { order book before execution was abandoned because such rules were not in place in other } \\
\text { markets, which were considered to meet international standards. The current status is to protect } \\
\text { customers and market efficiency through requiring most trades to be executed on the central } \\
\text { market. }\end{array}$ \\
\hline Assessment & Fully Implemented. \\
\hline Comments & $\begin{array}{l}\text { The implementation of changes in market structure should be evaluated to determine whether, } \\
\text { and how, the techniques of the market regulator for monitoring the market should be altered. }\end{array}$ \\
\hline Principle 28. & $\begin{array}{l}\text { Regulation should be designed to detect and deter manipulation and other unfair trading } \\
\text { practices. }\end{array}$ \\
\hline Description & $\begin{array}{l}\text { Market or price manipulation, misleading information, insider trading, front running and other } \\
\text { abuses are prohibited by law and also by the regulated market. A number of mechanisms are } \\
\text { used to deter and detect improper practices, including: design of the contracts traded or listed, } \\
\text { rules of conduct and related oversight of market intermediaries, data collected on the market } \\
\text { and analyzed by the market undertaking and by the AMF, and inspections and investigations. } \\
\text { The AMF requires the market authority, whose compliance personnel act under license from the } \\
\text { regulatory authority, to monitor the market in real time and the regulator using its electronic } \\
\text { system performs surveillance on information received at the end of the day by batch. The } \\
\text { regulator identifies conduct for further surveillance and the market authority can also claim } \\
\text { against its participants for failure to follow market rules and impose contractual damages, } \\
\text { restrictions or suspensions of trading. AMF investigations that identify potential price } \\
\text { manipulation or insider trading may give rise to sanctions by the AMF and must be referred to } \\
\text { the Public Prosecutor (see Principle 9). } \\
\text { The regulator approves market rules, clearing rules, can object to contract terms for derivative } \\
\text { contracts and permits listings by nonobjection. Electronic trading permits a complete audit } \\
\text { trail of all transactions. The AMF also requires investment service providers to maintain } \\
\text { orders for } 5 \text { years and telephone tapes, which are required to be obtained, for six months. The } \\
\text { market operator must maintain an archive of its trading transaction tapes for ten years. See } \\
\text { also discussion above under Principle } 26 \text {. }\end{array}$ \\
\hline Assessment & Fully Implemented. \\
\hline Comments & See also discussions at Principle 9, Principle 10 and Principle 13. \\
\hline Principle 29. & $\begin{array}{l}\text { Regulation should aim to ensure the proper management of large exposures, default risk and } \\
\text { market disruption. }\end{array}$ \\
\hline Description & $\begin{array}{l}\text { The market itself has contractual rules which are contained in the trading algorithm that } \\
\text { effectively halt trading if prices move a specified percentage as a cooling off provision. These } \\
\text { price limits apply to individual securities and other products. CRBF, now superseded by } \\
\text { CCLRF, through regulation } 97-04 \text {, extended the large exposure limits of } 93-05 \text { and other risk } \\
\text { management requirements to investment firms as well as credit institutions. These regulations } \\
\text { require risk diversification and define large exposures as } 10 \text { percent of "own funds" or } \\
\text { maximum of } 25 \text { percent exposure of own funds to any one counterparty. }\end{array}$ \\
\hline
\end{tabular}




\begin{tabular}{|c|c|}
\hline & 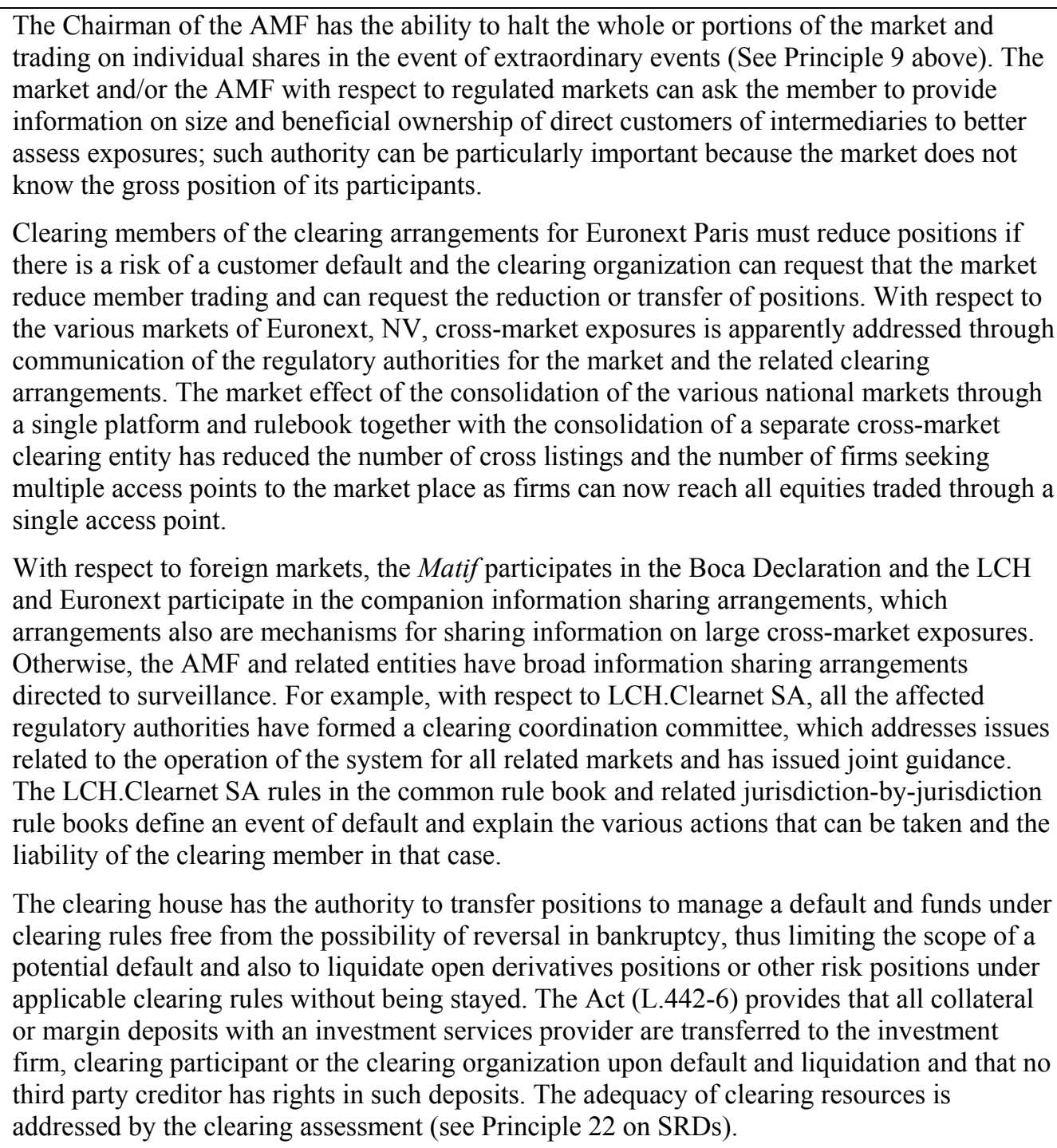 \\
\hline Assessment & Fully Implemented. \\
\hline Comments & $\begin{array}{l}\text { There are three issues of additional concern, which while not specifically addressed by the } \\
\text { IOSCO standard being assessed should nonetheless be reviewed: } \\
\text { (1) Euronext Paris only knows net positions in its markets, including derivatives markets. } \\
\text { This means that its clearing members may be carrying undisclosed risk in that the market risk } \\
\text { and the credit risk of the netted position will not be the same. } \\
\text { (2) Euronext offers an SRD ( } 30 \text {-day deferred settlement facility) on securities that are } \\
\text { specified (about } 200 \text { highly liquid securities). These transactions are settled through standard } \\
\text { clearing and settlement arrangements between buying and selling brokers on T+3, but the } \\
\text { broker assumes the risk vis-à-vis its customer on the deferred settlement. The transaction is } \\
\text { margined ( } 20 \text { percent down if in cash; } 40 \text { percent if in securities) at the broker, but the margin } \\
\text { oversight is not at the clearing house. The positions can also be rolled forward. Therefore, the } \\
\text { broker is effectively carrying a futures style position on behalf of its customer and is } \\
\text { maintaining a net exposure against its customer. The risk to the broker who is a clearing } \\
\text { member is not necessarily transparent to the market or to the clearing arrangement for the }\end{array}$ \\
\hline
\end{tabular}




\begin{tabular}{|c|c|}
\hline & $\begin{array}{l}\text { market; the risk to the broker from other brokers doing the same type of transactions for its } \\
\text { customers also is not transparent across brokers. The positions are traded within the } 30 \text {-day } \\
\text { settlement period and only the net positions are settled against the broker, which must meet } \\
\text { the EUR } 1.9 \text { million capital requirement and make monthly per customer position reports to } \\
\text { the CB. } \\
\text { It appears that this trading occurs in accordance with Euronext rules. Basically it is as if there } \\
\text { is a leveraged off-market that is sponsored by the market. The question is whether the } \\
\text { monitoring that is in place by the CB and the procedures of the intermediaries that engage in } \\
\text { this conduct are sufficient to contain the risks and how big are these risks- i.e., what are the } \\
\text { capital positions of the brokers engaged in this business, how does the broker use the } \\
\text { securities it has committed to deliver and what are the characteristics of the clients (See } \\
\text { Principle } 22 \text { rating and discussion). } \\
\text { (3) Now that the market and clearing institutions are separate entities is it sufficient that under } \\
\text { the rules of the clearing organization all that it can do is request the market to restrict trading, } \\
\text { even after a default? (See also Principles } 22 \text { and } 24 \text { on intermediary oversight.) In that the } \\
\text { positions are carried by brokers and settlement has been made within the clearing structure, } \\
\text { the rating has been adjusted in the intermediary section. Nonetheless, depending on the size } \\
\text { of the brokers that are clearing members, this could equally become a clearing question (see } \\
\text { above remarks under Principle } 22 \text { in which the regime with respect to SRDs affects the } \\
\text { rating). } \\
\text { The assessor believes that the matters identified with respect to relationships between the } \\
\text { market and clearing might be better addressed in any clearing and settlement assessment. }\end{array}$ \\
\hline Principle 30. & $\begin{array}{l}\text { Systems for clearing and settlement of securities transactions should be subject to regulatory } \\
\text { oversight, and designed to ensure that they are fair, effective and efficient and that they } \\
\text { reduce systemic risk. }\end{array}$ \\
\hline Description & $\begin{array}{l}\text { Where there is a specialist assessing securities settlement, clearing and payment systems, as } \\
\text { in this case, the IOSCO assessor is to coordinate with the specialist rather than to undertake } \\
\text { an independent assessment under Principle } 30 \text {. The systems for clearing and settlement of } \\
\text { securities transactions are subject to regulatory oversight by the AMF and also by the CECEI, } \\
\text { the CB and the BdF. Members of such systems (direct participants) who must be investment } \\
\text { firms or credit institutions are also subject to oversight in accordance with the competence of } \\
\text { each competent authority. The arrangements between the oversight authorities, for the } \\
\text { monitoring of these systems, and between the markets are innovative ways to address } \\
\text { operational risks that originate on a common system where trades are initiated from various } \\
\text { access points. }\end{array}$ \\
\hline Assessment & Not Rated. \\
\hline Comments & $\begin{array}{l}\text { Not rated in deference to assessments of the Recommendations for Securities Settlement } \\
\text { Systems and for Central Counterparties, adopted jointly by the Committee on Payment and } \\
\text { Settlement Systems of the BIS and IOSCO, which will be assessed by a specialist. The } \\
\text { specialist may wish to consider any implications to clearing of the SRD facilities provided by } \\
\text { brokers, which are also clearing members. } \\
\text { See also Principles } 29,26 \text { and } 24 \text {. }\end{array}$ \\
\hline
\end{tabular}


Table 21. Summary Implementation of the IOSCO Objectives and Principles of Securities Regulation

\begin{tabular}{|l|c|l|}
\hline \multirow{2}{*}{ Assessment Grade } & \multicolumn{2}{|c|}{ Principles Grouped by Assessment Grade } \\
\cline { 2 - 3 } & Count & \multicolumn{1}{c|}{ List } \\
\hline Fully implemented & 18 & $\begin{array}{l}3,4,5,8,9,11,12,13,14,18,19,23,24,25,26,27,28, \\
\text { and } 29 .\end{array}$ \\
\hline Broadly implemented & 7 & $1,2,1015,17,20$, and 21. \\
\hline Partly implemented & 2 & 16 and 22. \\
\hline Not implemented & 0 & -- \\
\hline Not applicable & 3 & 6 and 7 not applicable and 30 not rated. \\
\hline
\end{tabular}

\section{Recommended actions and authorities' response to the assessment}

\section{Recommended Actions}

Table 22. Recommended Plan of Actions to Improve Implementation of the IOSCO Objectives and Principles of Securities Regulation

The AMF, together with the other agencies responsible for securities regulation in France, administer a regulatory framework that clearly has been designed with international standards well in mind. The following are some general suggestions to continue pursuing planned improvements and encouragement to make the innovative and well-designed cooperative arrangements for surveillance of its cross border markets effective.

\begin{tabular}{|l|l|}
\hline \multicolumn{1}{|c|}{ Reference Principle } & \multicolumn{1}{|c|}{ Recommended Action } \\
\hline Principles Relating to the & $\begin{array}{l}\text { With respect to Principle 1, the current wording of the Act does not } \\
\text { specifically require the sharing of information between the CB and the } \\
\text { AMF. Information is in fact being shared, but the CB and the AMF should } \\
\text { explore whether additional arrangements could assure the timeliness and } \\
\text { certainty that information with respect to prudential matters that is } \\
\text { important to oversight of conduct of business is readily available to each } \\
\text { other as needed. In particular, the limitation of the function of the AMF to } \\
\text { conduct of business issues should not prevent it from receiving prudential } \\
\text { information as relevant to its oversight of conduct of business or as } \\
\text { necessary to its securities counterparts in other jurisdictions engaged in } \\
\text { investigations of securities or futures misconduct. } \\
\text { With respect to Principle 2, independence, the actual effectiveness of the } \\
\text { arrangements for protecting the independence of the AMF, in particular the } \\
\text { Commission des Sanctions should be kept under review, to assure that the } \\
\text { presence of the Ministry does not permit political considerations to affect, } \\
\text { or there to be the perception that they could affect, the outcome of decisions } \\
\text { on individual cases. } \\
\text { As to Principle 3, the AMF should continue to assess how best to deploy its } \\
\text { resources between off-site and on-site oversight activities, assure human }\end{array}$ \\
\hline
\end{tabular}




\begin{tabular}{|c|c|}
\hline & $\begin{array}{l}\text { resources are sufficient to support expanded monitoring powers, and } \\
\text { address functions such as review of prospectuses and miss-selling of } \\
\text { products through the banking network as well as other investment services } \\
\text { providers. } \\
\text { Principle 5, the AMF should continue to assure that conflicts of interest are } \\
\text { appropriately addressed at the Board as well as the staff level. }\end{array}$ \\
\hline $\begin{array}{l}\text { Principles of Self-Regulation } \\
\text { (P 6-7) }\end{array}$ & Not applicable. \\
\hline $\begin{array}{l}\text { Principles for the Enforcement of } \\
\text { Securities Regulation (P 8-10) }\end{array}$ & $\begin{array}{l}\text { The enforcement and cooperation powers of the AMF are exemplary. The } \\
\text { timeliness of proceedings using those powers and the effect of the overall } \\
\text { program should be evaluated after the new organizational structure has had } \\
\text { some time to function. The AMF should aggressively pursue overturning } \\
\text { recent judiciary interpretations of the doctrine of impartiality that could } \\
\text { undermine its capacity to exercise its monitoring and enforcement functions } \\
\text { effectively (Principle 10). } \\
\text { The development of readily understandable public statistics to demonstrate } \\
\text { enforcement and investigatory performance also would be useful. }\end{array}$ \\
\hline $\begin{array}{l}\text { Principles for Cooperation in } \\
\text { Regulation (P 11-13) }\end{array}$ & $\begin{array}{l}\text { The cooperation powers of the AMF are exemplary. As to Principle 13, the } \\
\text { assessor believes that the ideal channel for exchange of information and } \\
\text { delivery of assistance to foreign securities regulators is through the } \\
\text { securities regulatory authority, although direct arrangements should not be } \\
\text { prohibited. For example, information on the relationships within groups } \\
\text { should be available to a requesting "solo" securities regulator requesting } \\
\text { through the AMF. The CB and the AMF should consider working together } \\
\text { to articulate further cooperative arrangements with respect to inspections } \\
\text { (see also Principle 21-ongoing oversight of intermediaries). }\end{array}$ \\
\hline Principles for Issuers (P 14-16) & $\begin{array}{l}\text { As to Principle 15, the AMF should consider a materiality standard for } \\
\text { immediate disclosure to the public of large shareholder and management } \\
\text { "insider" transactions. Further work on minority shareholder rights should } \\
\text { be encouraged-and issues of concern that emerge from experience of } \\
\text { oversight operations of the AMF should be referred to the consultative } \\
\text { commission in its considerations. On Principle 16, the AMF should assist } \\
\text { in the development of robust oversight of auditors and auditing standards } \\
\text { and the new Haut Conseil should take adequate account of the views of the } \\
\text { AMF. }\end{array}$ \\
\hline $\begin{array}{l}\text { Principles for Collective } \\
\text { Investment Schemes (P 17-20) }\end{array}$ & $\begin{array}{l}\text { As to Principle 17, the AMF should consider more robust guidance on } \\
\text { related party transactions in CIS. Regarding Principle 20, the AMF should } \\
\text { consider using its legal authority to provide more guidance with respect to } \\
\text { suspension of redemptions. }\end{array}$ \\
\hline $\begin{array}{l}\text { Principles for Market } \\
\text { Intermediaries (P 21-24) }\end{array}$ & $\begin{array}{l}\text { As to Principle } 21 \text { the AMF and the CECEI should promptly assure that } \\
\text { needed licensing information is readily available to the public. As to } \\
\text { Principle 22, the CB and AMF should assure that adequate provisions exist } \\
\text { to detect deteriorating capital situations promptly, so that ameliorations } \\
\text { (corrective actions) are possible without systemic impact or adverse effects } \\
\text { on customers. }\end{array}$ \\
\hline
\end{tabular}


Principles for the Secondary Market (P 25-30)
There are no recommendations other than maintaining vigilance to assure measures to address risk within clearing brokers is not transmitted to the clearing system, assurance cross border cooperation arrangements can be made effective in a market event and markets and clearing organizations coordinate approaches to addressing market disruptions. (Principles 28,29 and 30) The SRD issue is addressed in remarks relative to capital monitoring.

\section{Authorities' response to the assessment}

107. The AMF contends that within the French system, AMF's structure has been designed explicitly to be as independent as possible. While the AMF disputes that its current structure is in any way susceptible to political interference, the AMF understands that the issues raised with respect to structure are issues that could be of relevance to outside observers and appearances and indicates that it expects to continue its record of assuring that no improper interference in individual cases occurs.

108. The AMF also notes that its enforcement system, which the assessor has found to have appropriate powers and authorities and to have produced significant cases, is currently effective and that the processes for working with the Public Prosecutor with respect to offenses that are both criminal and civil, such as insider trading and market abuse, have proved effective to date. The AMF does not have a history of settlement procedures or a process for administrative restitution, which are not required as a matter of international standards, but which may constitute enhancements. The AMF (and its predecessor authorities) has always kept its programs under review and may consider further enhancing its existing enforcement powers over time. Where the judiciary has potentially put certain powers into question, the AMF has acted aggressively to contest the adverse judicial interpretation.

109. Although the AMF has contested some characterizations of the regulatory structure with respect to independence and transparency, has indicated that despite lack of a specific requirement to cooperate, in all cases domestic regulators do so in fact, and provided substantial comment addressing the detail and fact of application of their regulatory framework, the AMF essentially does not disagree with the specific recommendations and indicates that most recommended areas of enhancement are currently under consideration or in train.

110. In particular it supports assuring human resources are sufficient to execute its expanded powers, among other things, with respect to depositories and having sufficient authority to effect the outcomes with respect to audit oversight of the Haut Conseil. 


\section{OBSERVANCE OF THE CPSS/IOSCO RECOMMENDATIONS FOR SECURITIES SETTLEMENT SYSTEMS}

\section{General}

111. As part of the Financial Sector Assessment Program, an assessment of the observance of the infrastructure for clearing, settlement and custody of securities of the CPSS/IOSCO Recommendations for Securities Settlement Systems was prepared by Jan Woltjer, IMF (MFD). Prior to the mission, the BdF made a thorough self-assessment of the securities settlement systems of Euroclear France, which was used as basis for the assessment.

\section{Scope of the assessment}

112. The assessment covers Euroclear France as Central Securities Depository (CSD) for a broad range of securities, such as treasury bills, all other negotiable short-term instruments, public sector and corporate bonds, and equities. Almost all securities in France (99.7 percent) are dematerialized in Euroclear France. The residual securities are immobilized in this CSD.

113. Euroclear France operates two systems for the settlement of the aforementioned securities:

(i) Relit+ ensures delivery versus payments on a gross-net basis (model 2 DvP). The multilateral net positions at the cash side are settled three times a day in Transferts Banque de France (TBF), the Real-Time Gross Settlement (RTGS) payment system operated by the $\mathrm{BdF}$. LCH-Clearnet SA settles via Relit+ its positions vis-à-vis its counterparties stemming from the transactions on the stock exchange;

(ii) RGV2 irrevocable channel (further on called RGV2-TFT) clears all transactions on a trade for trade basis with intraday finality (model $1 \mathrm{DvP}$ ). The cash leg is settled on dedicated cash accounts opened with the BdF and is directly operated by Euroclear France. A so-called liquidity bridge enables participants to transfer cash between these dedicated cash accounts in RGV2 and their cash account held in TBF and vice versa to optimize liquidity management. RGV2-TFT is, among other things, used for the executions of monetary transactions and the collateralization of intraday credit operations.

\section{Institutional and market structure}

114. Capital markets in France are large and sophisticated. In terms of stock market capitalization (in dollar value terms) and debt securities market capitalization, France ranks fourth in the world and the value of all listed securities amounted slightly above 200 percent of GDP at end-2003.

115. The stock exchange in Paris has been managed by Euronext-Paris, which since September 2000 is a wholly owned subsidiary of Euronext NV, a holding company incorporated under Dutch law. Euronext is the result of a merger between the stock exchanges of Belgium, France and the Netherlands. However, to meet regulatory 
requirements, the stock exchanges in the different countries retained a separate identity. Euronext Holding also operates the stock exchange in Portugal (Euronext Lisbon) and, since the beginning of 2002, the international futures and options exchange in London (Euronext Liffe).

116. Both securities and derivatives are traded on Euronext Paris platforms. In the secondary market for securities, total turnover amounted to EUR 905 billion in 2003, against EUR 1,045 billion in the previous year (average daily turnover in 2003 amounted to EUR 3.5 billion).

117. All stock exchange transactions are cleared via Clearnet, a central counterparty. Clearnet is the single clearing house of the Euronext group and clears transactions in Belgium, France, the Netherlands and Portugal; it also clears over-the-counter (OTC) transactions in different markets in France and abroad. At the beginning of 2004, an alliance was formed between Clearnet and London Clearing House and Clearnet was renamed LCHClearnet SA.

118. The settlement of securities transactions on the French markets takes place via the securities settlement systems of Euroclear France. Euroclear France is fully owned by the Belgian Euroclear Bank, which also possesses CSDs in Belgium, the Netherlands and the U.K.

119. The total value of all trades settled in Euroclear France's securities settlement systems amounted to EUR 52,996 billion in 2002.

Table 23. Trades Settled in Euroclear France's Securities Settlement Systems

\begin{tabular}{lrrrrrrr}
\hline Year & 1997 & 1998 & 1999 & 2000 & 2001 & 2002 & 2003 \\
\hline $\begin{array}{l}\text { Instructions } \\
\text { (millions) }\end{array}$ & 18 & 22 & 28 & 41 & 31 & 29 & 28 \\
$\begin{array}{l}\text { Value } \\
\text { (Euro billions) }\end{array}$ & 22,660 & 32,046 & 38,892 & 36,835 & 43,635 & 52,996 & 52,528 \\
\hline
\end{tabular}

Source: Euroclear France.

\section{Description of regulatory structure and practices}

120. In France, the Autorité des Marchés Financiers (AMF) and the BdF are the competent authorities for the regulation and oversight of Securities Clearing and Settlement Systems (SCSS). According to Art. 621-7 of the COMOFI, the AMF specifies the general organization and operational principles of securities settlement systems. It also has to approve the operating rules of these systems. Furthermore, the AMF regulates the activities of custodians. Without any prejudice to the competencies of the AMF, the BdF is charged with the oversight of SCSS. There is a close cooperation between the AMF as securities regulator and the $\mathrm{BdF}$ as overseer. Representatives of the $\mathrm{BdF}$ have consultative roles on the 
Board of the AMF and in some committees and the activities with respect to the regulations and oversight of SSS are clearly coordinated.

121. Being a credit institution, LCH-Clearnet SA is not only supervised/overseen by the $\mathrm{AMF}$ and BdF but also by the CB.

122. The cross-jurisdictional nature of the Euronext group, LCH-Clearnet and the Euroclear group has led to the implementation of rather innovative cooperative cross-border arrangements between the French authorities and the supervisors/overseers in the other jurisdictions in which these firms are active. These arrangements for cooperative oversight/regulations for the individual institutions are codified in MoUs signed by all relevant authorities in the different countries.

\section{Information and methodology used for the assessment}

123. The assessment was based on the self-assessment conducted by the BdF using the CPSS/IOSCO assessment methodology for the Recommendations for Securities Settlement Systems. Discussions were held with the BdF, the AMF, Euroclear France and market participants. Relevant rules and regulations, audit reports, Memoranda of Understanding $(\mathrm{MoU})$, business plans, and discussion papers between Euroclear and market participants on the development of the infrastructure for cross-border clearing and settlement and custody services were made available.

124. Although the self-assessment of the BdF of the systems of Euroclear France contained an assessment of risk management in the context of recommendation 4 , in consultation with the authorities, it was decided to postpone the assessment of LCH-Clearnet SA until the new CPSS/IOSCO recommendations for central counterparties are finalized in order to take into account all relevant activities, governance structures, etc. This complete assessment of LCH-Clearnet will be conducted in the framework of an Art. IV Consultation based on a self-assessment carried out by the French authorities.

\section{Assessment against the CPSS/IOSCO recommendations for securities settlement systems}

Table 24. Detailed Assessment of Euroclear France as a Central Securities Depository and the RGV2-Irrevocable Trade for Trade Settlement System operated by Euroclear France of CPSS/IOSCO Recommendations for Securities Settlement Systems

\begin{tabular}{|l|l|}
\hline Recommendation 1. & $\begin{array}{l}\text { Securities settlement systems should have a well-founded, clear, and transparent } \\
\text { legal basis in the relevant jurisdiction. }\end{array}$ \\
\hline Description & $\begin{array}{l}\text { 1. Underlying legal framework and public accessibility } \\
\text { There is a consistent set of laws, regulations and contracts that form the legal } \\
\text { foundation for central custody and the clearing and settlement of securities. Not all } \\
\text { of these texts are publicly available. Those not published are: (i) the agreements } \\
\text { between Euroclear France and the BdF on the settlement in central bank money and }\end{array}$ \\
\hline
\end{tabular}


the outsourcing of the execution of the settlement bank function to Euroclear France for the RGV2-irrevocable trade for trade system (in this assessment called RGV2-TFT); and (ii) the agreements between Euroclear France and Central Depositories in other countries and Euroclear bank Brussels concerning links between the systems involved.

\section{Legal assurance of the key aspect for custody and clearing and settlement}

\section{Enforceability of transactions}

Laws and contracts are fully enforceable in the French jurisdiction. The courts of the jurisdiction function adequately; property rights are fully defined and respected; and there are proper procedures for legal processes. An individual or firm, which believes its basic rights are violated and not respected in a court of law or the judicial treatment of its case was not ruled correctly, can appeal the decision by submitting its complaints to the Court of Justice in the EU.

The access criteria ensure that participants have the legal capacity to do this.

The purpose and content of services to be provided by Euroclear France have to be approved by the AMF and within this framework, the AMF will assess whether these services comply with the relevant laws, statutes, and regulations.

\section{Customers asset protection}

Euroclear France as the CSD has no legal title to the securities on its books, and customer assets are legally protected against the insolvency of the CSD and/or a custodian or intermediary. The securities owned by the end-investor/client fall outside the bankruptcy estate and cannot be claimed by the creditors of the aforementioned institutions (Art. L.431-6 COMOFI).

\section{Dematerialization of securities}

Dematerialization is based on Art. L.211-4 of the COMOFI. This article provides for dematerialization of securities and specifies that transfer of ownership is arranged for by electronic book entry. Almost all securities in France are dematerialized. Only a small segment is represented by paper-often immobilized by way of a global note.

\section{Netting arrangements}

In RGV2-TFT, transactions are settled on a trade-for-trade basis and normally no netting of transactions is involved. However, there is an optimization routine in place allowing participants, who have resold immediately the securities they have bought, to settle simultaneously the combined transactions in which they have a flat securities position (back-to-back operation). This form of netting is endorsed by the COMOFI (Art. L.330-1).

\section{Securities lending arrangements}

The legal framework supports securities lending by recognizing explicitly securities loans (art L 432-6 to L.432-11) and repurchase agreements (COMOFI, Art. L.43212 to L432 -19). These provisions define the instrument, the range of securities which can be lent or repurchased and the eligible counterparties. Enforceability of the securities lending and repurchase agreements toward third parties is ensured. Collateral provided in the context of securities loan or repurchase agreements will not expose the lending party to the risk that the transaction can be challenged by a third party or a liquidator by re-characterizing the securities lending or the repo as an improper pledge. 


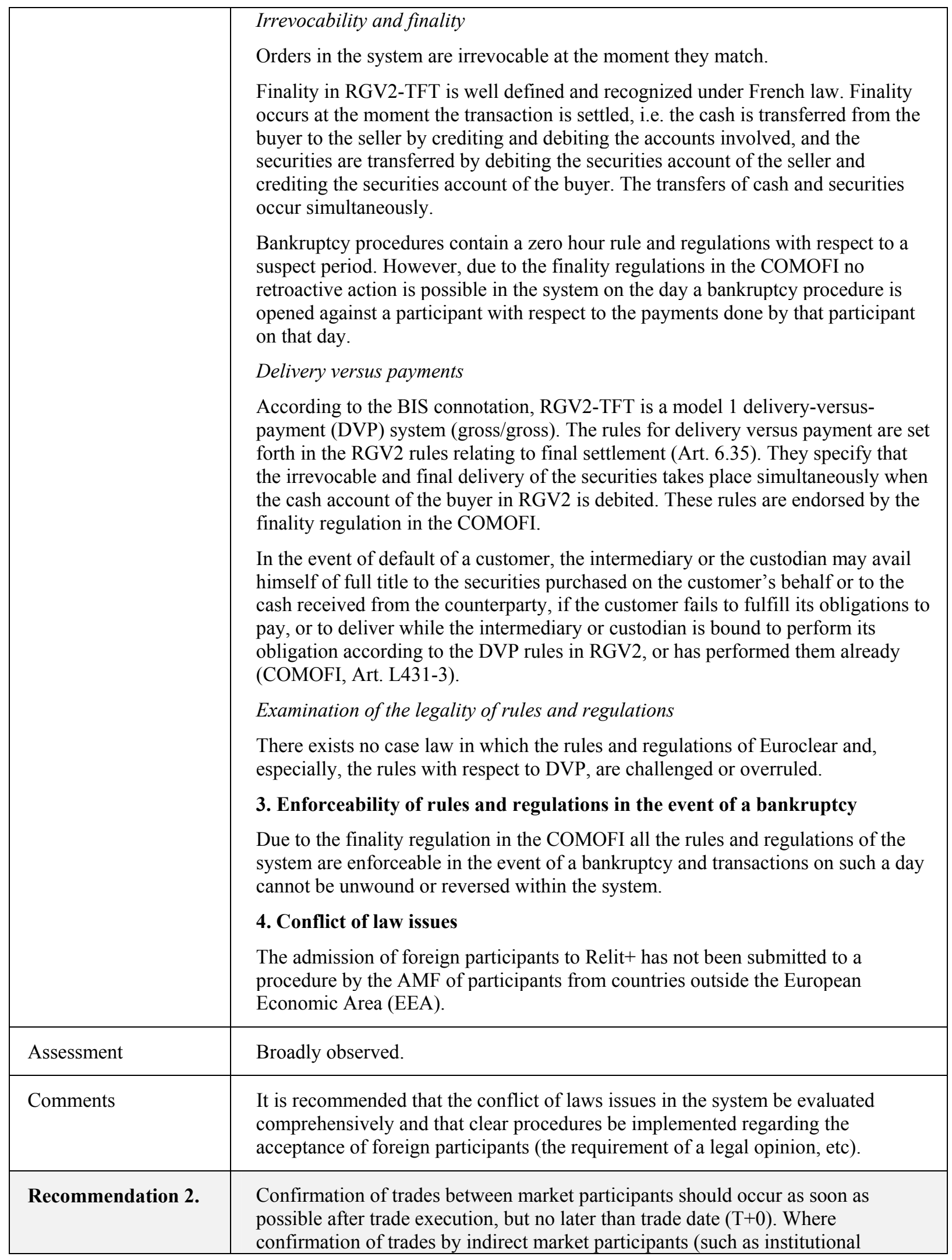




\begin{tabular}{|c|c|}
\hline & $\begin{array}{l}\text { investors) is required, it should occur as soon as possible after trade execution, } \\
\text { preferably on } \mathrm{T}+0 \text {, but no later than } \mathrm{T}+1 \text {. }\end{array}$ \\
\hline Description & $\begin{array}{l}\text { All settlement instructions in RGV2-TFT are prior to settlement matched and } \\
\text { confirmed on trade date }(\mathrm{T}+0) \text { or at the latest at } 12.00 \text { on } \mathrm{T}+1 \text {. The aforementioned } \\
\text { trades are generally confirmed by indirect participants by } \mathrm{T}+1 \text {. }\end{array}$ \\
\hline Assessment & Observed. \\
\hline \multicolumn{2}{|l|}{ Comments } \\
\hline Recommendation 3. & $\begin{array}{l}\text { Rolling settlement should be adopted in all securities markets. Final settlement } \\
\text { should occur no later than } \mathrm{T}+3 \text {. The benefits and costs of a settlement cycle shorter } \\
\text { than } \mathrm{T}+3 \text { should be assessed. }\end{array}$ \\
\hline \multirow[t]{6}{*}{ Description } & Settlement cycles \\
\hline & $\begin{array}{l}\text { RGV2-TFT clears transactions and repos done in the primary market, the OTC } \\
\text { market, the money market, as well as monetary policy operations on a trade-for- } \\
\text { trade basis. These are all large-value transactions. For some transactions, for } \\
\text { instance, for monetary repos standardized settlement practices are in place. In } \\
\text { situations where there are none, counterparties are free to negotiate other terms for } \\
\text { the settlement date. Parties select their counterparties deliberately and the pre- } \\
\text { settlement risk is entirely born by the parties involved, who are fully able to } \\
\text { manage the risk appropriately. Most transactions, } 70 \text { percent and more, are settled } \\
\text { within three days and around } 35 \text { percent are settled the same day }(\mathrm{T}+0) \text {. }\end{array}$ \\
\hline & Failed trades and facilities to smooth the settlement process \\
\hline & $\begin{array}{l}\text { The number of failed settlements is small and has not exceeded } 0.3 \text { percent in the } \\
\text { period January } 2002 \text { to June } 2003 \text {. }\end{array}$ \\
\hline & $\begin{array}{l}\text { On the cash side, participants can obtain intraday credit from the BdF to facilitate } \\
\text { the settlement of pending transactions through an intraday repo, against securities } \\
\text { on the tier } 1 \text { list of the Eurosystem and deposited in Euroclear France. These } \\
\text { intraday repos are executed automatically by the system-providing that there are } \\
\text { sufficient eligible securities in the account of the involved participant- the moment } \\
\text { a participant has insufficient balances in his RGV2 cash settlement account }{ }^{34} \text { to } \\
\text { settle pending transactions. Also, the securities bought and to be delivered, } \\
\text { fulfilling the eligibility criteria set forth by the Eurosystem, can be used as } \\
\text { collateral for intraday operations through back-to-back operations (self } \\
\text { collateralization). In that case the securities will be automatically delivered to the } \\
\text { account of the BdF as collateral for the intraday loan with the seller being paid with } \\
\text { the proceeds of the intraday credit granted to the buyer by the BdF. The buyer has } \\
\text { to reimburse the intraday credit operation at the end of the day. }\end{array}$ \\
\hline & $\begin{array}{l}\text { Euroclear France does not operate a securities lending facility. However, the } \\
\text { securities can be borrowed relatively easily in the market, via a repo or a securities } \\
\text { lending transaction to be settled on the same day, in real time through RGV2-TFT. }\end{array}$ \\
\hline
\end{tabular}

${ }^{34}$ The RGV2-TFT cash settlement account is an account with the Banque de France. Euroclear France is allowed to operate these accounts within the framework of RGV2-TFT. 


\begin{tabular}{|c|c|}
\hline & $\begin{array}{l}\text { Rolling settlement } \\
\text { The system has a rolling settlement procedure in place. Failed trades are recycled } \\
\text { up to } 30 \text { days after the initial settlement date. } \\
\text { Incentives to settle on contractual dates } \\
\text { If a seller is unable to deliver the securities at the end of the contractual settlement } \\
\text { date, Euroclear charges this participant a fine of around EUR } 40 \text { a day and for each } \\
\text { instrument. }\end{array}$ \\
\hline Assessment & Observed. \\
\hline Comments & $\begin{array}{l}\text { Although not all transactions on the over-the-counter (OTC) market are settled } \\
\text { within three days after the day the transaction has been conducted, this is not seen } \\
\text { as a major violation of the recommendation. Longer settlement cycles in the OTC } \\
\text { market have not been assessed as exposing parties to unmanageable pre-settlement } \\
\text { risk, because (i) only professional parties, fully capable of handling these risks are } \\
\text { involved;, (ii) parties have deliberately chosen a longer settlement period and are } \\
\text { not forced by market rules, nor do they have to accept the added risks due to long } \\
\text { processing times of trades in the back offices of a stock exchange, a clearing house } \\
\text { or another involved third party; and (iii) only a very small portion of transactions } \\
\text { fail to settle timely in the underlying markets. }\end{array}$ \\
\hline Recommendation 4. & $\begin{array}{l}\text { The benefits and costs of a central counterparty should be assessed. Where such a } \\
\text { mechanism is introduced, the central counterparty should rigorously control the } \\
\text { risks it assumes. }\end{array}$ \\
\hline Description & $\begin{array}{l}\text { Transactions conducted on the Euronext trading platforms in Paris, Amsterdam, } \\
\text { Brussels and Lisbon are cleared and settled via LCH-CLearnet SA, which acts as } \\
\text { the central counterparty. LCH-Clearnet SA also clears and settles derivatives and } \\
\text { commodities contracts and cash and derivatives transactions traded on the OTC } \\
\text { market or negotiated through interdealer brokers. LCH-Clearnet SA will be } \\
\text { assessed in due time against the newly drafted recommendations for central } \\
\text { counterparties, which for the moment are under consultation. }\end{array}$ \\
\hline Assessment & Not applicable \\
\hline \multicolumn{2}{|l|}{ Comments } \\
\hline Recommendation 5. & $\begin{array}{l}\text { Securities lending and borrowing (or repurchase agreements and other } \\
\text { economically equivalent transactions) should be encouraged as a method for } \\
\text { expediting the settlement of securities transactions. Barriers that inhibit the practice } \\
\text { of lending securities for this purpose should be removed. }\end{array}$ \\
\hline \multirow[t]{4}{*}{ Description } & Institutional framework \\
\hline & $\begin{array}{l}\text { Securities lending operations can be conducted through securities loans or } \\
\text { repurchase agreements. The law recognizes both instruments, as well as the validity } \\
\text { of collateral transfers within the framework of securities lending. The transactions } \\
\text { cannot be re-characterized as improper pledges by third parties or a liquidator. }\end{array}$ \\
\hline & $\begin{array}{l}\text { Accounting schemes and tax treatment for the aforementioned instruments are } \\
\text { detailed in the regulations in the COMOFI (Art. L.432-6 to L.432-19). }\end{array}$ \\
\hline & To prevent tax avoidance, only legal entities are allowed to enter into repurchase \\
\hline
\end{tabular}




\begin{tabular}{|c|c|}
\hline & $\begin{array}{l}\text { agreements. For this reason securities yielding interest/dividends submitted to a } \\
\text { withholding tax are not allowed to be used in a securities lending transaction or a } \\
\text { repo during the period the interest/dividends will fall due. } \\
\text { Automated securities lending facilities } \\
\text { At the moment, no automated securities lending facility is in place for the OTC } \\
\text { markets in order to expedite the settlement of securities in RGV2-TFT. Plans to } \\
\text { launch such a facility in } 1998 \text { were not executed since the business case for such a } \\
\text { facility seemed to be insufficient. This does not imply that there is no market for } \\
\text { securities lending in this area. Interested participants can easily tailor their needs by } \\
\text { directly transacting with institutional investors (insurance companies, mutual } \\
\text { funds) or banks willing to increase their custody incomes. } \\
\text { Currently, Euroclear France is considering launching a lending and borrowing } \\
\text { facility to expedite settlements of trades in government bonds in RGV2-TFT } \\
\text { between primary dealers. In this facility, the settlement of an obligation to deliver } \\
\text { would be facilitated for these groups, initially by allowing an intraday overdraft on } \\
\text { the securities accounts of the primary dealer who is selling the underlying } \\
\text { securities. This overdraft should be backed by the general approval of the Ministry } \\
\text { of Finance through acceptance of intraday extensions of securities it has issued and } \\
\text { a readiness to act as lender of last resort (issue new government securities } \\
\text { temporarily) when securities lent by the Ministry cannot be reimbursed by } \\
\text { borrowing from a pool of securities made available by the primary dealers. Its } \\
\text { compliance with the CPSS/IOSCO Recommendation for Securities Settlement } \\
\text { Systems still has to be assessed in due time. } \\
\text { Supervision of the risk involved in securities lending } \\
\text { Especially with respect to securities lending transactions in case of deferred } \\
\text { settlement, regulation is in place to ensure that sufficient collateral is made } \\
\text { available by the client to his broker, who is its counterparty in this securities } \\
\text { lending operations. }\end{array}$ \\
\hline Assessment & Observed. \\
\hline Comments & \\
\hline Recommendation 6. & $\begin{array}{l}\text { Securities should be immobilized or dematerialized and transferred by book entry } \\
\text { in CSDs to the greatest extent possible. }\end{array}$ \\
\hline Description & $\begin{array}{l}\text { Dematerialization and immobilization } \\
\text { At least } 99.7 \text { percent of securities issued in France (representing over } 29000 \text { ISIN } \\
\text { codes) are dematerialized and the other securities issues, mostly warrants, euro- } \\
\text { bonds and foreign securities ( } 80 \text { issues in total) are immobilized, mostly via a } \\
\text { global note. Adequate safety procedures are in place within Euroclear France. } \\
\text { Transfer of title } \\
\text { Transfer of title is only possible by book-entry (Art. } 1 \text { of decree 83-359 of } \\
\text { May } 2,1983 \text { ). In France no separate "Registrars of the Issuers" exists. Issuers open } \\
\text { an "investors account" directly with Euroclear France in which all securities issued } \\
\text { are booked-the amount which represents the total of all outstanding commitments } \\
\text { of the issuer (Art. } 8 \text { of the decree of August } 4,1949 \text { ) and which balances the } \\
\text { number of securities in the custodian's accounts in Euroclear France. }\end{array}$ \\
\hline
\end{tabular}




\begin{tabular}{|c|c|}
\hline Assessment & Observed. \\
\hline \multicolumn{2}{|l|}{ Comments } \\
\hline Recommendation 7. & $\begin{array}{l}\text { Securities settlement systems should eliminate principal risk by linking securities } \\
\text { transfers to funds transfers in a way that achieves delivery versus payment. }\end{array}$ \\
\hline \multirow[t]{11}{*}{ Description } & $\begin{array}{l}\text { According to the BIS connotation, RGV2-TFT is a model } 1 \text { DVP system } \\
\text { (gross/gross). The technical, legal and contractual framework ensures DVP. }\end{array}$ \\
\hline & Legal framework \\
\hline & $\begin{array}{l}\text { The rules for DVP are set forth in the RGV2 rules relating to final settlement (Art. } \\
6.35 \text { ) and, which specify that the final delivery of the securities takes place at the } \\
\text { moment the cash account of the buyer in RGV2 is debited. }\end{array}$ \\
\hline & Technical framework \\
\hline & $\begin{array}{l}\text { While the execution of all transfers of funds related to the securities transactions of } \\
\text { the participant's cash-account held with the BdF is outsourced to Euroclear France, } \\
\text { the transfer of cash is executed on the same platform as the settlement of the } \\
\text { securities leg. Settlement of the cash and securities leg are therefore executed } \\
\text { simultaneously on the Euroclear France platform. This means that no exchange of } \\
\text { messages between the systems of Euroclear France and the BdF is necessary within } \\
\text { the framework of the DVP procedure to ensure blocking of cash and/or securities } \\
\text { during the settlement procedure and the final settlement thereof. }\end{array}$ \\
\hline & Within the framework of the DVP procedure: \\
\hline & $\begin{array}{l}\text { 1) Euroclear France checks that the buyer and the seller respectively have the } \\
\text { required amount of cash and securities to settle the trade; and }\end{array}$ \\
\hline & $\begin{array}{l}\text { 2) RGV2 debits the seller's securities account and the buyer's cash account, and } \\
\text { credits simultaneously the buyer's securities account and the seller's cash account; } \\
\text { at this moment, the settlement is final. }\end{array}$ \\
\hline & Pending transactions are held in a queue. \\
\hline & Amount of transactions to be settled on DVP basis \\
\hline & $\begin{array}{l}\text { More than } 95 \text { percent of securities transactions done are on a delivery versus } \\
\text { payment basis. Only a small segment of transactions are free of payment transfers } \\
\text { of securities, of which possibly the larger part are internal deliveries between the } \\
\text { custodian's own account and its clients' accounts, the transfer of clients securities } \\
\text { to another custodian, the transfer of collateral, and so on. }\end{array}$ \\
\hline Assessment & Observed. \\
\hline \multicolumn{2}{|l|}{ Comments } \\
\hline Recommendation 8. & $\begin{array}{l}\text { Final settlement on a DVP basis should occur no later than the end of the settlement } \\
\text { day. Intra-day or real-time finality should be provided where necessary to reduce } \\
\text { risks. }\end{array}$ \\
\hline \multirow[t]{2}{*}{ Description } & Intraday finality \\
\hline & $\begin{array}{l}\text { Final settlement is done on-line and real-time on a gross basis and allows for } \\
\text { intraday finality. Settlement with value day D is possible during } 19 \text { hours a day }\end{array}$ \\
\hline
\end{tabular}




\begin{tabular}{|c|c|}
\hline & 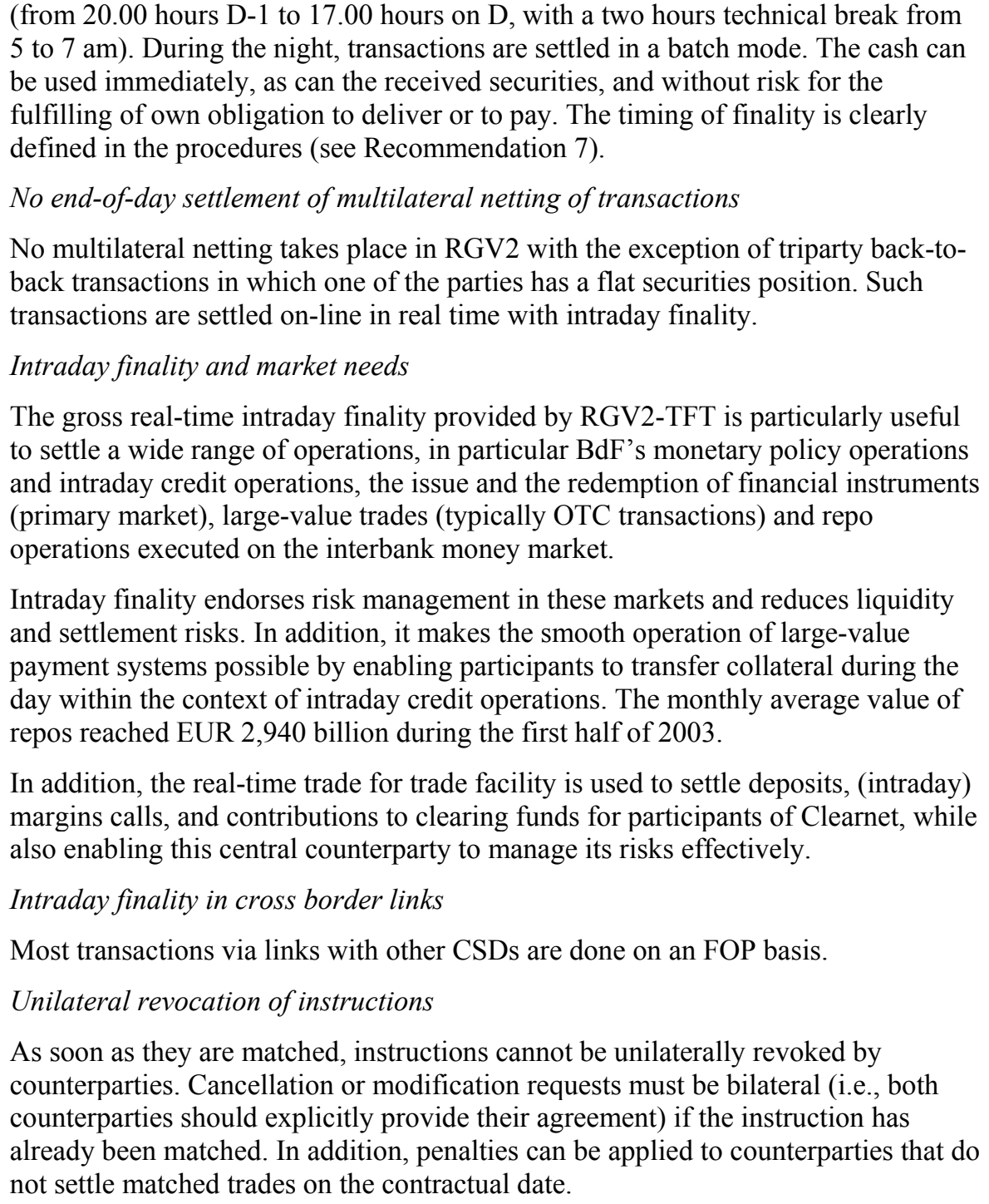 \\
\hline Assessment & Observed. \\
\hline Comments & \\
\hline Recommendation 9. & $\begin{array}{l}\text { Deferred net settlement systems should institute risk controls that, at a minimum, } \\
\text { ensure timely settlement in the event that the participant with the largest obligation } \\
\text { is unable to settle. In any system in which a CSD extends credit or arranges } \\
\text { securities loans to facilitate settlement, best practice is for the resulting credit } \\
\text { exposures to be fully collateralized. }\end{array}$ \\
\hline Description & $\begin{array}{l}\text { Need for safeguards in case of multilateral netting } \\
\text { RGV2-TFT is a trade-for-trade settlement system that settles on line in real time } \\
\text { with intraday finality. No multilateral netting with settlement late during the day } \\
\text { takes place. }\end{array}$ \\
\hline
\end{tabular}




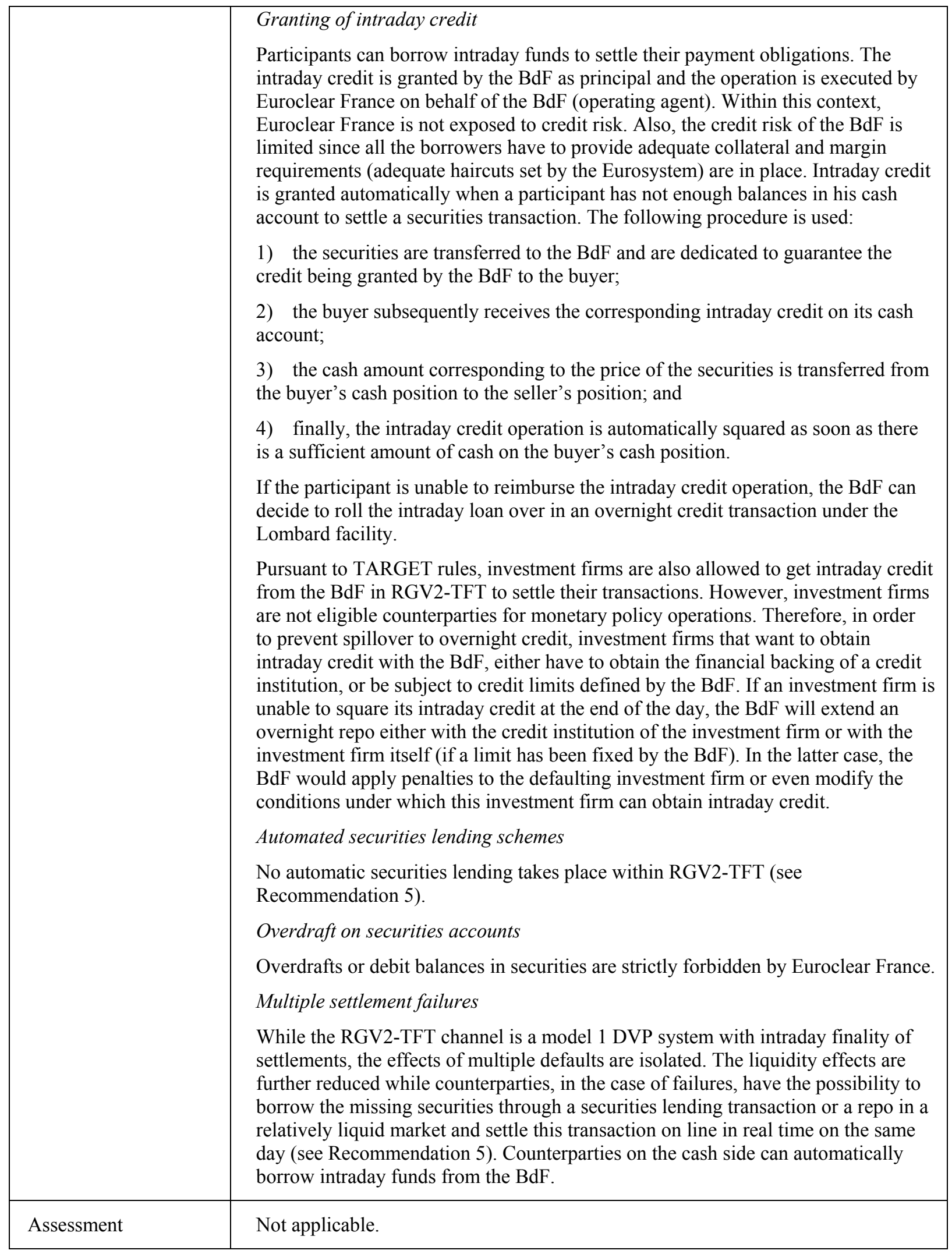




\begin{tabular}{|c|c|}
\hline Comments & \\
\hline Recommendation 10. & $\begin{array}{l}\text { Assets used to settle the cash leg of securities transactions between CSD members } \\
\text { should carry little or no credit risk. If central bank money is not used, steps must be } \\
\text { taken to protect CSD members from potential losses and liquidity pressures arising } \\
\text { from the failure of a settlement bank. }\end{array}$ \\
\hline \multirow[t]{5}{*}{ Description } & Use of central bank money \\
\hline & $\begin{array}{l}\text { Participants that have the status of a bank or an investment firm can open a cash } \\
\text { settlement account with the BdF that is operated by Euroclear France. Euroclear } \\
\text { France itself does not act as a settlement agent and participants have a direct claim } \\
\text { on the BdF and not on Euroclear France. The cash settlement services offered by } \\
\text { the BdF and operated by Euroclear are fully integrated in the RGV2-TFT } \\
\text { settlement system and fully dedicated for the settlement of securities and to } \\
\text { securities related payments (such as reimbursements, interest etc). Cash in these } \\
\text { accounts is immediately available for the fulfillment of the account holders' own } \\
\text { securities settlement obligations. If the participant wishes to use the money in the } \\
\text { account for other purposes, the balances have to be transferred via the liquidity } \\
\text { bridge between TBF and RGV2-TFT to TBF. }\end{array}$ \\
\hline & Use of private settlement bank assets \\
\hline & $\begin{array}{l}\text { Participants not fulfilling the access criteria for opening of a cash account with the } \\
\text { BdF according to the TARGET guidelines, or not willing to open a cash settlement } \\
\text { account in the system, have to use another participant/cash position holder as their } \\
\text { settlement bank. Fourteen out of } 188 \text { participants do so. No explicit rules and } \\
\text { requirements regarding the financial soundness of settlement banks have been set } \\
\text { by the operator, regulator or overseer. However, settlement banks are subject to } \\
\text { prudential supervision whether by the CB (for French institutions) or by banking } \\
\text { supervisors of their home countries. Information on concentration and settlement } \\
\text { flows on behalf of their customers is monitored by the BdF as overseer. }\end{array}$ \\
\hline & $\begin{array}{l}\text { Noncash account holders can reuse the amounts of cash received during the day in } \\
\text { the system via their settlement bank. Whether the amounts received can be } \\
\text { transferred to their account in TBF, if any, or to another bank the same day for } \\
\text { general payment purposes is not known. Probably it is the case. }\end{array}$ \\
\hline Assessment & Observed. \\
\hline \multicolumn{2}{|l|}{ Comments } \\
\hline Recommendation 11. & $\begin{array}{l}\text { Sources of operational risk arising in the clearing and settlement process should be } \\
\text { identified and minimized through the development of appropriate systems, controls, } \\
\text { and procedures. Systems should be reliable and secure and have adequate, scalable } \\
\text { capacity. Contingency plans and back-up facilities should be established to allow } \\
\text { for timely recovery of operations and completion of the settlement process. }\end{array}$ \\
\hline \multirow[t]{3}{*}{ Description } & Identification and managing of operational risk \\
\hline & $\begin{array}{l}\text { An independent risk management function was created in } 2001 \text { that directly reports } \\
\text { to the management committee and the board of Directors of Euroclear France. The } \\
\text { Management committee and the board have to validate all measures taken. }\end{array}$ \\
\hline & The objectives of the risk management function are: \\
\hline
\end{tabular}




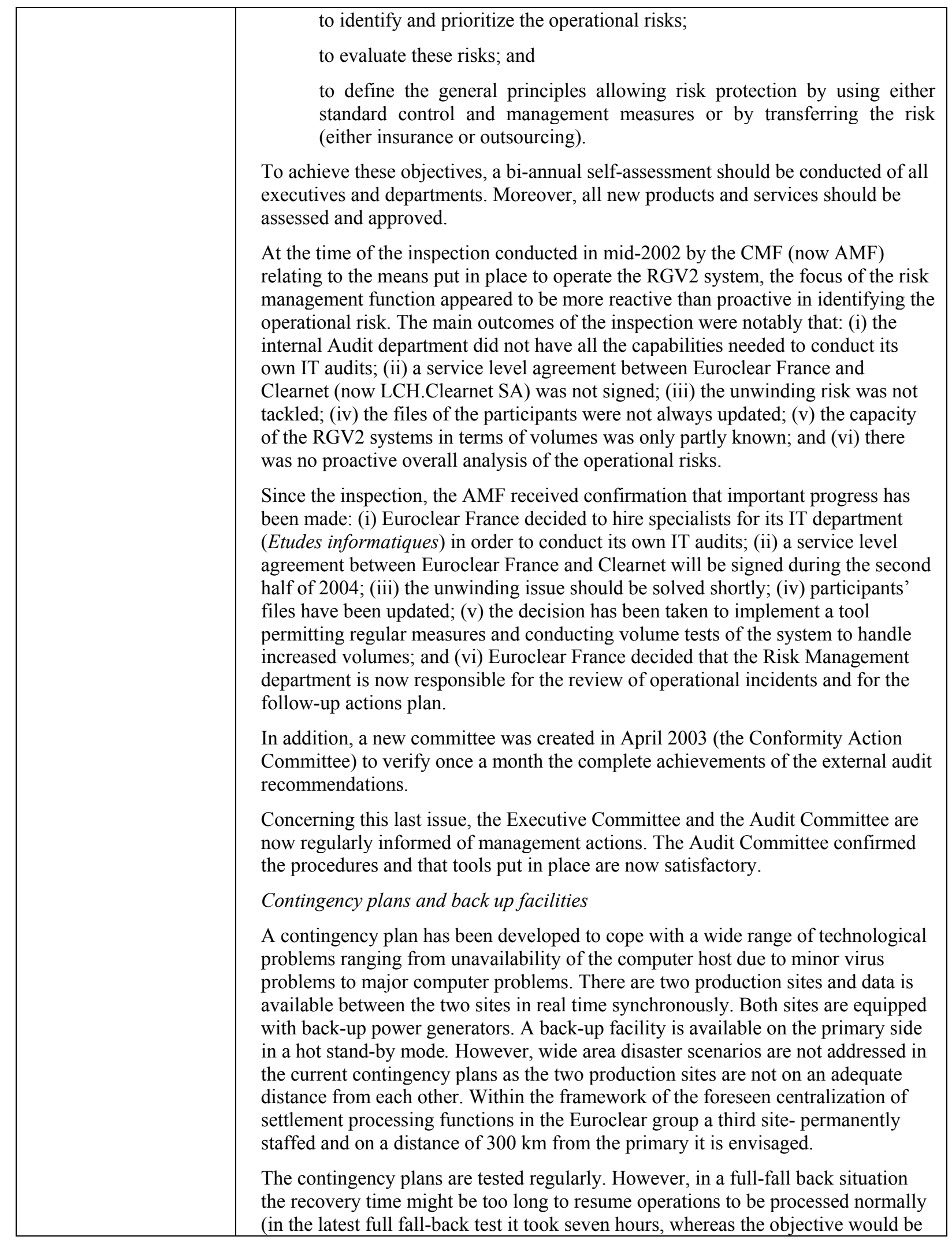




\begin{tabular}{|c|c|}
\hline & $\begin{array}{l}\text { about four hours). However, users do not participate in these test. } \\
\text { Protection of data communication } \\
\text { Adequate measures are taken to ensure integrity, authentication, confidentiality, } \\
\text { and nonrepudiability of data flows and data storage, and effective firewalls are in } \\
\text { place to protect the systems from intrusion attempts. } \\
\text { Availability and scalability } \\
\text { Euroclear France has sufficient and qualified staff at its disposal. } \\
\text { Although there were no major failures in the period July 2002-July } 2003 \text { numerous } \\
\text { medium and minor incidents occurred. All operations could however be resumed } \\
\text { within two hours, which is in line with Euroclear France's business continuity } \\
\text { objectives. } \\
\text { Capacity test are carried out for each key system individually, but there have been } \\
\text { no complete capacity tests to ensure availability under stressful circumstances, } \\
\text { which means that the maximum capacity levels are not known exactly. } \\
\text { Development and procurement } \\
\text { Special procedures are in place for development, procurement and testing. For } \\
\text { development, as well as for testing, dedicated IT environments are used that are } \\
\text { strictly separated from the operational environment. } \\
\text { Audits } \\
\text { The internal audit department performs internal audits according to the results of } \\
\text { risk analysis and on special request from senior management. These audits are } \\
\text { carried out with a three-year plan. } \\
\text { Feparate external audits were performed by the AMF, the supervisor of Euroclear } \\
\text { supervisor of Euroclear Bank (the owner of the Euroclear France). Within this } \\
\text { context an audit was performed on the operations of RGV2. Further on the CBFA } \\
\text { carried out bi-annual audits of the internal control procedures. No formal } \\
\text { respect to specific audits nor with respect to periodical routine audits. }\end{array}$ \\
\hline Assessment & Broadly observed. \\
\hline Comments & $\begin{array}{l}\text { It is recommended: } \\
\text {-to implement adequate tools for complete stress tests; } \\
\text {-to take adequate measures to be able to resume operations in case a full } \\
\text { back up is necessary on a timely basis and in line with the objectives set within } \\
\text { Euroclears business continuity policy (within two hours); and } \\
\text {-to conclude appropriate service level agreements in case of outsourcing of } \\
\text { tasks, such as with respect to the operation of ISB, an inter-dealer broker facility } \\
\text { operated by LCH-Clearnet SA. } \\
\text { Further on, in line with the AMF/KPMG recommendation, Euroclear France } \\
\text { may wish to consider the strengthening of their operational risk policy by putting in } \\
\text { place a proactive risk analysis methodology to conducting an overall analysis of } \\
\text { operational risks (threats) in the systems and organization of Euroclear France, and } \\
\text { that adequate measures are taken to contain the indicated risks or to transfer or }\end{array}$ \\
\hline
\end{tabular}




\begin{tabular}{|c|c|}
\hline & outsource them through insurance or other means. \\
\hline Recommendation 12. & $\begin{array}{l}\text { Entities holding securities in custody should employ accounting practices and } \\
\text { safekeeping procedures that fully protect customers' securities. It is essential that } \\
\text { customers' securities be protected against the claims of a custodian's creditors. }\end{array}$ \\
\hline \multirow[t]{10}{*}{ Description } & Legal protection of customers assets \\
\hline & $\begin{array}{l}\text { Ownerships rights on securities are evidenced by the records of the authorized } \\
\text { custodian of the beneficial owner (Art. } 1 \text { of the executive order no 83-359 of } \\
\text { May 2, 1983). }\end{array}$ \\
\hline & $\begin{array}{l}\text { Customer assets are legally protected against the insolvency of Euroclear France, a } \\
\text { custodian or a intermediary. They fall outside the bankruptcy estate and cannot be } \\
\text { claimed by the creditors of the aforementioned institutions (COMOFI, Art. L.431- } \\
\text { 6). }\end{array}$ \\
\hline & $\begin{array}{l}\text { In case of insolvency of a custodian, there is a clear restitution procedure. Within } \\
\text { this framework the administrators or liquidators appointed by the court and the } \\
\text { temporary administrator appointed by the } \mathrm{CB} \text {, verify, financial instrument, by } \\
\text { instrument, whether all the securities in the accounts held by the custodian with the } \\
\text { CSD or with another intermediary, meet its obligation to the end investors/owners } \\
\text { of the securities. If there are enough securities in the relevant account(s), their } \\
\text { owners can instruct the aforementioned administrators to transfer their securities to } \\
\text { another custodian. If there is a shortage of securities, the securities are apportioned } \\
\text { pro rata between the end-investors/owners. }\end{array}$ \\
\hline & $\begin{array}{l}\text { Investors can be compensated for the loss of their securities or for the loss of cash } \\
\text { in unfinished settlement procedures under the securities guarantee scheme } \\
\text { established under Art. L.312-4 of the COMOFI and managed by the DGF. }\end{array}$ \\
\hline & Segregation of customers assets and own investment \\
\hline & $\begin{array}{l}\text { Custodians are obliged to segregate the assets of end investors from their own } \\
\text { assets at the CSD level. Segregation at the level of Euroclear France is possible } \\
\text { under two different options: the custodian can open different securities accounts for } \\
\text { each (category of) customer(s) or establish a specific subaccount to its main } \\
\text { securities account. The custodian has the possibility to separate assets for a } \\
\text { category of owners (mutual funds for instance) or for individual owners, depending } \\
\text { on customer needs and the range of custodial services provided. }\end{array}$ \\
\hline & Appropriate procedures and internal organization of custodians \\
\hline & $\begin{array}{l}\text { The general regulations of the AMF contain provisions regarding the duties of } \\
\text { custodians. In particular, the custodian may not make any use of the financial } \\
\text { instruments in its custody without the holder's express consent. The custodian shall } \\
\text { organize its internal procedures to ensure that any movement affecting the financial } \\
\text { instruments it holds in custody on behalf of customers is justified by a properly } \\
\text { recorded transaction. The custodian has an obligation to return any financial } \\
\text { instruments entrusted to it. The custodian shall describe the organization of its } \\
\text { accounting in an appropriate document. For the purpose of ascertaining and } \\
\text { monitoring the rights of account holders, financial instrument accounts shall be } \\
\text { maintained according to the rules of double-entry bookkeeping. }\end{array}$ \\
\hline & $\begin{array}{l}\text { The general regulations of the AMF are supplemented by a specific range of } \\
\text { requirements applicable to custodians ("Performance requirements for custody } \\
\text { account keepers," Decision No. 2001-01 of the CMF). These very detailed and } \\
\text { stringent harmonized standards encompass transparency requirements (publicity of }\end{array}$ \\
\hline
\end{tabular}




\begin{tabular}{|c|c|}
\hline & $\begin{array}{l}\text { the organizational chart), requirements related to human and IT resources, } \\
\text { accounting procedures, categories of services and customer protection, relations } \\
\text { with other providers of services (brokers), and control and monitoring procedures. } \\
\text { Previously mentioned regulations require custodians to reconcile their records daily } \\
\text { and maintain audit trails of all cash and securities transfers. } \\
\text { Supervision } \\
\text { The general regulations of the AMF require custodians to be credit institutions, } \\
\text { investment firms, public bodies or full subsidiaries of credit institutions and } \\
\text { investment firms. Credit institutions and investment firms are subject to prudential } \\
\text { supervision of the CB. } \\
\text { The AMF is in charge of the ongoing control of the observance of the rules and } \\
\text { regulations it has set forth for custody and clearing and settlement activities through } \\
\text { off-site and on-site inspections of custodians and Euroclear France (COMOFI, } \\
\text { L.622-9). }\end{array}$ \\
\hline Assessment & Observed. \\
\hline Comments & \\
\hline Recommendation 13. & $\begin{array}{l}\text { Governance arrangements for CSDs and central counterparties should be designed } \\
\text { to fulfill public interest requirements and to promote the objectives of owners and } \\
\text { users. }\end{array}$ \\
\hline Description & $\begin{array}{l}\text { Euroclear France is a private sector entity fully owned by Euroclear Bank SA/NV } \\
\text { and is organized on a for-profit basis (société anonyme de forme commerciale). } \\
\text { Internal governance arrangements } \\
\text { Clear internal governance arrangements are in place that give the decision makers } \\
\text { the incentives and the skills needed to achieve the system's objectives, ensuring the } \\
\text { accountability of management. Management has appropriate tools for management } \\
\text { control and monitoring. There is an independent internal audit department that } \\
\text { reports directly to management. Several committees are in place to discuss relevant } \\
\text { issues, such as a risk committee, an audit committee, and a compliance committee. } \\
\text { Board members attend the meetings of these various committees. In addition, the } \\
\text { chief operations officer, although not a member of the Board, attends the Boards' } \\
\text { meetings in order to provide its expertise on operational issues. } \\
\text { The composition of the Board is determined by Euroclear Bank, the parent } \\
\text { company of Euroclear France. } \\
\text { Public information is available on the main activities and projects of the Euroclear } \\
\text { group and Euroclear Bank with published annual reports and account information. } \\
\text { Users participation } \\
\text { A clear structure for consultation of the users/participants has been implemented. } \\
\text { In } 2001 \text {, a Market Advisory Committee (MAC) was established, composed of } \\
\text { representatives of participants in Euroclear France (around 20). The MAC is } \\
\text { chaired by a representative of the participants. Euroclear France management } \\
\text { participates in the meetings. } \\
\text { The MAC, which has a consultative role, is in charge of three missions: } \\
\text { formulating proposals and recommendations regarding guidelines and }\end{array}$ \\
\hline
\end{tabular}




\begin{tabular}{|c|c|}
\hline & $\begin{array}{l}\text { evolutions of Euroclear France; } \\
\text { - considering the maintenance of efficient tools for the users; and } \\
\text { - observing the policy of fees of Euroclear France. } \\
\text { Since November 2002, the MAC directly reports to the Board of Euroclear Bank, } \\
\text { which is in charge of approving the nomination of its members. The MAC also } \\
\text { reports to the Board of Euroclear France. The work of the MAC, which meets at } \\
\text { least quarterly, is prepared by a users group and, if needed, by "ad hoc" working } \\
\text { groups, which may be launched on specific topics and projects (i.e., avoiding } \\
\text { duplication with the working groups of the French securities association). } \\
\text { In addition, the chairman of the MAC was appointed as "censor" (censeur) of } \\
\text { Euroclear France and participates in the Board Meetings with a consultative role. } \\
\text { He is in charge of ensuring that the users' points of views are communicated to the } \\
\text { Board. The mission of censor(s) is defined in Euroclear France's by-laws. }\end{array}$ \\
\hline Assessment & Observed. \\
\hline Comments & $\begin{array}{l}\text { Although the governance structure of Euroclear France has substantially improved } \\
\text { after the take-over by Euroclear Bank Brussels (EBB), and-although, it has still to } \\
\text { be assessed-the governance arrangement of Euroclear Bank Brussels seems not to } \\
\text { have had adverse affects on its effectiveness. However, things might change rapidly } \\
\text { in the near future when the operational activities of local CSD's and Euroclear } \\
\text { Bank Brussels will be integrated within the context of centralization of settlement } \\
\text { processing functions. Key questions within these developments might be whether } \\
\text { the present governance structure is effective to deal with potential conflicts of } \\
\text { interest that could arise between the owner/operator and the users, who are } \\
\text { competitors in the market for clearing and settlement and custodial services. } \\
\text { Another key issue that has to be dealt with in this new operational context seems to } \\
\text { be how to define and serve the public interest of the new cross-border } \\
\text { infrastructure. A blueprint for an ideal governance structure in this situation is not } \\
\text { easy to design, but should get adequate attention of the overseers/regulators and it } \\
\text { should be ensured that all relevant market participant are involved in the discussion } \\
\text { and are able to express their opinion. At present, there exist distinct fears in the } \\
\text { market, that future developments might harm their interest will negatively influence } \\
\text { their competitive position. }\end{array}$ \\
\hline Recommendation 14. & $\begin{array}{l}\text { CSDs and central counterparties should have objective and publicly disclosed } \\
\text { criteria for participation that permit fair and open access. }\end{array}$ \\
\hline Description & $\begin{array}{l}\text { Access criteria } \\
\text { The following entities are allowed to become participants in RGV2, pursuant to the } \\
\text { general access criteria: } \\
\text { - credit institutions and investment firms incorporated in France; } \\
\text { - clearnet Clearing Members having the status of specialized firm; } \\
\text { - French public entities (Treasury, BdF, financial services of the Post office); } \\
\text { - legal entities incorporated within the EEA and allowed to provide } \\
\text { investment services pursuant to the free provision of services and free } \\
\text { establishment principles as organized by the European Directives; } \\
\text { - custodians duly authorized by the AMF to hold securities accounts on behalf }\end{array}$ \\
\hline
\end{tabular}




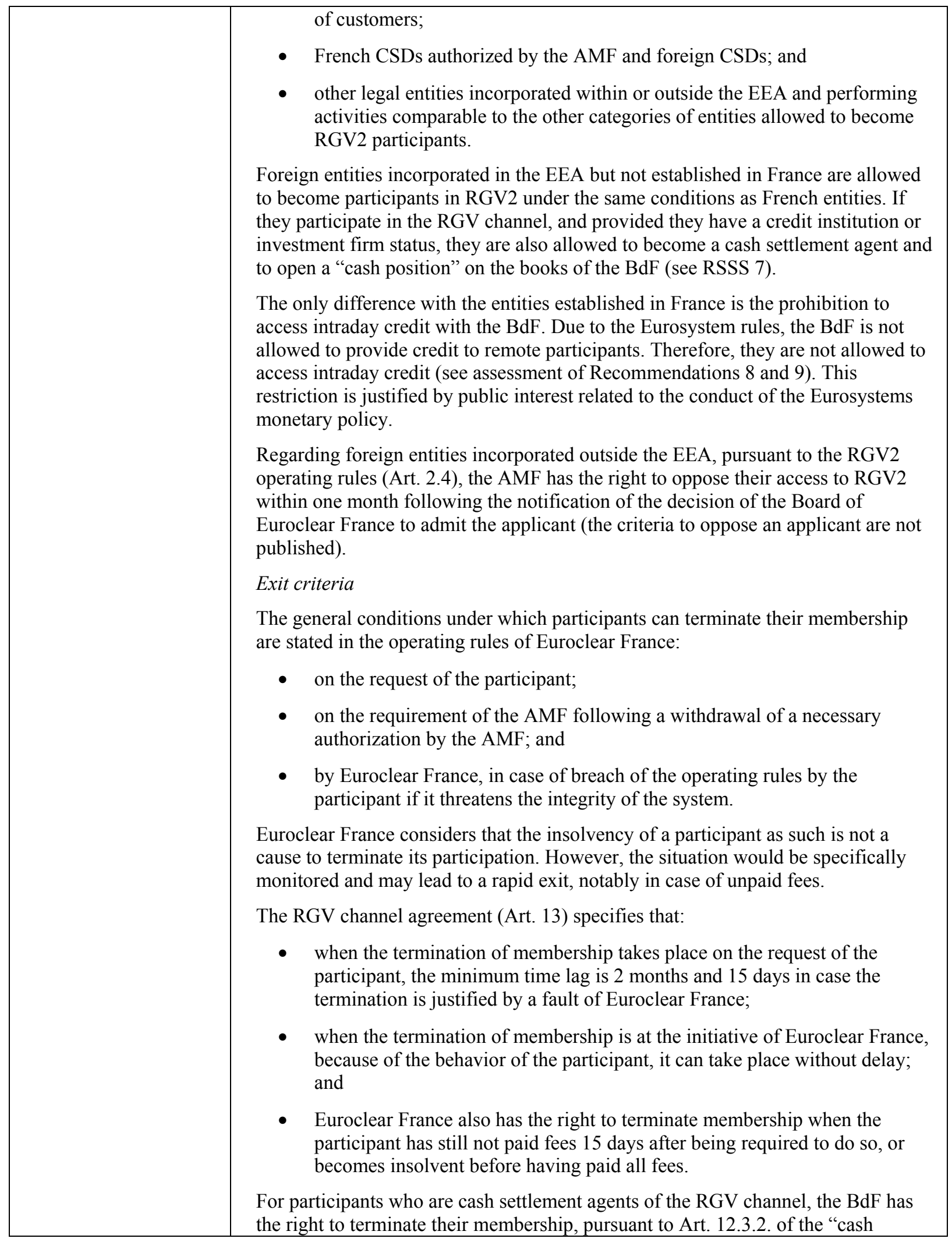




\begin{tabular}{|c|c|}
\hline & $\begin{array}{l}\text { position agreement," for four reasons: } \\
\text { payment incident; } \\
\text { abnormal functioning of the cash position; } \\
\text { opening of an insolvency procedure against the participant; and } \\
\text { its financial soundness may endanger the smooth operating of RGV or TBF (the } \\
\text { French RTGS system part of TARGET). }\end{array}$ \\
\hline Assessment & Observed. \\
\hline Comments & $\begin{array}{l}\text { It is recommended: } \\
\text { - to develop and make public the criteria on which the AMF can oppose an } \\
\text { applicant from outside the EEA and the procedure followed. In addition to } \\
\text { the requirement that an applicant has to be adequately overseen or } \\
\text { supervised, it might be worthwhile to consider whether a legal opinion } \\
\text { should be made available that determines whether there might be a conflict } \\
\text { of laws that could threaten the smooth and secure functioning of custody } \\
\text { and settlement of securities in France. } \\
\text { to specify in the rules and regulations the consequences of a termination of } \\
\text { an RGV2 cash position of a settlement participant. }\end{array}$ \\
\hline Recommendation 15. & $\begin{array}{l}\text { While maintaining safe and secure operations, securities settlement systems should } \\
\text { be cost-effective in meeting the requirements of users. }\end{array}$ \\
\hline Description & $\begin{array}{l}\text { Budgetary process } \\
\text { Euroclear France manages its costs on an annual budget system. The new budget is } \\
\text { based an a bottom-up approach. Sales are estimated and the strategic plan is taken } \\
\text { into account is the evolution of wages and overhead. During the year, the budget is } \\
\text { monitored. } \\
\text { Price structure } \\
\text { Prices are set in agreement with the users. Owing to the absence of a } \\
\text { comprehensive analytical accounting method, the present price structure is not } \\
\text { directly related to the cost of each of the services. Introduction of such an } \\
\text { accounting framework might be difficult due to the large amount of services } \\
\text { provided (over 155). The prices charged by Euroclear allow it to make a profit. } \\
\text { Cross subsidization between product or services cannot be ruled out in the present } \\
\text { structure. } \\
\text { Euroclear France indicates that it plans to implement a comprehensive analytical } \\
\text { accounting of its operations, which is only partly available at present. Such a } \\
\text { project would clearly improve the degree of observance of Recommendation } 15 . \\
\text { However, no clear planning has been disclosed so far on the following steps that } \\
\text { would enable the extension of analytical accounting to the entire cost structure of } \\
\text { Euroclear France. } \\
\text { Benchmarking } \\
\text { Euroclear does not benchmark its costs, prices and service levels against those of } \\
\text { other CSDs. However the integration and harmonization of prices of the Euroclear } \\
\text { group's CSDs will be a key component of the group's operational integration. }\end{array}$ \\
\hline
\end{tabular}




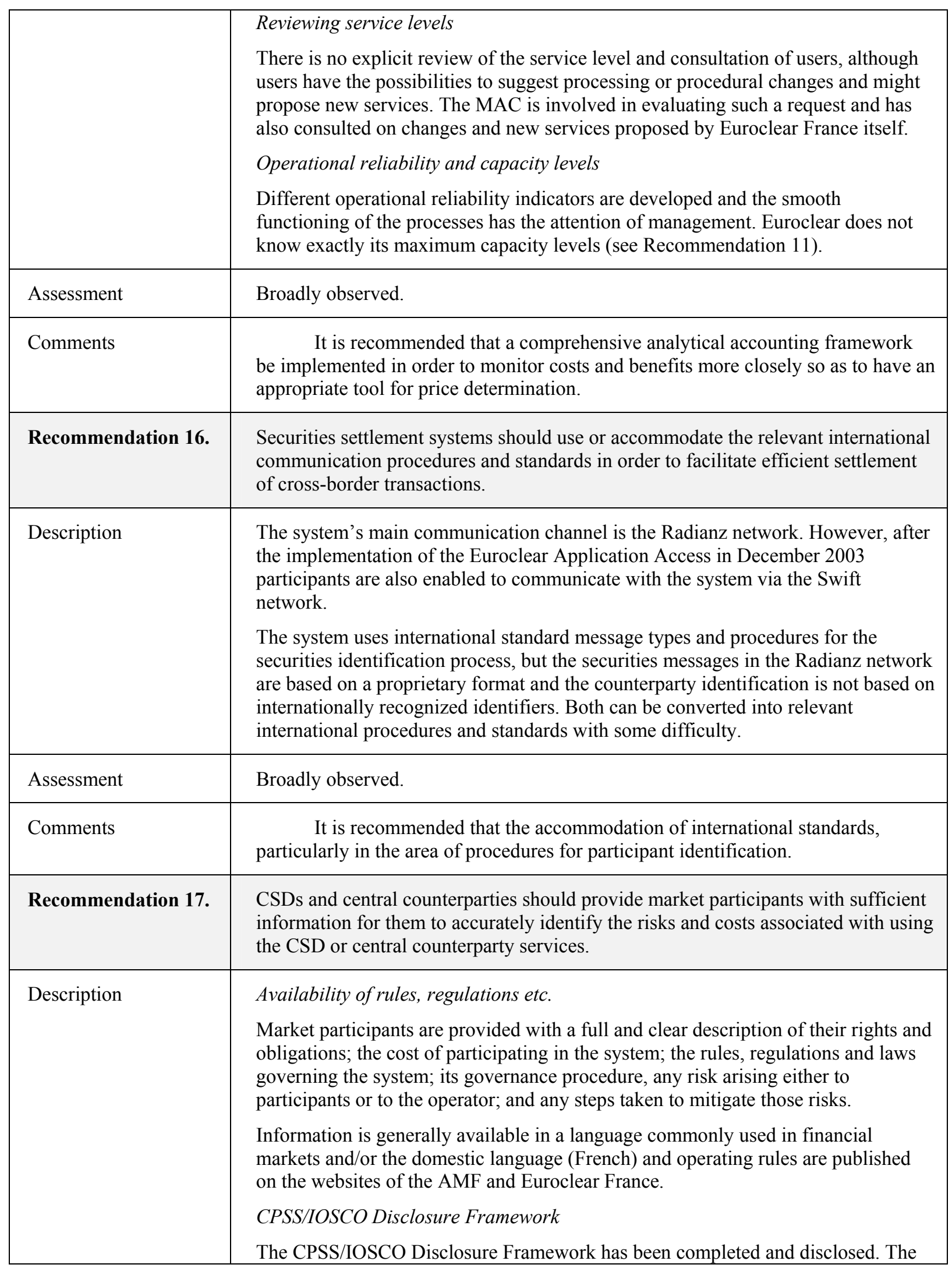




\begin{tabular}{|c|c|}
\hline & $\begin{array}{l}\text { last updated version was made available in March 2002, and contains changes on } \\
\text { some issues (e.g., the oversight /supervision of Euroclear France). }\end{array}$ \\
\hline Assessment & Broadly observed. \\
\hline Comments & $\begin{array}{l}\text { It is recommended that the Disclosure framework be updated. Alternatively, } \\
\text { Euroclear France could also publish the assessed answers to "key questions." }\end{array}$ \\
\hline Recommendation 18. & $\begin{array}{l}\text { Securities settlement systems should be subject to regulation and oversight. The } \\
\text { responsibilities and objectives of the securities regulator and the central bank with } \\
\text { respect to SSSs should be clearly defined, and their roles and major policies should } \\
\text { be publicly disclosed. They should have the ability and resources to perform their } \\
\text { responsibilities, including assessing and promoting implementation of these } \\
\text { recommendations. They should cooperate with each other and with other relevant } \\
\text { authorities. }\end{array}$ \\
\hline \multirow[t]{8}{*}{ Description } & Entities involved in the oversight/supervision \\
\hline & $\begin{array}{l}\text { The RGV2 system is subject to both regulations by the AMF and oversight by the } \\
\text { BdF. Since Euroclear France is a corporate company which does not have either the } \\
\text { status of a credit institution or of an investment firm, the French banking supervisor } \\
\text { (CB) is not involved in its supervision. }\end{array}$ \\
\hline & $\begin{array}{l}\text { The regulatory competences of the AMF toward SSSs are organized by French law. } \\
\text { Under the terms of Art. L.622-7 of the COMOFI, the AMF "shall authorize central } \\
\text { depositories according to the procedures established in its General Regulations and } \\
\text { approve their operating rules; shall set in its general regulations the general } \\
\text { principles for organizing and operating securities settlement systems and approve } \\
\text { the operating rules for such systems, without prejudice to the powers granted to the } \\
\text { BdF under Art. L.141-4." }\end{array}$ \\
\hline & $\begin{array}{l}\text { The oversight competence of BdF also relies on a legal provision, in Art. L.141-4 } \\
\text { of the COMOFI, which states that: "As part of the duties of the European System of } \\
\text { Central Banks and without prejudice of the competences of the Financial Markets } \\
\text { Council [Authority] and of the Banking Commission, the Banque de France is in } \\
\text { charge of monitoring the safety of securities clearing and settlement systems." }\end{array}$ \\
\hline & $\begin{array}{l}\text { Moreover, the Belgian CBFA has an interest in Euroclear France, which is the } \\
\text { French subsidiary of Euroclear Bank. This interest stems from the prudential } \\
\text { supervision of the consolidated and nonconsolidated situation of the Euroclear } \\
\text { Group according to the concept of "close link" between Euroclear France and } \\
\text { Euroclear Bank. }\end{array}$ \\
\hline & Roles, responsibilities and resources \\
\hline & $\begin{array}{l}\text { The regulatory and oversight framework for SSS is based on a statute-based } \\
\text { approach. The respective roles of the AMF and the BdF are clearly defined and } \\
\text { legally enforceable. Their roles and major policies are publicly disclosed. The } \\
\text { oversight mission of the BdF is published on its website. Within the framework of } \\
\text { oversight, regular meeting takes place between the overseers and Euroclear France, } \\
\text { information is gathered based on public reports as well as on special requests by the } \\
\text { overseer. The AMF can carry out on-site inspections if deemed necessary. The } \\
\text { AMF can conduct external audits on the systems, internal controls and organization } \\
\text { of Euroclear France. }\end{array}$ \\
\hline & The BdF could also carry out such audits based on the agreement it has concluded \\
\hline
\end{tabular}




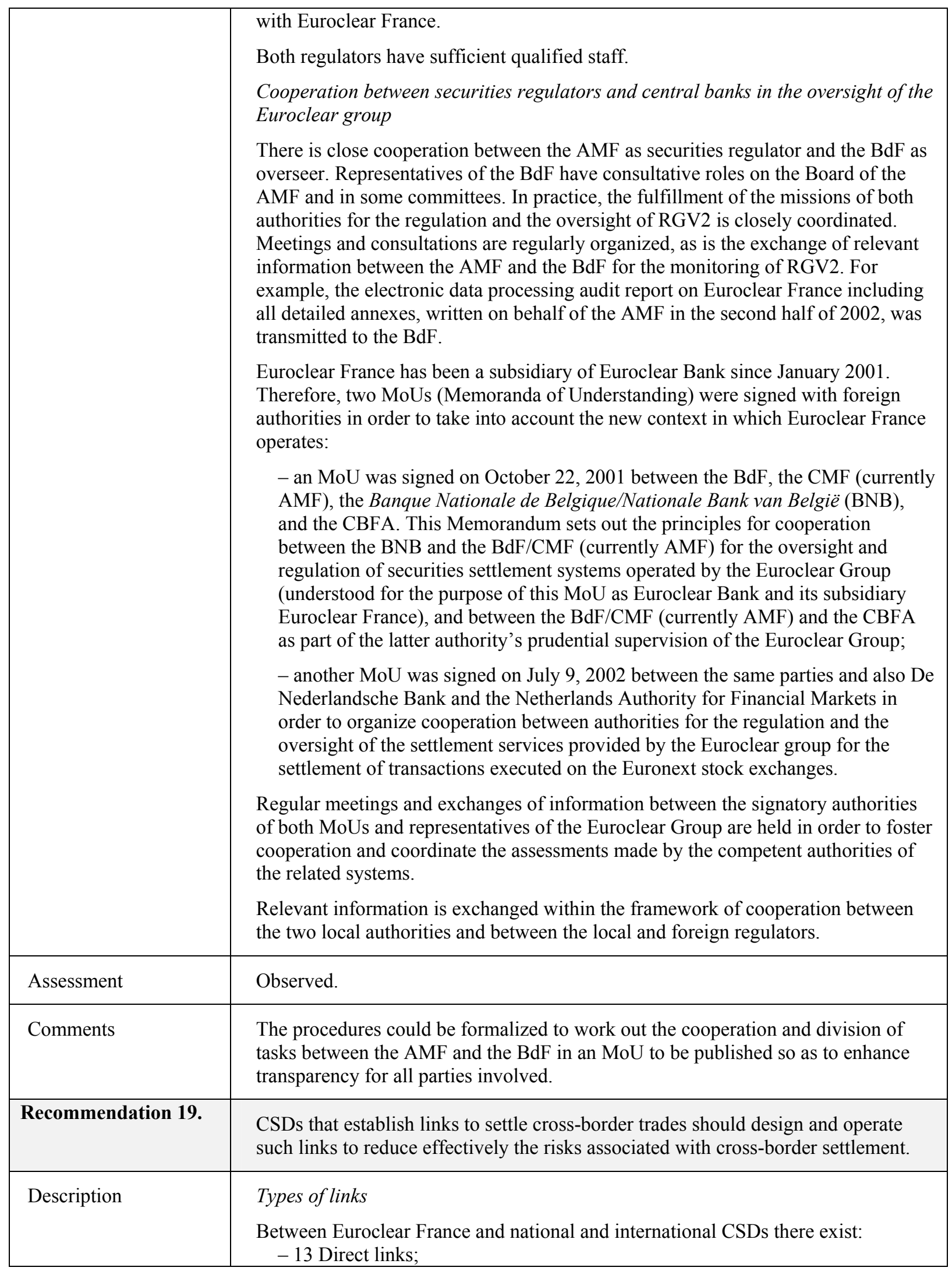




\begin{tabular}{|c|c|}
\hline & $\begin{array}{l}\text { - } 1 \text { Indirect link; and } \\
-14 \text { Relayed links in which Euroclear Bank Brussels is used as the intermediary } \\
\text { CSD. } \\
\text { Risk analysis } \\
\text { Risk analysis is conducted with respect to the financial and operational integrity of } \\
\text { the linked CSD, although the legal risk involved in depositing, clearing, and } \\
\text { settlement of foreign securities in Euroclear France might not be fully assessed. } \\
\text { Delivery versus Payment } \\
\text { All of the links are only used for Free-of-Payment transfers except the direct and } \\
\text { indirect link with Euroclear Bank Brussels and the direct link with Clearstream } \\
\text { Banking Luxembourg which allow for Delivery versus Payments in commercial } \\
\text { bank money. } \\
\text { In principle, provisional transfers are prohibited in both directions (inward and } \\
\text { outward links). Credits and debits of the omnibus securities accounts of foreign } \\
\text { CSDs open on the books of Euroclear France, which reflect either holdings of their } \\
\text { participants in French securities or holdings of Euroclear France participants in } \\
\text { foreign securities, can be made only when final (in RGV2 and/or in the foreign } \\
\text { SSS). } \\
\text { Credit extensions } \\
\text { Euroclear France does not extend credit to its participants, nor is it involved in } \\
\text { securities lending schemes. }\end{array}$ \\
\hline Assessment & Observed. \\
\hline Comments & \\
\hline
\end{tabular}

Table 25. Summary Observance of Euroclear France as a Central Securities Depository and of the RGV2 irrevocable Trade for Trade channel operated by Euroclear France of the CPSS/IOSCO recommendation for Securities Settlement Systems

\begin{tabular}{|l|c|l|}
\hline \multirow{2}{*}{ Assessment Grade } & \multicolumn{2}{|c|}{ Recommendation Grouped by Assessment Grade } \\
\cline { 2 - 3 } & Count & \multicolumn{1}{c|}{ List } \\
\hline Observed & 12 & Rec. 2, 3, 5, 6, 7, 8, 10, 12, 13, 14, 18 and 19 \\
\hline Broadly observed & 5 & Rec. 1, 11, 15, 16 and 17 \\
\hline Partly observed & 0 & -- \\
\hline Non-observed & 0 & -- \\
\hline Not applicable & 2 & Rec. 4, 9 \\
\hline
\end{tabular}




\section{Recommended actions}

\section{Table 26. Recommended Actions to Improve Observance of Euroclear France and the RGV2 of CPSS/IOSCO Recommendations for Securities Settlement Systems}

\begin{tabular}{|c|c|}
\hline Reference Recommendation & Recommended Action \\
\hline Rec. 1 Sound legal basis & $\begin{array}{l}\text { - evaluate comprehensively the conflict of law issues in the system and } \\
\text { implement clear procedures regarding the acceptance of foreign } \\
\text { participants. }\end{array}$ \\
\hline \multirow[t]{4}{*}{ Rec. 11 Operational reliability } & - implement adequate tools to conduct complete stress tests; \\
\hline & $\begin{array}{l}\text { - take adequate measures to be able to resume operations in a timely } \\
\text { manner in case of a full fall back to the second site; }\end{array}$ \\
\hline & $\begin{array}{l}\text { - conduct appropriate service level agreements in case of outsourcing } \\
\text { of tasks: }\end{array}$ \\
\hline & $\begin{array}{l}\text { - consider putting in place a proactive risk analysis methodology and } \\
\text { conducting within this framework an overall analysis of potential } \\
\text { operational risks. Ensure that adequate measures will be taken to } \\
\text { contain the indicated risks or transfer or outsource them through } \\
\text { insurance or other means. }\end{array}$ \\
\hline Rec. 13 Governance arrangements & $\begin{array}{l}\text { - the overseer/regulator should pay attention whether the present } \\
\text { governance structure will still be adequate when the operational } \\
\text { activities of local CSD's and Euroclear Bank Brussels will be } \\
\text { integrated in the near future. }\end{array}$ \\
\hline \multirow[t]{2}{*}{ Rec. 14 Access criteria } & $\begin{array}{l}\text { - develop and publish the criteria on the basis of which the AMF can } \\
\text { oppose an applicant from outside the EEA and the procedures } \\
\text { followed. Consider in this context whether a legal opinion on possible } \\
\text { conflicts of laws should be made available by the applicant; }\end{array}$ \\
\hline & $\begin{array}{l}\text { - specify in the rules and regulations the consequences of a termination } \\
\text { of an RGV2 cash position of a settlement participant. }\end{array}$ \\
\hline Rec. 15 Cost-effectiveness & $\begin{array}{l}\text { - implement a comprehensive analytical accounting methodology in } \\
\text { order to monitor more closely costs and benefits in order to facilitate } \\
\text { price determination of the different services offered. }\end{array}$ \\
\hline $\begin{array}{l}\text { Rec. } 16 \text { International communication } \\
\text { standards }\end{array}$ & $\begin{array}{l}\text { - facilitate the adoption of international standards in all } \\
\text { communication channels used, particularly in the area of procedures } \\
\text { for participants identification. }\end{array}$ \\
\hline Rec. 17 Disclosure of risks and costs & $\begin{array}{l}\text { - update the Disclosure framework or alternatively publish the assessed } \\
\text { answers to key questions. }\end{array}$ \\
\hline Rec. 18 Oversight & $\begin{array}{l}\text { - consider to work out the cooperation and the division of tasks } \\
\text { between the AMF and the Banque de France in a Memorandum of } \\
\text { Understanding that could be made available to all parties concerned } \\
\text { and to the public. }\end{array}$ \\
\hline
\end{tabular}


Table 27. Detailed Assessment of Relit+, the Multilateral Netting Scheme for the Clearing and Settlement of Stock Exchange and OTC Securities Transactions of the CPSS/IOSCO Recommendations for Securities Settlement Systems

\begin{tabular}{|c|c|}
\hline Recommendation 1. & $\begin{array}{l}\text { Securities settlement systems should have a well-founded, clear, and transparent legal } \\
\text { basis in the relevant jurisdiction. }\end{array}$ \\
\hline Description & 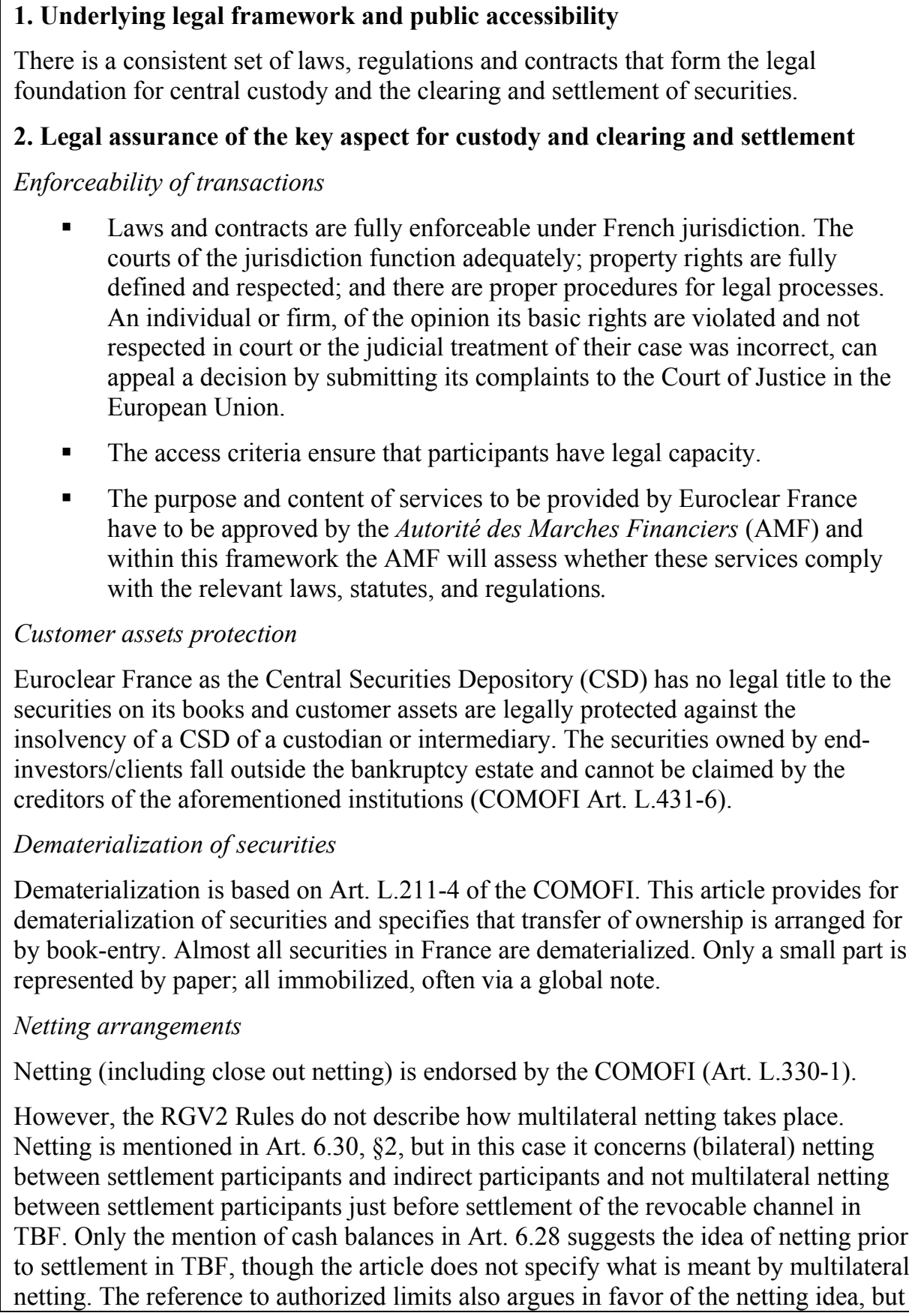 \\
\hline
\end{tabular}


in all events it is not clear from a reading of the RGV2 Rules whether the limits are bilateral or multilateral. In addition, the fact that netting is mentioned in the rules of the irrevocable channel (RGV2-TFT), in Art. 6.44, $§ 1$, despite the fact that in principle no netting occurs in this channel (except for back-to-back transactions), may be confusing.

\section{Securities lending arrangements}

The legal framework supports securities lending by recognizing explicitly securities loans (Art. L.432-6 to L.432-11) and repurchase agreements COMOFI (Art. L.432-12 to L.432-19). These provisions define the instrument, the range of securities which can be lent or repurchased and the eligible counterparties. Enforceability of the securities lending and repurchase agreements towards third parties is ensured. Collateral provided in the context of securities loan or repurchase agreements will not expose the lending party to the risk that the transaction can be challenged by a third party or a liquidator by re-characterizing the securities lending or the repo as an improper pledge.

Irrevocability and finality

- Orders in the system are irrevocable at the moment they match. However, there are some exemptions. No matching takes place for certain types of transactions; in this case they are irrevocable once they are entered in the system.

- Finality in Relit+ is well defined and recognized under French law. The preliminary transfers of securities become final as soon as the settlement of the netted cash positions takes place in TBF, and the BdF has informed Euroclear France on the final settlement of the cash position.

- Bankruptcy procedures contain a zero hour rule and regulations with respect to a suspect period. However, due to the finality regulations in the COMOFI, no retroactive action or unwinding by the liquidator is possible in the system on the day a bankruptcy procedure is opened against a participant with respect to the payments done by that participant on that day.

Delivery versus payments

- According to the BIS connotation, Relit+ is a model 2 DVP system (gross/net). The legal and contractual basis of the Relit+ DVP settlement procedure is based on Articles 6.32 and 6.33 of the RGV2 Rules. These articles state that the settlement of the securities leg, which is processed on a gross basis, does not become final as long as the cash leg, which is operated on a net basis, is not settled in TBF. These rules are endorsed by the finality regulation in the COMOFI.

- In the event of a default of a customer, the intermediary or the custodian may avail himself of full title to the securities purchased on his customer's behalf or to the cash received from the counterparty; the custodian may also avail himself of full title to the securities purchased or cash received from the counterparty if the customer does not fulfill its obligations to pay or to deliver while the intermediary or custodian is bound to perform its obligation according to the DVP rules in RGV2 or has performed them already (COMOFI Art. L.431-3).

Examination of the legality of rules and regulations

There exists no case law in which the rules and regulation of Euroclear and, 


\begin{tabular}{|c|c|}
\hline & $\begin{array}{l}\text { especially, the rules with respect to DVP, are challenged or overruled in court. } \\
\mathbf{3} \text { Enforceability of rules and regulations in the event of a bankruptcy } \\
\text { Due to the finality regulation in the COMOFI all the rules and regulations of the } \\
\text { system are enforceable in the event of a bankruptcy and transactions on such a day } \\
\text { cannot be unwound or reversed within the system. } \\
\mathbf{4} \text { Conflict of law issues } \\
\text { The admission of foreign participants to Relit+ has not been submitted to procedures } \\
\text { analyzing conflict of law issues. Nor is a legal opinion to be provided within the } \\
\text { context of the approval procedure by the AMF of participants from countries outside } \\
\text { the European Economic Area (EEA). }\end{array}$ \\
\hline Assessment & Broadly observed. \\
\hline Comments & $\begin{array}{l}\text { It is recommended that conflict of laws issues in the system be evaluated } \\
\text { comprehensively and that clear procedures be implemented regarding the acceptance } \\
\text { of foreign participants (the requirement of a legal opinion etc). }\end{array}$ \\
\hline Recommendation 2. & $\begin{array}{l}\text { Confirmation of trades between market participants should occur as soon as possible } \\
\text { after trade execution, but no later than trade date }(\mathrm{T}+0) \text {. Where confirmation of trades } \\
\text { by indirect market participants (such as institutional investors) is required, it should } \\
\text { occur as soon as possible after trade execution, preferably on } \mathrm{T}+0 \text {, but no later than } \\
\mathrm{T}+1 \text {. }\end{array}$ \\
\hline Description & $\begin{array}{l}\text { All settlement instructions in Relit }+ \text { are prior to settlement matched and confirmed on } \\
\text { trade date }(T+0) \text { or at the latest at } 12.00 \text { on } T+1 \text {. The aforementioned trades are } \\
\text { generally confirmed by indirect participants by } T+1 \text {. }\end{array}$ \\
\hline Assessment & Observed. \\
\hline Comments & \\
\hline Recommendation 3. & $\begin{array}{l}\text { Rolling settlement should be adopted in all securities markets. Final settlement should } \\
\text { occur no later than } \mathrm{T}+3 \text {. The benefits and costs of a settlement cycle shorter than } \mathrm{T}+3 \\
\text { should be assessed. }\end{array}$ \\
\hline Description & $\begin{array}{l}\text { Settlement cycles } \\
\text { Ninety-five percent of the outright trades, } 100 \text { percent of the issuance of debt } \\
\text { instruments, } 84 \text { percent of repos and above } 75 \text { percent of subscription and repurchase } \\
\text { transactions of mutual funds are cleared and settled on } \mathrm{T}+3 \text { or a shorter settlement } \\
\text { cycle in Relit+. } \\
\text { Failed trades and facilities to smooth the settlement process } \\
\text { In Relit+, the monthly value of unsettled trades, which amounted to } 1.76 \text { percent on } \\
\text { average during the period January } 2002 \text { to June } 2003 \text {, has never exceeded } \\
2.65 \text { percent. It remained below } 2 \text { percent during } 13 \text { of the } 18 \text { months in this period. } \\
\text { The average duration of end-of-day fails never exceeds two working days, that is, on } \\
\text { average, trades remaining unsettled at the end of the contractual settlement day, are } \\
\text { settled at the latest within the two following working days. } \\
\text { The cash leg is settled three times a day in TBF. The timely settlement of Relit }+\end{array}$ \\
\hline
\end{tabular}




\begin{tabular}{|c|c|}
\hline & 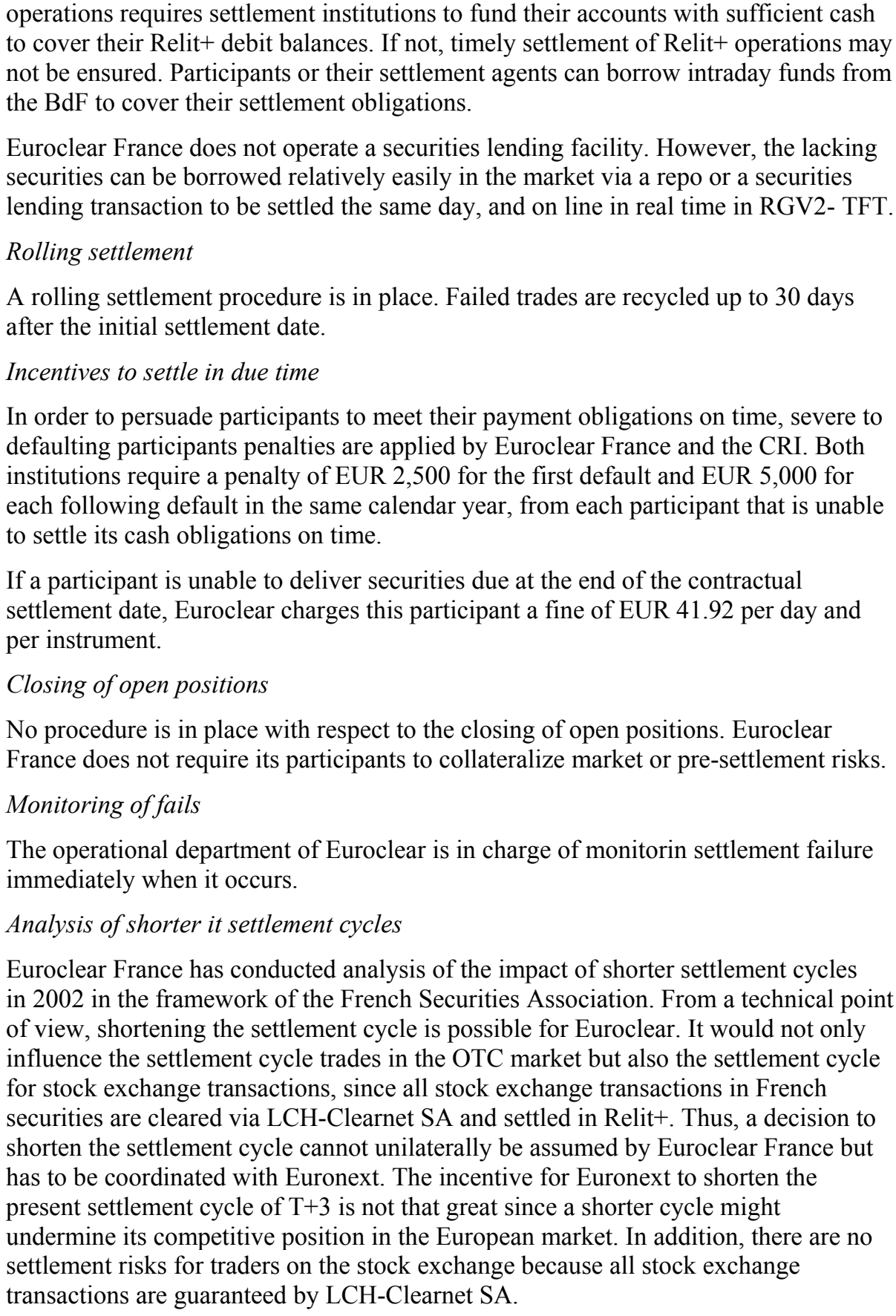 \\
\hline Assessment & Observed. \\
\hline Uin & \\
\hline
\end{tabular}




\begin{tabular}{|c|c|}
\hline Recommendation 4. & $\begin{array}{l}\text { The benefits and costs of a central counterparty should be assessed. Where such a } \\
\text { mechanism is introduced, the central counterparty should rigorously control the risks } \\
\text { it assumes. }\end{array}$ \\
\hline Description & $\begin{array}{l}\text { Transactions conducted on the Euronext trading platforms in Paris, Amsterdam, } \\
\text { Brussels, and Lisbon are cleared and settled via LCH-Clearnet SA, which acts as the } \\
\text { central counterparty. LCH-Clearnet SA also clears and settles derivatives and } \\
\text { commodities contracts and cash and derivatives transactions traded on the OTC } \\
\text { market or negotiated through interdealer brokers. LCH-Clearnet SA will be assessed } \\
\text { in due time against the newly drafted recommendations for central counterparties that } \\
\text { at present are under consultation. }\end{array}$ \\
\hline Assessment & Not applicable \\
\hline Comments & \\
\hline Recommendation 5. & $\begin{array}{l}\text { Securities lending and borrowing (or repurchase agreements and other economically } \\
\text { equivalent transactions) should be encouraged as a method for expediting the } \\
\text { settlement of securities transactions. Barriers that inhibit the practice of lending } \\
\text { securities for this purpose should be removed. }\end{array}$ \\
\hline Description & $\begin{array}{l}\text { Institutional framework } \\
\text { Securities lending operations can be conducted through securities loans or } \\
\text { repurchase agreements. The law recognizes both instruments, as well as the } \\
\text { validity of collateral transfers within the framework of securities lending. } \\
\text { The transactions cannot be re-characterized as improper pledges by third } \\
\text { parties or a liquidator. } \\
\text { Accounting schemes and tax treatment for the aforementioned instruments are } \\
\text { detailed in the regulations in the COMOFI (Art. L.432-6 to L.432-19). } \\
\text { To prevent tax avoidance, only legal entities are allowed to enter into repurchase } \\
\text { agreements. For this reason, securities yielding interest/dividends submitted } \\
\text { to a withholding tax are not allowed to be used in a securities lending } \\
\text { transaction or a repo during the period the interest/dividends will fall due. } \\
\text { Automated securities lending facilities } \\
\text { At the moment, no automated securities lending facility is in place for the OTC } \\
\text { markets in order to expedite the settlement of securities in RGV2-TFT. Plans } \\
\text { to launch such a facility in } 1998 \text { were not executed since the business case } \\
\text { for such a facility seemed to be insufficient. This does not imply that there is } \\
\text { no market for securities lending in this area. Interested participants can } \\
\text { easily tailor their needs by doing transactions directly with institutional } \\
\text { investors (insurance companies, mutual funds) or banks willing to increase } \\
\text { their custody incomes. } \\
\text { Supervision of the risk involved in securities lending } \\
\text { Especially with respect to securities lending transactions in case of deferred } \\
\text { settlement, regulations are in place to ensure that sufficient collateral is made } \\
\text { available by the client to his broker who is its counterparty in this securities lending } \\
\text { operation. }\end{array}$ \\
\hline
\end{tabular}




\begin{tabular}{|c|c|}
\hline Assessment & Observed. \\
\hline \multicolumn{2}{|l|}{ Comments } \\
\hline Recommendation 6. & $\begin{array}{l}\text { Securities should be immobilized or dematerialized and transferred by book entry in } \\
\text { CSDs to the greatest extent possible. }\end{array}$ \\
\hline Description & $\begin{array}{l}\text { Dematerialization and immobilization } \\
\text { At least } 99.7 \text { percent of securities issued in France (representing over } 29000 \text { ISIN } \\
\text { codes) are dematerialized and the other securities issues, mostly warrants, euro-bonds } \\
\text { and foreign securities ( } 80 \text { issues in total) are immobilized, mostly via a global note. } \\
\text { Adequate safe procedures are in place within Euroclear France. } \\
\text { Transfer of title } \\
\text { Transfer of title is only possible by book-entry (Art. } 1 \text { of decree } 83-359 \text { of } \\
\text { May } 2,1983 \text { ). In France, no separate "Registrars of the Issuers" exists. Issuers open } \\
\text { an "investors account" directly in Euroclear France, in which the amount of securities } \\
\text { issued is booked- the amount which represents the total of all outstanding } \\
\text { commitments of the issuer (see Art. } 8 \text { of the decree of August } 4 \text {, 1949) and which } \\
\text { balances the number of securities in the custodian's accounts in Euroclear France. }\end{array}$ \\
\hline Assessment & Observed. \\
\hline Comments & \\
\hline Recommendation 7. & $\begin{array}{l}\text { Securities settlement systems should eliminate principal risk by linking securities } \\
\text { transfers to funds transfers in a way that achieves delivery versus payment. }\end{array}$ \\
\hline Description & $\begin{array}{l}\text { Legal framework } \\
\text { The legal and contractual basis of the Relit+ DVP settlement procedure is based on } \\
\text { Articles } 6.32 \text { and } 6.33 \text { of the RGV2 Rules. These articles state that the securities leg's } \\
\text { settlement, which is processed on a gross basis, does not become final as long as the } \\
\text { cash leg, which is operated on a net basis, is not settled in TBF. } \\
\text { Technical framework } \\
\text { Participants' cash legs are settled on the basis of their net technical cash balances, } \\
\text { which are computed on a real-time basis by Euroclear France according to the } \\
\text { securities transfers posted on their securities accounts. The securities transfers occur } \\
\text { once Euroclear France has checked that the securities are available on the seller's } \\
\text { account. If they are available, Euroclear France transfers the securities from the } \\
\text { seller's to the buyer's account, and simultaneously effects the counterparties' } \\
\text { technical cash balances. If securities are not available, the settlement is recycled. } \\
\text { Cash net settlement occurs three times a day-once in the morning and twice in the } \\
\text { afternoon, after Euroclear France has communicated to the BdF the cash balances that } \\
\text { participants' settlement banks have to settle in TBF. Once cash balances are } \\
\text { communicated to BdF, participants' settlement banks benefit from a time lag called } \\
\text { "the checking period" to verify the accuracy of the amounts communicated and fund } \\
\text { their TBF accounts. Finally, they settle the Relit+ cash balances on their TBF } \\
\text { accounts during the settlement periods. } \\
\text { If the cash leg can be settled in due time, Euroclear France performs the procedure to }\end{array}$ \\
\hline
\end{tabular}




\begin{tabular}{|c|c|}
\hline & $\begin{array}{l}\text { ensure the final posting of securities' deliveries. This procedure takes place two } \\
\text { minutes after receiving the confirmation that the cash leg has been properly settled, } \\
\text { and can last from one to six minutes (according to the number of trades processed } \\
\text { during the chaining). Securities transfers become final within a short time lag } \\
\text { (between three and eight minutes) after the cash leg settlement, thus reducing the } \\
\text { length of participants' exposure to the operational risks that may arise during the } \\
\text { settlement. In addition, in case of technical failure, Euroclear France's secondary site } \\
\text { would be able to properly register the final delivery of securities and consequently } \\
\text { ensure the technical DVP link between the settlement of the cash and securities legs. } \\
\text { If the cash settlement cannot be completed in time because one (or several) Relit+ } \\
\text { participant(s) is (are) not able to meet its (their) payment obligation(s), Euroclear } \\
\text { France has to implement one of the procedures described in Art. 6.33 of its rules. } \\
\text { These procedures include the possibility to partially (or even totally) unwind the } \\
\text { securities transfers validated during the related chaining. In such a situation, having } \\
\text { excluded all or part of the defaulting participant's operations, Euroclear France } \\
\text { recalculates new securities transfers and new net cash balances. The excluded } \\
\text { securities will not be part of the final posting but be transferred back to the account of } \\
\text { the seller. }\end{array}$ \\
\hline Assessment & Observed. \\
\hline \multicolumn{2}{|l|}{ Comments } \\
\hline Recommendation 8. & $\begin{array}{l}\text { Final settlement on a DVP basis should occur no later than the end of the settlement } \\
\text { day. Intra-day or real-time finality should be provided where necessary to reduce } \\
\text { risks. }\end{array}$ \\
\hline Description & $\begin{array}{l}\text { Intraday finality } \\
\text { Relit+ settles three times a day. Finality is clearly defined in the rules of RGV2 (see } \\
\text { Recommendation 7). The received securities and cash can be used immediately } \\
\text { afterwards by the seller or the buyer. } \\
\text { Need for intraday real time finality } \\
\text { The settled transactions in Relit+ are for the larger part retail transactions done on the } \\
\text { stock exchange. Relit+ is not used for the settlement of monetary transactions; } \\
\text { participants who require on line, real-time finality can use RGV2-TFT. } \\
\text { Securities delivered through a link are normally settled on a Free-of-Payment basis. } \\
\text { However, transactions of participants in Euroclear bank in French securities } \\
\text { conducted on Euronext are within the framework of the Flux Bourse project settled } \\
\text { via Relit+, with al the risk involved for this participants or Euroclear Bank in case of } \\
\text { an unwinding of the transaction in Relit+. }\end{array}$ \\
\hline Assessment & Observed. \\
\hline \multicolumn{2}{|l|}{ Comments } \\
\hline Recommendation 9. & $\begin{array}{l}\text { Deferred net settlement systems should institute risk controls that, at a minimum, } \\
\text { ensure timely settlement in the event that the participant with the largest obligation is } \\
\text { unable to settle. In any system in which a CSD extends credit or arranges securities } \\
\text { loans to facilitate settlement, best practice is for the resulting credit exposures to be } \\
\text { fully collateralized. }\end{array}$ \\
\hline
\end{tabular}




\begin{tabular}{|c|c|}
\hline Description & $\begin{array}{l}\text { Although Relit+ can be classified as a deferred net settlement system, at present, there } \\
\text { are no measures taken to ensure timely settlement in the event the participant with the } \\
\text { largest payment obligation is unable to settle this debit position in the multilateral } \\
\text { clearing scheme. In such an event, Euroclear France partially or totally unwinds the } \\
\text { defaulting participant's operations. Then, new net cash balances are recalculated. The } \\
\text { unwinding procedure and recalculation of positions can take several hours to deliver } \\
\text { to Euroclear France. Consequently, such a procedure can create significant delays in } \\
\text { the settlement time schedule, by postponing the settlement of obligations until the late } \\
\text { afternoon or even the following settlement day. This procedure would also generate } \\
\text { liquidity pressures or shortfalls of securities for nondefaulting participants that may } \\
\text { be difficult to cover. } \\
\text { The BdF and the AMF, as overseers, in } 2002 \text { required Euroclear France to define and } \\
\text { implement, in cooperation with all interested parties, adequate measures to ensure the } \\
\text { timely settlement in case of a default. Recently the implementation was launched of } \\
\text { measures to ensure timely settlement even in the event the participant with the largest } \\
\text { obligation to pay is not able to fulfill his obligation. The heart of these measures is } \\
\text { formed by a mutual guarantee fund, supplemented by a set of limits applied to the net } \\
\text { cash positions. The full implementation is foreseen before the end of } 2004 \text {. The } \\
\text { measures will not cover multiple failures. }\end{array}$ \\
\hline Assessment & Non-observed. \\
\hline Comments & $\begin{array}{l}\text { It is recommended that adequate measures be implemented ASAP to ensure the } \\
\text { timely settlement in the event the participant with the largest position to pay is not } \\
\text { able to settle its payment obligation. }\end{array}$ \\
\hline Recommendation 10. & $\begin{array}{l}\text { Assets used to settle the cash leg of securities transactions between CSD members } \\
\text { should carry little or no credit risk. If central bank money is not used, steps must be } \\
\text { taken to protect CSD members from potential losses and liquidity pressures arising } \\
\text { from the failure of a settlement bank. }\end{array}$ \\
\hline Description & $\begin{array}{l}\text { Multi-tiered structure } \\
\text { Cash settlement in Relit+ is based on a multi-tiered structure. The first level of this } \\
\text { architecture relies on the participants that own a Relit+ technical cash balance, and } \\
\text { which are called "cash clearers." These technical balances enable one to compute the } \\
\text { cash clearers' net payment obligations in accordance with the securities movements } \\
\text { posted on their securities accounts. In addition, cash clearers have the possibility to } \\
\text { offer settlement services by posting the operations of other Relit+ participants on } \\
\text { their technical cash balances, as well as aggregating these operations with their own } \\
\text { trades into a net cash balance. There are no clear criteria in the rules and regulations } \\
\text { of Euroclear France regarding which institutions can act as cash clearers. } \\
\text { While all cash positions are in euro and cleared in TBF, the French RTGS system } \\
\text { operated by the BdF, the second level of the Relit+ settlement architecture relies on } \\
\text { those participants in Euroclear France who have opened an account in TBF. This TBF } \\
\text { account holders can act as Relit+ settlement participants. The settlement participants, } \\
\text { which can settle their own Relit+ operations in TBF, also have the possibility to settle } \\
\text { other Relit+ cash clearers' balances in TBF. } \\
\text { Participation in TBF is open to credit institutions and investment firms established in } \\
\text { France as well as from other parts of the European Economic Area (EEA), when they } \\
\text { are authorized to carry on activities in France under a European passport. Also, credit } \\
\text { and investment firms incorporated outside the EEA are allowed to participate, }\end{array}$ \\
\hline
\end{tabular}




\begin{tabular}{|c|c|}
\hline & $\begin{array}{l}\text { provided they have a European passport. } \\
\text { TBF is a systemically important payment system that largely complies with the BIS } \\
\text { core principles for payment systems. } \\
\text { Settlement bank risk } \\
\text { Although in principle the settlement of cash obligations takes place in central bank } \\
\text { money, a large amount of participants make direct or indirect use of private } \\
\text { settlement agents to settle their obligations or receive their funds. This category is } \\
\text { exposed to deposit or settlement bank risk. There are no explicit rules or requirements } \\
\text { set by the operator and/or by the regulators or overseer of the system for settlement } \\
\text { agents regarding financial soundness etc. However, settlement agents are subject to } \\
\text { prudential supervision whether by the Commission Bancaire (for French institutions) } \\
\text { or by banking supervisors in their home countries. Information on concentration and } \\
\text { settlement flows on behalf of their customers is monitored by the BdF as overseer. } \\
\text { Payment flows stemming from Relit+ settlements are rather concentrated with some } \\
\text { settlement banks. During the first three quarters of } 2003 \text {, nearly } 20 \text { percent of the } \\
\text { Relit+ payment flows were settled via the largest settlement bank/TBF account } \\
\text { holder. Three groups of accounts have concentrated more than } 50 \text { percent in average } \\
\text { of payment flows (in value) stemming from the Relit+ settlements, whereas the first } \\
10 \text { groups of accounts have concentrated slightly above } 80 \text { percent of payment flows } \\
\text { on average in the same period. } \\
\text { Same day funds } \\
\text { It is not known whether institutions could transfer the money received on the account } \\
\text { with their settlement bank on the same day as their own account in TBF, if any, or to } \\
\text { an account of another bank, for instance for general payments purposes or within the } \\
\text { framework of money market transactions. }\end{array}$ \\
\hline Assessment & Observed. \\
\hline Comments & $\begin{array}{l}\text { It is recommended that adequate criteria be established in the rules and regulations of } \\
\text { Euroclear France for the access to Relit }+ \text { technical cash balances (definition of cash } \\
\text { clearers). }\end{array}$ \\
\hline Recommendation 11. & $\begin{array}{l}\text { Sources of operational risk arising in the clearing and settlement process should be } \\
\text { identified and minimized through the development of appropriate systems, controls, } \\
\text { and procedures. Systems should be reliable and secure and have adequate, scalable } \\
\text { capacity. Contingency plans and back-up facilities should be established to allow for } \\
\text { timely recovery of operations and completion of the settlement process. }\end{array}$ \\
\hline Description & $\begin{array}{l}\text { Identification and managing of operational risk } \\
\text { An independent risk management function was created in } 2001 \text { that directly reports to } \\
\text { the management committee and the board of Directors of Euroclear France. The } \\
\text { management committee and the board have to validate all measures taken. } \\
\text { The objectives of the risk management function are: } \\
\text { - to identify and prioritize the operational risks; } \\
\text { - to evaluate these risks; and } \\
\text { - to define the general principles allowing risk protection by using either } \\
\text { standard control and management measures or by transferring the risk (either }\end{array}$ \\
\hline
\end{tabular}


insurance or outsourcing).

To achieve these objectives, a bi-annual self-assessment should be conducted of all executives and departments. Moreover, all new products and services should be assessed and approved.

At the time of the inspection conducted in mid-2002 by the CMF (now AMF) regarding to the means put in place to operate the RGV2 system, the focus of the risk management function appeared to be more reactive than proactive in identifying the operational risk. The main outcomes of the inspection were notably that (i) the internal Audit department did not have all the capabilities needed to conduct its own IT audits; (ii) a service level agreement between Euroclear France and Clearnet (now LCH.Clearnet SA) was not signed; (iii) the unwinding risk was not tackled; (iv) the files of the participants were not always updated; (v) the capacity of the RGV2 systems in terms of volumes was only partly known; and (vi) there was no proactive overall analysis of the operational risks.

Since the inspection, the AMF received confirmation that important progress has been made: (i) Euroclear France decided to hire competences in its IT department (Etudes informatiques) in order to conduct its own IT audits; (ii) a service level agreement between Euroclear France and LCH-Clearnet SA will be signed during the second half of 2004; (iii) the unwinding issue should be resolved shortly and measures to ensure timely settlement in case of a default shall be implemented before the end of 2004; (iv) participants' files have been updated; (v) the decision has been taken to implement a tool permitting regular measures and conducting volumes tests of the system to handle increased volumes; and (vi) Euroclear France decided that the Risk Management department is now responsible for the review of the operational incidents and for follow-up action plans.

In addition, a new committee was sat up in April 2003 (the Conformity Action Committee) to verify once a month the complete achievements of the externals audit recommendations.

Concerning this last issue the Executive Committee and the Audit Committee are now regularly informed of management actions. The Audit Committee confirmed that procedures and tools put in place are now satisfactory.

\section{Contingency plans and back-up facilities}

A contingency plan has been developed to cope with a wide range of technological problems ranging from unavailability of the computer host due to minor virus problems to major computer downtime. There are two production sites and data is available between the two sites in real time synchronously. Both sites are equipped with back-up power generators. A back-up facility is available on the primary site in a hot stand bye mode. However, wide area disaster scenarios are not addressed in the current contingency plans since the two production sides are not an adequate distance of each other. Within the foreseen centralization of settlement processing functions in the Euroclear group, a third site, permanently staffed and at a distance of $300 \mathrm{~km}$ from the primary site, is envisaged.

The contingency plans are tested regularly. However, in a full fall-back situation (switch to the second site) the recovery time might be too long to resume operations (in the latest test it took seven hours, whereas the objective would be more like four hours). Thus for, users have not participated in these test.

\section{Protection of data communication}

Adequate measures are taken to ensure integrity, authentication, confidentiality, and 


\begin{tabular}{|c|c|}
\hline & $\begin{array}{l}\text { nonrepudiability of data flows and data storage and effective firewalls are in place to } \\
\text { protect the systems from intrusion attempts. } \\
\text { Availability and scalability } \\
\text { Euroclear France has sufficient and qualified staff at its disposal. } \\
\text { Although there were no major failures in the period July 2002-July 2003, numerous } \\
\text { small and medium incidents occur. All operations could, however, be resumed within } \\
\text { two hours, which is in line with Euroclear France's business continuity objectives. } \\
\text { Capacity test are carried out for each key system individually, but there have been no } \\
\text { complete capacity tests to ensure availability under stressful circumstances. As a } \\
\text { result, the maximum capacity levels are not exactly known. } \\
\text { Development and procurement } \\
\text { Special procedures are in place for development, procurement and testing. For } \\
\text { development and for testing, dedicated IT environments are used that are strictly } \\
\text { separated from the operational environment. } \\
\text { Audits } \\
\text { The internal audit department performs internal audits according to the results of risk } \\
\text { analysis and on special request from senior management. These audits are carried out } \\
\text { with a three-year plan. } \\
\text { Separate external audits have been conducted on behalf of the AMF, supervisors of } \\
\text { Euroclear France and on behalf of the Belgian CBFA, the supervisor of Euroclear } \\
\text { Bank (owner of the Euroclear France). Within this context, an audit was performed } \\
\text { on the operations of RGV2. The CBFA also carries out bi-annual audits on the } \\
\text { internal control procedures. No formal procedures exist covering when an external } \\
\text { audit should be conducted, neither with respect to specific audits, nor with respect to } \\
\text { periodical routine audits. }\end{array}$ \\
\hline Assessment & Broadly observed. \\
\hline Comments & $\begin{array}{l}\text { It is recommended: } \\
\text { - } \quad \text { to implement adequate tools for complete stress tests; } \\
\text { to take adequate measures to be able to resume operations in case a } \\
\text { full fall back to the second site is necessary on a timely basis and in } \\
\text { line with the objectives set within Euroclear's business continuity } \\
\text { policy (within two hours); } \\
\text { to conduct appropriate service level agreements in case of outsourcing } \\
\text { of tasks, such as with respect to the operation of ISB, an inter-dealer } \\
\text { broker facility operated by LCH-Clearnet SA; } \\
\text { that in line with the AMF/KPMG recommendation: the authorities } \\
\text { consider the strengthening of their operational risk policy by putting } \\
\text { in place a proactive risk analysis methodology; } \\
\text { conduct an overall analysis of operational risks (threats) in the } \\
\text { systems and organization of Euroclear France; and } \\
\text { to ensure that adequate measures be taken to contain the indicated } \\
\text { risks or to transfer or outsource them through insurance or other } \\
\text { means. }\end{array}$ \\
\hline
\end{tabular}




\begin{tabular}{|c|c|}
\hline Recommendation 12. & $\begin{array}{l}\text { Entities holding securities in custody should employ accounting practices and } \\
\text { safekeeping procedures that fully protect customers' securities. It is essential that } \\
\text { customers' securities be protected against the claims of a custodian's creditors. }\end{array}$ \\
\hline Description & 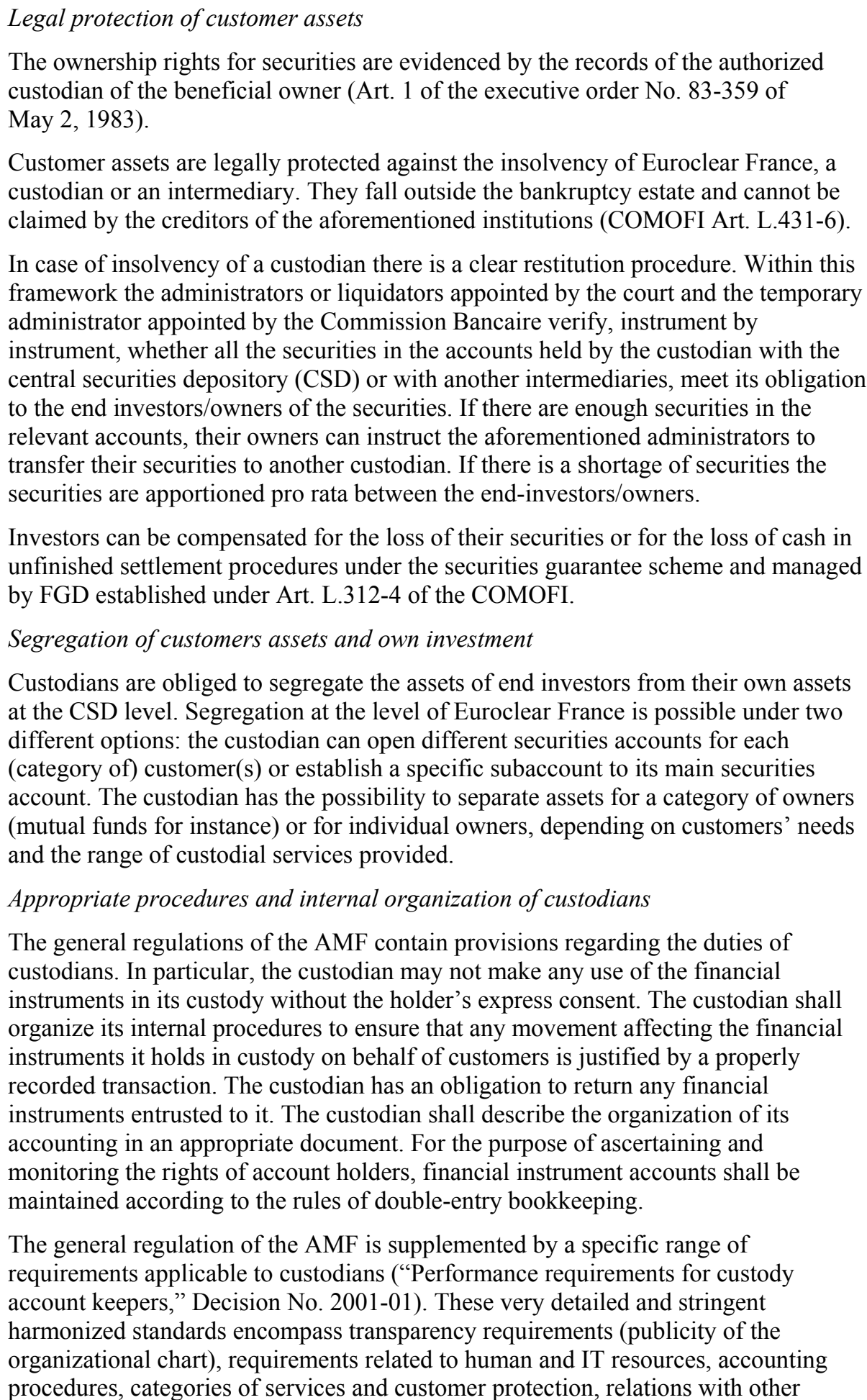 \\
\hline
\end{tabular}




\begin{tabular}{|c|c|}
\hline & $\begin{array}{l}\text { providers of services (brokers), and control and monitoring procedures. } \\
\text { Previously mentioned regulations require custodians to reconcile their records daily } \\
\text { and maintain audit trails of all cash and securities transfers. } \\
\text { Supervision } \\
\text { The general regulation of the AMF requires custodians to be credit institutions, } \\
\text { investment firms, public bodies or full subsidiaries of credit institutions and } \\
\text { investment firms. Credit institutions and investment firms are subject to prudential } \\
\text { supervision of the Commission Bancaire. } \\
\text { The AMF is in charge of the ongoing control of the observance of the rules and } \\
\text { regulations it has set forth for custody and clearing and settlement activities through } \\
\text { off-site and on-site inspections of custodians and Euroclear France (COMOFI, } \\
\text { Art. L.622-9). }\end{array}$ \\
\hline Assessment & Observed. \\
\hline Comments & \\
\hline Recommendation 13. & $\begin{array}{l}\text { Governance arrangements for CSDs and central counterparties should be designed to } \\
\text { fulfill public interest requirements and to promote the objectives of owners and users. }\end{array}$ \\
\hline Description & $\begin{array}{l}\text { Euroclear France is a private sector entity fully owned by Euroclear Bank SA/NV and } \\
\text { is organized on a for profit basis (société anonyme de forme commerciale). } \\
\text { Internal governance arrangements } \\
\text { Clear internal governance arrangements are in place that give the decision makers the } \\
\text { incentives and the skills needed to achieve the system's objectives, ensuring the } \\
\text { accountability of management. Management has appropriate tools for management } \\
\text { control and monitoring. There is an independent internal audit department that reports } \\
\text { directly to management. Several committees are in place to discuss relevant issues, } \\
\text { such as a risk committee, an audit committee, and a compliance committee. Board } \\
\text { members attend the meetings of these various committees. In addition, the chief } \\
\text { operations officer, although not a member of the Board, attends the Boards meetings } \\
\text { in order to provide its expertise on operational issues. } \\
\text { The composition of the Board is determined by Euroclear Bank, the parent company } \\
\text { of Euroclear France. } \\
\text { Public information is available on the main activities and projects of the Euroclear } \\
\text { group and Euroclear Bank including in published annual reports and accounting } \\
\text { information. } \\
\text { Users participation } \\
\text { A clear structure for consultations of the users/participants has been implemented. } \\
\text { In } 2001 \text { a Market Advisory Committee (MAC) was established, composed of } \\
\text { representatives of Euroclear France participants (around 20). The MAC is chaired by } \\
\text { a representative of the participants. Euroclear France management participates in the } \\
\text { meetings. } \\
\text { The MAC, which has a consultative role, is in charge of three missions: } \\
\quad \text { evolutions of Euroclear France; }\end{array}$ \\
\hline
\end{tabular}




\begin{tabular}{|c|c|}
\hline & $\begin{array}{l}\text { - considering the maintenance of efficient tools for the users; and } \\
\text { - observing the policy of fees of Euroclear France. } \\
\text { Since November 2002, the MAC directly reports to the Board of Euroclear Bank, } \\
\text { which is in charge of approving the nomination of its members. The MAC also } \\
\text { reports to the Board of Euroclear France. The work of the MAC, which meets at least } \\
\text { quarterly, is prepared by a users group and if needed by "ad hoc" working groups, } \\
\text { which may be launched on specific topics and projects (i.e., avoiding duplication with } \\
\text { the working groups of the French securities association). } \\
\text { In addition, the chairman of the MAC was appointed as "censor" (censeur) of } \\
\text { Euroclear France and participates in the Board Meetings, in a consultative role. He is } \\
\text { in charge of ensuring that the users' points of views are communicated to the Board. } \\
\text { The mission of censor(s) is defined in Euroclear France by-laws. }\end{array}$ \\
\hline Assessment & Observed. \\
\hline Comments & $\begin{array}{l}\text { Although the governance structure of Euroclear France has substantially improved } \\
\text { after the take over by Euroclear Bank Brussels (EBB), and-although it has still to be } \\
\text { assessed-the governance arrangements of Euroclear Bank Brussels seem not to have } \\
\text { had adverse affects on its effectiveness, things might rapidly change in the near future } \\
\text { when the operational activities of local CSD's and Euroclear Bank Brussels will be } \\
\text { integrated within the context of centralization of settlement processing functions. Key } \\
\text { questions within these developments might be whether the present governance } \\
\text { structure is effective in that case to deal with potential conflicts of interest that could } \\
\text { arise between the owner/operator and the users, who are competitors in the market for } \\
\text { clearing and settlement and custodial services. Another aspect that has to be dealt } \\
\text { with in this new operational context seems to be how to define and serve the public } \\
\text { interest in the new infrastructure. A blueprint for an ideal governance structure in this } \\
\text { situation is not easy to design but should get adequate attention of the } \\
\text { overseers/regulators and involvement of relevant market participating the discussion } \\
\text { should be ensured. In the market, there exist distinct fears that future developments } \\
\text { might harm their interest and will negatively influence their competitive position. }\end{array}$ \\
\hline Recommendation 14. & $\begin{array}{l}\text { CSDs and central counterparties should have objective and publicly disclosed criteria } \\
\text { for participation that permit fair and open access. }\end{array}$ \\
\hline Description & $\begin{array}{l}\text { Access criteria } \\
\text { The following entities are allowed to become participants in RGV2, pursuant to the } \\
\text { general access criteria: } \\
\text { credit institutions and investment firms incorporated in France; } \\
\text { LCH-Clearnet SA Clearing Members having the status of specialized firm; } \\
\text { French public entities (Treasury, BdF, financial services of the Post office); } \\
\text { legal entities incorporated within the EEA and allowed to provide investment } \\
\text { services pursuant to the free provision of services and free establishment } \\
\text { principles as organized by the European Directives; } \\
\text { custodians duly authorized by the AMF to hold securities accounts on behalf of } \\
\text { customers; } \\
\text { French CSDs authorized by the AMF and foreign CSDs; and }\end{array}$ \\
\hline
\end{tabular}


other legal entities incorporated within or outside the EEA and performing activities comparable to the other categories of entities allowed to become RGV2 participants.

Foreign entities incorporated in the EEA but not established in France are allowed to become participants in RGV2 under the same conditions as French entities. If they participate to the RGV channel, and provided they have a credit institution or investment firm status, they can also open a cash account in TBF and settle their own Relit+ operations as well as the operations of other Relit+ participants (see RSSS 7).

The only difference with entities established in France is the prohibition of access to intraday credit with the BdF. Due to the Eurosystem rules, the BdF is not allowed to provide credit to remote participants. Therefore, they are not allowed to access intraday credit (see assessment of Recommendations 8 and 9). This restriction is justified by public interest related to the conduct of the Eurosystem's monetary policy.

Regarding foreign entities incorporated outside the EEA, pursuant to the RGV2 operating rules (Art. 2.4), the AMF has the right to oppose their access to RGV2 within one month following the notification of the decision of the Board of Euroclear France to admit the applicant (the criteria to oppose an applicant are not published).

\section{Exit criteria}

The general conditions under which participants can terminate their membership are stated in the operating rules of Euroclear France:

the request of the participant;

on the requirement of the AMF following a withdrawal of a necessary authorization by the AMF; or

by Euroclear France, in case of breach of the operating rules by the participant that threatens the integrity of the system.

Euroclear France considers that the insolvency of a participant as such is not a cause to terminate its participation. However, the situation would be specifically monitored and may lead to a rapid exit, notably in case of unpaid fees.

\begin{tabular}{|l|l|}
\hline Assessment & Observed. \\
\hline Comments & $\begin{array}{l}\text { It is recommended: } \\
\text { to develop and make public the criteria on that basis of which the AMF can } \\
\text { oppose an applicant from outside the EEA and the procedure followed. In } \\
\text { addition to the requirement that an applicant has to be adequately overseen } \\
\text { or supervised, it might be worthwhile to consider whether a legal opinion } \\
\text { should made available that determines whether there might be a conflict of } \\
\text { laws that could threaten the smooth and secure functioning of custody and } \\
\text { settlement of securities in France; and } \\
\text { to determine whether the status of indirect participant could be introduced in } \\
\text { the rules and regulations for RGV2, in line with the finality regulations in } \\
\text { the COMOFI and whether this could apply to noncash position holders using } \\
\text { a settlement bank to settle their cash obligations. }\end{array}$ \\
\hline Recommendation 15. & $\begin{array}{l}\text { While maintaining safe and secure operations, securities settlement systems should be } \\
\text { cost-effective in meeting the requirements of users. }\end{array}$ \\
\hline
\end{tabular}




\begin{tabular}{|c|c|}
\hline Description & $\begin{array}{l}\text { Budgetary process } \\
\text { Euroclear France manages its costs using an annual budget system. The new budget is } \\
\text { based an a bottom-up approach. Sales are estimated and the strategic plan is taken } \\
\text { into account, as is the evolution of wages and overhead. During the year the budget is } \\
\text { monitored. } \\
\text { Price structure } \\
\text { Prices are set in agreement with the users. Owing to the absence of a comprehensive } \\
\text { analytical accounting method, the present price structure is not directly related to the } \\
\text { cost of each services. Introduction of such an accounting measure might be difficult } \\
\text { due to the large amount of services provided (over 155). The prices charged by } \\
\text { Euroclear allow the latter to make a profit. Cross subsidization between product or } \\
\text { services cannot be ruled out in the present structure. } \\
\text { Euroclear France indicates that it plans to implement a comprehensive analytical } \\
\text { accounting of its operations, which is at present only partly available. Such a project } \\
\text { would clearly improve the degree of observance of Recommendation } 15 \text {. However, } \\
\text { no clear planning has been disclosed so far on the following steps that would enable } \\
\text { the extension of analytical accounting to the entire cost structure of Euroclear France. } \\
\text { Benchmarking } \\
\text { Euroclear does not benchmark its costs, prices and service levels against those of } \\
\text { other CSDs. However the integration and harmonization of prices of the Euroclear } \\
\text { group's CSD will be a key component of the group's operational integration. } \\
\text { Reviewing service levels } \\
\text { There is no explicit review of the service level and consultation of users, although } \\
\text { propose new services. The MAC is involved in evaluating such a request and has also } \\
\text { consulted on changes and new services proposed by Euroclear France itself. } \\
\text { Operational reliability and capacity levels } \\
\text { of the processes has the attention of management. Euroclear does not know exactly its } \\
\text { maximum capacity levels (see Recommendation } 11 \text { ). }\end{array}$ \\
\hline Assessment & Broadly observed. \\
\hline Comments & $\begin{array}{l}\text { It is recommended that a comprehensive analytical accounting system be } \\
\text { implemented in order to monitor costs and benefits more closely, so as to have an } \\
\text { appropriate tool for price determination. }\end{array}$ \\
\hline Recommendation 16. & $\begin{array}{l}\text { Securities settlement systems should use or accommodate the relevant international } \\
\text { communication procedures and standards in order to facilitate efficient settlement of } \\
\text { cross-border transactions. }\end{array}$ \\
\hline Description & $\begin{array}{l}\text { The system's main communication channel is the Radianz network. However, after } \\
\text { the implementation of the Euroclear Application Access in December 2003, } \\
\text { participants are also enabled to communicate with the system via the Swift network. } \\
\text { The system uses international standard message types and procedures for the } \\
\text { securities identification process, but the securities messages in the Radianz network } \\
\text { are based on a proprietary format and the counterparty identification is not based on }\end{array}$ \\
\hline
\end{tabular}




\begin{tabular}{|c|c|}
\hline & $\begin{array}{l}\text { internationally recognized identifiers. Both can be converted into relevant } \\
\text { international procedures and standards with some difficulty. }\end{array}$ \\
\hline Assessment & Broadly observed. \\
\hline Comments & $\begin{array}{l}\text { It is recommended that the implementation of international standards be facilitated, } \\
\text { particularly in the area of participant identification procedures. }\end{array}$ \\
\hline Recommendation 17. & $\begin{array}{l}\text { CSDs and central counterparties should provide market participants with sufficient } \\
\text { information for them to accurately identify the risks and costs associated with using } \\
\text { the CSD or central counterparty services. }\end{array}$ \\
\hline Description & $\begin{array}{l}\text { Availability of rules, regulations etc. } \\
\text { Market participants are provided with a full and clear description of their rights and } \\
\text { obligations, the cost of participating in the system, the rules, regulations and laws } \\
\text { governing the system, its governance procedure, any risk arising either to participants } \\
\text { or to the operator, and any steps taken to mitigate those risks. } \\
\text { Information is generally available in a language commonly used in financial markets } \\
\text { and/or the domestic language (French) and operating rules are published on the } \\
\text { websites of the AMF and Euroclear France. } \\
\text { CPSS/IOSCO Disclosure Framework } \\
\text { The CPSS/IOSCO Disclosure Framework has been completed and disclosed. The last } \\
\text { update version was made available in March } 2002 \text { and is updated on some issues } \\
\text { (e.g., the oversight /supervision of Euroclear France). }\end{array}$ \\
\hline Assessment & Broadly observed. \\
\hline Comments & $\begin{array}{l}\text { It is recommended that the Disclosure framework be updated. Alternatively, } \\
\text { Euroclear France could publish the assessed answers to "key questions." }\end{array}$ \\
\hline Recommendation 18. & $\begin{array}{l}\text { Securities settlement systems should be subject to regulation and oversight. The } \\
\text { responsibilities and objectives of the securities regulator and the central bank with } \\
\text { respect to SSSs should be clearly defined, and their roles and major policies should be } \\
\text { publicly disclosed. They should have the ability and resources to perform their } \\
\text { responsibilities, including assessing and promoting implementation of these } \\
\text { recommendations. They should cooperate with each other and with other relevant } \\
\text { authorities. }\end{array}$ \\
\hline Description & $\begin{array}{l}\text { Entities involved in oversight/supervision } \\
\text { The RGV2 system is subject to both regulations by AMF and oversight by the BdF. } \\
\text { Since Euroclear France is a corporate company, which does not have the status of a } \\
\text { credit institution or of an investment firm, the French banking supervisor } \\
\text { (Commission Bancaire) is not involved in its supervision. } \\
\text { The regulatory competences of the AMF towards securities settlement systems } \\
\text { (SSSs) are organized by French law. Under the terms of Art. L.622-7 of the } \\
\text { COMOFI, the AMF "shall authorize central depositories according to the procedures } \\
\text { established in its General Regulations and approve their operating rules; shall set in } \\
\text { its general regulations the general principles for organizing and operating securities } \\
\text { settlement systems and approve the operating rules for such systems, without }\end{array}$ \\
\hline
\end{tabular}


prejudice to the powers granted to the BdF under Art. L.141-4.”

The oversight competence of the BdF also relies on a legal provision, Art. L.141-4 of the COMOFI, which states that: "As part of the duties of the European System of Central Banks and without prejudice to the competences of the Financial Markets Council Authority and of the Banking Commission, the BdF is in charge of monitoring the safety of securities clearing and settlement systems."

Moreover, the Belgian CBFA has an interest in Euroclear France, which is the French subsidiary of Euroclear Bank. This interest stems from the prudential supervision of the consolidated and nonconsolidated situation, of the Euroclear Group according to the concept of "close link" between Euroclear France and Euroclear Bank.

Roles, responsibilities and resources

The regulatory and oversight frameworks for SSSs are based on a statute-based approach. The respective roles of the AMF and the BdF are clearly defined and legally enforceable. Their roles and major policies are publicly disclosed. The oversight mission of BdF is published on its website. Within the framework of oversight regular meetings take place between the overseers and Euroclear France, information is gathered based on public reports as well as on special request by ignore the overseer. The AMF can carry out on-site inspections if deemed necessary. The AMF can conduct external audits of the systems, internal controls and organization of Euroclear France. Also the BdF could carry out such audits based on the agreement it has conducted with Euroclear France.

Both regulators have sufficient qualified staff.

Cooperation between securities regulators and central banks in the oversight of the Euroclear group

There is a close cooperation between the AMF as securities regulator and the BdF as overseer. Representatives of the BdF have consultative roles on the Board of the $\mathrm{AMF}$ and in some committees. In practice, the fulfillment of the missions of both authorities for the regulation and the oversight of RGV2 is closely coordinated. Meetings and consultations are regularly organized, as well as exchange of relevant information between the AMF and the BdF for the monitoring of RGV2. For example, the electronic data processing audit report on Euroclear France, including all detailed annexes, written on behalf of the AMF in the second half of 2002, was transmitted to the BdF.

Euroclear France has been a subsidiary of Euroclear Bank since January 2001. Therefore, two MoUs (Memoranda of Understanding) were signed with foreign authorities in order to take into account the new context in which Euroclear France operates:

- an MoU was signed on October 22, 2001 between the BdF, the CMF (currently $\mathrm{AMF}$ ), the Banque Nationale de Belgique (BNB), and the Belgian CBFA. This Memorandum sets out the principles for cooperation between the BNB and the $\mathrm{BdF} / \mathrm{CMF}$ (currently AMF) for the oversight and regulation of securities settlement systems operated by the Euroclear Group (understood for the purpose of this $\mathrm{MoU}$ as Euroclear Bank and its subsidiary Euroclear France), and between the BdF/CMF (currently AMF) and the Belgian CBFA as part of the latter authority's prudential supervision of the Euroclear Group;

- another MoU was signed on July 9, 2002 between the same parties and also De Nederlandsche Bank and the Netherlands Authority for Financial Markets in order to organize cooperation between authorities for the regulation and the oversight of the 


\begin{tabular}{|c|c|}
\hline & $\begin{array}{l}\text { settlement services provided by the Euroclear group for the settlement of transactions } \\
\text { executed on the Euronext stock exchanges. } \\
\text { Regular meetings and exchanges of information between the signatory authorities of } \\
\text { both MoUs and representatives of the Euroclear Group are held in order to foster } \\
\text { cooperation and coordinate the assessments made by the competent authorities of the } \\
\text { related systems. } \\
\text { Relevant information is exchanged within the framework of cooperation between the } \\
\text { two local authorities and between the local and foreign regulators. }\end{array}$ \\
\hline Assessment & Observed. \\
\hline Comments & $\begin{array}{l}\text { The procedures could be formalized to work out the cooperation and division of tasks } \\
\text { between the AMF and the BdF in an MoU to be published so as to enhance } \\
\text { transparency for all parties involved. }\end{array}$ \\
\hline Recommendation 19. & $\begin{array}{l}\text { CSDs that establish links to settle cross-border trades should design and operate such } \\
\text { links to reduce effectively the risks associated with cross-border settlement. }\end{array}$ \\
\hline Description & $\begin{array}{l}\text { Types of links } \\
\text { Between Euroclear France and national and international CSDs there exist: } \\
\text { - } 13 \text { Direct links; } \\
\text { - } 1 \text { Indirect link; and } \\
\text { - } 14 \text { Relayed links in which Euroclear Bank Brussels is used as the intermediary } \\
\text { CSD. } \\
\text { Risk analysis } \\
\text { Risk analysis is conducted with respect to the financial and operational integrity of } \\
\text { the linked CSD, although the legal risk involved in depositing, clearing, and } \\
\text { settlement of foreign securities in Euroclear France might not be fully assessed. } \\
\text { Delivery versus Payment } \\
\text { Most of the links are used only for Free-of-Payment transfers. All transfers are } \\
\text { normally final and irrevocable and no provisional transfer occurs. The only exception } \\
\text { is related to the outward link with Euroclear Bank in French securities through its } \\
\text { direct participation in Relit+, which allows provisional transfers to the benefit of } \\
\text { Euroclear Bank participants, the night before the final settlement of the cash balances } \\
\text { stemming from Relit. } \\
\text { This link was implemented in July } 2002 \text { following the so-called Flux Bourse Project, } \\
\text { which aimed at permitting LCH-Clearnet SA Clearing Members to choose the } \\
\text { settlement location for transactions executed on Euronext Paris, between Euroclear } \\
\text { France and Euroclear Bank. Provisional transfers are only allowed for securities } \\
\text { settled in the Relit channel and not in the RGV2-TFT channel. The provisional } \\
\text { transfer may raise risks for Euroclear Bank participants in case of unwinding of Relit } \\
\text { operations following a cash default (see assessment against RSSS 9). In addition, in } \\
\text { case of the unwinding of Relit+ processes leading to a negative securities balance of } \\
\text { LCH-Clearnet SA in Euroclear Bank, an undue creation of French securities may } \\
\text { result, at least temporarily (i.e. before the LCH-Clearnet SA "buy-in procedure" and } \\
\text { the loss-sharing procedure of Euroclear Bank are performed), from these provisional } \\
\text { transfers in Euroclear Bank. }\end{array}$ \\
\hline
\end{tabular}




\begin{tabular}{|l|l|}
\hline Assessment & Non-observed. \\
\hline Comments & \\
\hline
\end{tabular}

Table 28. Summary Observance of Relit+ of the CPSS/IOSCO Recommendations for Securities Settlement Systems

\begin{tabular}{|l|c|l|}
\hline \multirow{2}{*}{ Assessment Grade } & \multicolumn{2}{|c|}{ Recommendations Grouped by Assessment Grade } \\
\cline { 2 - 3 } & Count & \multicolumn{1}{c|}{ List } \\
\hline Observed & 11 & Rec. $2,3,5,6,7,8,10,12,13,14$ and 18. \\
\hline Broadly observed & 5 & Rec. $1,11,15,16$ and 17. \\
\hline Partly observed & 0 & -- \\
\hline Non-observed & 2 & Rec. 9 and 19. \\
\hline Not applicable & 1 & Rec. 4 \\
\hline
\end{tabular}

\section{Recommended action plan and authorities' response to the assessment}

\section{Recommended action plan}

Table 29. Recommended Actions to Improve Observance of Relit+ of the CPSS/IOSCO Recommendations for Securities Settlement Systems

\begin{tabular}{|c|c|}
\hline Reference Recommendation & Recommended Action \\
\hline Rec. 1 Sound legal basis & - see the recommendation for the RGV2_-Trade for Trade channel. \\
\hline $\begin{array}{l}\text { Rec. } 9 \text { Risk controls in deferred net } \\
\text { settlement systems }\end{array}$ & $\begin{array}{l}\text { - implement as soon as possible adequate measures to ensure timely } \\
\text { settlement in the event the participant with the largest position to pay is } \\
\text { not able to settle its obligations. }\end{array}$ \\
\hline Rec. 10 Settlement assets & $\begin{array}{l}\text { - establish adequate criteria in the rules and regulations of Euroclear } \\
\text { France for the access to Relit+ technical cash balances. }\end{array}$ \\
\hline Rec. 11 Operational reliability & - see the recommendations for RGV2_-Trade for Trade channel \\
\hline Rec. 13 Governance arrangements & - see the recommendation for RGV2-Trade for Trade channel \\
\hline Rec. 14 Access criteria & $\begin{array}{l}\text { - develop and publish the criteria on the basis of which the AMF can } \\
\text { oppose an applicant from outside the EEA and the procedures to be } \\
\text { followed. Consider in this context whether a legal opinion on possible } \\
\text { conflicts of laws should be made available by the applicant; } \\
\text { - determine whether the status of indirect participant could be introduced. }\end{array}$ \\
\hline
\end{tabular}




\begin{tabular}{|l|c|}
\hline \multicolumn{1}{|c|}{ Reference Recommendation } & Recommended Action \\
\hline Rec. 15 Cost-effectiveness & - see the recommendation for RGV2 - Trade for Trade channel \\
\hline $\begin{array}{l}\text { Rec. 16 International } \\
\text { communication standards }\end{array}$ & - see the recommendation for RGV2 - Trade for Trade channel \\
\hline $\begin{array}{l}\text { Rec. } 17 \text { Disclosure of risks and } \\
\text { costs }\end{array}$ & - see the recommendation for RGV2 - Trade for Trade channel \\
\hline Rec. 18 Oversight & - see the recommendation for RGV2 - Trade for Trade channel \\
\hline
\end{tabular}

\section{Authorities' response to the assessment}

125. The recommendations of the IMF are in line with the findings of the BdF and the $\mathrm{AMF}$, the relevant overseers/regulators of Euroclear France.

\section{OBSERVANCE OF THE IMF CODE OF GOOD PRACTICES ON TRANSPARENCY IN Monetary ANd Financial Policies}

\section{A. Introduction}

126. This assessment of observance of the IMF's Code of Good Practices on Transparency in Monetary and Financial Policies (MFP) assesses the transparency of France's policies and practices in the areas of (i) banking regulation and supervision; (ii) deposit insurance; (iii) insurance regulation and supervision; (iv) payment and settlement systems oversight; and (v) securities regulation. Being a member of the euro area, France's monetary policy is covered by the assessment of transparency in monetary policy of the European System of Central Banks (see IMF Country Report No. 01/195). The assessments were carried out by Mr. Wim Fonteyne (IMF/MFD), with Ms. Andrea Corcoran (US Commodity Futures Trading Commission) and Mr. Toni Gravelle (IMF/ICM) for securities regulation and supervision, Mr. Jan-Willem van der Vossen (IMF/MFD) for banking supervision and deposit insurance, Ms. Andrea Maechler (IMF/MFD) and Mr. Helmut Müller (formerly German Bundesaufsichtsamt für das Versicherungswesen) for insurance regulation and supervision, and Messrs. Jan Woltjer (IMF/MFD) and Daniel Heller (Swiss National Bank) for payment and settlement systems oversight.

127. The assessments are based on discussions held during the FSAP missions of January-February and May 2004, with representatives of the relevant regulatory and supervisory agencies as well as representatives of major banks, rating agencies and the accounting and auditing profession. It was further based on pre-mission self-assessments prepared by the authorities; study of the relevant laws and regulations; a review of the annual reports, other publications and websites of the relevant agencies; and earlier assessments made by an IMF team in the context of the 2000 Art. IV consultation (see www.imf.org). 


\section{B. Transparency of Banking Supervision}

128. The legal framework for banking regulation and supervision in France is defined by the Code Monétaire et Financier (Monetary and Financial Code, COMOFI). This code allocates different responsibilities to three main players: the CB for supervision, the CECEI for licensing, and the Minister in charge of the economy for regulation. In the current government set-up, the MINEFI handles regulation. Until earlier this year, this last function was performed by the CRBF. The CRBF has now been transformed in an advisory body, the CCLRF, advising the MoE in drawing up bank legislation and regulations. The CB, CECEI, and CCLRF are set up as specialized agencies within the group. They draw on the BdF for their staff and other resources and the Governor of the BdF is also president of the $\mathrm{CB}$ and the CECEI.

\section{Practice-by-practice assessment}

Table 30. Detailed Assessment of Observance of IMF's MFP Transparency Code_-Banking Supervision

\begin{tabular}{|c|c|}
\hline \multicolumn{2}{|c|}{$\begin{array}{l}\text { V. Clarity OF Roles, ReSPONSIBILITIES AND OBJECTIVES OF FinANCIAL AgENCIES RESPONSIBLE FOR } \\
\text { FINANCIAL POLICIES }\end{array}$} \\
\hline 5.1 & $\begin{array}{l}\text { The broad objective(s) and institutional framework of financial agencies should be clearly } \\
\text { defined, preferably in relevant legislation or regulation. }\end{array}$ \\
\hline Practice & $\begin{array}{l}\text { The COMOFI outlines the legal and institutional framework governing banking regulation and } \\
\text { supervision in France. Articles L.611-1, L.612-1 through L.612-5 and L.613-1 of that code } \\
\text { identify the three agencies involved, responsible respectively for regulation (formerly the } \\
\text { Comité de la Réglementation Bancaire et Financière-CRBF, now the MoE assisted by the } \\
\text { Comité Consultatif de la Législation et de la Réglementation Financières-CCLRF), licensing } \\
\text { (Comité des Etablissements de Crédit et des Entreprises d'Investissement-CECEI) and } \\
\text { supervision (Commission Bancaire-CB). In addition, Art. L.614-1 establishes a consultative } \\
\text { body, the Comité Consultatif du Secteur Financier (CCSF), charged with analyzing issues and } \\
\text { presenting proposals regarding the relationships between, on the one hand, credit institutions, } \\
\text { investment firms, and insurance companies and, on the other hand, their clients. }\end{array}$ \\
\hline Assessment & Observed. \\
\hline 5.1 .1 & The broad objective(s) of financial agencies should be publicly disclosed and explained. \\
\hline Practice & $\begin{array}{l}\text { The broad objectives of the agencies responsible for banking supervision are laid down in } \\
\text { Articles L.611-1, L.612-1 and L.613-1 of the COMOFI and cover in particular (i) building a } \\
\text { system of prudential regulations addressing bank soundness and the maintenance of fair and } \\
\text { competitive markets; (ii) client asset protection; (iii) enforcement of applicable laws and } \\
\text { regulations; and (iv) maintenance of market and systemic liquidity. These objectives are further } \\
\text { disclosed and explained in official publications, such as the Journal Officiel de la République } \\
\text { Française (JORF), the semi-annual Bulletin de la Commission Bancaire, the monthly Bulletin } \\
\text { de la Banque de France ), and the Annual Reports of the CRBF/CCLRF, CECEI, CB, and BdF, } \\
\text { as well as on the websites of these bodies. }\end{array}$ \\
\hline
\end{tabular}




\begin{tabular}{|c|c|}
\hline Assessment & Observed. \\
\hline 5.1.2 & $\begin{array}{l}\text { The responsibilities of the financial agencies and the authority to conduct financial } \\
\text { policies should be publicly disclosed. }\end{array}$ \\
\hline Practice & $\begin{array}{l}\text { The agencies' responsibilities are set out in the COMOFI, Art. L.611-1 through L.611-9, L.612- } \\
1 \text { (licensing by the CECEI), and Art. L.613-1 and L.613-2 (supervision by the CB). The } \\
\text { agencies' authority to conduct financial policies is set out in many provisions of the COMOFI, } \\
\text { e.g. Art. L. } 611 \text { through L.613-20. This authority and the respective responsibilities are publicly } \\
\text { disclosed through official publications (see 5.1.1, above). In addition, a compendium of all } \\
\text { laws, regulations, and directives applicable to the banking and financial sectors (the Recueil des } \\
\text { Textes Relatifs à l'Exercice des Activités Bancaires et Financières) is published annually by the } \\
\text { CRBF/CCLRF and the BdF. }\end{array}$ \\
\hline Assessment & Observed. \\
\hline 5.1.3 & $\begin{array}{l}\text { Where applicable, the broad modalities of accountability for financial agencies should be } \\
\text { publicly disclosed. }\end{array}$ \\
\hline Practice & $\begin{array}{l}\text { The broad modalities of accountability for the agencies in charge of banking supervision and } \\
\text { regulation are provided in law. Art. L.143-1 of the COMOFI requires the Governor of the BdF, } \\
\text { who is also chairman of the CECEI and the CB, to issue an annual report to the President of the } \\
\text { Republic and to Parliament. The same article also prescribes that the Governor must appear } \\
\text { before the Finance Commissions of the National Assembly or the senate if so requested, or if he } \\
\text { wishes to be heard by these bodies. Further, Art. } 20 \text { of the Constitution of October } 4,1958 \\
\text { makes the minister in charge of economic affairs collectively responsible with other members } \\
\text { of the government to parliament for the design and implementation of public policies. }\end{array}$ \\
\hline Assessment & Observed. \\
\hline 5.1.4 & $\begin{array}{l}\text { Where applicable, the procedures for appointment, terms of office, and any general } \\
\text { criteria for removal of the heads and members of the governing bodies of financial } \\
\text { agencies should be publicly disclosed. }\end{array}$ \\
\hline Practice & $\begin{array}{l}\text { The procedures for appointments to the Chair of the CB and CECEI are specified in Art. } 13 \text { of } \\
\text { the Constitution of } 1958 \text { and Art. L.142-8 of the COMOFI, which states that the Governor of } \\
\text { the BdF, who is also the Chairman of the CECEI and the CB for the duration of his six-year } \\
\text { term of office, is appointed by decree of the Council of Ministers. The Director of the Treasury, } \\
\text { who is also a member of the CB and the CECEI, is also appointed by the latter. Pursuant to the } \\
\text { COMOFI, the remaining appointments to the agencies take place by decree of the Minister in } \\
\text { charge of economic affairs, and are irrevocable, The COMOFI also specifies the terms of office, } \\
\text { at } 5 \text { years, renewable once, for the CB (Art. L.613-3) and at } 3 \text { years for the CECEI (Art. L.612- } \\
3 \text { ). Appointments are irrevocable. However, civil service appointees, among which the } \\
\text { Governor of the BdF and the Director of the Treasury, may be removed for high treason or } \\
\text { serious professional misconduct, while other appointees may be removed for cause by virtue of } \\
\text { the provisions of the Penal Code applicable to holders of public office. Public disclosure of } \\
\text { appointment procedures, terms of office, and criteria for removal are found in the JORF and on } \\
\text { the latter's website. }\end{array}$ \\
\hline Assessment & Observed. \\
\hline
\end{tabular}




\begin{tabular}{|c|c|}
\hline 5.2 & The relationship between financial agencies should be publicly disclosed. \\
\hline Practice & $\begin{array}{l}\text { The relationships between the supervisory bodies can first of all be determined by their } \\
\text { respective terms of reference (see above). Furthermore, Art. L.631-2 of the COMOFI } \\
\text { establishes a Board of Supervisory Authorities of Financial Sector Enterprises (Collège des } \\
\text { Autorités de Contrôle des Entreprises du Secteur Financier-CACESF), comprising the chairs } \\
\text { of the CB, , the governor of the BdF, the Commission de Controle des Assurances, des } \\
\text { Mutuelles et des Institutions de Prévoyance (CCAMIP), the Autorité des Marchés Financiers } \\
\text { (AMF), as well as a representative of the MINEFI, in order to facilitate the exchange of } \\
\text { information and to address topics of interest among all three sectors. Art. 631-1 authorizes the } \\
\text { exchange of information between these bodies. The COMOFI also defines the relationships } \\
\text { among the CB, CECEI, MoE and CCLRF for banking regulation and supervision on the one } \\
\text { hand, and among the AMF, CECEI and CB for the regulation and supervision of investment } \\
\text { business. The agencies generally meet monthly, while the Board of the CACESF meets at least } \\
\text { three times a year. The COMOFI also specifies that the president of the CCAMIP sits on the } \\
\text { CB. More in general, the CB and the CCAMIP have developed close links and stepped up their } \\
\text { cooperation in recent years, as formalized in a } 2001 \text { charter between them, disclosed through } \\
\text { official publications and on the websites of both institutions. }\end{array}$ \\
\hline Assessment & Observed. \\
\hline 5.3 & $\begin{array}{l}\text { The role of oversight agencies with regard to payment systems should be publicly } \\
\text { disclosed. }\end{array}$ \\
\hline \multicolumn{2}{|l|}{ Practice } \\
\hline Assessment & Not applicable. \\
\hline Comments & $\begin{array}{l}\text { The agencies in charge of banking regulation and supervision have no oversight responsibilities } \\
\text { over payment systems. Payment systems oversight is a responsibility of the BdF's payment } \\
\text { systems department. }\end{array}$ \\
\hline 5.3.1 & $\begin{array}{l}\text { The agencies overseeing the payment system should promote the timely public disclosure } \\
\text { of general policy principles (including risk management policies) that affect the robustness } \\
\text { of systemically important payment systems. }\end{array}$ \\
\hline \multicolumn{2}{|l|}{ Practice } \\
\hline Assessment & Not applicable. \\
\hline Comments & $\begin{array}{l}\text { The agencies in charge of banking regulation and supervision have no oversight responsibilities } \\
\text { over payment systems. Payment systems oversight is a responsibility of the BdF's payment } \\
\text { systems department. }\end{array}$ \\
\hline 5.4 & $\begin{array}{l}\text { Where financial agencies have oversight responsibilities for self-regulatory organizations } \\
\text { (e.g., payment systems), the relationship between them should be publicly disclosed. }\end{array}$ \\
\hline \multicolumn{2}{|l|}{ Practice } \\
\hline Assessment & Not applicable. \\
\hline
\end{tabular}




\begin{tabular}{|c|c|}
\hline Comments & $\begin{array}{l}\text { The agencies in charge of banking regulation and supervision have no oversight responsibility } \\
\text { for self-regulatory organizations. }\end{array}$ \\
\hline 5.5 & $\begin{array}{l}\text { Where self-regulatory organizations are authorized to perform part of the regulatory and } \\
\text { supervisory process, they should be guided by the same good transparency practices } \\
\text { specified for financial agencies. }\end{array}$ \\
\hline \multicolumn{2}{|l|}{ Practice } \\
\hline Assessment & Not applicable. \\
\hline Comments & $\begin{array}{l}\text { The agencies in charge of banking regulation and supervision have no oversight responsibility } \\
\text { for self-regulatory organizations. }\end{array}$ \\
\hline \multicolumn{2}{|r|}{ VI. OPEn Process for Formulating ANd Reporting of FinanCial Policies } \\
\hline 6.1 & $\begin{array}{l}\text { The conduct of policies by financial agencies should be transparent, compatible with } \\
\text { confidentiality considerations and the need to preserve the effectiveness of actions by } \\
\text { regulatory and oversight agencies. }\end{array}$ \\
\hline Practice & $\begin{array}{l}\text { Through its publications and website, the CB provides extensive information on its policies and } \\
\text { actions. However, all data and decisions with regard to individual institutions remain } \\
\text { confidential, except in cases when an institution is closed. The latter cases are described in the } \\
\text { CB's annual report. CB/CECEI members and staff are subject to professional secrecy } \\
\text { requirements (Art. L.613-20 of the COMOFI). The CECEI's decisions are published in the } \\
\text { JORF (see Art. L.511-14 and L.612-2 of the COMOFI). }\end{array}$ \\
\hline Assessment & Observed. \\
\hline 6.1.1 & $\begin{array}{l}\text { The regulatory framework and operating procedures governing the conduct of financial } \\
\text { policies should be publicly disclosed and explained. }\end{array}$ \\
\hline Practice & $\begin{array}{l}\text { The regulatory framework is set out in legislation and regulations, and disclosed/explained } \\
\text { through official publications. Operating procedures for the conduct of banking supervision are } \\
\text { disclosed and explained through regulations, descriptive documentation, notices and technical } \\
\text { guides, as well as official publications (see also 5.1.1, above). }\end{array}$ \\
\hline Assessment & Observed. \\
\hline
\end{tabular}




\begin{tabular}{|c|c|}
\hline 6.1.2 & $\begin{array}{l}\text { The regulations for financial reporting by financial institutions to financial agencies } \\
\text { should be publicly disclosed. }\end{array}$ \\
\hline Practice & $\begin{array}{l}\text { The COMOFI L. } 613-8 \text { authorizes the CB to obtain all information it needs for the exercise of } \\
\text { its banking supervision role, and to set reporting requirements (content, format and reporting } \\
\text { deadlines) for the institutions under its supervision. Regulations on prudential standards, } \\
\text { internal controls and accounting, which specify the reporting requirements of banks, are } \\
\text { publicly disclosed through the JORF, the annual compendium and the websites of the different } \\
\text { supervisory and regulatory bodies. The CB also issues instructions that specify reporting } \\
\text { requirements in greater detail. These instructions are publicly disclosed in its publications and } \\
\text { on its website. }\end{array}$ \\
\hline Assessment & Observed. \\
\hline 6.1.3 & $\begin{array}{l}\text { The regulations for the operation of organized financial markets (including those for } \\
\text { issuers of traded financial instruments) should be publicly disclosed. }\end{array}$ \\
\hline \multicolumn{2}{|l|}{ Practice } \\
\hline Assessment & Not applicable. \\
\hline Comments & $\begin{array}{l}\text { The agencies in charge of banking regulation and supervision are not responsible for the } \\
\text { regulation of organized financial markets, which is the domain of the AMF. }\end{array}$ \\
\hline 6.1.4 & $\begin{array}{l}\text { Where financial agencies charge fees to financial institutions, the structure of such fees } \\
\text { should be publicly disclosed. }\end{array}$ \\
\hline \multicolumn{2}{|l|}{ Practice } \\
\hline Assessment & Not applicable. \\
\hline Comments & The agencies responsible for bank regulation and supervision in France do not charge fees. \\
\hline 6.1.5 & $\begin{array}{l}\text { Where applicable, formal procedures for information sharing and consultation between } \\
\text { financial agencies (including central banks), domestic and international, should be } \\
\text { publicly disclosed. }\end{array}$ \\
\hline Practice & $\begin{array}{l}\text { The framework for information sharing and consultation between the agencies responsible for } \\
\text { banking supervision and regulation and other domestic financial agencies is defined in the } \\
\text { COMOFI (see 5.2, above). In the case of the relationship between the CCA/CCAMIP and the } \\
\text { CB, a formal charter was agreed in } 2001 \text { that specified the cooperation procedures and } \\
\text { modalities in greater detail. This charter is published on the websites of both agencies. No such } \\
\text { detailed agreements exist governing the other domestic relationships. A more generalized use of } \\
\text { such bilateral and publicly disclosed agreements would further enhance transparency. } \\
\text { In the area of international cooperation, Art. L.613-12 of the COMOFI empowers the CB to } \\
\text { enter into bilateral agreements for the exchange of information with its European counterparts } \\
\text { and Art. L.613-13 of the COMOFI authorizes the same for non-European Economic Area } \\
\text { (EEA) countries. Art. L.612-6 of the COMOFI authorizes the CECEI to enter into bilateral } \\
\text { agreements for the exchange of information with its counterparts in other countries. Such } \\
\text { bilateral agreements are publicly disclosed in the Bulletin of the BdF and other official } \\
\text { publications (see 5.1.1, above). See, for example, the June } 2004 \text { issue of the Bulletin of the }\end{array}$ \\
\hline
\end{tabular}




\begin{tabular}{|c|c|}
\hline & BdF, which contains an agreement between the CB and its US counterparts. \\
\hline Assessment & Observed. \\
\hline 6.2 & $\begin{array}{l}\text { Significant changes in financial policies should be publicly announced and explained in a } \\
\text { timely manner. }\end{array}$ \\
\hline Practice & $\begin{array}{l}\text { New legislation is subject to the transparent consultation and disclosure practices applicable to } \\
\text { all French legislation. New regulations are subject to an extensive consultation process (see 6.4) } \\
\text { and typically do not enter into effect until three months or more after the consultation process } \\
\text { ends. Once approved, they are widely disseminated and clarified at press conferences and } \\
\text { public presentations. More in general, all jurisdictional decisions of the CB are published. } \\
\text { The annual reports of the bodies responsible for bank regulation and supervision (BdF, CECEI } \\
\text { and the CB) discuss financial policies in their annual reports and periodic bulletins. Officials of } \\
\text { these bodies are available to discuss these issues with Parliament and the media. }\end{array}$ \\
\hline Assessment & Observed. \\
\hline 6.3 & $\begin{array}{l}\text { Financial agencies should issue periodic public reports on how their overall policy } \\
\text { objectives are being pursued. }\end{array}$ \\
\hline Practice & $\begin{array}{l}\text { Annual reports are published separately by the BdF, CB, and CECEI. In addition, the CB } \\
\text { publishes a biannual Bulletin (Bulletin de la Commission Bancaire), as well as occasional } \\
\text { reports on selected topics and its jurisdictional decisions. In addition to its annual report, the } \\
\text { BdF published a biannual Financial Stability Review (FSR), to which the CB contributes. The } \\
\text { FSR discusses issues related to financial markets, financial regulation and the banking sector, } \\
\text { and publishes studies on selected issues. }\end{array}$ \\
\hline Assessment & Observed. \\
\hline 6.4 & $\begin{array}{l}\text { For proposed substantive technical changes to the structure of financial regulations, there } \\
\text { should be a presumption in favor of public consultations, within an appropriate period. }\end{array}$ \\
\hline Practice & $\begin{array}{l}\text { In the event of substantive amendments to regulations, the general public is informed and } \\
\text { industry closely involved in the amendment process. } \\
\text { With regard to regulations, the drafting/amendment process involves: } \\
\text { - Formulation by the MoE of the general principles and disclosure to the industry; } \\
\text { - Discussion of preliminary drafts with industry experts; } \\
\text { - Periodic consultations of the banks when new regulations are in the preparatory stage, with } \\
\text { the consultation period typically exceeding three months; } \\
\text { - Formal consultation of the banking and financial services sectors by the Secretary General of } \\
\text { the CCLRF. Typically, this involves sending drafts to the banking associations for their } \\
\text { comments. The broadest based of these is the Association Française des Etablissements de } \\
\text { Crédit et des Entreprises } d \text { 'Investissement, membership of which is mandatory. This association } \\
\text { works through study groups with experts and does not routinely distribute drafts to all members. } \\
\text { - For each legal or regulatory project, as well as any proposition of regulation or EU directive, } \\
\text { the CCLRF (Art. L.614-2 of the COMOFI) advises the MoE if the draft directive has a bearing } \\
\text { on the insurance or banking sector or investment firms. The CCLRF does not advise on texts }\end{array}$ \\
\hline
\end{tabular}




\begin{tabular}{|c|c|}
\hline & $\begin{array}{l}\text { within the field of competence of the AMF; } \\
\text { - Sometimes, other bodies, such as the AMF or the Commission Nationale de l'Informatique et } \\
\text { de la Liberté (the French Data Protection Authority), are also consulted; } \\
\text { - The final draft is sent to the members of the CCLRF for their approval; } \\
\text { - If the Committee produces a negative legal opinion and the MoE wants to ignore that opinion, } \\
\text { the MoE needs to request a second reading before it can proceed. } \\
\text { An additional stage is sometimes added, in which the European Central Bank (ECB) is } \\
\text { consulted. The ECB needs to see any draft legislation relating to financial institutions (except in } \\
\text { the case of measures implementing EU Directives), if the regulations in question might affect } \\
\text { the stability of these institutions and the financial markets. } \\
\text { The consultation process is helped by the fact that the banking industry has direct } \\
\text { representation on the CCLRF, and by the role played by the new Comité Consultatif du Secteur } \\
\text { Financier (CCSF) (see 5.1). This CCSF comprises two categories of members : on the one } \\
\text { hand, in majority, and in equal numbers, representatives of credit institutions, investment firms, } \\
\text { insurance companies, insurance agents and brokers; and, on the other hand, client } \\
\text { representatives. The composition of the Committee, the conditions of nomination of its } \\
\text { members and its president are decided by Decree. } \\
\text { The consultation process is transparent and comprehensive. Compulsory membership of all } \\
\text { licensed banks and investment firms in a professional organization allows for comprehensive } \\
\text { distribution of drafts to all market participants. However, by not distributing all drafts routinely } \\
\text { to all members, the Association Française des Etablissements de Credit et des Entreprises } \\
\text { d'Investissement may not always fully reflect market views. The new CCLRF will give a more } \\
\text { broad-based consultation process that will enhance the process as it would allow potential } \\
\text { market entrants to participate as well. }\end{array}$ \\
\hline Assessment & Observed. \\
\hline & VII. Public AVailability of Information on Financial Policies \\
\hline 7.1 & $\begin{array}{l}\text { Financial agencies should issue a periodic public report on the major developments of the } \\
\text { sector(s) of the financial system for which they carry designated responsibility. }\end{array}$ \\
\hline Practice & $\begin{array}{l}\text { Each year, the CB publishes (i) its annual report, which describes major developments in the } \\
\text { banking and financial sectors in addition to providing information on the CB's supervisory } \\
\text { policy and actions and (ii) its two-volume comparative analysis (Analyses Comparatives), } \\
\text { which contains comprehensive aggregate data on the activities and performance of credit } \\
\text { institutions. The CB also publishes a bi-annual Bulletin with information on new regulations } \\
\text { and studies on developments in the banking sector. The CECEI publishes an annual report and } \\
\text { maintains the current list of credit and investment institutions published in the JORF. The BdF } \\
\text { provides reports on a quarterly and annual basis and a biannual financial stability report. All } \\
\text { publications are available online on the website of the BdF. }\end{array}$ \\
\hline Assessment & Observed. \\
\hline 7.2 & $\begin{array}{l}\text { Financial agencies should seek to ensure that, consistent with confidentiality } \\
\text { requirements, there is public reporting of aggregate data related to their jurisdictional } \\
\text { responsibilities on a timely and regular basis. }\end{array}$ \\
\hline Practice & The CB's annual report, Analyses Comparatives and Bulletin provide aggregate data for the \\
\hline
\end{tabular}




\begin{tabular}{|c|c|}
\hline & $\begin{array}{l}\text { banking and financial sectors. The CECEI's annual report provides data on the number of } \\
\text { institutions by category, as does the BdF's annual report. }\end{array}$ \\
\hline Assessment & Observed. \\
\hline 7.3 & $\begin{array}{l}\text { Where applicable, financial agencies should publicly disclose their balance sheets on a } \\
\text { pre-announced schedule and, after a predetermined interval, publicly disclose information } \\
\text { on aggregate market transactions. }\end{array}$ \\
\hline \multicolumn{2}{|l|}{ Practice } \\
\hline Assessment & Not applicable. \\
\hline Comments & $\begin{array}{l}\text { The three financial agencies engaged in banking supervision and regulation (CB, CECEI, and } \\
\text { CCLRF) do not have separate balance sheets. Their staff and financial resources are provided } \\
\text { by the BdF by formal agreement. The BdF's annual report includes information on staff } \\
\text { seconded to supervisory functions. } \\
\text { Transparency could be helped by the creation and publication of pro forma balance sheets of the } \\
\text { different agencies within the BdF group. Such pro forma balance sheets could be published in } \\
\text { the BdF's annual report. }\end{array}$ \\
\hline 7.3 .1 & $\begin{array}{l}\text { Consistent with confidentiality and privacy of information on individual firms, aggregate } \\
\text { information on emergency financial support by financial agencies should be publicly } \\
\text { disclosed through an appropriate statement when such disclosure will not be disruptive to } \\
\text { financial stability. }\end{array}$ \\
\hline \multicolumn{2}{|l|}{ Practice } \\
\hline Assessment & Not applicable. \\
\hline Comments & $\begin{array}{l}\text { None of the three financial agencies engaged in banking supervision and regulation provide } \\
\text { emergency financial support to supervised institutions, although support operations can be } \\
\text { undertaken by the BdF (see COMOFI Art. L.141-3). In such cases this would be disclosed after } \\
\text { the fact, through the periodic publications of the BdF. Furthermore, the Deposit Guarantee Fund } \\
\text { (FGD) has the option, at the request of the CB, to provide support to an ailing institution. }\end{array}$ \\
\hline 7.4 & Financial agencies should establish and maintain public information services. \\
\hline Practice & $\begin{array}{l}\text { The CB, CECEI, and CCLRF all use the BdF's Communications Division to provide public } \\
\text { information services. The CB and the CECEI also have public websites. The services provided } \\
\text { by the BdF's Communications Division include the dissemination of information on: (i) policy } \\
\text { decisions and announcements; (ii) the operation of the financial agencies and their objectives; } \\
\text { (iii) speeches by senior officials; (iv) quantitative data; (v) staff research; and (vi) jurisdictional } \\
\text { decisions. They also include contact with news media representatives. }\end{array}$ \\
\hline Assessment & Observed. \\
\hline 7.4 .1 & $\begin{array}{l}\text { Financial agencies should have a publications program, including a periodic public report } \\
\text { on their principal activities issued at least annually. }\end{array}$ \\
\hline Practice & See 7.1, above. The CB's program includes (i) an annual report; (ii) bi-annual bulletins; \\
\hline
\end{tabular}




\begin{tabular}{|c|c|}
\hline & $\begin{array}{l}\text { (iii) research studies; (iv) speeches by senior or top officials; and (v) a brief description of its } \\
\text { role and functions. The CRBF/CCLRF's program comprises its annual report and its Recueil } \\
\text { (see 5.1.2, above). The CECEI publishes its annual report and makes public any changes in its } \\
\text { list of credit institutions and investment firms. Annual reports, bulletins of the CB, and the } \\
\text { Recueil are available online on the website of the BdF, and on the individual websites of the } \\
\text { different agencies. }\end{array}$ \\
\hline Assessment & Observed. \\
\hline 7.4.2 & $\begin{array}{l}\text { Senior financial agency officials should be ready to explain their institution's objective(s) } \\
\text { and performance to the public, and have a presumption in favor of releasing the text of } \\
\text { their statements to the public. }\end{array}$ \\
\hline Practice & $\begin{array}{l}\text { The Governor of the BdF (who also chairs the CB and the CECEI) and senior officials of the } \\
\text { CB's General Secretariat explain their agencies' objectives and performance at } \\
\text { parliamentary/senate hearings (for the Governor of the BdF/Chairman of the CB and the } \\
\text { CECEI), as well as through speeches in public fora and before members of the industry and } \\
\text { articles in the news media. Texts of such statements are generally released to the public, } \\
\text { including through the websites of the BdF. }\end{array}$ \\
\hline Assessment & Observed. \\
\hline 7.5 & $\begin{array}{l}\text { Texts of regulations and any other generally applicable directives and guidelines issued by } \\
\text { financial agencies should be readily available to the public. }\end{array}$ \\
\hline Practice & $\begin{array}{l}\text { Texts of regulations and any other generally applicable directives and guidelines issued by the } \\
\text { agencies responsible for banking regulation and supervision in France are made readily } \\
\text { available through different channels, including the website of the BdF; the official bulletin of } \\
\text { the BdF; the Bulletin of the CB; the JORF; the Recueil des Textes Relatifs à l'Exercice des } \\
\text { Activités Bancaires et Financieres, an annual publication that lists all official texts applicable to } \\
\text { the banking sector; and www.legifrance.gouv.fr, a public website that gives convenient access } \\
\text { to all French laws, decrees and regulations. }\end{array}$ \\
\hline Assessment & Observed. \\
\hline 7.6 & $\begin{array}{l}\text { Where there are deposit insurance guarantees, policy-holder guarantees, and any other } \\
\text { client asset protection schemes, information on the nature and form of such protections, } \\
\text { on the operating procedures, on how the guarantee is financed, and on the performance of } \\
\text { the arrangement, should be publicly disclosed. }\end{array}$ \\
\hline \multicolumn{2}{|l|}{ Practice } \\
\hline Assessment & Not applicable. \\
\hline Comments & $\begin{array}{l}\text { None of the agencies responsible for banking regulation and supervision is responsible for } \\
\text { operating a client asset protection scheme. The transparency of the FGD is subject of a separate } \\
\text { assessment. }\end{array}$ \\
\hline
\end{tabular}




\begin{tabular}{|c|c|}
\hline 7.7 & $\begin{array}{l}\text { Where financial agencies oversee consumer protection arrangements (such as dispute } \\
\text { settlement processes), information on such arrangements should be publicly disclosed. }\end{array}$ \\
\hline \multicolumn{2}{|l|}{ Practice } \\
\hline Assessment & Not applicable. \\
\hline Comments & $\begin{array}{l}\text { The banking regulatory and supervisory agencies have no oversight responsibilities for } \\
\text { consumer protection arrangements. However, the new Comité Consultatif du Secteur Financier } \\
\text { (CCSF) -which replaced the Comité Consultatif of the CNCT (Art. L.614-1 of the COMOFI)- } \\
\text { will be in charge of the relations between credit institutions, investment firms, insurance } \\
\text { companies and their clients. The Governor of the BdF leads the Comité de la Médiation } \\
\text { Bancaire created at the end of } 2002 \text { which, in particular, surveys the activities of each mediator } \\
\text { or ombudsman designated by credit institutions in application of Art. L.312-1-3 of the } \\
\text { COMOFI. }\end{array}$ \\
\hline \multicolumn{2}{|r|}{ VIII. ACCOUNTABILITY AND ASSURANCES OF INTEGRITY BY FINANCIAL AGENCIES } \\
\hline 8.1 & $\begin{array}{l}\text { Officials of financial agencies should be available to appear before a designated public } \\
\text { authority to report on the conduct of financial policies, explain the policy objective(s) of } \\
\text { their institution, describe their performance in pursuing their objective(s), and, as } \\
\text { appropriate, exchange views on the state of the financial system. }\end{array}$ \\
\hline Practice & $\begin{array}{l}\text { For these purposes, Art. L.143-1 of the COMOFI specifies that the Governor of the BdF may be } \\
\text { heard by the Finance Commissions of the National Assembly or the Senate and may request to } \\
\text { be heard by them. }\end{array}$ \\
\hline Assessment & Observed. \\
\hline 8.2 & $\begin{array}{l}\text { Where applicable, financial agencies should publicly disclose audited financial statements } \\
\text { of their operations on a pre-announced schedule. }\end{array}$ \\
\hline \multicolumn{2}{|l|}{ Practice } \\
\hline Assessment & Not applicable. \\
\hline Comments & $\begin{array}{l}\text { The CB and CECEI do not have balance sheets separate from that of the BdF (see } 7.3 \text { above). } \\
\text { The audited financial statements of the BdF are published in the JORF and form part of the } \\
\text { BdF's annual report. }\end{array}$ \\
\hline 8.2.1 & $\begin{array}{l}\text { Financial statements, if any, should be audited by an independent auditor. Information on } \\
\text { accounting policies and any qualification to the statements should be an integral part of } \\
\text { the publicly disclosed financial statements. }\end{array}$ \\
\hline \multicolumn{2}{|l|}{ Practice } \\
\hline Assessment & Not applicable. \\
\hline Comments & $\begin{array}{l}\text { The CB and CECEI do not have balance sheets separate from that of the BdF (see } 7.3 \text { and } 8.2 \\
\text { above). Financial statements of the BdF are audited by two private sector firms of chartered } \\
\text { accountants. Information on auditing and accounting policies as well as qualifications to the }\end{array}$ \\
\hline
\end{tabular}




\begin{tabular}{|c|c|}
\hline & financial statements, are disclosed in the published statements. \\
\hline 8.2.2 & $\begin{array}{l}\text { Internal governance procedures necessary to ensure the integrity of operations, including } \\
\text { internal audit arrangements, should be publicly disclosed. }\end{array}$ \\
\hline \multirow[t]{2}{*}{ Practice } & $\begin{array}{l}\text { The BdF provides the CB, CECEI and CCLRF all material support and staff they need for the } \\
\text { performance of their functions (Art. L } 613-6 \text { and L } 613-7 \text { of the COMOFI). Insurance of the } \\
\text { integrity of operations rests with the internal audit office of the BdF (l'Inspection Générale). } \\
\text { This internal office, together with the risk management unit, falls under the authority of the } \\
\text { Contrôleur Général, and is responsible for the systematic monitoring of the BdF's management } \\
\text { procedures and internal control systems. The existence (and mission) of the internal audit office } \\
\text { is publicly disclosed in the BdF's annual report and its organization chart. Developments in the } \\
\text { area of internal audit are also discussed in the BdF's annual report (for example, section } 8.2 .8 \text { of } \\
\text { the } 2002 \text { Annual Report). }\end{array}$ \\
\hline & $\begin{array}{l}\text { Transparency could be further enhanced by posting an extensive description of the internal } \\
\text { audit unit and other internal governance procedures on the website of the BdF, and on the } \\
\text { website of the other agencies that are covered by the same system. }\end{array}$ \\
\hline Assessment & Observed. \\
\hline 8.3 & $\begin{array}{l}\text { Where applicable, information on the operating expenses and revenues of financial } \\
\text { agencies should be publicly disclosed annually. }\end{array}$ \\
\hline \multicolumn{2}{|l|}{ Practice } \\
\hline Assessment & Not applicable. \\
\hline Comments & $\begin{array}{l}\text { Since the resources of the CB, CECEI and CCLRF are provided by the BdF, these agencies do } \\
\text { not have their own separately identified operating expenses and revenues. }\end{array}$ \\
\hline 8.4 & $\begin{array}{l}\text { Standards for the conduct of personal financial affairs of officials and staff of financial } \\
\text { agencies and rules to prevent exploitation of conflicts of interest, including any general } \\
\text { fiduciary obligation, should be publicly disclosed. }\end{array}$ \\
\hline Practice & $\begin{array}{l}\text { Internal standards for the conduct of personal financial affairs are set out in the BdF's Code de } \\
\text { déontologie financière, which is published in the Official Bulletin of the BdF. A recent internal } \\
\text { rule (also published) relating to the implementation of the Code de déontologie financière } \\
\text { focuses more specifically on good practices to be applied by officials and staff when they are } \\
\text { offered gifts in the conduct of their official duties. }\end{array}$ \\
\hline Assessment & Observed. \\
\hline 8.4 .1 & $\begin{array}{l}\text { Information about legal protections for officials and staff of financial agencies in the } \\
\text { conduct of their official duties should be publicly disclosed. }\end{array}$ \\
\hline Practice & $\begin{array}{l}\text { The CB enjoys a suitable level of protection within the framework of the general principles of } \\
\text { administrative law, laid down in case law in administrative courts in France. With regard to the } \\
\text { CB's performance of its administrative duties, current Conseil d'État jurisprudence indicates } \\
\text { that the State may incur liability on the CB's account mainly for gross negligence. The trend in } \\
\text { case law seems to be moving toward the possibility of the State incurring liability for simple } \\
\text { negligence. If this shift were to be confirmed, the legal protection afforded to the CB would be }\end{array}$ \\
\hline
\end{tabular}




\begin{tabular}{|c|c|}
\hline & $\begin{array}{l}\text { diminished. } \\
\text { With respect to employee liability, CB staff is protected by the general principles of } \\
\text { administrative law applicable to persons in charge of a public function. Where civil liability is } \\
\text { concerned, a distinction should be made between administrative error and personal fault. A civil } \\
\text { servant does not incur personal liability for an administrative error, which-by its nature- } \\
\text { cannot be separated from the exercise of a public office. A civil servant may incur personal } \\
\text { liability for personal fault, such as malevolence or abusive behavior, which can be separated } \\
\text { from the exercise of a public office. In criminal matters, liability is personal. CB staff may } \\
\text { therefore incur criminal liability for their acts. } \\
\text { Since these legal protections stem from administrative case law in France, they are public by } \\
\text { nature. The essential relevant judicial rulings are widely publicized and discussed in the legal } \\
\text { press and literature. } \\
\text { While legal journals and literature publicly disclose and discuss jurisprudence on the legal } \\
\text { responsibility of civil servants, these sources are not easily accessible and comprehensible to the } \\
\text { general public. Therefore, transparency would benefit from the publication in a more accessible } \\
\text { medium of the specific legal status and liability limitations applicable to the BdF, CB, CECEI } \\
\text { and CCLRF and their staff members and officials. While the content of the rule of } \\
\text { administrative law, as well as established jurisprudence, are not at issue, the public, the agencies } \\
\text { concerned and their staff would benefit from a clear overview of the legal issues and } \\
\text { confirmation of the protection of civil servants, which is particularly relevant in the area of bank } \\
\text { supervision. }\end{array}$ \\
\hline Assessment & Observed. \\
\hline
\end{tabular}

Table 31. Summary Observance of IMF's MFP Transparency Code-Banking Supervision

\begin{tabular}{|l|c|l|}
\hline \multirow{2}{*}{ Assessment Grade } & \multicolumn{2}{|c|}{ Principles Grouped by Assessment Grade } \\
\cline { 2 - 3 } & Count & \multicolumn{1}{c|}{ List } \\
\hline Observed & 23 & $\begin{array}{l}5.1,5.1 .1,5.1 .2,5.1 .3,5.1 .4,5.2,6.1,6.1 .1, \\
6.1 .2,6.1 .5,6.2,6.3,6.4,7.1,7.2,7.4,7.4 .1, \\
7.4 .2,7.5,8.1,8.2 .2,8.4,8.4 .1 .\end{array}$ \\
\hline Largely observed & 0 & -- \\
\hline Partly observed & 0 & -- \\
\hline Not observed & 0 & -- \\
\hline Not applicable & 13 & $\begin{array}{l}5.3,5.3 .1,5.4,5.5,6.1 .3,6.1 .4,7.3,7.3 .1,7.6, \\
7.7,8.2,8.2 .1,8.3 .\end{array}$ \\
\hline
\end{tabular}




\section{Recommended action plan and authorities' response to the assessment}

\section{Recommended action plan}

Table 32. Recommended Action Plan to Improve Observance of IMF's MFP Transparency Code Practices-Banking Supervision

\begin{tabular}{|l|l|}
\hline Reference Practice & Recommended Action \\
\hline None. & \\
\hline
\end{tabular}

\section{Authorities' response to the assessment}

129. The authorities are in broad agreement with the assessment.

\section{Transparency of Deposit Insurance}

130. The FGD was established by the Savings and Financial Security Act of June 25, 1999, which was subsequently transposed into the COMOFI. This basic legal framework is complemented by two decrees, as well as by a series of regulations issued by the CRBF. The FGD is set up as a special purpose legal entity under private law, of which all credit institutions licensed in France must be members. It is overseen by a supervisory council composed of representatives of the member credit institutions. On a day-to-day basis, the FGD is managed by a board consisting of three directors, one of which is designated President. The directors and President are nominated by the supervisory council, but the nomination of the President is subject to approbation by the MoE. The FGD covers bank deposits, certain securities, and a specific type of bank guarantees (cautions) that some professions in France must obtain. The limit of its coverage is set at EUR 70,000 per individual per bank. In addition, it can preventatively intervene in a financial institution at the request of the $\mathrm{CB}$.

\section{Practice-by-practice assessment}

Table 33. Detailed Assessment of Observance of IMF's MFP Transparency Code_-Deposit Insurance Supervision

\begin{tabular}{|l|l|}
\hline \multicolumn{2}{|c|}{ V. CLARITY OF RoleS, RESPONSIBILITIES AND OBJECTIVES OF FINANCIAL AGENCIES RESPONSIBLE FOR } \\
FINANCIAL POLICIES-PROTECTION OF DEPOSITS, SECURITIES AND BENEFICIARIES OF "CAUTIONS" \\
\hline 5.1 & $\begin{array}{l}\text { The broad objective(s) and institutional framework of financial agencies should be clearly } \\
\text { defined, preferably in relevant legislation or regulation. }\end{array}$ \\
\hline Practice & $\begin{array}{l}\text { The Fonds de Garantie des Dépôts was established by the Savings and Financial Security Act } \\
\text { of June 25, 1999, replacing the previously existing separate guarantee funds. The text of } \\
\text { the } 1999 \text { Law is now transposed into the COMOFI of December } 14,2000, \text { Articles L.312-4 }\end{array}$ \\
\hline
\end{tabular}




\begin{tabular}{|c|c|}
\hline & $\begin{array}{l}\text { through 18, Articles L.313-50 and 51, Articles L.322-1 through 4, and Art. L.352-1. } \\
\text { The COMOFI states that the FGD guarantees deposits, investments, and "caution." The latter } \\
\text { are specified in Decree 99-776 as referring to mandatory guarantees, which certain professions } \\
\text { in France (e.g, contractors in the construction sector) must obtain from a credit institution to } \\
\text { provide their clients protection concerning the completion of certain contracts. Rights of } \\
\text { insurance policy holders are not protected by the FGD but by other entities, governed by the } \\
\text { Code des Assurances (namely, the Fonds de Garantie des Assurances Obligatoires de } \\
\text { Dommages and the Fonds de Garantie des Assurés Contre la Défaillance des Sociétés } \\
\text { d'Assurance). The FGD's legal personality, activation, scope, governance, funding, intervention } \\
\text { powers, its right to sue managers of a financial institution, as well as an enabling clause for the } \\
\text { MoE to issue more detailed regulations, are also clearly set out in the COMOFI. } \\
\text { Regulation 99-05 of the CRBF provides more detail on the functioning of the FGD, including } \\
\text { information on the extent of cover it provides, the pay-out modalities, and the procedures to } \\
\text { notify depositors. Regulation 99-06 regulates the FGD's financial resources, including the } \\
\text { methodology for the calculation of the contributions of covered financial institutions. } \\
\text { Regulation 99-07 regulates how claims on branches in France of institutions outside the EEA } \\
\text { are covered. It also gives the FGD the authority to conclude agreements with deposit protection } \\
\text { schemes in other countries, regarding foreign banks with subsidiaries in France. }\end{array}$ \\
\hline Assessment & Observed. \\
\hline 5.1 .1 & The broad objective(s) of financial agencies should be publicly disclosed and explained. \\
\hline Practice & $\begin{array}{l}\text { The broad objectives of the FGD are clearly specified in the COMOFI, as being: (i) to } \\
\text { reimburse depositors in cases of unavailability (indisponibilité) of deposits (Art. L.312) or } \\
\text { (ii) securities instruments (Art. L.322-2); and (iii) to honor cautions in case a credit institution } \\
\text { becomes insolvent (Art. L.313-50). Preventive action against an institution is another broad } \\
\text { objective stated in Art. L.312-5 of the COMOFI: the CB may request the FGD to intervene in a } \\
\text { preventive capacity when a member's situation gives rise to concerns that the deposits or } \\
\text { financial instruments may become unavailable at some point in the future, taking into } \\
\text { consideration any support from which the distressed institution may otherwise benefit. } \\
\text { These objectives are further explained on the FGD's informative website } \\
\text { ( www.garantiedesdepots.fr ). }\end{array}$ \\
\hline Assessment & Observed. \\
\hline 5.1 .2 & $\begin{array}{l}\text { The responsibilities of the financial agencies and the authority to conduct financial } \\
\text { policies should be publicly disclosed. }\end{array}$ \\
\hline Practice & $\begin{array}{l}\text { The responsibilities and authority of the FGD are laid out in the COMOFI and associated } \\
\text { regulations as cited above (see } 5.1 \text { and 5.1.1). }\end{array}$ \\
\hline Assessment & Observed. \\
\hline 5.1 .3 & $\begin{array}{l}\text { Where applicable, the broad modalities of accountability for financial agencies should be } \\
\text { publicly disclosed. }\end{array}$ \\
\hline Practice & $\begin{array}{l}\text { COMOFI, Art. L.312-10 stipulates that the FGD submits an annual financial statement to the } \\
\text { MoE every year, after external audit and the approval of the statement by the supervisory } \\
\text { council of the FGD. Art. L.312-13 provides the possibility for the Minister in charge of } \\
\text { economic affairs, the Governor of the BdF, and the President of the Commission Bancaire and }\end{array}$ \\
\hline
\end{tabular}




\begin{tabular}{|c|c|}
\hline & $\begin{array}{l}\text { the President of the AMF to be heard by the FGD at their request. Art. L.312-10 prescribes that } \\
\text { decisions by the FGD on the management and use of the guarantee fund need to be ratified by } \\
\text { the Minister in charge of economic affairs. Art. L.312-5 of the COMOFI stipulates that } \\
\text { decisions taken by the FGD are subject to administrative review by the administrative judicial } \\
\text { authorities. The decisions of the administrative judicial authorities are publicly disclosed. } \\
\text { Transparency could be further improved by putting in place provisions for the FGD to regularly } \\
\text { report on its activities to the public and to a designated public body. }\end{array}$ \\
\hline Assessment & Observed. \\
\hline 5.1.4 & $\begin{array}{l}\text { Where applicable, the procedures for appointment, terms of office, and any general } \\
\text { criteria for removal of the heads and members of the governing bodies of financial } \\
\text { agencies should be publicly disclosed. }\end{array}$ \\
\hline Practice & $\begin{array}{l}\text { Articles L.312-9, L.312-10, L. } 312-11 \text { and } 12 \text { of the COMOFI specify that the FGD is governed } \\
\text { by a supervisory council consisting of } 12 \text { members (plus } 2 \text { members for the Securities } \\
\text { Guarantee mechanism) and is managed on a day-to-day basis by a directorate of three members, } \\
\text { nominated by the supervisory council. Additional rules on the governance of the FGD are } \\
\text { disclosed in Regulation } 99-06 \text {, Articles } 10-14 \text {. The members of the supervisory council appoint } \\
\text { one of the members of the directorate as president of the FGD. The members of the supervisory } \\
\text { council are appointed by the members for a period of four years. The four largest contributors } \\
\text { each have one voting representative on the supervisory Council; banks that are members of a } \\
\text { central body (as defined in the COMOFI) together provide two voting representatives, and other } \\
\text { credit institutions together supply six. Investment firms that are not credit institutions provide } 2 \\
\text { representatives. The latter eight (plus } 2 \text { ) representatives are not "ex officio" members of the } \\
\text { supervisory council. Voting rights reflect financial contributions. The president of the } \\
\text { directorate must be confirmed by the Minister of Economics, Finance and Industry. } \\
\text { The procedures for appointment, terms of office and general criteria for removal of members of } \\
\text { the supervisory council are further specified in CRBF regulation } 99-06 \text {. This regulation sets the } \\
\text { terms of office of council members at } 4 \text { years. It also puts the responsibility for particular } \\
\text { supervisory council seats at the level of qualifying member institutions. Those institutions are } \\
\text { reponsible for replacing a council member who is no longer able to fulfill his or her mandate. } \\
\text { The procedures for electing and removing the president of the supervisory council are outlined } \\
\text { in the internal rules (Règlement intérieur) of the CDG, which are posted on its website. These } \\
\text { rules also specify the procedures for the nomination by the supervisory council of the members } \\
\text { of the board of directors, their terms of office, and the procedures for revoking their mandate. }\end{array}$ \\
\hline Assessment & Observed. \\
\hline 5.2 & The relationship between financial agencies should be publicly disclosed. \\
\hline Practice & $\begin{array}{l}\text { The FGD has relations with the CB, the AMF, the CECEI and the MINEFI. In particular, the } \\
\text { relationship between the CB and the FGD is regulated in COMOFI Articles L.312-5, L.313-50, } \\
\text { and L. } 322-1 \text {, on the activation of the FGD by the CB with regard to the insurance of deposits, } \\
\text { "cautions" and claims on investment companies. Art. L. } 312-5 \text { contains provisions on the } \\
\text { authority of the CB to request intervention by the FGD, as well as the authority of the FGD to } \\
\text { refuse intervention, respectively to set the conditions for its intervention. Other rules on the } \\
\text { relation between the CB and the FGD are disclosed to the public in a range of regulations and } \\
\text { instructions. Exchange of information with the relevant supervisory bodies is regulated in } \\
\text { COMOFI Art. L.631-1. }\end{array}$ \\
\hline
\end{tabular}




\begin{tabular}{|c|c|}
\hline Assessment & Observed. \\
\hline 5.3 & $\begin{array}{l}\text { The role of oversight agencies with regard to payment systems should be publicly } \\
\text { disclosed. }\end{array}$ \\
\hline \multicolumn{2}{|l|}{ Practice } \\
\hline Assessment & Not applicable. \\
\hline Comments & The FGD has no responsibility in the area of payment systems oversight. \\
\hline 5.3 .1 & $\begin{array}{l}\text { The agencies overseeing the payment system should promote the timely public disclosure } \\
\text { of general policy principles (including risk management policies) that affect the robustness } \\
\text { of systemically important payment systems. }\end{array}$ \\
\hline \multicolumn{2}{|l|}{ Practice } \\
\hline Assessment & Not applicable. \\
\hline Comments & The FGD has no responsibility in the area of payment systems oversight. \\
\hline 5.4 & $\begin{array}{l}\text { Where financial agencies have oversight responsibilities for self-regulatory organizations } \\
\text { (e.g., payment systems), the relationship between them should be publicly disclosed. }\end{array}$ \\
\hline \multicolumn{2}{|l|}{ Practice } \\
\hline Assessment & Not applicable. \\
\hline Comments & The FGD has no oversight responsibilities for self-regulatory organizations. \\
\hline 5.5 & $\begin{array}{l}\text { Where self-regulatory organizations are authorized to perform part of the regulatory and } \\
\text { supervisory process, they should be guided by the same good transparency practices } \\
\text { specified for financial agencies. }\end{array}$ \\
\hline \multicolumn{2}{|l|}{ Practice } \\
\hline Assessment & Not applicable. \\
\hline Comment & The FGD has no oversight responsibilities for self-regulatory organizations. \\
\hline \multicolumn{2}{|r|}{ VI. OPEN PROCESS FOR ForMulating AND REPORTING OF FinANCIAL Policies } \\
\hline 6.1 & $\begin{array}{l}\text { The conduct of policies by financial agencies should be transparent, compatible with } \\
\text { confidentiality considerations and the need to preserve the effectiveness of actions by } \\
\text { regulatory and oversight agencies. }\end{array}$ \\
\hline Practice & $\begin{array}{l}\text { The FGD only reports on its financial condition, in an annual report issued to the MoE. } \\
\text { Information on its actions and policies are not disclosed through specific publications or other } \\
\text { forms of disclosure. }\end{array}$ \\
\hline
\end{tabular}




\begin{tabular}{|c|c|}
\hline Assessment & Not observed. \\
\hline 6.1.1 & $\begin{array}{l}\text { The regulatory framework and operating procedures governing the conduct of financial } \\
\text { policies should be publicly disclosed and explained. }\end{array}$ \\
\hline Practice & $\begin{array}{l}\text { The FGD's regulatory framework and operating procedures are laid down in the COMOFI, as } \\
\text { well as in associated regulations and instructions, all of which are publicly disclosed. Also, the } \\
\text { FGD maintains a public website in which this information is provided in a very clear way. The } \\
\text { website also lists useful links, references and applicable regulations. }\end{array}$ \\
\hline Assessment & Partly observed. \\
\hline Comments & $\begin{array}{l}\text { There is no transparency toward depositors on the fact that branches and subsidiaries of foreign } \\
\text { banks in France may not have the same level of coverage (EUR 70,000) as domestic } \\
\text { institutions. The EU Directive on deposit insurance requires a minimum coverage of only } \\
\text { EUR 20,000. }\end{array}$ \\
\hline 6.1 .2 & $\begin{array}{l}\text { The regulations for financial reporting by financial institutions to financial agencies } \\
\text { should be publicly disclosed. }\end{array}$ \\
\hline \multicolumn{2}{|l|}{ Practice } \\
\hline Assessment & Not applicable. \\
\hline Comments & $\begin{array}{l}\text { The FGD does not itself receive reports from its member institutions, which report instead to } \\
\text { the relevant supervisory agencies. }\end{array}$ \\
\hline 6.1 .3 & $\begin{array}{l}\text { The regulations for the operation of organized financial markets (including those for } \\
\text { issuers of traded financial instruments) should be publicly disclosed. }\end{array}$ \\
\hline \multicolumn{2}{|l|}{ Practice } \\
\hline Assessment & Not applicable. \\
\hline Comments & The FGD is not responsible for the operation of organized financial markets. \\
\hline 6.1 .4 & $\begin{array}{l}\text { Where financial agencies charge fees to financial institutions, the structure of such fees } \\
\text { should be publicly disclosed. }\end{array}$ \\
\hline \multirow[t]{2}{*}{ Practice } & $\begin{array}{l}\text { Art. L. } 312-7 \text { of the COMOFI authorizes the FGD to levy contributions from covered credit } \\
\text { institutions. The overall amount of the member banks' annual contributions is set in } \\
\text { Regulation 2002-11. Individual banks' contributions toward this overall amount are calculated } \\
\text { by the CB according to the rules outlined in Regulation } 99-06 \text { and its Annex C. The calculation } \\
\text { is done twice a year, based on information reported to the CB concerning the levels of deposits } \\
\text { and credits, and on the risks of each member institution calculated as a composite indicator. The } \\
\text { formula of risk calculation is disclosed but the amounts levied upon individual banks are not. } \\
\text { Once determined, the CB informs the individual members of the FGD of the amount of their } \\
\text { contributions to be paid to the FGD. }\end{array}$ \\
\hline & $\begin{array}{l}\text { A similar arrangement for the funding of the guarantee for securities is outlined in CRBF } \\
\text { regulation 99-15 and its annex, while CRBF regulation 2000-06 outlines the mechanism for the }\end{array}$ \\
\hline
\end{tabular}




\begin{tabular}{|c|c|}
\hline & funding of the guarantee for "cautions." \\
\hline Assessment & Observed. \\
\hline 6.1 .5 & $\begin{array}{l}\text { Where applicable, formal procedures for information sharing and consultation between } \\
\text { financial agencies (including central banks), domestic and international, should be } \\
\text { publicly disclosed. }\end{array}$ \\
\hline \multirow[t]{3}{*}{ Practice } & $\begin{array}{l}\text { COMOFI Art. L.631-1 authorizes information sharing between the FGD and the relevant } \\
\text { financial sector supervisory authorities, the BdF, the CECEI, the CB, the CCAMIP, the CCA, } \\
\text { the CEA, the AMF, the Fonds de Garantie des Assurances Obligatoires de Dommages and the } \\
\text { Fonds de Garantie des Assurés Contre la Défaillance des Sociétés d'Assurance. Information } \\
\text { sharing is subject to mutual application of professional secrecy to the exchanged information. } \\
\text { Art. L.312-13 provides the possibility for the Minister in charge of economic affairs, the } \\
\text { Governor of the BdF, and the President of the Commission Bancaire and the President of the } \\
\text { AMF to be heard by the FGD at their request. COMOFI Art. L.631-2 stipulates the creation of } \\
\text { the Collège des Autorités de Contrôle des Entreprises du Secteur Financier (CACESF). } \\
\text { Although the FGD is not represented on this body, its functioning enhances the effective } \\
\text { circulation among the different agencies of any information received from the FGD. }\end{array}$ \\
\hline & $\begin{array}{l}\text { Other than these general provisions, there is no public disclosure of the detailed procedures for } \\
\text { information sharing and consultation among domestic financial authorities. }\end{array}$ \\
\hline & $\begin{array}{l}\text { CRBF regulation 99-07 allows the FGD to cooperate with foreign deposit insurance agencies, } \\
\text { but it does not provide any guidance on the handling of information exchanges that could be } \\
\text { part of such cooperation. According to the FGD, no cooperation agreements have been agreed } \\
\text { with foreign agencies, but negotiations are ongoing with a number of European counterparts. } \\
\text { These agreements will cover the exchange of information on changes in applicable regulations } \\
\text { and in cases of interventions in insured financial institutions with cross-border activities. It is } \\
\text { not clear at this stage whether such agreements will be published. }\end{array}$ \\
\hline Assessment & Broadly observed. \\
\hline Comments & $\begin{array}{l}\text { Disclosure in greater detail of the formal procedures for information sharing and consultation } \\
\text { between the FGD and other financial agencies and a policy of publicly disclosing international } \\
\text { cooperation agreements are required for an "observed" rating. }\end{array}$ \\
\hline 6.2 & $\begin{array}{l}\text { Significant changes in financial policies should be publicly announced and explained in a } \\
\text { timely manner. }\end{array}$ \\
\hline Practice & $\begin{array}{l}\text { The system for the protection of deposits, claims on securities forms and beneficiaries of } \\
\text { cautions is well explained and disclosed in the relevant laws and regulations and on the FGD's } \\
\text { website. Changes in these laws and regulations are subject to the same information and } \\
\text { consultation procedures as other laws and regulations (see also 6.4). }\end{array}$ \\
\hline Assessment & Observed. \\
\hline 6.3 & $\begin{array}{l}\text { Financial agencies should issue periodic public reports on how their overall policy } \\
\text { objectives are being pursued. }\end{array}$ \\
\hline Practice & $\begin{array}{l}\text { The FGD does not publicly disclose its financial statements, nor does it prepare or disclose } \\
\text { other reports on its policies and activities. In case the FGD is activated, the interested parties, } \\
\text { i.e., claim holders and institutions, would be informed as outlined in the relevant regulations. In }\end{array}$ \\
\hline
\end{tabular}




\begin{tabular}{|c|c|}
\hline & $\begin{array}{l}\text { case of activation of the FGD and/or its interventions at the request of the } \mathrm{CB} \text {, it is to be } \\
\text { assumed that the } \mathrm{CB} \text { would mention this in its report. }\end{array}$ \\
\hline Assessment & Not observed. \\
\hline Comment & $\begin{array}{l}\text { For an "observed" rating, the FGD needs to issue a periodic public report that provides an } \\
\text { update on how its policy objectives are being pursued. }\end{array}$ \\
\hline 6.4 & $\begin{array}{l}\text { For proposed substantive technical changes to the structure of financial regulations, there } \\
\text { should be a presumption in favor of public consultations, within an appropriate period. }\end{array}$ \\
\hline Practice & $\begin{array}{l}\text { Involved parties, i.e., the members of the CECEI, are consulted before each change to the } \\
\text { regulations regarding the FGD. COMOFI Art. L.614-1 has created a new consultative body, the } \\
\text { CCLRF, which will henceforth be consulted on any change in the regulations with regard to the } \\
\text { FGD. Representatives of financial firms and depositors will be part of the membership of the } \\
\text { CCLRF. }\end{array}$ \\
\hline Assessment & Observed. \\
\hline & VII. Public Availability of Information on Financial Policies \\
\hline 7.1 & $\begin{array}{l}\text { Financial agencies should issue a periodic public report on the major developments of the } \\
\text { sector(s) of the financial system for which they carry designated responsibility. }\end{array}$ \\
\hline Practice & \\
\hline Assessment & Not applicable. \\
\hline Comments & $\begin{array}{l}\text { The distribution of tasks and responsibilities between the FGD, the CB and the CECEI is such } \\
\text { that the mandate of the FGD does not include following developments in the sectors relevant to } \\
\text { its activities. The BdF, CB and the CECEI, however, follow the developments in the banking } \\
\text { sector in detail and publish periodic reports and bulletins on these developments. }\end{array}$ \\
\hline 7.2 & $\begin{array}{l}\text { Financial agencies should seek to ensure that, consistent with confidentiality } \\
\text { requirements, there is public reporting of aggregate data related to their jurisdictional } \\
\text { responsibilities on a timely and regular basis. }\end{array}$ \\
\hline Practice & $\begin{array}{l}\text { The FGD does not disclose aggregate data on areas related to its jurisdictional responsibilities. } \\
\text { In particular, it does not publicly disclose data on its financial operations, i.e., collected } \\
\text { contributions, investments and other forms of finance, nor on pay-outs. } \\
\text { The BdF, CB and the CECEI publish aggregate data on the banking sector. }\end{array}$ \\
\hline Assessment & Partly observed. \\
\hline Comment & For an observed rating, the FGD should periodically publish aggregate data on its operations. \\
\hline 7.3 & $\begin{array}{l}\text { Where applicable, financial agencies should publicly disclose their balance sheets on a } \\
\text { pre-announced schedule and, after a predetermined interval, publicly disclose information } \\
\text { on aggregate market transactions. }\end{array}$ \\
\hline Practice & The FGD prepares audited annual financial statements, which are presented to the MoE. Public \\
\hline
\end{tabular}




\begin{tabular}{|c|c|}
\hline & $\begin{array}{l}\text { disclosure does not take place. There is an internal reporting system on its investments and } \\
\text { market transactions, but no public disclosure takes place. }\end{array}$ \\
\hline Assessment & Not observed. \\
\hline Comment & $\begin{array}{l}\text { For an "observed" rating, the FGD would need to publicly disclose its balance sheet on a pre- } \\
\text { announced schedule, and report on its aggregate market transactions. }\end{array}$ \\
\hline 7.3 .1 & $\begin{array}{l}\text { Consistent with confidentiality and privacy of information on individual firms, aggregate } \\
\text { information on emergency financial support by financial agencies should be publicly } \\
\text { disclosed through an appropriate statement when such disclosure will not be disruptive to } \\
\text { financial stability. }\end{array}$ \\
\hline Practice & There is no established practice of disclosure of this type of information by the FGD. \\
\hline Assessment & Not observed. \\
\hline Comments & $\begin{array}{l}\text { For an "observed" rating, aggregate information on any emergency financial support by the } \\
\text { FGD to a credit institution should be publicly disclosed through an appropriate statement, after } \\
\text { a sufficient delay to ensure that this disclosure will not be disruptive to financial markets. }\end{array}$ \\
\hline 7.4 & Financial agencies should establish and maintain public information services. \\
\hline Practice & $\begin{array}{l}\text { The FGD has built a website on the structure and functioning of the FGD, easily accessed by } \\
\text { consumers: www.garantiedesdepots.fr. The website provides information on the functioning } \\
\text { and coverage of the different guarantee mechanisms, institutional information on the FGD, } \\
\text { updates on recent developments (e.g., the election of the president and vice-president of the } \\
\text { supervisory council), and lists the applicable laws and regulations. } \\
\text { No other public information services or publications program exists. }\end{array}$ \\
\hline Assessment & Partly observed. \\
\hline Comments & $\begin{array}{l}\text { For an observed rating, the FGD should establish a publications program and a more proactive } \\
\text { policy for public communication by its senior officials. }\end{array}$ \\
\hline 7.4 .1 & $\begin{array}{l}\text { Financial agencies should have a publications program, including a periodic public report } \\
\text { on their principal activities issued at least annually. }\end{array}$ \\
\hline Practice & The FGD has no publications program, other than the periodic update of the website. \\
\hline Assessment & Partly observed. \\
\hline Comments & $\begin{array}{l}\text { For an "observed" rating, the FGD should establish a publications program that, as a minimum, } \\
\text { includes a periodic report on its principal activities that is issued at least once a year. }\end{array}$ \\
\hline 7.4 .2 & $\begin{array}{l}\text { Senior financial agency officials should be ready to explain their institution's objective(s) } \\
\text { and performance to the public, and have a presumption in favor of releasing the text of } \\
\text { their statements to the public. }\end{array}$ \\
\hline Practice & $\begin{array}{l}\text { Senior officials of the FGD have the authority to explain their policies, objectives and } \\
\text { performance to the public. This has not occurred in practice, however, other than through the }\end{array}$ \\
\hline
\end{tabular}




\begin{tabular}{|c|c|}
\hline & $\begin{array}{l}\text { website, because no perceived need for doing so has arisen. There have been no public } \\
\text { statements of high FGD officials and publication has therefore not been an issue. }\end{array}$ \\
\hline Assessment & Partly observed. \\
\hline Comments & $\begin{array}{l}\text { A more proactive approach to informing the public, a formal policy on public communications } \\
\text { by senior FGD officials and on the release of the texts of public statements, as well as a track } \\
\text { record in this area would contribute to an "observed" rating. }\end{array}$ \\
\hline 7.5 & $\begin{array}{l}\text { Texts of regulations and any other generally applicable directives and guidelines issued by } \\
\text { financial agencies should be readily available to the public. }\end{array}$ \\
\hline Practice & $\begin{array}{l}\text { All legal provisions, regulations and instructions relative to the functioning of the FGD are } \\
\text { readily available to the public, through publication in the Recueil de Textes Réglementaires of } \\
\text { the CRBF, the JORF, the websites of the FGD and the BdF (www.banque-france.fr), and a } \\
\text { general public website that offers easy access to all French laws, decrees and regulations ( } \\
\text { www.legifrance.gouv.fr ). }\end{array}$ \\
\hline Assessment & Observed. \\
\hline 7.6 & $\begin{array}{l}\text { Where there are deposit insurance guarantees, policy-holder guarantees, and any other } \\
\text { client asset protection schemes, information on the nature and form of such protections, } \\
\text { on the operating procedures, on how the guarantee is financed, and on the performance of } \\
\text { the arrangement, should be publicly disclosed. }\end{array}$ \\
\hline Practice & $\begin{array}{l}\text { The website and the publications mentioned under } 7.5 \text {, which are readily accessible to the } \\
\text { public, provide all the necessary information. The law and the various regulations state that } \\
\text { insured deposits will be paid out promptly, two months after a request by the CB. Depositors } \\
\text { are notified by mail. The ceiling of coverage is set at EUR 70,000 per depositor. The funding } \\
\text { mechanisms are disclosed in the COMOFI, Art. L.312-7, and in Regulations } 99-06 \text { and 99-07 } \\
\text { (for depositors), 99-15 and 99-17 (for securities) and 99-12 (cautions). If necessary, } \\
\text { contributors to the FGD have to provide additional funds to meet all of the FGD's obligations. }\end{array}$ \\
\hline Assessment & Observed. \\
\hline 7.7 & $\begin{array}{l}\text { Where financial agencies oversee consumer protection arrangements (such as dispute } \\
\text { settlement processes), information on such arrangements should be publicly disclosed. }\end{array}$ \\
\hline \multicolumn{2}{|l|}{ Practice } \\
\hline Assessment & Not applicable. \\
\hline Comments & The FGD does not oversee any consumer protection arrangements. \\
\hline \multicolumn{2}{|r|}{ VIII. ACCOUnTABILITY AND ASSURANCES OF INTEGRITY BY FinANCIAL AGENCIES } \\
\hline 8.1 & $\begin{array}{l}\text { Officials of financial agencies should be available to appear before a designated public } \\
\text { authority to report on the conduct of financial policies, explain the policy objective(s) of } \\
\text { their institution, describe their performance in pursuing their objective(s), and, as } \\
\text { appropriate, exchange views on the state of the financial system. }\end{array}$ \\
\hline
\end{tabular}




\begin{tabular}{|c|c|}
\hline Practice & $\begin{array}{l}\text { Art. L.312-10 of the COMOFI states that the Conseil de Surveillance oversees the management } \\
\text { of the FGD, and that an annual financial report is issued to the MoE. Although no specific rule } \\
\text { provides for appearance of FGD officials before designated authorities to publicly report on the } \\
\text { FGD's activities, objectives and performance, and to exchange views on the state of the } \\
\text { financial system, there are no rules that prohibit this. Thus far, no occasions have arisen that } \\
\text { created a perceived need for doing so, primarily because the FGD has little room for discretion } \\
\text { in its objectives and policies, in view of its very limited mandate, except for instance when it is } \\
\text { asked by the CB to intervene in a bank. } \\
\text { Decisions of the FGD can be challenged before an administrative judicial authority. } \\
\text { The BdF, CB and the CECEI disclose information on the state of the financial system and are } \\
\text { available for debate on these issues. }\end{array}$ \\
\hline Assessment & Partly observed. \\
\hline Comments & $\begin{array}{l}\text { For an "observed" rating, a stated policy and/or track record regarding the appearance of FGD } \\
\text { officials before a designated public authority, presumably parliament or a parliamentary } \\
\text { commission, is needed. Such an arrangement would be especially relevant in case of an } \\
\text { intervention by the FGD or in case of differences of opinion between the FGD and the CB on } \\
\text { (the need for) an intervention. }\end{array}$ \\
\hline 8.2 & $\begin{array}{l}\text { Where applicable, financial agencies should publicly disclose audited financial statements } \\
\text { of their operations on a pre-announced schedule. }\end{array}$ \\
\hline Practice & $\begin{array}{l}\text { COMOFI Art. L. } 312-10 \text { states that the FGD prepares an audited annual financial report, which } \\
\text { is sent to the MoE. Furthermore, based on COMOFI Art. L.312-10 the FGD is subject to } \\
\text { controls by the Inspection Générale des Finances (General Inspection of Finances). The FGD } \\
\text { has not yet published audited statements. }\end{array}$ \\
\hline Assessment & Not observed. \\
\hline Comments & $\begin{array}{l}\text { For an "observed" rating, the FGD's audited accounts should be publicly disclosed on a pre- } \\
\text { announced schedule. }\end{array}$ \\
\hline 8.2.1 & $\begin{array}{l}\text { Financial statements, if any, should be audited by an independent auditor. Information on } \\
\text { accounting policies and any qualification to the statements should be an integral part of } \\
\text { the publicly disclosed financial statements. }\end{array}$ \\
\hline Practice & $\begin{array}{l}\text { The FGD's annual financial statements must be audited by virtue of the FGD's status as a } \\
\text { commercial firm. The auditor is appointed by the Conseil de Surveillance. The report is not } \\
\text { published but transmitted to the MoE. Based on the regular rules on the annual accounts of legal } \\
\text { entities, the information on accounting policies and any qualifications on the accounts would be } \\
\text { disclosed in the annual financial statement if the latter were published. }\end{array}$ \\
\hline Assessment & Observed. \\
\hline 8.2.2 & $\begin{array}{l}\text { Internal governance procedures necessary to ensure the integrity of operations, including } \\
\text { internal audit arrangements, should be publicly disclosed. }\end{array}$ \\
\hline Practice & $\begin{array}{l}\text { COMOFI Art. L. } 312-10 \text { determines that the Conseil de Surveillance exercises oversight over } \\
\text { the FGD's management, and sets the internal rules of the FGD, after agreement of the MoE. }\end{array}$ \\
\hline
\end{tabular}




\begin{tabular}{|c|c|}
\hline & These internal rules are published on the FGD's website. \\
\hline Assessment & Observed. \\
\hline 8.3 & $\begin{array}{l}\text { Where applicable, information on the operating expenses and revenues of financial } \\
\text { agencies should be publicly disclosed annually. }\end{array}$ \\
\hline Practice & The financial report of the FGD is not publicly disclosed. \\
\hline Assessment & Not observed. \\
\hline Comments & $\begin{array}{l}\text { For an "observed" rating, the FGD's financial statements should be published annually, and } \\
\text { should include the FGD's operating expenses and revenues. }\end{array}$ \\
\hline 8.4 & $\begin{array}{l}\text { Standards for the conduct of personal financial affairs of officials and staff of financial } \\
\text { agencies and rules to prevent exploitation of conflicts of interest, including any general } \\
\text { fiduciary obligation, should be publicly disclosed. }\end{array}$ \\
\hline Practice & $\begin{array}{l}\text { There are no specific rules of conduct on separation of private financial matters from those of } \\
\text { the FGD, nor on avoidance of conflict of interest, abuse of insider information and similar rules. } \\
\text { Officials of the FGD Conseil de Surveillance, management and staff are bound to professional } \\
\text { secrecy rules. Breach of the secrecy rules is a criminal offense. Furthermore, based on } \\
\text { COMOFI Art. L.312-19, members of the directorate and of the supervisory board must be fit } \\
\text { and proper as defined in the regulations for bank licensing. Members of the directorate cannot } \\
\text { receive funds from any contributor to the Fund. All these rules are publicly disclosed. }\end{array}$ \\
\hline Assessment & Observed. \\
\hline 8.4 .1 & $\begin{array}{l}\text { Information about legal protections for officials and staff of financial agencies in the } \\
\text { conduct of their official duties should be publicly disclosed. }\end{array}$ \\
\hline Practice & $\begin{array}{l}\text { There is no specific legal protection for officials of the FGD personally. However, under French } \\
\text { administrative law, suits must be brought against the legal entity, not against individual } \\
\text { managers or officials. Standard jurisprudence on the liability of public bodies and their officials } \\
\text { is routinely published in legal journals. Nevertheless, the applicability of this administrative } \\
\text { legislation and jurisprudence to the officials of the FGD is not disclosed in a readily accessible } \\
\text { way. }\end{array}$ \\
\hline Assessment & Partly observed. \\
\hline Comment & $\begin{array}{l}\text { For an "observed" rating, the existing legal arrangements governing the protection of officials } \\
\text { and staff of the FGD need to be clarified and publicly disclosed. }\end{array}$ \\
\hline
\end{tabular}


Table 34. Summary Observance of IMF’s MFP Transparency Code-Deposit Insurance Supervision

\begin{tabular}{|l|c|l|}
\hline \multirow{2}{*}{ Assessment Grade } & \multicolumn{2}{|c|}{ Principles Grouped by Assessment Grade } \\
\cline { 2 - 3 } & Count & \multicolumn{1}{c|}{ List } \\
\hline Observed & 14 & $\begin{array}{l}5.1,5.1 .1,5.1 .2,5.1 .3,5.1 .4,5.2,6.1 .4,6.2,6.4, \\
7.5,7.6,8.2 .1,8.2 .2,8.4 .\end{array}$ \\
\hline Broadly observed & 1 & 6.1 .5$. \\
\hline Partly observed & 7 & $6.1 .1,7.2,7.4,7.4 .1,7.4 .2,8.1,8.4 .1$. \\
\hline Not observed & 6 & $6.1,6.3,7.3,7.3 .1,8.2,8.3$. \\
\hline Not applicable & 8 & $5.3,5.3 .1,5.4,5.5,6.1 .2,6.1 .3,7.1,7.7$. \\
\hline
\end{tabular}

\section{Recommended action plan and authorities' response to the assessment}

\section{Recommended action plan}

Table 35. Recommended Action Plan to Improve Observance of IMF's MFP Transparency Code Practices-Deposit Insurance Supervision

\begin{tabular}{|l|l|}
\hline Reference Principle & \multicolumn{1}{c|}{ Recommended Action } \\
\hline VI. Open Process for Formulating and Reporting of Financial Policies \\
\hline 6.1 .1 & $\begin{array}{l}\text { Increase transparency on the fact that deposits in branches and subsidiaries of foreign } \\
\text { banks in France may not have the same level of coverage as domestic institutions. }\end{array}$ \\
\hline 6.1 .5 & $\begin{array}{l}\text { Disclose the formal procedures for information sharing between the FGD and } \\
\text { domestic and international financial agencies in greater detail. }\end{array}$ \\
\hline 6.3 & $\begin{array}{l}\text { The FGD should issue a periodic public report that provides an update on how its } \\
\text { policy objectives are being pursued. }\end{array}$ \\
\hline VII. Public Availability of Information on Financial Policies \\
\hline 7.2 & Periodically publish aggregate data on the FGD's operations. \\
\hline 7.3 and 7.3.1 & $\begin{array}{l}\text { Publicly disclose the FGD's balance sheet on a pre-announced schedule, as well as a } \\
\text { report on its market operations and, after an appropriate delay, aggregate information } \\
\text { on any emergency financial support by the FGD to financial institutions. }\end{array}$ \\
\hline $7.4,7.4 .1$ and 7.4.2 & $\begin{array}{l}\text { The FGD should establish a publications program and a more proactive policy for } \\
\text { public communication by its senior officials. }\end{array}$ \\
\hline VIII. Accountability and Assurance of Integrity by Financial Agencies \\
\hline
\end{tabular}




\begin{tabular}{|l|l|}
\hline Reference Principle & \multicolumn{1}{c|}{ Recommended Action } \\
\hline 8.1 & $\begin{array}{l}\text { Establish a policy or practice on the appearance of FGD officials before a designated } \\
\text { public authority to report on the conduct of the FGD's policies, explain its policy } \\
\text { objectives and describe its performance. }\end{array}$ \\
\hline 8.2 and 8.3 & $\begin{array}{l}\text { Publicly disclose the FGD's audited accounts, including its operating expenses and } \\
\text { revenues, on a pre-announced schedule and at least annually. }\end{array}$ \\
\hline 8.4 .1 & $\begin{array}{l}\text { Clarify and publicly disclose the existing legal arrangements governing the protection } \\
\text { of officials and staff of the FGD. }\end{array}$ \\
\hline
\end{tabular}

\section{Authorities' response to the assessment}

131. The authorities are broadly in agreement with the assessment.

\section{Transparency of Insurance Supervision}

132. Insurance regulation and supervision in France was significantly reformed by the August 2003 Financial Security Law (Loi de sécurité financière-LSF). Formerly, insurance supervision was divided between two agencies - the CCAMIP for insurers governed by the Code des Assurances (Insurance Code), and the Commission de Contrôle des Mutuelles et des Institutions de Prévoyance (CCMIP) for mutual and provident insurers, dependent respectively from the Ministry of Finance and the Ministry of Social Affairs. The LSF merged those two agencies into a single autonomous insurance supervisor, the CCAMIP. Insurance regulation remains the responsibility of the Ministry of Finance.

133. Insurance regulation and supervision in France is governed by the Insurance Code, the Mutuality Code (Code de la Mutualité) and the Social Security Code (Code de la Sécurité Sociale), as amended by the Financial Security Law, and by accompanying regulations. These three codes contain the same provisions on prudential matters, applied to different types of institutions. 


\section{Practice-by-practice assessment}

\section{Table 36. Detailed Assessment of Observance of IMF's MFP Transparency Code-Insurance Supervision}

\begin{tabular}{|c|c|}
\hline \multicolumn{2}{|c|}{$\begin{array}{l}\text { V. CLARITy OF Roles, ResPonsibilities AND OBJECTIVES OF FinANCIAL AgENCIES ReSPONSIBLE FOR } \\
\text { FINANCIAL POLICIES }\end{array}$} \\
\hline 5.1 & $\begin{array}{l}\text { The broad objective(s) and institutional framework of financial agencies should be clearly } \\
\text { defined, preferably in relevant legislation or regulation. }\end{array}$ \\
\hline Description & $\begin{array}{l}\text { The broad objectives and institutional framework of the insurance supervisory agency are set in a } \\
\text { specific code, le Code des Assurances. Book III of this code, in Titre I-Dispositions générales et } \\
\text { contrôle de l'Etat (Section II) sets out the activities of the Commission de Contrôle des } \\
\text { Assurances, des mutuelles et des institutions de prévoyance (CCAMIP), the independent public } \\
\text { authority (autorité publique indépendante) responsible for supervision of insurance firms } \\
\text { authorized and regulated in France and their compliance with legislation and regulations } \\
\text { Public access to legislation, regulations and arrests (arrêtés) is provided through a variety of } \\
\text { means, including written publications, such as the JORF, and public websites (in particular, } \\
\text { www.legifrance.gouv.fr). }\end{array}$ \\
\hline Assessment & Observed. \\
\hline 5.1.1 & The broad objective(s) of financial agencies should be publicly disclosed and explained. \\
\hline Description & $\begin{array}{l}\text { The broad objectives of the supervisory authority are (i) the protection of policy holders (each } \\
\text { insurance contract clearly displays the address of the information cell, inviting each policy } \\
\text { holder to contact it for any information or assistance need); and (ii) the enforcement of relevant } \\
\text { laws and regulations. These objectives are set out in the Code des Assurances. A simple } \\
\text { presentation is available on the websites of the CCAMIP, the MINEFI at } \\
\text { www.minefi.gouv.fr/minefi/ministere/dossiers/index.htm and several other administrations. }\end{array}$ \\
\hline Assessment & Observed. \\
\hline 5.1 .2 & $\begin{array}{l}\text { The responsibilities of the financial agencies and the authority to conduct financial policies } \\
\text { should be publicly disclosed. }\end{array}$ \\
\hline Description & $\begin{array}{l}\text { The responsibilities of the supervisory authority are set out in Art. L.310-12 of the Code des } \\
\text { Assurances, and its enforcement powers are set out in Articles L.310-12 through L.310-25, and } \\
\text { in Articles L.321-1 of this Code. } \\
\text { The CCAMIP is not in charge of producing regulation. This competence falls within the scope of } \\
\text { the MoE. } \\
\text { The MINEFI prepares draft legislation in close and informal cooperation with the CCAMIP } \\
\text { staff. } \\
\text { The drafts are examined by an integrated consultative body at the MINEFI, the CCLRF. The } \\
\text { same role, be it limited to the insurance sector, was fulfilled until recently by the Commission de } \\
\text { la Réglementation des Assurances (CRA). } \\
\text { The CCLRF issues an opinion on any draft legislation relating to financial matters including } \\
\text { insurance. For that purpose, it brings together finance professionals, consumers, and }\end{array}$ \\
\hline
\end{tabular}




\begin{tabular}{|c|c|}
\hline & $\begin{array}{l}\text { representatives of the employees from the various sectors. The terms and conditions for } \\
\text { appointing the committee's members and chairman and the rules for its organization and } \\
\text { operations are established by decree. } \\
\text { As compared to the CRA, the CCLRF has a wider field of jurisdiction in two respects: } \\
\quad \text { - it is competent for banking as well as insurance; and } \\
\text { - it reviews decrees and issue opinions regarding all regulations, draft legislation and EU } \\
\text { legislation. } \\
\text { The new committee has enhanced powers to make recommendations with respect to draft orders } \\
\text { and decrees. In these fields, the Minister has the option of requesting another deliberation if he of } \\
\text { she does not wish to follow the first one the CCLRF expressed. }\end{array}$ \\
\hline Assessment & Observed. \\
\hline 5.1 .3 & $\begin{array}{l}\text { Where applicable, the broad modalities of accountability for financial agencies should be } \\
\text { publicly disclosed. }\end{array}$ \\
\hline Description & $\begin{array}{l}\text { The broad modalities of accountability for the CCAMIP are set out in the legislative and } \\
\text { regulatory parts of the Code des Assurances. Art. L.310-12-1 of that code provides a form of } \\
\text { accountability through the presence of a nonvoting representative of the Treasury in the } \\
\text { CCAMIP. This representative can request, under certain conditions and except in matters of } \\
\text { sanctions, that the CCAMIP reconsider a decision (once). Art. L.310-12-1 also empowers the } \\
\text { CCAMIP's president to act in its name before any court, while Articles L.310-18 and L.310-18-1 } \\
\text { provide the possibility for sanctions imposed by the CCAMIP to be appealed before the Conseil } \\
\text { 'Etat. Art. R.310-12 establishes the obligation and modalities for the CCAMIP to establish a } \\
\text { budget, maintain financial accounts, and report on its finances to the Cour des comptes and to the } \\
\text { responsible ministries. French general administrative law also stipulates that any civil servant } \\
\text { can be called to appear before parliament or a parliamentary commission, and this rule applies } \\
\text { also to the board members and staff of the CCAMIP. Although not required to do so by law, the } \\
\text { CCAMIP publishes an annual report, which discloses nonconfidential material. The practice of } \\
\text { publishing an annual report is publicly disclosed on the CCAMIP's website. }\end{array}$ \\
\hline Assessment & U \\
\hline
\end{tabular}




\begin{tabular}{|c|c|}
\hline 5.1 .4 & $\begin{array}{l}\text { Where applicable, the procedures for appointment, terms of office, and any general } \\
\text { criteria for removal of the heads and members of the governing bodies of financial agencies } \\
\text { should be publicly disclosed. }\end{array}$ \\
\hline Description & $\begin{array}{l}\text { Art. L.310-12-1 of the Code des Assurances sets the procedures for appointment of the nine } \\
\text { members of the CCAMIP-the Treasury and the social security directorate, both sitting on the } \\
\text { board of the Commission as representatives of the government without right to vote: } \\
\text { - the Commission's chairperson, appointed by a decree of the President of the Republic, } \\
\text { - the Governor of the BdF, chairman of the Banking Commission, } \\
\text { - three members of supreme jurisdictions (the Conseil d'Etat, the Cour de Cassation, and the } \\
\text { Cour des Comptes), appointed by those jurisdictions, } \\
\text { - four persons selected on the basis of their particular expertise in matters relating to } \\
\text { insurance, mutual world, and provident institutions are appointed by both the ministers of } \\
\text { Finance and social affairs. } \\
\text { The chairman, the three members of the supreme jurisdictions and the persons with particular } \\
\text { experience are appointed for five years. The appointment of the governor of the BdF, his term of } \\
\text { office and the criteria for his removal are governed by the section on the BdF of the COMOFI. } \\
\text { Members (and their alternates) cannot be revoked, unless they are convicted of penal offences, as } \\
\text { specified in the penal provisions applicable to holders of public office. Public disclosure of } \\
\text { appointment procedures and terms of office proceeds through official publications (see } 5.1 \text { and } \\
\text { 5.1.1, above). }\end{array}$ \\
\hline Assessment & Observed. \\
\hline 5.2 & The relationship between financial agencies should be publicly disclosed. \\
\hline Description & $\begin{array}{l}\text { The relationships between the CCAMIP and other financial agencies are publicly disclosed in } \\
\text { relevant laws, the CCAMIP's annual report, and other official publications and websites. } \\
\text { Articles L.310-20, L.310-20-1, and L.310-21 of the Code des Assurances allow information } \\
\text { sharing between the CCAMIP and respectively other domestic supervisors, the National } \\
\text { Statistics Institute, and foreign financial agencies, subject to applicable confidentiality protocols. } \\
\text { Art. } 60 \text { of the Savings and Financial Security Act of June, } 251999 \text { establishes a committee } \\
\text { comprising the Chairpersons of the CCAMIP, the CB (i.e., governor of the BdF), the AMF, } \\
\text { together with a representative of the MINEFI to facilitate exchange of information and to address } \\
\text { topics of interest among all three sectors. Art. } 45 \text { of Act no. 92-665, "loi portant adaptation au } \\
\text { marché unique européen de la législation applicable en matière d'assurance et de crédit," } \\
\text { allows the CCAMIP, the CECEI, BdF, CB, and the AMF to share information when it is helpful } \\
\text { for achievement of their respective objectives. Until now, the supervisors have generally met } \\
\text { monthly on an informal basis. } \\
\text { The CCAMIP's 2000-01 report discussed its relationship with the CB (p. 54) and with foreign } \\
\text { counterparts (p. 59-67). The relationship between the CCAMIP and the CB is also discussed in } \\
\text { detail on the former website (www.cca.gouv.fr). }\end{array}$ \\
\hline Assessment & Observed. \\
\hline 5.3 & The role of oversight agencies with regard to payment systems should be publicly disclosed. \\
\hline Description & \\
\hline Assessment & Not applicable. \\
\hline
\end{tabular}




\begin{tabular}{|c|c|}
\hline Comments & The CCAMIP has no responsibility for payment systems oversight. \\
\hline 5.3 .1 & $\begin{array}{l}\text { The agencies overseeing the payment system should promote the timely public disclosure of } \\
\text { general policy principles (including risk management policies) that affect the robustness of } \\
\text { systemically important payment systems. }\end{array}$ \\
\hline \multicolumn{2}{|l|}{ Description } \\
\hline Assessment & Not applicable. \\
\hline Comments & The CCAMIP has no responsibility for payment systems oversight. \\
\hline 5.4 & $\begin{array}{l}\text { Where financial agencies have oversight responsibilities for self-regulatory organizations } \\
\text { (e.g., payment systems), the relationship between them should be publicly disclosed. }\end{array}$ \\
\hline \multicolumn{2}{|l|}{ Description } \\
\hline Assessment & Not applicable. \\
\hline Comments & There are no self-regulatory organizations in the French insurance market. \\
\hline 5.5 & $\begin{array}{l}\text { Where self-regulatory organizations are authorized to perform part of the regulatory and } \\
\text { supervisory process, they should be guided by the same good transparency practices } \\
\text { specified for financial agencies. }\end{array}$ \\
\hline \multicolumn{2}{|l|}{ Description } \\
\hline Assessment & Not applicable. \\
\hline Comments & There are no self-regulatory organizations in the French insurance market. \\
\hline \multicolumn{2}{|r|}{ VI. OPEn Process fOR Formulating ANd RePORTING OF FinANCIAL Policies } \\
\hline 6.1 & $\begin{array}{l}\text { The conduct of policies by financial agencies should be transparent, compatible with } \\
\text { confidentiality considerations and the need to preserve the effectiveness of actions by } \\
\text { regulatory and oversight agencies. }\end{array}$ \\
\hline Description & $\begin{array}{l}\text { The supervisory procedures of the CCAMIP are transparent. The agency publishes an annual } \\
\text { report informing the public about the French insurance market, supervision of the insurance } \\
\text { companies (important decisions, new laws and regulations, cooperation with other agencies at } \\
\text { home and abroad, involvement in the international standard setting, discussions with the } \\
\text { consumer protection associations, etc.). The CCAMIP also issues reports and publishes (mostly) } \\
\text { aggregated economic figures of the French insurance market (Tableaux de synthèse). Board } \\
\text { members and staff of the CCAMIP are subject to strict confidentiality obligations on- and off } \\
\text { duty. }\end{array}$ \\
\hline Assessment & Observed. \\
\hline
\end{tabular}




\begin{tabular}{|c|c|}
\hline 6.1.1 & $\begin{array}{l}\text { The regulatory framework and operating procedures governing the conduct of financial } \\
\text { policies should be publicly disclosed and explained. }\end{array}$ \\
\hline Description & $\begin{array}{l}\text { The regulatory framework and operating procedures governing the conduct of insurance } \\
\text { supervision are set out in the legislation and regulations, see Code des Assurances (Partie } \\
\text { Législative) and its regulations (Partie réglementaire - Décrets en Conseil d'Etat and Partie } \\
\text { Arrêtés) and disclosed/explained through official publications (see } 5.1 \text { and 5.1.1, above). The } \\
\text { framework and procedures are addressed in the CCAMIP's annual report (see 6.1, above). }\end{array}$ \\
\hline Assessment & Observed. \\
\hline 6.1.2 & $\begin{array}{l}\text { The regulations for financial reporting by financial institutions to financial agencies should } \\
\text { be publicly disclosed. }\end{array}$ \\
\hline Description & $\begin{array}{l}\text { The Code des Assurances authorizes the CCAMIP (and the MoE) to impose reporting } \\
\text { requirements on insurance companies (e.g. Articles L.310-14, L.322-2-4 and L.341 and } \\
\text { subsequent). The reporting requirements are further specified in detail in regulations and arrests } \\
\text { (e.g., Art. R } 341-1 \text { and A.341-1 Code des Assurances), all of which are publicly disclosed (see } \\
\text { 5.1). }\end{array}$ \\
\hline Assessment & Observed. \\
\hline 6.1.3 & $\begin{array}{l}\text { The regulations for the operation of organized financial markets (including those for } \\
\text { issuers of traded financial instruments) should be publicly disclosed. }\end{array}$ \\
\hline \multicolumn{2}{|l|}{ Description } \\
\hline Assessment & Not applicable. \\
\hline Comments & The CCAMIP has no responsibility for the oversight of organized financial markets. \\
\hline 6.1.4 & $\begin{array}{l}\text { Where financial agencies charge fees to financial institutions, the structure of such fees } \\
\text { should be publicly disclosed. }\end{array}$ \\
\hline Description & $\begin{array}{l}\text { The CCAMIP is financed through a specific contribution it levies. The contribution regime is } \\
\text { detailed in Art. L. } 310-12-4 \text { of the Code des Assurances. }\end{array}$ \\
\hline Assessment & Observed. \\
\hline 6.1.5 & $\begin{array}{l}\text { Where applicable, formal procedures for information sharing and consultation between } \\
\text { financial agencies (including central banks), domestic and international should be publicly } \\
\text { disclosed. }\end{array}$ \\
\hline Description & $\begin{array}{l}\text { As discussed under 5.2, the law permits the CCAMIP to share information and consult with } \\
\text { various domestic and foreign counterparts, subject to respect of confidentiality requirements. } \\
\text { Information on the formal procedures through which some of these exchanges take place is } \\
\text { publicly available on the CCAMIP's website. For example, the agreement between the CCA and } \\
\text { the CB is available under } \\
\text { www.ccamip.fr/info/Charte entre_la_CCA_et_la_Commission_Bancaire/040202. } \\
\text { However, while summary information is available on the website regarding the international }\end{array}$ \\
\hline
\end{tabular}




\begin{tabular}{|c|c|}
\hline & cooperation of the CCAMIP, no detailed information on the formal procedures is published. \\
\hline Assessment & Partly observed. \\
\hline 6.2 & $\begin{array}{l}\text { Significant changes in financial policies should be publicly announced and explained in a } \\
\text { timely manner. }\end{array}$ \\
\hline Description & $\begin{array}{l}\text { The MINEFI and the CCAMIP publicly announce and explain significant changes in regulations } \\
\text { and supervisory policies in the annual report, on the authorities' website(s) and through circulars } \\
\text { to the supervised companies. These circulars are also published on the website and mentioned in } \\
\text { the annual report. }\end{array}$ \\
\hline Assessment & Observed. \\
\hline 6.3 & $\begin{array}{l}\text { Financial agencies should issue periodic public reports on how their overall policy } \\
\text { objectives are being pursued. }\end{array}$ \\
\hline Description & $\begin{array}{l}\text { The CCAMIP issues an annual report, which sets out how its overall policy objectives are being } \\
\text { pursued (see also 6.1). }\end{array}$ \\
\hline Assessment & Broadly observed. \\
\hline Comments & The annual report should be published every year, on schedule. \\
\hline 6.4 & $\begin{array}{l}\text { For proposed substantive technical changes to the structure of financial regulations, there } \\
\text { should be a presumption in favor of public consultations, within an appropriate period. }\end{array}$ \\
\hline Description & $\begin{array}{l}\text { Proposed substantive technical changes to the structure of insurance regulations are always } \\
\text { subjected to two main rounds of consultations. In a first-informal-round, the MINEFI } \\
\text { consults with professional organizations. In a second-more formal-round, consultations are } \\
\text { held through the CCLRF (see } 5.1 .2 \text {, above), which reunites all interested parties, including } \\
\text { consumer organizations as representatives of the general public. Insurance companies and other } \\
\text { relevant parties are always consulted prior to any significant change in insurance policies. }\end{array}$ \\
\hline Assessment & Observed. \\
\hline & VII. Public AVailability of Information on Financial Policies \\
\hline 7.1 & $\begin{array}{l}\text { Financial agencies should issue a periodic public report on the major developments of the } \\
\text { sector(s) of the financial system for which they carry designated responsibility. }\end{array}$ \\
\hline Description & $\begin{array}{l}\text { The CCAMIP reports major developments in the insurance business in its annual report. This } \\
\text { report is widely disseminated and publicized in the economic press. The CCAMIP also makes a } \\
\text { summary of its annual report available and posts the annual report on its website. } \\
\text { While the annual report is in principle published within six months of the end of each year, the } \\
\text { CCAMIP issued only two reports during the last four years, covering two years each ( } 2000-2001 \\
\text { and } 2002-2003) \text {. Transition problems are blamed for this, and the CCAMIP expects to be able to } \\
\text { publish its annual report annually in the future. }\end{array}$ \\
\hline Assessment & Broadly observed. \\
\hline
\end{tabular}




\begin{tabular}{|c|c|}
\hline Comments & The annual report should be published each year, on schedule. \\
\hline 7.2 & $\begin{array}{l}\text { Financial agencies should seek to ensure that, consistent with confidentiality requirements, } \\
\text { there is public reporting of aggregate data related to their jurisdictional responsibilities on } \\
\text { a timely and regular basis. }\end{array}$ \\
\hline Description & $\begin{array}{l}\text { The CCAMIP provides aggregate data from the accounts of the economically significant insurers } \\
\text { in quarterly and annual reports (see Tableau de Synthèse des entreprises d'assurance et de } \\
\text { réassurance). }\end{array}$ \\
\hline Assessment & Observed. \\
\hline 7.3 & $\begin{array}{l}\text { Where applicable, financial agencies should publicly disclose their balance sheets on a pre- } \\
\text { announced schedule and, after a predetermined interval, publicly disclose information on } \\
\text { aggregate market transactions. }\end{array}$ \\
\hline Description & $\begin{array}{l}\text { The CCAMIP is endowed with budgetary autonomy. It establishes its own budget under its sole } \\
\text { responsibility. This budget is transmitted to and reviewed by the Cour des comptes, the supreme } \\
\text { body in charge of the auditing all public accounts. In case of shortcomings in financial } \\
\text { management or noncompliance with budgetary rules, the Cour des comptes does have the } \\
\text { possibility to mention observations in its annual report. This report is public and is extensively } \\
\text { covered in the press. The new insurance law requires the CCAMIP to publish its accounts. } \\
\text { However, the decrees that specify the practical modalities, including the publication schedule (if } \\
\text { any), have not yet been issued. } \\
\text { The CCAMIP does not conduct market transactions. }\end{array}$ \\
\hline Assessment & Broadly observed. \\
\hline Comments & $\begin{array}{l}\text { For an "observed" rating, the publication of the CCAMIP's accounts will need to happen on a } \\
\text { pre-announced schedule. }\end{array}$ \\
\hline 7.3 .1 & $\begin{array}{l}\text { Consistent with confidentiality and privacy of information on individual firms, aggregate } \\
\text { information on emergency financial support by financial agencies should be publicly } \\
\text { disclosed through an appropriate statement when such disclosure will not be disruptive to } \\
\text { financial stability. }\end{array}$ \\
\hline \multicolumn{2}{|l|}{ Description } \\
\hline Assessment & Not applicable. \\
\hline Comments & The CCAMIP does not provide emergency financial support. \\
\hline 7.4 & Financial agencies should establish and maintain public information services. \\
\hline Description & $\begin{array}{l}\text { The CCAMIP has its own public information service. This service disseminates (i) policy } \\
\text { decisions and announcements; (ii) information on the operating framework, targets and } \\
\text { objectives of the CCAMIP; (iii) quantitative data; and (iv) staff public research. A web access to } \\
\text { some basic information is provided by a dedicated locus on the MINEFI site. }\end{array}$ \\
\hline Assessment & Observed. \\
\hline
\end{tabular}




\begin{tabular}{|c|c|}
\hline 7.4.1 & $\begin{array}{l}\text { Financial agencies should have a publications program, including a periodic public report } \\
\text { on their principal activities issued at least annually. }\end{array}$ \\
\hline Description & $\begin{array}{l}\text { The CCAMIP's publications program comprises: (i) the annual report; (ii) occasional research } \\
\text { publications; and (iii) statistical publications. Most of these items are available free or at nominal } \\
\text { charge. However, the annual reports are currently issued with considerable delays due to a lack } \\
\text { of staff and transition issues. Over the last four years, the CCAMIP has only issued two reports, } \\
\text { covering two years each (2000-2001 and 2002-2003). The reforms of the supervisory framework } \\
\text { that are currently being implemented are expected to allow the CCAMIP to obtain the necessary } \\
\text { financial and human resources to issue the annual report within six months of the end of each } \\
\text { year, which is its objective. }\end{array}$ \\
\hline Assessment & Broadly observed. \\
\hline Comments & $\begin{array}{l}\text { For an observed rating, the publications program, in particular the schedule for the publication of } \\
\text { the annual report, should be implemented strictly. }\end{array}$ \\
\hline 7.4.2 & $\begin{array}{l}\text { Senior financial agency officials should be ready to explain their institution's objective(s) } \\
\text { and performance to the public, and have a presumption in favor of releasing the text of } \\
\text { their statements to the public. }\end{array}$ \\
\hline Description & $\begin{array}{l}\text { Senior officials of the CCAMIP stand ready to explain the institution's objectives and } \\
\text { performance to the public, and do so through a range of channels: (i) public hearings before } \\
\text { parliamentary committees; (ii) formal or informal speeches in various public and professional } \\
\text { forums; (iii) interviews with the media; (iv) articles issued in business publications, and } \\
\text { (v) official publications like the annual report. Texts of public statements are systematically } \\
\text { released to the media. }\end{array}$ \\
\hline Assessment & Observed. \\
\hline 7.5 & $\begin{array}{l}\text { Texts of regulations and any other generally applicable directives and guidelines issued by } \\
\text { financial agencies should be readily available to the public. }\end{array}$ \\
\hline Description & $\begin{array}{l}\text { Texts of regulations and generally applicable directives and guidelines are available to the public } \\
\text { through official publications, the CCAMIP annual report and the Code des Assurances. The latter } \\
\text { is published in updated form by private sector publishers several times annually, and is easily } \\
\text { accessible in its currently applicable state through a public website (www.legifrance.gouv.fr). }\end{array}$ \\
\hline Assessment & Observed. \\
\hline 7.6 & $\begin{array}{l}\text { Where there are deposit insurance guarantees, policy-holder guarantees, and any other } \\
\text { client asset protection schemes, information on the nature and form of such protections, on } \\
\text { the operating procedures, on how the guarantee is financed, and on the performance of the } \\
\text { arrangement, should be publicly disclosed. }\end{array}$ \\
\hline Description & $\begin{array}{l}\text { Two guarantee schemes exist. The first one (Fonds de garantie des assurances obligatoires de } \\
\text { dommages-FGAO) protects policyholders and beneficiaries from the consequences of the } \\
\text { winding up of companies involved in compulsory insurance. The second one (Fonds de garantie } \\
\text { des assurés contre la défaillance des sociétés d'assurance de personnes) protects policyholders } \\
\text { and beneficiaries from the consequences of the winding up of companies involved in life, } \\
\text { provident and medical insurance. The information on these guarantee schemes is disseminated } \\
\text { through mention on contracts, by the MINEFI and/or by the CCAMIP (Bureau des relations }\end{array}$ \\
\hline
\end{tabular}




\begin{tabular}{|c|c|}
\hline & $\begin{array}{l}\text { avec le public) on request. Disclosure proceeds through official publications by the MINEFI and } \\
\text { the CCAMIP. }\end{array}$ \\
\hline Assessment & Observed. \\
\hline 7.7 & $\begin{array}{l}\text { Where financial agencies oversee consumer protection arrangements (such as dispute } \\
\text { settlement processes), information on such arrangements should be publicly disclosed. }\end{array}$ \\
\hline Description & $\begin{array}{l}\text { Each insurance contract informs the policyholder of the possibility to transmit information } \\
\text { requests or claims to the CCAMIP (Bureau des relations avec le public) (see also 5.1.1., above). } \\
\text { Further information on consumer's rights is available on the CCAMIP's website. }\end{array}$ \\
\hline Assessment & Observed. \\
\hline \multicolumn{2}{|r|}{ VIII. ACCOUNTABILITy AND ASSURANCES OF INTEGRITy by FINANCIAL AgENCIES } \\
\hline 8.1 & $\begin{array}{l}\text { Officials of financial agencies should be available to appear before a designated public } \\
\text { authority to report on the conduct of financial policies, explain the policy objective(s) of } \\
\text { their institution, describe their performance in pursuing their objective(s), and, as } \\
\text { appropriate, exchange views on the state of the financial system. }\end{array}$ \\
\hline Description & $\begin{array}{l}\text { As required under French administrative law, senior officials of the CCAMIP stand ready to } \\
\text { appear before parliament-on an "as required" basis-to: (i) report on the conduct of the } \\
\text { CCAMIP's supervisory policies; (ii) explain the CCAMIP's policy objectives; (iii) describe the } \\
\text { CCAMIP's performance in pursuing its objectives; and (iv) exchange views on the state of the } \\
\text { financial system (see also 7.4.2). }\end{array}$ \\
\hline Assessment & Observed. \\
\hline 8.2 & $\begin{array}{l}\text { Where applicable, financial agencies should publicly disclose audited financial statements } \\
\text { of their operations on a pre-announced schedule. }\end{array}$ \\
\hline Description & $\begin{array}{l}\text { Since the CCAMIP did not have financial autonomy, there is no established track record of } \\
\text { financial reporting. Nevertheless, although not required by law, the CCAMIP intends to publish } \\
\text { its accounts and is preparing to do so. The accounting and financial reporting framework for the } \\
\text { CCAMIP are specified in Art. R. 310-12 of the Code des Assurance, which came into effect in } \\
\text { July 2004. The new text specifies that the CCAMIP's financial accounts are to be established } \\
\text { according to general accounting rules, by an accounting agent who is independent from the } \\
\text { CCAMIP itself. These financial accounts are verified by the Cour des Comptes, at the latter's } \\
\text { discretion and according to the rules that are applicable to all French administrative institutions. } \\
\text { Art. R.310-12 does not prescribe a publication schedule. } \\
\text { While this arrangement will likely provide high-quality financial statements and a high degree of } \\
\text { transparency and integrity, it would still be useful to have a second independent party audit the } \\
\text { work of the accountant on a regular basis. }\end{array}$ \\
\hline Assessment & Partly observed. \\
\hline Comments & $\begin{array}{l}\text { For an "observed" rating, the newly established accounting and reporting framework will need to } \\
\text { be implemented, the CCAMIP's financial statements will need to be published on a pre- } \\
\text { announced schedule and the statements will need to be audited on a regular basis by an auditor } \\
\text { independent from the accountant. }\end{array}$ \\
\hline
\end{tabular}




\begin{tabular}{|c|c|}
\hline 8.2 .1 & $\begin{array}{l}\text { Financial statements, if any, should be audited by an independent auditor. Information on } \\
\text { accounting policies and any qualification to the statements should be an integral part of the } \\
\text { publicly disclosed financial statements. }\end{array}$ \\
\hline Description & $\begin{array}{l}\text { Art. R. 310-12 of the Code des Assurances specifies that the CCAMIP's accounts are to be } \\
\text { audited by the Cour des Comptes which is an independent government agency. Full audits will } \\
\text { happen at the discretion of the Cour des comptes, and therefore, not necessarily every year. The } \\
\text { CCAMIP intends to publish its financial statements, but the practical modalities, including the } \\
\text { contents of the disclosed statements, remain to be determined. }\end{array}$ \\
\hline Assessment & Partly observed. \\
\hline Comments & $\begin{array}{l}\text { For an "observed" rating, the financial statements to be published by the CCAMIP will have to } \\
\text { be audited on a regular basis, and will need to include information on accounting policies as well } \\
\text { as any qualification of the statements. }\end{array}$ \\
\hline 8.2.2 & $\begin{array}{l}\text { Internal governance procedures necessary to ensure the integrity of operations, including } \\
\text { internal audit arrangements, should be publicly disclosed. }\end{array}$ \\
\hline Description & There is no such disclosure. \\
\hline Assessment & Not observed. \\
\hline Comments & $\begin{array}{l}\text { For an observed rating, the CCAMIP's internal governance procedures and its internal audit } \\
\text { arrangements should be publicly disclosed. }\end{array}$ \\
\hline 8.3 & $\begin{array}{l}\text { Where applicable, information on the operating expenses and revenues of financial } \\
\text { agencies should be publicly disclosed annually. }\end{array}$ \\
\hline Description & $\begin{array}{l}\text { The CCAMIP intends to publish its operating expenses and revenues as part of its financial } \\
\text { statements. However, as for the latter, the modalities remain to be determined. }\end{array}$ \\
\hline Assessment & Partly observed. \\
\hline Comments & $\begin{array}{l}\text { Publication of the operating expenses and revenues of the CCAMIP on an annual basis, as part } \\
\text { of the financial statements, will warrant an "observed" rating. }\end{array}$ \\
\hline 8.4 & $\begin{array}{l}\text { Standards for the conduct of personal financial affairs of officials and staff of financial } \\
\text { agencies and rules to prevent exploitation of conflicts of interest, including any general } \\
\text { fiduciary obligation, should be publicly disclosed. }\end{array}$ \\
\hline Description & $\begin{array}{l}\text { The CCAMIP's staff and board members are civil servants or staff under a public law contract, } \\
\text { and hence submitted to the general rules of ethics that are part of the general status of the French } \\
\text { civil service, which is publicly available information. In addition, Art. L.310-12-1 of the Code } \\
\text { des Assurances gives the CCAMIP the task of setting specific rules of conduct for its staff. A } \\
\text { Code of Conduct (Code de Déontologie) was already prepared and informally in force for some } \\
\text { time, and was approved by the new Commission in July 2004. The Code of Conduct is publicly } \\
\text { disclosed on the CCAMIP's website. }\end{array}$ \\
\hline Assessment & Observed. \\
\hline
\end{tabular}




\begin{tabular}{|l|l|}
\hline 8.4.1 & \multicolumn{1}{l|}{$\begin{array}{l}\text { Information about legal protections for officials and staff of financial agencies in the } \\
\text { conduct of their official duties should be publicly disclosed. }\end{array}$} \\
\hline Description & $\begin{array}{l}\text { By law, the board members and staff of the CCAMIP do not incur any liability for the } \\
\text { consequences of their professional activity, with the exception of personal faulty behavior (faute } \\
\text { détachable), which is by nature separated from the performance of normal duty. The law also } \\
\text { specifies that, in criminal matters, liability is personal. }\end{array}$ \\
\hline Assessment & Observed. \\
\hline
\end{tabular}

Table 37. Summary Observance of IMF’s MFP Transparency Code-Insurance Supervision

\begin{tabular}{|l|c|l|}
\hline \multirow{2}{*}{ Assessment Grade } & \multicolumn{2}{|c|}{ Principles Grouped by Assessment Grade } \\
\cline { 2 - 3 } & Count & \multicolumn{1}{c|}{ List } \\
\hline Observed & 21 & $\begin{array}{l}5.1,5.1 .1,5.1 .2,5.1 .3,5.1 .4,5.2,6.1,6.1 .1, \\
6.1 .2,6.1 .4,6.2,6.4,7.2,7.4,7.4 .2,7.5,7.6, \\
7.7,8.1,8.4,8.4 .1 .\end{array}$ \\
\hline Broadly observed & 4 & $6.3,7.1,7.3,7.4 .1$. \\
\hline Partly observed & 4 & $6.1 .5,8.2,8.2 .1,8.3$. \\
\hline Not observed & 1 & 8.2 .2$. \\
\hline Not applicable & 6 & $5.3,5.3 .1,5.4,5.5,6.1 .3,7.3 .1$. \\
\hline
\end{tabular}

\section{Recommended action plan and authorities' response to the assessment}

\section{Recommended action plan}

Table 38. Recommended Action Plan to Improve Observance of IMF's MFP Transparency Code Practices-Insurance Supervision

\begin{tabular}{|l|l|}
\hline Reference Practice & \multicolumn{1}{c|}{ Recommended Action } \\
\hline \multicolumn{2}{|l|}{ VI. Open Process for Formulating and Reporting of Financial Policies } \\
\hline 6.3 & The annual report should be published every year, on schedule. \\
\hline VII. Public Availability of Information on Financial Policies \\
\hline 7.1 and 7.4.1 & $\begin{array}{l}\text { The publications program, in particular the schedule for the publication of the annual } \\
\text { report, should be strictly implemented. }\end{array}$ \\
\hline 7.3 & \begin{tabular}{l} 
The publication of the CCAMIP's accounts should happen on a pre-announced \\
\hline
\end{tabular}
\end{tabular}




\begin{tabular}{|c|l|}
\hline Reference Practice & \multicolumn{1}{|l|}{ Recommended Action } \\
\hline VIII. Accountability and Assurance of Integrity by Financial Agencies \\
\hline 8.2 & $\begin{array}{l}\text { Publication of the CCAMIP's financial statements will need to occur on a pre- } \\
\text { announced schedule and the statements will need to be audited on a regular basis by an } \\
\text { auditor independent from the accountant. }\end{array}$ \\
\hline 8.2 .1 & $\begin{array}{l}\text { The financial statements to be published by the CCAMIP should be audited on a regular } \\
\text { basis, and should include information on accounting policies as well as any qualification } \\
\text { of the statements. }\end{array}$ \\
\hline 8.2 .2 & $\begin{array}{l}\text { The CCAMIP's internal governance procedures and its internal audit arrangements } \\
\text { should be publicly disclosed. }\end{array}$ \\
\hline 8.3 & $\begin{array}{l}\text { The operating expenses and revenues of the CCAMIP should be published on an annual } \\
\text { basis, preferably as part of the financial statements. }\end{array}$ \\
\hline
\end{tabular}

\section{Authorities' response to the assessment}

134. The CCAMIP's report for the years 2002 and 2003 has been endorsed by the board, and is to be published.

135. 8.2.2. The respective roles of the board and the Secretary General are defined by the law (L.310-12-1). More detailed rules will be specified in the decrees establishing the CCAMIP, to be published soon.

136. The CCAMIP's financial accounts will be established according to general accounting rules, by an accounting agent, who will not have any hierarchical link with the CCAMIP staff and cannot be given any order by the CCAMIP management. These financial accounts will be verified by the Cour des Comptes according to rules that are applicable to all administrative institutions.

\section{E. Transparency of Payment and Settlement Systems Oversight}

137. Payment systems oversight and the oversight of securities settlement systems in France are based on a legal and regulatory framework established at the European level, by the European Central Bank (ECB) and the European System of Central Banks (ESCB), as well as on the French Monetary and Financial Code. It encompasses France's contribution to the oversight of pan-European systems such as the Trans-European Automated Real-time Gross settlement Express Transfer system (TARGET), Clearnet and the Euroclear group, as well as the oversight of purely domestic systems such as Paris Net Settlement System (PNS) and Système Interbancaire de Télécommunications (SIT), for which the BdF bears sole responsibility. 


\section{Practice-by-practice assessment} Table 39. Detailed assessment of Observance of IMF's MFP Transparency Code Practices-
Payment and Settlement Systems (November 2003 update)

\section{Clarity OF Roles, RESPONSIBILITIES AND OBJECTIVES OF FinANCIAL AGENCIES RESPONSIBLE FOR Financial Policies-Payment and Settlement Systems (November 2003 UPdate)}

\begin{tabular}{|c|c|}
\hline 5.1 & $\begin{array}{l}\text { The broad objective(s) and institutional framework of financial agencies should be } \\
\text { clearly defined, preferably in relevant legislation or regulation. }\end{array}$ \\
\hline \multirow[t]{5}{*}{ Practice } & $\begin{array}{l}\text { The institutional framework of the ECB and the ESCB (the latter comprising the ECB and the } \\
\text { National Central Banks of all } 15 \text { European Union Member States) is defined by the Treaty } \\
\text { establishing the European Community, as amended, and by the Protocol (No. 18) on the } \\
\text { Statute of the ESCB and of the ECB ("the Statute") (notably Articles } 3 \text { and 22) which form } \\
\text { part of the Treaty. With respect to payment systems, the Statute's Art. 22, "Clearing and } \\
\text { Payment Systems" provides that; "the ECB and the national central banks may provide } \\
\text { facilities, and the ECB may make regulations to ensure efficient and sound clearing and } \\
\text { payment systems within the Community and with other countries." }\end{array}$ \\
\hline & $\begin{array}{l}\text { The principles stated in the Statute have been implemented at the national level, i.e., all } \\
\text { NCBs that are part of the ESCB, including the BdF, have had their governing statutes } \\
\text { amended accordingly. }\end{array}$ \\
\hline & $\begin{array}{l}\text { For the BdF, Art. L.141-4 of the COMOFI states that the BdF shall "ensure the smooth } \\
\text { operation and security of payment systems, within the framework of the task of the ESCB } \\
\text { relating to the promotion of the smooth operation of payment systems." In } 2001 \text { (Law } \\
\text { no. } 2001-1062 \text { of November } 15,2001 \text { ) the oversight role of the BdF in matters of security of } \\
\text { means of payment was further specified by adding: "The BdF shall ensure the security of } \\
\text { means of payment, other than banknotes and coins, as defined in Art. L.311-3, and the } \\
\text { relevance of the standards applicable thereto. If it deems that such means of payment are } \\
\text { insufficiently secure, it may invite the issuer to take steps to remedy the situation." }\end{array}$ \\
\hline & $\begin{array}{l}\text { With respect to securities clearing and settlement systems (SCSS), a further amendment to art. } \\
\text { L.141-4 (Law 2001-1168 of December 11,2001) stipulated that "As part of the duties of the } \\
\text { ESCB and without prejudice to the powers of the Financial Markets Council and the CB, the } \\
\text { BdF shall ensure the security of securities clearing, payment and settlement systems." }\end{array}$ \\
\hline & $\begin{array}{l}\text { The applicable legislation is publicly available on the website of the BdF (see Information } \\
\text { Bancaires \& Financières) and at www.legifrance.gouv.fr. }\end{array}$ \\
\hline Assessment & Observed. \\
\hline 5.1.1 & The broad objective(s) of financial agencies should be publicly disclosed and explained. \\
\hline \multirow[t]{2}{*}{ Practice } & $\begin{array}{l}\text { The BdF's broad objectives are: (i) financial stability; (ii) market and systemic stability; and } \\
\text { (iii) competitive and fair markets. These objectives are set out in legislation (i.e., Art. } 4 \\
\text { and } 105 \text { (2) of the Treaty; Art. } 3 \text { of the Statute of the ESCB and the ECB; Art. L.141 of the } \\
\text { COMOFI) and disclosed and explained in official publications (e.g., the FSR, Bulletin de la } \\
\text { BdF, and the BdF's annual report and website), and in senior officials' written and oral } \\
\text { reports to the legislature. }\end{array}$ \\
\hline & $\begin{array}{l}\text { Every year, the BdF annual report emphasizes the importance of ensuring the efficiency and } \\
\text { security of payment systems as one of the key tasks of central banks, along with the conduct }\end{array}$ \\
\hline
\end{tabular}




\begin{tabular}{|c|c|}
\hline & $\begin{array}{l}\text { of monetary policy and oversight of the financial system. The French Parliament defined the } \\
\text { BdF's role with regard to payment systems in Art. L.141-4 of the COMOFI stating that it } \\
\text { "shall ensure the smooth operation and security of payment systems." In the BdF } 2002 \text { annual } \\
\text { report, for the first time, an entire chapter was dedicated to the oversight of payment systems } \\
\text { and payment instruments as well as SCSS. }\end{array}$ \\
\hline Assessment & Observed. \\
\hline 5.1 .2 & $\begin{array}{l}\text { The responsibilities of the financial agencies and the authority to conduct financial } \\
\text { policies should be publicly disclosed. }\end{array}$ \\
\hline Practice & $\begin{array}{l}\text { The BdF's responsibilities and authority for payment systems oversight are defined in } \\
\text { Art. 105(2) of the Treaty; Art. } 3 \text { of the Statute of the ESCB and ECB; and Art. L.141 of the } \\
\text { Financial and Monetary Code, and are disclosed in official publications (e.g., Financial } \\
\text { Stability Review, Bulletin de la BdF; and the annual report and website of the BdF), and in } \\
\text { senior officials' written and oral reports to the legislature. See also 5.1.1, above. }\end{array}$ \\
\hline Assessment & Observed. \\
\hline 5.1 .3 & $\begin{array}{l}\text { Where applicable, the broad modalities of accountability for financial agencies should } \\
\text { be publicly disclosed. }\end{array}$ \\
\hline Practice & $\begin{array}{l}\text { The BdF's broad modalities of accountability are set out in Art. L.143-1 of the } \\
\text { COMOFI which provides that the Governor is required to appear before the Finance } \\
\text { Commission of the National Assembly or the Senate (Finance Commission) if requested. } \\
\text { Further, the Governor is obliged to deliver to the President of the Republic and to the } \\
\text { Presidents of the National Assembly and the Senate, the annual report on the BdF's } \\
\text { operations, monetary policy, and views on economic and financial affairs. The transmittal } \\
\text { letter from the Governor to the President of the Republic makes clear that the annual report's } \\
\text { delivery is required by law. The BdF's accounts, together with the report of the auditors } \\
\text { thereon, are delivered to the Finance Commission. This accountability framework applies to } \\
\text { all of the BdF's areas of responsibility, including payment systems oversight. }\end{array}$ \\
\hline Assessment & Observed. \\
\hline 5.1 .4 & $\begin{array}{l}\text { Where applicable, the procedures for appointment, terms of office, and any general } \\
\text { criteria for removal of the heads and members of the governing bodies of financial } \\
\text { agencies should be publicly disclosed. }\end{array}$ \\
\hline Practice & $\begin{array}{l}\text { Procedures for appointment, terms of office, and general criteria for removal of heads and } \\
\text { members of the governing bodies of the BdF are found in Articles L.142-3, 142-5 and 142-8 } \\
\text { of the COMOFI. These articles specify that the governor and the two Deputy Governors are } \\
\text { appointed by decree of the Council of Ministers, and appointments to the Monetary Policy } \\
\text { Council are also made by the Council of Ministers. The terms of office are specified in the } \\
\text { law. Members of the Monetary Policy Council are appointed for a nonrenewable term of nine } \\
\text { years, and Governors and Deputy Governors for a term of six years, once renewable. General } \\
\text { criteria for removal are (i) incapacity and (ii) faute grave; with a majority vote by the Conseil } \\
\text { de la Politique Monetaire needed in the case of the latter. }\end{array}$ \\
\hline Assessment & Observed. \\
\hline 5.2 & The relationship between financial agencies should be publicly disclosed. \\
\hline
\end{tabular}




\begin{tabular}{|c|c|}
\hline Practice & 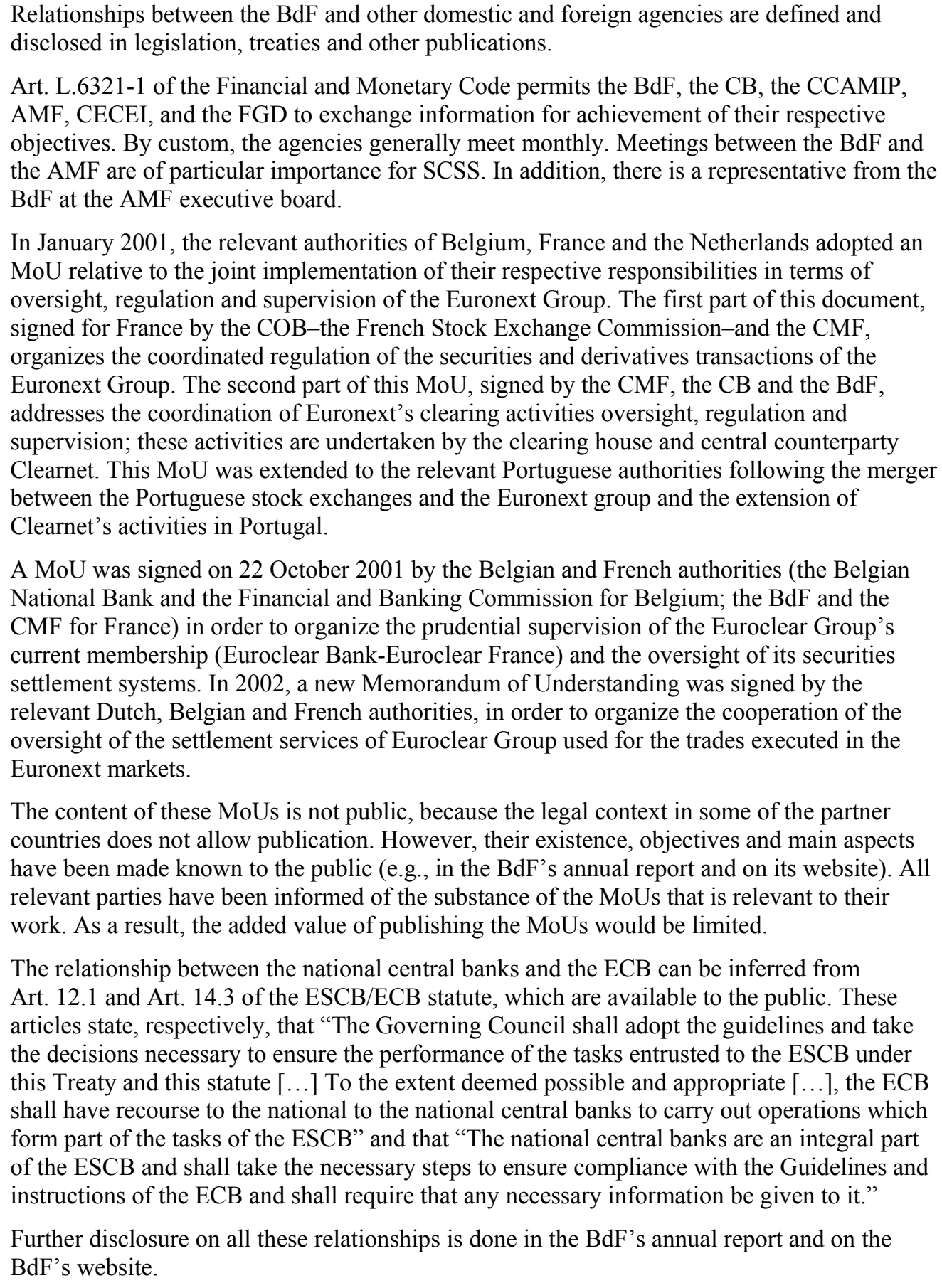 \\
\hline Assessment & Observed. \\
\hline 5.3 & $\begin{array}{l}\text { The role of oversight agencies with regard to payment systems should be publicly } \\
\text { disclosed. }\end{array}$ \\
\hline Practice & $\begin{array}{l}\text { The role of the BdF with regard to the oversight of payment systems, payment instruments, } \\
\text { and SCSS is defined and disclosed in legislation and is also known through the BdF's official }\end{array}$ \\
\hline
\end{tabular}




\begin{tabular}{|c|c|}
\hline & publications (annual report, monthly bulletin, FSR). \\
\hline Assessment & Observed. \\
\hline 5.3 .1 & $\begin{array}{l}\text { The agencies overseeing the payment system should promote the timely public } \\
\text { disclosure of general policy principles (including risk management policies) that affect } \\
\text { the robustness of systemically important payment systems. }\end{array}$ \\
\hline \multirow[t]{5}{*}{ Practice } & $\begin{array}{l}\text { The BdF promotes timely public disclosure of general policy principles through published } \\
\text { reports in official publications (e.g., the FSR, Bulletin de la BdF; annual report of the BdF, } \\
\text { and the latter's website), through promulgation of domestic or international standards, and } \\
\text { through its participation in interbank working groups. }\end{array}$ \\
\hline & $\begin{array}{l}\text { In the BdF's } 2002 \text { annual report, an entire chapter was dedicated to the oversight of payment } \\
\text { systems and SCSS. This exercise was repeated in the } 2003 \text { annual report. These texts report } \\
\text { extensively on the standards that payment systems are required to adhere to, and summarizes } \\
\text { their compliance. Pursuant to the Decree } \mathrm{n}^{\circ} 2003-195 \text { of } 7 \text { March } 2003 \text {, the BdF is also in } \\
\text { charge of disclosing on request to any interested party the list and address of payment systems } \\
\text { and Securities Settlement Systems notified to the EU Commission under the Settlement } \\
\text { Finality Directive, as well as the list of direct and indirect participants in the systems, } \\
\text { following information of their operators. These data are available on the BdF website. }\end{array}$ \\
\hline & $\begin{array}{l}\text { The BdF's website also provides an overview of all payment systems and their functioning, } \\
\text { through its own texts and through links to the websites of the payment system operators. The } \\
\text { information thus provided largely includes the system's risk management policies. The } \\
\text { website also contains several papers discussing the safety of systemically important payment } \\
\text { systems, as well as the applicable European and international standards. }\end{array}$ \\
\hline & $\begin{array}{l}\text { The BdF uses international standards as the basis of its oversight policy and aims to have all } \\
\text { systems under its oversight fully observe all relevant standards. These standards include } \\
\text { provisions that require payment systems to be transparent about their general policy principles } \\
\text { and their risk management policies. Hence, by promoting these standards, the BdF promotes } \\
\text { the transparency of those payment systems. }\end{array}$ \\
\hline & $\begin{array}{l}\text { Nevertheless, the BdF could more directly and more specifically promote the transparency of } \\
\text { the payment systems it oversees. }\end{array}$ \\
\hline Assessment & Observed. \\
\hline 5.4 & $\begin{array}{l}\text { Where financial agencies have oversight responsibilities for self-regulatory } \\
\text { organizations (e.g., payment systems), the relationship between them should be publicly } \\
\text { disclosed. }\end{array}$ \\
\hline \multicolumn{2}{|l|}{ Practice } \\
\hline Assessment & Not applicable. \\
\hline Comments & The payment systems the BdF oversees are not self-regulatory organizations. \\
\hline
\end{tabular}




\begin{tabular}{|c|c|}
\hline 5.5 & $\begin{array}{l}\text { Where self-regulatory organizations are authorized to perform part of the regulatory } \\
\text { and supervisory process, they should be guided by the same good transparency practices } \\
\text { specified for financial agencies. }\end{array}$ \\
\hline \multicolumn{2}{|l|}{ Practice } \\
\hline Assessment & Not applicable. \\
\hline Comments & The payment systems the BdF oversees are not self-regulatory organizations. \\
\hline \multicolumn{2}{|r|}{ VI. OPEN Process for Formulating AND Reporting of FinanCial Policies } \\
\hline 6.1 & $\begin{array}{l}\text { The conduct of policies by financial agencies should be transparent, compatible with } \\
\text { confidentiality considerations and the need to preserve the effectiveness of actions by } \\
\text { regulatory and oversight agencies. }\end{array}$ \\
\hline Practice & See 6.1.1 to 6.1.5. \\
\hline \multicolumn{2}{|l|}{ Assessment } \\
\hline 6.1.1 & $\begin{array}{l}\text { The regulatory framework and operating procedures governing the conduct of financial } \\
\text { policies should be publicly disclosed and explained. }\end{array}$ \\
\hline Practice & $\begin{array}{l}\text { The regulatory framework for payment systems oversight is based on international standards } \\
\text { and mostly set at the European level by the ECB and ESCB. The ECB and ESCB publicly } \\
\text { disclose and explain this framework. This European framework is complemented at the } \\
\text { French level with legislation, as well as with decrees and ordinances issued by the } \\
\text { government. The BdF itself has no regulatory powers in the area of payment systems. } \\
\text { The BdF discloses and explains this regulatory framework through published reports in } \\
\text { official publications (e.g., the FSR, the BdF Bulletin, and the BdF's annual report, and its } \\
\text { website (http://www.banque-france.fr/gb/infobafi/main.htm), and through its participation in } \\
\text { interbank working groups. } \\
\text { Nevertheless, the BdF's efforts to explain this framework can be significantly improved upon. } \\
\text { In particular, there is a need for the BdF to be more proactive in explaining how international } \\
\text { standards and European regulations are to be implemented in the French context, and in } \\
\text { clarifying those areas in which the international standards are not sufficiently comprehensive } \\
\text { or specific. There is also a need for the BdF to explain more clearly and in greater detail how } \\
\text { it oversees the implementation of the international standards and European regulations in } \\
\text { France. } \\
\text { For Securities Settlement Systems, the law entitles the AMF to (i) define in regulations the } \\
\text { main principles and requirements which apply to these systems; and (ii) to approve the } \\
\text { Rulebook of the systems in regulations. These regulations are published by the AMF. } \\
\text { Although the BdF publishes its general approach in implementing its payment systems } \\
\text { oversight function on its website and in its annual report (e.g., } 2003 \text { annual report, Section } \\
\text { 6.1.3, p. 71), at present there is no overall set of operating procedures in place governing the } \\
\text { conduct of payment systems oversight. Instead, the operational aspects of the BdF's oversight } \\
\text { function are governed by internal BdF documents and bilateral agreements with individual } \\
\text { payment systems operators. These documents are not published. }\end{array}$ \\
\hline
\end{tabular}




\begin{tabular}{|c|c|}
\hline Assessment & Partly observed. \\
\hline \multirow[t]{2}{*}{ Comments } & $\begin{array}{l}\text { For an "observed" rating, the BdF should clearly specify, publicly disclose and explain the } \\
\text { operating procedures governing the conduct of its payment systems oversight function. }\end{array}$ \\
\hline & $\begin{array}{l}\text { In addition, efforts to explain and clarify international standards and the way they should be } \\
\text { implemented in the French context by the different payment systems operators, need to be } \\
\text { improved. }\end{array}$ \\
\hline 6.1 .2 & $\begin{array}{l}\text { The regulations for financial reporting by financial institutions to financial agencies } \\
\text { should be publicly disclosed. }\end{array}$ \\
\hline \multicolumn{2}{|l|}{ Practice } \\
\hline Assessment & Not applicable. \\
\hline Comments & $\begin{array}{l}\text { There are no regulations in place governing the financial reporting of payment systems and } \\
\text { the SCSS to the BdF, and no special reporting on the systems' financial situation is required. } \\
\text { However, in its role as overseer of payment systems and instruments as well as SCSS, the } \\
\text { BdF requests some reporting (e.g., statistics) from the operators of the systems, as provided } \\
\text { for in the law. The reporting of these data is arranged through specific agreements tailored to } \\
\text { each of the payment systems, not through universally applicable regulations. } \\
\text { Formalization and disclosure of these reporting requirements would increase transparency. }\end{array}$ \\
\hline 6.1.3 & $\begin{array}{l}\text { The regulations for the operation of organized financial markets (including those for } \\
\text { issuers of traded financial instruments) should be publicly disclosed. }\end{array}$ \\
\hline \multicolumn{2}{|l|}{ Practice } \\
\hline Assessment & Not applicable. \\
\hline Comments & $\begin{array}{l}\text { The BdF, in its role as agency responsible for payment systems oversight, is not responsible } \\
\text { for regulating the operation of organized financial markets. }\end{array}$ \\
\hline 6.1 .4 & $\begin{array}{l}\text { Where financial agencies charge fees to financial institutions, the structure of such fees } \\
\text { should be publicly disclosed. }\end{array}$ \\
\hline \multicolumn{2}{|l|}{ Practice } \\
\hline Assessment & Not applicable. \\
\hline Comments & $\begin{array}{l}\text { The BdF does not charge any fees related to its responsibility for payment systems oversight. } \\
\text { The fees it charges as operator of the TBF payment system have been publicly disclosed in } \\
\text { the TBF procedures. }\end{array}$ \\
\hline 6.1.5 & $\begin{array}{l}\text { Where applicable, formal procedures for information sharing and consultation between } \\
\text { financial agencies (including central banks), domestic and international, should be } \\
\text { publicly disclosed. }\end{array}$ \\
\hline Practice & $\begin{array}{l}\text { Formal procedures for information sharing and consultation between the BdF, in its capacity } \\
\text { as payment system overseer, and other financial agencies (the ECB, other Eurozone central }\end{array}$ \\
\hline
\end{tabular}




\begin{tabular}{|c|c|}
\hline & $\begin{array}{l}\text { banks, domestic financial agencies, ...) exist. The existence of these procedures, and other } \\
\text { general information about international and domestic cooperation arrangements, are publicly } \\
\text { disclosed in the BdF's annual report (see, for example, the discussion on coordinated } \\
\text { oversight of Euronext and Euroclear in section } 6.1 .3 \text { of the } 2001 \text { Annual Report), its website } \\
\text { and in publications and websites of the ECB and ESCB. Substantive summaries of the MoUs } \\
\text { between the BdF and its counterparts in other Euronext countries are disclosed by the BdF in } \\
\text { a number of paper publications. These MoUs are, however, not fully disclosed because of } \\
\text { legal constraints in some of the partner countries. Nevertheless, the BdF examines any request } \\
\text { for access to them. Until now, requests have only come from other authorities and disclosure } \\
\text { was never refused. } \\
\text { The detailed (formal) procedures for information sharing and consultation are only partially } \\
\text { disclosed. Unless specified in law, the disclosure is mostly limited to general principles and } \\
\text { the identification of counterparties with whom the BdF cooperates. }\end{array}$ \\
\hline Assessment & Broadly observed. \\
\hline Comments & $\begin{array}{l}\text { Disclosure in greater detail of the formal procedures for information sharing and consultation } \\
\text { is needed for an "observed" rating. }\end{array}$ \\
\hline 6.2 & $\begin{array}{l}\text { Significant changes in financial policies should be publicly announced and explained in a } \\
\text { timely manner. }\end{array}$ \\
\hline Practice & $\begin{array}{l}\text { Significant changes in policy (e.g., decisions of the Governing Council of the ECB regarding } \\
\text { payment systems) are released on the BdF's website and, when applicable, on the website of } \\
\text { the ECB, immediately after the decision is made, usually in the form of a press release. These } \\
\text { announcements, which usually include an explanation of the decision, can be recirculated by } \\
\text { the French Banking Federation or the media. In addition, the BdF communicates and explains } \\
\text { such changes directly to the payment system operators it oversees. }\end{array}$ \\
\hline Assessment & Observed. \\
\hline 6.3 & $\begin{array}{l}\text { Financial agencies should issue periodic public reports on how their overall policy } \\
\text { objectives are being pursued. }\end{array}$ \\
\hline Practice & $\begin{array}{l}\text { Reports on pursuit of overall policy objectives are issued quarterly and annually (and even } \\
\text { more frequently when judged necessary). Typically, reports take the form of written reports to } \\
\text { the legislature, the official bulletin and the annual report, as well as postings on the BdF's } \\
\text { website. Chapter } 6 \text { of the BdF's annual report is dedicated to the oversight of payment and } \\
\text { securities settlement systems and is comprehensive. In addition, BdF launched a FSR in } \\
\text { June } 2002 \text {, where it can report on the pursuit of its policy objectives. For example, an article } \\
\text { on the Protection of deferred net payment and SSS in France is published in the } \\
\text { November } 2003 \text { issue. }\end{array}$ \\
\hline Assessment & Observed. \\
\hline 6.4 & $\begin{array}{l}\text { For proposed substantive technical changes to the structure of financial regulations, } \\
\text { there should be a presumption in favor of public consultations, within an appropriate } \\
\text { period. }\end{array}$ \\
\hline Practice & $\begin{array}{l}\text { The structure of payment systems regulations in France is determined by standards that are } \\
\text { defined at the G10 level, at the ESCB level or, for the fields not covered by the latter, at the } \\
\text { BdF's level. Whatever the type of standards, a public consultation is systematically organized }\end{array}$ \\
\hline
\end{tabular}




\begin{tabular}{|c|c|}
\hline & $\begin{array}{l}\text { in case of substantive changes. A link to ongoing public consultations regarding payment } \\
\text { system issues is provided on the BdF's website. }\end{array}$ \\
\hline Assessment & Observed. \\
\hline \multicolumn{2}{|r|}{ VII. Public Availability of Information on Financial Policies } \\
\hline 7.1 & $\begin{array}{l}\text { Financial agencies should issue a periodic public report on the major developments of } \\
\text { the sector(s) of the financial system for which they carry designated responsibility. }\end{array}$ \\
\hline Practice & $\begin{array}{l}\text { The BdF reports on developments in payment and settlement systems in its annual report } \\
\text { (e.g., Chapter } 6 \text { of the } 2002 \text { and } 2003 \text { annual reports). Payment system statistics are also } \\
\text { published on a continuous on the BdF's website and on a monthly basis in the BdF's bulletin. } \\
\text { Occasional articles on important payment systems developments are included in most of the } \\
\text { BdF's publications, including the monthly bulletin and the FSR. }\end{array}$ \\
\hline Assessment & Observed. \\
\hline 7.2 & $\begin{array}{l}\text { Financial agencies should seek to ensure that, consistent with confidentiality } \\
\text { requirements, there is public reporting of aggregate data related to their jurisdictional } \\
\text { responsibilities on a timely and regular basis. }\end{array}$ \\
\hline Practice & $\begin{array}{l}\text { Aggregate data on payment systems are published in the BdF's annual report, its monthly } \\
\text { bulletin, and on the BdF's website. }\end{array}$ \\
\hline Assessment & Observed. \\
\hline 7.3 & $\begin{array}{l}\text { Where applicable, financial agencies should publicly disclose their balance sheets on a } \\
\text { pre-announced schedule and, after a predetermined interval, publicly disclose } \\
\text { information on aggregate market transactions. }\end{array}$ \\
\hline \multicolumn{2}{|l|}{ Practice } \\
\hline Assessment & Not applicable. \\
\hline Comments & $\begin{array}{l}\text { The payment systems department of the BdF does not have a separate balance sheet. The } \\
\text { balance sheet of the BdF is published monthly in the Monthly bulletin, and the BdF's audited } \\
\text { financial statements, including its balance sheet, are published in the BdF's annual report. } \\
\text { Both bulletin and annual report are available on BdF's website. }\end{array}$ \\
\hline 7.3 .1 & $\begin{array}{l}\text { Consistent with confidentiality and privacy of information on individual firms, } \\
\text { aggregate information on emergency financial support by financial agencies should be } \\
\text { publicly disclosed through an appropriate statement when such disclosure will not be } \\
\text { disruptive to financial stability. }\end{array}$ \\
\hline \multicolumn{2}{|l|}{ Practice } \\
\hline Assessment & Not applicable. \\
\hline Comments & $\begin{array}{l}\text { The BdF does not provide emergency financial support to payment systems operators. } \\
\text { Emergency liquidity support is only provided to participants in payment systems, and this is }\end{array}$ \\
\hline
\end{tabular}




\begin{tabular}{|c|c|}
\hline & outside the scope of the BdF's responsibilities for payment systems oversight. \\
\hline 7.4 & Financial agencies should establish and maintain public information services. \\
\hline Practice & $\begin{array}{l}\text { The BdF's Communications Division provides public information services and disseminates; } \\
\text { (i) policy decisions and announcements; (ii) information on the operating framework, targets, } \\
\text { and objectives; (iii) texts of speeches by senior officials; (iv) quantitative data and; (v) staff } \\
\text { research. It also maintains the website and has major involvement in the production of } \\
\text { quarterly and annual publications. The website has a dedicated part on payment system, } \\
\text { instruments and SCSS oversight issues. }\end{array}$ \\
\hline Assessment & Observed. \\
\hline 7.4 .1 & $\begin{array}{l}\text { Financial agencies should have a publications program, including a periodic public } \\
\text { report on their principal activities issued at least annually. }\end{array}$ \\
\hline Practice & $\begin{array}{l}\text { The BdF's publications program includes; (i) the annual report; (ii) the official bulletin; } \\
\text { (iii) the Financial Stability Review, (iv) research and statistical publications; and (v) speeches } \\
\text { of senior officials; all of which are available free or at nominal cost, and most of which can be } \\
\text { downloaded from its website. Reports on the BdF's principal activities are published quarterly } \\
\text { and annually (although the monthly bulletin and FSR address aspects of its principal activities } \\
\text { on a nonperiodic basis), approximately one quarter after the end of the period to which they } \\
\text { refer. The BdF is required by legislation (Art. } 113 \text { of the Treaty and Art. } 15 \text { of the Statute of } \\
\text { the ESCB and the ECB) to issue a periodic report. } \\
\text { COMOFI Art. L.143-1 requires that a report be made on the BdF's principal activities, } \\
\text { including payment system, instruments and SCSS oversight issues, to the President of the } \\
\text { Republic and to Parliament at least once annually. }\end{array}$ \\
\hline Assessment & Observed. \\
\hline 7.4 .2 & $\begin{array}{l}\text { Senior financial agency officials should be ready to explain their institution's } \\
\text { objective(s) and performance to the public, and have a presumption in favor of releasing } \\
\text { the text of their statements to the public. }\end{array}$ \\
\hline Practice & $\begin{array}{l}\text { The Governor of the BdF explains the objectives and performance of the BdF, including } \\
\text { regarding its responsibility for payment systems oversight, at parliamentary hearings. The } \\
\text { Governor and other officials further explain the objectives and performance of the BdF } \\
\text { through speeches in public fora (texts published on the BdF's website), before members of the } \\
\text { industry, and through interviews or articles in the news media. Prior internal clearance is } \\
\text { required for officials (other than the Governor) to do so. }\end{array}$ \\
\hline Assessment & Observed. \\
\hline 7.5 & $\begin{array}{l}\text { Texts of regulations and any other generally applicable directives and guidelines issued } \\
\text { by financial agencies should be readily available to the public. }\end{array}$ \\
\hline Practice & $\begin{array}{l}\text { The texts of regulations and other generally applicable directives and guidelines are made } \\
\text { available free or at nominal charge through the JORF, France's official legislative website } \\
\text { (www.legifrance.gouv.fr), and on the BdF's website. }\end{array}$ \\
\hline Assessment & Obsery \\
\hline
\end{tabular}




\begin{tabular}{|c|c|}
\hline 7.6 & $\begin{array}{l}\text { Where there are deposit insurance guarantees, policy-holder guarantees, and any other } \\
\text { client asset protection schemes, information on the nature and form of such protections, } \\
\text { on the operating procedures, on how the guarantee is financed, and on the performance } \\
\text { of the arrangement, should be publicly disclosed. }\end{array}$ \\
\hline \multicolumn{2}{|l|}{ Practice } \\
\hline Assessment & Not applicable. \\
\hline Comments & $\begin{array}{l}\text { The BdF does not oversee any client asset protection scheme as part of its responsibilities for } \\
\text { payment systems oversight. }\end{array}$ \\
\hline 7.7 & $\begin{array}{l}\text { Where financial agencies oversee consumer protection arrangements (such as dispute } \\
\text { settlement processes), information on such arrangements should be publicly disclosed. }\end{array}$ \\
\hline \multicolumn{2}{|l|}{ Practice } \\
\hline Assessment & Not applicable. \\
\hline Comments & $\begin{array}{l}\text { The BdF does not oversee any consumer protection arrangements as part of its responsibilities } \\
\text { for payment systems oversight. }\end{array}$ \\
\hline \multicolumn{2}{|r|}{ VIII. ACCOUNTABILITY AND ASSURANCES OF INTEGRITY BY FINANCIAL AGENCIES } \\
\hline 8.1 & $\begin{array}{l}\text { Officials of financial agencies should be available to appear before a designated public } \\
\text { authority to report on the conduct of financial policies, explain the policy objective(s) of } \\
\text { their institution, describe their performance in pursuing their objective(s), and, as } \\
\text { appropriate, exchange views on the state of the financial system. }\end{array}$ \\
\hline Practice & $\begin{array}{l}\text { For these purposes, COMOFI Art. L.143-1 provides that the Governor may be heard by the } \\
\text { Finance Commission of the National Assembly or the Senate if they so desire, or may request } \\
\text { to be heard by them (see also Art. } 107 \text { of the EC Treaty and the confidentiality rules of the } \\
\text { ECB). These arrangements cover payment systems oversight as well as the other areas of the } \\
\text { BdF's responsibilities. There is no possibility for parliament to demand that BdF officials } \\
\text { more directly involved in payment systems oversight appear before it, except in the context of } \\
\text { a commission of inquiry. }\end{array}$ \\
\hline Assessment & Observed. \\
\hline 8.2 & $\begin{array}{l}\text { Where applicable, financial agencies should publicly disclose audited financial } \\
\text { statements of their operations on a pre-announced schedule. }\end{array}$ \\
\hline \multicolumn{2}{|l|}{ Practice } \\
\hline Assessment & Not applicable. \\
\hline Comments & $\begin{array}{l}\text { The BdF's department responsible for payment systems oversight does not have a separate } \\
\text { balance sheet. The BdF's financial statements are of little relevance to the transparency of } \\
\text { payment systems oversight, since they are largely determined by the BdF's monetary policy } \\
\text { and other functions, while payment systems oversight constitutes only a small part of its } \\
\text { operations. }\end{array}$ \\
\hline
\end{tabular}




\begin{tabular}{|c|c|}
\hline & $\begin{array}{l}\text { The audited financial statements of the BdF are published in the JORF and form part of the } \\
\text { annual report. Pursuant to the COMOFI, the audited financial statements are to be laid before } \\
\text { the Finance Commissions of the two chambers of Parliament. }\end{array}$ \\
\hline 8.2.1 & $\begin{array}{l}\text { Financial statements, if any, should be audited by an independent auditor. Information } \\
\text { on accounting policies and any qualification to the statements should be an integral part } \\
\text { of the publicly disclosed financial statements. }\end{array}$ \\
\hline \multicolumn{2}{|l|}{ Practice } \\
\hline Assessment & Not applicable. \\
\hline \multirow[t]{2}{*}{ Comments } & $\begin{array}{l}\text { The BdF's department responsible for payment systems oversight does not have a separate } \\
\text { balance sheet. }\end{array}$ \\
\hline & $\begin{array}{l}\text { Two private sector firms, approved by the European Council of Ministers on the } \\
\text { recommendation of the ECB's Governing Council and appointed by the General Council of } \\
\text { the BdF, audit the BdF's financial statements. Information on accounting policies used and } \\
\text { any qualifications to the accountants' opinion appear with the financial statements. }\end{array}$ \\
\hline 8.2.2 & $\begin{array}{l}\text { Internal governance procedures necessary to ensure the integrity of operations, } \\
\text { including internal audit arrangements, should be publicly disclosed. }\end{array}$ \\
\hline \multirow[t]{2}{*}{ Practice } & $\begin{array}{l}\text { Insurance of the integrity of operations rests with the internal audit office of the BdF } \\
\text { (l'Inspection Générale). This internal office, together with the risk management unit, falls } \\
\text { under the authority of the Contrôleur Générale, and is responsible for the systematic } \\
\text { monitoring of the BdF's management procedures and internal control systems. The existence } \\
\text { (and mission) of the internal audit office is publicly disclosed in the annual report and on the } \\
\text { organization chart of the BdF. Developments in the area of internal audit are also discussed in } \\
\text { the annual report (for example, section } 8.2 .8 \text { of the } 2002 \text { Annual Report). }\end{array}$ \\
\hline & $\begin{array}{l}\text { Transparency could be further enhanced by posting an extensive description of the internal } \\
\text { audit unit and other internal governance procedures on the website of the BdF. }\end{array}$ \\
\hline Assessment & Observed. \\
\hline 8.3 & $\begin{array}{l}\text { Where applicable, information on the operating expenses and revenues of financial } \\
\text { agencies should be publicly disclosed annually. }\end{array}$ \\
\hline \multicolumn{2}{|l|}{ Practice } \\
\hline Assessment & Not applicable. \\
\hline \multirow[t]{2}{*}{ Comments } & $\begin{array}{l}\text { The BdF's department responsible for payment systems does not have its own accounts, and } \\
\text { hence, the operating expenses and revenues of the BdF related to its role as overseer of } \\
\text { payment and settlement systems cannot be isolated. }\end{array}$ \\
\hline & $\begin{array}{l}\text { Disclosure on the BdF's overall operating expenses and revenues are made in the audited } \\
\text { financial statements, which are published annually. }\end{array}$ \\
\hline
\end{tabular}




\begin{tabular}{|l|l|}
\hline 8.4 & $\begin{array}{l}\text { Standards for the conduct of personal financial affairs of officials and staff of financial } \\
\text { agencies and rules to prevent exploitation of conflicts of interest, including any general } \\
\text { fiduciary obligation, should be publicly disclosed. }\end{array}$ \\
\hline Practice & $\begin{array}{l}\text { Internal standards for the conduct of personal financial affairs are set out in the BdF's Code } \\
\text { de déontologie financière, which is publicly available in paper form. A recent internal rule } \\
\text { (also published) relating to the implementation of the Code de déontologie financière focuses } \\
\text { more specifically on good practices to be applied by officials and staff when they are offered } \\
\text { gifts in the conduct of their official duties. }\end{array}$ \\
\hline Assessment & Observed. \\
\hline 8.4.1 & $\begin{array}{l}\text { Information about legal protections for officials and staff of financial agencies in the } \\
\text { conduct of their official duties should be publicly disclosed. }\end{array}$ \\
\hline Practice & $\begin{array}{l}\text { Officials and staff of the BdF benefit from the standard legal protection granted to civil } \\
\text { servants in the good faith execution of their duties. This protection is outlined in, and publicly } \\
\text { disclosed through, the relevant legislation (see COMOFI Articles L.144-2 and 144-3). }\end{array}$ \\
\hline Assessment & \begin{tabular}{l} 
Observed. \\
\hline
\end{tabular} \\
\hline
\end{tabular}

Table 40. Summary Observance of IMF's MFP Transparency Code Practices-Payment and Settlement Systems

\begin{tabular}{|l|c|l|}
\hline \multirow{2}{*}{ Assessment Grade } & \multicolumn{2}{|c|}{ Principles Grouped by Assessment Grade } \\
\cline { 2 - 3 } & Count & \multicolumn{1}{c|}{ List } \\
\hline Observed & 21 & $\begin{array}{l}5.1,5.1 .1,5.1 .2,5.1 .3,5.1 .4,5.2,5.3,5.3 .1,6.2, \\
6.3,6.4,7.1,7.2,7.4,7.4 .1,7.4 .2,7.5,8.1, \\
8.2 .2,8.4,8.4 .1 .\end{array}$ \\
\hline Broadly observed & 1 & 6.1 .5$. \\
\hline Partly observed & 1 & 6.1 .1$. \\
\hline Not observed & 0 & -- \\
\hline Not applicable & 12 & $\begin{array}{l}5.4,5.5,6.1 .2,6.1 .3,6.1 .4,7.3,7.3 .1,7.6,7.7, \\
8.2,8.2 .1,8.3 .\end{array}$ \\
\hline
\end{tabular}




\section{Recommended action plan and authorities' response to the assessment}

\section{Recommended action plan}

Table 41. Recommended Actions to Improve Observance of IMF's MFP Transparency Code Practices-Payment and Settlement Systems

\begin{tabular}{|l|l|}
\hline Reference Practice & \multicolumn{1}{c|}{ Recommended Action } \\
\hline VI. Open Process for Formulating and Reporting of Financial Policies \\
\hline 6.1 .1 & $\begin{array}{l}\text { Clearly specify, publicly disclose and explain the operating procedures governing the } \\
\text { conduct of the BdF's payment systems oversight function. } \\
\text { Improve efforts to explain and clarify international standards and the way they should be } \\
\text { implemented in the French context by the different payment systems operators. }\end{array}$ \\
\hline 6.1 .5 & Disclose the formal procedures for information sharing and consultation in greater detail. \\
\hline
\end{tabular}

\section{Authorities' response to the assessment}

138. The BdF welcomes the IMF assessment that it reaches a very high level of transparency in its payment systems oversight function and takes note of the IMF recommendations.

\section{F. Transparency of Securities Regulation and Supervision}

139. Securities regulation and supervision in France is governed by the Monetary and Financial Code (COMOFI), as modified by the Loi de Sécurité Financière (Financial Security Law-LSF) of August 1, 2003. The law gives the Autorité des Marchés Financiers (AMF) responsibility for ensuring the protection of public savings invested in financial instruments and gives it the authority to issue regulations and to supervise issuers and markets. The CB, the CECEI, and the BdF are also involved in securities oversight, although to a lesser extent than the AMF. The LSF of August 2003 significantly reformed the framework for securities regulation and supervision in France, in part by merging three existing agencies, the Commission des Opérations en Bourse (COB), the Conseil des Marchés Financiers (CMF), and the Conseil de Discipline de la Gestion Financière (CDGF) into a single new agency, the AMF. The implementation of this merger was still ongoing at the time of the FSAP missions. For this assessment, where there was an insufficiently long track record of practices at the AMF, it was assumed that good transparency practices of the former agencies would be maintained to the extent the changed legal and regulatory framework allowed so. 


\section{Practice-by-practice assessment}

\section{Table 42. Detailed Assessment of Observance of IMF’s MFP Transparency Code Practices- Transparency of Securities Regulation}

\section{Clarity of Roles, ResPonsibilities AND OBJECTIVES OF FinANCIAL AGENCIES ReSPONSIBLE FOR Financial Policies-Securities Regulation and SuPERVision}

\begin{tabular}{|c|c|}
\hline 5.1 & $\begin{array}{l}\text { The broad objective(s) and institutional framework of financial agencies should be clearly } \\
\text { defined, preferably in relevant legislation or regulation. }\end{array}$ \\
\hline Practice & $\begin{array}{l}\text { The broad objectives and institutional framework of the Autorité des Marchés Financiers } \\
(A M F) \text { are defined by the LSF No. 2003-706 of } 1^{\text {st }} \text { August } 2003 \text { providing for the merger of the } \\
\text { COB, established by the Ordinance (Executive Order) No. 67-833 of September 28, 1967, the } \\
\text { CMF instituted by the Act No. 96-597 of July 2, } 1996 \text { (Financial Activity Modernization Act) } \\
\text { and the CDGF, and integrated in the COMOFI and certain appurtenant Decrees, in particular } \\
\text { Decree No. } 1109 \text {, dated November 21, } 2003 \text {. }\end{array}$ \\
\hline Assessment & Observed. \\
\hline 5.1.1 & The broad objective(s) of financial agencies should be publicly disclosed and explained. \\
\hline \multirow[t]{4}{*}{ Practice } & $\begin{array}{l}\text { The LSF, codified into the COMOFI, describes the broad objectives of the French financial } \\
\text { agencies for the banking, insurance and securities sectors. The provisions concerning the AMF } \\
\text { are found under its Book VI, Title II "L'Autorité des marchés financiers." }\end{array}$ \\
\hline & $\begin{array}{l}\text { The general purpose and mission of the AMF is stated clearly in Art. L.621-1 of the COMOFI } \\
\text { (as amended by the LSF): the AMF ensures the protection of public savings invested in } \\
\text { financial instruments and all other investment leading to a public offering, supervises financial } \\
\text { information conveyed to investors and the proper functioning of financial markets. It } \\
\text { contributes to the regulation of these markets at the European and international level. }\end{array}$ \\
\hline & $\begin{array}{l}\text { The scope of the mission of the AMF is stated under Section } 4 \text { "Powers" : Sub section } 1 \\
\text { "Regulations and Decisions." This section states that the AMF adopts a General Regulation } \\
\text { (Règlement général) published in the JORF, which determines, among other things, the } \\
\text { provisions applicable to issuers, public offerings, take over bids, conduct of business rules, } \\
\text { providers of investment services, market undertakings, regulated markets, clearing houses, } \\
\text { portfolio management on behalf of third parties, collective investment schemes, depositaries } \\
\text { and financial analysts. }\end{array}$ \\
\hline & $\begin{array}{l}\text { The functions of the } \mathrm{CB} \text {, the CECEI, and the BdF, respectively, pertaining to the oversight of } \\
\text { investment services providers, clearing and settlement systems, and custodians also are } \\
\text { articulated in the COMOFI. }\end{array}$ \\
\hline Assessment & Observed. \\
\hline 5.1.2 & $\begin{array}{l}\text { The responsibilities of the financial agencies and the authority to conduct financial policies } \\
\text { should be publicly disclosed. }\end{array}$ \\
\hline Practice & $\begin{array}{l}\text { The responsibilities of the agencies involved in supervising and regulating financial markets are } \\
\text { publicly disclosed through the publication of the relevant laws and regulations in the JORF, on } \\
\text { the French public service website www.legifrance.gouv.fr and on the website of relevant } \\
\text { financial agencies, such as www.amf-france.org. Summaries and relevant links are also }\end{array}$ \\
\hline
\end{tabular}




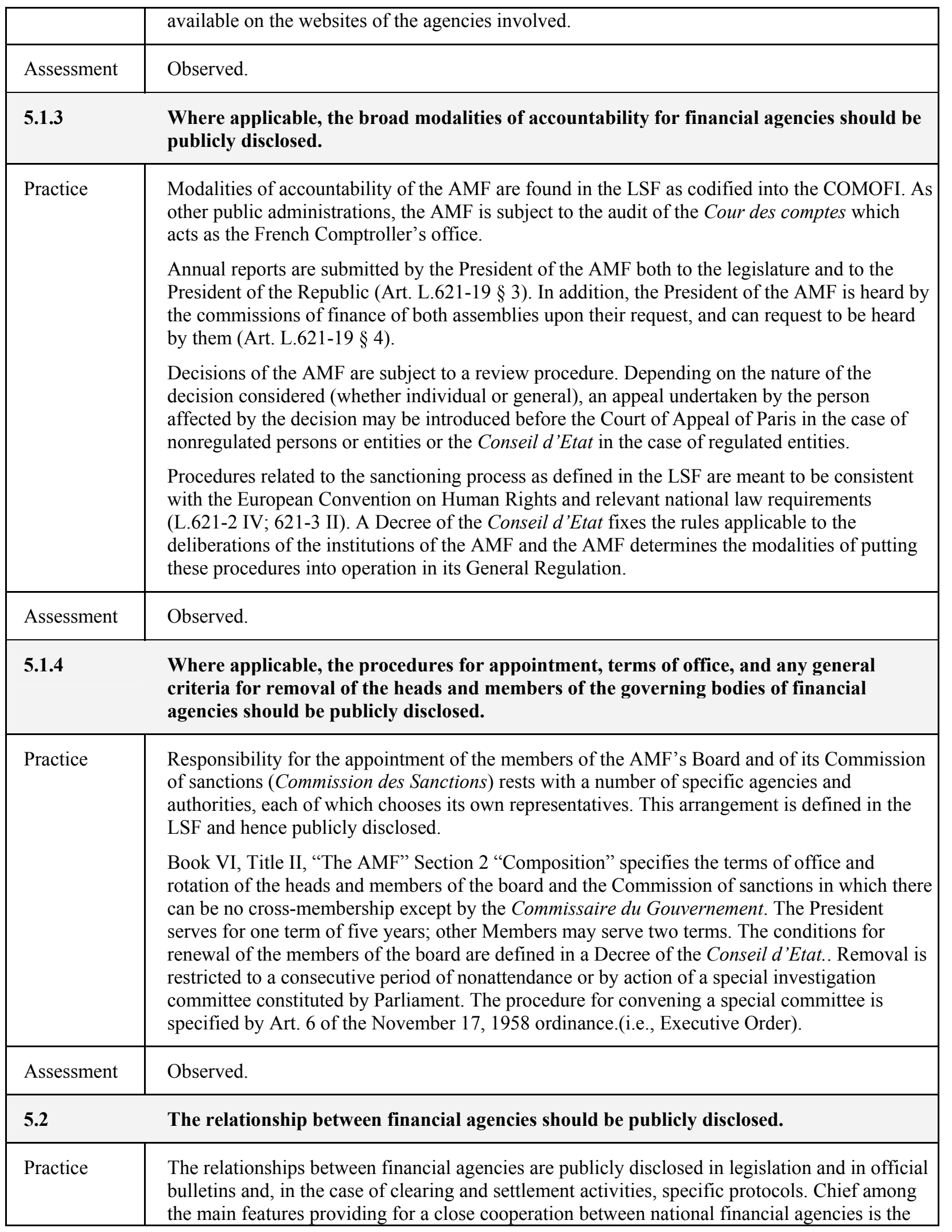




\begin{tabular}{|c|c|}
\hline & $\begin{array}{l}\text { "cross membership rule" according to which one representative of a financial institution sits as } \\
\text { a member on another regulatory body so as to constitute a permanent mechanism for exchange } \\
\text { of information. Book VI, Title II "Exchange of information," Chapter I, "Exchange of } \\
\text { information on the national territory" explicitly provides arrangements for "Cross membership." } \\
\text { Art. L.631-1 states the general capacity of national regulators to exchange information free } \\
\text { from requirements of professional secrecy. Art. L.631-2. creates a Board of Financial sector } \\
\text { supervisory agencies composed of the Governor of the BdF, the president of the CB, the } \\
\text { president of the CCAMIP, and of the President of the AMF, or their representatives. It is } \\
\text { chaired by the Minister of Finance or his representative. The various functions of each of the } \\
\text { financial agencies are clearly spelled out in the Code, and the website of the AMF contains a } \\
\text { diagram of the changes in functions effectuated by the LSF. }\end{array}$ \\
\hline Assessment & Observed. \\
\hline 5.3 & $\begin{array}{l}\text { The role of oversight agencies with regard to payment systems should be publicly } \\
\text { disclosed. }\end{array}$ \\
\hline Practice & $\begin{array}{l}\text { The role of the AMF as regards to payments and settlements systems is provided for under } \\
\text { Art. L. } 621-7 \text { of the COMOFI which states that "The general regulations of the AMF determine } \\
\text { the following: }[\ldots] 2^{\circ} \text { ) the conditions of activities of the members of the clearing houses } \\
\text { mentioned under Art. L. } 442-2 ;[\ldots] \text { [and } 7^{\circ} \text { ) the conditions in which, in accordance to } \\
\text { Art. L. } 442-1 \text {, the AMF approves the rules of the clearing houses, without prejudice to the } \\
\text { competences conferred to the BdF under Art. L.141.4. }\end{array}$ \\
\hline Assessment & Observed. \\
\hline 5.3 .1 & $\begin{array}{l}\text { The agencies overseeing the payment system should promote the timely public disclosure } \\
\text { of general policy principles (including risk management policies) that affect the robustness } \\
\text { of systemically important payment systems. }\end{array}$ \\
\hline \multicolumn{2}{|l|}{ Practice } \\
\hline Assessment & Not applicable. \\
\hline Comments & This task is a responsibility of the BdF. \\
\hline 5.4 & $\begin{array}{l}\text { Where financial agencies have oversight responsibilities for self-regulatory organizations } \\
\text { (e.g., payment systems), the relationship between them should be publicly disclosed. }\end{array}$ \\
\hline \multicolumn{2}{|l|}{ Practice } \\
\hline Assessment & Not applicable. \\
\hline Comments & The French securities regulatory system does not make use of self-regulatory organizations. \\
\hline 5.5 & $\begin{array}{l}\text { Where self-regulatory organizations are authorized to perform part of the regulatory and } \\
\text { supervisory process, they should be guided by the same good transparency practices } \\
\text { specified for financial agencies. }\end{array}$ \\
\hline Practice & \\
\hline
\end{tabular}




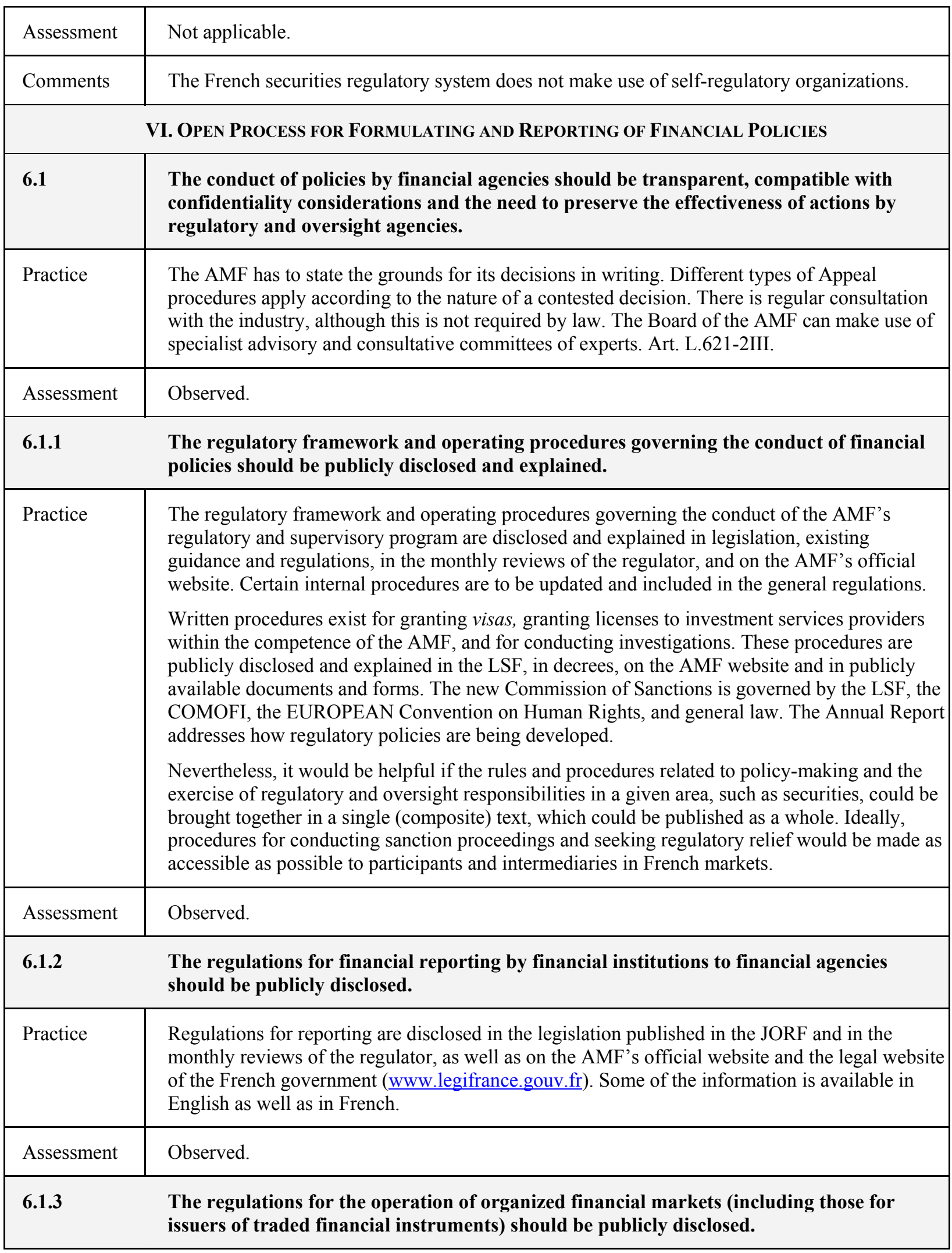




\begin{tabular}{|c|c|}
\hline Practice & $\begin{array}{l}\text { Regulations are published on the AMF website and as required by law, in official bulletins. The } \\
\text { rules of the markets, clearing organizations and information on the interests traded are readily } \\
\text { available on the Euronext website and on the websites of its complex of markets (e.g., } \\
\text { www.euronext.com). Those rules that are harmonized are particularly identified; as are those } \\
\text { that are not. }\end{array}$ \\
\hline Assessment & Observed. \\
\hline 6.1.4 & $\begin{array}{l}\text { Where financial agencies charge fees to financial institutions, the structure of such fees } \\
\text { should be publicly disclosed. }\end{array}$ \\
\hline Practice & $\begin{array}{l}\text { The parameters (rates, amounts) for the applicable fees are publicly stated in the COMOFI and } \\
\text { specified by a decree (Art L.621-5-3). They are disclosed and publicly available. }\end{array}$ \\
\hline Assessment & Observed. \\
\hline 6.1.5 & $\begin{array}{l}\text { Where applicable, formal procedures for information sharing and consultation between } \\
\text { financial agencies (including central banks), domestic and international, should be } \\
\text { publicly disclosed. }\end{array}$ \\
\hline Practice & $\begin{array}{l}\text { Formal procedures providing for information sharing mechanisms are publicly disclosed in } \\
\text { legislation and published in official bulletins. As stated under 5.2, Art L.631.1 provides for } \\
\text { domestic mechanisms for cooperation and information sharing, while Art L.632.1 provides for } \\
\text { exchange of information to foreign counterparts under the condition that the competent } \\
\text { counterpart to the AMF, the market undertakings, or clearing houses of the regulated markets is } \\
\text { submitted to professional secrecy requirements in a legislative framework that provides } \\
\text { equivalent guarantees to those applicable in France and that reciprocity can be observed. } \\
\text { Memoranda of understanding are public documents and are available on the AMF website. }\end{array}$ \\
\hline Assessment & Observed. \\
\hline 6.2 & $\begin{array}{l}\text { Significant changes in financial policies should be publicly announced and explained in a } \\
\text { timely manner. }\end{array}$ \\
\hline Practice & $\begin{array}{l}\text { Significant changes in financial market regulation and supervision are announced and explained } \\
\text { through the AMF's monthly review, its annual reports, its website and the media. In order to be } \\
\text { applied to market participants and regulated entities, rules must be made public as a matter of } \\
\text { law. As a consequence, changes are timely announced and explained to the public. }\end{array}$ \\
\hline Assessment & Observed. \\
\hline 6.3 & $\begin{array}{l}\text { Financial agencies should issue periodic public reports on how their overall policy } \\
\text { objectives are being pursued. }\end{array}$ \\
\hline Practice & $\begin{array}{l}\text { The AMF reports on how its overall policy objectives are being pursued on a monthly basis in } \\
\text { the AMF Review ( Formerly COB and CMF monthly reviews), as well as in its annual reports, } \\
\text { in the media, and on an ongoing basis on its website. Announcements are also made on matters } \\
\text { of emergent interest- for example, specific guidance was provided on certain issues after the } \\
\text { Parmalat crisis. }\end{array}$ \\
\hline Assessment & Observed. \\
\hline
\end{tabular}




\begin{tabular}{|c|c|}
\hline 6.4 & $\begin{array}{l}\text { For proposed substantive technical changes to the structure of financial regulations, there } \\
\text { should be a presumption in favor of public consultations, within an appropriate period. }\end{array}$ \\
\hline Practice & $\begin{array}{l}\text { For proposed substantive technical changes to the structure of financial regulations, } \\
\text { consultations take place with market participants and working groups of experts. Some } \\
\text { consultations have included the posting of a draft document on the website with a call for } \\
\text { comments from the public. The AMF also works through the Committee of European Securities } \\
\text { Regulators (CESR), which has a comprehensive consultation process. The COMOFI also makes } \\
\text { specific provision for certain consultative committees: the Comite Consultatif du Secteur } \\
\text { Financier (CCSF) (Art. L.614-1) is charged with studying questions as to relations between } \\
\text { banks, investment firms, and insurance companies on the one hand and their respective clients } \\
\text { on the other, and with formulating opinions or recommendations for appropriate measures It } \\
\text { may act in response to the Ministry, organizations representing their respective clients or } \\
\text { professional organizations to which its members belong, or it can act on its own initiative. The } \\
\text { Comité Consultatif de la Législation et de la Réglementation Financières (CCLRF) (Art. L.614- } \\
2 \text { \&3) is a new institution that will be convened with respect to every rule or general directive } \\
\text { except for texts within the sole competence of the AMF. These will not be adopted without an } \\
\text { opinion of the CCLRF, which is the successor agency to the CRBF. The composition of the } \\
\text { CCLRF is set by decree and includes industry representatives. The Ministry (except in the case } \\
\text { of the AMF) itself develops all prudential rules. As the CCLRF's deliberations are relevant to } \\
\text { rulemaking, they may be public on request. Additionally, the AMF Board can constitute } \\
\text { specialist committees from its members presided over by the Chair to consider individual issues } \\
\text { and can constitute consultative committees of experts, which the Board names, if the need arises } \\
\text { to consider specific issues (Art. L.621-2III). } \\
\text { While the AMF states that its policy is to seek consultations on all significant issues whenever } \\
\text { possible and appropriate, it has not publicly committed itself to doing so for all substantive } \\
\text { technical changes to the structure of its regulations. Such a commitment, formulated in a } \\
\text { publicly available policy statement, regulation or law, would further enhance transparency. }\end{array}$ \\
\hline Assessment & Observed. \\
\hline \multicolumn{2}{|r|}{ ViI. Public Availability of Information on Financial Policies } \\
\hline 7.1 & $\begin{array}{l}\text { Financial agencies should issue a periodic public report on the major developments of the } \\
\text { sector(s) of the financial system for which they carry designated responsibility. }\end{array}$ \\
\hline Practice & $\begin{array}{l}\text { The AMF reports extensively on financial market developments in its annual report. It also } \\
\text { publishes a set of quarterly statistical publications on its website, which provide data on } \\
\text { developments in different markets and market segments. }\end{array}$ \\
\hline Assessment & Observed. \\
\hline 7.2 & $\begin{array}{l}\text { Financial agencies should seek to ensure that, consistent with confidentiality } \\
\text { requirements, there is public reporting of aggregate data related to their jurisdictional } \\
\text { responsibilities on a timely and regular basis. }\end{array}$ \\
\hline Practice & $\begin{array}{l}\text { Aggregate data are published on a monthly and annual basis. Information is available on certain } \\
\text { sanctions and also on the status of authorized institutions on the official website of either the } \\
\text { AMF (which is updated monthly) or the CECEI, with respect to their specific areas of } \\
\text { competence. }\end{array}$ \\
\hline
\end{tabular}




\begin{tabular}{|c|c|}
\hline Assessment & Observed. \\
\hline 7.3 & $\begin{array}{l}\text { Where applicable, financial agencies should publicly disclose their balance sheets on a } \\
\text { pre-announced schedule and, after a predetermined interval, publicly disclose information } \\
\text { on aggregate market transactions. }\end{array}$ \\
\hline Practice & $\begin{array}{l}\text { The COB and CMF used to publish their financial statements annually. Specific provisions for } \\
\text { the publication of the AMF's annual financial statement are found under Art } 32 \text { of the } \\
\text { Decree } 2003-1119 \text { of } 21 \text { November } 2003 \text {. The balance sheet is disclosed in the Annual Report. } \\
\text { Further details on publication arrangements remain to be specified. } \\
\text { The AMF does not engage in market transactions. }\end{array}$ \\
\hline Assessment & Observed. \\
\hline 7.3 .1 & $\begin{array}{l}\text { Consistent with confidentiality and privacy of information on individual firms, aggregate } \\
\text { information on emergency financial support by financial agencies should be publicly } \\
\text { disclosed through an appropriate statement when such disclosure will not be disruptive to } \\
\text { financial stability. }\end{array}$ \\
\hline \multicolumn{2}{|l|}{ Practice } \\
\hline Assessment & Not applicable. \\
\hline Comments & The AMF does not provide emergency financial support. \\
\hline 7.4 & Financial agencies should establish and maintain public information services. \\
\hline Practice & $\begin{array}{l}\text { The AMF has a regularly updated website: www.amf-france.org, which contains an } \\
\text { organization chart, policy announcements, descriptions of its operating framework, data and } \\
\text { speeches. Furthermore, the AMF currently posts information on Collective Investment Schemes } \\
\text { in an online database known as GECO (Gestion collective). For example, the AMF makes } \\
\text { information on the Net Asset Valuations of Collective Investment Schemes (CIS) available to } \\
\text { the public on a daily basis for the majority of funds, and on a required schedule for the } \\
\text { remainder. All relevant information on new issues, listed securities and the issuers it supervisors } \\
\text { is available in another online database known as "Décisions et informations financières (DIF)." } \\
\text { Both databases are available on its website. Additional information will be posted on the site in } \\
\text { the future. }\end{array}$ \\
\hline Assessment & Observed. \\
\hline 7.4.1 & $\begin{array}{l}\text { Financial agencies should have a publications program, including a periodic public report } \\
\text { on their principal activities issued at least annually. }\end{array}$ \\
\hline Practice & $\begin{array}{l}\text { By law, the AMF has to publish an Annual Report. In addition, it publishes an official monthly } \\
\text { bulletin, research publications, speeches of officials, nontechnical descriptions of its role and } \\
\text { functions, newsletters and pamphlets for educational purposes. Educational pamphlets are free } \\
\text { of charge, and the AMF maintains a public document room. }\end{array}$ \\
\hline Assessment & Observed. \\
\hline
\end{tabular}




\begin{tabular}{|c|c|}
\hline 7.4.2 & $\begin{array}{l}\text { Senior financial agency officials should be ready to explain their institution's objective(s) } \\
\text { and performance to the public, and have a presumption in favor of releasing the text of } \\
\text { their statements to the public. }\end{array}$ \\
\hline Practice & $\begin{array}{l}\text { In addition to the requirement to publish an annual public report, the AMF's senior officials are } \\
\text { committed to increasing transparency by explaining the AMF's actions, objectives and } \\
\text { performance through participation in conferences, speeches, public meetings and media } \\
\text { interviews. Texts are released in the review, the media, and on the website. }\end{array}$ \\
\hline Assessment & Observed. \\
\hline 7.5 & $\begin{array}{l}\text { Texts of regulations and any other generally applicable directives and guidelines issued by } \\
\text { financial agencies should be readily available to the public. }\end{array}$ \\
\hline Practice & $\begin{array}{l}\text { Regulatory texts are available on the website. The website is well organized and provides } \\
\text { information by type (Law, regulation); by theme, and a special search facility. Nonetheless, it is } \\
\text { sometimes difficult to retrieve information on old but still applicable law. Other guidance is } \\
\text { available in the Monthly Bulletin, and in some cases in the BALO (Bulletin des annonces } \\
\text { légales officiel). }\end{array}$ \\
\hline Assessment & Observed. \\
\hline 7.6 & $\begin{array}{l}\text { Where there are deposit insurance guarantees, policy-holder guarantees, and any other } \\
\text { client asset protection schemes, information on the nature and form of such protections, } \\
\text { on the operating procedures, on how the guarantee is financed, and on the performance of } \\
\text { the arrangement, should be publicly disclosed. }\end{array}$ \\
\hline Practice & $\begin{array}{l}\text { The Fonds de Garantie des Titres (FGT-Securities Guarantee Fund, also called Fonds de } \\
\text { Garantie des dépotts - Mécanisme de Garantie des Titres or Deposit Guarantee Fund-Securities } \\
\text { Guarantee Mechanism) was established by the Act dated } 25 \text { June } 1999 \text { on savings and financial } \\
\text { security. It is managed by the FGD. The latter is a legal entity under private law governing three } \\
\text { guarantee mechanisms, for bank deposits, securities, and warranties. It is governed by a } \\
\text { Management Board under the control of a Supervisory Board. The guaranteed securities } \\
\text { (equity, debt, mutual fund units, and futures) are defined under Art. L.211-1 of the COMOFI. } \\
\text { The guarantees are in the process of being consolidated. } \\
\text { The amounts collected and managed by each Guarantee Mechanism (Depositors, Securities and } \\
\text { Collaterals) are determined by CRBF* Regulations n } \text { n }^{\circ} 99-06 \text { and } 99-07 \text { (for depositors), } 99-15 \\
\text { and } 99-17 \text { (for securities) and 99-12 (warranties). Moreover, if necessary, contributors to the } \\
\text { FGD have to provide it enough funds to enable it to meet its obligations. The maximum } \\
\text { guarantee per individual is EUR } 70,000 \text { per institution (which is more generous than required } \\
\text { under the European Directives), irrespective of the number of accounts, the assets contained in } \\
\text { the accounts, or the type of currency. Information on the system is publicly available, see } \\
\text { www.banque-france.fr/fr/infobafi/regles/11.htm. Also see Art. L.312-2 to } 18 \text {. }\end{array}$ \\
\hline
\end{tabular}

* The CRBF no longer is in existence ; it is succeeded by the Comité consultatif de la législation et de la réglementation financières (CCLRF), Article L.614-1 to 3. The CCLRF will be responsible for developing prudential regulation, subject to the particular competences of the AMF with respect to asset management. 


\begin{tabular}{|c|c|}
\hline Assessment & Observed. \\
\hline 7.7 & $\begin{array}{l}\text { Where financial agencies oversee consumer protection arrangements (such as dispute } \\
\text { settlement processes), information on such arrangements should be publicly disclosed. }\end{array}$ \\
\hline Practice & $\begin{array}{l}\text { The ombudsman of the AMF assists in the out-of-court settlement of disputes between retail } \\
\text { investors and professionals. The AMF also plays a role in the recognition of minority } \\
\text { shareholders' rights and in the minority shareholders' association (in accordance with the } \\
\text { January } 5,1988 \text { Company Law). This is publicly disclosed, including through an extensive } \\
\text { presentation of the mediating role of the AMF on its website. Summaries of types of mediations } \\
\text { are reported in the Annual Report. }\end{array}$ \\
\hline Assessment & Observed. \\
\hline \multicolumn{2}{|r|}{ 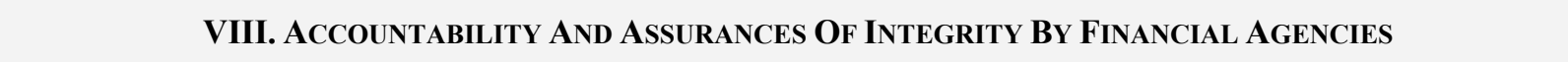 } \\
\hline 8.1 & $\begin{array}{l}\text { Officials of financial agencies should be available to appear before a designated public } \\
\text { authority to report on the conduct of financial policies, explain the policy objective(s) of } \\
\text { their institution, describe their performance in pursuing their objective(s), and, as } \\
\text { appropriate, exchange views on the state of the financial system. }\end{array}$ \\
\hline Practice & $\begin{array}{l}\text { Officials are available to appear before designated public agencies. The main accountability } \\
\text { procedures stated above are organized before the President of the Republic and the } \\
\text { Commissions of finance of both parliamentary assemblies, and also at the public audit of the } \\
\text { Cour des comptes, a judicial body responsible for overseeing the accounts of the public sector. } \\
\text { The President may request to be heard or may be called at any time. }\end{array}$ \\
\hline Assessment & Observed. \\
\hline 8.2 & $\begin{array}{l}\text { Where applicable, financial agencies should publicly disclose audited financial statements } \\
\text { of their operations on a pre-announced schedule. }\end{array}$ \\
\hline \multirow[t]{5}{*}{ Practice } & $\begin{array}{l}\text { Financial statements are prepared by an official of the Ministry, the Agent Comptable, who is a } \\
\text { public accountant, and who serves at the discretion of the Ministry. This accountant is } \\
\text { independent from the AMF itself and is personally liable for his work. He prepares the financial } \\
\text { statements for approval by the Board of the AMF. Subsequent to this approval, the statements } \\
\text { are submitted to the Cour des comptes, which has the power to conduct an audit of the accounts } \\
\text { The balance sheet, a statement of operations, and summary information on these statements are } \\
\text { published in the Annual Report. Exceptions are also published either in a report of the Cours } \\
\text { des comptes or in the report of the AMF. However, financial statements of the AMF are not } \\
\text { audited on a specified periodic basis, and audited statements are not published on a pre- } \\
\text { announced schedule. }\end{array}$ \\
\hline & $\begin{array}{l}\text { Articles } 33 \text { and } 34 \text { of the } 2003 \text { Decree establish the accounting rules according to which the } \\
\text { AMF's accounts are established and published: }\end{array}$ \\
\hline & The accounts are established and their operations validated by a public civil servant. \\
\hline & $\begin{array}{l}\text { They are transmitted to the Secretary General of the AMF for presentation to, and approval by, } \\
\text { the board. }\end{array}$ \\
\hline & $\begin{array}{l}\text { The accounting figures are sent to the Cour des comptes (dépôt sur chiffres) and all justifying } \\
\text { documents are kept at their disposal for ten years by the AMF. }\end{array}$ \\
\hline
\end{tabular}




\begin{tabular}{|c|c|}
\hline & $\begin{array}{l}\text { The accounts are not audited every year (but at random) by the Cour des comptes. } \\
\text { While the present arrangements do likely provide high-quality financial statements and a high } \\
\text { degree of transparency and integrity, it would still be useful to have a second independent party } \\
\text { audit the work of the Agent Comptable on a regular basis. } \\
\text { It is understood that the treatment of financial statements for the new organization of the AMF } \\
\text { may evolve in coming years as a result of internal discussions. } \\
\text { See also 8.2.2. }\end{array}$ \\
\hline Assessment & Partly observed. \\
\hline Comments & $\begin{array}{l}\text { For an "observed" assessment, the AMF's financial statements should be audited on a regular } \\
\text { basis, rather than exceptionally, they should be fully publicly disclosed, and the annual report } \\
\text { that contains them should be published on a pre-announced schedule. }\end{array}$ \\
\hline 8.2 .1 & $\begin{array}{l}\text { Financial statements, if any, should be audited by an independent auditor. Information on } \\
\text { accounting policies and any qualification to the statements should be an integral part of } \\
\text { the publicly disclosed financial statements. }\end{array}$ \\
\hline Practice & $\begin{array}{l}\text { Financial statements are audited, but not on a systematic schedule, by the Cour des Comptes, } \\
\text { which is an independent government agency (see also 8.2). The Cour des Comptes is similar to } \\
\text { a Comptroller General's office in other jurisdictions. } \\
\text { The AMF is in the process of determining what will be disclosed with respect to accounting } \\
\text { policies and qualifications to audited statements under the new regulatory structure. }\end{array}$ \\
\hline Assessment & Broadly observed. \\
\hline Comments & $\begin{array}{l}\text { For an "observed" rating, audits should be done annually, and the accounting policies and any } \\
\text { qualifications to the statements should be published as an integral part of the AMF's publicly } \\
\text { disclosed financial statements. }\end{array}$ \\
\hline 8.2 .2 & $\begin{array}{l}\text { Internal governance procedures necessary to ensure the integrity of operations, including } \\
\text { internal audit arrangements, should be publicly disclosed. }\end{array}$ \\
\hline Practice & $\begin{array}{l}\text { The organigram of the AMF is posted on its website (www.amf-france.org), as are its main } \\
\text { governance procedures. The AMF is in the process of creating an internal audit division that } \\
\text { reports directly to the Chair. The internal audit division is already marked on the organizational } \\
\text { chart and is expected to be led by two staff to be appointed this summer. This division will } \\
\text { make a review of operating procedures and propose refinements intended to increase efficiency. } \\
\text { Division heads within the AMF are responsible for the oversight of the operations of their } \\
\text { Division and report on such operations to the Secretary General. The AMF staff must comply } \\
\text { with requirements on securities ownership and on transaction reporting. These requirements are } \\
\text { available to the public. } \\
\text { Internal by-laws (the Statut des personnels) of the AMF related to internal provisions aimed at } \\
\text { ensuring that the highest professional standards are observed can be obtained on request. The } \\
\text { information provided to the AMF Officer of Ethics (Déontologue) is only accessible to the } \\
\text { auditors and to the president of the AMF. In cases of investigation, these forms are also } \\
\text { available to the judge. In addition, the President, the members of the AMF and the staff are } \\
\text { subject to the rules of the Penal Code concerning professional secrecy. Financial controls are } \\
\text { audited in connection with the financial statements as set forth above. }\end{array}$ \\
\hline
\end{tabular}




\begin{tabular}{|c|c|}
\hline Assessment & Broadly observed. \\
\hline Comments & $\begin{array}{l}\text { This practice will be "observed" when the internal governance procedures are fully elaborated, } \\
\text { operational, and publicly disclosed. Among other things, this requires the internal audit division } \\
\text { to be staffed and operational (which is expected to be during the Summer of 2004). It is } \\
\text { suggested that the review of operational efficiencies also encompasses a review of the } \\
\text { operational integrity of the structure. }\end{array}$ \\
\hline 8.3 & $\begin{array}{l}\text { Where applicable, information on the operating expenses and revenues of financial } \\
\text { agencies should be publicly disclosed annually. }\end{array}$ \\
\hline Practice & The AMF publicly discloses and presents its budget in its annual report. \\
\hline Assessment & Observed. \\
\hline 8.4 & $\begin{array}{l}\text { Standards for the conduct of personal financial affairs of officials and staff of financial } \\
\text { agencies and rules to prevent exploitation of conflicts of interest, including any general } \\
\text { fiduciary obligation, should be publicly disclosed. }\end{array}$ \\
\hline Practice & $\begin{array}{l}\text { Standards for the conduct of personal financial affairs are set by the law. They apply to the } \\
\text { President of the AMF, the members of the commission and the staff. In addition, by law the } \\
\text { president and members of the AMF are required to disclose to the commission any other } \\
\text { financial functions or interests. Art. L. } 621-4 \text { provides specific rules for preventing conflicts of } \\
\text { interests. By AMF regulation adopted in March, Members are also restricted with respect to the } \\
\text { holding and trading of securities. }\end{array}$ \\
\hline Assessment & Observed. \\
\hline 8.4.1 & $\begin{array}{l}\text { Information about legal protections for officials and staff of financial agencies in the } \\
\text { conduct of their official duties should be publicly disclosed. }\end{array}$ \\
\hline Practice & $\begin{array}{l}\text { Officials, the Members of the Board and staff of the AMF are not personally liable in the bona } \\
\text { fide discharge of their functions, and those protections are publicly disclosed. The AMF has } \\
\text { legal personality and therefore can itself sue and be sued. The scope of liability is established } \\
\text { under the law, but the principle does not apply to the regulator itself. }\end{array}$ \\
\hline Assessment & Observed. \\
\hline
\end{tabular}


Table 43. Summary Observance of IMF's MFP Transparency Code-Securities Regulation

\begin{tabular}{|l|c|l|}
\hline \multirow{2}{*}{ Assessment Grade } & \multicolumn{2}{|c|}{ Practices Grouped by Assessment Grade } \\
\cline { 2 - 3 } & Count & \multicolumn{1}{c|}{ List } \\
\hline Observed & 29 & $\begin{array}{l}5.1,5.1 .1,5.1 .2,5.1 .3,5.1 .4,5.2,5.3,6.1,6.1 .1, \\
6.1 .2,6.1 .3,6.1 .4,6.1 .5,6.2,6.3,6.4,7.1,7.2, \\
7.3,7.4,7.4 .1,7.4 .2,7.5,7.6,7.7,8.1,8.3,8.4, \\
8.4 .1 .\end{array}$ \\
\hline Broadly observed & 2 & $8.2 .1,8.2 .2$. \\
\hline Partly observed & 1 & 8.2. \\
\hline Not observed & 0 & -- \\
\hline Not applicable & 4 & $5.3 .1,5.4,5.5,7.3 .1$. \\
\hline
\end{tabular}

\section{Recommended action plan and authorities' response to the assessment}

\section{Recommended action plan}

Table 44. Recommended Action Plan to Improve Observance of IMF's MFP Transparency Code Practices-Securities Regulation

\begin{tabular}{|c|c|}
\hline Reference Principle & Recommended Action \\
\hline \multicolumn{2}{|c|}{ VIII. Accountability and Assurance of Integrity by Financial Agencies } \\
\hline $\begin{array}{l}\text { Public disclosure of audited financial } \\
\text { statements ( } 8.2 \text { and } 8.2 .1)\end{array}$ & $\begin{array}{l}\text { Have the AMF's financial statements audited at least annually, } \\
\text { rather than on an occasional basis. Publish the audited financial } \\
\text { statements fully, on a pre-announced schedule. Include the } \\
\text { accounting policies and any qualifications to the statements as } \\
\text { an integral part of these publicly disclosed financial statements }\end{array}$ \\
\hline $\begin{array}{l}\text { Disclosure of internal governance } \\
\text { procedures }(8.2 .2)\end{array}$ & $\begin{array}{l}\text { Elaborate and publicly disclose the AMF's internal governance } \\
\text { procedures, and make them operational. }\end{array}$ \\
\hline
\end{tabular}




\section{Authorities' response to the assessment}

140. The AMF notes that its financial statements are subject to several statutory mechanisms of accountability to the President of the Republic, to the Parliament and its commissions of finance, a special investigative committee that can be convened by the Parliament, and a routine basis accountability to the Cour des Comptes. The transmission of the financial statements to the latter is made yearly and the justifying documents are kept at its disposal for ten years. Those can be audited at any time by the Cour des Comptes and any practice that is not compliant with the principle of good governance shall be made public in its annual report. Moreover, it should be noted that the IOSCO principles and methodology, although defining clear accountability and transparency criteria, do not go as far as to require an external auditor to audit the regulator's account annually and to publish the findings of this audit on a pre-announced schedule.

141. The AMF notes that under this principle relating to internal governance, several interrelating issues seem to have to be taken into consideration. These include provisions on the governance of staff and members of the Board on conflict of interests, but might also encompass questions related to the integrity of the decision making process as a whole and the integrity of the internal procedure mainly of operational areas. In this regard, as noted by the experts in their conclusion, the AMF is in the process of hiring an internal control officer and his deputy and will therefore soon be able to comply with the requirements set forth under this principle, although it is worth noting that this new internal control division will only add an independent level of control on procedures already set up by the management of the AMF accountable to the Secretary General.

\section{COMPLIANCE WITH THE FATF RECOMMENDATIONS FOR ANTI-MONEY LAUNDERING AND COMBATING THE FINANCING OF TERRORISM}

\section{A. General}

\section{Information and methodology used for the assessment}

142. A detailed assessment of the anti-money laundering (AML) and combating the financing of terrorism (CFT) regime of France was prepared by a team of assessors that included staff of the International Monetary Fund (IMF), and two experts under the supervision of IMF staff. The team reviewed the relevant AML/CFT laws and regulations, and supervisory and regulatory systems in place to deter money laundering (ML) and financing of terrorism (FT) among prudentially regulated financial institutions as well as the regulatory systems in place for non-prudentially regulated sectors that are macro-relevant, specifically funds transfer businesses, currency exchangers, La Poste, insurance brokers, direct marketers of financial services and non-financial businesses and professions. The team staff reviewed the regulatory systems in place for the capacity and implementation of criminal law enforcement systems. 
143. The team consisted of Mr. Richard Lalonde (MFD), Mr. Nadim Kyriakos-Saad (LEG), Mr. Philippe Fleury (Switzerland's Autorité de contrôle en matière de lutte contre le blanchiment d'argent), and Mr. Ludovic D'Hoore (Belgium's Cellule de Traitement des Informations Financières).

144. To conduct the assessment, the team visited Paris from April 7 to April 22, 2004. The mission team held extensive discussions with representatives from the Ministry of Economy, Finance and Industry (MINEFI), the Ministry of Justice, the Ministry of Interior, the Commission Bancaire, the Commission de Contrôle des Assurances, the Autorité des Marchés Financiers, the Banque de France, licensing authorities, TRACFIN (Traitement du Renseignement et Action contre les Circuits Financiers Clandestins, France's FIU), Customs, and the Police. The assessment team also met with representatives from individual banks, la Poste, insurance companies, securities firms and financial sector associations.

145. The assessment team is appreciative of the time and cooperation received from all participants and would like to thank in particular the MINEFI for the organization of meetings and the coordination of inputs.

\section{General situation of money laundering and financing of terrorism}

146. France's FATF mutual evaluation report of 1996 stated that because of its stable economy and political situation and its strong currency, France was attractive to money launderers. The report also stated that while in France the problem was less one of placement of cash than of secondary laundering (layering) or third degree laundering (integration), traditional laundering techniques were still being used, including the simplest ones, such as foreign exchange transactions via money changers. France's mutual evaluation report noted that most laundering cases involved international networks and foreign nationals and that few such cases were linked to local drug trafficking. This would appear to remain the case today. It is believed that common methods of laundering money include the use of bank deposits, foreign currency and gold bullion transactions, corporate transactions, and purchases of real estate, hotels, and works of art. There are reports that foreign organized crime networks are using the French Riviera to launder assets (or invest those previously laundered) by buying up real estate. There are no statistics and no empirical estimates by which to evaluate the volume of revenues to be laundered. There are no statistics or estimates with regard to terrorist financing activities.

\section{Overview of measures to prevent money laundering and terrorism financing}

147. As an active member of the FATF, France has played a leading role in the development and promotion of the FATF 40+8 Recommendations as an international standard. It has been equally and steadily active since 1987, when it first criminalized money laundering, in developing a comprehensive AML/CFT regime. It established TRACFIN in 1990, thus becoming one of the first countries to establish a financial intelligence unit. A law on preventive measures was also enacted in 1990, among other things introducing a requirement to report suspicious transactions. In 1993, the scope of the suspicious transaction 
reporting requirement was extended to funds or transactions suspected of being related to organized crime, in addition to drug trafficking. In 1996, the scope of the predicate offences for money laundering was extended to all crimes and misdemeanors. In 1998 and 2001, the sectoral coverage of preventive measures was extended beyond the financial sector to certain non-financial businesses and professions (notably real estate professional, casinos and dealers in high value goods) and additional transaction reporting requirements were introduced. In 2003, sectoral coverage was again broadened to include individual and collective portfolio management firms, direct marketers of financial services and investment advisers, and the authorities of financial sector supervisors were clarified and strengthened. In 2004, the scope of the suspicious transaction reporting requirement was extended to funds or transactions suspected of being related to corruption and fraud against the financial interests of the European Communities. The reform of 2004 also broadened the coverage of requirements to the legal and accountancy professions. It also strengthened customer identification requirements. Following the revision of the FATF 40+8 Recommendations in 2003, work is well underway on the further development of the legal and institutional framework, further evidence of France's longstanding commitment to combating money laundering and terrorist financing.

148. The overall legal and institutional framework currently in place is comprehensive and France maintains a high level of compliance with the FATF 40+8 Recommendations. In many respects its regime has gone beyond the standard, including in the sectoral coverage of preventive measures and in the range of reporting requirements that apply to financial entities. That said, the assessment identified areas where further improvements could be achieved, mainly: the implementation of UN Security Council Special Resolution on terrorism financing, as in other European countries operating within the European Union regulatory framework; the overall quality of STRs; AML/CFT regulation, supervision and enforcement for sectors other than credit institutions and certain investment firms; and requirements for increased diligence and internal controls.

\section{B. Main Findings}

\section{Criminal justice measures and international cooperation}

149. France has ratified the United Nations Convention on Illicit Drugs and Psychotropic Substances (Vienna Convention), the UN International Convention for the Suppression of the Financing of Terrorism and the UN Convention Against Transnational Organized Crime 2000 (Palermo Convention). France is also a party to the Council of Europe Convention on Laundering, Search, Seizure and Confiscation of the Proceeds from Crime (Strasbourg Convention). Legal provisions for the criminalization of money laundering and terrorist financing are in place. The scope of predicate offences for ML is very extensive and covers all crimes and misdemeanors, including FT and fiscal fraud. FT is criminalized comprehensively.

150. French legislation provides broad possibilities to seize any assets in the course of investigations, either by officers of judicial police or on instruction of the judiciary. 
Although, in theory, all assets of a convicted person can be confiscated, in practice, confiscation measures generally apply to the assets seized in the course of the judicial procedure. As an alternative, fines can be increased to half the level of the laundered funds.

151. France implements the United Nations Security Council Resolutions 1267, 1269, 1333, 1373, and 1390 through directly applicable European Union legislation. France is currently unable to comply fully with UN Security Council Resolution 1373 with regard to terrorists or terrorist groups from within the European Union as they are not covered by EU Council Regulations. The Constitutional Treaty established by the European Convention includes provisions that would lift this distinction. Pending its adoption, a draft bill has been prepared to enable the government to impose financial sanctions and administratively freeze assets of terrorists or terrorist groups based within the European Union in compliance with UN Security Council Resolution 1373. The draft bill has to undergo a consultative process and the timeframe for its adoption is uncertain at this stage.

152. TRACFIN, the FIU in France, is an Egmont member and has been operational since 1991. It can issue blocking or freezing instructions which are valid for 12 hours where suspicious transactions are reported prior to their execution. This procedure was used only on seven occasions since TRACFIN became operational and has produced minimal results.

153. The interaction between TRACFIN, the supervisory authorities and law enforcement has improved markedly recently and appears to be reasonably efficient. TRACFIN can cooperate with its foreign counterpart units to share intelligence information and data likely to be linked to ML or FT on the basis of the national legislation that is consistent with the Egmont Group principles and has concluded cooperation agreements with 24 foreign counterparts.

154. The number of STRs has increased rapidly since 2000, but still seems rather low compared to the financial and economic activity on the French market and the recent increase in reporting has not been accompanied by a significant increase in the overall quality of reports. Although it has increased, the number of files forwarded by TRACFIN to the judicial authorities is still relatively limited. TRACFIN indicates that this is mainly due to the poor quality of a large number of STRs.

155. A working group of the Liaison Committee is currently working on establishing an electronic reporting form that should enhance the analytical capabilities of both the reporting parties and TRACFIN, improve the overall quality of STRs and the quantity and quality of transmissions by TRACFIN, and assist in the compilation of more detailed statistics.

156. ML and FT investigations are carried out by law enforcement under supervision of the judiciary. The Judiciary Police, the Préfecture de Police, the Gendarmerie and Customs have established divisions specialized in economic and financial crime, including ML, that also benefit from specific training programs. Depending on the stage of the enquiries, they can use a wide range of investigative techniques but a large number of cases are not pursued due to insufficient financial and human resources. A recent reform by the Law of March 9, 
2004 entering into force on October 1, 2004 and introducing specialized jurisdictions is expected to enhance the overall capacity of the judicial system to combat financial crime.

157. The number of convictions for ML is on the increase, although the ML offence does not appear to be used as frequently as it might be due mainly to the difficulty in establishing the illegal origin of the funds. Courts appear to have adopted a pragmatic solution to this difficulty that consists in qualifying the facts differently and pursuing cases under other offences than the ML offence (abus de biens sociaux, association de malfaiteurs, etc.). While a recent case indicates that a conviction for (general) ML can be pronounced without the predicate offence being specifically identified, additional reflection is needed on the obstacles that requiring proof of the predicate offence constitutes for an effective fight against ML.

158. Despite the efforts and determination of the authorities involved in fighting terrorism financing, no significant results in terms of convictions have been obtained so far, mainly due to the recent incrimination of FT and to the complicated and time consuming enquiries, in particular the difficulty of linking suspicious financial movements with terrorist activities. A pragmatic solution is to qualify the facts under investigation as association de malfaiteurs.

159. France pursues a policy of active international cooperation and has an impressive set of bilateral and multilateral treaties for MLA and extradition in ML and FT cases. It provides timely and effective follow-up to mutual legal assistance requests.

160. French law provides that the confiscation of assets on French territory operates as a transfer of property to the state unless otherwise agreed with the requesting state. In addition, the sharing of assets may be provided in a bilateral treaty.

\section{Preventive measures for financial institutions}

161. The institutional framework for financial sector regulation, supervision and licensing is organized sectorally. Regulation-making authority rests largely with the Minister of the Economy, as a result of the Law on Financial Security of 2003. The CECEI licenses credit institutions and investment firms other than portfolio management firms ("credit institutions and investment firms"), the CEA licenses insurance companies and the AMF licenses, inter alia, portfolio management firms, direct marketers of financial products ("démarcheurs) and investment advisers. Licensing requirements include "fit and proper" testing of managers and significant shareholders. Other financial entities are subject to registration requirements, notably insurance brokers, currency exchangers, direct marketers and investment advisors, with varying degrees of "fit and proper" testing. In general, AML/CFT internal controls policies and procedures are not taken into account for licensing purposes.

162. The CB supervises credit institutions and investment firms for AML/CFT compliance, the CCA has similar responsibilities for insurance companies and brokers and the AMF for portfolio management firms, direct marketers and investment advisers. The IGF is responsible for AML/CFT supervision of La Poste's financial services. 
163. Enforcement and sanction powers of supervisory authorities are generally appropriate. However, AML/CFT supervisory efforts and corresponding resources are relatively low with respect to life insurance companies and brokers, individual and collective portfolio management firms, direct marketers and La Poste. The number of on-site inspections and corresponding staff resources for these sectors is relatively low and there have been few sanctions imposed for failure to comply with AML/CFT requirements. When looked at in the context of historically relatively low rate of reporting of suspicious transactions from these sectors, it is consequently difficult to assess whether AML/CFT requirements are being effectively implemented overall.

164. The legal framework for AML/CFT preventive measures is comprehensive and the regulation and supervision of credit institutions and investment firms other than portfolio management firms is of a high standard. The scope of sectoral application extends well beyond the standard. That said, the regulatory framework remains a work in progress, notably with respect to insurance companies and brokers, individual and collective portfolio management firms, direct marketers and currency exchangers. Regulatory initiatives are underway however, notably in connection with the implementation of the revised FATF standards.

165. The CMF and Decree 91-160 of February 13, 1991 provide an adequate framework for customer identification. Nonetheless, beyond some supervisory and industry recommendations, there is generally insufficient guidance as to what constitutes adequate customer acceptance policies and procedures and, in particular, what are the reasonable steps to be taken to identify beneficial owners of accounts and transactions. The ongoing monitoring of accounts and transactions requirements also need to be broadened.

166. While the Minister of the Economy, Finance and Industry regularly informs financial entities of countries that do not have adequate AML/CFT systems, there is no specific legal requirement for financial entities to give special attention to business relations and transactions with persons in such countries.

167. Financial entities are required to have screening procedures for hiring employees. The requirements focus largely on competency and are silent on the issue of integrity. Employee training appears to be implemented effectively with respect to credit institutions, investment firms, insurance companies and La Poste.

168. The requirement that financial entities report suspicious transactions has evolved/expanded over the past decade. However, the scope of the reporting requirement is not aligned with and is indeed narrower than that of the predicate offences for money laundering, which covers all crimes and misdemeanors, including fiscal fraud. This may be a source of confusion for reporting entities and could potentially reduce the effectiveness of the regime.

169. Additional reporting requirements have been introduced in recent years. However, the benefits of these (notably the one in relation to trusts) are unclear and could potentially draw 
away resources (i.e., of financial entities and TRACFIN) that might otherwise be used in the detection of suspicious transactions.

170. The legal framework for AML/CFT internal controls is supplemented by comprehensive regulations for credit institutions and investment firms. In the case of insurance companies and portfolio management firms, there is reliance instead on supervisory and professional recommendations that are not as comprehensive.

171. Financial entities are required to ensure that their branches and subsidiaries that are located abroad comply with the requirement to pay special attention to certain transactions. However, other than for credit institutions and currency exchangers, there appears to be no specific requirements for financial entities to ensure the comprehensive application of AML/CFT requirements to branches and majority owned subsidiaries located abroad.

\section{Detailed Assessment}

172. The following detailed assessment was conducted using the October 11, 2002 version of Methodology for assessing compliance with the AML/CFT international standard, i.e., criteria issued by the Financial Action Task Force (FATF) 40+8 Recommendations ( the Methodology).

\section{Assessing Criminal Justice Measures and International Cooperation}

Table 45. Detailed Assessment of Criminal Justice Measures and International Cooperation

\section{I-Criminalization of ML and FT}

(compliance with criteria 1-6)

Description

International Conventions and United Nations Resolutions

France ratified the United Nations Convention on Illicit Drugs and Psychotropic Substances (Vienna Convention) on October 31, 1990, the UN International Convention for the Suppression of the Financing of Terrorism on January 7, 2002, and the UN Convention Against Transnational Organized Crime 2000 (Palermo Convention) on February 21, 2002. France is also a party to the Council of Europe Convention on Laundering, Search, Seizure and Confiscation of the Proceeds from Crime (Strasbourg Convention), ratified on October 8, 1996.

France has implemented the United Nations Security Council Resolutions 1267, 1269, 1333, 1373, and 1390 mainly through directly applicable European Union legislation, in particular Council Regulation (EC) 2580/2001 of 27 December 2001 on imposing certain specific restrictive measures directed against certain persons and entities in order to combat terrorism, and Council Regulation (EC) No 881/2002 of May 27, 2002 (and subsequent amendments) on imposing certain specific restrictive measures directed against certain persons and entities associated with Usama bin Laden, the Al-Qaida network and the Taliban. Both Council Regulations imposed directly applicable obligations within the European Union member States to freeze the assets of terrorists or terrorist organizations listed in the UNSCRs.

As discussed in more detail later in the report, France is currently unable to comply fully with UN Security Council Resolution 1373 with regard to terrorists or terrorist groups from within the European Union as they are 
not covered by EU Council Regulations.

\section{Criminalization of Money Laundering}

France has criminalized money laundering through Articles 222-38 and 324-1 of the Criminal Code and Article 415 of the Customs Code. Article 324-1 contains a general incrimination of ML and defines it as (i) the act of facilitating, by any means, the false justification of the source of property or income of the perpetrator of a crime or misdemeanor, from which the latter derived a direct or indirect profit; and (ii) the act of assisting in the investment, concealment, or conversion of the direct or indirect proceeds of a crime or misdemeanor. The constitutive elements of ML of the proceeds of drug trafficking as defined in Article 222-38 of the Criminal Code are identical to those of Article 324-1. Article 415 of the Customs Code criminalizes the act of carrying out or attempting to carry out a financial operation between France and another country involving funds known by the perpetrator to have originated directly or indirectly from an offense referred to in the Customs Code or from a violation of the drug laws. In addition, the offence of non-justification of resources in connection with drug trafficking was created by Article 222-39-1 of the Penal Code in 1996. A similar offence was created in 2001 for resources connected to criminal associations (association de malfaiteurs), trafficking in human beings and terrorism.

The Court of Cassation ruled on January 14, 2004 (Abdellaoui case) that Article 324-1, second paragraph, of the Criminal Code can apply to a person having laundered the proceeds of a predicate offence he committed himself.

French law does not require that a person be convicted of a predicate offence as a precondition for a ML conviction.

The scope of predicate offences for ML is very extensive and covers all crimes and misdemeanors, including FT and fiscal fraud.

The offense of money laundering extends to any type of property that directly or indirectly represents the proceeds of crime.

Although this is not explicitly stated in the Criminal or Criminal Procedures Codes in France, authorities indicate that conduct that occurs in another jurisdiction may constitute a predicate offense, provided it would have been incriminated as an offence had it taken place in France.

\section{Criminalization of FT}

FT is criminalized comprehensively in Article 421-2-2 of the Criminal Code, which covers an extensive list of acts (Article 421-1, 421-2, and 421-2-1 of the Criminal Code) and applies under certain conditions of competence when terrorists or terrorist organizations are located in another jurisdiction or when the terrorist acts take place in another jurisdiction.

\section{Scope of the offences of ML and FT}

The offences of ML and FT apply to individuals and also to legal entities that knowingly engage in ML (Article 324-9 Criminal Code) or FT activity (Article 422-5). The law of May 13, 1996 has introduced a certain measure of objectivity with regard to the knowledge element of the general ML offence under Article 324-1 of the Criminal Code in that it does not require the establishment that the suspect knew precisely the offence giving rise to the laundered proceeds. However, the knowledge of the predicate offence is still required with regard to the laundering of drug proceeds under Article 222-38 of the Criminal Code and with regard to aggravated laundering pursuant to Article 324-4 of the Criminal Code. Intent and purpose can be inferred from objective factual circumstances. 


\section{Sanctions}

Laws provide for an adequate range of criminal sanctions for ML and FT. However, sanctions for drug ML are twice as much as those provided for the general offence of ML which does not appear to be justified in view of the large proceeds that can be generated by other forms of serious crimes such as trafficking in human beings, for example. A number of mechanisms compensate the unequal status in principle between the general incrimination of ML and the drug ML offence. For instance, Article 324-4 of the Penal Code provides that the (general) ML offence is punished by the imprisonment sanction provided for the underlying offence if the latter is higher than the 5 or 10 years contemplated at Articles 324-1 and 324-2, respectively. On the other hand, a similar provision in Article 222-38, second paragraph, of the Penal Code still results in much higher sanctions for drug related ML.

\section{Adequacy of Legal Means and Resources}

France allocates significant resources to the implementation of ML and FT laws. Law 75-701 of August 6, 1975 established courts specializing in economic and financial matters to handle complex proceedings involving the offenses referred to in Article 704 of the Code of Criminal Procedure. Their jurisdiction in respect of investigation and judgment is concurrent with that of other courts. In 1998, these courts were reinforced with the creation of economic and financial divisions (pôles économiques et financiers) that comprise special assistant positions (Law of July 2, 1998) and specific material resources. To address the limitations of the economic and financial divisions, pertaining to their competence, their field of action, and the spread of organized crime, the law on adapting the administration of justice to the developments of criminality that entered into force in October 2004 creates interregional courts specializing in highly complex cases involving organized crime and economic and financial crime. These courts will work in concert with the economic and financial divisions to take account more effectively of criminal networks in their entirety and of the financing mechanisms they set up to launder the proceeds of their criminal activities.

For anti-terrorism and FT matters, France has established a system whereby proceedings, investigation, and judgment are centralized in the tribunal de grande instance of Paris. This system is based on the principle of concurrent jurisdiction between local courts and the special Paris court. As a result, all French courts are competent under ordinary law and may, in the interest of the proper administration of justice, relinquish jurisdiction to the Paris court.

Investigative agencies include the Central Office for the Suppression of Major Financial Crimes (Office Central pour la Répression de la Grande Délinquance Financière - OCRGDF), the Gendarmerie Nationale, the National Direction of Intelligence and Customs Investigations (Direction Nationale du Renseignement et des Enquêtes Douanières, DNRED) and the National Judicial Customs Service (Service National de la Douane Judiciaire SNDJ).

Analysis of Effectiveness

The legal framework relating to the criminalization of ML and FT is comprehensive. The main limitation is that France, like a number of other EU member countries, is currently unable to comply fully with UN Security Council Resolution 1373 with regard to terrorists or terrorist groups from within the European Union as they are not covered by EU Council Regulations.

Recommendations and Comments

As mentioned below, the authorities are encouraged to take the necessary measures to ensure full compliance with UNCSR 1373.

Implications for compliance with FATF Recommendations 1, 4, 5, SR I, SR II

R.1, R.4, R.5, SR.I, and SR.II: Compliant.

\section{II-Confiscation of proceeds of crime or property used to finance terrorism}

(compliance with criteria 7-16)

Description

French legislation enables the judicial authorities to seize and to confiscate the proceeds from crime involved in 
money laundering operations as well as the funds used to finance terrorism. It also provides for a legal basis and powers for law enforcement authorities to identify and trace such property.

\section{Temporary measures}

French legislation provides for broad possibilities to seize any assets in the course of investigations, either by officers of judicial police or on instruction of the judiciary. The main provisions governing seizure of assets are contained in the Code of Criminal Procedure (Articles 54, 56, 76, and 97).

Pursuant to Article 706-30 of the Code of Criminal Procedure, the juge des libertés et de la détention, at the request of the prosecutor, may seize any assets of a person against whom a judicial investigation is being carried out, in order to safeguard confiscation orders that would follow. At present, this is restricted to confiscation in drug trafficking or money laundering cases. The same mechanism exists for enquiries regarding trafficking in human beings and exploitation of prostitution on the basis of Article 706-36-1 of the Code of Criminal Procedure and for terrorism on the basis of Article 706-24-2. However, this does not apply for enquiries on the basis of money laundering that might be linked with these predicate offences.

The Act of 9 March 2004, that entered into force on 1 October 2004, repeals these provisions and inserts a new article 706-103 in the Code of Criminal Procedure that provides the same mechanism in terms of extended seizure possibilities in order to safeguard confiscation for the offences listed in Article 706-73 of the same Code. This article contains a broad list of predicate crimes, including drug trafficking, trafficking in human beings, terrorism, kidnapping, forgery as well as the laundering of the proceeds of any of these crimes. Besides, the mechanism of Article 706-103 applies to any other form of organized crime that would not be listed in Article 706-73, on the basis of Article 706-74.

Both movable goods and real estate can be seized.

Article 99-2 of the Code of Criminal Procedure provides for the possibility for the State to put the assets seized in the course of the judicial procedure on public sale, when it becomes clear that they will not be restituted and when they are not needed anymore for establishing the truth. This also applies when maintaining the seizure would result in a depreciation of the assets. In order to avoid management costs, the State Property

Administration Office (Administration des Domaines) systematically makes use of this procedure. The resulting funds are then placed with the Public Trustee Office (Caisse des Dépôts et Consignations) pending the outcome of the prosecution.

Customs Authorities also seize assets in the course of their activities. This is effected with regard to offences on customs legislation, including customs money laundering.

\section{Confiscation}

According to French law, confiscation is a complementary criminal sanction. Article 131-21 of the Penal Code provides the basic principles of the confiscation regime. The instrumentalities of the crime, its proceeds and its object can be confiscated, except in case of restitution to third parties. Moreover, the law provides for a mandatory confiscation of all objects that are either dangerous or can cause damage. When the confiscated object was not seized or could not be recovered, a value-confiscation is pronounced.

There is no provision that creates a mandatory confiscation of the proceeds of predicate offences or of laundered funds. Confiscation of these funds is always optional.

A confiscation can cover all assets of the offender (with the exception of certain goods that are not subject to confiscation).

As regards the money laundering offence, Article 324-7 of the Penal Code explicitly refers to the confiscation of the instrumentalities of the offence as well as the proceeds. 
Article 415 of the Code of Customs provides for a specific confiscation regime as regards money laundering operations between France and a foreign country involving drug trafficking funds. In this case, the funds (or an equivalent amount if they could not be seized) are confiscated. Moreover, the offender is sentenced to imprisonment between two and ten years and to a fine between one and five times the amount of the transactions. Article 459 of the Code of Customs provides for a similar seizure and confiscation regime as regards the financial embargos.

\section{Legal persons}

French legislation provides for criminal liability of legal persons. The principles governing the confiscation regime do not distinguish between individuals and legal entities.

\section{Civil forfeiture}

Confiscation is a complementary criminal sanction and thus limited to criminal proceedings only.

\section{Power to identify and trace property}

The responsibility for searching for proceeds from criminal activity mainly lies with the judiciary police that carries out the investigation under the supervision of the investigating judge. Apart from the temporary measures described above that are supervised by the judicial authorities (prosecutor or investigating judge) any agent with the status of judiciary police can seize relevant goods that can be useful for establishing the truth. Besides, the reporting mechanism described in Articles L. 561-1 and following of the CMF involves all reporting entities and the FIU in particular in the detection of suspected assets. Overall responsibility for seizure and confiscation lies with the judicial authorities.

\section{Identification and freezing of funds and other property of terrorists}

The Treasury Department has been assigned with the responsibility to implement the United Nations Security Council Resolutions (UNSCR) that impose the freezing of assets linked to terrorism and its financing. UNSCR 1390 concerning Al Qaeda and the Taliban is transposed into French legislation by the EU Council Regulation 881/2002, whereas EU Council Regulation 2580/2001 transposes UNSCR 1373. The regulations are directly applicable. Whenever the lists of suspected terrorists are updated, the Treasury Department communicates the information to the financial institutions. In case of a hit, the Treasury systematically checks the information with the FIU and other law enforcement agencies. If the information is confirmed the accounts involved are being frozen. The Treasury takes responsibility for the act of freezing rather than the financial institution.

France, like a number of other EU member countries, is currently unable to comply fully with UN Security Council Resolution 1373 with regard to terrorists or terrorist groups from within the European Union as they are not covered by EU Council Regulations.

Freezing orders being an administrative measure, they can be challenged before the Conseil d'Etat. One such case is pending. The Treasury department does not communicate any information to the judiciary.

The main obstacles identified by the financial institutions with the implementation of the UN and EU lists are the lack of identifying data, the difficulty to incorporate the lists into their computer systems and run the checks, and the period of uncertainty pending clarification of possible hits.

\section{Funds}

Proceeds from drug trafficking and from drug money laundering are affected to a special fund that was created by the Decree of 17 March 1995. Its purpose is to improve the equipment and general functioning of the authorities in charge of fighting drug trafficking. The French Authorities did not inform the Mission about the 
amount that had been transferred to this fund so far. It was noted that this amount does not represent the total amount of recovered funds. According to statistics on the convictions for drug trafficking, between 30 and 40 million FRF were seized every year from 1995 to 2000. A similar fund for assisting the victims of terrorist acts was created by the law of 9 September 1986.

Analysis of Effectiveness

\section{Judicial seizure and confiscation}

Though in theory a conviction can result in the confiscation of all the assets of the offender, in practice, the confiscation will almost exclusively apply to the assets that have been previously seized in the course of the judicial procedure. This results mainly from the optional character of confiscation measures. The judge will appreciate these sanctions in view of the available elements of the case, such as the offender's property that can be identified. Several authorities mentioned problems in uncovering these assets. In money laundering cases, it is rather exceptional that all or most of the laundered funds can be recovered in this manner. As an alternative, the fine can be increased to half the level of the laundered funds (Articles 222-38 and 324-3 of the Penal Code).

There are no statistics available on the amounts resulting from the seizure and confiscation orders, neither in general terms, nor as regards ML specifically. In the absence of such information, it is difficult to assess the effectiveness of the provisions governing the asset related aspects of the fight against serious crimes including ML and FT. In order to improve the management of seized and confiscated assets, the French authorities are reflecting on the establishment of a central body that would be in charge of dealing with these specific issues.

From discussions with officials, it appears that the judicial authorities are a bit reluctant to utilize systematically the tools at their disposal. Moreover, in the absence of a mandatory confiscation regime for financial and economic crimes, insufficient use is made of the procedure of Article 706-30 of the Code of Criminal Procedure which holds an important potential for seriously improving the effectiveness of an asset oriented approach to the combat against ML. Since about two years, additional efforts are being made by the Ministry of Justice to raise the awareness of magistrates about this approach, as demonstrated by the circular letter from the Minister of Justice of 15 February 2002. However, to date, these efforts have focused mainly on drug trafficking and drug money laundering.

\section{Administrative freezing of terrorist related funds}

The Constitutional Treaty established by the European Convention includes provisions that would lift the distinction currently preventing the authorities from administratively freezing assets of terrorists or terrorist groups based within the European Union. Pending its adoption, a draft bill has been prepared to enable the government to impose financial sanctions and administratively freeze such assets in compliance with UN Security Council Resolution 1373. The draft bill has to undergo a consultative process and the timeframe for its adoption is uncertain at this stage. Taking into account the difficulties encountered in implementing the UNSCR and subsequent EU regulations, four accounts were frozen on the basis of the UN and EU lists at the time of the assessment visit, amounting to about 30.000 EUR. No other assets, such as real estate, have been frozen. This is mainly due to the lack of definition of which assets and of what measures should be targeted and the need of ad hoc instruments to trace them.

Recommendations and Comments

The French authorities may wish to consider establishing some form of mandatory deprivation of the illegal profits of financial and economic criminality, in particular in the context of money laundering and terrorism financing. This could be achieved by means either of a fine or of a confiscation measure.

More efforts should be made to train magistrates and raise their awareness with regard to the available tools and their key role in the asset-oriented approach of the fight against all forms of crime that generate substantial illicit profits.

Particular attention should also be given to the compilation of relevant statistics. Comprehensive statistical data is a necessary tool, not only for outside evaluation but also and more importantly for the internal review of the 
performance of the system. The establishment of a central body responsible for managing seized and confiscated assets could remedy this lack of information. The French authorities are therefore encouraged to work further in this direction.

Also, increasing attention should be given to investigating and prosecuting legal entities that have been created to facilitate money laundering operations. In this area as well, the application of confiscation measures should be pursued systematically.

The authorities are encouraged to proceed with their plan to adopt a domestic act that would enable France to comply fully with UNSCR 1373.

Implications for compliance with FATF Recommendations 7, 38, SR III

R.7, R.38: Compliant. SR.III: Materially non-compliant.

III-The FIU and processes for receiving, analyzing, and disseminating financial information and other intelligence at the domestic and international levels

(compliance with criteria 17-24)

Description

Mandate of TRACFIN

The French FIU, TRACFIN (Traitement du Renseignement et Action contre les Circuits Financiers Clandestins) was created by the Act ${ }^{\circ}$ 90-614 of 12 July 1990 which was amended on several occasions. TRACFIN is placed within the Ministry of Economy, Finance and Industry. It meets the Egmont Group's definition of an FIU. Its main tasks are to receive, analyze and disseminate reports on suspicious transactions from reporting entities, not only in France, but in its overseas departments and territories as well. It has been a member of Egmont since the creation of the Group in June 1995.

The status of TRACFIN ensures operational independence and the confidentiality of its information is appropriately guaranteed.

In addition to the transmission to the prosecutor of cases of presumed money laundering on the basis of STRs, it is worth mentioning that TRACFIN falls under Article 40 of the Code of Criminal Procedure that requires State employees to report to the prosecutor any fact that they know to constitute an offence.

\section{Reporting to TRACFIN}

The scope of application ratione personae of the AML regime has been progressively extended to cover financial enterprises (banks, foreign exchange offices, insurance companies, investment enterprises, etc.) and a number of non-financial professions (real estate intermediaries, casinos, dealers in precious stones, metals, antiques or works of art, auctioneers and most recently accountancy and legal professions including lawyers, as well as gaming houses, lotteries and race gambling companies) (Article L. 562-1 of the Financial and Monetary Code). Reporting obligations apply in metropolitan France as well as in the DOM-TOM. The reporting institutions and individuals are required to disclose all transactions and facts suspected to derive from drug trafficking, organized crime, defrauding the financial interests of the European Communities or corruption, or that might be linked to terrorism financing. The reporting obligation of legal professions only apply when acting as intermediary in financial or real estate transactions. Besides, there is an obligation for reporting parties to communicate to TRACFIN all transactions where some doubts remain as to the client or the beneficiary, transactions involving trusts or similar structures and transactions involving Non-cooperating countries or territories (NCCTs - as defined by the FATF) against whom countermeasures have been decided. The latter applies to all transactions with Nauru and Myanmar amounting to 8.000 EUR or more. All STRs are directed to TRACFIN with the exception of disclosures made by lawyers. Lawyers' disclosures are addressed to the president of the bar association (Article L.562-2-1, §3) who communicates the information to TRACFIN except if he believes that there is no basis for suspicion of money laundering. 
Reports can be made orally or in writing. TRACFIN is currently working on an electronic web-based reporting form that is being elaborated within the Liaison Committee. Pilot projects are being run with the Bank of France and the insurance sector.

\section{Opposition to the execution of a transaction}

As a general rule and if this is still possible, reports have to be made prior to the execution of a transaction. This enables TRACFIN to oppose the execution of the transaction for 12 hours (Article L. 562-5 of the CMF). In practice, however, the overall majority of reports are made after a transaction takes place. In case of a prior report, TRACFIN consults with the judicial authority that will be in charge of the file to determine whether it will take over the case. The transaction is frozen only when the response is in the affirmative.

\section{Access to additional information}

The primary information that feeds TRACFIN's database consists of STRs from reporting entities. TRACFIN also receives a number of reports based on objective criteria. In order to carry out its assignment, TRACFIN can obtain additional information from a wide series of authorities. It can request production of financial and other information held by the reporting parties themselves. The obligation for financial institutions to comply with such requests from TRACFIN has been extended to the non-financial professions as well. Professional secrecy rules do not apply in this regard. Additional information can also be queried from the Judiciary Police (OCRGDF) and from the Gendarmerie, from the supervisory authorities, from the administrative services of the State including the Customs Department as well as from the Social Security Services. TRACFIN also established a number of informal contacts with the above mentioned institutions and authorities. Moreover TRACFIN has access to the Central Register of Bank Accounts (FICOBA) and has a security habilitation that provides access to all classified information.

\section{Dissemination to domestic authorities}

Where TRACFIN uncovers facts that are likely to constitute money laundering linked to drug trafficking or organized crime or that might be related to the financing of terrorism, it must refer them to the Public Prosecutor (Article L. 562-4 of the CMF). Forty percent of the transmissions by TRACFIN are made on this basis. The remaining sixty percent of its transmissions are based on Article 40 of the Code of Criminal Procedure which requires every public official to communicate information to the judicial authorities whenever it has knowledge of facts subject to criminal liability.

\section{Resources (human, technological) and training}

The Secretary General of TRACFIN is also Director General of the Customs Services. The operational head of the FIU is the Deputy Secretary General. TRACFIN has a staff of forty-eight, with thirty-three working in the operational section. The staff originates from the public administration, mainly from Customs and the different departments of the Ministry of Economy, Finance and Industry and also includes representatives of other authorities (judiciary, financial police (OCRGDF), Gendarmerie). Recently, there has been a trend to have a more diversified staff in order to enhance TRACFIN's capacity with regard to legal, economic and financial matters expertise.

The training system is internal and somewhat ad hoc in the sense that there are no well-defined training modules. On an occasional basis, training may include private sector training,

\section{Issuance of guidelines and feedback}

TRACFIN produces an annual report that contains general feedback in the form of sanitized cases. It also provides typological information for training programs organized by supervisors and professionals, including the FATF and Egmont Group typologies. It contributes actively to the initiatives in both fora. Beside its annual report, TRACFIN is attempting to emphasize direct contact between its agents and the reporting parties. 
Pursuant to the new Article L. 562-6 of the CMF, TRACFIN informs the reporting parties of every transmission of their initial suspicions to the judicial authorities. The law is silent with regard to the position that should be adopted by the institutions and individuals concerned with regard to the business relationship when making a report. The authorities report that there is a general tendency to put an end to such relationships. Reporting parties are not informed of the final judicial decisions that intervened on the basis of their initial report. As TRACFIN has been informed of these decisions only in a few number of cases, a recent amendment requires the judicial authorities to inform TRACFIN of the outcome of judicial procedures.

\section{IT and analytical capabilities}

All STRs are stored in TRACFIN's database. The objective reports are checked on their relevance and only stored if they are considered useful. TRACFIN has indicated that the overall quality of reports is uneven. As mentioned above, a working group of the recently established Liaison Committee whose purpose is to better inform reporting parties about their obligations under the relevant legislation and to make concrete proposals to improve the AML framework is currently working on establishing an electronic reporting form that should enhance the analytical capabilities of both TRACFIN and the reporting parties, in addition to improving the overall quality of the reports and the quantity and quality of transmissions by TRACFIN.

\section{Sanctions}

Sanctions in cases of non-compliance with AML obligations are not taken by TRACFIN but by the competent supervisory authority (Commission Bancaire, Commission de Contrôle des Assurances, Autorité des Marchés Financiers). All available disciplinary sanctions can be used (warning, fine, publication, withdrawal of license...). Moreover, such sanctions do not exclude criminal liability for money laundering or any predicate offence.

However, a number of reporting parties do not have a supervisory authority competent to impose sanctions, such as gaming houses (cercles de jeux), racehorse gambling institutions, and dealers in high value goods. With regard to casinos, while the Ministry of Interior is competent to supervise their compliance with the rules under which they operate, including through the conduct of on-site visits and the imposition of sanctions, it would seem that the AML/CFT focus of such supervision is still underdeveloped at this stage.

\section{Domestic cooperation and interaction with supervisory authorities}

The Decree $n^{\circ} 2002-770$ of 3 May 2002 created a Liaison Committee on the fight against money laundering. This Committee meets twice a year and is co-chaired by TRACFIN and the Ministry of Justice. Besides, it comprises 30 representatives of the reporting parties, the supervisory authorities and a number of State departments. The purpose of the Committee is to better inform the reporting parties about their obligations under the AML legislation and to make concrete proposals to improve the framework. Topics such as reporting requirements, feedback, security of reporting parties can be discussed in this forum and its sub-groups.

The interaction between TRACFIN and the supervisory authorities, like the Commission Bancaire, the Commission de Contrôle des Assurances, and the Autorité des Marchés Financiers, is based on Article L. 563-5 of the CMF and appears to be efficient, overall. TRACFIN reports deficiencies and cases of non-compliance with the AML requirements to the supervisors to enable them to focus their on-site controls. It also provides typological information for training programs organized by the supervisors.

\section{International cooperation}

Article L. 564-2 of the CMF enables TRACFIN to cooperate with its foreign counterpart units to share intelligence information and data likely to be linked to money laundering and drug trafficking on the basis of reciprocity and subject to similar professional secrecy provisions in the foreign unit. TRACFIN concluded cooperation agreements with 24 counterpart units so far. 
At the level of the European Union, TRACFIN is one of the FIUs already actively involved in the FIU.Net project and frequently uses this secure channel of communication.

\section{Statistics and implementation}

TRACFIN keeps a number of statistics regarding the received STRs and the transmissions to the judicial authorities. They give a general overview of the situation in this respect. TRACFIN received 6.896 STRs in 2002 ( 3.598 in $2001 ; 2.537$ in 2000). More than half of them originate from the Paris and Île-de-France region. Banks are the main reporting parties (still more than 60 percent in 2002) followed by the Public Financial Institutions ( 21,06 percent) and the changeurs manuels $(9,85$ percent). The number of reports from the insurance sector and other intermediaries like investment companies, casinos and dealers in high value goods is still very limited or nonexistent.

\section{Analysis of Effectiveness}

TRACFIN has an established a long-standing experience in terms of processing financial intelligence to support law enforcement. TRACFIN provides support to the reporting entities through direct and close contacts with them. It also provides some guidance by means of its annual report.

\section{Access to additional information}

TRACFIN has a broad legal basis to collect additional information from a wide range of entities. Direct contacts enable it to carry out its analysis functions more efficiently. However, in the absence of a central contact point with basic data on individuals and legal entities, it can prove difficult to verify the identification data contained in the STRs. The access to registers held by the Social Security services, as provided for by a recent amendment of Article L. 563-6 of the CMF, should improve this process.

\section{International cooperation}

As far as cross-border cooperation with counterpart FIUs is concerned, TRACFIN is able to and does provide assistance to comply with foreign requests for information without requiring specific formalities. Moreover, such requests are considered as domestic STRs in the sense that they enable the FIU to query other domestic sources of information. As regards its own analysis, TRACFIN is intensifying the input from other FIUs by sending out requests more frequently than before, though not systematically yet. As a general remark, TRACFIN takes into account the Best Practices of the Egmont Group regarding the exchange of information.

\section{Volume of STRs}

The volume of STRs received by TRACFIN is growing steadily. TRACFIN received about 6.900 reports in 2002. Although this is twice as much as the previous year, it would seem that this was not accompanied by a significant increase in the overall quality of reports. The number of reports produced by the reporting parties is still relatively low compared to the importance of the financial and economic activity on the French market. Moreover, as regards the results of the operational action of TRACFIN, only a rather limited number of cases are being forwarded to the Prosecutor's Office (269 in 2003, representing only eight to ten percent of all the STRs received). This may be partially due to a poor quality of STRs or to insufficient verifying information from other authorities.

Apart from a number of difficulties arising with the overseas departments and territories because of their geographical situation, in particular Guyana raises serious concerns as this department did not make a single report after 2000.

Also it appears from statistical data that a number of reporting entities do not comply with their AML/CFT obligations. From the 134 STRs received from the real estate industry in 2002, only 5 originated from the real 
estate agents, the remaining 126 being from notaries. No reports were received from dealers in high value goods and commissaires-priseurs (the latter are subject to STR requirements only since February 2004) so far. The country's 189 casinos made 9 reports, 6 of them after the authorities started an important information campaign in July 2003. These deficiencies are mainly due to the absence of a supervisory body for most of the parties concerned and the obvious difficulty to reach out to these professions.

Recommendations and Comments

All parties involved in the AML/CFT area should pursue their efforts in issuing guidelines to help financial institutions and other reporting parties in better implementing the AML/CFT requirements and in improving the detection and reporting of suspicious patterns of transactions. In particular, with regard to the professions and industries that are not adequately supervised yet, the French authorities should consider the establishment of an independent body that would be in charge of supervising the application of the AML/CFT and other legal obligations. TRACFIN as well as other authorities like the Commission Bancaire are already fulfilling a key role in this process and the Liaison Committee could be an ideal forum to work further on this. This should lead to an increase of the number and overall quality of reports to the FIU which still seems on the low side taking into account the economic and financial activity on the French market. In this regard, the establishment of an electronic reporting form should already lead to a better input into the AML/CFT chain.

The self-evaluation of the reporting system would benefit from more detailed statistics that would give a better insight on the performance and characteristics of all the components of the AML/CFT efforts. Beside the statistical data already available, TRACFIN may consider keeping more detailed figures on the nature of the reports it receives, the input from the different sectors, the type of transactions involved, the suspected criminal nature of the underlying facts, the reasons that motivate their transmission to the judicial authorities, nationality/country of residence of the individuals involved in the transmitted files, the amounts involved, the number of cases it is processing, etc.

Although the law provides for the possibility to oppose execution of a transaction for 12 hours, this procedure has led to very minimal results. This is probably the result of insufficient awareness of this tool with the reporting parties themselves. More important volumes of suspicious funds could be blocked, seized and eventually confiscated, for instance when clients announce the withdrawal of the funds from their bank account. Very few such transactions are being reported to TRACFIN. Another factor is the very short delay the FIU has at its disposal to collect complementary information in order to constitute a solid case for transmission to the judicial authorities. An extension of the delay of 12 hours should therefore be considered.

With regard to international cooperation, TRACFIN is encouraged to continue to enhance its efforts in intensifying the query of foreign FIUs to collect additional intelligence in cases with an international dimension.

With regard to deficiencies identified in the compliance with AML/CFT obligations in the DOM-TOM, TRACFIN appears to be aware that additional efforts in reaching out to these areas, in particular Guyana, and in monitoring them more closely are required on an urgent basis.

TRACFIN, as well as the supervisory authorities, are encouraged to continue their efforts and be more proactive in issuing guidelines and domestic and international typologies to help financial institutions and other reporting parties in better implementing AML/CFT requirements and in improving the detection and reporting of suspicious patterns of transactions. The Liaison Committee could be an ideal forum to work further on this issue and the French authorities may consider the creation of additional working groups within this Committee that could discuss other AML/CFT connected issues of common interest. Also as regards the Liaison Committee, consideration should be given to a more active involvement of the judiciary in this forum.

While no urgent need to increase the number of staff was reported to the mission; in view of the increasing volume of STRs and the perceived need for additional outreach efforts by TRACFIN towards a number of sectors, the authorities may wish to consider whether the current level of staffing of TRACFIN is adequate. Implications for compliance with FATF Recommendations 14, 28, 32

R.14: Largely compliant because the legislative requirements are narrower in scope than the FATF standard. 
(See section "III- Ongoing monitoring of accounts and transactions" for analysis of this preventive measure.) R.28: Largely compliant, as additional efforts are needed to provide guidance to reporting entities, notably outside the banking sector.

R.32: Compliant.

\section{IV_Law enforcement and prosecution authorities, powers and duties}

(compliance with criteria 25-33)

Description

ML and FT investigations are carried out by law enforcement under supervision of the judiciary. The Judiciary Police, the Préfecture de Police, the Gendarmerie and Customs have established divisions specialized in economic and financial crime, including ML, that also benefit from specific training programs. Depending on the stage of the enquiries, they can use a wide range of investigative techniques such as surveillance, infiltration, interception of mail, wire-tapping, etc.

\section{Customs}

The DGDDI (Direction générale des douanes et des droits indirects) operates at central, interregional and regional level. Its main tool in detecting cross-border circulation of suspicious funds and merchandises is the socalled 'declarative obligation'. Pursuant to Article 464 of the Code of Customs, every transfer of funds by an individual amounting to 7.600 EUR or more across the French national border has to be declared. Noncompliance with this requirement is subject to criminal liability. The DGDDI could also seize funds suspected of being related to FT in a number of cases. The DGDDI has at its disposal all investigative tools provided for by the Code of Customs. By the end of the year, the recently created SNDJ (Service national de douane judiciaire) should be up and running. This new entity will have similar powers and duties as the judiciary police for offences provided in the Code of Customs.

Customs also have a competence to control exchange agents on the basis of Article L. 520-4 of the CMF. An average of 40 on-site visits are scheduled every year

\section{Judiciary Police (OCRGDF)}

The OCRGDF has a general competence for carrying out judicial enquiries and investigation under the supervision and by delegation of a magistrate, for cases of money laundering, terrorism financing and defrauding the EU financial interests. It cooperates closely with other authorities like the Gendarmerie, the tax inspection service and TRACFIN with whom it can exchange operational information. The Judiciary Police has 25 investigators specialized in ML and FT, as well as 15 staff to assist them. It cooperates internationally through the police network of contact points.

\section{Gendarmerie}

Whereas the Judiciary Police concentrates it action in the cities, the Gendarmerie operates in suburban and rural areas. As its action covers all sorts of offences, any local unit can start investigating money laundering cases. However, specialized sections that work on economic and financial crime and consisting of 25 to 80 people are in place at the level of the Court of Appeal.

\section{Judicial Authorities}

ML and FT cases are being dealt with by the Tribunal de Grande Instance. The Paris Prosecutor's Office has two of its five divisions that prosecute ML cases: the financial division (that primarily receives the TRACFIN transmissions) and the division on serious organized crime. The latter is competent for investigating FT. The Prosecutor or the Juge d'Instruction heads the enquiry or investigation that is carried out by the Préfecture de Police de Paris or by the OCRGDF. 
Since the late "90s, about 4 so-called "assistants spécialisés" have been working in the financial divisions of Paris, Marseille, Lyon and Bastia, respectively, to support the investigating judges in complex cases. The same function was created for the deciding judges. Moreover, assistants en justice, mainly students, are also involved in coordinating the investigation.

\section{Ministry of Justice}

The Ministry of Justice plays an overall part in reaching out to the prosecution services. It establishes training material for, establishes guidelines to and raises the awareness of the relevant authorities when new legislation is being adopted. It also communicates the priorities set by the Government in terms of prosecution.

Analysis of Effectiveness

Despite all the efforts that have been produced to date, a large number of cases could not be dealt with due to insufficient resources and the need to pursue other priorities. In particular, the innovative aspects introduced by the institution of the assistants de justice do not seem to have yet produced the anticipated results. A recent reform by the Law of March 9, 2004 that entered into force on October 1, 2004 and introduces specialized jurisdictions should enhance the overall capacity of the judicial system to combat financial crime, both in terms of human resources and of on-going specialized training.

About seventy percent of the ML cases in Paris originate from TRACFIN and about ten percent from the Customs Department. Almost half of the sixty cases communicated by TRACFIN in 2003 that were dealt with by the financial division of the Paris Prosecutor's Office were new cases, while the remaining ones complemented already existing files. Half of them are being further investigated (preliminary enquiry or judicial investigation) and four of them have been closed.

The number of convictions for money laundering (including non-justification of resources) increased to fortyseven in 2001 against twenty-one in each of the two previous years. However, these results seem quite limited in view of the time the reporting mechanism has been in place and of the volume of reports sent by TRACFIN and other authorities to the judiciary. This is not only due to the time consuming judicial procedures, but also to the difficulties encountered by the prosecution services to establish the money laundering offence. Although jurisprudence does not require the establishment that the money launderer knew the specific origin of the illegal funds, a number of prosecutors still operate on the assumption that they have to prove the existence of the specific underlying offence. However, some case law indicates that a conviction for (general) money laundering can be pronounced without the predicate offence being specifically identified. Additional problems arise when a case has an international dimension and information has to be obtained from other jurisdictions. Therefore, there is a tendency to re-qualify the facts and to prosecute on a different basis.

None of the FT cases under investigation lead to judicial results so far. The main difficulties lie in the linking of suspicious or irregular financial movements with terrorist activities and also in the absence of an investigating body that combines a specialization in both financial and terrorism aspects. Most cases were initiated following terrorist attacks.

Recommendations and Comments

The authorities should continue to monitor closely the challenges posed by serious economic crime and the financial means required at the different stages to combat it effectively.

The creation of specialized sections within the OCRGDF and the brigade de recherche et d'investigation financière de la préfecture de police, within the Gendarmerie and within the judiciary is a commendable step towards more efficient law enforcement in the area of ML. Further consideration appears to be warranted for the pooling of expertise in financial and terrorism issues in one specialized service, in particular for investigating FT related cases.

With regard to ensuring an efficient prosecution of ML cases, the proof of the predicate offence still appears to be a serious challenge, particularly when committed in a foreign country. Re-qualifying the facts does not always provide a way out. In order for the reporting mechanism to produce more significant results, there should be less reliance on the classical approach of making ML depend on the establishment of the underlying crime. At 
present, even though the ML offence is incriminated separately, it is not fully autonomous as it should be, though some encouraging case law indicates that a conviction for (general) money laundering can be pronounced without the predicate offence being specifically identified. A change of mentality and openness for new approaches is therefore warranted. Experience can be drawn form jurisprudence in other jurisdictions where the proof of the illegal origin of the funds can be deduced from the circumstances of the case without the specific predicate offence being established.

Implications for compliance with the FATF Recommendation 37

R.37: Compliant.

\section{V-International Co-operation}

(compliance with criteria 34-42)

Description

France pursues a policy of active international cooperation and has an impressive set of bilateral and multilateral treaties for MLA and extradition in ML and FT cases. As a matter of principle, France does not condition mutual legal assistance to dual criminality. However, a number of mutual legal assistance treaties include such a condition particularly with regard to coercive measures. This condition is considered to be met when the offence for which the request for assistance is formulated is covered by a multilateral treaty to which the requesting country and France are party. Absent a treaty, assistance is available on a case-by-case basis and is subject to a condition of reciprocity. The Code of Criminal Procedure permits action on requests for mutual assistance from foreign authorities in a manner as close as possible to that provided for in the legislation of the requesting state.

With regard to property seizure and confiscation, the provisions of Articles 10-16 of Law No. 96-392 of May 13, 1996 on money laundering, drug trafficking, and international cooperation in the seizure and confiscation of the proceeds of crime apply to any request submitted pursuant to Chapter III of the Council of Europe Convention on Laundering, Search, Seizure and Confiscation of the Proceeds from Crime by a State Party to that Convention. Such requests may involve searching for or identifying the proceeds from an offense, items used or intended to be used in the commission of that offense or property whose value corresponds to the proceeds of the offense, the taking of conservation measures in respect of such items or proceeds, or their confiscation.

The grounds on which mutual assistance may be refused are specifically listed.

France provides timely and effective follow-up to mutual legal assistance requests and maintains statistics on all mutual legal assistance and other requests made or received, relating to ML, the predicate offences, and FT, as well as the outcome of such requests. However, the nature of the requests is not reflected in the statistics, which are devoted solely to quantifying flows (the major criteria are: active or inactive cases, country of origin or destination, date of receipt or dispatch, and date of action or rejection). Including details on the nature and result of requests would help in obtaining a clearer picture of France's efforts in this area.

France has a number of arrangements in place for law enforcement authorities to exchange information regarding the subjects of investigations with their international counterparts, based on agreements in force and by other mechanisms for co-operation, including liaison magistrates, and at the European level, participation in the European Judicial Network and Eurojust. However, there have been no efforts to record the number, source, and purpose of requests for information exchange and their resolution.

French law provides that the confiscation of assets on French territory operates a transfer of property to the state unless otherwise agreed with the requesting state. In addition, the sharing of assets may be provided in a bilateral treaty. France has currently one bilateral treaty providing for the transfer or the sharing of assets with another country when confiscation is a result of coordinated law enforcement actions. The authorities are encouraged to consider entering into similar arrangements with additional countries as they constitute useful incentives for an increased coordination and cooperation.

Analysis of Effectiveness

France provides timely and effective follow-up to mutual legal assistance requests and maintains statistics on all mutual legal assistance and other requests made or received, relating to ML, the predicate offences, and FT, as 
well as the outcome of such requests. The nature of MLA requests is not reflected in the statistics, which are devoted solely to quantifying flows.

Recommendations and Comments

The authorities are encouraged to consider including details on the nature and results of MLA requests in statistics in order to obtain a better understanding of France's efforts in this area.

Implications for compliance with FATF Recommendations 3, 32, 33, 34, 37, 38, 40, SR I, SR V

R.3, 32, 33, 34, 37, 38, 40, and SRV: Compliant.

SR.I: Materially non-compliant.

\section{Assessing Preventive Measures for Financial Institutions}

173. The assessment sought to confirm that : (a) the legal and institutional framework are in place and (b) there are effective supervisory/regulatory measures in force that ensure that those criteria are being properly and effectively implemented by all financial institutions. Both aspects are of equal importance.

\section{Table 46. Detailed Assessment of the Legal and Institutional Framework for Financial} Institutions and its Effective Implementation

\section{I-General Framework (compliance with criteria 43 and 44 ) \\ Description}

The legal framework for the prevention of money laundering and financing of terrorism in the financial sector.

Law No. 90-614 of July 12, 1990 on the participation of financial entities in combating the laundering of the proceeds of drug trafficking, codified in Title VI of Book V of the Code Monétaire et Financier (CMF), and Decree No. 91-160 set out the main AML/CFT preventive measures and their scope of application. The legal framework has evolved in successive waves since 1990:

- $\quad$ Law No. 93-122 of January 29, 1993 extended the scope of the suspicious transaction reporting requirement to funds or transactions suspected of being related to organized crime, in addition to drug trafficking. Law No. 96-392 broadened the application of the law to insurance and reinsurance brokers.

- $\quad$ Law No. 98-546 of July 2, 1998, extended coverage of the law to certain non-financial businesses and professions, i.e., real estate intermediaries, including brokers and notaries.

- Law No. 2001-420 of May 152001 ("relative aux nouvelles régulations économiques") refined the reporting suspicious transaction reporting requirement and established additional reporting requirements in relation to transactions involving trusts and non-cooperating countries and territories as identified by the FATF. It also broadened the application of the law to legal representatives and officers of casinos and dealers in certain high-value goods.

- Law No. 2003-706 of August 1, 2003 ("relative à la sécurité financière") broadened the application of the law inter alia to individual and collective portfolio management firms, direct marketers of financial services, investment advisers and dealers in miscellaneous goods, as well as clarified and strengthened the powers of financial sector supervisors.

- $\quad$ Law No. 2004-130 of February 11, 2004, implementing European Directive 2001/97/CE of December 4, 2001 extended the scope of the suspicious transaction reporting requirement to funds or transactions suspected of being related to corruption and fraud against the financial interests of the European 
Communities. It also broadened the coverage of requirements to the legal and accountancy professions. It also strengthened customer identification requirements.

- $\quad$ Law 2004-204 of March 9, 2004 (coming into effect October 1, 2004) amends the scope suspicious transaction reporting requirement to cover explicitly funds or transactions suspected of being related to the financing of terrorism. It also extends the application of the law to other sectors of the gaming industry.

Article L. 562.1 of the CMF sets out the following financial entities to which preventive measures apply:

- $\quad$ La Poste; Caisse des Dépôts et Consignations/Caisses d'Epargne and other entities governed by Title I of Book V of the CMF;

- $\quad$ The Banque de France;

- $\quad$ credit institutions;

- $\quad$ investment firms, individual and collective portfolio management firms, intermediaries in miscellaneous assets, direct marketers and investment advisers;

- $\quad$ insurance companies (including mutual insurance companies), and insurance and reinsurance agents and brokers;

- $\quad$ currency exchangers;

- $\quad$ persons who carry out, monitor, or advise on transactions relating to the purchase, sale, transfer, or rental of real estate;

- $\quad$ the legal representatives and managers of casinos, as well as groups, associations and legal entities engaged in games of chance, lotteries, betting, and sports and horse-racing odds-making;

- $\quad$ persons customarily trading in or organizing the sale of precious metals and stones, antiquities, and works of art;

- $\quad$ accountants and auditors;

- $\quad$ notaries, lawyers and other independent legal professionals when carrying out certain activities; and

- $\quad$ state-appointed liquidators and auction houses.

Few regulations or binding instructions supplementing the legal framework have been issued other than for credit institutions and investment firms other portfolio management firms. Supervisory and professional recommendations complement the framework though they are neither binding nor enforceable. There are no enforceable guidelines issued by financial sector supervisors.

\section{Competent authorities}

\section{Licensing and registration authorities}

Three different authorities are responsible for authorizing/licensing financial entities:

- $\quad$ the Comité des Établissements de Crédit et des Entreprises d'Investissement (CECEI) is responsible for issuing licenses to credit institutions and investment firms other than portfolio management firms;

- $\quad$ the Comité des Entreprises d'Assurance (CEA) issues licenses to insurance companies;

- the Autorité des Marchés Financiers (AMF) licenses individual and collective portfolio management firms.

Insurance brokers do not require any business authorization, but must register with the Registre du Commerce et des Sociétés. They are also strongly encouraged to register with the French insurance and reinsurance brokers federation (FCA) and a forthcoming EU directive will require EU insurance brokers to register in such a manner. Currency exchangers must also register with the Corporations Register and submit a declaration of activity to the Banque de 
France before commencing business. In the securities area, direct marketers ("démarcheurs") are to be registered jointly with the AMF, the CECEI and the CEA, as of January 1, 2005. Financial advisers will be required to join/register with a professional association, which in turn will be authorized by the AMF, as of January 1, 2005. Intermediaries in miscellaneous assets are not subject to any registration requirement.

\section{Supervisory authorities}

The Commission Bancaire (CB) is responsible for ensuring AML/CFT compliance by credit institutions, investment firms other than portfolio management firms and currency exchangers with the legislative provisions applicable to them and to sanction the failure to do so. The CB has authority to conduct on-site examinations and off-site surveillance/monitoring, though in the case of currency exchangers this has been partly delegated to Customs authorities in accordance with Article L. 320-3 of the Financial and Monetary Code.

In the insurance sector, the Commission de Contrôle des Assurances (CCA) is responsible for ensuring AML/CFT compliance by insurance companies active in life and non-life, including mutual insurance companies. The CCA also has the discretion to supervise insurance and reinsurance brokers. It has the authority to impose sanctions on brokers for non-compliance.

The Autorité des Marchés Financiers (AMF), created by Law No. 2003-706 of August 1, 2003, is the product of the merging of the Exchange Operations Commission (COB) and the Financial Markets Council (CMF), is the authority responsible for ensuring compliance with the AML/CFT requirements by:

- Individual or collective portfolio management firms;

- Direct marketers ("démarcheurs") that work for or on behalf licensed financial entities;

- $\quad$ Financial investment advisers;

- Intermediaries in miscellaneous assets.

The AMF is also responsible for ensuring the compliance with market conduct rules by these entities and all firms providing investment services.

Although not strictly a financial sector supervisor, the Inspection Générale des Finances (IGF) has broad oversight/audit responsibilities with respect to state entities. In particular, it is responsible for AML/CFT supervision of the Caisse des Dépôts et Consignations and La Poste's financial services. The IGF does not have the authority to impose sanctions for non-compliance, but reports its findings to the Minister of Economy, Finance and Industry.

\section{Professional secrecy}

Professional secrecy is a fundamental guarantee provided to French citizens. Article 34 of the Constitution of October 4, 1958, provides the legislative authority to establish the legal arrangements applicable to professional secrecy.

Prosecution and judicial authorities: While the scope of professional secrecy is not defined in law, Article 226-13 of the Criminal Code provides that the disclosure of confidential information by any person entrusted with such information, either because of his position or profession or because of a temporary function or mission, is punishable by imprisonment for one year and a fine of $€ 15,000$. However, Article 226-14 of the Criminal Code provides that Article 226-13 does not apply in cases where the law requires or authorizes disclosure of such information. Professional/banking/financial secrecy poses no obstacle to the conduct of judicial proceedings so long as the law provides the modalities for lifting it. This applies to all professions, though the specific modalities may vary from one profession to another, notably in the case of attorneys.

TRACFIN: Law No. 90-614 of July 12, 1990 , regarding the participation of financial institutions in combating the 
laundering of the proceeds of drug trafficking (subsequently incorporated into the CMF-CMF), effectively waives the obligation of professional secrecy by requiring financial institutions to report TRACFIN funds or transactions they know or suspect are related to proceeds of drug trafficking or organized criminal activity.

Supervisory authorities: Financial institutions subject to supervision by the CB, the CCA and the AMF may not invoke professional secrecy vis-à-vis the supervisory authority (Article L.511-33, L.533-2 and L.520-2 of the CMF for the CB; articles L-310-21 and L-310-22 of the Insurance Code for the CCA; and article L-621-9 section 3 for the $\mathrm{AMF}$ )

\section{Analysis of Effectiveness}

The legal framework for AML/CFT preventive measures is characterized by its comprehensive coverage of financial entities and its broad range of due diligence and reporting requirements that go beyond the FATF standard. The regulatory framework, however, is incomplete and remains a work in progress, notably for sectors other than credit institutions and investment firms other than portfolio management firms, where there is greater reliance on supervisory and professional recommendations rather than on regulation or other enforceable means. Industry associations in the banking, insurance and securities sectors have been proactive in developing guidance for their members. The missions and powers of the competent authorities for AML/CFT supervision are generally clear and appropriate. However, the regulatory and supervisory framework for non-financial businesses and professions is incomplete.

The duty of professional secrecy does not appear to pose any obstacle to the implementation of the FATF standard. Recommendations and Comments

Authorities should continue in their efforts to develop and implement detailed regulations in support of the underlying laws. They should also review options for the regulation and supervision of non-financial businesses and professions and designate competent supervisory authorities.

Implications for compliance with FATF Recommendation 2

\section{R.2: Compliant}

\section{II-Customer identification}

(compliance with criteria 45-48 for the (i) banking sector; (ii) insurance sector; (iii) securities sector; and (iv) other financial institutions sector, plus sector specific criteria 68-83 for the banking sector, criteria 101-104 for the insurance sector and criterion 111 for the securities sector)

Description

Recently amended Article L.563-1 of the CMF and Article 3 of Decree No. 91-160 set out the following customer identification requirements: before entering into contractual relations or assisting a customer in the preparation or carrying out of a transaction, financial entities that are subject to transaction reporting requirements must identify their customers and verify their identity via presentation of a reliable document bearing a photograph of the client. Prior to the recent amendment of Article L.563-1, the requirement focused on account rather than contractual relationships, which left some ambiguity as to whether the requirement applied in situations where financial entities had some form of ongoing relationship, though not an account relationship with their customers.

Financial entities must identify and verify the identity of occasional customers with respect to transactions above $€ 8000$ ( $€ 1500$ for casinos and other gaming) or rental of a safe-deposit box in a similar manner.

With respect to legal entities, financial entities are required to ask for the original or certified true copy of any instrument or extract from an official registry verifying the name, legal form, and head office, as well as the powers of the persons acting on behalf of the legal entity.

Financial entities must also obtain information about the true identity of the persons on whose behalf an account is opened or a transaction conducted if there are any doubts as to whether the customer is acting on his or her own behalf. Article 3 of Decree No. 91-160 of February 13, 1991 provides that this obligation does not apply when the person requesting the opening of an account or the conduct of a transaction is itself a financial entity. 
Article L.563-1 also requires financial entities to take appropriate measures, in circumstances prescribed by decree, to mitigate the risks associated with entering into contractual relations or in assisting a client in preparing or carrying out a transaction when the customer is not physically present for identification purposes. No decree has been issued.

While French legislation does not forbid use of a numbered accounts, there is no waiver of the identification and control requirements. Capitalization bonds and contracts, distributed by insurance companies, allow the bearer to remain anonymous only vis-à-vis tax authorities, and can only be transferred by physical transmission.

\section{Additional sector-specific measures:}

\section{Credit institutions and investment firms other than portfolio management firms}

In implementing Article 33 of Decree No. 92-456 of May 22, 1992, a credit institution must, prior to opening an account, verify the domicile of the applicant.

Lines 126-128 of Form QLB 3 (Annex III to CB Instruction No. 2000-09) recommend a number of additional measures for credit institutions and investment firms other than portfolio management firms intended to address the risks associated with non-face-to-face customer identification. Line 132 recommends assessing expected account activity relative to a new customer. Line 136 recommends measures to address possible structuring by occasional customers to avoid identification.

The AFEI professional recommendations provide additional guidance for compliance with the legal requirements.

\section{Insurance companies}

Articles A-310-5, A-310-6, and A-310-7 of the Code des Assurances supplement the provisions of the CMF and its implementing Decree No. 91-160. Under these articles, every insurance company must verify the identity of the customer and other persons participating in an insurance or capitalization contract whenever it gives rise to the establishment of a mathematical reserve. In addition, every insurance company must also verify the identity of the beneficiary of a life insurance contract when the benefit is paid, as well as the identity of the person requesting redemption of a capitalization bond or contract.

The CCA Recommendations of June 2001 sent to all members of the profession, and the Professional Recommendations Regarding Anti-Money Laundering and Combating the Financing of Terrorism issued by the Federation of Insurance Companies (FFSA), recommend verifying the identity of all stakeholders in an insurance contract: the insured, the subscriber, the possible principal or originator, the non-revocable beneficiaries and the person paying the premium or seeking a redemption, advance, or repurchase. They also address measures to be taken regarding non-face-to-face transactions.

\section{Portfolio management firms}

Article 18 of Commission des Opérations de Bourse (COB) Regulation No. 96-03 requires generally of portfolio management firms that they establish an organization and procedures to comply with AML requirements. The COB has not prescribed the measures that these companies must take in this regard. Article 19 of the same regulation requires that the service provider inquire about the goals, investment experience, and financial situation of the principal.

While not as extensive or detailed as the CCA's recommendations, the industry association (AFG-ASFFI) recommendations provide some suggestions as to what portfolio management firms should do when entering into business relationship with a customer and over the life of the business relationship. In particular, when a portfolio manager enters into a direct business relationship with the principal, it is recommended that the following information be obtained and maintained: 


\begin{abstract}
- $\quad$ The identity and nature of the activity carried out;
- $\quad$ Net worth of the client and the origin of the funds entrusted;

- $\quad$ The client's investment objectives and experience; and

- Information pertaining to how relations were initiated.
\end{abstract}

The AFG-ASFFI further recommends particular vigilance in riskier circumstances. When the portfolio manager is not the account holder, e.g., a collective investment fund whose products are distributed by a third party, the portfolio manager must be satisfied that the third-party distributor has implemented policies and procedures to comply with AML/CFT requirements and set out contractually the third-parties CDD requirements.

\title{
Currency exchangers
}

Further to CRBF Regulation 91-11 of July 1, 1991, currency exchangers must inter alia enter customer identification data in a transactions register that they must maintain.

\section{Other sectors}

There are no additional regulatory requirements, nor supervisory/industry recommendations that are specifically related to customer identification.

\section{Wire transfers}

There are currently no legislative requirements for financial entities to include complete originator information (i.e., name, address and account number or unique reference number if no account number exists) in message or payment forms accompanying wire transfers. There is reliance instead on rules of the Centrale des Règlements Interbancaires, as well as conduct standards issued by the Association Française des Banques requiring that certain originator information (i.e., name, address, and identifying code of the originator where the originator is a business entity) be included in message forms. The rules and standards apply to banks and do not extend to non-bank financial institutions, notably La Poste. It is also unclear as to what is required when the originator is a physical person. Analysis of Effectiveness

The laws are clear and complete. Questionnaire QLB 3 pursuant to CB Instruction No. 2000-09 provides a detailed checklist of the legal requirements and reminder of the need to have customer acceptance policies and procedures but offers little additional guidance. The CCA recommendations and to a lesser extent the AFG-ASFFI recommendations provide additional useful detailed guidance. However, they are neither binding nor enforceable, nor do they extend to insurance and reinsurance brokers or direct marketers. No further rules or guidance apply to currency exchangers. Financial industry representatives in general indicated strong interest in obtaining additional guidance from the authorities.

Regarding wire transfers there are indications that the $\mathrm{CB}$ has exercised its broad authority to ensure compliance with professional rules and standards. Contacts with the profession within the Liaison Committee and random checks carried out during on-site inspections indicate that credit institutions are including the information necessary to identify originators of the transfers they issue. However, it is unclear whether this has been fully implemented with regard to domestic transfers. In addition, these professional rules and standards do not specifically require inclusion of the originator's account number. Finally, the rules and standards apply to banks and do not extend to non-bank financial institutions. As such, the measures in place do not sufficiently implement the relevant FATF standard. However, work is underway at the level of the EU on implementing the relevant FATF standard and the authorities have indicated their intention to set out requirements in legislation.

Recommendations and Comments

The authorities should introduce more detailed requirements through regulation or enforceable guidance as to what constitutes adequate customer acceptance policies and procedures and, in particular, what are the reasonable steps to be taken to identify beneficial owners of accounts and transactions. 
The authorities should review the ML/FT risks associated with capitalization bonds/contracts and take corrective measures, as appropriate.

The authorities should proceed with plans to introduce legislation to comply fully with SR VII. Implications for compliance with FATF Recommendations 10, 11, SR VII

R. 10 \& R. 11: Compliant.

SR VII: According to the FATF Interpretive Note to Special Recommendation VII, countries will have up to February 2005 to comply with SR VII and as such France is not rated against this recommendation. Work is proceeding on a EU regulation that will directly apply in member states.

\section{III-Ongoing monitoring of accounts and transactions}

(compliance with Criteria 49-51 for the (i) banking sector; (ii) insurance sector; (iii) securities sector; and (iv) other financial institutions sector, plus sector specific criteria 84-87 for the banking sector, and criterion 104 for the insurance sector)

Description

\section{Increased diligence of financial entities}

Article L. 563-3 of the CMF, together with Article 4 of Decree 91-160 of February 13, 1991, requires financial entities to closely examine any large transaction in single or total amount that exceeds $€ 150,000$ (when the customer's transactions are not usually above this amount) and which, without falling into the category of transactions to be reported as a STR to the TRACFIN, are unusually complex and do not appear to have any economic or lawful purpose. In such case, the financial institution must obtain information from the customer regarding the source and destination of the amounts in question, as well as the purpose of the transaction and the identity of the beneficiary. The details of the transaction must be recorded in writing and kept by the financial entity in accordance with the provisions of Article L. 563-4 of the CMF, i.e., for five years from the date of completion of the transaction. TRACFIN and the relevant supervisory authority are authorized to have access to such information. Financial entities are required to take the necessary organizational steps to be able to forward this information to them as expeditiously as possible. Financial entities must also ensure that these requirements are complied with by their foreign branches and subsidiaries, unless the local legislation prohibits it, in which case they must so inform the TRACFIN.

\section{Credit institutions and investment firms other than portfolio management firms}

Pursuant to Article 2 of Regulation 91-07 of the CRBF, credit institutions must have written internal rules describing how due diligence should be carried out in order to comply with AML/CFT requirements. Such rules must indicate the amounts and types of transactions that require particular due diligence and may also be adapted to the nature of parties with whom they do business.

Article 4 of Regulation 91-07 of the CRBF applicable to credit institutions and the questionnaire referred to in CB Instruction No. 2000-09, applicable to credit institutions and investment firms other than portfolio management firms, list the information that subject entities must collect and record in writing in the event of transactions of this type. CB Instruction 2000-09 also requires firms to have internal procedures for assessing their clientele using customer profiles in order to flag unusual financial transactions.

\section{Insurance companies and brokers}

There are no regulations applicable to insurance companies further to Article L. 563-3 of the CMF. However, the Recommendations of the CCA set out a number of measures to be taken by insurance companies for transactions above the $€ 150000$ threshold and examples of unusual circumstances where enhanced vigilance should be exercised. The professional recommendations of the FFSA set out similar procedures. While not specifically targeted to insurance and reinsurance brokers, many of the recommendations would be directly applicable or could be adapted. 


\section{Measures to cope with the problem of countries with no or insufficient anti-money laundering measures}

While there are regulations requiring credit institutions and investment firms other than portfolio management firms to give special attention to business relations and transactions with persons in jurisdictions that do not have adequate AML/CFT systems, there are no laws or regulations that specifically require other financial entities to do so. That said, the Minister of the Economy, Finance and Industry informs financial entities periodically (via their professional associations) of updates in the FATF's list of NCCTs and the key role of supervisory authorities in ensuring that financial entities exercise enhanced due diligence with respect to transactions of customers residing in NCCTs. Moreover, as indicated above, Article L. 563-3 of the CMF, together with Article 4 of Decree 91-160 of February 13, 1991, requires financial entities to pay special attention to any large transaction that exceeds $€ 150,000$ (when the customer's transactions are not usually above this amount) and which, without falling into the category of transactions to be reported as a suspicious transaction to TRACFIN, are unusually complex and do not appear to have any economic or lawful purpose. Moreover, decrees issued pursuant to Article L. 562-2 of the CMF require financial entities to report transactions above $€ 8000$ with respect to Nauru and Myanmar.

Moreover, Articles 8 and 9 of CRBF Regulation 2002-01 of April 18, 2002 require credit institutions to exercise increased scrutiny on checks received from foreign financial institutions located in countries or territories whose laws or practices are considered by the FATF to create obstacles to the fight against money laundering (i.e., NCCTs). The list of NCCTs is annexed to the regulation and updated by the Ministry of Finance following each change in the list of NCCTs.

Pursuant to Article 2 of CRBF Regulation 91-07, credit institutions and currency exchangers must include in their internal procedures a list of transactions subject to enhanced scrutiny, although this requirement does not specifically mention transactions with persons in jurisdictions that do not have adequate AML/CFT systems. However, CB Instruction 2000-09 (QLB 3, lines 110-113) requires credit institutions and investment firms other than portfolio management firms to exercise particular care regarding transactions with NCCTs. CB Instruction 2000-09 also requires credit institutions to report annually to the $\mathrm{CB}$ their list of branches or subsidiaries located in countries or territories identified as non-cooperative by the FATF, as well as their total exposures per NCCT.

With respect to portfolio management firms, the AFG-ASFFI recommendations provide guidance on steps that should be taken to mitigate the risks of money laundering when conducting business with offshore financial centers or in NCCTs. The recommendations also set out a number of examples of circumstances where enhanced vigilance should be exercised.

\section{Wire transfers}

There are no specific provisions that would require financial institutions to adopt appropriate procedures to identify and handle wire transfers that lack complete originator information. That said, pending implementation of the future European regulation on strengthening the scrutiny of transfers, the supervisory authorities have asked representatives of the financial sector, notably within the context of the Money Laundering Liaison Committee established pursuant to Article L562-10 of the CMF, to be especially vigilant when funds transfers are not accompanied by complete information on the originator.

Analysis of Effectiveness

1. Increased diligence of financial entities

Article L. 563-3 of the CMF and Article 4 of Decree 91-160 set out the main legislative requirements with respect to enhanced vigilance. The requirements apply only to transactions above $€ 150000$ when the customer's transactions are not usually above this amount. The transactions must also be unusually complex and have no apparent economic purpose. Formulated as such, this requirement suggests that if a customer's transactions typically exceed this threshold, there would be no obligation to exercise enhanced vigilance, even though such transactions might be complex or display unusual patterns. Moreover, while it may be appropriate to set a threshold for "unusual large transactions", the FATF standard does not contemplate any threshold with respect to "complex" transactions or "unusual patterns of transactions". Rather, the standard calls for special attention to be paid to all such transactions. 
The authorities have indicated that, based on Article 2 of CRBF Regulation 91-07 and interpretation of Articles L. 562-2 and L. 563-3 of the CMF, financial entities are required to exercise enhanced diligence with respect to any transaction that is complex, unusual and has no apparent economic purpose, regardless of threshold. They have cited a number of decisions of the CB in support of this, some of which have been reviewed and upheld by the Conseil d'Etat. However, Article L. 563-3 of the CMF together with Article 4 of Decree 91-160 of February 13, 1991 remain the clearest expressions of FATF Recommendation 14. Moreover, the decisions of the CB only concern credit institutions and other entities under its supervision. In addition, most of the decisions of the $\mathrm{CB}$ concern instances involving inadequate KYC account-opening procedures/records and large transactions. These decisions do not specifically address the requirements of FATF Recommendation 14, notably with regard to the need to examine the background and purpose of such transactions and to establish the findings in writing, irrespective of their amount or the degree of the financial institution's suspicion. The explicit text of L. 563-3, with its threshold, and the broader expectations of the authorities as to what financial entities are required to do in the circumstances described in FATF Recommendation 14 argue for the need to review, clarify and broaden existing legislative requirements.

\section{Measures to cope with the problem of countries with no or insufficient anti-money laundering measures}

While there are some regulatory provisions requiring financial entities to give special attention to business relations and transactions with persons in jurisdictions that do not have adequate AML/CFT systems, their application is essentially restricted to credit institutions and investment firms other than portfolio management firms. However, authorities indicate that in practice financial entities generally comply with advisories issued by the Minister of the Economy, Finance and Industry. For credit institutions and investment firms other than portfolio management firms, compliance with the above requirements is verified in particular by means of responses to the QLB questionnaire, as well as on-site examinations. Credit institutions and investment firms must also report annually to the CB on the number of intelligence files created in the preceding fiscal year, as well as the largest amount involved. These financial entities are reminded of these obligations by mail and in meetings following up on on-site examinations and off-site surveillance/monitoring. During on-site examinations carried out by the CB, financial transactions with noncooperative jurisdictions are examined in depth. As a part of ongoing supervision, credit institutions and investment firms other than portfolio management firms have also been asked detailed questions on a systematic and standardized basis concerning the enhanced customer due diligence measures they have taken with respect to transactions with the above-mentioned jurisdictions.

Insurance companies are reminded of the above-requirements as frequently as possible, either through outreach activities or in the context of ongoing relationships between insurance companies and the Audit Department. Compliance is confirmed in on-site examinations and follow-up.

Recommendations and Comments

Authorities should review and broaden requirements to pay special attention to certain transactions.

A requirement should be introduced for financial entities other than credit institutions and investment firms other than portfolio management firms to pay special attention to business relations and transactions with persons and legal entities in jurisdictions that do not have adequate systems in place to prevent and deter ML or FT Implications for compliance with FATF Recommendations 14, 21, 28, SR VII

R.14: Largely compliant because the legislative requirements are narrower in scope than the FATF standard. R.21: Largely compliant because there is no specific law, regulation or other enforceable means to ensure compliance by financial entities other than for credit institutions and investment firms other than portfolio management firms. .

R.28: Largely compliant, as additional efforts are needed to provide guidance to reporting entities, notably outside the banking sector. (see also V-- Suspicious Transaction Reporting).

SR VII: According to the FATF Interpretive Note to Special Recommendation VII, countries will have up to February 2005 to comply with SR VII and as such France will not be rated against this recommendation. Work is proceeding on a EU regulation that will directly apply in member states. 


\section{IV-Record keeping}

(compliance with Criteria 52-54 for the (i) banking sector; (ii) insurance sector; (iii) securities sector; and (iv) other financial institutions sector, plus sector specific criterion 88 for the banking sector, criteria 106 and 107 for the insurance sector, and criterion 112 for the securities sector)

Description

Article L. 563-4 of the CMF requires financial entities to retain for five years, beginning with the closing of accounts or the termination of business relations with them, all documents relating to the identity of their regular and occasional customers. Article 3 of Decree 91-160 states that financial institutions are required to keep the references or a copy of the identification documents that are submitted to them.

Pursuant to Article L. 563-4 of the CMF, financial entities are required to retain documents pertaining to their transactions for five years from the date of completion.

These requirements are supplemented by regulations, instructions, as well as by supervisory and professional recommendations.

TRACFIN and the supervisory authorities may request that documents be submitted to them for the purpose of reconstructing all transactions carried out by a natural or legal person in connection with a suspicious transaction report. Supervisory authorities are also authorized to access any documents necessary for the performance of their duties, as well as for the purpose of informing their counterparts in other countries.

Moreover, the provisions pertaining to the powers of the supervisory authorities entitle them to access any document necessary for the performance of their duties(articles L. 613-8 and L. 520-2 of the CMF for the CB; articles L. 31014 and L. 310-28 Insurance Code for the CCA; Articles L. 621-9-3 and L. 621-10 of the CMF for the AMF).

Professional secrecy may not be invoked against the $\mathrm{CB}$, the CCA or the AMF, or against a legal authority acting in the context of criminal proceedings (Article L. 511-33 of the CMF).

Analysis of Effectiveness

The legislative and regulatory provisions are comprehensive and appear to be effectively implemented.

Recommendations and Comments

Implications for compliance with FATF Recommendation 12

R.12: Compliant.

\section{V-Suspicious transactions reporting}

(compliance with Criteria 55-57 for the (i) banking sector; (ii) insurance sector; (iii) securities sector; and (iv) other financial institutions sector, plus sector specific criteria 101-104 for the insurance sector)

Description

Article L. 562-2 of the CMF requires financial entities to report to TRACFIN funds or transactions they suspect are related to proceeds of drug trafficking, fraud against the financial interests of the European Communities, corruption or organized criminal activity or which they suspect are related to the financing of terrorism. ArticleL-561.1 requires persons, other than those mentioned in L-562.1, who carry out, supervise or advise on transactions resulting in capital movements, are required to report to the Public Prosecutor's Office any transaction involving funds they know to be proceeds of crime mentioned in Article L. 562-2.

Article 562-5, requires that the STR be submitted before the transaction is completed unless it is impossible to delay it or when it becomes apparent only after the transaction that the amounts could have come from drug trafficking or organized criminal activities or related to the financing of terrorism. Likewise, new information that could affect the assessment of the amounts and transactions reported, and information supplementary to that contained in an STR, must be brought to the attention of TRACFIN immediately.

Article L. 562-2-1 requires that the STR be forwarded to TRACFIN, with the exception of lawyers and other legal 
professionals who must forward their reports to their law society or bar association. The latter must in turn forward the STR to TRACFIN unless they do not consider the transaction to be suspicious of money laundering, in which case they must so inform the person that made the STR. They must also forward to the Minister of Justice a sanitized case, which is then forwarded to TRACFIN.

Article 6 of Decree 91-160 of February 13, 1991 requires financial entities to adopt written internal rules defining procedures for implementing the legal and regulatory provisions contained in Title VI of the CMF and in Decree 91160. They must ensure that all staff involved in AML are kept informed and receive training. Regulation 91-07 of the CRBF requires credit institutions, investment firms other than portfolio management firms and currency exchangers to establish internal controls and procedures to ensure compliance with the AML provisions of the CMF and the Décret 91-160, including an audit system to verify compliance with the above-mentioned procedures. There are no similar regulatory requirements for other financial entities.

TRACFIN provides guidance on the detection of suspicious transactions in the form of typologies appended to its annual reports. Additional guidance has been provided by other competent authorities has been limited.

Article L. 562-8 of the CMF protects financial entities from criminal and civil liability for reporting in good faith. Without prejudice to criminal sanctions that may be levied, Article L.574-1 provides for a fine of $€ 22,500$ for any executive or employee of a financial entity who informs the owner of sums of money or the originator of a transaction reported pursuant to Article L. 562-2 of the existence of the report or provides information on the followup action to be taken.

In addition to suspicious transaction reporting, Article L. 562-2 requires financial entities to report any other transaction, where the identity of the order-giver or beneficiary remains in doubt, notwithstanding performance of the requisite customer due diligence measures. Financial entities are also required to report transactions on their own account or for the account of others with natural or legal persons, operating as or for trusts or similar arrangements where the identities of the settlor, trustee or beneficiaries are not known. Finally, this article provides the authority to issue a decree to require financial entities to report transactions above a certain threshold on their own account or for the account of others with natural or legal persons domiciled, registered or established in countries or territories where the AML laws are recognized as deficient or where practices impede the fight against money laundering. Decree No 2002-145 issued pursuant to this article requires financial entities to report transactions above $€ 8000$ with respect to Nauru and Decree No 2003-1195 was issued in respect of Myanmar.

\section{Analysis of Effectiveness}

The scope of the reporting requirements is not aligned and is indeed narrower than that of the predicate offences for money laundering. The scope of predicate offences for money laundering is comprehensive and covers all crimes and misdemeanors, including the financing of terrorism and fiscal fraud. On the other hand, a suspicion funds stem from a fiscal misdemeanor is not required to be reported. This may be a source of confusion for reporting entities regarding whether or not to report particular transactions and could expose them to compliance risks. This could potentially reduce the effectiveness of the regime.

TRACFIN and the supervisory authorities have made some effort to provide guidance for improving the detection and reporting of suspicious patterns of transactions, but more is needed in light of the acknowledged generally poor quality of a large number of STRs. Moreover, greater efforts should be made to improve reporting from the DOMTOM.

The additional reports, notably the ones in relation to trusts, have raised compliance burden but their benefits are unclear and could potentially draw away resources (i.e., of financial entities and TRACFIN) that might otherwise be used in the detection of suspicious transactions.

Recommendations and Comments

Authorities are currently examining the issue of the misalignment of the scope of the suspicious transaction reporting requirement and that of the predicate offences for money laundering. 
In view of the generally lower rates of reporting outside the banking sector, TRACFIN and supervisory authorities should provide further guidance and ML typologies to reporting entities to improve detection and reporting of suspicious transactions, the quality of STRs and overall implementation of AML/CFT requirements.

Authorities should also reach out to the DOM-TOM and monitor their compliance with AML/CFT obligations.

The usefulness of the additional reporting requirements should be reviewed.

Implications for compliance with FATF Recommendations 15, 16, 17, 28 and SR IV

R.15 and SR IV: Compliant.

R.16: Compliant.

R.17: Compliant.

R.28: Largely compliant, as additional efforts are needed to provide guidance to reporting entities, notably outside the banking sector.

\section{VI-Internal controls, Compliance and Audit}

(compliance with Criteria 58-61 for the (i) banking sector; (ii) insurance sector; (iii) securities sector; and (iv) other financial institutions sector, plus sector specific criteria $89-92$ for the banking sector, criteria 109 and 110 for the insurance sector, and criterion 113 for the securities sector)

Description

Internal Controls

Article 6 of Decree 91-160 of February 13, 1991 requires financial entities to adopt written internal rules defining procedures for implementing the legal and regulatory provisions contained in Title VI of the CMF and in Decree 91160. They must ensure that all staff involved in AML are kept informed and receive training.

Regulation 91-07 of the CRBF requires credit institutions, investment firms other than portfolio management firms and currency exchangers to establish internal controls and procedures to ensure compliance with the AML provisions of the CMF and the Décret 91-160, including an audit system to verify compliance with the above-mentioned procedures.

More broadly, Regulation 97-02 of the CRBF requires credit institutions and investment firms other than portfolio management firms to establish an internal control mechanism specifically including a system for auditing transactions and internal procedures, as well as a means of monitoring flows of cash and securities. One of the purposes for requiring a system for auditing transactions and internal procedures is to ensure that a financial entity's transactions, as well as its organization and internal procedures, comply with all applicable laws and regulations, including AML/CFT. This system must be organized in such a way as to ensure the proper execution of transactions and observance of internal risk-management policies, as well as an independent internal audit the effectiveness of these controls.

Article 4 of Regulation 2002-01 of the CRBF requires credit institutions establish and carry out an annual control program for checks as part of their due diligence obligations. This program, which includes selection criteria defined by the institution based on its own activities, must take into account changes in ML typologies and incorporate publicly available information, particularly that disseminated by the FATF and the TRACFIN. Finally, CB Instruction 2000-09 of October 18, 2000 provides guidance on the content of the internal procedures of credit institutions and investment firms other than portfolio management firms.

There are no similar comprehensive regulatory requirements for other financial entities. The Insurance Code contains few provisions regarding internal controls and these focus mainly on investment policy and the preparation of a solvency report. With respect to asset management companies, the AMF has procedures to review appropriate internal controls, but the regulations do not currently provide significant guidance as to what is expected and there is no requirement that the assessment of controls be independent. With the exception of COB Regulation 96-03, there are no specific requirements to appoint a AML officer with responsibility for AML compliance. However, the Recommendations of the CCA and of the AFG-ASFFI suggest appointment of AML/CFT compliance officers. The 
former also recommend periodic audit and testing. There is no guidance at all with respect to currency exchangers, insurance brokers and direct marketers.

\section{Employee screening}

There are few requirements for financial entities to have adequate screening procedures to ensure high standards when hiring employees and these focus largely on competency rather than integrity. The Recommendations of the CCA suggest that insurance companies screen prospective employees for integrity and monitor activities employees in sensitive positions on an ongoing basis.

\section{Training}

CB Instruction 2000-09 provides some guidance on employee training for training, one of which is that any new employee of a credit institution or investment enterprise must receive AML training when hired or in the following weeks, and also that all concerned employees should be kept regularly informed on this subject. Credit institutions and investment enterprises must also report annually to the $\mathrm{CB}$ the number of employees who received AML training in the preceding fiscal year, the date of the last AML investigation conducted by the internal control department, and the date of the last update of the AML procedures manual. The Fédération Bancaire Française has developed an extensive employee audio-visual training tools customized according to the type of activity.

A decree of October 1, 2002 amended the minimum training programs for insurance company personnel. In particular, a special AML/CFT module was introduced. Modules for ongoing AML/CFT training have been developed by the FFSA and disseminated to its members.

The AFG-ASFFI also recommends that portfolio management firms establish formal employee training programs under the responsibility of the AML/CFT compliance officer. It is also recommended that the compliance officer make available to employees up-to-date copies of applicable laws and regulations, as well as internal policies and procedures.

\section{Application to foreign branches and subsidiaries}

Article 5 of Regulation No 91-07 of the CRBF requires credit institutions and currency exchangers headquartered in France to "make all necessary recommendations" 35 to their foreign branches and subsidiaries to protect themselves, by appropriate means, against the risk of being used for ML purposes. These branches and subsidiaries are required inform their headquarters, where necessary, of any local laws that prohibit the implementation of any or all of these recommendations and headquarters must so notify TRACFIN. Moreover, credit institutions and investment firms other than portfolio management firms must report annually to the $\mathrm{CB}$ a list of branches and subsidiaries located in countries where laws prohibit the implementation of these recommendations. No similar requirements apply to other financial entities.

Analysis of Effectiveness

The framework, which requires the establishment of internal rules defining procedures for implementing AML/CFT requirements, are supplemented by comprehensive regulations insofar as credit institutions and investment firms other than portfolio management firms are concerned. In the case of insurance companies and portfolio management firms, there is reliance on supervisory and professional recommendations, which while helpful in signaling what financial entities are expected to do, are neither binding nor enforceable. No apparent guidance is provided to other sectors, although representatives of La Poste described to the mission a relatively robust system of internal controls. There are few requirements for financial entities to have adequate screening procedures to ensure high standards when hiring employees and these focus largely on competency rather than integrity.

\footnotetext{
35 These "recommendations" are not prescribed in the regulation.
} 
Employee training appears to be effectively implemented with respect to credit institutions, investment firms other than portfolio management firms and insurance companies and La Poste.

Other than for credit institutions and currency exchangers, there are no specific requirements for financial entities to ensure the comprehensive application of AML/CFT requirements to branches and majority owned subsidiaries located abroad.

\section{Recommendations and Comments}

The regulatory framework for internal controls needs to be strengthened for all sectors other than credit institutions and investment firms other than portfolio management firms.

Financial entities should also be required to take integrity into account when hiring employees, notably for sensitive positions.

Other than for credit institutions and currency exchangers, a requirement should be established for financial entities to ensure that AML/CFT requirements are applied to branches and majority-owned subsidiaries located abroad.

Authorities should further assist financial entities in developing employee training programs.

Implications for compliance with the FATF Recommendations 19, 20

R.19: Largely compliant, as the regulatory framework for internal controls other than for credit institutions and investment firms other than portfolio management firms is incomplete and there are no requirements for taking into account integrity when hiring employees.

R.20: Largely compliant, owing to the absence of legal requirements other than for credit institutions and currency exchangers.

\section{VII-Integrity standards}

(compliance with Criteria 62 and 63 for the (i) banking sector; (ii) insurance sector; (iii) securities sector; and (iv) other financial institutions sector, plus sector specific criterion114 for the securities sector)

Description

Articles L 612-1, L 511-10, L 511-15, and L. 532-2 grant the CECEI the exclusive authority to issue to and withdraw licenses from banking and investment firms other than portfolio management firms. The CECEI may attach conditions to the license. Based on non-compliance with the terms and conditions of the original license, or when the institution requests, the CECEI can withdraw the license. Only the CB is authorized to withdraw the license as a sanction.

The CMF also sets out the conditions that must be met for the issuance of a license, including the program of operations (business plan) of the institution, its proposed technical and financial resources, the suitability (fit and properness) of the managers and shareholders and where applicable their guarantors. Any substantive change in the way a bank meets the condition must receive prior approval of the CECEI, including changes in .ownership and control.

Similar provisions apply to portfolio management firms. Pursuant to Article L.532-4 and L. 532-9 of the CMF and COB Regulation 96-02, the AMF assesses the qualifications of shareholders, partners, and limited partners of portfolio management firms with a view to ensuring their sound and prudent management.

Direct marketers are to be registered jointly with the AMF, the CECEI and the CEA, as of January 1, 2005. Direct marketing activities must be carried out by or on behalf (in the case of independent direct marketers) of a licensed credit institution, investment firm, insurance company or a financial adviser. Article L. 341.9 of the CMF prohibits anyone convicted of a crime from undertaking direct marketing activities. Article L. 341-4-IV will allow a "fit and proper" test to be implemented by decree. Financial advisers will be required to join/register with a professional association, which in turn will be authorized by the AMF, as of January 1, 2005. Article L. 547-7 prohibits anyone convicted of a crime from providing financial advice and L. 541-2 will allow a "fit and proper" test to be implemented by decree. 
Article L. 520-1 of the CMF requires currency exchangers to register with the Corporations register and submit a declaration of activity to the Banque de France. While there is no "fit and proper" test as such, currency exchangers must declare to the Banque de France that they do not have prior criminal convictions. and such declarations are examined for completeness by the Banque de France as part of the registration process (Articles 2 and 3 of the Instruction No. 1-97 of February 4, 1997 of the CB). There is no particular requirement concerning the suitability of shareholders.

Article 13 of Law No. 84-46 of January 24, 1984 prohibits persons who have been convicted pursuant to that article (particularly for a felony, theft, fraud, breach of trust, personal bankruptcy) from serving on the executive or supervisory board of a credit institution. Such persons may not operate, direct, or manage a credit institution in any capacity, whether directly or through another, nor may they be given authority to sign on behalf of such an institution. Anyone convicted under Article 13 of Law No. 84-46 is likewise prohibited from engaging in the profession of foreign exchange dealer. Identical prohibitions are specified for investment firms by Article 22 of Law No.96-597 of July 2, 1996.

The Comité des Entreprises d'Assurance (CEA) is responsible for issuing business authorizations to insurance companies. The CCA is responsible for issuing authorizations to companies that are only active in the reinsurance area. Article L. 322-2 of the Insurance Code requires that the board members and senior management of the company be fit and proper in the sense of competency, experience and integrity. No person may establish, direct or manage a firm if they have been convicted of a crime. The Insurance Code also requires insurance companies to notify to the CEA changes in control and whenever changes in shareholding are planned that cross a certain threshold. The CEA has the discretion to refuse a transaction. In all cases, the suitability of the new owners and the consequences of these changes for the business plan are checked, and on this basis the CEA can block a transaction or request commitments to ensure the soundness and stability of the insurance undertaking.

Article L. 511-2 of the Insurance Code similarly stipulates that a person convicted of a crime may not carry on the occupation of general agent or insurance or reinsurance broker. This applies also to insurance or reinsurance transactions conducted by agents and employees of firms, general agents, brokers and brokerage firms.

Analysis of Effectiveness

Measures in place are comprehensive and effectively implemented. There exists good cooperation between supervisory authorities.

Recommendations and Comments

AML/CFT internal controls should be required to be taken into account in the licensing of financial entities.

Authorities should consider introducing an explicit "fit and proper" test for currency exchangers

Implications for compliance with FATF Recommendation 29

R.29: Compliant.

\section{VIII-Enforcement powers and sanctions}

(compliance with Criteria 64 for the (i) banking sector; (ii) insurance sector; (iii) securities sector; and (iv) other financial institutions sector, plus sector specific criteria 93-96 for the banking sector and criteria 115117 for the securities sector)

Description

\section{Commission Bancaire}

Pursuant to the provisions of Article L.613-1 of the CMF, the CB is responsible for monitoring the compliance of credit institutions with the legislative and regulatory provisions applicable to them and for sanctioning them when necessary. Article L.613-2 of the CMF provides that the CB also ensures compliance by investment firms other than portfolio management firms with their legal and regulatory obligations. Pursuant to the provisions of Article 520-2 of the $\mathrm{CMF}$, the $\mathrm{CB}$ is also the supervisory authority for currency exchangers. Although most of the on-site examinations have been performed by the Customs authorities, the CB imposes sanctions for non-compliance. 
The CB has authority for on-site examinations and off-site surveillance/monitoring (Article L.613-6 of the CMF). For off-site audits, the $\mathrm{CB}$ determines the list, the form, and the deadlines for submission of the documents and information that must be forwarded to it (QLB-CB Instruction 2000-09 requiring written internal rules, etc.). For onsite audits, it may also extend its audit to the subsidiaries of a credit institution or investment firm, as well as to the legal entities that control, directly or indirectly, a credit institution or investment firm, as well as their subsidiaries.

When a financial entity has neglected its AML/CFT obligations owing to a serious lack of due diligence or a deficiency in its internal control procedures, the CB may institute disciplinary proceedings against it. The disciplinary sanctions that the CB can impose on a credit institution or investment enterprise are: warning; reprimand; disqualification from carrying out certain transactions or other limits on engaging in an activity; temporary suspension of one or more of the responsible officers, possibly including the appointment of a provisional administrator: removal from office of one or more of these same individuals, possibly including the appointment of a provisional administrator or removal of the financial institution from the register. It may also impose, in place or instead, a fine equal at most to the minimum capital of the legal entity. It may also prohibit or limit the distribution of a dividend to shareholders or the remuneration of corporate shares. Finally, the CB may decide that the sanctions imposed will be made public.

The disciplinary sanctions that the CB can impose on foreign exchange dealers are: warning, reprimand, or disqualification from dealing in foreign exchange. The law of August 1, 2003 on financial security extended the scope of the disqualification from dealing in foreign exchange to the officers of legal entities. It may also impose, in place or instead of these sanctions, a fine of no more than $€ 1$ million. The CB may decide that the de facto or de jure officers are jointly and severally liable for the payment of this sanction (Law of August 1, 2003).

In 2002, 34 disciplinary decisions were rendered, of which 18 involved breaches relating to AML/CFT requirements. The sanctions ranged from a warning to removal from the register, but the most frequent sanction was a warning plus a fine, amounting to as much as $€ 228,000$. In 2003, 28 disciplinary decisions were issued, of which 20 involved breaches relating to AML/CFT requirements. In 2003, a warning plus a fine was the most frequently imposed sanction. Decisions involving the imposition of sanctions mainly for failure to implement AML/CFT requirements were systematically publicized. The $\mathrm{CB}$ underscored the positive effect of such publication.

With respect to currency exchangers, the CB imposed 11 sanctions in 2003 for failure to comply with AML/CFT requirements. It also initiated 29 inquiries in 2003. Since 1986, eight currency exchangers have been barred from operating their business. Breaches in compliance ranged from inadequate record-keeping to failure to report suspicious transactions.

Funds transfer businesses are licensed and supervised as credit institutions. While strong enforcement action has been taken against unlicensed funds transfer businesses when they have been discovered, experience with such cases has not been extensive.

\section{Commission de Contrôle des Assurances}

The CCA is responsible for monitoring the compliance of insurance companies, and insurance and reinsurance brokers (but not reinsurance companies) with the legislative and regulatory provisions applicable to them and for sanctioning them when necessary.

The CCA carries out a range of on-site examinations and off-site surveillance/monitoring, as well as other compliance related activities. The annual examination program is established on a risk basis, targeting important or sensitive cases. Each team of examiners is assigned to the supervision of the same insurance companies for a number of years, which increases supervisory effectiveness.

The CCA can impose disciplinary sanctions on insurance companies that fail to comply with their legislative and regulatory obligations, ranging from fines, warnings and the withdrawal of the license to operate. It can make public its decisions to impose sanctions. To date, however, only two sanctions have been imposed for failure to comply with 
AML/CFT requirements.

In contrast to the system in place for insurance companies' examinations, the CCA must take a formal decision on a case-by-case basis to conduct on-site examinations of insurance brokers. While the CCA has had the authority to impose disciplinary sanctions against insurance brokers since 2003, this authority will be clarified with a legislative amendment to the Insurance Code that is expected to be adopted in the near future.

\section{Autorité des Marchés Financiers}

Article L.621-9 of the CMF grants the AMF the power to supervise, investigate, and sanction, both for market conduct and AML/CFT, collective investment schemes, portfolio management firms, direct marketers, financial advisers and intermediaries dealing in miscellaneous goods.

The on-site examination capacity of the AMF is organized in two different departments. The Inspection department is mainly responsible for investigating market abuses such as insider dealing, market manipulation and dissemination of false information; it does not examine specifically the AML/CFT requirements, but whenever a suspicion on money laundering exists, the investigation is carried out to its end. The other department is in charge of the Control of investment firms and market infrastructures, and is also responsible for verifying the compliance with AML/CFT requirements.

The applicable sanctions are: warning; reprimand; temporary or permanent disqualification from engaging in any or all the services provided; the sanctions committee can impose, in place or instead of these sanctions, a fine of up to $€ 1.5$ million or five times the amount of any profits realized. These amounts are paid to the guarantee fund with which the sanctioned person is affiliated or, failing that, to the Treasury. [To date, no sanctions have been imposed for non-compliance with AML/CFT requirements.]

\section{Inspection Générale des Finances}

Although not strictly a financial sector supervisor, the Inspection Générale des Finances (IGF) has broad oversight/audit responsibilities with respect to the Ministry of Economy, Finance and Industry. It can conduct special inquiries with respect to state entities and evaluate the effectiveness of public policies. It is responsible for AML/CFT supervision of the Caisse des Dépôts et Consignations and La Poste's financial services. The IGF does not have the authority to impose administrative sanctions for non-compliance with AML/CFT requirements and follow-up on their reports is the responsibility of the Minister of Economy and Finance, as well as the Conseil Supérieur des Postes et Télécommunications.

Analysis of Effectiveness

Enforcement and sanction powers of supervisory authorities are generally appropriate. The CB has a good range of enforcement actions that it can take against credit institutions, investment firms other than portfolio management firms and currency exchangers to ensure compliance with AML/CFT requirements. It has taken a broad range of enforcement actions and routinely publishes the results. However, it has had limited experience in taking enforcement action against unlicensed funds transfer businesses. The authorities have indicated that they have neither systematically sought out to identify unlicensed businesses nor have they conducted any outreach/awareness raising activities.

The CCA has a good range of enforcement actions that it can take against insurance companies and brokers to ensure compliance with AML/CFT requirements. However, the number sanctions imposed on insurance companies and brokers is relatively low. The AMF also has a good range of enforcement actions that it can take against portfolio management firms to ensure compliance with AML/CFT requirements. However, it has not imposed any sanctions for non-compliance with AML/CFT requirements.

There is too much reliance on La Poste's not inconsiderable internal control mechanisms and too little on programmed independent examinations by the IGF. It is unclear what, if any sanctions are available or have been 
levied for non-compliance.

Recommendations and Comments

The supervisory and enforcement efforts of the CCA, the AMF and with respect to La Poste need to be increased.

The authorities should review and monitor the adequacy of enforcement efforts with respect to unlicensed informal funds transfer businesses and develop complementary public outreach /awareness raising activities.

\section{IX-Cooperation between supervisors and other competent authorities}

(compliance with Criteria 65-67 for the (i) banking sector; (ii) insurance sector; (iii) securities sector; and (iv) other financial institutions sector, plus sector specific criteria 97-100 for the banking sector and criteria 118120 for the securities sector)

Description

\section{Supervision}

In 2003, the CB conducted 174 general on-site examinations, including for compliance with AML/CFT requirements, as well as 14 special AML/CFT examinations. Some 180 examiners were dedicated to this task. About 40 on-site examinations are conducted annually of currency exchangers by Customs authorities (covering six percent of the registered currency exchangers and about 40 percent of the volume of transactions).

The CCA has conducted 28 examinations of life insurance companies in the last four years or about 22 percent of all the licensed life insurance companies. Since 1996, it has conducted two on-site examinations of insurance brokers. It employs about 100 persons, including two persons in the AML/CFT unit and 35 persons in the inspection department. As of 2005, the CCA will become an independent authority and control its own budget. It also plans to increase its supervisory resources.

In 2003, the AMF conducted 85 on-site examinations of portfolio management firms, representing 20 percent of regulated entities. The majority of these examinations were delegated to and conducted by other supervisory authorities or auditing firms, under the control of the $\mathrm{AMF}^{36}$. The AML/CFT component of this examination is small. For example, there is no review for suspicious transaction reporting. The AMF employs 318 persons, including 30 investigators in its Inspection Department and 17 full-time examiners in its Supervision Department.

The IGF conducted two AML examinations of La Poste, leading to two reports issued in 1992 and 1995. These examinations had found some deficiencies that were communicated to La Poste and the Minister of Economy and Finance. In July 2004, the IGF launched a broad inquiry into and audit of France's AML/CFT regime, a component of which will address La Poste's financial services. The audit team consists of 6 persons. The inquiry is ongoing. The IGF employs some 70 inspectors.

\section{Supervisory guidelines}

In general, supervisory authorities have not issued guidelines to assist financial institutions in implementing AML/CFT requirements. In particular, the $\mathrm{CB}$ has not issued guidelines or guidance, including specific guidance provided by the Customer Due Diligence paper issued by the Basel Committee ${ }^{37}$. It instead relies on regulations and instructions, such as an annual questionnaire to signal what it considers to be the essential components of AML/CFT policies, procedures and internal controls. It also responds to questions of interpretation of and compliance with laws and regulations raised by financial institutions. The CCA has issued professional recommendations, which describe

\footnotetext{
${ }^{36}$ Whenever an examination is delegated to the CB's inspectors or to external auditors, the AMF retains ownership and control of the examination and for instance writes up the final report.

${ }^{37}$ Customer due diligence for banks, the Basel Committee, October 4, 2001.
} 
AML/CFT requirements in a detailed and systematic way and provide practical advice; however, these recommendations are neither binding nor do they extend specifically to insurance intermediaries. The AMF has not issued guidelines. Private sector representatives indicated that it would be very helpful if supervisory authorities were to issue guidelines to assist them in implementing AML/CFT requirements.

\section{Cooperation}

Articles L.631-1 and L. 631-2 of the CMF provide for a legal framework for comprehensive cooperation between supervisory and licensing authorities in the financial sector. These bodies have pursuant to Article L. 631-1 explicit legal authority to share specific, as well as general information with each other as necessary and appropriate to fulfill their own missions. The Collège des autorités de contrôle des entreprises du secteur financier, which is comprised of the Heads of the financial sector supervisory bodies, has been assigned, under Article L. 631-2, the task of developing information exchange and coordinating supervisory activities for financial groups that have entities that come under the supervision of different authorities.

Article L. 613-3 of the CMF organizes cross Board membership and joint meetings between CB and CCA. Further to Article L. 612-3, the Presidents of AMF and CB are members of the CECEI and pursuant to Articles L. 621-2 and L. 613-3 the Governor of the Banque de France is the President of the CB and a member of the "Collège" of the AMF. Article L. 532-2 requires the CECEI to consult with the AMF with respect to certain licensing decisions. A common database on financial institutions managers has been developed by CECEI, AMF and CB. Pursuant to Article 11 of Decree 2003-1109 of 21 November 2003 CB conducts on-site examinations on behalf of AMF. Pursuant to Article 11 of Decree 84-708 of 24 July 1984, the CB informs the CECEI and AMF of any decision concerning institutions under their common supervision. A similar procedure applies with respect to the AMF in Article 20 of Decree 20031109 of 21 November 2003. In addition, the CB and CCA have developed close links and stepped up their cooperation in 2001, which has been formalized in a charter.

Supervisory authorities and TRACFIN are also authorized to exchange information on suspicious transactions. Supervisory authorities are also required to inform the Public Prosecutor when, through a serious flaw in vigilance oversight or shortcoming in the organization of its internal audit procedures, a financial organization has failed to observe its vigilance obligations. They must also inform the Public Prosecutor whenever they have knowledge of a crime or misdemeanor.

Article L-613-12 of the CMF permits, on the one hand, information exchanges between the CB and its EEA counterparts responsible for the oversight of credit institutions and investment firms, and, on the other hand, responding to requests from counterpart authorities either by directly carrying out the audit requested or by permitting representatives of those authorities to do so. Article L-613-13 also provides that the CB may enter into bilateral agreements with non-EEA counterparts, so long as those authorities are subject to professional secrecy on terms equivalent to those affecting the $\mathrm{CB}$, for purposes of:

- $\quad$ exchanging information; and/or

- $\quad$ extending on-site inspections to the branches or affiliates of a French organization established in that State; and/or

- $\quad$ conducting, at the request of the foreign authority, on-site examinations of establishments located in France that are branches or affiliates of establishments located in the foreign State.

Cooperation between EEA insurance supervisors, including information sharing, is regulated through several directives and multilateral protocols of application. These arrangements allow for the unrestricted exchange of information, including on a cross- sector basis in the case of supervision of insurance groups or financial conglomerates. The French legislative has transferred these arrangements into French law.

As regards non-EEA insurance supervisors, the CCA has the authority to enter into agreements with foreign competent authorities on the exchange of relevant information (provided the foreign supervisor is subject to professional secrecy constraints), although none have been entered into to date; allowing the French supervisor to 
carry on on-site inspections in foreign branches of French undertakings; and allowing, under certain conditions, foreign supervisors to participate in the on-site inspections carried on by the CCA in French branches of foreign companies (Art. L.310-21 of the Insurance Code).

Article L-621-21 of the CMF authorizes the AMF to conduct investigations at the request of its counterparts subject to the same conditions, the same procedures, and the same sanctions as provided for the performance of its own mandate (Article L-621-21). It may also share with or obtain information for its foreign counterparts upon request, subject to reciprocity in the case of those outside the EEA, as well as to the condition that the competent foreign authority is subject to professional secrecy requirements that offer the same guarantees as in France (Article L-621-21).

Assistance to a foreign authority may only be refused if it jeopardizes French sovereignty, security, or public order or if criminal proceedings have already been initiated against the same persons for the same acts, or when the persons concerned have already been sanctioned by a final decision relating to the same acts.

Analysis of Effectiveness

\section{Supervision}

All supervisory authorities are appropriately structured. The CB appears to have a robust program of examinations and sufficient human and financial resources to carry it out.

AML/CFT supervisory efforts and corresponding resources are relatively low with respect to life insurance companies and brokers, individual and collective portfolio management firms, direct marketers and La Poste. The number of on-site inspections and corresponding staff resources for these sectors is relatively low and there have been few sanctions imposed for failure to comply with AML/CFT requirements. When looked at in the context of historically relatively low rate of reporting of suspicious transactions from these sectors, it is consequently difficult to assess whether AML/CFT requirements are being effectively implemented overall.

\section{Cooperation}

There is a long history of cooperation among domestic supervisory, licensing authorities and TRACFIN. The CB has concluded a number of bilateral agreements with foreign counterparts. In 2001 information provide by foreign authorities led to two AML/CFT sanctions decisions. The COB's cooperation with its foreign counterparts was extensive and of long standing. It had concluded more than thirty bilateral agreements and two multilateral agreements. While the CCA maintains general contact for AML/CFT purposes with foreign supervisory authorities and through the IAIS, the CCA does not routinely exchange case information with its foreign counterparts and no formal agreements exist with foreign counterparts. The reasons for this are not entirely clear.

Recommendations and Comments

The supervisory resources of the CCA and the AMF should be increased and training of supervisory staff formalized.

The responsibility for AML/CFT supervision and enforcement of La Poste's financial services should be shifted to the $\mathrm{CB}$ or at a minimum the supervisory efforts and resources of the IGF should be increased.

Where possible, supervisors should issue enforceable guidelines in support of the legal and regulatory framework Implications for compliance with FATF Recommendation 26

R. 26: Largely compliant, as a result of the relatively low supervisory efforts and resources other than for the CB. 


\title{
Description of the Controls and Monitoring of Cash and Cross Border Transactions
}

\author{
Table 47. Description of the Controls and Monitoring of Cash and Cross Border Transactions
}

\begin{abstract}
FATF Recommendation 22: Description

The Code des Douanes requires persons to declare all importations and exportations of cash and monetary instruments above a threshold of $€ 7600$. Failure to do so can result in the confiscation of the undeclared amounts or a fine that can be as high as the undeclared amount. The objective of this requirement is to combat tax evasion, money laundering and the financing of terrorism, and assist investigations. Moreover, Article L. 152-3 of the CMF requires credit institutions to communicate to fiscal and customs authorities, upon request, the date and amount of funds that are transferred abroad on behalf of persons corresponding to article L 152-2 of the same Code, the identity of both the originator of the transfer and the beneficiary, as well as the account references both in France and abroad.

Some 25,000 declarations are made annually, representing some $€ 1$ billion. There are some 1,800 cases of failure to declare annually, representing some $€ 150-230$ million. About 40 of such cases are forwarded to judicial authorities for prosecution of money laundering offences each year. This mechanism has notably led to the seizure of considerable sums of money suspected of being destined to finance terrorism.

Customs authorities are to be commended for their important efforts in this regard. It is recommended that authorities consider the possibility of extending the requirement to declare to importations and exportations effected through the mail and courier companies in order to address the possible displacement of smuggling activities through these means.
\end{abstract}

The mission took note of concerns expressed by authorities regarding an EU initiative to establish an EU-wide declaration requirement vis-à-vis third countries and of the importance of allowing EU members the flexibility to establish or maintain their own regime vis-à-vis EU members.

\section{FATF Recommendation 23:}

\section{Description}

Article L. 562-2 provides the authority to issue a decree to require financial entities to report transactions above a certain threshold, on their own account or for the account of others with natural or legal persons domiciled, registered or established in countries or territories where the AML laws are recognized as deficient or where practices impede the fight against money laundering. Decree No 2002-145 issued pursuant to this article requires financial entities to report transactions above $€ 8000$ with respect to Nauru and Decree No 2003-1195 was issued in respect of Myanmar.

\section{Interpretative Note to FATF Recommendation 22:}

Description

The Code des Douanes requires persons to declare all importations and exportations of cash and monetary instruments above a threshold of $€ 7600$. 


\section{Ratings of Compliance with FATF Recommendations, Summary of Effectiveness of AML/CFT Efforts and Recommended Action Plan}

Table 48. Ratings of Compliance with FATF Recommendations Requiring Specific Action

\begin{tabular}{|c|c|c|}
\hline FATF Recommendation & $\begin{array}{l}\text { Based on Criteria } \\
\text { Rating }\end{array}$ & Rating \\
\hline $\begin{array}{l}1 \text { - Ratification and implementation of the Vienna } \\
\text { Convention }\end{array}$ & 1 & Compliant \\
\hline $\begin{array}{l}2 \text { - Secrecy laws consistent with the } 40 \\
\text { Recommendations }\end{array}$ & 43 & Compliant \\
\hline $\begin{array}{l}3 \text { - Multilateral cooperation and mutual legal assistance } \\
\text { in combating ML }\end{array}$ & $34,36,38,40$ & Compliant \\
\hline $\begin{array}{l}\text { 4- ML a criminal offense (Vienna Convention) based on } \\
\text { drug ML and other serious offenses. }\end{array}$ & 2 & Compliant \\
\hline $\begin{array}{l}5-\text { Knowing ML activity a criminal offense (Vienna } \\
\text { Convention) }\end{array}$ & 4 & Compliant \\
\hline $\begin{array}{l}7 \text { - Legal and administrative conditions for provisional } \\
\text { measures, such as freezing, } \\
\text { seizing, and confiscation (Vienna Convention) }\end{array}$ & $7,7.3,8,9,10,11$ & Compliant \\
\hline $\begin{array}{l}8 \text { - FATF Recommendations } 10 \text { to } 29 \text { applied to non- } \\
\text { bank financial institutions; (e.g., foreign exchange } \\
\text { houses) }\end{array}$ & & See answers to 10 to 29 \\
\hline $\begin{array}{l}10-\text { Prohibition of anonymous accounts and } \\
\text { implementation of customer identification policies }\end{array}$ & $45,46,46.1$ & Compliant \\
\hline $\begin{array}{l}11 \text { - Obligation to take reasonable measures to obtain } \\
\text { information about customer identity }\end{array}$ & $46.1,47$ & Compliant \\
\hline $\begin{array}{l}12 \text { - Comprehensive record keeping for five years of } \\
\text { transactions, accounts, correspondence, and customer } \\
\text { identification documents }\end{array}$ & $52,53,54$ & Compliant \\
\hline $\begin{array}{l}14 \text { - Detection and analysis of unusual large or otherwise } \\
\text { suspicious transactions }\end{array}$ & $17.2,49$ & Largely compliant \\
\hline $\begin{array}{l}15 \text {-If financial institutions suspect that funds stem from } \\
\text { a criminal activity, they should be required to report } \\
\text { promptly their suspicions to the FIU }\end{array}$ & 55 & Compliant \\
\hline $\begin{array}{l}16 \text { - Legal protection for financial institutions, their } \\
\text { directors and staff if they report their suspicions in good } \\
\text { faith to the FIU }\end{array}$ & 56 & Compliant \\
\hline $\begin{array}{l}17 \text { - Directors, officers and employees, should not warn } \\
\text { customers when information relating to them is reported } \\
\text { to the FIU }\end{array}$ & 57 & Compliant \\
\hline $\begin{array}{l}18-\text { Compliance with instructions for suspicious } \\
\text { transactions reporting }\end{array}$ & 57 & Compliant \\
\hline $\begin{array}{l}19 \text { - Internal policies, procedures, controls, audit, and } \\
\text { training programs }\end{array}$ & $58,58.1,59,60$ & Largely compliant \\
\hline $\begin{array}{l}20-\text { AML rules and procedures applied to branches and } \\
\text { subsidiaries located abroad }\end{array}$ & 61 & Largely compliant \\
\hline $\begin{array}{l}21-\text { Special attention given to transactions with higher } \\
\text { risk countries }\end{array}$ & $50,50.1$ & Largely compliant \\
\hline $\begin{array}{l}26 \text { - Adequate AML programs in supervised banks, } \\
\text { financial institutions or intermediaries; authority to } \\
\text { cooperate with judicial and law enforcement }\end{array}$ & 66 & Largely compliant \\
\hline
\end{tabular}




\begin{tabular}{|c|c|c|}
\hline FATF Recommendation & $\begin{array}{l}\text { Based on Criteria } \\
\text { Rating }\end{array}$ & Rating \\
\hline 28 - Guidelines for suspicious transactions' detection & $17.2,50.1,55.2$ & Largely compliant \\
\hline $\begin{array}{l}29 \text { - Preventing control of, or significant participation in } \\
\text { financial institutions by criminals }\end{array}$ & 62 & Compliant \\
\hline $\begin{array}{l}32 \text { - International exchange of information relating to } \\
\text { suspicious transactions, and to persons or corporations } \\
\text { involved }\end{array}$ & $22,22.1,34$ & Compliant \\
\hline $\begin{array}{l}33 \text { - Bilateral or multilateral agreement on information } \\
\text { exchange when legal standards are different should not } \\
\text { affect willingness to provide mutual assistance }\end{array}$ & $34.2,35.1$ & Compliant \\
\hline $\begin{array}{l}34-\text { Bilateral and multilateral agreements and } \\
\text { arrangements for widest possible range of mutual } \\
\text { assistance }\end{array}$ & $34,34.1,36,37$ & Compliant \\
\hline $\begin{array}{l}37-\text { Existence of procedures for mutual assistance in } \\
\text { criminal matters for production of records, search of } \\
\text { persons and premises, seizure and obtaining of evidence } \\
\text { for ML investigations and prosecution }\end{array}$ & $27,34,34.1,35.2$ & Compliant \\
\hline $\begin{array}{l}38-\text { Authority to take expeditious actions in response to } \\
\text { foreign countries' requests to identify, freeze, seize and } \\
\text { confiscate proceeds or other property }\end{array}$ & $\begin{array}{l}11,15,16,34,34.1 \\
35.2,39\end{array}$ & Compliant \\
\hline $40-$ ML an extraditable offense & 34,40 & Compliant \\
\hline $\begin{array}{l}\text { SR I - Take steps to ratify and implement relevant United } \\
\text { Nations instruments }\end{array}$ & 1,34 & Compliant \\
\hline SR II - Criminalize the FT and terrorist organizations & $2.3,3,3.1$ & Compliant \\
\hline SR III - Freeze and confiscate terrorist assets & $7,7.3,8,13$ & Materially non-compliant \\
\hline $\begin{array}{l}\text { SR IV - Report suspicious transactions linked to } \\
\text { terrorism }\end{array}$ & 55 & Compliant \\
\hline $\begin{array}{l}\text { SR V - provide assistance to other countries' FT } \\
\text { investigations }\end{array}$ & $34,34.1,37,40,41$ & Compliant \\
\hline $\begin{array}{l}\text { SR VI - impose AML requirements on alternative } \\
\text { remittance systems }\end{array}$ & $\begin{array}{l}45,46,46.1,47,49,50 \\
50.1,52,53,54,55,56 \\
57,58,58.1,59,60,61 \\
62\end{array}$ & Compliant \\
\hline $\begin{array}{l}\text { SR VII - Strengthen customer identification measures for } \\
\text { wire transfers }\end{array}$ & 48,51 & Not rated \\
\hline
\end{tabular}

Table 49. Summary of Effectiveness of AML/CFT Efforts

\begin{tabular}{|l|l|}
\hline Heading & \multicolumn{1}{|c|}{ Assessment of Effectiveness } \\
\hline $\begin{array}{l}\text { Criminal Justice Measures and International } \\
\text { Cooperation }\end{array}$ & $\begin{array}{l}\text { The legal framework relating to the criminalization of } \\
\text { ML and FT is comprehensive. The main limitation is } \\
\text { I-Criminalization of ML and FT } \\
\text { that France is currently unable to comply fully with UN } \\
\text { Security Council Resolution 1373 with regard to } \\
\text { terrorists or terrorist groups from within the European } \\
\text { Union as they are not covered by EU Council } \\
\text { Regulations. }\end{array}$ \\
\hline $\begin{array}{l}\text { II-Confiscation of proceeds of crime or property used to } \\
\text { finance terrorism }\end{array}$ & $\begin{array}{l}\text { Judicial seizure and confiscation } \\
\text { Though in theory a conviction can result in the }\end{array}$ \\
\hline
\end{tabular}




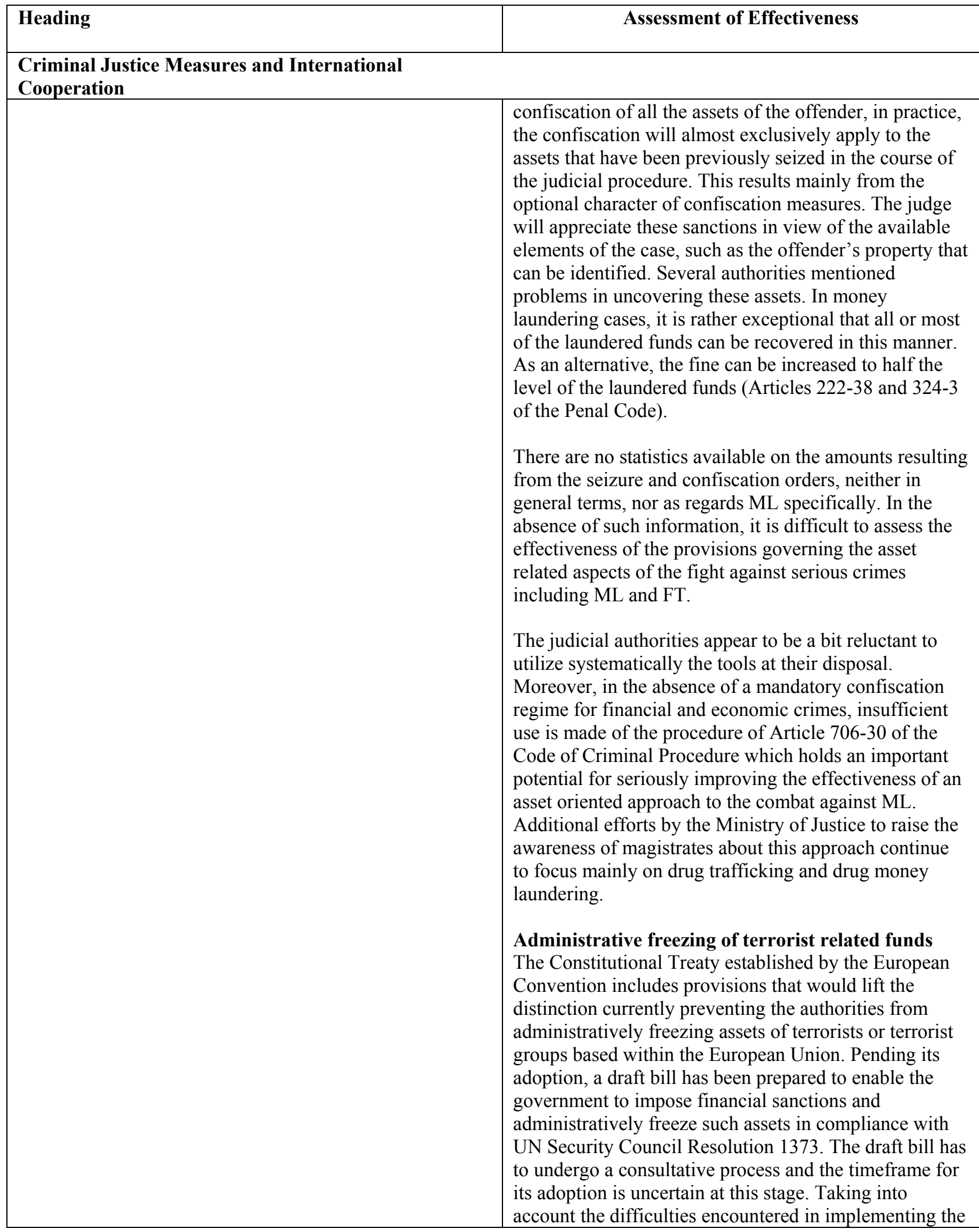




\begin{tabular}{|l|}
\hline Heading \\
\hline $\begin{array}{l}\text { Criminal Justice Measures and International } \\
\text { Cooperation }\end{array}$ \\
\hline \\
\hline III-The FIU and processes for receiving, analyzing, and
\end{tabular}
disseminating financial information and other intelligence at the domestic and international levels
UNSCR and subsequent EU regulations, four accounts were frozen on the basis of the UN and EU lists at the time of the assessment visit, amounting to about 30.000 EUR. No other assets, such as real estate, have been frozen. This is mainly due to the lack of definition of which assets and of what measures should be targeted and the need of ad hoc instruments to trace them.

\section{Access to additional information}

In the absence of a central contact point with basic data on individuals and legal entities, it can prove difficult for TRACFIN to verify the identification data contained in the STRs. The access to registers held by the Social Security services, as provided for by a recent amendment of Article L. 563-6 of the CMF, should improve this process.

\section{International cooperation}

As far as cross-border cooperation with counterpart FIUs is concerned, TRACFIN is able to and does provide assistance to comply with foreign requests for information without requiring specific formalities. Moreover, such requests are considered as domestic STRs in the sense that they enable the FIU to query other domestic sources of information. As regards its own analysis, TRACFIN is intensifying the input from other FIUs by sending out requests more frequently than before, though not systematically yet. As a general remark, TRACFIN takes into account the Best Practices of the Egmont Group regarding the exchange of information.

\section{Volume of STRs}

The volume of STRs received by TRACFIN is growing steadily. It would seem however that this is not accompanied by a significant increase in the overall quality of reports. The number of reports produced by the reporting parties is still relatively low compared to the importance of the financial and economic activity on the French market. Moreover, as regards the results of the operational action of TRACFIN, only a rather limited number of cases are being forwarded to the Prosecutor's Office (269 in 2003, representing only eight to ten percent of all the STRs received). This may be partially due to a poor quality of STRs or to insufficient verifying information from other authorities.

Apart from a number of difficulties arising with the overseas departments and territories because of their geographical situation, in particular Guyana raises 


\begin{tabular}{|c|c|}
\hline Heading & Assessment of Effectiveness \\
\hline \multicolumn{2}{|l|}{$\begin{array}{l}\text { Criminal Justice Measures and International } \\
\text { Cooperation }\end{array}$} \\
\hline & $\begin{array}{l}\text { serious concerns as this department did not make a } \\
\text { single report after } 2000 \text {. } \\
\text { Also it appears from statistical data that a number of } \\
\text { reporting entities do not comply with their AML/CFT } \\
\text { obligations. From the } 134 \text { STRs received from the real } \\
\text { estate industry in } 2002 \text {, only } 5 \text { originated from the real } \\
\text { estate agents, the remaining } 126 \text { being from notaries. No } \\
\text { reports were received from dealers in high value goods } \\
\text { and commissaires-priseurs so far. The country's } 189 \\
\text { casinos made } 9 \text { reports, } 6 \text { of them after the authorities } \\
\text { started an important information campaign in July } 2003 \text {. } \\
\text { These deficiencies are mainly due to the absence of a } \\
\text { supervisory body for most of the parties concerned and } \\
\text { the obvious difficulty to reach out to these professions. }\end{array}$ \\
\hline $\begin{array}{l}\text { IV-Law enforcement and prosecution authorities, powers } \\
\text { and duties }\end{array}$ & $\begin{array}{l}\text { Despite all the efforts that have been produced to date, a } \\
\text { large number of cases could not be dealt with due to } \\
\text { insufficient resources and the need to pursue other } \\
\text { priorities. In particular, the innovative aspects } \\
\text { introduced by the institution of the assistants de justice } \\
\text { do not seem to have yet produced the anticipated results. } \\
\text { A recent reform by the Law of March } 9,2004 \text { that } \\
\text { entered into force on October } 1,2004 \text { and introduces } \\
\text { specialized jurisdictions should enhance the overall } \\
\text { capacity of the judicial system to combat financial } \\
\text { crime, both in terms of human resources and of on- } \\
\text { going specialized training. } \\
\text { About seventy percent of the ML cases in Paris originate } \\
\text { from TRACFIN and about ten percent from the Customs } \\
\text { Department. Almost half of the sixty cases } \\
\text { communicated by TRACFIN in } 2003 \text { that were dealt } \\
\text { with by the financial division of the Paris Prosecutor's } \\
\text { Office were new cases, while the remaining ones } \\
\text { complemented already existing files. Half of them are } \\
\text { being further investigated (preliminary enquiry or } \\
\text { judicial investigation) and four of them have been } \\
\text { closed. }\end{array}$ \\
\hline
\end{tabular}




\begin{tabular}{|c|c|}
\hline Heading & Assessment of Effectiveness \\
\hline \multicolumn{2}{|c|}{$\begin{array}{l}\text { Criminal Justice Measures and International } \\
\text { Cooperation }\end{array}$} \\
\hline & $\begin{array}{l}\text { offence. Although jurisprudence does not require the } \\
\text { establishment that the money launderer knew the } \\
\text { specific origin of the illegal funds, a number of } \\
\text { prosecutors still operate on the assumption that they } \\
\text { have to prove the existence of the specific underlying } \\
\text { offence. However, some case law indicates that a } \\
\text { conviction for (general) money laundering can be } \\
\text { pronounced without the predicate offence being } \\
\text { specifically identified. Additional problems arise when a } \\
\text { case has an international dimension and information has } \\
\text { to be obtained from other jurisdictions. Therefore, there } \\
\text { is a tendency to re-qualify the facts and to prosecute on } \\
\text { a different basis. } \\
\text { None of the FT cases under investigation lead to judicial } \\
\text { results so far. The main difficulties lie in the linking of } \\
\text { suspicious or irregular financial movements with } \\
\text { terrorist activities and also in the absence of an } \\
\text { investigating body that combines a specialization in both } \\
\text { financial and terrorism aspects. Most cases were } \\
\text { initiated following terrorist attacks. }\end{array}$ \\
\hline $\mathrm{V}$-International cooperation & $\begin{array}{l}\text { France provides timely and effective follow-up to } \\
\text { mutual legal assistance requests and maintains statistics } \\
\text { on all mutual legal assistance and other requests made or } \\
\text { received, relating to ML, the predicate offences, and FT, } \\
\text { as well as the outcome of such requests. The nature of } \\
\text { MLA requests is not reflected in the statistics, which are } \\
\text { devoted solely to quantifying flows. }\end{array}$ \\
\hline \multicolumn{2}{|c|}{$\begin{array}{l}\text { Legal and Institutional Framework for All Financial } \\
\text { Institutions }\end{array}$} \\
\hline I-General framework & $\begin{array}{l}\text { The legal framework for AML/CFT preventive } \\
\text { measures is characterized by its comprehensive } \\
\text { coverage of financial entities and its broad range of due } \\
\text { diligence and reporting requirements that go beyond the } \\
\text { FATF standard. The regulatory framework, however, is } \\
\text { incomplete and remains a work in progress, notably for } \\
\text { sectors other than credit institutions and investment } \\
\text { firms other than portfolio management firms, where } \\
\text { there is greater reliance on supervisory and professional } \\
\text { recommendations rather than on regulation or other } \\
\text { enforceable means. Industry associations in the banking, } \\
\text { insurance and securities sectors have been proactive in } \\
\text { developing guidance for their members. The missions } \\
\text { and powers of the competent authorities for AML/CFT } \\
\text { supervision are generally clear and appropriate. } \\
\text { However, the regulatory and supervisory framework for } \\
\text { non-financial businesses and professions is incomplete. }\end{array}$ \\
\hline
\end{tabular}




\begin{tabular}{|c|c|}
\hline Heading & Assessment of Effectiveness \\
\hline \multicolumn{2}{|l|}{$\begin{array}{l}\text { Criminal Justice Measures and International } \\
\text { Cooperation }\end{array}$} \\
\hline & $\begin{array}{l}\text { The duty of professional secrecy does not appear to pose } \\
\text { any obstacle to the implementation of the FATF } \\
\text { standard. }\end{array}$ \\
\hline II-Customer identification & $\begin{array}{l}\text { The laws are clear and complete. Questionnaire QLB } 3 \\
\text { pursuant to CB Instruction No. 2000-09 provides a } \\
\text { detailed checklist of the legal requirements and reminder } \\
\text { of the need to have customer acceptance policies and } \\
\text { procedures but offers little additional guidance. The } \\
\text { CCA recommendations and to a lesser extent the AFG- } \\
\text { ASFFI recommendations provide additional useful } \\
\text { detailed guidance. However, they are neither binding } \\
\text { nor enforceable, nor do they extend to insurance and } \\
\text { reinsurance brokers or direct marketers. No further rules } \\
\text { or guidance apply to currency exchangers. Financial } \\
\text { industry representatives in general indicated strong } \\
\text { interest in obtaining additional guidance from the } \\
\text { authorities. } \\
\text { Regarding wire transfers there are indications that the } \\
\text { CB has exercised its broad authority to ensure } \\
\text { compliance with professional rules and standards. } \\
\text { Contacts with the profession within the Liaison } \\
\text { Committee and random checks carried out during on- } \\
\text { site inspections indicate that credit institutions are } \\
\text { including the information necessary to identify } \\
\text { originators of the transfers they issue. However, it is } \\
\text { unclear whether this has been fully implemented with } \\
\text { regard to domestic transfers. In addition, these } \\
\text { professional rules and standards do not specifically } \\
\text { require inclusion of the originator's account number. } \\
\text { Finally, the rules and standards apply to banks and do } \\
\text { not extend to non-bank financial institutions. As such, } \\
\text { the measures in place do not sufficiently implement the } \\
\text { relevant FATF standard. However, work is underway at } \\
\text { the level of the EU on implementing the relevant FATF } \\
\text { standard and the authorities have indicated their } \\
\text { intention to set out requirements in legislation.. } \\
\text { and }\end{array}$ \\
\hline III-Ongoing monitoring of accounts and transactions & $\begin{array}{l}\text { 1. Increased diligence of financial entities } \\
\text { Article L. } 563-3 \text { of the CMF and Article } 4 \text { of Decree } 91- \\
160 \text { set out the main legislative requirements with } \\
\text { respect to enhanced vigilance. The requirements apply } \\
\text { only to transactions above } € 150000 \text { when the } \\
\text { customer's transactions are not usually above this } \\
\text { amount. The transactions must also be unusually } \\
\text { complex and have no apparent economic purpose. } \\
\text { Formulated as such, this requirement suggests that if a } \\
\text { customer's transactions typically exceed this threshold, } \\
\text { there would be no obligation to exercise enhanced }\end{array}$ \\
\hline
\end{tabular}




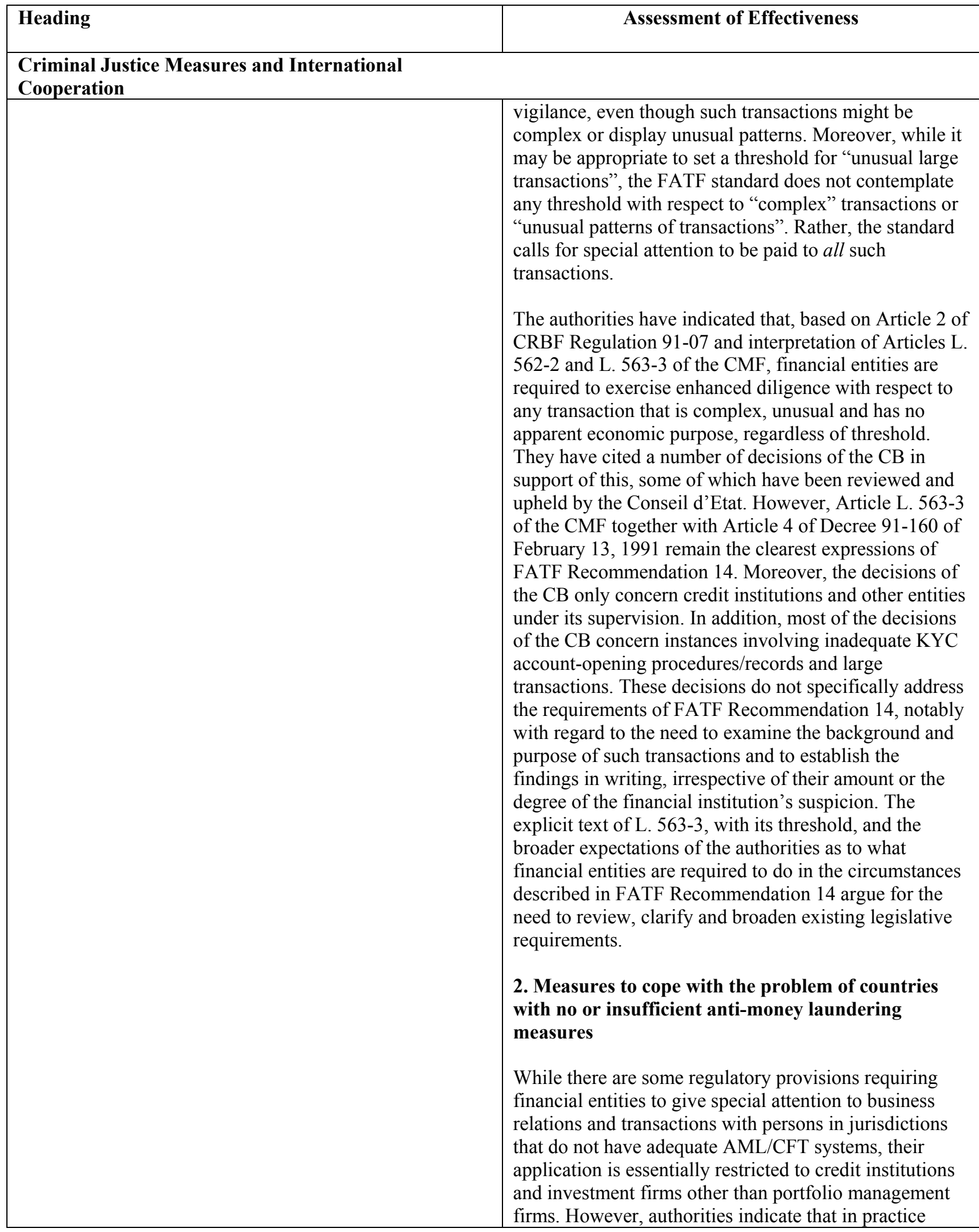




\begin{tabular}{|c|c|}
\hline Heading & Assessment of Effectiveness \\
\hline \multicolumn{2}{|c|}{$\begin{array}{l}\text { Criminal Justice Measures and International } \\
\text { Cooperation }\end{array}$} \\
\hline & $\begin{array}{l}\text { financial entities generally comply with advisories } \\
\text { issued by the Minister of the Economy, Finance and } \\
\text { Industry. For credit institutions and investment firms } \\
\text { other than portfolio management firms, compliance with } \\
\text { the above requirements is verified in particular by means } \\
\text { of responses to the QLB questionnaire, as well as on-site } \\
\text { examinations. Credit institutions and investment firms } \\
\text { must also report annually to the CB on the number of } \\
\text { intelligence files created in the preceding fiscal year, as } \\
\text { well as the largest amount involved. These financial } \\
\text { entities are reminded of these obligations by mail and in } \\
\text { meetings following up on on-site examinations and off- } \\
\text { site surveillance/monitoring. During on-site } \\
\text { examinations carried out by the CB, financial } \\
\text { transactions with non-cooperative jurisdictions are } \\
\text { examined in depth. As a part of ongoing supervision, } \\
\text { credit institutions and investment firms other than } \\
\text { portfolio management firms have also been asked } \\
\text { detailed questions on a systematic and standardized } \\
\text { basis concerning the enhanced customer due diligence } \\
\text { measures they have taken with respect to transactions } \\
\text { with the above-mentioned jurisdictions. } \\
\text { Insurance companies are reminded of the above- } \\
\text { requirements as frequently as possible, either through } \\
\text { outreach activities or in the context of ongoing } \\
\text { relationships between insurance companies and the } \\
\text { Audit Department. Compliance is confirmed in on-site } \\
\text { examinations and follow-up. }\end{array}$ \\
\hline IV_-Record keeping & $\begin{array}{l}\text { The legislative and regulatory provisions are } \\
\text { comprehensive and appear to be effectively } \\
\text { implemented. }\end{array}$ \\
\hline $\mathrm{V}$ - Suspicious transactions reporting & $\begin{array}{l}\text { The scope of the reporting requirements is not aligned } \\
\text { and is indeed narrower than that of the predicate } \\
\text { offences for money laundering. The scope of predicate } \\
\text { offences for money laundering is comprehensive and } \\
\text { covers all crimes and misdemeanors, including the } \\
\text { financing of terrorism and fiscal fraud. On the other } \\
\text { hand, a suspicion funds stem from a fiscal misdemeanor } \\
\text { is not required to be reported. This may be a source of } \\
\text { confusion for reporting entities regarding whether or not } \\
\text { to report particular transactions and could expose them } \\
\text { to compliance risks. This could potentially reduce the } \\
\text { effectiveness of the regime. } \\
\text { TRACFIN and the supervisory authorities have made } \\
\text { some effort to provide guidance for improving the } \\
\text { detection and reporting of suspicious patterns of } \\
\text { transactions, but more is needed in light of the }\end{array}$ \\
\hline
\end{tabular}




\begin{tabular}{|c|c|}
\hline Heading & Assessment of Effectiveness \\
\hline \multicolumn{2}{|l|}{$\begin{array}{l}\text { Criminal Justice Measures and International } \\
\text { Cooperation }\end{array}$} \\
\hline & $\begin{array}{l}\text { acknowledged generally poor quality of a large number } \\
\text { of STRs. Moreover, greater efforts should be made to } \\
\text { improve reporting from the DOM-TOM. } \\
\text { The additional reports, notably the ones in relation to } \\
\text { trusts, have raised compliance burden but their benefits } \\
\text { are unclear and could potentially draw away resources } \\
\text { (i.e., of financial entities and TRACFIN) that might } \\
\text { otherwise be used in the detection of suspicious } \\
\text { transactions. }\end{array}$ \\
\hline VI-Internal controls, compliance and audit & $\begin{array}{l}\text { The framework, which requires the establishment of } \\
\text { internal rules defining procedures for implementing } \\
\text { AML/CFT requirements, are supplemented by } \\
\text { comprehensive regulations insofar as credit institutions } \\
\text { and investment firms other than portfolio management } \\
\text { firms are concerned. In the case of insurance companies } \\
\text { and portfolio management firms, there is reliance on } \\
\text { supervisory and professional recommendations, which } \\
\text { while helpful in signaling what financial entities are } \\
\text { expected to do, are neither binding nor enforceable. No } \\
\text { apparent guidance is provided to other sectors, although } \\
\text { representatives of La Poste described to the mission a } \\
\text { relatively robust system of internal controls. There are } \\
\text { few requirements for financial entities to have adequate } \\
\text { screening procedures to ensure high standards when } \\
\text { hiring employees and these focus largely on competency } \\
\text { rather than integrity. } \\
\text { Employee training appears to be effectively } \\
\text { implemented with respect to credit institutions, } \\
\text { investment firms other than portfolio management firms } \\
\text { and insurance companies and La Poste. } \\
\text { Other than for credit institutions and currency } \\
\text { exchangers, there are no specific requirements for } \\
\text { financial entities to ensure the comprehensive } \\
\text { application of AML/CFT requirements to branches and } \\
\text { majority owned subsidiaries located abroad. }\end{array}$ \\
\hline VII-Integrity standards & $\begin{array}{l}\text { Measures in place are comprehensive and effectively } \\
\text { implemented. There exists good cooperation between } \\
\text { supervisory authorities. }\end{array}$ \\
\hline VIII-Enforcement powers and sanctions & $\begin{array}{l}\text { Enforcement and sanction powers of supervisory } \\
\text { authorities are generally appropriate. The CB has a good } \\
\text { range of enforcement actions that it can take against } \\
\text { credit institutions, investment firms other than portfolio } \\
\text { management firms and currency exchangers to ensure } \\
\text { compliance with AML/CFT requirements. It has taken a } \\
\text { broad range of enforcement actions and routinely }\end{array}$ \\
\hline
\end{tabular}




\begin{tabular}{|c|c|}
\hline Heading & Assessment of Effectiveness \\
\hline \multicolumn{2}{|l|}{$\begin{array}{l}\text { Criminal Justice Measures and International } \\
\text { Cooperation }\end{array}$} \\
\hline & $\begin{array}{l}\text { publishes the results. However, it has had limited } \\
\text { experience in taking enforcement action against } \\
\text { unlicensed funds transfer businesses. The authorities } \\
\text { have indicated that they have neither systematically } \\
\text { sought out to identify unlicensed businesses nor have } \\
\text { they conducted any outreach/awareness raising } \\
\text { activities. } \\
\text { The CCA has a good range of enforcement actions that } \\
\text { it can take against insurance companies and brokers to } \\
\text { ensure compliance with AML/CFT requirements. } \\
\text { However, the number sanctions imposed on insurance } \\
\text { companies and brokers is relatively low. The AMF also } \\
\text { has a good range of enforcement actions that it can take } \\
\text { against portfolio management firms to ensure } \\
\text { compliance with AML/CFT requirements. However, it } \\
\text { has not imposed any sanctions for non-compliance with } \\
\text { AML/CFT requirements. } \\
\text { There is too much reliance on La Poste's not } \\
\text { inconsiderable internal control mechanisms and too little } \\
\text { on programmed independent examinations by the IGF. } \\
\text { It is unclear what, if any sanctions are available or have } \\
\text { been levied for non-compliance. }\end{array}$ \\
\hline $\begin{array}{l}\text { IX-Co-operation between supervisors and other } \\
\text { competent authorities }\end{array}$ & $\begin{array}{l}\text { Supervision } \\
\text { All supervisory authorities are appropriately structured. } \\
\text { The CB appears to have a robust program of } \\
\text { examinations and sufficient human and financial } \\
\text { resources to carry it out. } \\
\text { AML/CFT supervisory efforts and corresponding } \\
\text { resources are relatively low with respect to life } \\
\text { insurance companies and brokers, individual and } \\
\text { collective portfolio management firms, direct marketers } \\
\text { and La Poste. The number of on-site inspections and } \\
\text { corresponding staff resources for these sectors is } \\
\text { relatively low and there have been few sanctions } \\
\text { imposed for failure to comply with AML/CFT } \\
\text { requirements. When looked at in the context of } \\
\text { historically relatively low rate of reporting of suspicious } \\
\text { transactions from these sectors, it is consequently } \\
\text { difficult to assess whether AML/CFT requirements are } \\
\text { being effectively implemented overall. } \\
\text { Cooperation }\end{array}$ \\
\hline
\end{tabular}




\begin{tabular}{|l|l|}
\hline Heading & \multicolumn{1}{|c|}{ Assessment of Effectiveness } \\
\hline $\begin{array}{l}\text { Criminal Justice Measures and International } \\
\text { Cooperation }\end{array}$ & $\begin{array}{l}\text { CB has concluded a number of bilateral agreements with } \\
\text { foreign counterparts. In 2001 information provide by } \\
\text { foreign authorities led to two AML/CFT sanctions } \\
\text { decisions. The COB's cooperation with its foreign } \\
\text { counterparts was extensive and of long standing. It had } \\
\text { concluded more than thirty bilateral agreements and two } \\
\text { multilateral agreements. While the CCA maintains } \\
\text { general contact for AML/CFT purposes with foreign } \\
\text { supervisory authorities and through the IAIS, the CCA } \\
\text { does not routinely exchange case information with its } \\
\text { foreign counterparts and no formal agreements exist } \\
\text { with foreign counterparts. The reasons for this are not } \\
\text { entirely clear. }\end{array}$ \\
\hline
\end{tabular}

Table 50. Recommended Action Plan to Improve the Legal and Institutional Framework and to Strengthen the Implementation of AML/CFT Measures

\begin{tabular}{|c|c|}
\hline $\begin{array}{l}\text { Criminal Justice Measures and International } \\
\text { Cooperation }\end{array}$ & Recommended Action \\
\hline $\mathrm{I}-$ Criminalization of ML and FT & $\begin{array}{l}\text { As mentioned below, the authorities are encouraged } \\
\text { to take the necessary measures to ensure full } \\
\text { compliance with UNCSR } 1373 \text {. }\end{array}$ \\
\hline $\begin{array}{l}\text { II-Confiscation of proceeds of crime or property used } \\
\text { to finance terrorism }\end{array}$ & $\begin{array}{l}\text { The French authorities may wish to consider } \\
\text { establishing some form of mandatory deprivation of } \\
\text { the illegal profits of financial and economic } \\
\text { criminality, in particular in the context of money } \\
\text { laundering and terrorism financing. This could be } \\
\text { achieved by means either of a fine or of a } \\
\text { confiscation measure. } \\
\text { More efforts should be made to train magistrates and } \\
\text { raise their awareness with regard to the available } \\
\text { tools and their key role in the asset-oriented approach } \\
\text { of the fight against all forms of crime that generate } \\
\text { substantial illicit profits. } \\
\text { Particular attention should also be given to the } \\
\text { compilation of relevant statistics. Comprehensive } \\
\text { statistical data is a necessary tool, not only for } \\
\text { outside evaluation but also and more importantly for } \\
\text { the internal review of the performance of the system. } \\
\text { The establishment of a central body responsible for } \\
\text { managing seized and confiscated assets could remedy } \\
\text { this lack of information. The French authorities are } \\
\text { therefore encouraged to work further in this } \\
\text { direction. } \\
\text { Also, increasing attention should be given to } \\
\text { investigating and prosecuting legal entities that have }\end{array}$ \\
\hline
\end{tabular}




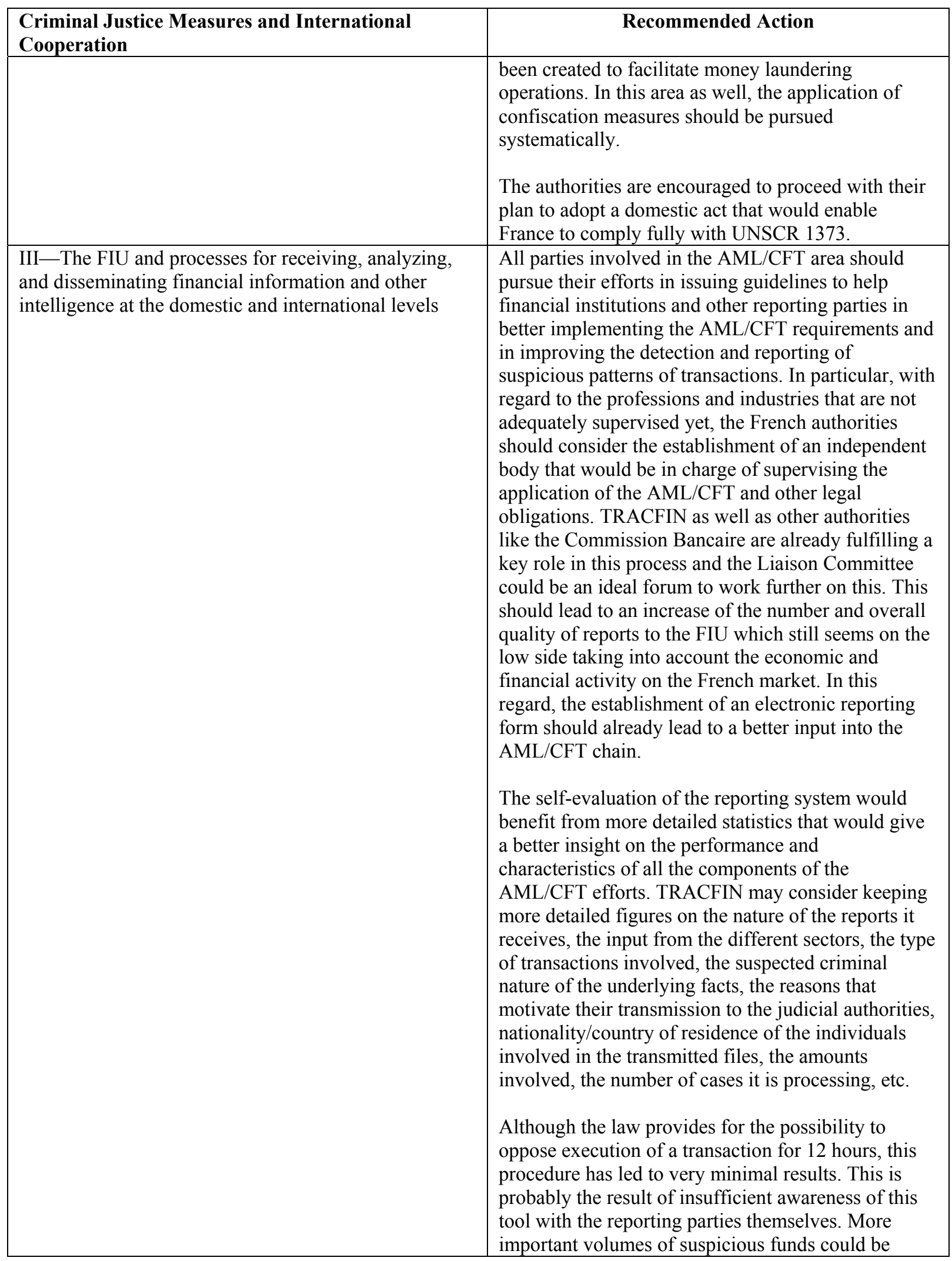




\begin{tabular}{|c|c|}
\hline $\begin{array}{l}\text { Criminal Justice Measures and International } \\
\text { Cooperation }\end{array}$ & Recommended Action \\
\hline & $\begin{array}{l}\text { blocked, seized and eventually confiscated, for } \\
\text { instance when clients announce the withdrawal of the } \\
\text { funds from their bank account. Very few such } \\
\text { transactions are being reported to TRACFIN. } \\
\text { Another factor is the very short delay the FIU has at } \\
\text { its disposal to collect complementary information in } \\
\text { order to constitute a solid case for transmission to the } \\
\text { judicial authorities. An extension of the delay of } 12 \\
\text { hours should therefore be considered. } \\
\text { TRACFIN is encouraged to continue to enhance its } \\
\text { efforts in intensifying the query of foreign FIUs to } \\
\text { collect additional intelligence in cases with an } \\
\text { international dimension. } \\
\text { With regard to deficiencies identified in the } \\
\text { compliance with AML/CFT obligations in the DOM- } \\
\text { TOM, TRACFIN appears to be aware that additional } \\
\text { efforts in reaching out to these areas, in particular } \\
\text { Guyana, and in monitoring them more closely are } \\
\text { required on an urgent basis. } \\
\text { TRACFIN, as well as the supervisory authorities, are } \\
\text { In view of the increasing volume of STRs and the } \\
\text { TRACFIN towards a number of sectors, the } \\
\text { authorities may wish to consider whether the current } \\
\text { level of staffing of TRACFIN is adequate. } \\
\text { proactive in issuing guidelines and domestic and } \\
\text { international typologies to help financial institutions } \\
\text { and other reporting parties in better implementing } \\
\text { AML/CFT requirements and in improving the } \\
\text { detection and reporting of suspicious patterns of } \\
\text { transactions. } \\
\text { Consideration should be given to a more active } \\
\text { involvement of the judiciary in the Liaison } \\
\text { Committee. }\end{array}$ \\
\hline $\begin{array}{l}\text { IV-Law enforcement and prosecution authorities, } \\
\text { powers and duties }\end{array}$ & $\begin{array}{l}\text { The authorities should continue to monitor closely } \\
\text { the challenges posed by serious economic crime and } \\
\text { the financial means required at the different stages to } \\
\text { combat it effectively. } \\
\text { Further consideration appears to be warranted for the } \\
\text { pooling of expertise in financial and terrorism issues } \\
\text { in one specialized service, in particular for } \\
\text { investigating FT related cases. } \\
\text { In order for the reporting mechanism to produce }\end{array}$ \\
\hline
\end{tabular}




\begin{tabular}{|c|c|}
\hline $\begin{array}{l}\text { Criminal Justice Measures and International } \\
\text { Cooperation }\end{array}$ & Recommended Action \\
\hline & $\begin{array}{l}\text { more significant results, there should be less reliance } \\
\text { on the classical approach of making ML depend on } \\
\text { the establishment of the underlying crime. A change } \\
\text { of mentality and openness for new approaches is } \\
\text { therefore warranted. }\end{array}$ \\
\hline $\mathrm{V}$-International cooperation & $\begin{array}{l}\text { The authorities are encouraged to consider including } \\
\text { details on the nature and results of MLA requests in } \\
\text { statistics in order to obtain a better understanding of } \\
\text { France's efforts in this area. }\end{array}$ \\
\hline \multicolumn{2}{|l|}{$\begin{array}{l}\text { Legal and Institutional Framework for Financial } \\
\text { Institutions }\end{array}$} \\
\hline I-General framework & $\begin{array}{l}\text { Authorities should continue in their efforts to } \\
\text { develop and implement detailed regulations in } \\
\text { support of the underlying laws. They should also } \\
\text { review options for the regulation and supervision of } \\
\text { non-financial businesses and professions and } \\
\text { designate competent supervisory authorities. }\end{array}$ \\
\hline II-Customer identification & $\begin{array}{l}\text { The authorities should introduce more detailed } \\
\text { requirements though regulation or enforceable } \\
\text { guidance as to what constitutes adequate customer } \\
\text { acceptance policies and procedures and, in } \\
\text { particular, what are the reasonable steps to be } \\
\text { taken to identify beneficial owners of accounts and } \\
\text { transactions. } \\
\text { The authorities should review the ML/FT } \\
\text { risks associated with capitalization } \\
\text { bonds/contracts and take corrective } \\
\text { measures, as appropriate. } \\
\text { The authorities should proceed with plans to } \\
\text { introduce legislation to comply fully with SR VII. }\end{array}$ \\
\hline III-Ongoing monitoring of accounts and transactions & $\begin{array}{l}\text { Authorities should review and broaden } \\
\text { requirements to pay special attention to certain } \\
\text { transactions. } \\
\text { A requirement should be introduced for financial } \\
\text { entities other than credit institutions and investment } \\
\text { firms other than portfolio management firms to pay } \\
\text { special attention to business relations and } \\
\text { transactions with persons and legal entities in } \\
\text { jurisdictions that do not have adequate systems in } \\
\text { place to prevent and deter ML or FT }\end{array}$ \\
\hline \multicolumn{2}{|l|}{ IV-Record keeping } \\
\hline V-Suspicious transactions reporting & $\begin{array}{l}\text { The scope of the suspicious transaction reporting } \\
\text { requirement should be aligned with that of the } \\
\text { predicate offences for money laundering. } \\
\text { In view of the generally lower rates of reporting } \\
\text { outside the banking sector, TRACFIN and }\end{array}$ \\
\hline
\end{tabular}




\begin{tabular}{|c|c|}
\hline $\begin{array}{l}\text { Criminal Justice Measures and International } \\
\text { Cooperation }\end{array}$ & Recommended Action \\
\hline & $\begin{array}{l}\text { supervisory authorities should provide further } \\
\text { guidance and ML typologies to reporting entities to } \\
\text { improve detection and reporting of suspicious } \\
\text { transactions, the quality of STRs and overall } \\
\text { implementation of AML/CFT requirements. } \\
\text { Authorities should also reach out to the DOM- } \\
\text { TOM and monitor their compliance with } \\
\text { AML/CFT obligations. } \\
\text { The usefulness of the additional reporting } \\
\text { requirements should be reviewed. }\end{array}$ \\
\hline VI-Internal controls, compliance and audit & $\begin{array}{l}\text { The regulatory framework for internal controls needs } \\
\text { to be strengthened for all sectors other than credit } \\
\text { institutions and investment firms other than portfolio } \\
\text { management firms. } \\
\text { Financial entities should also be required to take } \\
\text { integrity into account when hiring employees, notably } \\
\text { for sensitive positions. } \\
\text { Other than for credit institutions and currency } \\
\text { exchangers, a requirement should be established for } \\
\text { financial entities to ensure that AML/CFT } \\
\text { requirements are applied to branches and majority- } \\
\text { owned subsidiaries located abroad. } \\
\text { Authorities should further assist financial entities in } \\
\text { developing employee training programs. }\end{array}$ \\
\hline VII-Integrity standards & $\begin{array}{l}\text { AML/CFT internal controls should be required to } \\
\text { be taken into account in the licensing of financial } \\
\text { entities. } \\
\text { Authorities should consider introducing an explicit } \\
\text { "fit and proper" test for currency exchangers }\end{array}$ \\
\hline VIII-Enforcement powers and sanctions & $\begin{array}{l}\text { The supervisory and enforcement efforts of the CCA, } \\
\text { the AMF and with respect to La Poste need to be } \\
\text { increased. } \\
\text { The authorities should review and monitor the } \\
\text { adequacy of enforcement efforts with respect to } \\
\text { unlicensed informal funds transfer businesses and } \\
\text { develop complementary public outreach /awareness } \\
\text { raising activities. }\end{array}$ \\
\hline $\begin{array}{l}\text { IX-Co-operation between supervisors and other } \\
\text { competent authorities }\end{array}$ & $\begin{array}{l}\text { The supervisory resources of the CCA and the } \\
\text { AMF should be increased and training of } \\
\text { supervisory staff formalized. } \\
\text { The responsibility for AML/CFT supervision and } \\
\text { enforcement of La Poste's financial services } \\
\text { should be shifted to the CB or at a minimum the }\end{array}$ \\
\hline
\end{tabular}




\begin{tabular}{|l|l|}
\hline $\begin{array}{l}\text { Criminal Justice Measures and International } \\
\text { Cooperation }\end{array}$ & \multicolumn{1}{c|}{ Recommended Action } \\
\hline & $\begin{array}{l}\text { supervisory efforts and resources of the IGF should } \\
\text { be increased. }\end{array}$ \\
$\begin{array}{l}\text { Where possible, supervisors should issue } \\
\text { enforceable guidelines in support of the legal and } \\
\text { regulatory framework }\end{array}$ \\
\hline
\end{tabular}

\section{E. Authorities' Response to the Assessment}

The French authorities wish to thank the members of the IMF assessment team for all the work that had to be done to produce this report. They welcome the assessment that France maintains a high level of compliance with the FATF 40+8 Recommendations. They are pleased with the fact that IMF recognized its regime has gone beyond the standard in many respects.

The authorities note that some of the suggestions in the FSAP for further improvements should be soon implemented, notably by the way of the future decree of transposition of the second European directive AML/CFT.

However, the French authorities do not share the IMF's opinion concerning its rating related to the FATF Special Recommendation III. The IMF team rated France "materially non compliant" with SR III, because France would be currently unable to comply fully with UN Security Council Resolution 1373 with regard to terrorists or terrorist groups from within European Union not linked to Al Qaida and the Talibans, as they are not covered by EU Council Regulations.

Indeed, France does not have in place of a genuine national framework of assets freezing and rely on the Sanctions Committee of the UN Security Council and decisions taken at the UE level. However, our legal framework related to financial relationships with foreign countries allows us, in certain cases, to freeze assets of persons who are not targeted by the Sanctions Committee of the UN Security Council. In a recent decision, the French administrative High Court confirmed the possibility for France to freeze European resident's assets on the base of our legal framework. ${ }^{38}$

Nevertheless, in order to secure and perfect our legal framework, the French government is currently elaborating a specific national framework which would allow freezing assets of all terrorists without any conditions of nationality or residence.

${ }^{38}$ Conseil d'Etat, 2 novembre 2004, SEMONDE 